\author{
UNIVERSIDADE DE SÃO PAULO \\ FACULDADE DE FILOSOFIA, LETRAS E CIÊNCIAS HUMANAS \\ DEPARTAMENTO DE LETRAS CLÁSSICAS E VERNÁCULAS \\ PROGRAMA DE PÓS-GRADUAÇÃO EM LITERATURA BRASILEIRA
}

IEDA LEBENSZTAYN

Graciliano Ramos e a Novidade:

o astrônomo do inferno e os meninos impossíveis

São Paulo

2009 


\author{
UNIVERSIDADE DE SÃO PAULO \\ FACULDADE DE FILOSOFIA, LETRAS E CIÊNCIAS HUMANAS \\ DEPARTAMENTO DE LETRAS CLÁSSICAS E VERNÁCULAS \\ PROGRAMA DE PÓS-GRADUAÇÃO EM LITERATURA BRASILEIRA
}

\title{
Graciliano Ramos e a Novidade: \\ o astrônomo do inferno e os meninos impossíveis
}

\begin{abstract}
leda Lebensztayn
Tese apresentada ao Programa de PósGraduação em Literatura Brasileira, do Departamento de Letras Clássicas e Vernáculas da Faculdade de Filosofia, Letras e Ciências Humanas da Universidade de São Paulo, para a obtenção do título de Doutora em Letras.
\end{abstract}

Orientador: Prof. Dr. Alcides Celso Oliveira Villaça

São Paulo 


\section{RESUMO}

Apresento a Novidade, revista alagoana de 1931 que procurou combater chavões na política e na arte. Foram seus colaboradores: Alberto Passos Guimarães, Aurélio Buarque de Holanda, Aloísio Branco, Carlos Paurílio, Graciliano Ramos, Jorge de Lima, José Lins do Rego, Santa Rosa, Valdemar Cavalcanti, Willy Lewin. Como os jovens desse grupo reagiam ao "sem novidades" e foram chamados de meninos impossíveis, analiso uma cena de Sem novidades no front, de Erich Maria Remarque, e $O$ mundo do menino impossível, de Jorge de Lima, percebendo no grupo elementos de modernismo, regionalismo, atualidade crítica e preocupação social. A partir de textos de alguns escritores do semanário, esboço seus perfis e apreendo sua postura crítica contra o lugar-comum de miséria, ignorância, violência e política personalista. Centrados nessas questões, sobressaem os textos de Graciliano Ramos na Novidade: o capítulo XXIV de Caetés e as crônicas "Sertanejos", "Chavões" (inéditas em livro), "Milagres" e "Lampião". Constituem a melhor expressão crítica da revista e deixam ver os impasses contidos em estereótipos, que o escritor combateu ao construir suas personagens. Estudo esses textos, vinculando-os a "Nuvens" e "Os astrônomos" (Infância) e, num movimento analítico-interpretativo de cenas e imagens centrais de S. Bernardo, Angústia e Vidas secas, busco a poética, essencialmente ética, de Graciliano Ramos. Desvelando o impasse do intelectual num mundo de violência, ele configurou, artisticamente juntos, os problemas sociais e morais de seus protagonistas, de modo a evidenciar, a um tempo, a ordem social iníqua, a necessidade de compreensão do outro e um sentido de vanidade de tudo. Esforçando-se por compreender as semelhanças e diferenças entre as palavras, as coisas e os seres, resistiu ao lugar-comum por meio da escrita literária.

Palavras-chave: Graciliano Ramos, Revista Novidade, romance brasileiro, anos 1930, crônicas e memórias. 


\begin{abstract}
I introduce here Novidade, a magazine published in 1931 in Alagoas, a Brazilian northeastern state, whose main purpose was to combat platitudes in politics and art. Some of its contributors were: Alberto Passos Guimarães, Aurélio Buarque de Holanda, Aloísio Branco, Carlos Paurílio, Graciliano Ramos, Jorge de Lima, José Lins do Rego, Santa Rosa, Valdemar Cavalcanti and Willy Lewin. Since the young among the group reacted against the lack of novelties and were called meninos impossiveis ('impossible boys'), I analyze a scene of Erich Maria Remarque's Sem novidades no front (All quiet on the western front) and Jorge de Lima's $O$ mundo do menino impossivel, apprehending in the group traits of modernism, regionalism, critical current issues and social concern. From texts of some writers of the magazine, I present their profiles and apprehend their critical attitude against the commonplace of misery, ignorance, violence and personalistic politics. Focused on those questions, Graciliano Ramos' texts in Novidade stand out: the chapter XXIV of Caetés and the articles "Sertanejos", "Chavões" (unpublished in a book form), "Milagres" and "Lampião". They are the best critical expression of the magazine and permit seeing the impasses present in stereotypes, which the novelist fought against when he built his characters. I study those texts, linking them to "Nuvens" and "Os astrônomos" (Infância) and, in an analytical-interpretative movement of central scenes and images of S. Bernardo, Angústia and Vidas secas, I quest for Graciliano Ramos' essentially ethical poetic. Revealing the intellectual's impasse in a world of violence, he set up his protagonists' social and moral problems, artistically embodied together, showing, at the same time, the unequal social order, the need for understanding the other and a sense of vainness of everything. Straining to comprehend the similarities and differences among words, things and beings, Graciliano resisted the commonplace through literary writing.
\end{abstract}

Keywords: Graciliano Ramos, Magazine Novidade, Brazilian novel, the 1930's, chronicles and memoirs. 
Para Frida, Jacob e Élcio.

Para Ayde, Alcides e os meninos João, Davi e Pedro.

Onde não há jardim, as flores nascem de um secreto investimento em formas improváveis.

"Campo de flores", Claro enigma, Carlos Drummond de Andrade.

E os pretos não sabiam que eram pretos, e os brancos não sabiam que eram brancos.

S.Bernardo, capítulo 7,

Graciliano Ramos. 


\section{AGRADECIMENTOS:}

Aos meus pais Frida e Jacob e ao meu irmão Élcio.

Ao Professor Alcides Celso Oliveira Villaça, a quem desde sempre admiro porque, com argúcia e sensibilidade crítica, integridade ética, cultura e talento poético, é leitor, amigo e escritor: faz-me acreditar, qual Drummond, Machado e Graciliano, na vida e na literatura. Por acompanhar-me no trabalho, oferecendo valiosos colóquios sobre a realidade e a arte, indicações bibliográficas e também liberdade e confiança em meu caminho intelectual, sem jamais descuidar da agudez crítica e do respeito e gosto pelas palavras, pela possibilidade de interpretação e compreensão.

Ao Sr. Luiz Nogueira Barros, do Instituto Histórico e Geográfico de Alagoas, cuja generosidade foi fundamental para que eu obtivesse a revista Novidade. A Leonardo Cunha, da Biblioteca da Fundação Casa de Rui Barbosa, do Rio de Janeiro.

Aos professores Fábio Rigatto de Souza Andrade e Zenir Campos Reis, que leram atenciosa e criticamente meu relatório de qualificação, apoiaram-me com sugestões e me incentivaram no enfrentamento de questões de historiografia e interpretação literárias. Aos meus professores, em especial a Alfredo Bosi, Antonio Arnoni Prado, João Roberto Faria, José Miguel Wisnik, Ariovaldo José Vidal, Ieda Maria Alves, Ivone Daré Rabello, Iumna Maria Simon e Jeanne Marie Gagnebin; a César Braga-Pinto, Murilo Marcondes de Moura e Yêdda Dias Lima.

A Erwin Torralbo Gimenez, por confiar-me a Novidade, o partilhar de sonhos e pedras do caminho. A Hélio de Seixas Guimarães, por priorizar o afeto e o aperfeiçoamento intelectual, pelo interesse verdadeiro, olhar crítico e generosidade com que leu meu trabalho. A Alexandre Koji Shiguehara, por acompanhar meu trabalho com carinho e compreensão crítica, valorizando as palavras e a arte. A Ayde Veiga Lopes, por compartilhar o dom de traços, cores, palavras e gestos carregados de poesia. A André Luis Rodrigues, pelo apoio e exemplo de sua integridade ética e intelectual. A André, Luís e Mariana Villaça, Maria Claudete de Souza Oliveira, Jeane e Maria Rejane Araújo Tito, Cristiane Rodrigues, Fernanda Stock Bonzi, Mauricio Zuluaga Martinez, Saul Cabral Júnior, Ana Luiza Reis Bedê, Adriana Morelli, Érica Gonçalves de Castro, Guilherme Ignácio da Silva, Cecília Carla Lopes, Juliana A. Lopes, Mariangela de Araujo, Julio Rozenfeld. Aos meus colegas e amigos da revista Teresa, em especial à Prof ${ }^{\text {a }}$ Cilaine Alves Cunha, ao Prof. Marcos de Moraes, ao Arlindo, ao Ricardo, à Salete. A todos os meus familiares e amigos. Às pessoas queridas, que integram este trabalho e dão sentido a ele.

Aos funcionários da FFLCH, particularmente do Departamento de Letras Clássicas e Vernáculas.

À FAPESP, financiadora deste estudo, em especial ao parecerista de meus relatórios. 


\section{ÍNDICE}

APRESENTAÇÃO

INTRODUÇÃO

A partir de Caetés, o salto da precisão dramática das palavras 5

Caetés e a Revista Novidade: o resgate dos esquecidos 7

\section{CAPÍTULO 1 - "CARTÃO DE VISITA" DA NOVIDADE: AS REALIDADES DA VIDA}

Nem romantismo, nem ceticismo, nem esteticismo

Não uma "geração de turistas": o exemplo de Psichari 16

Nada de heróis no front $\quad 21$

"Vida, paixão e morte de Novidade": retrospectiva de uma Revista 22

CAPÍTULO 2 - SEM NOVIDADE NO FRONT 27

A "ética do rosto" contra a tautologia da guerra: com novidade na fronte 28

A experiência sem pátria $\quad 32$

Remarque na Novidade: uma geração de mutilados 35

Ambição míope: um mínimo de perdas

\section{CAPÍTULO 3 - A TERRA DOS MENINOS IMPOSSÍVEIS}

1. ACADEMIAS, ARTE NOVA E CANJICA: ANTECEDENTES DA NOVIDADE 43

A Academia dos Dez Unidos e a reação ao futurismo 43

José Lins e Jorge de Lima: regionalismo e modernismo para os meninos impossíveis

O Cenáculo, a Festa da Arte Nova e a revista Maracanan (1928) 47

O Grêmio "Guimarães Passos" (1927) e a Canjica Literária (1929) 51

Um olhar crítico sobre a região 53

A Liga contra o Empréstimo de Livros e a Festa de Arte Moderna 54

2. O MUNDO PELADO SE FAZ DE CONTA

(Novidade entre os mais velhos: Jorge de Lima e Graciliano Ramos) 56

A fortuna do mundo tirado do nada $\quad 62$

3. "PROBLEMA ENCRENCADO": O MODERNISMO NORDESTINO 66

\section{CAPÍTULO 4 - ITINERÁRIO POLÍTICO E CULTURAL: OS EDITORIAIS DA NOVIDADE}

Valdemar Cavalcanti: a agudez simpática - Nem ufanismo, nem tristeza 76

Alberto Passos Guimarães - Terra de escravos, não de milagres 85 


\section{CAPÍTULO 5 - NOVIDADE POLÍTICA: O RESGATE DOS SEM-LUGAR}

\section{A MAIOR CRIAÇÃO DE TRAÇAS DO NORTE: VIVA A BIBLIOTECA ALAGOANA!}

O ambiente agressivo para as letras 101

Direções provisórias da instrução pública em Alagoas. 103

3. A CIDADE MENDIGA

Multidão sob o relento e a seca 105

$\begin{array}{ll}\text { Os rostos de dez mendigos } & 108\end{array}$

4. LAMPIÕES E SANTAS: INDÚSTRIA DE MISÉRIAS 110

Nada de heróis no mundo de Lampião 112

Novidade: uma entrevista com Lampião 114

$\begin{array}{ll}\text { O bandido com a palavra } & 118\end{array}$

Homens sem cabeça: onde a "ética do rosto"? 119

$\begin{array}{ll}\text { Irrecusavelmente } & 123\end{array}$

$\begin{array}{ll}\text { Progressos da miséria } & 125\end{array}$

Milagres para o mundo: Novidade na pena irônica de Graciliano 129

5. O SENTIMENTO PARA ALÉM DO PERIÓDICO: O SEMBLANTE ÉTICO DA NOVIDADE 136

\section{CAPÍTULO 6 - NOVIDADE LITERÁRIA: O RESGATE DE PESSOAS}

Willy Lewin: a biblioteca de Cabral 145

O moderno e lírico na província: contra o standard, ruído da barbárie $\quad 146$

“Meus livros são teus livros": Santa Rosa 152

$\begin{array}{ll}\text { Santa, a flor do suor } & 156\end{array}$

A geração da Novidade: o empenho pela arte, contra preconceitos 162

Claro e denso, o horizonte das palavras: Aurélio

Ninharias e ninhos: as palavras. Aurélio e Graciliano 169

$\begin{array}{ll}\text { O poeta combalido da miséria silenciada } & 177\end{array}$

$\begin{array}{lr}\text { Taciturno menino, o mundo a definir } & 179\end{array}$

$\begin{array}{ll}\text { Senhores e cativos do território lírico } & 186\end{array}$

Carlos Paurílio, um moderno pungente

$\begin{array}{lr}\text { Poesia para todos: Leônidas Barletta } & 192\end{array}$

$\begin{array}{ll}\text { Descoberta de lirismo na cidade } & 196\end{array}$

Rostos anuviados de órfãos-números $\quad 198$

O poético dos impossíveis $\quad 205$

Os sonhos das moscas $\quad 213$

$\begin{array}{ll}\text { Relíquias de palavras } & 215\end{array}$

“Se o Aloísio Branco consentir": um inquieto em busca dos sentidos. 221 
Mundo menino ninando?

Fora da terra, com a guerra dentro $\quad 229$

$\begin{array}{ll}\text { O quarto de livros, gaiola azul } & 232\end{array}$

$\begin{array}{ll}\text { A literatura central dos homens da província } & 240\end{array}$

\section{CAPÍTULO 7 - GRACILIANO RAMOS E A NOVIDADE}

Caetés: novidade para o sem novidades 244

Novidade: os romances dos anos $1930 \quad 248$

Pena dos inteligentes 253

Contra os chavões: os astrônomos do inferno 258

Sertanejos no espelho. A pena sertaneja de tipos entrevê pessoas:

cartucheira e molambos por dentro 262

Lampião de palavras $\quad 266$

Laranjas e pitombas: as esferas ética e estética da obra de Graciliano Ramos

$\begin{array}{ll}\text { Nuvens: sombras e clarões } & 269\end{array}$

O sabor amar-amaro de saber laranjas e pitombas $\quad 271$

$\begin{array}{ll}\text { Homens no papel, modificados } & 277\end{array}$

Parado, o coração de Madalena Paulo Honório toca. Lembrança com propósito despropositado: S.Bernardo $\quad 279$

Mortos vivos em Angústia: ódio e compaixão aos vencedores vencidos

(o cangaceiro, o funcionário, o bacharel proprietário) 283

Fabiano, panela fervendo: mataria os que mandam. 297

Fabiano, força guardada: a ética do manso e a tautologia do governo 302

Baleia: misericórdia do manso 306

"Eqüidade opulenta": os meninos impossíveis e o astrônomo do inferno 315

$\begin{array}{ll}\text { BIBLIOGRAFIA } & 336\end{array}$

$\begin{array}{ll}\text { ANEXOS } & 346\end{array}$ 


\section{APRESENTAÇÃO}

Neste trabalho, resgato a Novidade, semanário alagoano de 1931, e a memória de alguns de seus colaboradores, que tiveram importante valor cultural, principalmente a partir dos anos 1940 no Rio de Janeiro. Impelida a buscar a revista por causa de Graciliano Ramos, tendo-o como guia e horizonte, pude conhecer melhor esse grupo de intelectuais com os quais ele conviveu e o contexto da escrita de seus romances. Parece-me relevante saber que as crônicas "Chavões", "Sertanejos" (inéditas em livro), "Milagres", "Lampião" e o capítulo XXIV de Caetés foram publicados em 1931: expressões marcantes da perspectiva crítica e do estilo do escritor, são reflexões sobre os problemas dos anos 30 , feitas antes de sua melhor criação ficcional. Trazem elementos que contribuem para uma análise estilística de seus romances, voltada a compreender a formalização artística dessa matéria histórica, de questões não apenas sociais mas também morais, psicológicas, existenciais.

Completada a escrita deste estudo, percebo como me foram iluminadoras várias sínteses interpretativas formuladas por Otto Maria Carpeaux, sobretudo a respeito de Angústia. Então, aumento aqui minha dívida para com ele, a culpa toda na conta de Luís da Silva e de seu criador: sem a pretensão de chegar ao distante e indecifrável das estrelas, mas considerando-as com admiração, eu diria que também construí meu Graciliano, bem como a minha Novidade. E esses possessivos sinalizam tão-só que delineei um recorte e um caminho interpretativo da obra do escritor e do semanário alagoano: meu propósito é partilhar a descoberta dessa revista de Maceió, de 1931, desconhecida da historiografia literária, e o gosto pela arte de Graciliano Ramos.

Na INTRODUÇÃO do trabalho, retomo o horizonte de meu mestrado sobre Caetés (1933), obra de estréia de Graciliano, e apresento a revista Novidade e alguns de meus pressupostos críticos.

No CAPÍTULO 1 - “CARTÃo DE VISITA” DA NOVIDADE: AS REALIDADES DA VIDA, analiso o "Cartão de visita", primeiro editorial da revista, de 11 de abril de 1931, escrito por Valdemar Cavalcanti. Esse artigo enfatiza que os jovens alagoanos necessitavam combater estereótipos e assumir uma postura crítica frente à realidade, sem passarem pela vida como turistas. O exemplo evocado era o francês Ernest Psichari, que se sacrificara na Primeira Guerra Mundial. Completando a leitura desse artigo-manifesto, detenho-me nos 
textos: "Vida, paixão e morte de Novidade", despedida do semanário (seis meses depois) pelas mãos de seus fundadores, Valdemar Cavalcanti e Alberto Passos Guimarães; e "Uma Revista", de Valdemar Cavalcanti, escrito 29 anos depois.

Existem na revista, além da própria sugestão do título, várias notas críticas sobre Sem novidades no front (In Westen Nichts Neues, 1929), de Erich Maria Remarque, e sobre o filme nele baseado. Então, no CAPÍTULO 2 - SEM NOVIDADE NO FRONT, debruço-me em uma cena do capítulo IX do romance, a partir da qual evoco os sentidos de "desmascaramento do heroísmo" (Otto Maria Carpeaux) e da "ética do rosto" (Emmanuel Lévinas), de grande valia também para a interpretação da Novidade e de seus escritores, em especial de Graciliano Ramos. E analiso alguns textos do semanário centrados no tema da guerra: a pequena crítica "All quiet...", de Jurandir Gomes, a breve ficção "T.G. 13" (Tiro de Guerra 13), de Willy Lewin, e o ensaio "A propósito de guerra", de Diégues Júnior.

No CAPÍTULO 3 - A TERRA DOS MENINOS IMPOSSÍVEIS, apresento elementos da formação dos jovens da Novidade: sua participação em grêmios literários e a promoção de eventos a um tempo modernistas, regionalistas e de empenho crítico e preocupação social, como a Festa da Arte Nova (1928), a Canjica Literária (1929), a Liga contra o Empréstimo de Livros (1932). Influenciados por José Lins do Rego e por Jorge de Lima, poeta d' "O mundo do menino impossível", os moços da Novidade foram chamados de meninos impossíveis. Analiso esse poema de Jorge e, recolhendo pareceres de vários escritores e críticos, acompanho, a partir de Carpeaux, o "encrencado" de falar-se em "modernismo nordestino". Em especial, apresento a resposta de Graciliano Ramos ao inquérito de Osório Nunes - "O modernismo morreu?” -, publicada em Dom Casmurro, em 1942. Dessas reflexões, resulta a perspectiva de que é necessário o movimento hermenêutico entre o contexto histórico e histórico-literário em que os escritores viveram e a singularidade de suas obras.

Reveladores do contexto histórico do semanário, no CAPÍTULO 4 - ITINERÁRIO POLÍTICO E CULTURAL analiso alguns editoriais da Novidade, escritos alternadamente a cada número por Valdemar Cavalcanti e por Alberto Passos Guimarães. Os chavões da Revolução de 1930, a violência do cangaço, o imperialismo e a arte comodista são alguns dos alvos dos editoriais, que desvelam problemas políticos, sociais e culturais da realidade de então e ainda atual, não apenas alagoana. 
Segundo o lema expresso na revista, "Novidade não é essencialmente literária nem essencialmente política". Então, no CAPÍTULO 5 - NOVIDADE POLÍTICA: O RESGATE DOS SEM-LUGAR, busco apreender a matéria histórica e a perspectiva crítica da revista, concentrando-me em artigos sobre questões da esfera política: personalismo, retórica, precariedade da educação e da cultura letrada em Alagoas, mendicância, miséria dos sertanejos retirantes, cangaço, santas milagreiras. Detenho-me na crônica de Graciliano "Milagres", como uma recolha desses problemas tratados no semanário - feita segundo o olhar crítico e a expressão singular do escritor. A partir de "Lampião", de 1931, analiso outras crônicas de Graciliano sobre o cangaço, escritas no Rio, após sua prisão, e também "Feira de cabeças" (1938), do menino impossível Aurélio Buarque de Holanda. Por fim, procuro compreender o sentido da Novidade, desse grupo de escritores que, reunidos nos anos 1930 em Maceió e depois no Rio de Janeiro, desempenharam importante papel na cultura do país.

Já o CAPÍTULO 6 - NOVIDADE LITERÁRIA: O RESGATE DE PESSOAS compõe-se de cinco ensaios, voltados para a expressão singular de alguns autores do periódico, que viveram a realidade dos anos 30 e deram forma artística a impasses sociais e existenciais. Traço-lhes o perfil com base em dados biográficos e num movimento analíticointerpretativo de sua criação literária. As crônicas e poemas de Willy Lewin revelam-no entusiasmado com as inovações modernas e, a um tempo, apegado ao lirismo da província, resistente à modernidade por conta da estandardização de opiniões e da mercantilização das relações pessoais. Santa Rosa Júnior é o menino impossível que escreveu poemas para a revista alagoana de 1931 e criaria as capas da José Olympio, sintetizando o espírito da literatura brasileira dos anos 30 e 40 . Hoje conhecido pelo trabalho fundamental de dicionarista, Aurélio Buarque de Holanda publicou poemas, dois na Novidade, e um livro de contos. Também apresento a produção literária e ensaística dos hoje desconhecidos Carlos Paurílio e Aloísio Branco.

No CAPÍTULO 7 - GRACILIANO RAMOS E A NOVIDADE, busco apreender a poética, essencialmente ética, do escritor. Contribuem para meu caminho analítico-interpretativo algumas reflexões de teoria e crítica sobre o romance, sobre o chamado romance de 30 brasileiro e, em especial, ensaios de Carpeaux, Lévinas e Schopenhauer. Detenho-me a princípio em Caetés (cujo capítulo 24 saiu primeiro na revista), observando a representação crítica da realidade, a resistência a estereótipos e a importância do Eclesiastes na obra. Estudo as crônicas "Chavões", "Sertanejos" (inéditas em livro) e 
"Lampião", articulando-as com os capítulos de Infância "Os astrônomos" e "Nuvens", e então redijo ensaios sobre S. Bernardo, Angústia e Vidas secas. Parto de momentos centrais desses romances, com destaque para imagens que concentram as simetrias e assimetrias do dramático defrontar-se com a morte do outro e com a própria vida: Paulo Honório cego ante as "linhas invisíveis" da carta de Madalena; a piedade de Luís da Silva diante dos "defuntos em pé" como Julião Tavares, ele próprio, milhares de "figurinhas insignificantes"; a "trempe" na cabeça de Fabiano, que ferve mas poupa o soldado amarelo e padece o frio de matar Baleia.

Assim, pretendo partilhar da Novidade dos meninos impossíveis e das criações de Graciliano, astrônomo do inferno, que, ante o lugar-comum de violência e o ambiente sócio-cultural limitado, representam o desejo e a possibilidade do diferente, da poesia, da ética do rosto.

Finalmente, as notas biobibliográficas de alguns colaboradores da Novidade, a bibliografia e os anexos (textos da revista alagoana de 1931; os artigos "Vida, paixão e morte de Novidade", de Valdemar Cavalcanti e Alberto Passos Guimarães, de outubro de 1931, e "Uma Revista", de Valdemar Cavalcanti, de 1960; e também a resposta de Graciliano Ramos ao inquérito de 1942, “O modernismo morreu?”). 


\section{INTRODUÇÃO}

\section{A partir de Caetés, o salto da precisão dramática das palavras.}

Em meu mestrado (Caetés: os incapazes de propriedade. Vencedores e vencidos na forma criada por Graciliano Ramos), dediquei-me ao estudo de Caetés (1933), romance de estréia de Graciliano Ramos, com vistas a compreender a formação da obra do escritor. Movia-me como problema investigar a composição do romance: ora foi alvo da rejeição de críticos (Álvaro Lins, Carlos Nelson Coutinho), como se marcado por pitoresco e pela desarticulação entre o conflito central do protagonista e os chamados "quadros de costumes", ora foi avaliado (especialmente por Antonio Candido), em seus defeitos e conquistas formais, como passo inicial para o amadurecimento do autor.

Apreendi a coerência e a força crítica de Caetés analisando a representação das relações sociais e a construção irônica com a imagem dos índios. Aparentemente pitorescos e desvinculados da ação central, os "quadros de costumes", no entanto, revelam a realidade de maroteiras, mentiras e usurpação em que tem lugar a trajetória arrivista do narrador-protagonista João Valério. Recorde-se, por exemplo, a significativa figura do bacharel Evaristo Barroca: foi mestre em falsidades e rasteiras para vencer como político. De modo paralelo, também Valério, descendente de aristocratas e guarda-livros protegido do patrão, traiu a confiança deste, ao tomar-lhe a esposa como amante: provocou-lhe o suicídio, até ocupar sua posição social.

Então, sobre tais figuras da classe dominante parasitárias recai a ironia de Graciliano Ramos, por meio da construção feita com a imagem dos índios. Ao fim de seu percurso vitorioso, João Valério abandona a idéia de escrever um romance histórico sobre os caetés, alegando ser inconveniente a literatura para um negociante, mas se afirma um caeté. Nessa auto-identificação do arrivista com os índios, sobretudo usando o argumento ideológico da preguiça e inconstância em comum, depreende-se a ironia criada pelo escritor, que combate estereótipos. Ao contrário dos caetés, cuja "preguiça" - resistência à escravização - significou a dizimação (foram vitoriosos tão-só no episódio de 1556 do bispo Sardinha), Valério é o vencedor, cuja preguiça se regozijou da usurpação do lugar do proprietário comercial. Canibal numa civilização assentada sobre barbárie, hábil em maroteiras disfarçadas ("um selvagem, ligeiramente polido, com uma tênue camada de 
verniz por fora" ${ }^{1}$ ), ele está muito distante das condições dos índios remanescentes, pobresdiabos "degenerados" e bêbados, miseráveis.

Percebi, pois, como a composição de Caetés, no plano da representação das relações sociais e no da configuração irônica por meio da imagem dos caetés, revela criticamente a lógica dos dominantes brasileiros - pautada em discursos falsamente democráticos e na exclusão de muitos, como os índios (veja-se a miséria dos remanescentes e o genocídio no passado), - e aponta sua origem na formação colonial escravista do país.

Portanto, a ambigüidade que constitui Caetés é advir do viés de um narrador de fisionomia social específica - o aristocrata decadente, guarda-livros arrivista, temeroso e protegido no círculo dos dominantes, que vence mediante safadezas e foge de dilemas -, o qual não tem motivos para escrever. Daí decorrem a coerência e a força do romance enquanto representação histórico-social e certa fragilidade por não expressar um conflito subjetivo. A constituição irônica de Caetés, recaindo sobre a ausência de drama do narrador-protagonista, garante o sentido crítico do romance e lhe dá um tom geral de frieza ("absoluta ausência de dós de peito", no dizer de Antonio Candido ${ }^{2}$ ). Valério afirma-se “incapaz de sofrer por muito tempo" (cap. 30), não sustenta conflitos por ter magoado Luísa ("ídolos que depois derrubo", cap. 31), nem por ter contribuído para a morte de Adrião ("Explosões súbitas de dor teatral, logo substituídas por indiferença completa...", cap. 31).

Numa depuração a partir de Caetés, a força artística dos romances posteriores de Graciliano deriva exatamente de que a representação crítica das relações sociais se constrói junto com a expressão de dramas subjetivos, éticos. Ao receber em 1942 um prêmio pelo conjunto de sua obra e uma homenagem, Graciliano a dedica aos protagonistas de $S$. Bernardo, Angústia e Vidas secas - que, "estacionando em degraus vários da sociedade, têm de comum o sofrimento" ${ }^{3}$ - e deixa de lado o de Caetés. Considerando Paulo Honório, Luís da Silva e Fabiano as "figuras responsáveis pelos seus livros", diz-se mero "aparelho registador" dos sofrimentos deles, para solidarizar-se com "todos os infelizes

\footnotetext{
${ }^{1}$ RAMOS, Graciliano. Caetés. (Introdução de Antonio Candido, "Ficção e confissão"). 5 a ed. Rio de Janeiro: José Olympio, 1955.

${ }^{2}$ CANDIDO, Antonio. Ficção e confissão. In: Ficção e confissão: ensaios sobre Graciliano Ramos. Rio de Janeiro: Ed. 34, 1992, pp. 13-70.

${ }^{3}$ Discurso de Graciliano Ramos. In: SCHMIDT, Augusto Frederico et alii. Homenagem a Graciliano Ramos. Rio de Janeiro: Alba, 1943, pp. 29-30.
} 
que povoam a terra". Assim, entende-se por que o escritor omite da homenagem o protagonista Valério, ele sim um "aparelho registador" para quem não há a necessidade nem condições de escrever um romance sobre si mesmo. Já para os protagonistas das obras posteriores de Graciliano, inclusive dos livros de memórias, o que impulsiona as narrativas é "a desgraça irremediável que os açoita", exigência ética da verdade de sua arte.

Desse modo, é justamente meu conhecimento sobre a composição de Caetés o primeiro fator que instiga meu projeto de compreender como, no amadurecimento formal de sua obra, Graciliano Ramos equacionou a força de representação realista e a construção irônica, já presentes no romance de estréia, a uma expressão subjetiva mais contundente de seus narradores - porque nascida de impasses e por eles limitada -, num tom nem de frieza, nem de derramamentos.

Gostaria de explicitar meus pressupostos críticos: aprendida de Alfredo Bosi, a compreensão da literatura como tripé das dimensões de construção, representação e expressão; com base em Theodor Adorno, a preocupação com a forma antidogmática na arte e na educação; depreendidos de Erich Auerbach e de Paul Ricoeur, o método estilístico e o empenho hermenêutico na análise e interpretação literárias. ${ }^{4}$

\section{Caetés e a Revista Novidade: o resgate dos esquecidos.}

Central em meu mestrado foi a análise do capítulo 24 de Caetés, que traz elementos fundamentais para se entenderem a construção do romance e a caracterização específica do narrador-protagonista. Guarda-livros, a um tempo dependia da proteção do patrão Adrião Teixeira e lhe prestava favores, como a maroteira de "encoivarar" partidas na firma comercial. Traindo-o com Luísa e almejando-lhe a posição social, Valério confessa que "seria uma felicidade" a morte do patrão, mas se mostra incapaz de descerrar criticamente a si mesmo as intenções e os limites da própria consciência e dos próprios sentimentos. Assim, esse arrivista representa um mecanismo historicamente configurado no grupo dos dominantes de que faz parte: bárbaro envernizado, além de "nunca ousar descobrir a si

\footnotetext{
${ }^{4}$ Cf. BOSI, Alfredo. Reflexões sobre a arte. $4^{\mathrm{a}}$ ed. São Paulo: Ática, 1991; ADORNO, Theodor W. Educação e emancipação. Tradução: Wolfgang Leo Mara. $2^{\mathrm{a}}$ ed. São Paulo: Paz e Terra, 2000 e O ensaio como forma. In: Notas de literatura I. Tradução e apresentação de Jorge M. B. de Almeida. São Paulo: Duas Cidades; Ed. 34, 2003; AUERBACH, Erich. Mímesis. A representação da realidade na literatura ocidental. $4^{\text {a }}$ ed. São Paulo: Perspectiva, 1998; RICOEUR, Paul. Interpretação e ideologias. Org., trad. e apresentação de Hilton Japiassu. $4^{\mathrm{a}}$ ed. Rio de Janeiro: Francisco Alves, 1990. Com novo título na reedição: Hermenêutica e ideologias. Tradução de Hilton Japiassu. Petrópolis, RJ: Vozes, 2008.
} 
mesmo o fundo do seu coração", suas idéias "flutuavam sempre", ao sabor dos interesses e sem uma base própria, apoiando-se na opinião alheia, admirando as frases brilhantes e filósofos desconhecidos. Em tal caracterização está o que há de pior no "homem cordial" estudado por Sérgio Buarque de Holanda: o "viver nos outros", a indistinção entre os domínios do público e do privado, a insuficiência para se elevar a produzir "qualquer moral social poderosa" 5 .

Também no capítulo 24, configurando o caráter flutuante de João Valério protagonista e narrador, está seu desinteresse por estudar história para terminar o romance sobre os caetés. Ele desmascara não só sua incapacidade para dedicar-se com esforço e com paciência à prática de ler e de refletir, mas também a inutilidade de ser instruído em seu ambiente. Como bom descendente de aristocratas, avesso ao trabalho braçal, Valério se projetava intelectual em busca de renome, porém não exercia um trabalho de fato com os livros. Não foi escritor de um romance histórico sobre os índios, nem propriamente de um romance sobre sua vida, entretanto realizou suas ambições econômicas aproveitando-se do alheio. Assim, Caetés manifesta um drama sentido por Graciliano: o impasse da educação num ambiente fundado em violência e em que se vence via safadezas.

Significativamente - constituindo o segundo fator a motivar este estudo - , o capítulo 24 de Caetés foi publicado a 06 de junho de 1931 (dois anos antes de sair o romance), no número 9 da revista Novidade, semanário de Maceió que permanece há 78 anos desconhecido da historiografia literária brasileira.

Por recomendação de Erwin Torralbo Gimenez, estudioso com quem partilho a predileção pela obra de Graciliano, li os artigos do Estado de S. Paulo, de 14 de outubro de 2001, "Grupo rejeitava literatura pitoresca", de Elias Thomé Saliba, Professor de História da Universidade de São Paulo, e “A invenção do País pelo regionalismo nordestino”, de Luiz Costa. Neles deparei com a existência dessa revista desconhecida, que me despertou grande interesse, por trazer a manifestação do grupo de escritores nordestinos ao qual Graciliano pertenceu (Jorge de Lima, José Lins do Rego, Aurélio Buarque de Holanda, Santa Rosa, Alberto Passos Guimarães, Valdemar Cavalcanti) e crônicas inéditas do

\footnotetext{
${ }^{5}$ HOLANDA, Sérgio Buarque de. O homem cordial. In: Raízes do Brasil. Prefácio de Antonio Candido. $4^{\mathrm{a}}$ ed. Brasília: Editora Universidade de Brasília, 1963.
} 
romancista. Antonio Candido já chamara a atenção para a necessidade de se estudar esse grupo de autores, cuja postura crítica de fato marcou a literatura dos anos $30^{6}$.

No entanto, meu entusiasmo logo esfriaria, pois a perspectiva de ver a revista Novidade se mostrava remota. Segundo indicava o jornal Estado de S. Paulo, esse material se encontrava nos arquivos do Instituto Histórico e Geográfico de Penedo, Alagoas. Pesquisando na internet, soube da existência da Casa do Penedo - e não Instituto Histórico. Após vários telefonemas no encalço da funcionária responsável pelo setor em que, confiava eu, se localizaria a revista, só experimentei decepção: ela nunca ouvira falar sobre a Novidade. Inconformada com a opção de desistir, que se afigurava a única, decidi-me a buscar informações no Instituto Histórico e Geográfico de Alagoas, Maceió. Concordo que havia uma feição de piada em perguntar, por telefone, à atendente do Instituto, se conhecia a Novidade, revista de Maceió de 1931. Embora eu insistisse, aludindo à participação de Graciliano Ramos e de Jorge de Lima na revista e enfatizando meu interesse em estudá-la, a resposta surgia imediata: nenhuma Novidade. Foi então que o acaso da escolha do nome de Luiz Nogueira dentre os vários que figuravam no site da Academia Alagoana de Letras veio perturbar minhas desilusões quanto às possibilidades de pesquisa e educação no Brasil.

Sócio do Instituto Histórico e Geográfico de Alagoas, o sr. Luiz Nogueira, em conversa telefônica, prontificou-se não só a verificar se o material integrava o acervo, como também a providenciar fotocópias e enviá-las para mim. Contudo, eu me decepcionaria ainda uma vez, e gravemente: ao entusiasmo de saber que sim, a Novidade existia e logo chegaria às minhas mãos, sucedeu o desalento com a notícia, por e-mail, de que a revista havia desaparecido quando foram fotocopiá-la. Mas não se tratava de sumiço e sim da apreensão de pesquisador do sr. Luiz Nogueira, temeroso de que o processo de cópia destruísse o original, esfacelado pelo tempo. Depois de semanas de impasse, o sr. Luiz, com a autorização do presidente do Instituto Histórico e mediante o meu pagamento, contratou uma firma especializada que microfilmou o material, gravou em CD e o enviou para mim, em junho de 2003.

Logo me surpreendeu constituir-se a revista Novidade de 24 números, cada qual com 16 páginas. Apesar de não ter durado sequer um ano (de 11 de abril a 26 de setembro

\footnotetext{
6 "Não sei se este conjunto de autores já foi estudado de maneira sistemática. Se não foi, deveria ser, porque representa um fato importante da sociabilidade literária, considerada como estímulo à produção e à formação de juízos críticos - o que significa que pode ter influído na própria natureza do discurso que se elaborava ou se projetava a partir de Maceió". (CANDIDO, Antonio. No aparecimento de Caetés. In: Ficção e confissão: ensaios sobre Graciliano Ramos. cit., p. 92).
} 
de 1931), o fato de ser semanal garantiu-lhe considerável quantidade de exemplares. Elias Thomé Saliba já sublinhava tal fato, levando em conta a efemeridade das revistas modernistas. Observe-se, por exemplo, que Klaxon, de São Paulo, a primeira revista modernista, de Mário de Andrade, Oswald de Andrade, Guilherme de Almeida, Sérgio Milliet, dentre outros, durou nove números (1922) e A Revista, de Belo Horizonte, de Carlos Drummond de Andrade, Emílio Moura, João Alphonsus, Pedro Nava, Abgar Renault, publicou três números (1925-1926).

Com satisfação, dediquei-me à leitura dos textos da Novidade e à preparação de um índice, o que me permitiu identificar, no corpus bastante variado da revista, uma estrutura e alguns temas recorrentes. Quanto à estrutura, compõe-se de: editorial, o chamado "artigo de fundo"; expediente e tópicos; uma seqüência de textos, podendo incluir artigos sobre política, contos, crônicas, ensaios de crítica literária ou teatral; a seção de poemas; fotografias; crítica e notas de cinema; notas da semana; sociedade ("moda", "registo de aniversários", "festas") e anúncios.

Quanto aos temas, a Novidade é reveladora dos problemas sociais nordestinos e brasileiros e da insatisfação que perduraram após a Revolução de 1930. Desnuda em suas várias faces uma realidade de miséria: a violência do cangaço, a indústria das santas milagreiras, o analfabetismo, a política personalista, a necessidade de reforma da Constituição.

Veja-se, então, o lema que desponta na revista, como a sintetizar os motivos por que conhecê-la: "Novidade não é essencialmente literária nem essencialmente política". Preenchendo uma lacuna da historiografia da literatura brasileira, o resgate da Novidade permite relativizar não só possíveis divisões bruscas entre "projeto estético" e "projeto ideológico" como também uma decorrência estrita do romance de 30 em relação ao modernismo de 22 ou ao regionalismo de Gilberto Freyre. O diálogo tecido aqui é com nossa melhor tradição crítica: Mário de Andrade ("O movimento modernista"), Antonio Candido ("Literatura e cultura de 1900 a 1945" e "A Revolução de 1930 e a cultura"), Alfredo Bosi ("Moderno e modernista na literatura brasileira" e "Situação de Macunaíma") e João Luiz Lafetá (Prefácio de 1930: a crítica e o modernismo) ${ }^{7}$. E são pressupostos dessa reflexão: a compreensão da arte como amálgama do estético com o social e a atenção

\footnotetext{
${ }^{7}$ Cf. ANDRADE, Mário de. Aspectos da literatura brasileira. São Paulo: Martins, s/d; CANDIDO, Antonio. Literatura e sociedade. Ensaios de teoria e história literária. São Paulo: Companhia Editora Nacional, 1965, e A educação pela noite \& outros ensaios. $2^{\mathrm{a}}$ ed. São Paulo: Ática, 1989; BOSI, Alfredo. Céu, inferno: ensaios de crítica literária e ideológica. São Paulo: Duas Cidades; Ed. 34, 2003; LAFETÁ, João Luiz. 1930: a crítica e o modernismo. São Paulo: Duas Cidades; Ed. 34, 2000.
} 
respeitosa ao caminho pessoal de formação dos escritores, em seu tempo e em seu ambiente de origem.

Nesse sentido, a atenção sobre a revista Novidade preenche também uma lacuna quanto ao conhecimento da obra de Graciliano Ramos. Possibilita entender melhor o momento em que ele escreveu e o modo como sua literatura sobressai em relação à geração nordestina. Se a Novidade se deseja como reação crítica ao lugar-comum da violência, aos estereótipos, à retórica dos bacharéis e políticos e expõe como problema o papel do intelectual num mundo de barbárie, os textos de Graciliano nela publicados, como a anunciar a obra posterior, são sua melhor expressão.

Leitora de Graciliano Ramos, é-me inevitável apreciar na Novidade a primeira edição do capítulo 24 de Caetés e das crônicas "Sertanejos", "Chavões" (inéditas para o público atual), "Lampião" e "Milagres" (publicadas respectivamente em Viventes das Alagoas e Linhas tortas). Esses textos, como se entrevê nos títulos, marcam-se pelo empenho de crítica à realidade histórica, próprio da geração da revista. Ao mesmo tempo, destacam-se pela expressividade do emprego de ironias e do estilo conciso, peculiares ao escritor, frutos da constante reelaboração lingüística. Julgo bastante significativo perceber como questões dessas crônicas de 1931 prenunciam os conflitos dos romances. Já em algumas expressões (“apanhar do governo não é desfeita" surge em "Lampião" e depois em Vidas secas) e, sobretudo, no vislumbrar de personagens para além de estereótipos (Paulo Honório, de S. Bernardo, insinua-se em "Sertanejos" e em "Lampião"), entrevê-se a configuração do impasse do intelectual num mundo em que parece vedada a possibilidade de mediações. Tal drama, delineado ante a realidade histórica apreendida nas crônicas de 1931 e em Caetés, formaliza-se em sua densidade nos romances subseqüentes e atinge depuração expressiva máxima, como verdade da formação pessoal do escritor, em Infância (1945).

Portanto, a órbita hermenêutica de meu trabalho é conhecer a Novidade (1931), singularidades e propósitos coletivos de seus colaboradores, e o caminho artístico de Graciliano Ramos, partindo do estudo de textos selecionados da revista, das crônicas do escritor nela publicadas e de capítulos de Infância. Esses textos trazem elementos da formação de sua consciência crítica e sensibilidade, os quais ele transfigurou nos romances. Para dar continuidade à minha dissertação de mestrado sobre Caetés, interessame, então, acompanhar como Graciliano atingiu a plenitude artística de S. Bernardo, Angústia, Vidas secas e de Infância, articulando as dimensões de construção estética, representação social e expressão subjetiva. Ao mesmo tempo, conhecer a revista Novidade 
possibilita-me entender como o romancista deu forma literária particular ao desejo de renovação política, social e cultural que partilhava com seus companheiros de geração intelectual, sobretudo os jovens, em Maceió nos anos 30.

Assim, esse estudo justifica-se por uma necessidade a um tempo pessoal - atender ao gosto pelo escritor dando seqüência ao trabalho do mestrado - e coletiva - não só desvelar e compartilhar as motivações desse gosto, como também compreender a singularidade de Graciliano e seu vínculo com o grupo da Novidade, o que procura preencher lacunas da fortuna crítica. 


\section{CAPÍTULO 1 - “CARTÃO DE VISITA” DA NOVIDADE: AS REALIDADES DA VIDA}

$O$ defeito mais grave com que nos defrontamos atualmente consiste em que os homens não são mais aptos à experiência, mas interpõem entre si mesmos e aquilo a ser experimentado aquela camada estereotipada a que é preciso se opor.

Theodor W. Adorno. ${ }^{8}$

\section{Nem romantismo, nem ceticismo, nem esteticismo}

No "Cartão de visita" da Novidade, de 11 de abril de 1931, Valdemar Cavalcanti, seu fundador e diretor ao lado de Alberto Passos Guimarães, apresenta ao leitor uma geração que precisa vencer a passividade generalizada, o "platonismo" da geração anterior, para, então, revelar sua força: a perspectiva crítica ante a realidade, a expressão de seus desejos e a autonomia de suas idéias.

Considerando-se o título da revista, todo esse primeiro editorial se marca pela oposição ao lugar-comum a que estavam presos os jovens intelectuais alagoanos - em nome da criação de alguma novidade. Se a situação dos intelectuais é caracterizada por palavras como dispersão, abafamento, silêncio, comodismo, a criação do novo surge como necessidade, carência e demanda esforço. Ou seja, parece não faltar a Valdemar Cavalcanti, ao apresentar a Novidade, a consciência do caráter problemático de sua proposta. O novo, a mudança do status quo, requer uma busca permanente e o enfrentamento do estabelecido, em que todos, bem ou mal, estão enquadrados.

O crítico insinua um vínculo entre a atitude desencantada de sua geração e um estereótipo de preguiça e incapacidade do brasileiro, fincado num "tradicional comodismo" e no "romantismo molengo da herança étnica". Esse estereótipo da herança romântica brasileira - creio que generalizado a partir do Retrato do Brasil (1928), de Paulo Prado carrega tensões, à medida que serve de pretexto para a continuidade do estado de coisas. Aparece em outros textos da Novidade, voltados para desmascarar os problemas do país. Note-se que Valdemar Cavalcanti a um tempo assume o estereótipo e o usa como

\footnotetext{
${ }^{8}$ ADORNO, Theodor W. Educação - para quê? In: Educação e emancipação. Tradução de Wolfgang Leo Mara. $2^{a}$ ed. São Paulo: Paz e Terra, 2000, pp. 148-9.
} 
argumento para contestá-lo. Faz do "Cartão de visita" um manifesto, em que enfatiza a necessidade de a geração combater o tal comodismo, para adotar uma postura crítica frente à realidade:

Sobre essa geração de hoje - uma geração de vinte-anos desencantados - sobre a nova geração intelectual de Alagoas recai a responsabilidade de cometer loucuras. De afirmar-se, de ter convicções. É preciso abafar o platonismo com que poderíamos ficar tecendo sonhos corde-rosa, em detrimento das realidades da vida. Se é grande a ânsia de novos ideais, maior deve ser o esforço por sua conquista. (...) Porém com esse tradicional comodismo de atitudes e esse romantismo molengo da herança étnica, é que não podemos entrar em luta pelos ideais. ${ }^{9}$

Além do romantismo em sentido amplo e literário (a crença nos "milagres estilísticos de Alencar e Chateaubriand"), são alvos da recusa de Valdemar Cavalcanti a ironia anatoliana, o "perigoso" ceticismo renaniano e a "sacrossanta literatura" $10 \mathrm{de}$ Flaubert. Esses elementos eram próprios da geração anterior, nascida entre 1890 e o início do século XX.

Alceu Amoroso Lima ${ }^{11}$ confessa que recebeu poderosa influência de Anatole France, no estilo e nas idéias: aprendeu com o escritor francês o humanismo clássico, a vocação socialista, o ceticismo, o diletantismo e a ironia. Porém, a tragédia da guerra de 1914 o despertou a não mais ignorar a realidade. Sua geração precisava abandonar "a fase da disponibilidade", o absenteísmo e o intelectualismo puro, em busca de um sentido de dignidade para a vida. Daí negarem Anatole France e seu diletantismo.

É interessante recordar A lição do amigo, em especial a carta de 1924 em que Mário de Andrade aconselha Drummond a desapegar-se do que aprendeu de Anatole France. Mário condena vários traços anatolianos: o "não ser exigente com a vida", o "literato puro", a "dúvida passiva", o "pessimismo diletante", o sentimento de vergonha em relação às "atitudes francas, práticas, vitais" 12 .

\footnotetext{
${ }^{9}$ CAVALCANTI, Valdemar. Cartão de visita. Novidade 1, 11 abr. 1931, p. 1.

${ }^{10}$ A expressão "sacrossanta literatura" aparece numa carta de Flaubert a George Sand, de Paris, entre 20 e 28 de fevereiro de 1872: "L'action, quelle qu'elle soit, me dégoûte de l'existence. J'ai mis à profit vos conseils, je me suis distrait. Mais ça m'amuse médiocrement. Décidément, il n'y a que la sacro-sainte littérature qui m'intéresse". ("A ação, qualquer que seja, desgosta-me a existência. Aproveitei seus conselhos e me distraí. Mas me alegrei pouco. Decididamente, só a sacrossanta literatura me interessa"). FLAUBERT, Gustave. Correspondance. Sixième Série (1869-1872). Paris: Louis Conard, 1930, p. 353.

${ }^{11}$ LIMA, Alceu Amoroso. As influências literárias. In: Memórias improvisadas - diálogos com Cláudio Medeiros de Lima; prefácio de Antônio Houaiss. Petrópolis: Vozes, 1973.

${ }^{12}$ ANDRADE, Mário de. A lição do amigo. Cartas de Mário de Andrade a Carlos Drummond de Andrade; notas e apresentação de Carlos Drummond de Andrade. $2^{\mathrm{a}}$ ed. Rio de Janeiro: Record, 1988, p. 28.
} 
Carlos Drummond de Andrade expusera em cartas a Mário, em fins de 1924, suas tensões entre o anatolismo ("velho vício dos brasileiros, e meu também"), o apego à cultura francesa, o descrédito em relação à realidade brasileira e a preocupação com ela. ("O Brasil não tem atmosfera mental; não tem literatura; não tem arte; tem apenas uns políticos muito vagabundos e razoavelmente imbecis ou velhacos. Entretanto, como não sou melhor nem pior do que os meus semelhantes, eu me interesso pelo Brasil” ${ }^{13}$ ). Então, em julho de 1925, no primeiro editorial de A Revista, de Belo Horizonte - "Para os céticos" -, o programa proposto por Drummond sintetiza-se em "ação intensiva" nos campos da literatura, da arte e da política: "vibração, luta, esforço construtor, vida" ante o imperativo da renovação intelectual do Brasil ${ }^{14}$.

A inquietação com os problemas sociais e com a necessidade de seriedade para minorá-los marcou também intelectuais da Novidade, junto com a rejeição do nacionalismo ufanista (Valdemar Cavalcanti deplorava a retórica de frase feita do Hino Nacional e o "porque-me-ufano"; Graciliano Ramos ironizou em crônicas os hinos de "amor febril pelo Brasil" e a oratória patrioteira de Julião Tavares, em Angústia; diretor da Instrução pública, eliminou das escolas o Hino Nacional).

Ou seja, houve um esforço de relativizar o apego excessivo ao ceticismo diletante de Anatole France, que era muito considerado no Brasil e depois foi desvalorizado ${ }^{15}$. Mas escritores como Drummond e Graciliano se marcaram sempre pela ironia descrente, em tensão com o desejo de participar da vida. Observe-se também, conforme revela Carpeaux, que o escritor francês foi paradoxal: esteticista e cético, quis fugir da injustiça social por

${ }^{13}$ Cf. ANDRADE, Mário de; ANDRADE, Carlos Drummond de. Carlos \& Mário: correspondência completa entre Carlos Drummond de Andrade (inédita) e Mário de Andrade. Prefácio e notas de Silviano Santiago; organização e pesquisa iconográfica de Lélia Coelho Frota. Rio de Janeiro: Bem-Te-Vi, 2003. Carta I, Belo Horizonte, 28 out. 1924, p. 40; Carta III, Belo Horizonte, 22 nov. 1924, pp. 56-7.

${ }^{14}$ ANDRADE, Carlos Drummond de. Para os céticos. In: A Revista. Belo Horizonte, ${ }^{\circ}{ }^{1}$, julho de 1925. Apud TELLES, Gilberto Mendonça. Vanguarda européia e modernismo brasileiro: apresentação dos principais poemas, manifestos, prefácios e conferências vanguardistas, de 1857 a 1972. 13ª ed. Petrópolis: Vozes, 1997, pp. 336-8.

${ }^{15}$ Recordando a devoção dedicada ao soberano Anatole France havia alguns anos, Valdemar Cavalcanti comenta em 1960 que então um escritor quase pediu desculpas para citar no jornal uma frase do francês. Define-o como o "sorriso sibilino" de uma época em que, mesmo quando homens e acontecimentos tinham "substância de drama", era possível sorrir assim. Por isso, não admira Valdemar que grande parte da obra de Anatole já não tivesse repercussão. No entanto, chama a atenção para o caprichado de sua escrita e para uma face do septuagenário Anatole: ao fim de uma vida dedicada à descrença, na velhice passou a crer - "na possibilidade de um aperfeiçoamento dos processos de convivência humana num mundo em transformação". CAVALCANTI, Valdemar. Anatole. In: Jornal literário. Rio de Janeiro: José Olympio, 1960, pp. 155-7. 
meio de recursos livrescos e se tornou enfim comunista; e o próprio ceticismo é utópico num século dedicado a dogmas ${ }^{16}$.

Assim, de forma semelhante a Alceu Amoroso Lima e a Mário de Andrade, Valdemar Cavalcanti aponta que os moços precisavam não só "olhar a vida, mas viver a vida. Principalmente viver a vida". Critica negativamente o seu "pudor de ter vinte-anos", o "assassino silêncio de caverna" que sugava as "energias dispersas mas capazes" dos jovens. Descarta que cumpririam seu destino apenas "se rebolando de deleites intelectuais por essa coisa atraente a que Flaubert chamava de "sacrossanta literatura"'. Em sua preocupação literária e política, a prioridade da revista era experienciar "as realidades da vida", com independência e sem retórica. Nem formalistas, nem proselitistas, vários escritores desse grupo viveram um conflito entre a "exigência com a vida" (mediada pela palavra escrita) e a inadaptação à vida prática.

Então, o fundador da Novidade conclama os companheiros de geração, de vinte anos, a não abafarem seus "gritos de idealismo". Significativamente, inclui entre esses moços "muitos trinta-anos independentes, gente a quem os horizontes novos fizeram exilar-se de sua própria geração": certamente aqui se refere a Graciliano Ramos e a Jorge de Lima, que contavam então com trinta e oito anos. Assim, Cavalcanti delineia a Novidade como porta-voz dos "esforços dispersivos" de jovens de talento e espírito crítico.

\section{Não uma "geração de turistas": o exemplo de Psichari}

Com senso de equilíbrio, Valdemar Cavalcanti logo relativiza ser o destino de sua geração tão-só vencer os erros da anterior, o romantismo e o ceticismo. Revelando compreensão histórica, aponta como programa da geração ponderar sobre os erros e também sobre as virtudes dos antepassados. Relembra de Nabuco o valor dos "exemplos do passado", as "marcas de passos" deixadas pelos pais aos filhos.

(...) como no programa de Psichari, apurar os defeitos e as virtudes de nossos pais, buscando nos exemplos do passado aquelas como que marcas de passos que Nabuco dizia ser dever dos bons pais deixarem pela

\footnotetext{
${ }^{16}$ CARPEAUX, Otto Maria. O utopista Anatole. (Respostas e perguntas, 1953). In: Ensaios reunidos 19421978. v. I. Organização, introdução e notas de Olavo de Carvalho. Rio de Janeiro: UniverCidade \& Topbooks, 1999, pp. 507-9.
} 
vida para orientar os filhos. E - aproveitando a imagem admirável dum ensaísta brasileiro - juntar, pedaço a pedaço, os restos do crucifixo quebrado pelo avô Renan.

Em sua argumentação, além de Nabuco, cita Psichari, um "ensaísta brasileiro" e o "avô Renan". Para bem compreender essas referências do "Cartão de visita" da Novidade, faz-se necessária a leitura de Apologia pro generatione sua, palestra de Gilberto Freyre realizada na Paraíba a 5 de abril de $1924^{17}$. É ele o ensaísta brasileiro a que alude Valdemar Cavalcanti. Nessa Apologia, Freyre apresenta à sua geração de desencantados do pós-guerra o exemplo dos adolescentes de 1914 - os franceses Ernest Psichari, neto de Ernest Renan, Charles Péguy, Jacques Maritain, o italiano Giovanni Papini, o americano Randolph Bourne -, que "não passaram pela vida como turistas".

Evocando os "cemitérios de guerra", Gilberto Freyre partilha sua sensibilidade em relação ao espírito desses intelectuais que morreram na Primeira Guerra: identifica-se como compatriota, passageiro do mesmo barco dessa geração que não era de turistas. Dedica atenção, em primeiro lugar, a Randolph Bourne (1886-1918), apreciando seu nacionalismo crítico, que pedia um "esforço criador" na cultura americana.

Em seguida, Freyre se centra em Ernest Psichari (1883-1914), cujo "patriotismo de geração" se fez por meio da "volúpia do sacrifício". Otto Maria Carpeaux aproxima Psichari dos 'spiriti della vigilia' ("espíritos da véspera") italianos, entre os quais inclui franceses como Péguy: "pessimistas angustiados", tais escritores ainda antes da guerra pressentiram um apocalipse. Carpeaux sintetiza a trajetória de Psichari:

(...) neto de Renan, convertendo-se ao catolicismo; oficial do exército colonial, celebrando o sacrifício que é essência do serviço militar; define-se como discípulo de Péguy ou como irmão espiritual de Sorge; morreu em batalha, na Bélgica, no primeiro mês da guerra. ${ }^{18}$

\footnotetext{
${ }^{17}$ Cf. FREYRE, Gilberto. Apologia pro generatione sua. In: Região e tradição. Prefácio de José Lins do Rego. Rio de Janeiro: José Olympio, 1941. O ensaio figurou também em Portugália - Revista de cultura, tradição e renovação nacional. N. ${ }^{\circ}$ 2: novembro de 1925, Lisboa. Diretor: Fidelino de Figueiredo. Cf. site da Biblioteca Nacional Digital de Portugal - http://bnd.bn.pt, em que vem a síntese: "Conferência de exaltação das virtualidades da geração nascida da Grande Guerra e que encerra um apelo à sua responsabilidade social e cultural". Edson Nery da Fonseca indica que o título da conferência foi inspirado na autobiografia do Cardeal John Henry Newman, Apologia pro vita sua. Cf. a Biblioteca Virtual Gilberto Freyre, http://bvgf.fgf.org.br/.

Significativamente, na "Abertura" de Testamento de uma geração, inquérito promovido com 26 intelectuais brasileiros nos anos 40, quando da Segunda Guerra Mundial, Edgard Cavalheiro evoca a Apologia pro generatione sua. (CAVALHEIRO, Edgard. Testamento de uma geração. Porto Alegre: Livraria do Globo, 1944).

${ }^{18}$ CARPEAUX, Otto Maria. Realismo mágico dos italianos; Péguy. In: As revoltas modernistas na literatura. Rio de Janeiro: Edições de Ouro, 1968, p. 137.
} 
Deixando de lado os caminhos da dúvida e do ceticismo, plantados pelo avô Renan, Psichari escolheu a rota da ordem e da fé: fez-se soldado e católico, para desenvolver suas possibilidades físicas, intelectuais, morais e espirituais. No silêncio do deserto africano, intensificadas sua inteligência e introspecção com vistas ao problema religioso, iniciou-se sua conversão ao catolicismo. Em sua ânsia de perfeição, o sacrifício era a forma de se aproximar de Cristo. Segundo conclui Jean Peyrade ${ }^{19}$, a "grandeza" de Psichari decorreu dessa escolha pelo exército e pela Igreja, em busca do essencial e do absoluto por meio da imitação de Cristo. Escreveu os romances: Terres de soleil et de sommeil (1908), L'appel des armes (1912), Le voyage du Centurion (1916, póstumo), Les voix qui crient dans le desert. Souvenirs d'Afrique (1920, póstumo).

Assim, conhecendo-se a trajetória singular desse escritor francês, entende-se por que Gilberto Freyre o resgatou. Se o paradoxo da geração de Psichari foi reagir contra os pais neófitos, ele se voltou contra duas gerações: reagiu também contra o avô.

Dir-se-ia que o caso de Psichari voltando à ordem, à tradição, à continuidade histórica foi todo um drama íntimo; que $o$ avô Renan quebrara um dia em mil e um pedaços o crucifixo da família; e veio o neto $e$ o recompôs. Tão simples, tudo - mas Deus sabe quanto custou à juventude de Ernesto Psichari reunir um a um os fragmentos. (Gilberto Freyre, Apologia pro generatione sua).

Note-se aqui a imagem do crucifixo recomposto, a qual Valdemar Cavalcanti resgatou de Gilberto Freyre: contrariamente a Renan, que trouxe a dúvida e o abalo da fé católica, seu neto Psichari lutou pela religião de Cristo, por juntar "os restos do crucifixo quebrado pelo avô Renan”. Após tortura interior, aliando fé grega e fé católica, Psichari buscou um senso de ordem e perfeição espiritual como soldado francês e filho da Santa Igreja. E cumpriu seu ideal de sacrifício indo à guerra, em que morreu.

Ao final da Apologia, Gilberto Freyre explicita sua intencionalidade em relação à realidade brasileira. O cerne de sua argumentação é que o neto "Ernesto" retificou o "Ernesto" avô: a inteligência e introspecção de Ernest Psichari lhe permitiram recobrar a ordem de que o avô Ernest Renan saíra pela "orgia da mesma inteligência". Analogamente, conforme Freyre, cumpria à mocidade brasileira um "programa de retificação", para reintegrar-se ao "Brasil brasileiro" dos avós. Temendo o artificialismo dos valores da civilização (a referência é o "vasto 202 de Jacinto", de Eça de Queiroz), defende que “o

\footnotetext{
${ }^{19}$ PEYRADE, Jean. Psichari, maître de grandeur. Paris: Julliard, 1948.
} 
ideal de cultura e de vida brasileira" exceda o conforto material, "dos fogões a gás, dos water closets de porcelana, da luz elétrica".

Freyre destaca nomes da nova geração brasileira (Agrippino Grieco, Oliveira Vianna, Jackson de Figueiredo, Gilberto Amado, Ronald de Carvalho, Renato Almeida, Tristão de Athayde, Andrade Muricy), desejando que o espírito crítico deles se dedicasse ao "grande esforço de introspecção nacional". Inspirado no idealismo de Psichari ("tout se joue sur nos têtes") e em seu sacrifício efetivo na guerra, Gilberto Freyre cobra dos contemporâneos a consciência quanto aos destinos em comum, enfatizando ser impossível passar impune à época de 1914-1920. Espera dos brasileiros o "esforço criador" e a responsabilidade de "pensar e de agir acima da mediocridade".

Desse modo, sobressai da Apologia pro generatione sua o desejo de se formar um olhar voltado para a vida e a cultura brasileira, recusando as falsidades do progresso técnico. Já se entrevê aí o sentido do regionalismo de Gilberto Freyre. A ênfase sobre a figura idealista do soldado francês mira sobretudo um empenho sobre a tradição e a região brasileiras, com algo de catolicismo.

José Lins do Rego, em “Gilberto Freyre” (1941), recorda-se da força das palavras com que o amigo, qual numa elegia, discorreu sobre os intelectuais mortos pela guerra.

Lembro-me de seus artigos sobre Psichari, o outro Ernesto, como ele chamava no Natal de 1924. (...) A conferência da Paraíba falava de uma geração que se consumira na guerra. Ernest Psichari, Rupert Brooke, Otto Braun eram criaturas tocadas da graça, gênios mutilados pela desgraça de um tempo de matança. Essa conferência tem qualquer coisa de litania, é como um canto pelos que deram o coração e a inteligência em holocausto pela sua geração, pelos que se entregaram à morte para viverem mais intensamente. Era um Gilberto Freyre que aparecia ali apaixonado pela Igreja Católica, mas de longe, seduzido pela ordem, pela liturgia, pelo esplendor de Deus, sem que se completasse na fé. Ele mesmo me dizia mais tarde. Ficara sempre de fora rondando a porta da Igreja, no sereno, sem a disposição de meter-se na festa. ${ }^{20}$

Como se vê, havia então um apego de Freyre pelo catolicismo, mas longínquo. Também em José Lins se combinavam senso crítico do real e tendência religiosa. Na "Carta de uma geração aos srs. Gilberto Freyre e Jackson de Figueiredo", espécie de resposta à Apologia, lamenta que faltara à sua geração o temor de Deus e que houvesse generalizada falta de espírito, privilegiado o progresso material. Ressente-se, por exemplo,

\footnotetext{
${ }^{20}$ REGO, José Lins do. Gilberto Freyre. In: Dias idos e vividos. Seleção, organização e estudos críticos de Ivan Junqueira. Rio de Janeiro: Nova Fronteira, 1981, pp. 255-6 (Também como "Notas sobre Gilberto Freyre", prefácio a FREYRE, Gilberto. Região e tradição. cit.).
} 
da má formação do exército brasileiro, que carecia de um exemplo como Psichari, de vida interior ${ }^{21}$. Em artigo da Novidade, José Lins discute questões sociais concluindo com a frase do título, "O Brasil precisa de catolicismo".

Com brechas para contradições, a revista acolhia pensamentos diversos. À primeira vista, parece paradoxal que a Novidade abra com a recusa ao platonismo e, a um tempo, com a menção a um escritor devotado à reintegração religiosa. Contudo, cumpre perceber que Psichari, ao contrário de Renan com seu "perigoso" ceticismo, simboliza o intelectual que se sacrifica pelos seus ideais. A evocação de seu nome norteia a responsabilidade de participação na vida, assumida pela geração da Novidade. Como na Apologia de Gilberto Freyre, o exemplo do intelectual morto na guerra vale como alerta para não se passar pela vida como turista.

$\mathrm{Na}$ conclusão do "Cartão de visita", fica sugerida a importância da Novidade: impedir que jovens intelectuais de valor se dispersassem, desencorajados ante as hostilidades do ambiente. Em sua angustiada busca de ordem, sem deixarem de ouvir os mais velhos, teriam na revista um meio fundamental - para expressarem suas idéias.

Assim, Novidade vem preencher uma lacuna em a ... etc. etc. Por aqui é que ia começar o artigo de fundo.

Atente-se para um significado concentrado nessas frases finais de Valdemar Cavalcanti, confirmação de seu estilo a um tempo coloquial e correto, equilibrado. Primeiramente, ele assume, em tom bem-humorado, o chavão: "Assim, Novidade vem preencher uma lacuna em a ... etc. etc." ${ }^{22}$. Depois, confessa haver tomado um rumo diferente desse no editorial: "Por aqui é que ia começar o artigo de fundo". Dessa forma, Valdemar Cavalcanti insinua ter-se deixado levar à vontade pelas idéias, seguindo a sua

\footnotetext{
${ }^{21}$ Devo a obtenção dessa Carta (publicada em Era Nova, 1924) a César Braga-Pinto, que depois a incluiu em Ligeiros traços. Estudioso da formação da obra de José Lins do Rego, César revela que a "conversão" do escritor ao Catolicismo foi marcante até meados dos anos 1930, fator a aproximá-lo do regionalismo tradicionalista de Gilberto Freyre e da literatura de Jorge de Lima. Cf. BRAGA-PINTO, César. José Lins do Rego, o panfletário e o católico. Introdução a REGO, José Lins. Ligeiros traços. Escritos da juventude. Rio de Janeiro: José Olympio, 2007.

Embora aqui pensados num horizonte idealmente harmônico, esses sentidos militar e religioso, ao se radicalizarem conforme a divisão ideológica intensificada nos anos 30, redundaram em fascismo. Antonio Candido observa que alguns jovens intelectuais, por uma "inquietação honesta", se deixaram levar pelo integralismo e depois recuaram ante seu aspecto fascista. Cf. CANDIDO, Antonio. Integralismo = Fascismo? In: Teresina etc. Rio de Janeiro: Paz e Terra, 1980, p. 122.

22 "Suprindo uma lacuna era a chamada de apresentação recorrente nas revistas paulistas da virada do século, mas, não só". Além dessa fórmula, com a qual Valdemar Cavalcanti brincou, a pesquisadora Ana Luiza Martins menciona: o cavaco preliminar (usado em publicações jocosas), o duas palavras (de revistas dinâmicas), o compenetrado a que se deve (de publicações solenes). MARTINS, Ana Luiza. Revistas em revista. São Paulo: EDUSP / FAPESP / Imprensa Oficial, 2001, p. 16.
} 
percepção pessoal e perspectiva crítica, buscando fugir de fórmulas estereotipadas. E é justamente esse o sentido almejado pela revista Novidade.

\section{Nada de heróis no front}

Conhecendo ou não todos os escritores aludidos no "Cartão de visita", certamente os leitores de hoje da Novidade, como os de 1931, apreendem sua proposta: apresentar criações próprias e opiniões críticas ante a realidade. Mas é curiosa a omissão do nome de Gilberto Freyre, talvez facilmente preenchida pelo contexto da época. Mais do que essa omissão, interessa-me a não explicitação, no "Cartão de visita", dos nomes de colaboradores e das diretrizes concretas da revista. Parece-me decorrer do desejo de não fixar os limites da Novidade: ela se constituiria exatamente como porta-voz de seus vários escritores. Ressalte-se, entretanto, que o fato de não restringir horizontes não significa ausência de princípios. Como revelaram as negativas de Valdemar Cavalcanti, o interesse da revista era voltar-se para a realidade e seus conflitos e dar voz ao caráter pessoal, original, da expressão, fosse literária ou política.

Relevante omissão do "Cartão de visita" - não comentar o título da revista - é preenchida quando se considera um dos seus temas: num impasse fecundo, Novidade parece responder a Sem novidades no front ${ }^{23}$, romance de Erich Maria Remarque e filme nele baseado. O livro, de 1929, e o filme, vencedor de Oscar em 1930 e veiculado nos cinemas de Maceió em 1931, - ambos de enorme êxito - são matéria recorrente da revista alagoana. Tendo conhecido de perto o horror da guerra, Remarque expressou com contundência o sem-sentido de jovens matarem-se em nome do poder de suas pátrias. Sem novidades no front desnuda a guerra como perda total da experiência e parece perguntar, provocando comoção intensa, como sobreviver ao lugar-comum da destruição e da morte.

Mais do que Psichari, morto na Primeira Guerra, Remarque, que também participou dela, afigura-se forte influência para os intelectuais da revista nordestina. De um lado, a imagem do primeiro, o intelectual idealista e ativo, - embora útil como exemplo contra o comodismo dos jovens alagoanos - guarda um sentido de herói. Diversamente, a contribuição do segundo, que encontra muitos ecos na Novidade, concentra-se no

\footnotetext{
${ }^{23}$ Cf. REMARQUE, Erich Maria. Sem novidades no front - O regresso (Dois romances). Tradução de José Geraldo Vieira. Rio de Janeiro: José Olympio, 1951 (Coleção Fogos Cruzados); REMARQUE, Erich Maria. Nada de novo no front. Tradução de Helen Rumjaneck. Porto Alegre: L\&PM, 2004. E também o filme: Sem novidade no front (All quiet on the western front), direção de Lewis Milestone.
} 
"desmascaramento do heroísmo" ${ }^{24}$, para usar a expressão certeira de Carpeaux. Como analisarei mais detidamente adiante, Remarque empreendeu a difícil tarefa de desvelar a barbárie generalizada, a mistificação da realidade, - de forma a apontar um necessário sentido de ética. O empenho de desmistificar o real e de olhar para os semelhantes, determinante em Sem novidades no front, também é exigência ética dos intelectuais da revista alagoana. Assim, a Novidade, acompanhando o sentimento do pós-1 ${ }^{\text {a }}$ guerra, insinua-se como desejo de renovação ante o lugar-comum da violência e das injustiças, sobretudo em termos da realidade brasileira.

Ao mesmo tempo, perguntar pelo novo guarda um sentido do Eclesiastes, livro da Bíblia de grande importância para a literatura, mencionado por Graciliano Ramos desde Caetés e por Jurandir Gomes na revista: "Nada de novo... Nem na frente ocidental, nem sob o sol. / Salomão e Remarque têm razão. (...)" (“All quiet...”, Jurandir Gomes, N 18 , p. 12). Com suas contradições, o inconformismo crítico e a consciência realista são buscas dos escritores da Novidade.

\section{"Vida, paixão e morte de Novidade": retrospectiva de uma Revista}

A 6 de outubro de 1931, seis meses após a Novidade aparecer, Valdemar Cavalcanti e Alberto Passos Guimarães publicam no Jornal de Alagoas sua despedida: "Vida, paixão e morte de Novidade" ${ }^{26}$. Do teor auto-irônico desse título, apreende-se uma tensão entre a sinceridade do idealismo heróico de seus jovens criadores e a consciência quanto à hostilidade do ambiente, - confluindo, num misto de bom-humor e melancolia, para a recusa de heroísmos mistificadores, que fôra uma das marcas da revista.

Valdemar Cavalcanti e Passos Guimarães desenvolvem uma construção metafórica irônica, dizendo-se "pais e médicos" da Novidade, para criticar a ausência de condições favoráveis aos intelectuais no país e a falta de caráter na imprensa e na política.

\footnotetext{
${ }^{24}$ CARPEAUX, Otto Maria. Guerra e literatura O Jornal, 19 dez. 1948. In: Ensaios reunidos 1946-1971. v. II. Prefácio de Ivan Junqueira. Rio de Janeiro: UniverCidade \& Topbooks, 2005, p. 399.

${ }^{25}$ Nas citações da Novidade ao longo da tese indicarei N.

${ }^{26}$ CAVALCANTI, Valdemar; GUIMARÃES, Alberto Passos. Vida, paixão e morte de Novidade. Jornal de Alagoas, 6 out. 1931, p. 1. Devo a obtenção desse artigo a Mauricio Zuluaga Martinez, que esteve em Maceió em junho de 2006. Depois adquiri o Documentário do modernismo (pesquisa e seleção de Moacir Medeiros de Sant'ana. Maceió: UFAL, 1978), que traz também o artigo.
} 
A princípio, não admitem que lhe estão passando o atestado de óbito, antes uma prescrição de repouso: ela precisava fortalecer-se com novos ares e se exilar da "palidez intelectual hereditária". Então, passam a expor a singularidade da revista a que vitalmente se dedicaram, personificada com todo o afeto como "filha do nosso melhor esforço". Confessando alegria e "consciência perfeita", os autores recordam as virtudes de coerência e retidão que marcaram a vida da Novidade, por oposição ao mal da época, a dupla personalidade, que variava segundo a cotação de interesses particulares.

Novidade atravessou a sua vida agitada com uma personalidade única, com uma única feição interior.

Assim, contrariando as "virtudes de plasticidade" dos políticos brasileiros - sua adaptação fácil a interesses particulares, "caso clínico endêmico" no país -, a revista sobreviveu com integridade, com personalidade única. Apresentou prosa, poesia, crítica de literatura e de cinema e artigos sobre temas sociais e políticos, desmascarando problemas que afligiam o Brasil e o mundo.

Após denunciarem que a situação desfavorável de grande parte da imprensa brasileira levava esta a uma "desgraçada falta de personalidade e de caráter", os escritores da revista realçam sua consciência de que um jornal com caráter representava "anomalia". Daí, a curta existência da Novidade, de seis meses, e conseqüente morte. Inferem-se alguns fatores, interligados, do seu desaparecimento: a hostilidade do meio social às letras, a falta de dinheiro (apesar dos vários anúncios nela publicados, que merecem análise) e a censura instituída pelo governo federal (apontada em "É e não é ....", nas Notas da Semana da N 17, p. 4). Na Novidade 13, com uma alusão ao poder fatídico atribuído a esse número pela superstição, uma nota ironizava a "desatenção do meio" e os agoureiros: comemoravam-se os três meses do semanário, e reforçava-se a consciência quanto aos impasses a resistir.

Confirmando os ideais traçados no "Cartão de visita", Valdemar Cavalcanti e Alberto Passos Guimarães relatam que se lançaram ao periodismo como a uma aventura, a um esporte, libertando-se do "pudor de surgir" da platônica geração anterior e do abafamento da inteligência por literatices. Contudo, ao enfatizarem o valor de sua busca de independência, por meio das imagens do mar alto e dos horizontes largos, já expressam sua consciência de que sofreriam decepções. Sua paixão foi enfrentarem perigos na avançada, sabendo que haveria perfídias, até sobrevir o término da revista:

Não nos assustaram a largueza dos horizontes que procuramos, nem as perfídias do mar alto. Antes nos animava essa volúpia romântica do perigo na avançada. De um perigo infelizmente sem surpresas, tanto conhecíamos nós as decepções que nos desestimulariam mais tarde. 
Ao mesmo tempo, demonstrando seu senso de justiça e o potencial do texto escrito para criar compreensão entre as pessoas, os mesmos autores que acusaram as "convulsões nervosas do meio" declaram gratidão aos muitos amigos, cuja ajuda não tinham previsto. Fica uma lição de alcance crítico e poético: a lucidez de prever decepções, junto com o desejo de surpreender "gente amiga e gente boa" na realidade hostil.

O que não prevíramos, e com sinceridade o confessamos, foi que nos ajudassem tantos amigos. Não nos faltava, dentre os descrentes, os indiferentes e os agressivos, gente amiga e gente boa que nos animava e nos compreendia. E a estes, mais do que a nós, ficou Novidade devendo a sua vida feliz e o seu bem-aventurado descanso.

Por fim, a exemplo do fechamento do "Cartão de visita", no de "Vida, paixão e morte de Novidade" há também um movimento de negar a convenção: recusa-se a "coroa mortuária sobre os restos mortais" da revista. No entanto, como aqui se trata do fechamento da Novidade, até simbolizado como morte, melancolicamente os autores parecem voltar atrás e, ironicamente, sugerem a convenção como a alternativa possível:

Fica entendido que não se trata de uma coroa mortuária sobre os restos mortais da filha do nosso melhor esforço. Ou talvez seja...

$* * * * * *$

Vinte e nove anos depois, em "Uma Revista" ${ }^{27}$, Valdemar Cavalcanti apresentava o que foi a Novidade aos leitores de 1960 de O Jornal, periódico do Rio de Janeiro. Esse artigo figura no livro de Cavalcanti Jornal literário, que, a despeito de ter recebido o prêmio Jabuti em 1965, é hoje uma raridade, não mais editado. Também rara, quanto ao caráter e à visibilidade, é a revista: sua integridade e ímpeto crítico, bem como a limitação de recursos financeiros de seus criadores, levaram-na a extinguir-se.

Orgulhando-se de que a Novidade refletiu todo um período fecundo da evolução cultural de Alagoas, Valdemar afirma crer que existam apenas duas coleções completas dela. Ao conjecturar que um pesquisador se debruce sobre esse material praticamente desconhecido, dá a medida do privilégio e da responsabilidade intelectuais desta tarefa.

Conforme conta Cavalcanti, a revista era pobre, feita no fundo da livraria VilasBoas, numa tipografia modesta: "composta à mão, em tipos de caixa, e impressa numa

\footnotetext{
${ }^{27}$ CAVALCANTI, Valdemar. Uma Revista. In: Jornal literário. cit., pp. 202-6.
} 
pequena máquina desesperadoramente ronceira”. Assim, sua impressão provinha de um "milagre de esforço e de boa vontade".

Quando sintetiza a importância da Novidade, percebe-se a sua dupla preocupação: debater problemas do seu tempo, do país e da região e divulgar boa literatura.

Uma revista pobre, de 16 páginas, que durante seis meses cumpriu o seu destino, realizando um trabalho intensivo de agitação intelectual: pôs em debate problemas da época e do meio, promoveu uma revisão de conceitos, difundiu idéias, estabeleceu correntes de opinião. E, ao lado disso, divulgou boa poesia e boa prosa.

É notável, para usar a expressão de Mário de Andrade, como a revista realizava a "atualização da inteligência brasileira": atenta aos escritores, artistas e também aos conflitos, tanto internacionais quanto brasileiros, buscava renovar o pensamento literário e político em Alagoas.

Assuntos, sempre os mais variados. Os temas locais, os problemas brasileiros, as questões do mundo. Literatura e arte, economia e finanças. Variações sobre Dostoiévski e Ramón Novarro; sobre o banditismo e sobre a reforma do ensino. Ao lado de contos, poemas e esboços de ensaios.

Destaco o propósito de revisão de conceitos, em termos literários e políticos. Respondia à ânsia dos jovens por experiências novas, insatisfeitos com a rotina local. Conforme Valdemar salienta, a marca do novo era o critério que presidia a seleção de colaborações literárias: na prosa e no verso, acolhiam valores novos e de outras gerações e até o ruim, desde que novidades. Igualmente nas reportagens e na seção de tópicos, o "tom seco e direto", com alguma ironia, representava para a província e para a época uma inovação em técnica de jornal. A fundamental tarefa de rever conceitos requeria "manter vivo o espírito de debate", num clima de isenção, aberto a opiniões pessoais e não a meros bate-bocas. A propensão de Valdemar Cavalcanti e de Alberto Passos Guimarães por noticiar os fatos cotidianos e por estimular a discussão de idéias continha um potencial de crítica social e de flexibilização pessoal, úteis no combate ao lugar-comum nas artes e na política.

O que era novidade - nas letras, nas artes, na política, na sociedade - era o que lhes interessava.

Para completar a apresentação da Novidade, quero acompanhar, com Valdemar Cavalcanti, a lista dos seus colaboradores, dividida em quatro. Ele reserva à primeira os escritores já consagrados em 1960, cuja presença na revista é o fator inicial a atrair os leitores. Chama a atenção para verdadeiros documentos literários: um capítulo do primeiro 
romance de Graciliano Ramos, além de "crônicas sobre tipos e aspectos do sertão"; poemas inéditos do pintor Santa Rosa, de Murilo Mendes e até de Álvaro Lins; artigos de Jorge de Lima e de José Lins do Rego.

Em seguida, o destaque é para os mais assíduos colaboradores, que, além de assinarem artigos ou poemas, contribuíam com sugestões e nos debates promovidos: Aloísio Branco, Carlos Paurílio, Manuel Diégues Júnior, Raul Lima, Aurélio Buarque de Holanda, Moacir Pereira, Téo Brandão, José Auto, Abellard França, Mendonça Júnior e Freitas Cavalcanti.

Completando a lista, Valdemar Cavalcanti sugere que, a partir dos vinte e quatro números da Novidade, seria possível organizar um cadastro de intelectuais de Alagoas: Abelardo Duarte, Álvaro Dória, Américo Melo, Arnóbio Graça, Artur Accioli, Aurino Maciel, Barreto Falcão, Carlos de Gusmão, Carlos J. Duarte, Claudionor Espírito Santo, Francisco Marroquim, Hildebrando Falcão, Humberto Bahia, Jaime d'Altavila, João Melo, José Morais da Rocha, Jurandir Gomes, Lauro Jorge, Lima Júnior, Lobão Filho, L. Lavenère, Luís Leça Dinis, Mendonça Braga, Moreno Brandão, Paulino Jorge, Pedro Maia Gomes, Pedro Nunes Vieira, Rocha Filho e Túlio Lavenère.

Relembra, ainda, intelectuais de outras terras que se juntaram aos alagoanos: Êider Pestana, Edmílson Falcão e Esdras Gueiros. Também os que, de Recife, enviavam trabalhos: Willy Lewin e Públio Dias.

Por fim, Valdemar Cavalcanti explica que, sem dinheiro, a Novidade acabou, entretanto não o gosto de renovação dos que a mantiveram de abril a setembro de 1931. E alude ao enterro de luxo, com direito a epitáfio a quatro mãos, que teve o semanário pobre de Maceió: "Vida, paixão e morte de Novidade". Evocando esse artigo, narração da iniciativa, das lutas e do fim da revista, enfatiza que ela não deixara dívidas, mas um exemplo:

Não fugira aos seus objetivos, nem se poluíra por interesses subalternos. Fôra fiel aos deveres da inteligência. 


\section{CAPÍTULO 2 - SEM NOVIDADE NO FRONT}

Hoje não há mais o ontem em que fomos espectadores.

(“Explicação")

A afeição tresmalhou. E no esterco fecundo

De mil invejas e ambições, abrolha

A flor de púrpura da guerra... E o mundo

Todo, a tremer nos seus arcanos olha.

(...)

O homem voltou ao seu estado primitivo:

Blasfema, odeia, trai, e sepulta-se vivo

Em trincheiras, sinistras como covas...

(“Devastação")

Mário de Andrade. ${ }^{1}$

Um dos aspectos mais impressionantes da guerra é o nivelamento que produz entre os homens. Diante da morte em perspectiva, só uma qualidade tem sentido: a que todos possuem e todos podem perder da mesma maneira para salvar a pátria ameaçada: a vida. O homem passa a valer na medida em que é capaz de matar e, subseqüentemente, de morrer. Desde que possa pegar em armas, o sábio e o vagabundo, o artista e o raté ficam para logo irmanados. A personalidade, o passado de cada um, glorioso ou humilde, como que se esvanecem. Um número os substitui. $O$ soldado $n^{o}$ tal toma o lugar do cidadão Fulano. Nada importa mais, senão possuir dois braços para manejar os instrumentos de morte.

\section{Lúcia Miguel Pereira. ${ }^{2}$}

\footnotetext{
${ }^{1}$ ANDRADE, Mário de. Há uma gota de sangue em cada poema. In: Obra imatura. São Paulo: Martins, 1960, p. 13, p. 33.

2 PEREIRA, Lúcia Miguel. O sonho e a máquina (1935). In: A leitora e seus personagens: seleta de estudos publicados em periódicos (1931-1943). Rio de Janeiro: Graphia Editorial, 1992, p. 14.
} 


\section{A "ética do rosto" contra a tautologia da guerra: com novidade na fronte}

(...) Exatamente quando ia me virar um pouco, ouço um baque e um corpo pesado se joga na cratera, rola e cai em cima de mim...

Não penso e nem reflito... Golpeio furiosamente e sinto apenas que o corpo dá uns repelões, depois se torna mole e amolga como um saco.

(...)

É o primeiro homem que matei com minhas mãos, aquele de que me posso certificar que sua morte é obra minha. (...)

O silêncio se dilata... Preciso falar! E falo, dirijo-me a ele, dizendo-lhe:

- Camarada, eu não queria te matar. (...) Só agora é que averiguo - e tão tarde! - que és um homem como eu. Mas, naquele instante pensei nas tuas granadas, na tua baioneta, nas tuas armas, ao passo que penso agora em tua mulher, e nesse teu rosto humano, aí e em tanta coisa que há de comum entre nós dois. Perdoa-me, camarada. Sempre vemos as coisas tarde demais. Urgia repetir sempre, sempre, que vós outros sois também pobres cães como nós, que vossas mães se atormentam como as nossas e que temos todos, vós e nós, o mesmíssimo medo da morte, que padecemos os mesmos transes e que nosso modo de morrer é idêntico!... Perdoame, camarada. Como pudeste ser meu inimigo? Se jogássemos fora estas armas e estes uniformes, tu poderias ser meu irmão... Como Kat... Como Albert... Camarada, toma vinte anos da minha vida e levanta-te... Mais de vinte, mesmo, pois doravante não sei mais o que ainda poderei fazer dela.

Tudo plácido. A linha de frente está sossegada. Só um ou outro crepitar de tiros.

(...) Este morto está atado à minha vida (...). Juro às cegas que só existirei para ele e para sua família... (...) Por isso, abro a carteira e leio devagar: Gérard Duval, tipógrafo. (...)

Matei o tipógrafo Gérard Duval. Devo me tornar tipógrafo, penso completamente zonzo. Vou ser tipógrafo. Sim. Tipógrafo...

(...) A crise passou. Digo ao morto ali ao meu lado:

- Camarada, hoje tu, amanhã eu. - Mas estou falando com serenidade. - Mas se eu sair disto, hei de lutar contra esta coisa que nos abateu a ambos. A ti, tirando-te a vida... E a mim... tirando-me também a vida. Prometo-te, camarada. É preciso que isto não se repita nunca mais.

(...)

Eu próprio agora não me compreendo mais. Respondo:

- Fiquei assim só porque tive que ficar uma porção de tempo junto dele. - Afinal, guerra é guerra. ${ }^{3}$

Na Novidade 14, Raul Lima se refere a Sem novidades no front (1929), de Erich Maria Remarque, como uma das grandes "novidades literárias" 4 traduzidas para o português. Creio que a análise dessa cena do capítulo IX do romance - momento intenso de conflito subjetivo diante e dentro do conflito mundial de 1914 - permitirá compreender o romance e dimensionar seu valor nos anos 30 e até hoje.

\footnotetext{
${ }^{3}$ REMARQUE, Erich Maria. Sem novidades no front. Tradução de José Geraldo Vieira. cit., cap. IX, pp. 145, 148, 149, 150, 151, 153. As citações do romance são dessa edição.

${ }^{4}$ LIMA, Raul. Memórias íntimas de Josephina Baker. Novidade 14, p. 5.
} 
De volta de uma licença, e por isso sentindo mal-estar perante os companheiros, o narrador-protagonista Paul Baumer, soldado do front alemão, dispõe-se a fazer uma patrulha de reconhecimento. Alvo de metralhadoras e quase de uma granada, transido de pânico, esconde-se, grudado à terra, em uma cratera. De modo contundente, Remarque constrói uma imagem a um tempo concreta e de teor psicológico para a situação sufocante de Baumer: a "imensa depressão". E cria uma imagem abstrata para a contraparte dessa degradação - o alto valor de existirem companheiros: vozes humanas, poucas palavras em que o rosto deseja mergulhar. A solidão e o pavor da morte se aplacam quando o soldado ouve vozes dos homens com quem partilha "a mesma angústia e a mesma vida":

Quisera mergulhar meu rosto naquelas vozes, naquelas poucas palavras que me salvaram e que me susterão.

No entanto, temendo entrar no setor adversário, Baumer não reconhece ao certo a direção a seguir - e aqui, como na "imensa depressão", a imagem traz concreta e metaforicamente o sem-sentido da guerra. Rastejando pelo solo, a vida em jogo, vê irromper um bombardeio e se deita no fundo de uma grande cratera. $\mathrm{O}$ ataque dos adversários é bem próximo, e, em meio a intenso tiroteio, sucede a cena transcrita.

Após apunhalar um homem que se joga na cratera em que se escondia, Paul acompanha-lhe os estertores e é espectador de sua morte. Embora soldado em plena guerra, era a primeira vez que lhe sobrevinha a consciência trágica de estar ali para defender-se e tirar a vida de outras pessoas.

- Camarada, eu não queria te matar. (...) Só agora é que averiguo e tão tarde! - que és um homem como eu. Mas, naquele instante pensei nas tuas granadas, na tua baioneta, nas tuas armas, ao passo que penso agora em tua mulher, e nesse teu rosto humano, aí e em tanta coisa que há de comum entre nós dois. Perdoa-me, camarada.

Ao assistir à morte do soldado francês, a compaixão lhe permite ver-se igual ao outro: eram pobres-diabos impelidos sem motivo a uma guerra, para matarem outros homens cujas mães igualmente sofriam e que padeciam do mesmo medo da morte e da mesma mortalidade. De modo comovente, Paul pede perdão ao morto e, percebendo-se, tarde demais, assassino de um irmão, reconhece que sua vida também não tem mais sentido.

Aqui, para melhor compreender Sem novidades no front, cumpre evocar, do Eclesiastes, o "nada de novo sob o sol" e, de Schopenhauer, a importância da compaixão como fundamento da moral. A um tempo, a consciência culpada de Paul Baumer aponta 
para o senso trágico da igualdade dos homens perante a morte (a vanidade de tudo, do livro de Salomão) e para uma rara abertura ética, especialmente de condenação à guerra, já que ele foi espectador do sofrimento alheio. ${ }^{5}$

Paradoxo dramático, configura-se a grandeza ética do protagonista à medida que se identifica com o soldado morto, pensando na mãe, na mulher, no "rosto humano" dele e na mortalidade em comum. Remarque expõe com precisão como o horror da guerra se torna lugar-comum: depois do bombardeio e do soldado francês apunhalado, a placidez que assume o front, com um ou outro crepitar de tiros, não diz da guerra interior de Baumer. Atordoado, ele entende que só será sujeito se dispuser sua vida à responsabilidade pelo morto, por sua família.

$\mathrm{Na}$ construção da cena da cratera, desmascara-se o sem-sentido do conflito mundial, por meio de sua particularização no conflito subjetivo de Paul Baumer. Daí o peso que tem o defrontar-se do protagonista com o "rosto humano" do outro.

Diante do adversário moribundo, o tempo e os pensamentos são "punhal invisível" a consumir Baumer. Embora não quisesse, encara bem o outro, cujos olhos vê gritarem, urrarem, num esforço concentrado por viver, com horror da morte e de seu algoz. Entretanto, se era insuportável olhar o agonizante e ouvir-lhe os estertores, mais confrangedor foi viver o silêncio de sua morte. Por isso, Baumer tem necessidade de falar com o camarada morto e pedir-lhe perdão. Desesperado, sabe que, se olhar na carteira o nome de sua vítima, essa cena sempre se reproduzirá na sua memória.

Rente ao morto, sofre ainda mais ao conhecer sua identidade: Gérard Duval, tipógrafo, tinha família e era pobre. Transtornado de ver retratos de uma mulher e de uma menina e cartas indecifráveis em francês, pensa, como num consolo, mandar para elas notícias e dinheiro, mas logo admite que não o fará.

(...) Este morto está atado à minha vida (...). Juro às cegas que só existirei para ele e para sua família... (...) Por isso, abro a carteira e leio devagar: Gérard Duval, tipógrafo. (...)

Matei o tipógrafo Gérard Duval. Devo me tornar tipógrafo, penso completamente zonzo. Vou ser tipógrafo. Sim. Tipógrafo...

Assim, a configuração do drama de Paul Baumer delineia um horizonte ético. Além de espectador do sofrimento alheio, ao se identificar como assassino do tipógrafo, ele

\footnotetext{
${ }^{5}$ Cf. SCHOPENHAUER, Arthur. Sobre o fundamento da moral. Tradução: Maria Lúcia Mello Oliveira Cacciola. $2^{\mathrm{a}}$ ed. São Paulo: Martins Fontes, 2001 (Coleção Clássicos), p. 162, p. 167, p. 186.

Devo a indicação desse livro ao ensaio "O enigma do olhar", de Alfredo Bosi (In: Machado de Assis: o enigma do olhar. São Paulo: Ática, 1999, p. 70).
} 
necessita ser também tipógrafo, ser responsável pela família do morto. Apenas quando fica face a face com a fragilidade do outro e deseja responder por ele, sua existência ganha algum sentido. Dessa forma, ciente de que perderia a vida como o francês - e de que já a perdera com ele -, Baumer lhe promete que, sobrevivendo, lutará para que a guerra nunca mais se repita.

- Camarada, hoje tu, amanhã eu. - Mas estou falando com serenidade. - Mas se eu sair disto, hei de lutar contra esta coisa que nos abateu a ambos. A ti, tirando-te a vida... E a mim... tirando-me também a vida. Prometo-te, camarada. É preciso que isto não se repita nunca mais.

Eis que Remarque projeta para o futuro uma lição ética, aprendida ante o "rosto humano" de um soldado morto na guerra de 1914. Confirma-se o alcance universal dessa cena de confronto interpessoal e subjetivo, quando se evoca, da obra do filósofo Emmanuel Lévinas, o sentido de ética a partir da relação com o rosto do outro. Incontível, o rosto fala, é expressivo: a um tempo está exposto à violência e proíbe de matar. Então, a subjetividade se define como responsabilidade pelo outro: ser sujeito é sujeitar-se a outrem, o que perfaz a "suprema dignidade do único" 6 .

Mesmo que se admita, com o próprio Lévinas, o traço utópico dessa concepção, surge muito fecunda a imagem do rosto, alteridade eterna, como pedido de ética. Sua conseqüência é a compreensão, até etimológica, do sujeito como responsável pelo outro, o que implica a ética como busca infinita. Advinda da impossibilidade de matar, que, na situação extrema da guerra, problematiza dramaticamente o instinto de autoconservação, a ética do rosto transparece também nestas passagens terríveis do capítulo 6 do romance de Remarque (e aqui a tradução de Helen Rumjaneck é mais expressiva): "não consigo atirar nestes olhos estranhos", "sabemos que não lançamos as granadas contra homens, mas contra a Morte".

Desse modo, é profundamente moral a cena em que Paul Baumer, confrangido diante do semblante do francês morto, se responsabiliza pelos seus semelhantes. E tal

\footnotetext{
${ }^{6}$ LÉVINAS, Emmanuel. Ética e infinito: diálogos com Philippe Nemo. Tradução de João Gama. Lisboa: Edições 70, 2000, p. 93. Cf., do mesmo autor: Totalidade e infinito. Tradução de José Pinto Ribeiro. Lisboa: Edições 70, 2000 (em especial, pp. 176-9, 229-231, 284-7); Entre nós - ensaios sobre a alteridade. Tradução de Pergentino Stefano Pivatto (coord). Petrópolis: Vozes, 2004 (pp. 193-8, 268-275, 283-5); Humanismo do outro homem. Tradução de Pergentino S. Pivatto (coord). Petrópolis: Vozes, 1993 (pp. 48-53); POIRIÉ, François. Emmanuel Lévinas: ensaio e entrevistas. Tradução de J. Guinsburg, Marcio Honorio de Godoy e Thiago Blumenthal. São Paulo: Perspectiva, 2007.

Devo a indicação da obra de Lévinas ao ensaio "Cerimônias da destruição", de Olgária Matos. In: NOVAES, Adauto (Org.). Civilização e barbárie. São Paulo: Companhia das Letras, 2004, pp. 281-299.
} 
responsabilidade, de lutar para que a guerra jamais se repita, se exerce por meio da narrativa de Remarque, cuja marca é o realismo. Por isso, contra ilusões mascaradoras, ao final do capítulo IX, reproduzindo a lógica cruel do front, aplaca sua sensibilidade ante o episódio do tipógrafo: “Guerra é guerra”. Essa conclusão tautológica exprime justamente a falta de alteridade e de ética que define a guerra. Para a trincheira, não existem outras palavras, a não ser a repetição da morte. "Guerra é guerra": sem novidades no front.

\section{A experiência sem pátria}

À medida que o assassinato do francês cometido por Baumer na cratera expõe, num paradoxo dramático, o sentido ético da responsabilidade subjetiva pelo outro, compreendese a falsidade do patriotismo e do heroísmo generalizados como matança pela guerra. Logo na cena inicial do romance, impõe-se o "desmascaramento do heroísmo" 7 ao desvelar-se a massificação da morte e da vida pela guerra, com sua tecnologia desumanizadora: a fome dos soldados alemães torna bem-vindo o massacre que vitimou os próprios compatriotas, pois redundou em refeição farta. De modo aterrador, o morticínio que os reduziu de 150 a 80 homens significa a "sorte" de terem "ração dobrada".

Remarque desnuda como o egoísmo ou, se preferirmos, o instinto de conservação apaga a sensibilidade do indivíduo pelos outros. E isso ocorre tanto no plano coletivo, patente nessa crua cena da fome, como no plano individual. Basta lembrar o caso das botas do jovem moribundo Kemmerich, almejadas pelo companheiro Müller. Terrível é a tensão do narrador: de um lado, padece de comoção diante do amigo Kemmerich, cuja perna foi amputada e que logo morrerá, para o qual as botas se tornaram inúteis; de outro, enfatiza a compreensão diante do realismo prático de Müller, jovem em guerra para quem as botas do outro tinham grande serventia.

Assim, partilhando com o leitor sua sensibilidade lúcida, Remarque revela como sua geração, mesmo havendo sobrevivido, foi inutilizada pela guerra. Eis a epígrafe do romance, que também abre o filme:

Este livro não pretende ser um libelo nem um depoimento. Tenciona apenas informar a respeito duma geração que ficou arruinada pela guerra - muito embora tenha escapado às suas granadas.

\footnotetext{
${ }^{7}$ CARPEAUX, Otto Maria. Guerra e literatura. O Jornal, 19 dez. 1948. In: Ensaios reunidos 1946-1971. cit., v. II, p. 399.
} 
Apresentando com realismo uma geração de homens destruídos, o romance desmascara os discursos do poder, que incentivavam a guerra como heroísmo e patriotismo. Os soldados esperavam a própria morte por granadas ou a morte dos companheiros, para herdar deles a comida ou as botas, e até disputavam o pão com ratos não havia heróis nas trincheiras, sequer havia homens. Pior: eram "mortos insensíveis" a matar. Remarque enfatiza o equívoco de, adolescentes, terem idealizado romanticamente a guerra e confiado na autoridade dos professores: o discurso que apregoava à "mocidade de ferro" o dever de servir ao Estado se esfacelava ante o pavor da morte e os moribundos. O patriotismo e a disciplina inculcados nos jovens não eram mais que o despojamento da personalidade. Incitados à guerra como "mocidade de ferro", com pouco tempo no front viam-se velhos, porém sem passado e sem possibilidade de algum dia se habituarem a uma profissão.

O drama dos soldados era desejarem com saudade uma comunhão com a natureza e com os fatos e coisas de sua existência, mas saberem que nunca mais poderiam senti-la como antes; afinal viram o empilhar de mortos ocorrer como se fosse natural. Não acreditavam mais na vida fora da guerra. No período de sua licença, da qual se arrepende, Baumer se vê um estranho, deslocado e desiludido na cidade: assusta-o como granadas o barulho dos bondes; causam-lhe inveja e desprezo os afazeres dos homens, mesquinhos enquanto há companheiros morrendo no front; surgem-lhe incompreensíveis os muitos desejos e preocupações dos outros, pois para ele há mais valor em permanecer sentado num jardim. Quando o pai e o professor lhe pedem para contar sobre a guerra, ele recua, temeroso da loucura e do tormento de transformar os acontecimentos do front em palavras.

É inevitável recordar os ensaios em que Walter Benjamin desvela como a baixa da experiência na modernidade implicou a impossibilidade da narração. Ele chama a atenção para o silêncio dos combatentes da guerra de 1914 quando voltavam do campo de batalha, "mais pobres em experiências comunicáveis". Evidencia que jamais houvera experiências mais "radicalmente desmoralizadas" ${ }^{8}$ do que a guerra de trincheiras, a inflação, a fome e a falta de moral dos governantes. Ao mesmo tempo, para esse homem moderno, abandonado numa paisagem em tudo diferente, "exceto nas nuvens", persiste a necessidade do relato.

\footnotetext{
${ }^{8}$ BENJAMIN, Walter. Experiência e pobreza; O narrador. Considerações sobre a obra de Nikolai Leskov. In: Magia e técnica, arte e política - Ensaios sobre literatura e história da cultura. $5^{\text {a }}$ ed. São Paulo: Brasiliense, 1993, p. 115; p. 198.

Cf. também GAGNEBIN, Jeanne Marie. Não contar mais?. In: História e narração em Walter Benjamin. $2^{\mathrm{a}}$ ed. São Paulo: Perspectiva, 1999.
} 
Por isso, contra a repetição de uma não-experiência como a guerra, ganham forma o livro de Remarque e o filme. Neste, é marcante a cena da sala de aula, em que Baumer, durante a licença do front, contrariando a expectativa patrioteira e belicosa do professor, declara aos alunos mais jovens que não pode contar nada da guerra. Explica-lhes que o professor os engana, pois não sabe o que é a guerra, não sabe que é sujo e doloroso morrer pelo país e que os soldados, vivos ou mortos, estão perdidos no front. No filme como no livro, é forte a crítica aos educadores, piores do que os inimigos na guerra, porque portavozes de um nacionalismo desumano.

Promovido pela escola, igreja e imprensa, o patriotismo como mentira ideológica que redundava no anulamento das subjetividades era combatido por Remarque. Num expressivo diálogo do mesmo capítulo IX analisado, os soldados alemães dão voz ao impasse que os afligia: tanto eles como os franceses, apoiados por seus professores, pastores e jornais, estavam na guerra para defender cada qual a sua pátria e presumiam ter razão; como é possível que uns e outros estivessem com a razão?

Eis que o veterano Katczinsky, amigo de Baumer no front, descortina serem eles próprios, como os soldados franceses, trabalhadores do povo, que se matavam entre si sem motivo e sem haverem sido consultados, em nome do governo, ávido de poder e prestígio.

- (...) Por que motivo há de um serralheiro ou um sapateiro francês querer nos atacar? Não, isso é obra dos governos. Antes de vir aqui eu nunca tinha visto um francês, o mesmo devendo acontecer à maioria dos franceses, quanto a nós. Nem eles nem nós fomos consultados. (...) / E todo grande imperador necessita pelo menos duma guerra para poder se tornar célebre.

Em entrevista a Frédéric Lefêvre, de 25 de outubro de 1930, Remarque, que parou de estudar aos dezoito anos para lutar na guerra de 1914, confessa ter escrito Sem novidades no front porque necessitava discutir consigo mesmo um problema que o tocava pessoalmente e que, segundo entendia, preocupava milhões de outros homens. Explica que se debatera entre dois sentimentos igualmente intangíveis: por um lado, a guerra the havia surgido como uma necessidade para salvar a cultura; por outro, venceu nele a convicção de que "nada vale que tantos milhões de homens pereçam" 9 . O equilíbrio desejado era conciliar o apego à cultura nacional com o respeito pelos outros povos:

9 “(...) je pensais que rien ne vaut que tant de millions d'hommes périssent". "E. M. Remarque”. In: LEFÈVRE, Frédéric. Une heure avec... VI série. Paris: Flammarion, 1933, pp. 141-151. 
Pode-se amar toda a humanidade, trabalhar com todas as forças para a compreensão recíproca dos povos e, entretanto, amar acima de tudo a pátria. ${ }^{10}$

Portanto, a leitura de Sem novidades no front, complementada a partir de Lévinas e de Benjamin, revela como a guerra, ao opor ideologicamente pátrias, destrói, abala a experiência humana e a possibilidade de atividade narrativa, porém contraditoriamente a incita como exigência ética. A cena em que Baumer mata o tipógrafo francês e o mencionado diálogo entre os soldados concentram esse sentido ético do romance: a condição de mortais, as limitações igualam os homens, ao tempo em que é infinita a responsabilidade do sujeito pelo outro, por suas diferenças.

\section{Remarque na Novidade: uma geração de mutilados}

Em "Romances da Guerra" 11, Otto Maria Carpeaux chama a atenção para o que considera um dos mais estranhos fenômenos de toda a história literária: nos dez anos subseqüentes a 1918, a guerra foi praticamente esquecida pela literatura. Destacando Le feu, de Barbusse, publicado durante o conflito, aponta que havia a censura e o desejo de esquecer o horror. Contraditoriamente, como revela Walter Benjamin, a guerra trazia o silêncio, a falta de experiências transmissíveis, e a necessidade de o dizer. Então, Carpeaux enfatiza que, só exatamente dez anos após o armistício, o conflito foi evocado pelo alemão Erich Maria Remarque com In Westen Nichts Neues (Nada de Novo na Frente Ocidental), de 1929. Julgando-o "notável pela franqueza do realismo e pela composição novelística", Carpeaux observa que o romance "fez história na história literária".

Segundo Eric Hobsbawm ${ }^{12}$, que também indica terem os grandes ecos literários da Primeira Guerra reverberado apenas no final da década de 1920, o livro de Remarque vendeu 2,5 milhões de exemplares em um ano e meio, em 25 línguas. Pensando-se em sua

\footnotetext{
10 "On peut aimer l'humanité tout entière, travailler de toutes ses forces à la compréhension réciproque des peuples et cependant aimer par-dessus tout sa patrie". Idem. Ibidem, p. 146.

${ }^{11}$ CARPEAUX, Otto Maria. Romances da Guerra. In: Tendências contemporâneas na literatura. Um esboço. Rio de Janeiro: Edições de Ouro, 1968, p. 37.

${ }^{12}$ HOBSBAWM, Eric J. Era dos extremos: o breve século XX (1914-1991). Tradução de Marcos Santarrita. Revisão técnica de Maria Célia Paoli. São Paulo: Companhia das Letras, 1995, p. 189.
} 
recepção no Brasil, é esclarecedora uma crônica de Mário de Andrade, de março de $1930^{13}$. Ao comentar a moda, na França, dos romances de guerra escritos por alemães, ele a atribui à publicação de Remarque: a competente Livraria Stock teria vendido, em seis meses, 440 mil exemplares. E Mário julga o romance uma excelente transposição literária da guerra “o que dá mais a sensação de guerra, a guerra que nós criamos dentro de nós”. Presume-se que os brasileiros tenham conhecido o romance por meio dessa tradução francesa da Librairie Stock, A l'ouest rien de nouveau, de $1929^{14}$.

A narrativa foi publicada em folhetins no Wossiche Zeitung, em 1928, e, devido ao êxito, apareceu em livro em 1929. Carpeaux ressalta os méritos literários de Remarque, muitas vezes esquecidos diante da fama que ele adquiriu. Seus livros posteriores, igualmente de atualidade política, também se tornaram best-sellers. São eles: $O$ regresso (1931), Três camaradas (1937), Náufragos (1941), Arco do triunfo (1946), A centelha da vida (1952), Tempo para amar, tempo para morrer (1954), O obelisco negro (1956), O céu não tem favoritos (1961), A noite de Lisboa (1962) e Sombras no paraíso (póstumo, 1971). Nada de novo no front foi traduzido para 58 idiomas, tendo sido vendidos mais de dez milhões de exemplares em todo o mundo ${ }^{15}$.

Se a tendência antimilitarista do romance foi muito aplaudida já na época, na Alemanha causou reações hostis. Vencedor dos Oscars de melhor filme e melhor diretor (Lewis Milestone), All quiet on the western front, de 1930, foi proibido em 1933 pelos nazistas, e queimados os livros de Remarque. Nascido em 1898 na Alemanha, ele se exilou em 1932 na Suíça, e, em 1939, nos Estados Unidos. Em 1938, as autoridades alemãs retiraram a cidadania alemã do escritor, acusando sua obra de apresentar uma visão antigermânica da guerra. Sua irmã foi morta na Alemanha em 1943. Em 1947, naturalizouse norte-americano. Morreu na Suíça em 1970.

\footnotetext{
${ }^{13}$ ANDRADE, Mário de. Livros de guerra (27 de março de 1930). In: Táxi e crônicas no Diário Nacional. Estabelecimento de texto, introdução e notas de Telê Porto Ancona Lopez, São Paulo: Duas Cidades, Secretaria da Cultura, Ciência e Tecnologia, 1976, pp. 197-8.

${ }^{14}$ Mas logo surgiram também traduções em português (Nada de novo na frente ocidental, editora América Latina, 1930) e em espanhol (Sin novedad en el frente. $8^{\mathrm{a}}$ ed. Madrid: España, 1930).

15 As palavras de Modris Eksteins, confirmando a força artística do livro de Remarque, ajudam a compreender o êxito editorial do romance, que combinava estas duas faces: era "uma confissão de desespero pessoal" e também "uma denúncia indignada contra uma ordem social e política insensata"; "acusava uma civilização mecanicista de destruir valores humanos, de negar a caridade, o amor, o humor, a beleza e a individualidade"; "e esse estilo direto e passional estava no âmago de seu apelo popular". EKSTEINS, Modris. Sagração da primavera: a grande guerra e o nascimento da era moderna. Tradução de Rosaura Eichenberg. Rio de Janeiro: Rocco, 1991, p. 360. Devo a indicação desse livro ao Prof. Murilo Marcondes de Moura, a quem agradeço.
} 
Na Novidade, J.B. (José Braga) e um "observador cinematográfico" são responsáveis por várias notas críticas sobre o filme, nas quais a princípio se detêm sobre o "livro admirável" de Remarque. No número 5 da revista, de 9 de maio de 1931 (CINEMA - All quiet on the western front, p. 13), J.B. destaca como inédita a "força de dramaticidade" do romance, o realismo com que desmascara a carnificina, revelando o drama de uma geração de jovens cujo idealismo logo terminou em luto e desencanto.

Profundamente realista, profundamente humano, este livro traz episódios da grande guerra, descritos com uma força de dramaticidade pode-se dizer inédita em toda a literatura que se fez em torno do conflito mundial. São cenas de trincheira, sob o horror da fome, da sede e do frio. É a carnificina, no ardor das linhas de frente, de pobres idealistas desencantados - adolescências mal separadas do calor materno e veteranos da caserna, cujos olhos bem cedo se acostumaram à dor e ao luto.

Na Novidade 19, de 15 de agosto de 1931 (CINEMA - Sem novidade no front, $\mathrm{p}$. 12), despertando os leitores para criarem consciência quanto aos problemas de seu tempo, o observador cinematográfico explica que Remarque não foi simplesmente o mais arguto espectador da guerra, mas ator, pois viveu no "palco da tragédia universal, cujas conseqüências ainda hoje nos abalam". No mesmo sentido de "desmascaramento do heroísmo" (identificado por Carpeaux na obra de Remarque), o observador aponta que a geração do romancista, por um "paradoxal impulso de vida", se lançou a um suicídio que foi antes um assassinato, provocado pela "desumanidade de certa classe dos espectadores".

Sensível ao potencial de comover do livro, J.B. aposta que Lew Ayres saberá interpretar o drama de Paul Baumer e o filme incutirá nos moços o horror pela guerra, permitindo à obra de Remarque atingir o "fim humaníssimo" a que se destinou. Provavelmente quando foi escrita essa nota crítica, na Novidade 5, de 9 de maio de 1931, o filme ainda não estava sendo veiculado em Alagoas. Nesse mesmo número, Sem novidade no front é anunciado como sucesso de bilheteria no Rio.

Na Novidade 10, de 13 de junho de 1931 (CINEMA - "Filmes da guerra", p. 8), denunciando o excesso de exploração do tema da guerra pelo cinema, J.B. salienta o valor de originalidade da "extraordinária produção da Universal" extraída do romance de Erich Maria. Compreende que se tivesse tornado o maior filme do ano:

É um filme original, porque é um filme intensamente dramático e real, vivido por uma geração ferida pela tragédia, uma geração de mutilados mesmo sem muletas. 
Observe-se que Mário de Andrade, em crônica de $1932{ }^{16}$, também condena a vasta literatura e cinegrafia de guerra, que transformava a frase "a guerra é um horror" num chavão, desvitalizado e desumano. Grave, o problema era que a guerra verdadeira e não artística se tornara uma normalidade cotidiana: a patriotada, a vadiagem, a gatunice, capitalismo e desigualdade social. Mário destaca o Nada de novo, diverso da vulgaridade dos filmes de guerra: chocando pela violência e provocando intensa comoção, tinha a força de inculcar-se como a própria verdade.

No número 16 da revista, de 25 de julho de 1931, o filme sobressai no topo da lista em CINEMA - "Os dez grandes filmes de 1930", p. 10:

Em primeiro lugar, colocou-se Sem Novidade no Front, da Universal, direção do russo Lewis Milestone, interpretada por Lew Ayres, Louis Wolheim, John Wray e Raymond Griffith.

Finalmente, na Novidade 18, de 8 de agosto de 1931, em CINEMA - "Espécie de notícias", anuncia-se o filme em Maceió:

Vamos assistir por estes dias o grande filme que a Universal calcou sobre o livro formidável de Eric Maria Remarque - Sem Novidade no Front. Ao que se diz o Floriano vai passar o maior film do ano em soirée de gala, às 8 horas da noite.

No número 19, de 15 de agosto de 1931, o observador cinematográfico comenta o filme, em cartaz desde o dia anterior. Com seu olhar crítico, lamenta que o drama das trincheiras, ainda mais cru por meio do efeito visual e auditivo do cinema, fosse recebido com "gargalhadas imbecis" pelos espectadores em Alagoas. Algo curiosa, a revolta do crítico parece-me justa: formador de opinião no meio provinciano, cumpre-lhe chamar a atenção de todos para a gravidade da situação do mundo com a guerra, momento "das maiores angústias". Se a tragédia do filme é carregada de comoção, não deveria provocar risos. O inconformismo do observador cinematográfico sinaliza o despreparo de certo público de Maceió dos anos 30, não habituado à seriedade, muito menos diante do cinema.

Essas gargalhadas imbecis entristecem ainda mais o espectador de sensibilidade do que a própria história de Remarque.

Evidenciam-se aqui os problemas dos anos 1930, brasileiros e mundiais. Além dos risos inconcebíveis ante o filme da guerra, o próprio fato de as sessões de cinema em Maceió serem anunciadas por sirenes insuportáveis já indica que o novo enquanto

${ }^{16}$ ANDRADE, Mário de. Filmes de guerra (6 mar. 1932). In: Táxi e crônicas no Diário Nacional. cit., pp. 507-8. 
tecnologia constituía ruído frente às carências da realidade ${ }^{17}$. Assim, a Novidade revela que marcavam a mocidade de Alagoas o desejo de renovação, a atração pelo moderno (como o cinema) e, a um tempo, a consciência crítica de que nada seria novo enquanto persistisse o quadro de miséria, de alienação social, política e cultural. Em termos gerais, o sentimento da época, identificado por Eksteins na obra de Remarque, fundia esperança e desespero, "desejo e desolação" 18 .

\section{Ambição míope: um mínimo de perdas}

Além das notas sobre cinema, uma pequena crítica ("All quiet...”, de Jurandir Gomes), uma breve ficção (“T.G. 13”, de Willy Lewin) e um ensaio (“A propósito de guerra”, de Diégues Júnior) foram as contribuições da Novidade centradas diretamente no tema da guerra. Mas já se viu que esse tema, com sua gravidade, se desdobra em reflexões sobre política, nacionalismo, educação, que também aparecem na revista.

Em “All quiet..." (N 18, p. 12), Jurandir Gomes, evocando Salomão e Remarque, confirma que não há nada de novo, "nem na frente ocidental, nem sob o sol". Seu propósito é mostrar que n' $O$ infante na trincheira, sobre o qual acabara de ler um estudo escrito havia doze anos por Vito Lombardi, já estava condensada a tragédia agora apresentada por Remarque. Porém, ressalta o valor das duas obras que, pungentes e críticas, possuíam os mesmos temas: dentre outros, a fome, o desejo de botas novas, o descompasso entre o horror vivido pelo soldado no front e o estereótipo de herói com que o cercam quando em licença.

Jurandir Gomes ironiza a barbárie a que chegou o homem na guerra européia, “o humilde descendente do homem das cavernas". Sensível à angústia da guerra, lembra o paradoxo dos dias de calmaria no front, nos quais morrem suas vítimas anônimas. É o caso de Paul Baumer, cuja morte vem em terceira pessoa, em conformidade com o silêncio do front.

\footnotetext{
${ }^{17}$ Nos "Tópicos" da Novidade 1, Valdemar Cavalcanti se queixa das sirenes dos cinemas, "agourentos pássaros noturnos" a "conspirar sovieticamente contra o sossego e a santa paz provinciana". Elas seriam "marinética reação contra os crepúsculos", seus gritos lancinantes pareciam lastimar a falta de gosto da pacata população pelo cinema e logo fariam de Maceió "a cidade que sofre dos nervos".

${ }^{18}$ EKSTEINS, Modris. Sagração da primavera: a grande guerra e o nascimento da era moderna. cit., p. 373.
} 
“T.G. 13" (N 7, p. 6), pequena ficção autobiográfica de Willy Lewin, abre-se qual um tiro cujo alvo se tensiona em dois: surge em frase nominal a idade de dezessete anos, com que o jovem, encantado com a primeira namorada, teve de submeter-se aos treinamentos do exército.

Dezessete anos A minha primeira namorada coincidiu com os meus exercícios militares no Tiro de Guerra 13 (Pernambucano).

Mira do texto, a lembrança dos olhos da namorada é o ímpeto de vida que move a resistência do soldado em concentrar-se na disciplina militar. $\mathrm{Na}$ expressiva escolha vocabular de Willy Lewin, a lembrança dos olhos da amada é "obsidente" ("que cerca ou sitia'), adjetivo cujo teor bélico fala da divisão do jovem, perturbado entre a paixão e os exercícios militares.

Contudo, a verdade da conquista amorosa emerge como preferível aos combates simulados e à obrigação de decorar cânticos guerreiros que apregoavam o sacrifício pela pátria. De modo contundente, Lewin se revolta contra a guerra, atacando a naturalidade com que os sargentos consideravam a morte de cem homens em mil "um mínimo de perdas". Ao individualizar essas perdas hipotéticas nas figuras de Charles Vidrac, Jean Cocteau e Blaise Cendrars, demonstra que todas as pessoas têm um valor singular, não redutível à massificação numérica.

Eu não podia compreender que o sargento falasse calmamente de 'um mínimo de perdas' como se se tratasse de uma ninharia.

Por fim, à semelhança da crítica de Erich Maria Remarque contra os discursos dos educadores, que incentivavam o heroísmo dos jovens desconhecendo a realidade da guerra, Lewin sente os tiros de festim dos treinos militares soarem como repetição dos discursos patrióticos, ilusórios. Então, essa associação de balas de festim e discursos patrioteiros se completa com uma imagem a ela oposta, expressão dos desejos do adolescente-narrador: "uma mulher sem pátria nos espera". A falsidade da ordem de sacrificar-se pela pátria é sobrepujada pela voz sincera dos dezessete anos "cheios de ternura e sonhos ainda intactos", em cujo horizonte há uma mulher sem pátria a esperar.

As detonações secas dos cartuchos de festim repetiam-me espetaculosamente os velhos discursos: 'A Pátria exige o sacrifício da nossa mocidade, das nossas vidas, das nossas esperanças!' Mas, dominando esse grito, eu sentia outra voz mais forte, mais sincera, mais instintiva que se erguia do fundo dos meus dezessete anos cheios de ternura e sonhos ainda intactos: 'Uma mulher sem pátria nos espera!' 
Assim, por meio de uma construção poética com força crítica e bom-humor, Willy Lewin privilegia, contra a insensibilidade e o pragmatismo bélicos, a singeleza dos sonhos da mocidade.

A preocupação com o mundo, que marchava para outro conflito, obriga Manuel Diégues Júnior a escrever “A propósito de guerra” (N 16 - 25 jul. 1931, p. 5). Apontando que Ludendorff, general alemão, previa o novo conflito para 1932, Diégues Júnior apreende daí, contrariado, certo prazer sádico desse militar (que participara da guerra). Então, o jovem intelectual alagoano se dirige contra o que julga a matriz do conflito de 1914 e de sua continuidade agora anunciada: a miopia da ambição de meia dúzia de estadistas, sacrificando milhares de vidas e inutilizando gerações.

Acabara de adquirir, em modesta livraria de Recife, uma "magnífica" edição espanhola de Postguerra de Ludwig Renn. Nela, Diégues Júnior encontrou o "ambiente doloroso" do front e a consciência de que os discursos dos estadistas, favoráveis à luta entre povos, eram "balela política". Aproxima o Postguerra da obra de Remarque, à qual atribui o poder de evitar guerras, caso fosse lida por estadistas autênticos.

É isso o que nos mostram as páginas do Sem novidade no front, de Remarque, continuadas no Depois..., outro livro que, se estadistas verdadeiros, procurando a segurança e o bem-estar das nações, lessem, nunca teriam a ambição de provocar lutas.

Essa crença na força de humanização da literatura, guardando embora um componente utópico, acompanha-se de uma atitude crítica em relação à perspectiva pragmática de outras áreas, que acobertavam a crueza da guerra: aos "olhos metálicos" dos financistas interessavam os aspectos econômicos do conflito mundial; aos políticos, algum programa de governo; os militares elogiavam façanhas heróicas; outros apreciavam a divisão do mapa da Europa.

Assim, destacando o livro de Renn, que surgiu no momento agudo da crise mundial, Diégues Júnior alerta que os estadistas precisavam dominar-se em meio à "vertigem de ambição e de ódios". Desmascara que a tragédia de 1914 se devia aos estadistas, nunca aos míseros soldados, por fim mortos ou inutilizados, nem a desejos de expansão do Reno ou dos Alpes (aqui a ironia a partir dos elementos da natureza retoma a do livro de Remarque). Acusa os chefes de impelirem as multidões para a guerra sem consultá-las. 
Finalmente, depois de atribuir os desastres mundiais à ânsia de poder dos estadistas, Diégues Júnior declara seu sonho: o mundo atingirá a paz quando os chefes perceberem a miopia de sua ambição, origem de tantos males.

Quando os estadistas chegarem a compreender que tem sido a ambição de poder e a ânsia de governo a causa de tantos desastres, então, terá o mundo chegado à paz definitiva, à segurança inabalável por que há milhares de anos anseia a humanidade.

Paradoxalmente, na mesma medida tal desejo se desfaz como utopia e sobressai, ainda mais frente às terríveis manifestações de barbárie posteriores à de 1914.

Recorde-se "Terra de Espanha" 19, crônica de setembro de 1937 em que Graciliano Ramos condena justamente a ambição e a impostura dos políticos que, com alma selvagem e linguagem cristã, provocam a morte e o sofrimento de multidões. Desgosta-lhe a hipocrisia dos invasores: apresentando-se com lugares-comuns como salvadores e alegando que pouparão crianças, velhos e mulheres, de fato pilham, escravizam, devastam e atiram bombas que matam inocentes.

Naturalmente não pensamos em Franco e em Largo Caballero, figuras que facilmente se podem transformar em símbolos. Pensamos nas populações assassinadas, nas multidões que não entram na História e sofrem porque um político ambicioso, Aníbal ou qualquer um desses de hoje, deseja crescer.

${ }^{19}$ RAMOS, Graciliano. Terra de Espanha (setembro de 1937). In: Linhas tortas. $14^{\text {a }}$ ed. Rio de Janeiro: Record, 1989, p. 156. 


\section{CAPÍTULO 3 - A TERRA DOS MENINOS IMPOSSÍVEIS}

\section{ACADEMIAS, ARTE NOVA E CANJICA: ANTECEDENTES DA NOVIDADE}

A formação dos jovens artistas e intelectuais da Novidade incluiu elementos privilegiados pelo movimento modernista de 1922 e pelo movimento regionalista do Nordeste, além de uma origem acadêmica que se acompanhou de uma perspectiva crítica em relação à realidade. Para tal compreensão contribuíram a História do modernismo em Alagoas, de Moacir Medeiros de Sant'ana, e o Documentário do modernismo, por ele organizado ${ }^{1}$.

Saliente-se, de imediato, que vários escritores da Novidade pertenceram a agremiações literárias de Maceió, nas quais desenvolveram suas tendências modernistas, regionalistas e críticas. Ora apresentarei informações de suas trajetórias nos grêmios, principalmente a partir dos livros de Moacir Medeiros.

\section{A Academia dos Dez Unidos e a reação ao futurismo}

A Academia dos Dez Unidos, fundada em 1923, reunia adolescentes sonhadores, que desejavam expressar-se por meio de uma revista literária. Cientes da hostilidade do ambiente, tinham por lema: “Um de nós vencerá". Eram eles: Félix Lima Júnior, Paulino Jorge, Mendonça Braga (autores de ensaios sobre política na Novidade) e Carlos Paurílio (poeta e contista), entre outros. Nesse mesmo ano, conheceram poemas futuristas, provavelmente de Marinetti (Lussuria Valicitá, 1920). Em 1930, findou-se a Academia dos Dez Unidos: o aperfeiçoamento dos estudos e a luta pela vida impeliram alguns de seus integrantes a deixarem Alagoas.

Moacir Medeiros, admitindo que houvesse confusão entre modernismo e futurismo para os alagoanos, contesta as teses segundo as quais não teriam recebido informação sobre o movimento modernista. Relembra sua expansão fora do eixo São

\footnotetext{
${ }^{1}$ SANT'ANA, Moacir Medeiros de. História do modernismo em Alagoas (1922-1932). $2^{\mathrm{a}}$ ed. revista e aumentada. Maceió: EDUFAL, 2003; Idem. (pesquisa e seleção). Documentário do modernismo. Maceió: UFAL, 1978. Esse livro é uma reunião de artigos publicados na imprensa alagoana entre 1922 e 1931.
} 
Paulo-Rio, em 1925, quando Guilherme de Almeida viajou pelo Brasil, estabelecendo contato em Recife com Joaquim Inojosa, principal divulgador do modernismo em Pernambuco. E a viagem de Mário de Andrade a Maceió, em dezembro de 1928, recebido por Jorge de Lima e José Lins do Rego.

Para mostrar que, mesmo nos primeiros momentos do movimento modernista, os alagoanos não lhe foram alheios, o pesquisador recorre a diversas publicações do Nordeste. Em 1924, os jornais alagoanos divulgaram a retirada de Graça Aranha ("O espírito moderno") da Academia Brasileira de Letras e publicaram poemas-piada de crítica ao futurismo, visto como uma desgraça. Gilberto Freyre (em artigo do Diário de Pernambuco, reproduzido n'O Semeador) criticava o modernismo, ressaltando a necessidade de uma reação a favor da tradição brasileira. Em 1925, Artur Ramos se opunha a Graça Aranha e aos demais futuristas do Brasil, imitadores das "baboseiras" enviadas da Velha Europa por Marinetti e Appolinaire.

As argumentações de Lima Júnior, da Academia Alagoana de Letras, em 1926, e de Valdemar Cavalcanti, em 1927, são relevantes, à medida que evidenciam problemas derivados do modernismo: o verso livre rebaixado como facilitação e a criação de falsos mitos nacionais. Lima Júnior, atacando o futurismo por ser uma panacéia para a incurável "falta de talento", afirmava que, embora devoto do parnasianismo, admitia certa liberdade para a poesia. Valdemar Cavalcanti elogiava Catulo Cearense e condenava como futilidade e mistificação as correntes Pau-Brasil (primitivistas) e Verde-amarela (nacionalistas).

Em 1926, quando da visita de Marinetti ao Rio de Janeiro, vaiado o tempo todo, o Jornal de Alagoas dirigiu-lhe ironias:

(...) não podia deixar de revolucionar os nossos meios, ou os nossos fins intelectuais um homem que prega o fechamento de bibliotecas, a extinção de museus e a queima total de Academias. (p. 134)

Emílio de Maya criticou os poemas dos futuristas brasileiros, improvisados sem idéia nem inspiração e de títulos quilométricos. Em 1928, o modernismo ainda sofria críticas: Guedes de Miranda, presidente da Academia Alagoana de Letras, lamentava que não mais se exigisse a prosa perfeita, porque o estilo moderno tinha de ser "rápido, simples, nervoso, elétrico".

Entretanto, aos poucos os alagoanos se acostumavam com o que a princípio não admitiam: a deserção de Jorge de Lima, eleito "Príncipe dos Poetas Alagoanos" em 1921, dos arraiais parnasianos. Em meados de 1927, surgia o Jorge modernista de "O mundo do 
menino impossível”. Também em 1927, Poemas, com posfácio de José Lins e, na segunda edição, no ano seguinte, posfácio de Valdemar Cavalcanti (com 16 anos). Em 1928, o folheto Essa Negra Fulô teve tal êxito, que Ranulfo Goulart, poeta da velha guarda, dedicou a Jorge de Lima o soneto "Nega Fulô".

\section{José Lins e Jorge de Lima: regionalismo e modernismo para os meninos impossíveis}

Em dezembro de 1926, como fiscal de bancos, José Lins do Rego chegou a Maceió, onde permaneceu até 1935, quando foi para o Rio de Janeiro. Adepto do Movimento Regionalista do Nordeste, influenciaria profundamente alguns jovens intelectuais alagoanos. A princípio crítico e ensaísta, contribuiu também para que compreendessem a poesia moderna. A influência do futuro autor de Menino de engenho (escrito em Maceió) se exerceu fortemente: desde 1921 sobre Jorge de Lima, de mais idade do que a geração nova de intelectuais; e a partir de 1927 sobre esses jovens, que tinham entre 15 e 19 anos (Manuel Diégues Júnior, Valdemar Cavalcanti, Carlos J. Duarte, Raul Lima, Aurélio Buarque, Mendonça Júnior etc.).

Nos depoimentos "José Lins, cronista" e "Revelações sobre José Lins do Rego", Valdemar Cavalcanti e Aurélio Buarque ${ }^{2}$, respectivamente, evocam, mais de vinte anos depois, o tempo em que se tornaram amigos de José Lins do Rego e aceitaram a poesia moderna. Mostram como foi marcante para eles a chegada, a Maceió, daquele paraibano de 26 anos, monóculo e costeletas, que colaborava aos domingos no Jornal de Alagoas. Valdemar se recorda de que José Lins, sem papas na língua, criou um "ambiente de inquietude e excitação": escrevia com paixão e sinceridade tudo o que pensava, provocando polêmicas literárias e políticas.

Aurélio conta que, graças aos artigos do futuro romancista, eles, jovens, conheceram figuras como Gilberto Freyre e Manuel Bandeira e, abandonando o culto dos antigos valores como o parnasianismo, passaram a aceitar a poesia moderna. Traduzindo uma tensão particular e de sua terra, entre o apego à tradição e o desejo do novo, Aurélio

\footnotetext{
2 CAVALCANTI, Valdemar. José Lins, cronista. In: Jornal literário. cit., pp. 237-247; FERREIRA, Aurélio Buarque de Holanda. Revelações sobre José Lins do Rego (1947). In: Seleta em prosa e verso. Organização, estudo e notas do prof. Paulo Rónai. Rio de Janeiro: José Olympio; Brasília: INL, 1979, pp. 165-174.
} 
relata o misto entre "abalo dos diabos" e satisfação que sentiu quando José Lins "desancou" um poeta semiparnasiano de Alagoas e lhe indicou novos caminhos; além disso, o futuro dicionarista admirava o crítico José Lins, porém lhe reprovava os deslizes de escrita, como "os pés felinos de gato", atacados no jornal por um velho dado a lutas gramaticais.

Se José Lins influenciou Jorge de Lima, a força do lirismo deste atuou sobre os jovens, sobretudo após a chamada "adesão" do poeta ao modernismo em 1927, com a publicação de "O mundo do menino impossível", impresso no Rio de Janeiro e dedicado a Gilberto Freyre, José Lins do Rego e Manuel Bandeira. Tamanho o poder dessa nova poesia para os moços, futuros escritores da Novidade, que foram chamados de meninos impossíveis.

Porém, em discurso de 1929, Jorge de Lima nega que tenha sido chefe de escola, futurista ou demolidor: os novos haviam descoberto que era melhor pensar por si, ainda que errado, em Maceió do que certíssimo na terra dos outros. Recordando-se de que fôra atacado como futurista até acolherem enfim o seu "menino impossível", o poeta enfatiza que desejava o clássico e as tradições alagoanas, brasileiras. Buscando equilíbrio, voltavase contra estrangeirismos, "exageros" como a antropofagia modernista, desrespeitos à Academia Alagoana de Letras ou ao Instituto Histórico e Geográfico.

No entanto, eu não queria então nem futurismo, nem maluqueiras. Eu queria era o clássico. A tradição. $\mathrm{O}$ que era nosso. E o que era humano.

Eu queria a terra do Brasil. As coisas de Alagoas. O Nordeste. A nossa imperfeição.

A mocidade dessa Alagoas estava era empanturrada de estrangeirismos; de helenismos, de banvilismos, de lecontismos, de besteirismos. $^{3}$

Assim, é marcante a tendência regionalista de Jorge de Lima, apegado a uma tradição brasileira, que abarca o tupi, o africano e o português. Afirmou que combateria o futurismo caso existisse e lamentou, numa alusão a Joaquim Inojosa, que uma campanha de pilhérias quisesse sujar essa tradição.

Ao mesmo tempo, é marcante a tendência modernista do poeta alagoano: leitor de Jean Cocteau, saúda os intelectuais que se revoltam e se empenham pela libertação

\footnotetext{
${ }^{3}$ LIMA, Jorge de. A propósito de futurismo. Jornal de Alagoas, 28 jun. 1929, p. 1. Apud SANT’ANA, Moacir Medeiros de. História do modernismo em Alagoas (1922-1932). cit., p. 42.
} 
poética. E reconhece como incongruente o ideal futurista para os parnasianos de Alagoas, que jamais haviam visto sobrados mais altos que os da rua do Comércio.

José Paulo Paes depreende argutamente da "poesia localista" de Jorge de Lima uma tensão entre a "modernidade da visão" e o "provincianismo do visto", a qual se resolve "menos numa recusa perempta do anacrônico que num reconhecimento (um ver com olhos novos) de índole a um só tempo nostálgica e irônica" ${ }^{4}$. Sublinha que a nostalgia ante o paradoxo moderno/arcaico se acompanhava do olhar crítico do poeta para a questão social, antecipando a prosa de 30 .

\section{O Cenáculo, a Festa da Arte Nova e a revista Maracanan (1928)}

Como se vê, em Alagoas o surgimento do novo não se dissociou do respeito à tradição. Em 1928, numa solenidade para a nova diretoria do Cenáculo Alagoano de Letras (fundado em 1926), Mendonça Júnior fez o elogio de Ciridião Durval, patrono de sua cadeira e que tinha sido poeta da velha escola.

Sob o pseudônimo Armênio, Valdemar Cavalcanti, também sócio do Cenáculo, estranhou que Mendonça Júnior, já às voltas com o modernismo, desejasse "imortalizarse" e se "academizar" no Cenáculo por meio daquele elogio. Mas provavelmente foi o mesmo Valdemar o jornalista anônimo que noticiou ter Mendonça Júnior fustigado corajosamente os velhos moldes literários e causado riso à assistência da solenidade.

Durante o elogio a Ciridião Durval, Mendonça Júnior propôs que se realizasse em Alagoas uma Semana de Arte Moderna, nos moldes do modernismo paulista de 1922. A idéia logo contou com a adesão do pintor Lourenço Peixoto (futuro xilógrafo da Novidade), que se comprometeu a preparar uma exposição, além de Carlos Paurílio, Mário Brandão e Valdemar Cavalcanti.

Publicou-se uma carta n' $O$ Semeador (periódico católico), para esclarecer que, embora quatro integrantes do Cenáculo tivessem promovido a Festa da Arte Nova "Semana de Arte Moderna de um dia só" de Alagoas -, a agremiação não era patrocinadora de sua parte literária. Paurílio, Cavalcanti, Mendonça Júnior e Mário Brandão leriam seus trabalhos modernistas e "não críticas ofensivas", sem a

\footnotetext{
${ }^{4}$ PAES, José Paulo. Revisitação de Jorge de Lima. In: Armazém literário: ensaios. Organização e apresentação de Vilma Arêas. São Paulo: Companhia das Letras, 2008, pp. 138-143.
} 
responsabilidade do Cenáculo. A correspondência enfatizava que o grêmio, como a Academia Alagoana de Letras, abarcava diferenças - tanto os "passadistas conscientes" como os "modernistas extremados"-, concedendo a todos liberdade de opinião, porém evitando ferir suscetibilidades com excessos de partidarismo.

O convite da Festa da Arte Nova era em formato de losango, influência dos vanguardistas de São Paulo, conforme destaca Moacir Medeiros. Mas repare-se a formalidade própria da província, flagrante na mesóclise e no tratamento por V. Excia.

\author{
Junho \\ 17 \\ Domingo \\ 1928 - Realizar-se-á \\ no \\ INSTITUTO ROSALVO RIBEIRO \\ à Avenida Presidente Bernardes, $\mathrm{n}^{\circ} 362$
}

A

\author{
FESTA DA ARTE NOVA \\ Convidam V. Excia. e Família: \\ Lourenço Peixoto, Mendonça Júnior, \\ Valdemar Cavalcanti, \\ Mário Brandão, \\ Carlos Paurílio.
}

E na Festa foi afixado o dístico usado em 22 em São Paulo, ditado por Mendonça Júnior com a devida adaptação: “A FESTA DA ARTE NOVA É UM ZÉ-PEREIRA CANALHA PARA DAR UMA VAIA DEFINITIVA NOS DEUSES DO PARNASO..... 5

Valdemar Cavalcanti anunciava n'O Semeador que um "bando de jovens" tentariam realizar na província, ambiente "tão cheio de pudores e de academismo", a Festa da Arte Nova, "festa de inteligência, de sonoridade, de inquietude". Moacir Medeiros nos oferece o Programa da Festa, que não foi cumprido totalmente ${ }^{6}$ :

\footnotetext{
${ }^{5}$ A referência de Moacir Medeiros é: RAMIL. Comentários. Jornal de Alagoas, 19 jun. 1928, p. 3. É ótimo que ele esclareça ser Ramil anagrama de Raul Lima - esse cronista colaborou na Novidade com ambas as assinaturas. (SANT'ANA, Moacir Medeiros de. História do modernismo em Alagoas (1922-1932). cit., p. 23).

${ }^{6}$ Esse Programa saiu no Jornal de Alagoas, 17 jun. 1928, p. 6. (Apud SANT’ANA, Moacir Medeiros de. História do modernismo em Alagoas (1922-1932). cit., p. 24).
} 


\section{PROGRAMA}

Às 16 horas

Abertura da exposição de quadros modernos, falando Mendonça Júnior sobre 0 incêndio do Olimpo e os símbolos de nossa raça.

\section{Às 19:30 horas}

Hora da Arte Nova

1 - Carta de Jorge de Lima a Carlos Paurílio sobre a "Arte Nova Brasileira"

2 - Jayme de Altavila - "A velha casa colonial"

3 - Mário Brandão - "O beliscão"

4 - Mendonça Júnior - "Ritmos bárbaros"

5 - José Lins do Rego - "Idéias novas"

6 - Carlos Paurílio - "3 poemetos"

7 - Valdemar Cavalcanti - "Literatura Moderna e Arte Nova"

8 - Emílio de Maya - "Versos modernos"

\section{E depois?}

DANÇAS

Abrilhantarão a festa o Jazz-Band dos Meninos, executando um lindo programa de charlestons, tangos e fox-trots.

No discurso de abertura da Festa, José da Costa Aguiar, da desaparecida Academia dos Dez Unidos, então bacharelando de Direito em Recife, apresentou a nova literatura, diferenciando-a do Futurismo de Marinetti, classificado como absurdo. Antes de ser lida a carta de Jorge de Lima, declamou-se seu poema moderno "Água de açude", ao que parece não conservado. Jaime de Altavila não leu “A velha casa colonial”, porque, atrasado, não pôde atravessar a "muralha humana" entre a porta e a mesa das sessões. Esse poema foi publicado em Canto nativo, de 1949.

“O beliscão", conto regional de Mário Brandão, saiu no Jornal de Alagoas dias depois. O sertão era o cenário de "Ritmos bárbaros", versos modernos de Mendonça Júnior. Quanto aos versos de Emílio de Maya, também modernos, e de conotações regionalistas, intitulavam-se "Meu Brasil do Nordeste”. Não se guardaram esses poemas, nem se conhecem os títulos dos "poemetos" de Carlos Paurílio. José Lins do Rego não compareceu, nem a imprensa explicou sua ausência.

Poeta e contista, Carlos Paurílio, um dos organizadores da Festa, assinou um manifesto aos intelectuais paulistas. Provável resposta é a carta e o poema "A noite africana" (do livro então no prelo República dos E.E.U.U. do Brasil) que Menotti del 
Picchia enviou aos promotores da Festa da Arte Nova. Como não chegaram a tempo de serem lidos, os "Versos inéditos de Menotti del Picchia" foram publicados no Jornal de Alagoas em julho. E em setembro figuraram na revista Maracanan, sob a epígrafe "Saudades da Festa da Arte Nova". Na carta, Menotti saúda "a revolução das consciências novas", enfatizando um viés patriótico.

Em "A gostosa pateada dos modernos", Valdemar Cavalcanti tratou da Festa da Arte Nova: foi a "primeira vaia" dos novos às coisas acadêmicas, combate à "arte indolente" dos antigos. Seu dever era escandalizar, provocar uma revolução no meio, com a "gritaria fantástica dos verbos novos e a algazarra das cores espalhafatosas". 7

Houve a "Festa das Cores", exposição de telas de Lourenço Peixoto, Messias de Melo, Luiz Silva, Eurico Maciel, Zaluarte de Santana e José Menezes. No entanto, os dois últimos não apresentavam tendência modernista alguma. Já Lourenço Peixoto, com "Negra Fulô", "Almocreve" e, sobretudo, "Corista", foi o destaque, "o inventor do modernismo na arte, em Alagoas", segundo o parecer de Valdemar Cavalcanti. E o segundo melhor quadro da exposição seria "Flor de lótus", de Messias de Melo, que também apresentou caricaturas de Carlos Paurílio e de Valdemar Cavalcanti. Após a mostra, apenas Lourenço Peixoto e Luiz Silva se afastaram dos velhos cânones artísticos; ambos contribuíram na Novidade com a arte de suas xilogravuras.

Em setembro de 1928, com a epígrafe "Arte e Pensamento", surgiu a revista Maracanan, porta-voz da Festa da Arte Nova. Tinha por diretor artístico Lourenço Peixoto, autor da capa da revista - uma arara ensaiando o vôo (do "pensamento moço") sobre uma palha de coqueiro - e da xilogravura "Oração" (Esta também aparece na Novidade 4, de 02 de maio de 1931, p. 12).

Em “La vae mecha!”, artigo de apresentação, Da Costa Aguiar assegurou aos acadêmicos que não iria devorá-los, mas oferecer a liberdade de pensamento na vertigem moderna. Depois vinham, dentre outros: os textos em prosa "Caderno de lembranças", de Carlos Paurílio, e "O verdadeiro símbolo", de Barreto Falcão; os poemas "O elogio lírico do vento", de Aloísio Branco, "Moça fugida", de Jorge de Lima, "Poema de todos os dias”, de Valdemar Cavalcanti, "O teu escravo”, de Mendonça Júnior, “Árvore humana”,

\footnotetext{
${ }^{7}$ CAVALCANTI, Valdemar. A gostosa pateada dos modernos. A República, Maceió, 20 jun. 1928, p. 1. Apud SANT'ANA, Moacir Medeiros de. Documentário do modernismo. cit., pp. 71-2; Idem. História do modernismo em Alagoas (1922-1932). cit., p. 30.
} 
de Aurélio Buarque de Holanda; a já referida carta de Menotti del Picchia e o poema "A noite africana".

$\mathrm{Na}$ seção "Cadernos de poesias", figuravam o soneto "Condor”, de Clóvis de Holanda, e "Palácio do sonho", trecho do cancioneiro Noivado, de Aristeu de Andrade (de 1900), ambos então falecidos. Como observa Moacir Medeiros, é curioso que uma revista de novos, de vanguarda, tenha dado guarida a trabalhos de escritores da velha escola.

Ao contrário do que se desejava, Maracanan não passou do primeiro número. Porém, contribuiu com a divulgação de artigos sobre a renovação dos valores artísticos no meio alagoano, ficando como registro do impulso realizador dos jovens da época. São palavras provavelmente de Carlos Paurílio, um dos faz-tudo da revista:

MARACANAN nasceu. Foi um parto difícil, foi. Mas nasceu mesmo. E nasceu sem defeitos. Não é nenhuma aleijada não. $\mathrm{O}$ mau agouro não pegou. Agora vai andar na boca dos néscios e dos despeitados: Maracanan só dura um mês! Pode ser. Ela é mortal. É humana. Não tem pruridos de eternidade. Isto fica para os acadêmicos.

Em abril de 1929 o Cenáculo Alagoano de Letras já não existia, tendo vários de seus membros ingressado no Grêmio Literário "Guimarães Passos".

\section{O Grêmio “Guimarães Passos” (1927) e a Canjica Literária (1929)}

Em 1927, após a publicação d' "O mundo do menino impossível" de Jorge de Lima, Manuel Diégues Júnior (de quem já analisei “A propósito de guerra”, N 16) fundou em sua residência o Grêmio Literário "Guimarães Passos”, junto com Aurélio Buarque, Valdemar Cavalcanti, Raul Lima e outros. Seu objetivo era desenvolver a inteligência da gente moça do Brasil.

Conforme mostra Moacir Medeiros, de início os rapazes do Grêmio eram fiéis à escola literária do patrono, Guimarães Passos (1867-1909), primeiro alagoano a ingressar na Academia Brasileira de Letras. Não repudiavam os valores antigos, tanto que chegaram a prestigiar Coelho Neto. Começavam com alexandrinos e rimas ricas, parnasianos como os antigos, presos a um mundo anterior à Primeira Guerra. Porém, aos poucos compreenderam a poesia de Jorge de Lima e então prepararam uma festa moderna com elementos regionalistas. 
A Canjica Literária, a 23 de junho de 1929, foi a primeira manifestação pública da adesão de integrantes do Grêmio "Guimarães Passos" ao modernismo. Após explicações de Diégues Júnior, uma banda de pífanos e dois repentistas apresentaram emboladas e desafios, à tarde, no Cinema Floriano. A parte noturna transcorreu no Clube de Regatas Brasil, com sambas de sabor regional e trabalhos literários de características modernistas e regionalistas.

Raul Lima falou dos "Méritos da Canjica"; declamou-se um poema inédito de Jorge de Lima; Carlos J. Duarte leu o conto regional "Miss Boneca de Milho"; Abelard de França fez o "Elogio da pamonha"; Diégues Júnior leu os versos "Traque de chumbo", publicados no jornal como "Meu tempinho de menino".

Moacir Medeiros ressalta que, realizada um ano antes (1928) por integrantes do Cenáculo Alagoano de Letras, a Festa da Arte Nova, embora tenha representado a introdução "oficial" do Modernismo em Alagoas, pecou por certa falta de brasilidade. Por exemplo, executou ritmos musicais estrangeiros, como charlestons, fox-trots e tangos. Já a Canjica Literária, de 1929, teve conotações mais caracteristicamente brasileiras, sobretudo regionalistas.

Entre 1928 e 1930, o Grêmio Literário “Guimarães Passos” promoveu diversas festas culturais, como homenagens a seu patrono, a Castro Alves, a Oscar Wilde, a José de Alencar. Em 1930, o Grêmio passou a ser Academia “Guimarães Passos”, tendo provavelmente terminado em 1934.

Moacir Medeiros relata que Jorge de Lima, ileso de um atentado a tiro em 31 de agosto de 1931 (provavelmente por perseguições políticas), decidiu mudar-se para o Rio de Janeiro. Como o poeta e ensaísta Aloísio Branco também ia para o Rio, um jantar de despedida foi oferecido a 26 de setembro no Bar Alemão pelo grupo da Novidade. Por isso, os tópicos "Um jantar" e "O jantar a Aloísio Branco" aparecem nos dois últimos números da revista. ${ }^{8}$ Segundo o pesquisador, a viagem dessas duas maiores figuras do modernismo em Alagoas encerrou a fase mais importante do movimento na província.

\footnotetext{
${ }^{8}$ Cf. a seção “Se o Aloísio Branco consentir": um inquieto em busca dos sentidos, no capítulo 6.
} 


\section{Um olhar crítico sobre a região}

Praticamente lacunas da historiografia literária, merecem ênfase o conhecimento de Marinetti pelos alagoanos da Academia dos Dez Unidos (1923-1930) e a existência da Festa da Arte Nova, com sua revista Maracanan (1928), seguida da festa regionalista Canjica Literária (1929).

Observando que houve em Alagoas rejeição ao futurismo, visto como cisão com o passado, Moacir Medeiros a atribui ao fato de a tradição se conservar menos marcada por influências alienígenas no Nordeste. Chama a atenção para a coexistência, em Alagoas, de críticas contrárias ao modernismo e elogios à chamada Arte Nova. $\mathrm{O}$ fato é que os jovens alagoanos queriam inovar sem desprezar a tradição. ${ }^{9}$

Quanto à Festa da Arte Nova, em 1950 Valdemar Cavalcanti se referiu a ela como "uma ruidosa e caricatural manifestação modernista" ${ }^{10}$. Soa mesmo paradoxal que uma idéia renovadora como a da Festa tenha surgido numa Academia e em meio do elogio ao sonetista de "Amor materno". Curiosamente, esse poema de Ciridião Durval foi resgatado na seção "Versos de antigamente" da Novidade 19 (agosto de 1931).

Parece-me que, para os intelectuais da revista Maracanan (que também publicou poemas parnasianos) e, depois, da Novidade, conviviam a recusa de formas antigas, ou melhor, o desejo do novo, de liberdade para escrever, e o valor da tradição. Na singularidade de seu caminho alagoano, apresentam semelhanças a um tempo com o modernismo de 1922 e com o regionalismo de 1926: tanto o anseio pelo novo como pela formação de uma tradição eram necessidades. Veja-se certa ambigüidade entre aproximação e distanciamento em relação ao soneto de Ciridião Durval, apresentado com um tom que contém afetividade pelo passado da região, senso de dever histórico e uma dose de ironia ao excesso de preciosidades dos antiqüíssimos sonetistas:

Noutros tempos os jornais de Maceió tinham os seus "Cofres de Pérolas" ou "Escrínios Literários", nomes que se davam a um canto de página onde saíam, dentro de uma abundância formidável de vinhetas, as preciosidades poéticas de então. Eram sonetos a três por dois. Junto ao título um passarinho levava ao bico um envelope ou uma linda cestinha de

\footnotetext{
${ }^{9}$ Em 1926, em Alagoas, houve repúdio ao futurismo, até apontado como "fascismo na literatura". Mas em São Paulo também o futurismo foi rejeitado; basta lembrar os problemas que Mário de Andrade teve com o artigo "O meu poeta futurista" (1921), que Oswald de Andrade escreveu sobre ele. E se Mário consentia em ser chamado de original, extravagante, maluco, não era futurista, nem aceitava ser atrelado a escolas. (Cf. BRITO, Mário da Silva. História do modernismo brasileiro - I. Antecedentes da Semana de Arte Moderna. $2^{\text {a }}$ ed. rev. Rio de Janeiro: Civilização Brasileira, 1964).
}

${ }^{10}$ SANT'ANA, Moacir Medeiros de. História do modernismo em Alagoas (1922-1932). cit., p. 26. 
flores. É como uma espécie de documento histórico que NOVIDADE publica hoje, quase na véspera de centenário da imprensa alagoana, estes sonetos de antiquííssimos poetas de Alagoas.

Assim, é importante saber que a Festa da Arte Nova se realizou, conciliando a abertura para o verso livre, inovações na pintura e traços regionalistas. Seu aspecto caricatural deriva de base histórica: mesmo seis anos depois da Semana de Arte Moderna de São Paulo, existe em Alagoas certa estreiteza provinciana diante das técnicas poéticas e materiais da modernidade, mais difundidas e aceitas no sul do país. Ao mesmo tempo, guardando uma espécie de resistência, o aspecto caricato terá por contraparte o interesse mais premente em Alagoas pela renovação político-social do país, marca da produção dos escritores da Novidade.

\section{A Liga contra o Empréstimo de Livros e a Festa de Arte Moderna}

Prova dessa preocupação dos meninos impossíveis com os problemas brasileiros foi a criação da Liga contra o Empréstimo de Livros. Depois de apresentar o que foi a revista Novidade, Moacir Medeiros nos possibilita saber sobre essa iniciativa do grupo do semanário. A Liga foi fundada em Maceió, em fevereiro de 1932, por Alberto Passos Guimarães, Carlos Paurílio, Luiz Ramalho de Azevedo, Manuel Diégues Júnior, Raul Lima e Valdemar Cavalcanti. Nela ingressaram, entre outros, José Lins do Rego, Mendonça Braga, Théo Brandão, Abelardo Duarte, Aurélio Buarque de Holanda, Moacir Pereira, Santa Rosa Júnior.

De forma chistosa, Valdemar Cavalcanti publicou no Jornal de Alagoas, a 6 de março de 1932, "Os dez-mandamentos (contra o empréstimo de livros) e suas explicações". Alberto Passos Guimarães complementou-os com o artigo "Sobre um programa de ação" (Jornal de Alagoas, 13 mar. 1932, p. 3).

A Liga visava a "despertar o interesse da comunidade alagoana pelas coisas do espírito". Realizou, então, a Festa de Arte Moderna, no Instituto Histórico de Alagoas, em agosto de 1932. Santa Rosa Júnior fez uma exposição de desenho e pintura, e Valdemar Cavalcanti falou sobre o movimento moderno em pintura ${ }^{11}$. Em seguida, coube a Manuel Diégues Júnior uma palestra sobre a música moderna: as primeiras

\footnotetext{
${ }^{11}$ Cf. a seção "Meus livros são teus livros": Santa Rosa, no capítulo 6.
} 
inovações de Debussy; a influência da guerra no movimento modernista; as tendências ecléticas da música, abertas com o Grupo dos 6, da França; o papel do jazz; a música moderna no Brasil (Villa Lobos, Lorenzo Fernandez, Gallet). Dentre outras composições, ilustraram a palestra, ao piano, o "Arabesque n ${ }^{\text {2 }}$ ", de Debussy, e "Kankukus" ("Dança dos Velhos"), das "Danças Africanas" de Villa Lobos. Continuação do espírito da Novidade, a Liga era contra as velhas praxes de conferências cujos oradores se exibiam livrescos, superiores ao auditório. Propunha palestras amplamente explicativas, a fim de orientar a sociedade sobre a arte moderna.

Com o propósito de construir um abrigo para menores abandonados, a Liga realizou em pavilhão na Praça D. Pedro II uma Grande Feira de Livros, "para vendagem popular absolutamente acessível a todos”. Doados por dezenas de pessoas, foram então vendidos cerca de 1500 volumes. O grande saldo positivo da feira "foi colocar em mãos pobres, sob o preço menor possível, os livros que, pelo seu elevado custo, não lhes era permitido adquirir nas livrarias". ${ }^{12}$

Assim, a Liga constituiu uma ação movida pela mesma preocupação com o abandono social e cultural em Alagoas, a qual impulsionara os artigos de política e de literatura da Novidade. Ressalte-se que a Biblioteca Municipal de Maceió foi inaugurada em 1938, muito em função do empenho de Aurélio Buarque de Holanda, seu diretor e organizador, que obteve cerca de 4000 volumes em menos de um ano. ${ }^{13}$

\footnotetext{
${ }^{12}$ LIGA Contra o Empréstimo de Livros. Nota Oficial, Jornal de Alagoas, 5 maio 1932, p. 1. Apud SANT’ANA, Moacir Medeiros de. História do modernismo em Alagoas (1922-1932). cit., p. 237.

${ }^{13}$ Cf. DIÉGUES JÚNIOR, Manuel. Evolução urbana e social de Maceió no período republicano (Rio, nov. 1939). In: COSTA, Craveiro. Maceió. Vinhetas de Santa Rosa. Rio de Janeiro: José Olympio, 1939, p. 210. Cf. a seção Claro e denso, o horizonte das palavras: Aurélio, no capítulo 6.
} 


\section{O MUNDO PELADO SE FAZ DE CONTA}

(Novidade entre os mais velhos: Jorge de Lima e Graciliano Ramos)

Ora, o poeta é da raça dos incontentáveis. (...) O poeta é da têmpera dos que não se satisfazem unicamente com pão e sabe que a humanidade sempre se rirá dele, sempre zombará de suas palavras, de suas profecias, de seus protestos, de sua incapacidade de adaptação ao comum.

Jorge de Lima. ${ }^{14}$

Após a leitura da História do modernismo em Alagoas (1922-1932), de Moacir Medeiros de Sant'ana, conheci que, no horizonte de meu trabalho, se configuraria um arco entre $O$ mundo do menino impossível (1927), de Jorge de Lima, e A terra dos meninos pelados (1937), de Graciliano Ramos.

O poema de Jorge de Lima perfaz um movimento de recusa ao exterior e superficial e de busca por uma experiência autêntica a partir do cotidiano. Tal movimento de certa forma condensa a significação da revista Novidade na história literária brasileira. Nesse mesmo sentido, permite a alusão ao embate do menino Raimundo (d'A terra dos meninos pelados) com o mundo estereotipado, o qual aponta para o caminho pessoal de Graciliano, reconstruído na plenitude artística de Infância. Significativamente, no Rio de Janeiro, saído da prisão, quando escrevia A terra dos meninos pelados, o romancista mandava lembranças a companheiros do tempo da Novidade (os meninos impossíveis Valdemar Cavalcanti, Aurélio Buarque, Diégues Júnior, Barreto Falcão), em cartas à esposa Heloísa, chamando-os com afeto de "meninos pelados" 15.

A princípio, minha atenção se centrará no "menino impossível” de Jorge de Lima. Como já observei, ele é ao lado de Graciliano um dos trinta-anos independentes que se juntaram à geração de vinte-anos desencantados para criar a Novidade, aos quais Valdemar Cavalcanti se refere no "Cartão de visita". O médico e poeta alagoano Jorge de

\footnotetext{
${ }^{14}$ LIMA, Jorge de. Compreensão da poesia (1938-39). Auto-retrato intelectual. In: Poesia completa: volume único. Org. Alexei Bueno; textos críticos: Marco Lucchesi et al. Rio de Janeiro: Nova Aguilar, 1997, p. 37.

${ }^{15}$ RAMOS, Graciliano. Cartas a Heloísa de Medeiros Ramos. Rio de Janeiro, 1937, fevereiro, março e abril (n. 90, 92, 94, 95, 97, 101). In: Cartas. $7^{\text {a }}$ ed. Rio de Janeiro: Record, 1992.
} 
Lima (1893-1953), que viveu praticamente o mesmo intervalo de tempo que Graciliano (1892-1953), contava 38 anos quando escreveu para a Novidade os artigos "Nota religiosa" (N 3, p. 4) e "Padre Feijó - uma página do livro inédito Notas sobre o sentimento religioso no Brasil" (N 5, p. 11), ao que parece até hoje não publicados em livro. Neles, respectivamente, o autor sublinha a tradição jesuítica de Nóbrega e Anchieta e apresenta a figura enérgica do Padre Feijó, preocupado antes com o Estado do que com a religião. Já se verifica nesses artigos a inquietação com a questão religiosa, que marcaria a poesia de Jorge sobretudo a partir de 1935.

Mais do que esses textos, cumpre neste momento analisar "O mundo do menino impossível"16, a fim de compreender por que teve grande importância para os jovens da Novidade, chamados de meninos impossíveis. A força lírica do poema se irradia desde o título. Sua combinação de palavras, ao potenciar uma ambigüidade do adjetivo “impossível”, anuncia o desajuste recíproco menino-mundo e a possibilidade fantasiosa de superação. O título instiga a que se adivinhe o teor da ambigüidade da expressão "menino impossível". De um lado, o mundo convencional não o agüenta, ninguém pode com sua agitação e inquietação, com suas artes e reinações. Ao mesmo tempo, o menino é impossível porque não pode ser, precisa encontrar meios para existir. Numa contaminação pelo adjetivo, lê-se que o mundo é impossível, insuficiente para o menino inadaptável.

Jorge de Lima construiu esse "impossibilismo" 17 do menino desdobrando o poema num movimento duplo: o menino quebra os brinquedos importados que ganhou dos avós, para inventar, sozinho, com os objetos de seu cotidiano e seu faz-de-conta, os próprios brinquedos, criando novas formas de habitar o mundo.

"Fim da tarde, boquinha da noite": esse verso que abre o poema, sem verbos e com um diminutivo, cria um cenário de serenidade e afeto para a transição entre o dia que termina e a noite que se abre, qual um bocejo, para o sono das crianças. O eu-lírico parece reviver uma sensação antiga dos últimos sinos da igreja, das primeiras estrelas e da lua

\footnotetext{
${ }^{16}$ LIMA, Jorge de. O mundo do menino impossível. Poemas. In: Poesia completa: volume único. cit., pp. 203-5.

${ }^{17}$ Em “"Menino impossível' da poesia brasileira”, Benjamin Lima usa a expressão "impossibilismo" para referir-se à puerilidade e à poesia puras de Jorge de Lima. E imagina o adjetivo "impossível" segundo a entonação especial das "lindas mães brasileiras" em suas "zangas encantadoramente fingidas". (LIMA, Benjamin. Esse Jorge de Lima. Rio de Janeiro: Adersen Editores, 1933. Apud LIMA, Jorge de. Poesia completa. cit., pp. 78-81).
} 
cheia, céu dos poetas melancólicos. Recompondo assim o clima propício para se recolherem o sol e os meninos, "as duas coisas novas desse mundo", aproxima-se da infância e de sua vitalidade. Veja-se que até o Eclesiastes, com a vanidade de tudo, é subvertido, tamanho o desejo do eu-lírico pelo novo, tão intensa sua aposta no poder criador próprio do sol e dos meninos.

Jorge de Lima criou ilustrações para $O$ mundo impossível do menino (o adjetivo qualificava o mundo), no folheto impresso no Rio de Janeiro em 1927. Nessa versão inicial, o primeiro verso era tão-só "Lusco-fusco", também síntese da passagem entre o entardecer e o anoitecer, porém isenta da carga afetiva da solução poética posterior. Por outro lado, havia uma estrofe sobre o aconchego dos ninhos, em que os pintinhos sonham.

\section{O mundo impossível do menino}

Lusco-fusco

As primeiras estrelas

vêm ouvir

os derradeiros sinos.

As velhas luas

vêm chorar

com os últimos poetas.

Os ninhos vão dormir

Os pintinhos vão sonhar

O senhor D. Galo

deixa de galantear.

E as duas únicas

cousas novas

desse mundo:

o sol e as crianças

vão deitar-se.

\section{O mundo do menino impossível}

Fim da tarde, boquinha da noite com as primeiras estrelas e os derradeiros sinos.

Entre as estrelas e lá detrás da igreja, surge a lua cheia para chorar com os poetas.

E vão dormir as duas coisas novas desse [mundo:

O elo de proteção destinado às crianças completa-se com o acalanto da "Mãe-negra Noite", numa alusão à natureza maternal das escravas africanas do Nordeste brasileiro. Contudo, nesse cenário afetivo do sono de "crianças mansas", desponta, a velar, o menino impossível:

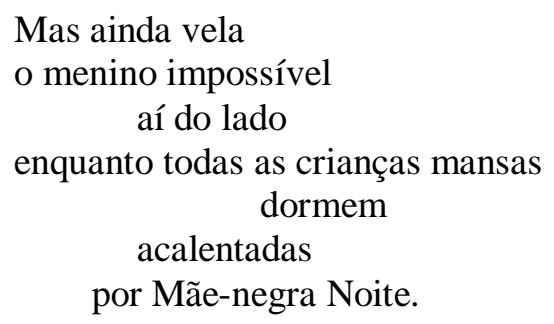


O menino impossível

que destruiu

os brinquedos perfeitos

que os vovós lhe deram:

A rebeldia de seu ato, de destruir os "brinquedos perfeitos", traduz-se na enumeração destes por meio de versos livres e de uma mescla de línguas que acompanha a procedência dos bonecos, carrinhos e trens: "as poupées de Paris", "o polichinelo italiano / made in England", "o trem de ferro de U.S.A.", "o macaco brasileiro / de Buenos Aires / moviendo la cola y la cabeza". É interessante lembrar, do editorial "Estados Unidos do Brasil" (Novidade 4), que Alberto Passos Guimarães criticava como doloroso o "desencontrado cosmopolitismo dos brinquedos" da época. Provavelmente faltava a estes brinquedos o necessário elemento de singularidade que cativasse uma identificação - que fossem menos industriais e mais humanos, flexíveis a novas formas, próprias da realidade das crianças e da afetividade da tradição regional.

Ajuda a compreender o gesto revoltado do menino impossível a crítica de Roland Barthes nos anos 1950 aos brinquedos franceses, a qual pode estender-se a todos os brinquedos industriais. Estes sempre significam alguma coisa ligada às técnicas da vida moderna adulta, como o exército, a medicina, os transportes. São brinquedos de imitação, que, prefigurando funções humanas literalmente, preparam as crianças para aceitá-las e morrem rapidamente. Diante desses "objetos fiéis e complicados", em geral de plástico e não de madeira, os meninos são como proprietários que utilizam o mundo, nunca o inventam ${ }^{18}$. Também Walter Benjamin, em 1928, apontava que os brinquedos mais atraentes para os adultos são menos autênticos, pois se distanciam dos "instrumentos de brincar", das possibilidades de as crianças criarem para si "o pequeno mundo próprio" ${ }^{19}$.

Então, à perfeição dos brinquedos importados que não satisfaziam as exigências da imaginação do menino impossível opõe-se uma inteireza outra, das brincadeiras não estabelecidas, em aberto, inventadas por ele com os objetos da natureza que faziam parte de seu cotidiano, como sabugos, paus, pedrinhas:

\footnotetext{
${ }^{18}$ BARTHES, Roland. Brinquedos. In: Mitologias. Tradução de Rita Buongermino, Pedro de Souza e Rejane Janowitzer. $2^{\text {a }}$ ed. Rio de Janeiro: Difel, 2006, pp. 59-62.

${ }^{19}$ BENJAMIN, Walter. 8. Velhos brinquedos. Sobre a exposição de brinquedos no Märkische Museum; 9. História cultural do brinquedo (1928). In: Reflexões sobre a criança, o brinquedo e a educação. Tradução, apresentação e notas de Marcus Vinicius Mazzari. Posfácio de Flávio Di Giorgi. São Paulo: Duas Cidades; Ed. 34, 2002, pp. 85, 93. Agradeço a Alexandre Koji Shiguehara lembrar-me desses ensaios.
} 
O menino impossível

que destruiu até

os soldados de chumbo de Moscou

e furou os olhos de um Papá Noel,

brinca com sabugos de milho,

caixas vazias,

tacos de pau,

pedrinhas brancas do rio...

O eu-lírico prioriza o faz-de-conta do menino, alçado de sua realidade: ouve mugirem sabugos e balirem pedras, apiedando-se dessas ovelhas, afastadas das mães por "currais de papelão". Significativamente, transforma tacos em cangaceiros, não em soldadinhos de chumbo: como se verá na Novidade, aqueles concentravam a imagem do heroísmo nordestino.

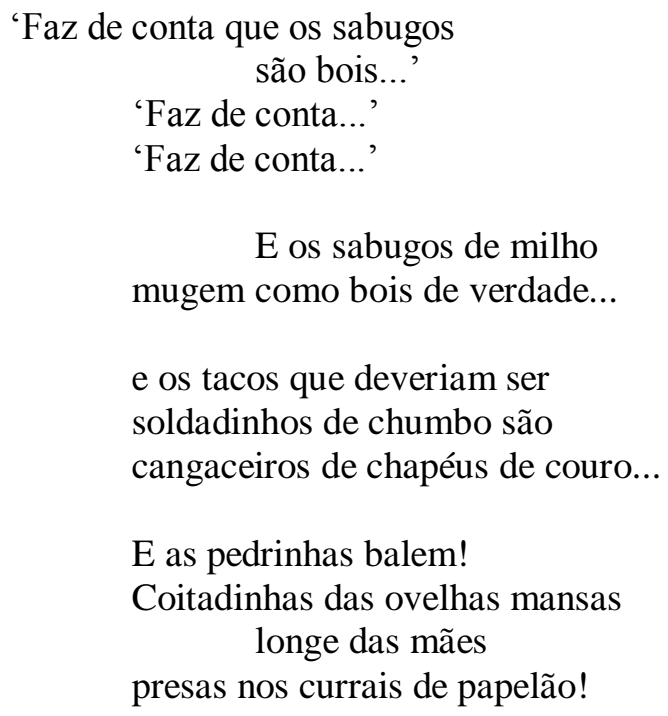

Se o universo infantil conta com a simpatia do poeta, tem-na em especial o menino impossível, porque "povoou sozinho" o seu mundo.

É boquinha da noite no mundo que o menino impossível povoou sozinho! ${ }^{20}$

Agora é esmeradamente simples a construção do espaço interno da casa à noite, afetivo e fantasmagórico:
A mamãe cochila.
O papai cabeceia.
O relógio badala.

\footnotetext{
${ }^{20}$ A versão inicial era: "Faz lusco-fusco / no mundo que o menino impossível / povoou sozinho! // É tão tarde!" (grifos meus). Na segunda versão, a opção por "boquinha da noite" agora parece condensar os sentidos denotativo de "lusco-fusco" e afetivo de "É tão tarde!".
} 
Três versos curtos, formados de frases diretas apenas com sujeito e verbo intransitivo (e verbos carregados dos sentidos de sono, sonho e passagem do tempo), revelam como a solidão do menino não é absoluta, porque ele tem a protegê-lo, próximos e distantes, os pais que cochilam, além dos minutos da infância. E aqui ficam claramente indissociáveis o menino impossível e o poeta, cuja companhia é a recomposição de seu projetar-se em sonhos desde criança. Menino e poeta impossíveis aplacam sua solidão construindo um mundo a partir da matéria real (os objetos cotidianos), da tradição (os pais distantes tornados próximos) e do esforço de sua imaginação poética (o faz-de-conta verbalizado em palavras).

Compensando o seu desamparo no mundo pelo potencial imagético de suas criações pessoais, o menino se entrega ao sono e aos sonhos: a fantasmagoria da lâmpada na parede é "noite encantada". Assim, aplicando-se com imaginação a elementos simples, acompanhado do silêncio e da escuridão, cria um mundo maravilhoso:

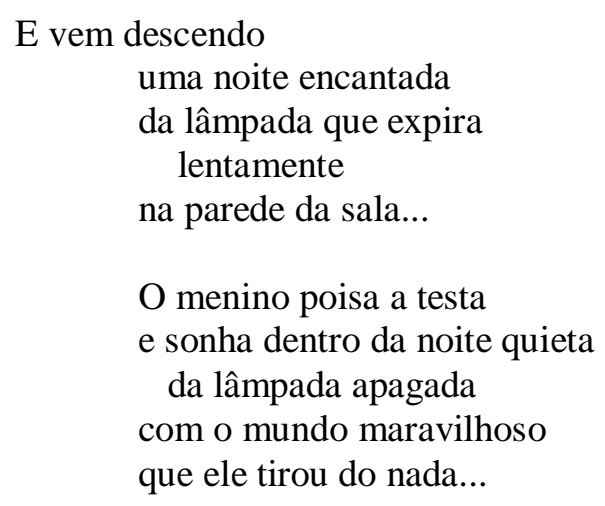

Por fim, incorporando a cantiga de ninar do folclore nordestino, o poeta afasta do menino o mal, para proteger-lhe o soninho.

\section{Xô! Xô! Pavão! \\ Sai de cima do telhado \\ Deixa o menino dormir \\ Seu soninho sossegado! ${ }^{21}$}

Desse modo, num primeiro movimento interpretativo, "O mundo do menino impossível" é a recordação de uma experiência autêntica da infância. O menino travesso quebrara os brinquedos artificiais por preferir a eles as coisas comuns animadas pela ênfase de sua imaginação. Resistira acordado à noite, porque desejava sonhar. Assim, com o fazde-conta aplicado ao cotidiano, num prazer feito de solidão, ele constitui sua identidade, tirando do nada um mundo outro.

\footnotetext{
${ }^{21}$ Na primeira versão do poema, vinha apenas: "Chô! Chô! Pavão!”.
} 
Num segundo movimento interpretativo, entrevê-se junto com a experiência da criança o esboçar de uma poética do adulto, desejoso de destruir o mundo e recriá-lo ${ }^{22}$. Tamanha é a força lírica do percurso do menino impossível - sua recusa do mundo estereotipado e a busca solitária de identidade por meio da criação imagética -, que atinge universalização como "poética impossível”.

Recorde-se Graciliano Ramos, que, num empenho de concisão lingüística para configurar o essencial de vidas desgraçadas, "tirou do nada" uma obra extraordinária. $\mathrm{Na}$ criação poética de Infância, é o menino que, identificado com as criaturas desamparadas, tendo a companhia dos pais entre parênteses, enfrentou estigmas e povoou sozinho o seu mundo, com os Astrônomos, Paulo Honório, Luís da Silva, Fabiano, num esforço de mediação pelas palavras.

Agora se compreende a influência do poema de Jorge de Lima até sobre a denominação meninos impossíveis para os moços da Novidade: insones diante da paralisia de um ambiente em que havia cultura postiça e iniqüidade social, queriam construir alternativas para a política e educação. Conforme se depreendeu tanto do poema quanto do "Cartão de visita", combatiam estereótipos e buscavam as realidades da vida, conciliando a liberdade inventiva com o respeito pela tradição.

\section{A fortuna do mundo tirado do nada}

A fortuna crítica apreende das imagens d' "O mundo do menino impossível" (1927) uma síntese da trajetória particular de Jorge de Lima, que acompanha as fases poéticas da literatura brasileira: o abandono do parnasianismo e a adesão ao modernismo. Evocando a epígrafe escolhida por Jorge para Novos poemas, de 1929 ("E o menino impossível quebrou todos os brinquedos que os vovós lhe deram..."), Manuel Bandeira aponta, entre esses brinquedos recebidos dos avós e agora rejeitados, as formas tradicionais dos XIV Alexandrinos, primeiro livro de Jorge de Lima, de $1914^{23}$. Também para o crítico Benjamin Lima, os brinquedos desdenhados - complicados, caros e mecânicos -

\footnotetext{
${ }^{22}$ Minha análise tem inspiração na leitura de "Coleção de cacos" por Alcides Villaça, que apreende em sua plenitude a construção das imagens do menino-poeta na "Poética da memória" de Drummond (VILLAÇA, Alcides. Passos de Drummond. São Paulo: Cosac Naify, 2006).

${ }^{23}$ Cf. BANDEIRA, Manuel. Apresentação da Poesia Brasileira. In: Poesia completa e prosa. Volume único. Rio de Janeiro: José Aguilar, 1967, p. 728.
} 
equivaliam a odes e sonetos parnasianos, produtos de uma cultura velha, incapaz de expressar a alma brasileira. Segundo afirma, menino e poeta passaram a brincar com "coisas humildes e ingênuas". ${ }^{24}$

Desde sua gênese, o poema de Jorge de Lima se vincula aos sentidos tanto do modernismo quanto do regionalismo. Conforme relata José Lins do Rego, “O mundo do menino impossível" nascera de uma vontade de fazer pilhéria com a "Evocação do Recife", de Manuel Bandeira. Quando Jorge de Lima leu este poema (publicado em 1925 no Livro do Nordeste, comemorativo do centenário do Diário de Pernambuco, por encomenda de Gilberto Freyre), quis ridicularizar a poesia moderna. No entanto, acabou aderindo ao modernismo. Foi maior a força do poema de Bandeira, de evocação da cidade natal, tendo pois a brincadeira custado a Jorge de Lima a coroa de príncipe parnasiano obtida com o soneto "O acendedor de lampiões" em 1921.

Note-se que, no folheto ilustrado impresso no Rio em 1927, “O mundo do menino impossível" era dedicado a Gilberto Freyre, José Lins do Rego e Manuel Bandeira. E um exemplar especial foi dado a Oswald de Andrade. Infelizmente de uma edição rara, o posfácio escrito em latim nesse folheto é esclarecedor do anseio por uma poesia de menino, nova e autêntica como expressão pessoal e nacional, livre de imitações e de artificialismos:

$\mathrm{Tu}$, poeta brasileiro, o mais estulto dos meninos, não imites o andar cauto e diligente dos meninos mais vigorosos. Age, anda, salta e corre com as tuas forças. Poeta brasileiro, menino pródigo em agilidade, tu te alegraste com os brinquedos estrangeiros. Artífice profundo, faz tua obra com singularidade. ${ }^{25}$

Assim, o poema de 1927 interessou amplamente aos meninos impossíveis da Novidade, à medida que sua construção poética, de um lirismo de sinceridade singela, aliava perspectiva crítica, apego regionalista contra a cultura de importação e recusa de formas parnasianas a favor da liberdade modernista. (O menino destrói por fim o "macaco

\footnotetext{
${ }^{24}$ Cf. LIMA, Benjamin. 'Menino impossível' da poesia brasileira. In: Esse Jorge de Lima. cit. Apud LIMA, Jorge de. Poesia completa. cit., pp. 78-81.

${ }^{25}$ Houve 300 exemplares do folheto, numerados e rubricados pelo poeta, além de dois em finíssima cambraia, um para Oswald de Andrade e o outro para Hildebrando de Lima, que coloriu as ilustrações feitas por seu irmão Jorge. "Tu, brasiliensis vates, unus omnium stultissimus puer, validiorum puerorum cautum et expedditum incessum noli imitari. Age, incede, emica et curre pro viribus tuis; brasiliensis vates, puerulus maximis levitatibus profusus, alienis ludis gavisus fueris. Cave opifex, opus tuum singulariter confice". LIMA, Jorge Matheus de. O mundo impossível do menino. Rio de Janeiro: S.N., 1927, pp. 14 -5. (O folheto consta da Biblioteca do IEB, e algumas de suas ilustrações estão reproduzidas em "Jorge de Lima e as artes plásticas", de Gênese Andrade. Cf. Teresa revista de Literatura Brasileira 3. São Paulo: Editora 34 / USP, 2002).
} 
brasileiro"; "os tacos que deveriam ser / soldadinhos de chumbo são / cangaceiros de chapéus de couro...").

Vários artigos dos meninos impossíveis, escritos entre 1927 e 1930 e recolhidos por Moacir Medeiros no Documentário do modernismo, confirmam a importância da poesia de Jorge de Lima para eles. No posfácio à segunda edição de Poemas ("Em nome dos editores", 1928), Valdemar Cavalcanti compreende o lirismo de Jorge: ressalta o gosto ingênuo e o sentido real e humano, sem tragicidades misteriosas, desses versos, que permitem ao leitor identificar-se com os sentimentos do poeta ("Negra Fulô fica sendo irmã da gente. Pode-se até brincar com os brinquedos do Menino Impossível. Pai João bem que faz encher de águas os nossos olhos piedosos" ${ }^{26}$ ).

Em "Notas" e em "Um professor de estupidez" ${ }^{27}$, Carlos Paurílio defende a si mesmo e os demais meninos impossíveis, em especial os amigos Valdemar Cavalcanti e Aloísio Branco: alguém, usando o pseudônimo João Caçamba, os acusava de "meninos estragados" pela influência dita futurista de Jorge de Lima. Paurílio ironiza a "adiposidade mental" e a falta de verdade do embuçado, que julgava Jorge uma "mamã futurista" a abortar vários "Jorge-de-Limazinhos" seus seguidores. Apontando que estes sim - sonetoschave de ouro, rimas perfeitas e sílabas "bem contadinhas" - estragam, provocam calo "na alma e na ponta dos dedos", Carlos Paurílio queria tão-só declarar seu entusiasmo ante os Novos poemas de Jorge de Lima. Segundo a bela imagem que concebe, cada leitor deveria tirar outra edição do livro, imprimindo na memória o acalanto de seus versos, tocantes em seus motivos infantis, saudosismo e pitoresco.

Também Diégues Júnior e Raul Lima expressaram em artigos em 1929 sua admiração pelos Novos poemas. Apreendendo a verdade de uma tendência que se intensificaria, o primeiro declarou sua predileção pela poesia mística de Jorge de Lima. E o segundo destaca a ousadia do poeta, que se impôs à ambiência literária do país e deixou muito colega alagoano "grogue-grogue" 28.

\footnotetext{
${ }^{26}$ CAVALCANTI, Valdemar. Em nome dos editores. Posfácio aos Poemas. $2^{\mathrm{a}}$ ed. Maceió: Casa Trigueiros, 1927, 1928, p. I-IV. Apud SANT'ANA, Moacir Medeiros de. (pesquisa e seleção). Documentário do modernismo. cit., pp. 97-9.

${ }^{27}$ PAURílIO, Carlos. Notas. Jornal de Alagoas, 30 ago. 1929, p. 3; Idem. Um professor de estupidez. Jornal de Alagoas, 6 set. 1929, p. 3. Apud SANT’ANA, Moacir Medeiros de. (pesquisa e seleção). Documentário do modernismo. cit., pp. 132-5.

${ }^{28}$ DIÉGUES JÚNIOR, Manuel. Novos poemas. O Semeador, 30 set. 1929, p. 1; LIMA, Raul. Outro livro de Jorge de Lima. Jornal de Alagoas, 5 dez. 1929, p. 3. Apud SANT'ANA, Moacir Medeiros de. (pesquisa e seleção). Documentário do modernismo. cit., pp. 135-8.
} 
Otto Maria Carpeaux observa que, exceto o próprio Manuel Bandeira, Jorge de Lima é o único dos nossos poetas cuja obra "acompanha e evidencia todas as fases da evolução da poesia brasileira moderna" ${ }^{29}$. Escreveu versos parnasianos e, contendo os "germes de uma renovação integral", dedicou-se à poesia modernista, folclórica e religiosa. Carpeaux indica ser a pluralidade a marca de Jorge de Lima: poeta de muitas facetas, autor de romance surrealista ( $O$ Anjo), romance regional e social (Calunga), pintor, ensaísta (Dois Ensaios, de 1929, incluindo "Proust" e "Todos cantam sua terra", sobre Mário de Andrade).

Então, procurando o centro de gravidade dessa personalidade artística, o crítico compreende-o como poeta "em caminho". Imerso nos assuntos regionais e na linguagem coloquial e também poeta cristão, Jorge de Lima foi alagoano, "brasileiríssimo", universal. A figuração dos pobres em sua poesia nordestina revela natural o caminho do regionalismo para o cristianismo. Em "Cristianismo e Civilização", depoimento de 1941 a Edgard Cavalheiro, evidencia-se como o caminho cristão de Jorge de Lima, se visava a uma civilização perfeita e à eternidade, realizava-se por meio do olhar para o mundo concreto, necessitado da caridade ${ }^{30}$.

Resta salientar que, evidentemente, a esboçada comparação entre Jorge de Lima e Graciliano Ramos guarda aproximações e distâncias. Na singularidade do caminho cristão de Jorge, a insatisfação com a realidade parece resolver-se por meio da sempre invenção de imagens, mundo maravilhoso do faz-de-conta. Já Graciliano cria Tatipirun (A terra dos meninos pelados), experiência libertadora para o menino magoado de preconceitos. Contudo, se um olho é azul, o outro é preto: ele retorna, desenhados os sonhos, para o mundo de injustiças.

\footnotetext{
${ }^{29}$ CARPEAUX, Otto Maria. Introdução (novembro de 1949). In: LIMA, Jorge de. Obra poética; Org. Otto Maria Carpeaux. Rio de Janeiro: Ed. Getulio Costa, 1949.

30 “O verdadeiro cristão é assim obrigado ao mundo temporal pela lei da caridade. (...) Como poderemos testemunhar a caridade, senão fazendo nossas as questões do nosso próximo, e nossos os problemas de seu ofício, de sua classe, as suas obrigações para com seus camaradas, parentes e amigos? Jamais pudemos nos julgar turistas neste mundo miserável de todos nós", Jorge de Lima. (In: CAVALHEIRO, Edgard. Testamento de uma geração: 26 figuras da intelectualidade brasileira prestam o seu depoimento no inquérito promovido por Edgard Cavalheiro. Porto Alegre: Livraria do Globo, 1944, p. 165).
} 


\section{3. "PROBLEMA ENCRENCADO": O MODERNISMO NORDESTINO}

Mas pode-se falar em 'modernismo nordestino'? Manuel Bandeira, pernambucano autêntico, pertence no entanto ao movimento literário que começou em 1922, em São Paulo e, pouco depois, no Rio de Janeiro. O lugar do nascimento não é portanto decisivo. Por outro lado, há quem negue a relação entre o movimento nordestino de 1930 e a agitação paulista de 1922. Quanto à obra dos romancistas e sociólogos citados eu gostaria de apoiar essa última tese. Com respeito à poesia, basta recordar que o modernismo paulista-carioca de 1922 e 1924 é sobretudo renovação poética enquanto Jorge de Lima é, no Nordeste, figura quase isolada. Talvez só futuros historiadores da literatura brasileira cheguem a resolver esse problema encrencado. ${ }^{31}$

Permanece o problema percebido por Otto Maria Carpeaux. A questão é buscar compreender as complexas relações entre o modernismo de 1922 e a produção nordestina de 1930. Para isso, cumpre recorrer a depoimentos de escritores dos anos 20 e 30, tendo em mente suas obras, e também a estudos críticos posteriores.

Com razão, Carpeaux situa Jorge de Lima como grande poeta lírico isolado nos anos 30 no Nordeste, numa geração de romancistas e sociólogos a cujos temas deu forma em versos. Ao mesmo tempo, com base no livro de Moacir Medeiros e no de Tadeu Rocha (Modernismo e regionalismo), é preciso levar em conta o vínculo do poeta, por intermédio de José Lins do Rego, não apenas com o modernismo paulista (até com Mário de Andrade), mas também com o movimento regionalista de Gilberto Freyre. E ver sua influência sobre os meninos impossíveis da Novidade, por exemplo sobre o também poeta lírico Aloísio Branco e o sociólogo em formação Diégues Júnior.

Assim, considerando que havia preocupações partilhadas entre Jorge de Lima, José Lins do Rego, os jovens da Novidade e também Graciliano Ramos, talvez se possa falar num modernismo nordestino, interessado em trazer o novo criticamente para a região, contra os chavões na arte e na política. Entretanto, para evitar o perigo das generalizações, é necessário apreender as especificidades desse modernismo alagoano, buscando o valor pessoal das obras e as diferenças no posicionamento crítico dos escritores.

Quanto ao modernismo na poesia, merecem ser conhecidos, ao lado de Jorge de Lima, o poeta e ensaísta Aloísio Branco, que morreu jovem e sem obras publicadas, o poeta e contista Carlos Paurílio, que igualmente faleceu jovem e quase não deixou livros, e

\footnotetext{
${ }^{31}$ CARPEAUX, Otto Maria. Introdução (novembro de 1949). In: LIMA, Jorge de. Obra poética. cit.
} 
o cronista e poeta Willy Lewin, que escrevia de Recife para a Novidade e também publicou poucas obras. Veja-se que, se pode ter havido influência do modernismo de 1922 e do regionalismo de 1923 na formação de suas identidades, ao mesmo tempo eram-lhes também genuínos a crítica à retórica acadêmica, o desejo de liberdade de criação e o apego às tradições regionais.

Jorge de Lima, recusando mitos de uma conversão sua ao modernismo, explicava que a sua liberdade formal respondia a uma necessidade de seu lirismo. Contava que assistira à conferência de Marinetti no Brasil, porém não sentira afinidade pelas idéias daquele "cabotino". Influências decisivas para todos julgava serem Proust, Pirandello, Freud e Einstein. Enfatizava que desagradavam aos jovens de Alagoas a Grécia dos parnasianos, a Itália dos marinettistas, a antropofagia e as blagues dos primeiros grupos modernistas. ${ }^{32}$ Em entrevista a Homero Senna em 1945, declara que os alagoanos se prendiam aos próceres do Rio e de São Paulo tão-só pelos laços que unem escritores com as mesmas idéias, já que era generalizada em todo o país a necessidade de renovação, a "preparação psicológica para o advento de uma nova estética":

Não passamos a fazer literatura modernista para imitar os nossos confrades de São Paulo e daqui. Abandonamos os velhos moldes porque também em Maceió, como em todo o Nordeste, àquele tempo, amadureceu e tomou forma, no espírito dos escritores, o desejo de fazer alguma coisa nova e diferente do que então se perpetrava por esse Brasil afora, na poesia, no romance, no ensaio etc. ${ }^{33}$

Enquanto Jorge de Lima defendia a origem autônoma do modernismo nordestino e via sua afinidade com o movimento do Sul, José Lins do Rego recusava como "modernização de superfície" 34 a dos poetas paulistas, artificiais e não sinceros. Em "Espécie de história literária”, de 1935, ataca Sérgio Milliet, que atribuía à Semana de Arte Moderna uma ascendência sobre toda a literatura brasileira posterior a 1922. José Lins

\footnotetext{
${ }^{32}$ Cf. Auto-retrato intelectual. Jorge de Lima visto por Jorge de Lima. In: LIMA, Jorge de. Poesia completa. cit., pp. 35-67.

${ }^{33}$ Idem. Ibidem. Cf. também SENNA, Homero. O mistério poético (Entrevista com Jorge de Lima publicada em 29-07-1945). In: República das letras: Entrevistas com vinte grandes escritores brasileiros. $3^{\mathrm{a}}$ ed. rev. e atualizada. Rio de Janeiro: Civilização Brasileira, 1996, pp. 121-140.

${ }^{34}$ REGO, José Lins do. Notas sobre um caderno de poesia (Originalmente no Jornal de Alagoas, Maceió, 1512-1927). In: LIMA, Jorge de. Poesia completa. cit., pp. 71-7. Também em REGO, José Lins do. Jorge de Lima e o modernismo. Gordos e magros. In: Dias idos e vividos. Rio de Janeiro: Nova Fronteira, 1981, pp. 51-9.

Cf. "Enquanto os futuristas de S. Paulo fazem ridículos, uma geração no Rio salva a cultura brasileira", 1922 (In: Ligeiros traços. Escritos da juventude. cit., pp. 248-250), em que José Lins critica as "originalidades fáceis" da mocidade de São Paulo.
} 
contra-argumenta lembrando o papel que teve desde 1923 Gilberto Freyre e o eixo literário de Recife, independente do Rio e de São Paulo e até um tanto hostil a estes. Ressalta que o movimento literário do Nordeste tinha muito pouco a ver com o modernismo do Sul, até em relação à língua. Segundo ele, a língua de Macunaíma, tão arrevesada quanto a dos sonetos parnasianos, era de fabricação, não instrumento de comunicação oral ou escrita ${ }^{35}$.

Em "Presença do Nordeste na literatura", embora julgando a Semana de 1922 um escândalo necessário, momento de "tensão criadora", José Lins a acusava de ter derrubado alguns ídolos de mármore para fixar outros preconceitos. Distinguia Manuel Bandeira, que "evocou a terra dos avós e ligou o moderno ao eterno": agradava-lhe esse modernista vinculado ao movimento paralelo, de Gilberto Freyre. José Lins entendia que, não capricho de saudosista mas filosofia de conduta, ao apegar-se à terra natal para dar-lhe universalidade, o regionalismo nordestino absorvia o movimento moderno no que este possuía de mais sério ${ }^{36}$.

Já em 1942, na véspera da conferência de Mário de Andrade no Itamarati, a distância temporal e o conhecimento da seriedade do autor de Macunaíma possibilitaram a José Lins do Rego relativizar as antigas críticas a ele dirigidas. Enaltece o empenho de Mário por destruir formas velhas em nome de uma forma "de seu tempo". Reconhece que errara ao imaginar o paulista limitado ao jogo fácil da anedota: marcavam-no, antes, a gravidade e o sofrimento ${ }^{37}$.

No Prefácio de Região e tradição, de $1940^{38}$, logo de início Gilberto Freyre confessa terem-no atraído, desde a meninice, tanto a inovação literária quanto as tradições da província. A isso atribui seu quase alheamento em relação ao modernismo do Sul em 1923, quando retornava ao Recife após cinco anos de estudos no exterior.

Aponta que, por um lado, o regionalismo tradicionalista iniciado em 1923 no Recife sofreu hostilidade dos modernistas mais ortodoxos do Rio e de São Paulo; por outro, teve afinidades com o modernismo, quanto à técnica experimental, reação contra as convenções acadêmicas e puristas, e quanto ao interesse pelo folclore brasileiro.

\footnotetext{
${ }^{35}$ Idem. Espécie de história literária (1935), Gordos e magros. In: Dias idos e vividos. cit., p. 97.

${ }^{36}$ Idem. Presença do Nordeste na literatura. In: Dias idos e vividos. cit., pp. 118-126.

${ }^{37}$ Idem. História do nosso modernismo. Poesia e vida. In: Dias idos e vividos. cit., pp. 126-7.

${ }^{38}$ FREYRE, Gilberto. Introdução do autor (1940). In: Região e tradição. Prefácio de José Lins do Rego. Rio de Janeiro: José Olympio, 1941, pp. 23-42.
} 
Destaca que, em especial sobre Valdemar Cavalcanti e Aurélio Buarque de Holanda, em Alagoas, José Lins do Rego exerceu forte influência no sentido de uma conciliação do regionalismo artístico com o modernismo. Então, Freyre enfatiza que os renovadores nordestinos tinham a tendência de conciliar o regional com o humano, e a tradição com a experimentação, com a renovação de métodos literários e científicos - tanto no estudo histórico-social das regiões e das tradições brasileiras, quanto no romance (José Américo de Almeida, José Lins do Rego) e na poesia (Jorge de Lima, Ascenso Ferreira).

Finalmente, afirmando haver sido insignificante a repercussão do modernismo do Sul sobre o grupo nordestino, Gilberto Freyre defende que o regionalismo tradicionalista se formou de seus próprios contatos com a Europa e com os Estados Unidos e de suas próprias forças. Conforme explica, o movimento dos renovadores nordestinos, longe de convenções de escola, derivou de um sentido de equilíbrio entre o gosto pela tradição e o entusiasmo pela experimentação.

É preciso conhecer-se a resposta de Graciliano Ramos ao inquérito de Osório Nunes, “O modernismo morreu?”, publicada em Dom Casmurro, em $1942{ }^{39}$. O romancista afirma que o modernismo, expressando o desejo de destruição dos cânones "que precisavam desaparecer", concretizou-se em 1922 e morreu por volta de 1930. Nesse período de combate, "nada pôde ser realizado até 30, quando começou um trabalho de criação dos mais brilhantes, até 1936".

Numa contribuição significativa para a fortuna crítica do modernismo, o escritor explica que a rebelião se impunha ante "as restrições e a improdutividade do ambiente que cercava os novos". Ironiza que, se o grande na poesia era Bilac, já se infere o que eram os outros. Quanto ao romance, realça apenas Lima Barreto como digno de consideração. Nas palavras de Graciliano: “o modernismo viria derrubar, num autêntico trabalho de menino, os gigantes de pé de barro, os ídolos sem consistência”. Apreende-se daí um sentido crítico que também mobilizou o "modernismo alagoano" dos anos 1930: o desejo dos meninos impossíveis de se expressarem de forma própria, diferente do estabelecido, reagindo contra as limitações do ambiente intelectual.

Assim, Graciliano entende que, excelente como reação, o movimento teve como melhor fruto a "libertação das cadeias do espírito": possibilitou "limpar, preparar o terreno

\footnotetext{
${ }^{39}$ Cf., em anexo, "O modernismo morreu?" - Resposta de Graciliano Ramos ao Inquérito de Osório Nunes. In: Dom Casmurro. Rio de Janeiro, 12 de dezembro de 1942. Ano VI, n. 280, p. 3.
} 
para as gerações vindouras". O escritor destaca a poesia, que "adquiria expressão", enquanto o romance modernista "não tinha conteúdo". Segundo concebe, Mário de Andrade e Oswald de Andrade haviam falhado em suas tentativas de romance; porém, ao sublinhar essa falta de realizações na prosa, Graciliano observa que a "independência do modernismo" permitiu a José Lins do Rego escrever seu romance da forma como é. Movido por uma preocupação radical de partilhar sofrimentos humanos e não procedimentos de vanguarda, no horizonte de Graciliano apreende-se o romance como uma construção que combinasse representação crítica da realidade e expressão de impasses subjetivos, de modo a abrir para o leitor as "pequenas verdades" da vida, atingindo universalidade.

Confirmando-se o rigor, a sabedoria de sua postura crítica, sobretudo o romancista se volta contra os diluidores do modernismo. "As portas largas do modernismo abriram caminho não só às mediocridades: a autênticas burrices." Graciliano condena os indivíduos que, sem saberem escrever, agarravam-se a "liberalidades e extravagâncias", o que redundava na nociva glorificação de falsos valores. Critica esses autores apressados de romances e de poemas, que queriam imitar Manuel Bandeira por exemplo, sem terem sua cultura.

Por fim, Graciliano conta que vendia fazendas no interior de Alagoas quando soube do "barulho" modernista do Sul: lia tudo, acompanhando-o de longe, e somente aplaudiu. Além de não se sentir ligado à rebelião de 1922, demonstra ante a própria obra o mesmo rigor com que a fez extraordinária e nos desperta o sorriso, numa dura lição crítica para um mundo de vaidades "sem consistência":

Não fui modernista, nem sou 'post-modernista'. Sou apenas um romancista de quinta ordem. Estava fora e estou.

Sua crítica ao modernismo carrega o aprendizado de se desconfiar das generalizações, em especial das classificações literárias, em nome da singularidade das pessoas, dos escritores, comprovada em sua própria formulação irônica:

- Como pode explicar, então, as versões que o classificam entre as expressões conseqüentes à 'Semana'? - queremos saber.

Graciliano Ramos esboça um sorriso divertido e diz:

- O modernismo presta-se, admiravelmente, a todas as confusões...

Também a entrevista de Graciliano Ramos a Homero Senna em 1948 deixa clara a distância do romancista em relação ao modernismo de 22. À semelhança de José Lins do 
Rego, admirava a poesia de Manuel Bandeira, vendo na origem parnasiana deste um diferencial frente ao grupo de modernistas. Salvas muito raras exceções, considerava o modernismo uma "tapeação desonesta", de cabotinos que importavam Marinetti enquanto outros escritores buscavam "estudar alguma coisa, ver, sentir". Para Graciliano, os modernistas brasileiros haviam errado quando, considerando Coelho Neto e a Academia a encarnação da literatura brasileira, desejaram destruir tudo o que viera antes. Ataca os modernistas de modo veemente porque, ao traçarem linhas arbitrárias entre o bom e o mau, condenaram muitos autores injustamente, "por ignorância ou safadeza" 40 .

Compreende-se a contundência dessa crítica: organizando à época uma antologia de contos brasileiros, o romancista não se conformava com o esquecimento de grandes autores pelos modernistas. Graciliano acusa intencional o silêncio quanto a contos como "O ratinho Tique-Taque", de Medeiros e Albuquerque, "Tílburi de praça”, de Raul Pompéia, "Coração de velho", de Mário de Alencar, "Os brincos de Sara", de Alberto de Oliveira, a seu ver superiores às criações dos líderes modernistas ${ }^{41}$.

Recorde-se aqui uma polêmica de 1939, traçada nos ensaios "A palavra em falso" e "A raposa e o tostão", de Mário de Andrade, "A solidão é triste", provavelmente de Jorge Amado, "O tostão e o milhão", de Joel Silveira, e "Os tostões do Sr. Mário de Andrade", de Graciliano Ramos ${ }^{42}$. Se concordavam quanto a viverem uma fase de livros ruins, Graciliano defendia o rigor crítico ao apontar o perigo da total perda de valores, de se chamarem bons escritores como Joel Silveira injustamente de tostões. Essa polêmica ajuda a formar um conceito de arte e a reconhecer impasses e realizações artísticas da literatura brasileira desde o movimento modernista. No tempo do estreito formalismo parnasiano, Mário lutara pela liberdade da técnica. Porém, ao se generalizarem as conquistas do modernismo, à medida que a extravagância e a facilidade adentraram a arte, ele passou a combater pela necessidade de consciência técnica do artista. Ao mesmo tempo, ante a

\footnotetext{
${ }^{40}$ Cf. SENNA, Homero. Revisão do modernismo (Entrevista com Graciliano Ramos publicada em 18-121948). In: República das letras. cit., pp. 197-210.

${ }^{41}$ Cf. RAMOS, Graciliano. Seleção de contos brasileiros. 3 v. (Norte e Nordeste; Leste; Sul e Centro-oeste). Rio de Janeiro: Edições de Ouro, 1966.

${ }^{42}$ ANDRADE, Mário de. A palavra em falso. Diário de notícias, Rio de Janeiro, 6 ago. 1939. In: Vida literária. Pesquisa, estabelecimento de texto, introdução e notas de Sonia Sachs. São Paulo: Hucitec, Edusp, 1993, pp. 90-5; Idem. A raposa e o tostão. Diário de notícias, Rio de Janeiro, 27 ago. 1939. In: $O$ empalhador de passarinho. $3^{\mathrm{a}}$ ed. São Paulo: Martins; Brasília: INL, 1972, pp. 101-7; RAMOS, Graciliano. Os tostões do Sr. Mário de Andrade. In: Linhas tortas. cit., pp. 185-6. "A solidão é triste", provavelmente de Jorge Amado, e "O tostão e o milhão", de Joel Silveira, saíram em Dom Casmurro. Marcos Antonio de Moraes analisa a polêmica em Orgulho de jamais aconselhar: a epistolografia de Mário de Andrade. São Paulo: Edusp / FAPESP, 2007, pp. 162-6.
} 
Segunda Guerra, enfatizou o sentido social da arte, "força interessada na vida", inconformista. Por isso, apontava criticamente as construções literárias frágeis e apressadas dos estreantes, confiante no potencial de superação moral e estética próprio da busca de técnica. Assim, ambos, Mário de Andrade e Graciliano Ramos, empenhavam-se pela técnica literária e seu sentido moral, preocupados com a negligência de muitos literatos metidos a escritores. Se a concepção de arte de Mário exigia a combinação das esferas estética e social, a técnica pessoal e o "pensamento inconformável aos imperativos exteriores" ${ }^{43}$, Graciliano a realizou plenamente.

Significativa fonte para se refletir sobre o vínculo do romance nordestino com o modernismo do Sul é a seqüência de três ensaios "Fluxo e refluxo", de 1951, de Sérgio Buarque de Holanda ${ }^{44}$. Decorrem de seu interesse por compreender como houve um movimento de expansão (diástole) do modernismo brasileiro até os anos 40 , ocasião em que refluiu numa reação de sístole, representada sobretudo por alguns poetas contrários ao regionalismo modernista.

A princípio, o crítico observa que a consideração ou não do papel do modernismo de 1922 para a literatura nordestina de 1930 oscila ao sabor das idiossincrasias dos escritores. No entanto, apoiado na distância temporal, Sérgio Buarque reconhece que, independentemente de uma relação de causa e efeito, ambos se enlaçaram, num movimento expansivo, como tendências regionalistas. Identifica que o modernismo de 1922, universalista e até cosmopolita, foi ao mesmo tempo nacional, regionalista e tradicionalista, assim se aproximando do romance social e regional do Nordeste. Entende que tanto os modernistas como os renovadores de Recife, em sua preocupação do nacional, do regional e do tradicional, tinham uma atitude universalista, voltada para nivelar as nossas letras às correntes mais avançadas da literatura européia e norte-americana.

Em 1951, Sérgio Buarque enfatizava que ainda não havia sido escrita de fato a história de nosso modernismo. Segundo ele, faltava perceber como se agregaram e se consolidaram as correntes ao mesmo tempo regionalistas e rebeldes formadas em todo o país. Relembra o contato fecundo dos poetas Jorge de Lima e Ascenso Ferreira com os

\footnotetext{
${ }^{43}$ Cf. ANDRADE, Mário de. A elegia de abril (1941); O movimento modernista (1942). In: Aspectos da literatura brasileira. São Paulo: Martins, s/d, pp. 185-195; pp. 231-255.

${ }^{44}$ HOLANDA, Sérgio Buarque de. Fluxo e refluxo - I, II e III, 1951. In: O espírito e a letra. v. 2. Organização, introdução e notas: Antonio Arnoni Prado. São Paulo: Companhia das Letras, 1996, pp. 331345.
} 
modernistas do Sul. E, sem falar em filiação, nota como no romance do Nordeste a fome modernista de colorido regional e do tradicional brasileiro encontrou alimento mais adequado.

Assim, Sérgio Buarque contesta a tese segundo a qual o regionalismo nordestino se teria desenvolvido indiferente e até em oposição ao modernismo. E combate também a outra, de que os responsáveis pelo movimento de 22 seriam hostis às manifestações artísticas do Nordeste. Compreende que, formado também por outras fontes, o romance social regionalista seria um prolongamento da mentalidade do modernismo de 1922, para além dos domínios primitivos deste, de polêmica, poesia e pesquisa erudita.

Por fim, considerando ter havido muita improvisação em meio ao modernismo, o crítico aponta a saturação dos motivos nacionais e regionais, praticamente abandonados pelos autores então novos, em geral poetas do refluxo modernista. Com sensibilidade crítica, Sérgio Buarque destaca que, para permanecer, uma obra de arte deveria mesmo transbordar do brasileirismo, contudo lhe dedicando ainda "secreta - ou discreta fidelidade".

Referência evidente de Sérgio Buarque de Holanda é a conferência "O movimento modernista", de 1942. Nela, Mário de Andrade, motivado pela "fase integralmente política da humanidade" que se vivia, culpa-se de certo abstencionismo dos jovens de 1922, ligados aos aristocratas paulistas. Ao mesmo tempo, vendo a continuidade entre o sentido revolucionário de 1922 e a fase de construção a partir de 1930, enfatiza que o movimento modernista criou um "estado de espírito nacional". Como se sabe, concebe as conquistas do modernismo como fusão de três princípios: “o direito permanente à pesquisa estética, a atualização da inteligência artística brasileira e a estabilização de uma consciência criadora nacional" ${ }^{45}$.

Também na linha de Mário de Andrade e um ano antes da sequiência de ensaios de Sérgio Buarque, destaca-se o panorama para estrangeiros "Literatura e cultura de 1900 a 1945 " ${ }^{46}$. Antonio Candido compreende o modernismo, inclusive seu amadurecimento nos anos 1930-40, como a "tendência mais autêntica da arte e do pensamento brasileiro", que

\footnotetext{
${ }^{45}$ ANDRADE, Mário de. O movimento modernista, 1942. In: Aspectos da literatura brasileira. cit., pp. 231255.

${ }^{46}$ CANDIDO, Antonio. Literatura e cultura de 1900 a 1945 (1950). In: Literatura e sociedade. Ensaios de teoria e história literária. São Paulo: Companhia Editora Nacional, 1965, pp. 129-165.
} 
fundiu a libertação do academismo e dos recalques históricos à ânsia de conhecer o país e possibilitar a educação política e a reforma social. Preocupado com as novas tendências formalizantes dos anos 40 (como Sérgio Buarque), Candido sublinha o esforço das décadas de 20 e 30: por meio da "fidelidade ao local", construíram uma "literatura universalmente válida", integrada nos problemas do momento.

Em ensaio de 1980, o crítico nota que as inovações modernistas se incorporaram em dois níveis: diretamente nas obras ou genericamente, à medida que incentivavam a rejeição de padrões antigos. Entende que, depois de 1922, o inconformismo e o anticonvencionalismo deixaram de ser uma transgressão para se tornarem um direito, até para os que ignoravam ou rejeitavam o modernismo. Antonio Candido salienta que os bons escritores foram beneficiados pela libertação modernista, que incluía a depuração antioratória da linguagem e a incorporação do coloquial. Exemplifica com as escritas clássicas de Graciliano Ramos ou de Dionélio Machado, que, mesmo sem influência modernista, foram aceitas como normais: "a sua despojada secura tinha sido também assegurada pela libertação que o Modernismo efetuou" 47 .

Para completar a reflexão crítica sobre o "problema encrencado" apreendido por Carpeaux, é preciso relativizar também as perspectivas de Sérgio Buarque e de Antonio Candido. Eles aproximam como rebeldes e regionalistas as literaturas paulista de 1922 e nordestina de 1930, por oposição ao refluxo dos anos 40, da chamada "geração de 1945". Esta era formalizante e centrada em temas universais, para criar uma poesia pretensamente profunda. Sendo assim, se interessam as semelhanças entre o modernismo do Sul e o do Nordeste, importam também as singularidades que os diferenciam.

Recorde-se, com Alfredo Bosi, que, se os modernistas se apegaram miticamente ao progresso técnico e à origem indígena do país, os romancistas e ensaístas de 30 se centraram no "Brasil histórico e concreto, isto é, contraditório e já não mais mítico". O crítico esclarece que o modernismo fôra apenas "uma porta aberta" para o caminho da cultura como "inteligência histórica" da realidade brasileira, que engloba não apenas "os extremos do mundo indígena e do mundo industrial" ${ }^{48}$.

\footnotetext{
${ }^{47}$ Idem. A Revolução de 1930 e a cultura. In: A educação pela noite \& outros ensaios. $2^{\text {a }}$ ed. São Paulo: Ática, 1989, pp. 181-198.

${ }^{48}$ Cf. BOSI, Alfredo. Moderno e modernista na literatura brasileira. In: Céu, inferno. São Paulo: Duas Cidades; Ed. 34, 2003, pp. 209-226.
} 
Com perspicácia crítica, Bosi desmascara o aspecto mistificador do modernismo de 22, encantado pelas conquistas técnicas. Diferencia-o, então, da literatura moderna nordestina que, diante das graves contradições da realidade, respondia como arte crítica.

(...) O mundo da experiência sertaneja ficava muito aquém da indústria e dos seus encantos; por outro lado, sofria de contradições cada vez mais agudas que não se podiam exprimir na mitologia tupi, pois exigiam formas de dicção mais chegadas a uma sóbria e vigilante mimese crítica. ${ }^{49}$

Desse modo, percebe-se como é complexo compreender os estilos de época, que envolvem diferenças de idéias e de gosto literário. Para retificar generalidades, o ideal é "uma diferenciação no rumo do concreto" ${ }^{50}$. Sobressaem exemplares, segundo explica Alfredo Bosi, os exercícios de crítica dialética realizados por Otto Maria Carpeaux e por Antonio Candido. Ambos procedem ao "afinamento das categorias sociais e culturais à procura da quadratura do círculo que seria a definição de indivíduo".

Portanto, cabe ao crítico exercer sua consciência quanto à diversidade literária de um período e, no limite, seguindo a recomendação de Benedetto Croce indicada por Bosi, dedicar-se a uma história literária por monografias.

Confirma-se, assim, o caminho desejado para este estudo. A princípio, vou centrarme nos temas da Novidade e em seguida nos perfis artísticos de seus escritores, com vistas a conhecer melhor o contexto histórico e histórico-literário dos anos 1930 em Maceió, época da formação da obra de Graciliano Ramos. Em especial, buscarei compreender seu trabalho artístico de, percebendo as tensões abafadas pelos estereótipos, construir as personagens dos romances e a voz singular dos livros de memórias.

\footnotetext{
${ }^{49}$ Idem, p. 222.

${ }^{50}$ Idem. Por um historicismo renovado: reflexo e reflexão em história literária. In: Literatura e resistência. São Paulo: Companhia das Letras, 2002, pp. 7-53.
} 


\section{CAPÍTULO 4 - ITINERÁRIO POLÍTICO E CULTURAL: OS EDITORIAIS DA NOVIDADE}

Hoje não muito conhecidos, Valdemar Cavalcanti e Alberto Passos Guimarães foram os fundadores e diretores da Novidade, responsáveis alternadamente pela autoria de seus editoriais, além de Tópicos e de Notas da Semana. Esbocei suas biografias na seção final da tese, NOTAS BIOBIBLIOGRÁFICAS. Ora apresento em síntese os editoriais de ambos, buscando delinear os caminhos dos meninos impossíveis.

\section{Valdemar Cavalcanti: a agudez simpática}

\section{Nem ufanismo, nem tristeza}

Na Novidade, além de 12 editoriais, muitos Tópicos e Notas da Semana, Valdemar Cavalcanti publicou o esboço de novela "Raul Marques, proprietário de Rio Comprido", a crítica de Oscarina, de Marques Rebelo, e, conforme revelou anos depois em "Uma Revista”, vários artigos sob pseudônimos. É interessante notar sua proximidade com a obra nascente do grupo no início dos anos 30: lia poemas inéditos de Jorge de Lima, ouviu de José Lins do Rego a leitura de originais, datilografou Menino de engenho, Doidinho e Bangüê, além de S. Bernardo, de Graciliano. Jornalista e crítico literário, foi para o Rio em 1937, onde trabalhou no IBGE, fez várias traduções e teve larga colaboração na imprensa.

Seus editoriais e tópicos no semanário marcam-se pela busca de equilíbrio entre correção formal e coloquialismo e pela preocupação de formular e transmitir idéias com sinceridade e clareza. Tal estilo ponderado corresponde a um anseio de justiça nas relações sociais. Assim, no próprio estilo de Cavalcanti se reconhece que a formação de um pensamento crítico e o combate às iniqüidades alarmantes da sociedade alagoana constituem o sentido cultural e político da renovação almejada por esse criador da Novidade.

Parece-me decisiva a leitura de "Os técnicos da Segunda República", editorial do número 15 da revista, que concentra questões-chave da Novidade, desdobradas nos outros editoriais. Nesse artigo, a arma crítica de Valdemar é a ironia, dirigida contra a ineficiência dos governantes tanto da Primeira República (1889-1930) quanto da Segunda (1930-1937). 
Desmascara falsa a atitude dos dirigentes desta, que se arvoravam técnicos e acusavam de românticos os da Primeira República, no fim das contas tão-só para derrotá-los em nome do poder pessoal.

A falta de ação político-social da República Velha escondia-se ideologicamente sob o chavão de terem os brasileiros um temperamento sentimentalista de herança étnica. Valdemar Cavalcanti exemplifica essa "fraqueza sentimental" da Primeira República ironizando o regime do "esplêndido e dúbio far-se-á" de Washington Luiz, "a que faltava naturalmente o 'se Deus quiser"'. O crítico explica que, alardeando a beleza e a riqueza do país, os antigos chefes legalizaram, contudo, uma triste condescendência para com os "fiéis da mesma igreja". Por isso, foram atacados pela gíria revolucionária como "Ladrões da Velha República".

No entanto, conforme desvela Cavalcanti, os pretensos técnicos do Brasil Novo só fizeram aprofundar o "baixo temperamento sentimentalista" brasileiro. Embora houvessem anunciado a "revolução purificadora", não cuidaram sequer de diagnosticar com exatidão os males do país, muito menos de apresentar as receitas de "médicos especialistas". À semelhança dos dirigentes anteriores, os novos não se dignavam a enfrentar a gravidade dos problemas do Brasil, continuamente adiando qualquer ação transformadora.

Os técnicos vão sendo abafados pelo peso dos problemas a resolver. E deixam para amanhã o que podiam fazer hoje. Instintivamente pensando em depois-de-amanhã...

A conclusão irônica de Valdemar Cavalcanti, cujo teor amargo se confirma até hoje, é que os "erros políticos", sob o pretexto de sentimentalismo de herança étnica, são a nossa identidade, dispensando até a importação do que é estrangeiro.

Se bem que sejam talvez os nossos erros políticos a única coisa verdadeiramente nossa que o Brasil possui. Porque está se vendo que são erros do nosso temperamento, não são erros importados da estranja.

Dessa forma, combatendo o chavão do nosso pretenso romantismo étnico, o crítico descortina institucional no Brasil a inoperância dos políticos quanto aos problemas sociais, mas não quanto às relações de favor que atendem seus interesses particulares.

Bastante vinculado a esse editorial é o da Novidade 21, "Nós somos mesmo do amor". Nele, um dos focos da reflexão de Valdemar Cavalcanti é o Retrato do Brasil, de Paulo Prado, certamente referência central para se compreender esse estereótipo do Brasil como país romântico. 
Esse livro atingiu grande êxito quando lançado. Informa-nos Alfredo Bosi terem sido quatro edições entre 1928 e 1931, época de forte busca de uma definição da identidade nacional. Para o retratista Paulo Prado, os brasileiros seriam marcados por melancolia e romantismo, conseqüência da luxúria e cobiça dos colonizadores portugueses. Os críticos Dante Moreira Leite e Alfredo Bosi ${ }^{1}$ atestam o aspecto arbitrário desse vínculo entre cupidez e tristeza. Além disso, Moreira Leite pondera sobre o paradoxo de Paulo Prado definir como caráter brasileiro a melancolia e aventar possibilidades de transformação desse retrato - a guerra ou a revolução. Nessas possibilidades esboçadas no Retrato do Brasil, o crítico vê a irresolução do representante da burguesia cafeeira em crise: o caminho pela violência revela o fascismo então emergente, e a saída revolucionária (prenúncio da revolução de 1930) apontaria para uma aproximação com a esquerda. Recorde-se, com Alfredo Bosi, que em Macunaíma, dedicado a Paulo Prado, há também um sentimento depressivo em relação ao ethos brasileiro, alternando-se pessimismo e otimismo quanto aos destinos do país.

De todo modo, importa destacar a preocupação de Valdemar Cavalcanti em refletir a partir dos estereótipos atribuídos ao brasileiro, questionando-os. Desvela como a imagem de romântico, melancólico, apático serviu de justificativa para a falta de ação política na Primeira e na Segunda Repúblicas. Diferentemente de "Os técnicos da Segunda República", em que a ironia de intenção crítica é mais direta, a de "Nós somos mesmo do amor" disfarça-se na bonomia de que por fim trata o texto.

Valdemar Cavalcanti aponta a pouca sorte do Brasil com fotógrafos: ou é o retrato sombrio de Paulo Prado, ou o ufanista de Afonso Celso. O crítico observa, contudo, que, apesar dos pontos falsos ao depreender dos brasileiros um caráter melancólico, o Retrato do Brasil é uma obra séria, que instiga reflexão e já em 1928 anunciava a revolução como saída para os desregramentos políticos. Já o Porque-me-ufano-do-meu-país (1900) é incisivamente rejeitado por Valdemar: imbecil e perigoso, o livro repete qual estribilho a falsa imagem do Brasil como paraíso, melhor país do mundo.

Julgando ruim essa mistura de visões do país, triste e ufanista, Valdemar Cavalcanti repudia sobretudo a falsidade da visão eufórica de Afonso Celso, mas identifica nos brasileiros antes uma "compreensão boêmia da vida" do que melancolia. Ironiza essa bonomia exemplificando que a própria revolução de 1930, "a coisa mais séria" dos últimos

\footnotetext{
${ }^{1}$ Cf. BOSI, Alfredo. Situação de Macunaíma. In: Céu, inferno. cit., pp. 187-207; LEITE, Dante Moreira. Luxúria, cobiça e tristeza. In: $O$ caráter nacional brasileiro: história de uma ideologia. $6^{a}$ ed. rev. São Paulo: Editora UNESP, 2002, pp. 343-353.
} 
anos, pareceu acompanhar-se mais de distração do que de gravidade. Valdemar recusa como estereótipo ideológico essa solução aparente dos males do país pela bonomia e, a um tempo, reconhece a sua força. Enfatiza, num inconformismo justamente sequioso de bomhumor, que o Brasil vive uma centena de problemas urgentes, instabilidade política, uma hesitação entre a paralisia da cadeira de rodas e a morte, restando apenas às pessoas "a instituição do sorriso".

Com um punhado de máximas de caráter mardeniano, o brasileiro enfrenta o seu mundo de dificuldades. O açúcar está baixando que não pode mais - e fazemos a cara alegre de quem nunca sofreu de calos. A importação estrangeira é ninharia - o sorriso é o mesmo. Por dentro a gente está sentindo. Se roendo. Mas pra que entristecer?...

É da cantiga carioca: nós somos mesmo do amor... ${ }^{2}$

Veja-se que, ao retomar as imagens da tristeza (Retrato do Brasil) e da euforia (Porque-me-ufano) e julgar mais adequado o sentido da bonomia brasileira (sintetizada no título da cantiga, "Nós somos mesmo do amor"), criticando-lhe o teor ideológico, Valdemar Cavalcanti problematiza agudamente a identidade do país. Esse mesmo material sociológico serviu de base para o conceito de homem cordial, de Sérgio Buarque de Holanda (Raízes do Brasil, 1936) e para a visão positiva de Gilberto Freyre quanto à formação brasileira pela miscigenação (Casa-grande \& senzala, 1933).

Nos outros editoriais Valdemar Cavalcanti também denuncia a mistificação da realidade operada por uma prática retórica, seja em âmbito político ("OO prestígio da mulher na Segunda República”, “A fábula que La Fontaine não pôde escrever”), seja em âmbito cultural - educacional, artístico, jornalístico ("Minha terra tem coqueiros", "Nomes de ruas", "Lampião", "Ouviram do Ipiranga as Margens Plácidas", "Sol de inverno", "Aristarco, filhos e netos", "Imprensa de Alagoas"). E note-se como são intimamente vinculados tais âmbitos.

\footnotetext{
${ }^{2}$ A cantiga é "Batucada", marchinha de Eduardo Souto e João de Barro, gravada Parlophon por Almirante e Bando de Tangarás (1930):

"Ô, ô / Nós semo é memo do amô // Mulatinha frajola / Entra aqui no cordão (cordão) / Que a fuzarca consola / As mágoa que a gente / Traz no coração // Mulata, benzinho / Vem pra mim de uma vez / Dou-te amor e carinho / Dinheiro não tenho / Não sou português // Vou comprá uma redoma / Nela eu vou te guardá (guardá) / Que os malandros te oiando / Meu bem, são capaz / De te profaná // Vem, meu bem, pro Salgueiro / Leblon não vale nada / Pois nos bairros de lá / Mulata, meu anjo / Não tem batucada".
}

http://www.geocities.com/locbelvedere/Cronologia29/cronologia1931.htm http://saudosamaloca.tripod.com/batucada.htm 
Como em "Os Técnicos da Segunda República" e "Nós somos mesmo do amor", a crítica à continuidade do estado de coisas na República Nova também é o cerne de "O prestígio da mulher na Segunda República", editorial da Novidade 13. Valdemar acusa a "amoralidade administrativa da Segunda República" e a falsidade de seus discursos, ironizando que as mulheres deveriam apreciar o novo regime, que lhes teria dado mais prestígio. Um de seus exemplos é que José Maria Whitaker, Ministro da Fazenda, mandara cunhar nas novas moedas a efígie da Miss Brasil, ou seja, Miss Rio Grande do Sul. Desvela nos "galanteios" dos republicanos novos às mulheres a intenção de suavizarem "as profundas cogitações reformadoras do Brasil Velho".

Na Novidade 23, Valdemar Cavalcanti criou "A fábula que Lafontaine não pôde escrever", para ironizar a instabilidade política da Segunda República, feita de muitas quedas e ascensões de dirigentes, conforme os interesses dos mais poderosos.

A fábula figura a República livre dos passarinhos, fruto de uma revolução na República Central do Reino Animal, que depusera os bichos detentores do poder, "cambada de preguiçosos e aproveitadores".

Com a revolução, o melro ocupou o poleiro dourado. Contudo, o canário belga, que era da terra mesmo, com empáfia irritante entrou para o poleiro de ouro e passou a cantar mais alto do que o melro. Este entristeceu e, perdido o jeito de cantar, vitrolava. Então, insatisfeito com o concerto, percebendo a incapacidade do melro e a manobra do canário que queria ser águia - de ridicularizar o chefe do governo para tomar-lhe o lugar -, o povo depôs ambos.

Restou ao melro consultar o Corvo de Poe sobre a possibilidade de voltar à sua terra como soberano. Ouviu o estribilho secular “- Nunca mais! Nunca mais!”, augúrios da entrada de um governador estrangeiro (o rouxinol) e o desejo do povo por um pássaro da terra, um caboclinho inteligente, cantador original. Enfim, o melro se suicidou. Nos jornais, o retrato com a legenda "O suicida desconhecido" parecia aludir a mais um suicídio de amor.

Assim, por meio da fábula, Valdemar deseja despertar a consciência crítica do leitor quanto à política brasileira, hábil em discursos falsos, em rasteiras e arranjos pessoais, ineficaz em relação aos problemas do país. A graça da fábula decorre em muito de chamarse Freitas Melro o primeiro interventor alagoano da República Nova e de a maioria dos interventores terem governado durante apenas meses (como Melro, de outubro de 1930 até agosto de 1931). 
“Nós, os descendentes de Deodoro e Floriano", artigo não-assinado da Novidade 20 que provavelmente teve a colaboração de Valdemar Cavalcanti, trata exatamente da exoneração de Freitas Melro e da substituição na Interventoria Federal. Esse texto é incisivo na crítica aos alagoanos, interessados tão-só por fuxicos de casos domésticos, não por questões políticas. Acusa a indiferença generalizada ante a saída de Freitas Melro, estranhando por meio de ironia a ausência até de fuxicos, próprios da índole da terra. E enfatiza a necessidade de se compreender a política em seu sentido coletivo, ético.

Em "Minha terra tem coqueiros" (N 3), Valdemar critica a "pintura comodista" dos alagoanos, para os quais a única paisagem eram beiras de praia ou fundos de quintal. Destaca o pintor Lourenço Peixoto (um dos idealizadores da Festa da Arte Nova e criador de xilogravuras da Novidade), por identificar em sua obra um contínuo esforço e uma luta da inteligência contra a deficiência cultural. Cobra dos pintores um contato mais íntimo com a viva paisagem alagoana do interior, que, segundo entende, lhes permitiria criar uma obra "mais pura, mais nossa, e, assim, mais universal".

Confessa desgostar-lhe a pintura de José Paulino, marcada por uma "vocação para o mimoso". Imagina como seria perigoso se este retratasse o sertão: ele o pintaria como um saudável jardim de infância, transformando mandacarus em bogaris. Esses "quadros tão desastradamente otimistas" seriam um crime, num momento em que o sertão começava a receber alguma atenção dos dirigentes da Nova República; o Ministro da Viação suspenderia a construção de açudes e mandaria fazer jardins.

Assim, apreendem-se critérios do crítico Valdemar Cavalcanti: para atingir universalidade, a arte deve configurar as tensões da realidade, por meio de um trabalho estético inconformista, contrário a mistificações.

Em "Nomes de ruas" (N 5), critica que os "ruídos da civilização" em Maceió só tenham feito substituírem-se as designações antigas das ruas, saborosas, por nomes de figuras das "poucas letras" alagoanas. Por exemplo, um nome "com doçuras de poema" como rua do Cravo passou a dr. Antonio Pedro de Mendonça.

Se Valdemar louva o sentido humano dessa iniciativa das prefeituras, de tirar do anonimato os homens ilustres da terra, condena-a sob o aspecto intelectual, por dar relevo a nomes sem eco. Sobretudo desagrada ao crítico o caráter de antitradicionalismo dessa mudança: lamenta que se percam os nomes intimamente populares de certas ruas, gostosos 
e nordestinos, brasileiros (Sovaco da Ovelha, Pilão sem Boca, Furna da Onça, Beco de Castola, Beco do Sururu).

O que não vai é essa história de uns finos de paladar macio tirarem da boca do povo isso que depende justamente de sua criação fertilíssima.

No editorial 7, Valdemar Cavalcanti aponta criticamente vários problemas da realidade alagoana, a partir da figura de "Lampião": o "lampionismo semicivilizado" (os pretensamente civilizados, porém politiqueiros, imorais, preguiçosos), a justificativa ideológica de ser a seca obstáculo fatal dos sertanejos, a violência naturalizada ${ }^{3}$.

Com bem-humorado senso crítico, Valdemar ironiza a retórica bacharelesca cultivada no Brasil, em “Ouviram do Ipiranga as Margens Plácidas” (N 9). Condena o hino nacional brasileiro, "amostra de nossos fáceis entusiasmos verbais", "retórica, apenas retórica, e, além de tudo, retórica sem força, idiota, de frase feita". Recorde-se, especialmente, do segundo capítulo das Memórias do cárcere, que Graciliano Ramos também se revoltava contra os hinos, considerando-os uma idiotice para emburrecer as crianças. "O emburrecimento era necessário. Sem ele, como se poderiam agüentar políticos safados e generais analfabetos? (...) Ficava a estupidez: 'Ouviram do Ipiranga as Margens Plácidas'. Para que meter semelhante burrice na cabeça das crianças, Deus do céu?" 4.

Valdemar reforça lucidamente que as crianças e muita gente grande não entendem o hino, cantam somente por dever, o que resulta num aborrecimento profundo desse "porqueme-ufanismo idiota". Enfatiza que, condenadas a "vitrolarem todo santo dia" o hino nacional em fileira militar nas escolas, as crianças merecem compaixão e serão pessoas desencantadas dessa história de civismo.

O mote do editorial é a idéia de um professor de Campinas, que propusera a Getúlio Vargas um novo hino, o da Segunda República. Ao defendê-la, Valdemar combate não apenas a retórica de frase feita, mas também a falsa teoria de que não se pode pensar e ser grande na província. Significativos, seus exemplos são Manuel Bandeira, "o maior poeta brasileiro em qualquer canto onde se encontre", e A Bagaceira, escrita na "cidadezinha" Paraíba, "e o dr. José Américo foi para o Sul depois de grande...".

\footnotetext{
${ }^{3}$ Cf., no capítulo seguinte, a seção 4. Lampiões e santas: indústria de misérias.

${ }^{4}$ RAMOS, Graciliano. Memórias do cárcere. Rio de Janeiro: José Olympio, 1953, v. I, cap. 2, p. 17. Quando diretor da Instrução Pública, Graciliano suprimiu das escolas o Hino de Alagoas, "uma estupidez com solecismos".
} 
Em "Sol de inverno" (N 11), Valdemar Cavalcanti defende a gente nova, cuja visão crítica lhe surge capaz de proceder a uma revisão imparcial de suas próprias heranças intelectuais. Para ele, donos de "independência admirável”, os jovens da época haviam vencido o "imbecil preconceito de idade", a impotência em geral verificada ante o "prestígio da barba".

Entende que a nova geração precisava livrar-se da beleza decorativa de certas velhices tidas como sagradas, porém inúteis (daí o título "Sol de inverno"). Os moços deviam confiar em sua capacidade de análise e julgamento, para acabar com os bezerros de ouro, com os ídolos falsos.

Extinto esse amor místico a uns tantos senhores prudentemente inéditos, teremos feito obra sincera de crítica.

Em “Aristarco, filhos e netos" (N 17), Valdemar evoca a figura de Aristarco, relembrando o retrato pintado pelo extraordinário talento de Raul Pompéia em O Ateneu. O ensaísta aponta criticamente em Aristarco a preocupação muito exterior de mostrar-se voltado para dentro, de exibir um ar de quem se ausentava da vida em demorados passeios psicológicos por dentro de si mesmo. O teor de falsidade dessa "imponência de sábio silencioso" repugna ao crítico, que identifica no "brilhante educador" uma enfermidade atroz: "a obsessão da própria estátua". Ironiza-o afirmando que, "facho de pedagogia", “intelectualmente já nascera morto".

Então, a mordacidade de Valdemar se acirra ao deter-se na "herança caridosa" de Aristarco. Nos "netos", pseudo-intelectuais, afeitos à pose e à retórica vazia, reconhece "a tara dolorosa do avô: a doença de querer ser maior do que era realmente, a obsessão da própria estátua".

Os netos de Aristarco como que exigem para um simples JockeyClub requintes de abstração interior, perfeições de obra de arte. Jogam fora a cinza do cigarro com uma displicência estudada de quem sacode paradoxos wildeanos. E a fumaça é lançada ao ar como se fossem baforadas de sabedoria. Eles não fumam cigarros: administram cigarros.

Conversando, arrastam-se pela palestra, como se fizessem da reflexão uma bagagem de chumbo. E abstraem-se de vez em quando, naquelas fugas psicológicas tão comuns ao avô.

Ao caracterizar esses netos de Aristarco - vazios em seus gestos geniais, com sua aparência de sabedoria, feita de serenidade e silêncio -, Valdemar Cavalcanti deixa ver o quanto the desagradavam futilidade, pseudo-intelectualidade e vaidades ostentatórias. Ao contrário, entendia que reflexões e conversas intelectuais não deveriam ser ou parecer uma 
"bagagem de chumbo": deveriam enfrentar de fato as questões em sua complexidade e pautar-se por sinceridade, buscando conhecimento e compreensão. Alfredo Bosi afirma, ao analisar $O$ Ateneu: "a efígie da vaidade aniquila a comunhão do homem com o outro e consigo mesmo: para esse extremo tende a propaganda como auto-ostensão" 5 . Significativamente, Aristarco, figura do sábio de fachada e pedagogo dominador, remete a Abílio César Borges, o barão de Macaúbas, cujos folhetos de leitura angustiaram o menino de Infância, que se julgava incapaz de desembaraçar-se dos "cipoais escritos". Do repúdio de Graciliano por esses livros, em que bichos empregavam a "linguagem dos doutores" e davam "opiniões sisudas e bons conselhos", sobressaem a crítica ao pedantismo bacharelesco e a concepção de ser imprescindível à literatura a clareza, voltada para a compreensão do outro, para a comunicação.

Assim, Valdemar Cavalcanti critica os Aristarcos devido ao perigo de, estátuas obsessivas de si mesmas, serem figuras de uma falsa sabedoria. Já se reconhece aí o escritor da Novidade, que teme imagens mistificadoras do real. E a frase final condensa ironicamente sua repulsa a pretensas profundidades intelectuais: "Uns poços, os netos de Aristarco...”.

Como se comemorava em 1931 o centenário da "Imprensa de Alagoas" (N 19), Valdemar observa que, propriamente, seu Estado nunca tivera imprensa, apenas jornais de caminhos incertos. Para ele, um verdadeiro jornal deveria reunir utilidade e beleza, e bem organizada era a imprensa de Pernambuco.

Nota que, enquanto alguns jornais de sua época tinham o "hábito das curvaturas" aos poderosos, jornais de antigamente se marcavam por invejável independência, diziam verdades nuas e cruas: "quando o governador não chegava a tempo de botar-lhes rolha, eram eles que botavam rolha no governador”.

Então, Valdemar atribui ao público o reduzido papel social da imprensa nos destinos alagoanos. Desvela ínfima a cifra de leitores da folha diária, sendo os leitores avulsos, que pediam emprestado o jornal do vizinho, maioria na terra pequena. Concluindo que a imprensa não existia porque faltava o principal - o público, cobra que o jornal viesse a ter um público curioso em Alagoas. Confessa tristemente que se lançar ao jornal em sua pequenina terra constituía arriscada aventura intelectual.

\footnotetext{
${ }^{5}$ BOSI, Alfredo. O Ateneu, opacidade e destruição. In: Céu, inferno. cit., p. 61.
} 
Assim, ao denunciar a subserviência da imprensa aos poderosos e a inexistência de um público leitor de jornais, revela a estreiteza intelectual e política alagoana.

Portanto, apreende-se dos editoriais como a perspectiva crítica de Valdemar Cavalcanti desvela problemas políticos, sociais e culturais da realidade alagoana: a conservação do status quo após a chamada Revolução de 1930; o antitradicionalismo e a arte do mimoso, comodista e mascaradora da realidade; a violência do cangaço e também o "lampionismo semi-civilizado", ou seja, os pretensamente civilizados, porém politiqueiros e imorais; o falseamento da realidade pela retórica de frase feita e pelo cultivo da sabedoria oca, da doença de se ostentar superior ao que se é realmente; a falta de um público leitor em Alagoas e o hábito dos jornais de se curvarem aos poderosos.

\section{Alberto Passos Guimarães Terra de escravos, não de milagres}

De Alberto Passos Guimarães, queria a princípio dedicar-me a “...país essencialmente agrícola", da Novidade 14. Nesse editorial, o futuro autor de Quatro séculos de latifúndio (1963), de A crise agrária (1979) e de As classes perigosas: banditismo urbano e rural (1981, reeditado em 2008) ${ }^{6}$ aborda uma questão central da formação da sociedade brasileira, a qual tem repercussões significativas na literatura. Trata-se dos impasses relativos à compreensão do trabalho numa sociedade de origem colonial, que fôra baseada na exploração escravista do latifúndio exportador.

Alberto Passos abre seu artigo afirmando que só após o abolicionismo o trabalho foi verdadeiramente compreendido no Brasil. Explica de modo contundente que, antes, imperava a comodidade do latifundiário, cujas vontades se cumpriam por "elementos invisíveis", movidos "automaticamente no mesmo sentido da impetuosidade dos relhos". Então, desmascara que, herança da "aristocracia indolente dos tempos idos", se constituiu

\footnotetext{
${ }^{6}$ Esses livros, que Alberto Passos Guimarães publicaria no Rio anos depois, denotam sua preocupação com a reforma agrária e o banditismo no Brasil. Conforme enfatiza José Paulo Netto, Alberto Passos investigou os fatores econômico-sociais e históricos da violência no país, compreendendo o pauperismo como "entrecruzamento" da concentração de propriedade, de renda e de poder político. Considerou não apenas a violência das "classes perigosas", mas também a dos "de cima" e do Estado. (Cf. GUIMARÃES, Alberto Passos. As classes perigosas: banditismo urbano e rural. Apresentação de José Paulo Netto. Rio de Janeiro: Editora UFRJ, 2008).
} 
o estereótipo do trabalho como moralmente inferior e, por isso, a incompatibilidade entre o produtor e o intelectual.

O texto de Alberto Passos parece-me interessante por incidir sobre os sentidos recíprocos da questão. Ao julgar desastrosa a separação entre o trabalho braçal e o intelectual, de um lado ele condena a literatice bacharelesca, capricho da elite, de jovens que vão para as cidades "queimar as safras dos pais à sombra das academias"; de outro lado, critica a falta de bons cérebros no campo, abandonada a produção segundo uma crença semibárbara na "fertilidade inextinguível do solo". Assim, fica evidente a necessidade de articularem-se estudo e ação. Os melhores resultados intelectuais e artísticos, alimentados pelos conflitos da vida prática, decorrem do trabalho de seus criadores, e igualmente os componentes de racionalidade devem integrar o trabalho manual.

Configurando o sentido da Novidade, o escritor combate a fama de "terra de milagres" que se criou para o Brasil por causa de sua grande extensão territorial. Por isso, identificando como problema grave a falta de intelectualização do campo e de racionalização da produção, sugere que fossem criadas escolas técnicas, especializadas no trabalho agrícola. Mais do que isso, propõe que, sob todos os aspectos, se elevasse o nível moral do trabalho, eliminando qualquer pudor de se carregarem os próprios livros e as cestas de compras.

Desse modo, revelam-se algumas contradições da realidade brasileira, de origem escravista e marcada por conseqüências desastrosas da intensa divisão entre capital e trabalho e entre trabalho manual e intelectual. A criação literária e a vida de vários de nossos escritores, como Graciliano e Drummond, contêm os dramas de descendentes de proprietários rurais, em geral funcionários públicos, divididos entre a seriedade do trabalho intelectual (contrastante com a bacharelice oca) e o sofrimento com seus limites em relação à ação prática.

Essa questão discutida por Alberto Passos Guimarães é relevante em especial para a interpretação de Angústia e suas "figurinhas insignificantes", junto com as passagens "Os antigos senhores" e "Os antigos escravos", da Pequena História da República, de Graciliano Ramos, e o capítulo I - "Um escravo entre escravos”, de Memórias de um negro, de Booker Washington, traduzido em 1940 por Graciliano ${ }^{7}$. Seus romances

\footnotetext{
${ }^{7}$ RAMOS, Graciliano. Pequena História da República. In: Alexandre e outros heróis. $3^{\text {a }}$ ed. São Paulo: Martins, 1966, pp. 160-2; WASHINGTON, Booker. Memórias de um negro. (Up from slavery autobiography). Tradução de Graciliano Ramos. São Paulo: Companhia Editora Nacional, 1940.
} 
desmascaram os estereótipos de ser o bacharelismo retórico valoroso e o Brasil uma terra de milagres, configurando as tensões do intelectual inadaptado no mundo, entre a consciência anti-ilusionista e o desejo de aproximação com o outro social e de minoração das iniqüidades.

O questionamento da crença nacionalista no país como terra de milagres comparece em outros textos da Novidade. A fé nas possibilidades econômicas do solo brasileiro e também o muito respeito ao hino nacional são apontados criticamente por Alberto Passos como "mentiras políticas" usadas para mascarar as realidades brasileiras. Porém, em “Torre de Babel” (N 20), ele observa que, enfraquecido na nova conjuntura política, esse respeito à pátria, embora retórico, talvez fosse melhor do que o seu substituto, o falso amor a uma teoria de liberdade. Desnuda perigoso, porque dissolvente, o "abuso de liberdade". E o país era comandado por "blocos desarmoniosos, facções personalistas, regionais e sociais": reacionários silenciosamente unidos ou revolucionários publicamente dissociados, regionalistas restritos a campos limitados, socialistas espalhados sem olhar limites. Enfim, Alberto Passos diagnostica no país uma Torre de Babel de "interesses desencontrados", em que os homens falavam muito e se compreendiam pouco.

Também em "Espírito brasileiro e espírito revolucionário" (N 22), o escritor retoma o chavão de que no Brasil "a terra é fértil”, para mostrar que, apesar ou por causa disso, não se sustentavam ideais políticos e sociais, não havendo um sentimento de nacionalidade no país. Enfatiza que aqui são muitas as pátrias, o homem parece viver para si, indiferente ao Estado e à nação.

Então, pensando-se na historiografia da revolução de 1930, é significativo que Alberto Passos Guimarães evidencie as limitações desse movimento. Compreende que o espírito revolucionário não se integrou como pensamento da nação, e sim foi absorvido pelo "interesse personalista" de elementos facciosos: "tornou-se portanto em teoria partidária o que se tinha proposto ser aspiração brasileira”.

Saliente-se ainda o editorial da última Novidade: abre-se com a imagem de crianças a franzir responsabilidades em lugar de sobrancelhas e fecha-se com a imagem do mundo asfixiado, até a extinção da "última geração de burgueses" (título do editorial). Identificando lucidamente a máquina e o imperialismo como causadores de desemprego e 
pauperismo, alerta para a "situação insuportável" do mundo, para o irremediável de se sobreporem as razões financeiras às humanitárias.

Em síntese, Alberto Passos Guimarães em seus editoriais, salientando a responsabilidade dos jovens, acusa o problema da desigualdade social, conseqüente da industrialização e do imperialismo mundiais e do caráter "impolítico" do Brasil. São alvos de sua crítica: a inexistência de uma fisionomia brasileira em termos de arquitetura ("Fisionomia das ruas brasileiras"); a falta de apego a uma tradição nacional ("Estados Unidos do Brasil"); a imitação, por parte dos alagoanos, dos grandes centros do Sul, afeitos à americanização e europeização dos hábitos brasileiros ("Navegação de cabotagem"); o caráter impolítico do país, marcado por analfabetismo, absolutismo dos governos, flacidez de caráter das elites, indiferentismo ou oportunismo dos jovens ("Também sobre política"); a desordem da República Nova, sob os pretextos de liberdade e de romantismo dos dirigentes (“Oh! liberdade formosa...”); o artificialismo e a mecanização do mundo, que trouxeram consigo a fome de muitos ("Tristezas de uma época"); o falso ufanismo e o imperialismo desumano ("Novos e velhos").

Então, defende a formação de uma identidade nacional e o empenho pela autonomia intelectual do Nordeste, que se voltasse para os valores e necessidades regionais. Inclui aí a educação e a independência da mulher ("Notas sobre um sexo").

A leitura dos editoriais ilumina o caminho interpretativo da Novidade até aqui percorrido e é por ele iluminada. Condensando os temas e a perspectiva crítica da revista, os editoriais cumprem o propósito desejado no "Cartão de visita" de que os jovens alagoanos se concentrassem nas realidades da vida, combatendo estereótipos ideológicos. Tanto Valdemar Cavalcanti quanto Alberto Passos Guimarães condenam que as imagens do país como etnicamente romântico e triste ou terra de milagres servissem de justificativas para a falta de ações efetivamente transformadoras.

À medida que os fundadores da Novidade descortinam que o nacionalismo revolucionário de 1930 não passou muito de um movimento conforme os interesses de uma política personalista, vale até como expressão o "sem novidades no front". Mais do que isso, à semelhança do romance de Remarque, desmascaram o heroísmo e o nacionalismo como instrumentos da ambição dos dirigentes, cujo poder se constitui sobre muitas vítimas. Recusando "passar pela vida como turistas", os jovens intelectuais desejam criar uma 
consciência crítica em relação ao imperialismo e aos problemas da realidade política e social brasileira; voltam-se contra a sobreposição das razões financeiras às humanitárias.

Por fim, acrescente-se que o anseio de independência intelectual dos alagoanos, incluindo a defesa das tradições regionais, pauta vários editoriais da Novidade, o que confirma o epíteto de meninos impossíveis para essa geração de jovens admiradores da poesia de Jorge de Lima. 


\section{CAPÍTULO 5 - NOVIDADE POLÍTICA: O RESGATE DOS SEM-LUGAR}

\section{OS NOSSOS ERROS POLÍTICOS: PERSONALISMO E RETÓRICA}

Já analisados, alguns editoriais de Valdemar Cavalcanti - "Os técnicos da Segunda República", "O prestígio da mulher na Segunda República" - desmascaram que, após a Revolução de 1930, conservou-se o personalismo político característico da Primeira República (1889-1930). Conforme revela Valdemar, os políticos da Segunda República (1930-1937) arvoraram-se técnicos e renovadores, acusando os antecessores de românticos, por sua inércia, e de "Ladrões da Velha República", na gíria revolucionária; contudo, não diagnosticaram com exatidão os problemas do país, muito menos apresentaram propostas efetivas - as receitas de "médicos especialistas", segundo a analogia da época. Como se preocuparam tão-só em atingir o poder e garantir seus interesses particulares, adiando sempre a resolução dos problemas do país, percebe-se constituírem os "erros políticos" a identidade brasileira.

Recorde-se, de "Torre de Babel" e "Espírito brasileiro e espírito revolucionário", editoriais de Alberto Passos Guimarães, a crítica aos revolucionários de 1930, que se dissociaram segundo o "interesse personalista" de suas facções, sobreposto a qualquer “aspiração brasileira”.

Esses editoriais refletem sobre as questões do momento político as quais também inquietaram outros colaboradores da Novidade. Dentre os artigos de crítica à manutenção do estado de coisas após a Revolução de 1930, sobressai “O novo menù político" (N 4, p. 13), do viçosense Barreto Falcão. Ao lado de Aurélio Buarque e de Valdemar Cavalcanti, ele é um dos "meninos pelados" a quem Graciliano manda lembranças por intermédio de Heloísa em várias cartas de fevereiro, março e abril de 1937. Provavelmente em meados desse ano Barreto foi ao Rio de Janeiro, para a mesma pensão em que viviam Graciliano Ramos, Rubem Braga, Moacir Werneck de Castro ${ }^{1}$.

Em "O novo menù político", comparando a alteração do quadro político, advinda da Revolução de 1930, a uma mudança de cardápio que conserva ruim a comida, Barreto Falcão ironiza a falta de substância ética administrativa dos políticos brasileiros.

\footnotetext{
${ }^{1}$ MORAES, Dênis de. $O$ velho Graça: uma biografia de Graciliano Ramos. $3^{\text {a }}$ ed. Rio de Janeiro: José Olympio, 1996, p. 157.
} 
Desmascara que a subida dos novos ao poder foi movida tão-só por interesses pessoais, garantidos por discursos retóricos e relações de favor: os políticos introduzidos com a Revolução no "cardápio" diário foram proclamados como valores por um desses "contos de vigário da camouflage política" ou pelo "afeto pessoal de um dos chefes".

Desenvolvendo seu símile irônico, Barreto Falcão associa os novos a "pratos ruins enfeitados, de nome francês ou inglês", experimentados e logo repugnados pelo caboclo brasileiro. Assim, ataca a postura pretensamente civilizada, cosmopolita, dos políticos ditos revolucionários, a qual, de fato, perpetuava os problemas da realidade brasileira, desconsiderando-lhe as necessidades. Terrivelmente atual, vem a conclusão: se o hoteleiro suprime do cardápio a refeição repugnada, ao contrário o político "neófito" recomendado pelo chefe, embora repugnado, continua no cardápio. No "restaurantezinho político" brasileiro, o prato diário é péssimo, mas "a gente tem que comê-lo todos os dias, sem fazer cara feia. E ainda dando mostras de que o prato é excelente".

Sobressai do artigo uma imagem significativa do impasse dos brasileiros (nos anos 1930) em relação à política nacional, entre expectativas de mudanças sociais e recorrentes frustrações: "nossa gulodice democrática de povo desenganado de democracia". Ao indicar que, do imenso cardápio novo, com tantos pratos desconhecidos, poucos satisfizeram ao paladar, Barreto Falcão revela criticamente o Brasil como país de "mudanças conservadoras".

Então, relembra os políticos afastados pela Revolução, pratos eliminados do cardápio todos de uma vez. A ironia agora é que alguns, apesar de não haverem deixado saudades, já voltavam a despertar o apetite no cardápio de outros hotéis e eram servidos como ótimos pratos. A estratégia consistia em mudar de hotel, onde os clientes fossem outros: um prato regional, como um sururu, por exemplo, agradava ao esnobismo de um hotel cosmopolita. Esgotado o gênio culinário dos cozinheiros, os hoteleiros, com o intuito de matarem a fome dos clientes, iam permutando e servindo-lhes os pratos eliminados do cardápio dos outros. Assim, por meio do paralelo culinário, Barreto Falcão desnuda a mobilidade astuciosa dos acordos políticos, que possibilitavam aos dirigentes afastados de um Estado do país estabelecerem-se com grande cotação em outros Estados.

Entretanto, segundo o ensaísta, o pior era que muitos dirigentes "revolucionários" tinham sido riscados do cardápio como péssimos pelos próprios agentes que os haviam propagandeado excelentes. E o povo, acostumado a comer tanta coisa ruim, deixava-se atrair por esses maus políticos como por frutos proibidos. Ou seja, desmascarada também a 
má alimentação dos brasileiros, sobressai desnorteante a falta de valores autênticos na política nacional.

Desse modo, num tom leve, com o símile do menù, Barreto Falcão combate os falsos discursos da política brasileira, que oferecem novidades em seus cardápios, para, na verdade, se realimentarem sempre os velhos arranjos pessoais dos dominantes. Intenta desmistificar a falsa imagem de que os representantes da República Nova, imbuídos de ideais e de programas políticos renovadores, promoveriam mudanças profundas na realidade brasileira.

Outro documento vivo de reação crítica aos arranjos pessoais que subsistiram à Revolução de 1930 é “Carta a um antigo correligionário político” (N 9, p. 6), de Lima Júnior. Significativamente, em 1929, quando o Jornal de Alagoas reimprimiu o primeiro Relatório do prefeito Graciliano Ramos, foi Alfredo de Barros Lima Júnior o autor de uma nota, em que expressava sua "deliciosa surpresa". Isto resultou numa notícia no Jornal do Brasil, provavelmente a fonte em que Schmidt descobriu o romancista alagoano.

Como o texto de Barreto Falcão, o de Lima Júnior também sobressai pela construção irônica, voltada para a única convicção da maioria dos políticos brasileiros: o apego ao poder. Em sua construção ficcional, a carta, escrita numa "manhã chuvinhenta de maio" pelo "seu afetuoso Libanio", é um conselho para o "generoso patrício". Este, provocando comovedora candura (segundo a ironia da carta) no interlocutor, indagara-lhe se deveria ou não aderir à nova situação política do país. A resposta de Libanio expressa sua surpresa por verificar que o "generoso patrício" ainda não se afirmara revolucionário. Afinal, vencedor o movimento de Outubro, "verdadeira enxurrada" já confluíra para "o mar crespo da vitória": ao lado de revolucionários autênticos, figuravam "respeitáveis e honestos cavalheiros" que, nas vésperas, juravam ser mais legalistas do que o próprio presidente deposto.

Assim, Lima Júnior desvela com agudeza a flutuação dos políticos entre afirmaremse conservadores ou revolucionários, segundo as conveniências. E prossegue enfaticamente no desmascaramento da falta de princípios dos nossos políticos, movidos, conforme as circunstâncias, apenas por seus interesses pessoais.

Descreve com comicidade a rápida mudança dos legalistas. A princípio, ansiosos por afirmar solidariedade ao poder estabelecido, "acotovelaram-se" para subir as escadas do Palácio dos Martírios e jurar as suas convicções. Contudo, no dia seguinte à "noite lúgubre" em que a casa do governo foi abandonada, já eram revolucionários. E Lima 
Júnior é mordaz com esses políticos: "só não pint[aram] de vermelho os próprios cabelos porque já os havia[m] pintado, de preto".

Aquele cidadão ilustre que lhe falou tantas vezes das virtudes dos homens que estavam no leme do Estado mal o leme ficara sem ter quem o segurasse, os apodava de desonestos e incapazes. Aquele moço cheio de brilho que tanta dedicação afirmava aos governantes que em Outubro foram vencidos, mal lhe chegou aos ouvidos o ruído da vitória da Revolução saiu à rua para arrolar as pessoas que lhe conheciam as convicções revolucionárias, desde, talvez, antes de Juarez e João Alberto.

Então, Libanio explica ao "antigo correligionário político" que ele deveria logo ter colocado o seu lenço encarnado e aparecido no Relógio Oficial para chamar de ladrões "os mesmíssimos cavalheiros" que lhe haviam merecido até Outubro "as palavras mais enternecidas". Observe-se que, autor da carta, Libanio representa a voz da experiência: recrimina a "pudicícia política" do outro, acusando-o de não ser "um homem moderno". Por meio de um tom irônico, Lima Júnior desvela que o ideal político é a decisão imediata de estar sempre ao lado do governo vigente:

Você, porém, não foi na onda e, agora, após sete meses de república nova, é que se resolve a deixar essa incômoda situação de não estar com o governo.

Por fim, Libanio aponta para o amigo que a atitude recomendada é recorrente nas páginas da História, tendo como exemplos Sila, Pompeu, César, Cícero e, mais modernamente, Disraeli. Sugere que, a fim de se justificar, o correligionário não recorra aos exemplos daqui, mas a Disraeli, para ficar melhor amparado. Desse modo, Lima Júnior mais uma vez revela criticamente a política nacional, vazia de ética, de valores autênticos.

\section{Em “Uma mentalidade nova para o Brasil” (N 15, pp. 3, 13), Lima Júnior} expõe seu desalento porque, após as agitações do movimento de outubro, sentia diante de si "a melancolia da mesma paisagem", feita de figuras semelhantes, da "planície árida da política brasileira".

Contudo, interessa-se por alguns sonhadores ingênuos que, desejosos de um Brasil novo, queriam golpear num segundo o que se consolidara em vários anos de "insensatez e indiferença”. Então, utilizando a imagem do país doente, comum na época, pondera que a "cura completa" dos males brasileiros dependia da criação de uma "mentalidade nova", de nova educação política. Com espírito crítico em relação aos "ingênuos patriotas da nova 
República", ressalta que a formação de um "espírito cívico" exige tempo e "mãos capazes", sobretudo num país em cuja organização política se haviam consolidado vícios desde o Império e em quarenta anos de república.

Assim, conclui que "destruir o que foi feito não é fácil. Construir o que se promete ainda mais difícil". Segundo entende, mesmo que os homens do novo cenário do país tivessem a mais firme vontade de acertar, sua educação política não diferia da dos antecessores; além disso, a mentalidade de um povo não se constrói ao ímpeto das revoluções, que servem de ponto de partida para o seu preparo. Por isso, Lima Júnior enfatiza que, aceitando haver o movimento de Outubro destruído a mentalidade estabelecida pela velha República, não se estava em face de uma simples reforma administrativa, mas de firmar uma "consciência nova para a nacionalidade". Com lucidez em relação aos ingênuos da época, aponta que a criação da nova mentalidade política seria trabalho para várias gerações de políticos brasileiros. Ao mesmo tempo, como se confirma passados quase oitenta anos, era um idealista, confiante em que, como os corredores da Antigüidade, os políticos da época passariam às mãos dos vindouros "a flama da idéia de um Brasil melhor, cada vez melhor".

Raul Lima, irmão de Lima Júnior, trata o assunto criticamente e com humor em "A Revolução e o Álcool - Da influência da aguardente na evolução política do Brasil”" Relata que a Revolução criou a medida policial de proibir a venda de bebidas alcoólicas sempre que se esperava alguma exaltação do povo, como o carnaval ou um comício. Então, pondera que, segundo os estadistas do Brasil novo, não existindo cachaça, não haveria exaltações, nem ideais, nem opiniões.

Conclui com ironia que o civismo e o patriotismo do brasileiro seriam aguardente; tudo de engraçado ou criminoso feito no meio da rua seria efeito dela. Por conseguinte, a ironia se intensifica: os novos sociólogos nacionais teriam razão de considerar os nossos movimentos políticos, como a própria revolução, uma questão de dois cálices a mais.

"Estariam todos fumados os patriotas que gritaram uma República nova?": condenando a mentalidade policial do novo regime com suas proibições de bebida, a pergunta de Raul Lima acusava a falta de ideais e de opiniões não só do povo, mas sobretudo dos dirigentes. 
Dentre os artigos que se detêm mais profundamente em questões de política, para cobrar mudanças efetivas da Revolução de 1930, destaca-se “O voto proporcional” (N 10, p. 6), de Moacyr Pereira.

Sendo o horizonte da Revolução de Outubro reabilitar a política nacional, Pinto Serva, João Cabral e Assis Brasil constituíram uma subcomissão encarregada de elaborar o anteprojeto da reforma eleitoral brasileira, preparatório da Constituinte. Contudo, interessado num remédio capaz de integrar de fato o país na "sadia política", Moacyr Pereira lamenta que Pinto Serva se tivesse declarado numa entrevista contrário ao voto proporcional.

Relembrando a conferência de Gilberto Amado sobre a "Representação proporcional, seus efeitos e modalidades", Moacyr explica que, segundo esse sistema, o eleitor não vota em indivíduos, em nomes determinados, mas em chapas de partidos, em listas completas por estes organizadas. Assim, entende que o voto proporcional representaria o antídoto para o "veneno caótico do personalismo brasileiro", à medida que substituiria o indivíduo-pessoa pelo indivíduo-idéia, o caudilho pelo estadista, o analfabetismo pela cultura.

Moacyr Pereira contesta o argumento de Pinto Serva que, alardeando-se apegado às realidades brasileiras, descartava o sistema de voto proporcional por faltarem partidos políticos ao país. Para Moacyr, aí mesmo residia a questão: em geral, os partidos existentes não defendiam princípios de conduta, sendo tão-só expressões individuais, agregados de pessoas ambiciosas do poder. Como Graciliano na crônica de 1915 em que revela o país comandado por muitos caciques e não por leis ${ }^{2}$, Moacyr enfaticamente ataca "os nossos complexos problemas... municipais":

É o caso do padre fulano que disputa ao coronel sicrano a chefia do arraial, é ainda o genro-doutor do Chefe que quer ser Prefeito... As soluções daqueles problemas decidem a sorte dos Estados e indicam em última estância as diretrizes da União.

São essas as 'realidades brasileiras'.

A crítica de Moacyr Pereira dirige-se contra as relações de favor, "diretrizes" vigentes desde o âmbito dos pequenos arraiais até o federal. Ele sublinha que caberia exatamente à reforma eleitoral dar um rumo diferente à nossa velha política, "caricatura de governo democrático". Sua finalidade seria justamente "corrigir, melhorando, a realidade política brasileira".

\footnotetext{
${ }^{2}$ Cf. Linhas tortas. cit., pp. 8-9.
} 
Dessa forma, Moacyr Pereira defende a representação proporcional: não pressupondo a existência de partidos, ela os criaria automaticamente, ao colher e organizar as aspirações nacionais. $\mathrm{E}$ a necessidade de partidos políticos era flagrante, para que o Brasil deixasse de ser modelo "de incultura cívica e de incapacidade administrativa".

Em "Novos rumos" (N 13, p. 10), Moacyr Pereira ataca os febris renovadores, que, desejando tudo "novinho em folha", rejeitavam o passado alegando impossível a harmonização deste com a aceleração dinâmica dos novos tempos.

A ponderação de Moacyr é reveladora dos anos 1930 na Europa e no Brasil: considera essa radical recusa do passado pelas intelectualidades jovens um fenômeno próprio do espírito pós-guerra europeu e do "período convulsivo" atravessado pelo Brasil. Vítima de uma crise generalizada, de ordem política, econômica e financeira, o país surgia como um enfermo que aspira à saúde, conforme a imagem então recorrente.

Moacyr ironiza que alguns preconizassem reformas políticas, econômicas ou sociais e outros pregassem a salvação do país por meio da graça divina, implorada nas rezas ensinadas nas escolas. Mesmo compreendendo tratar-se de uma idade ansiosa pela ação, volta-se principalmente contra as fórmulas extremistas da mocidade, que renegavam vínculos com o passado. Então, Moacyr Pereira defende que, em busca de acertar, é preciso conhecer os erros do passado, inquirir suas causas para não mais incorrer neles. Recusa o apego da mocidade a teorias flutuantes, que ainda não haviam sofrido o "batismo do Tempo". Considerando o passado como "o grande Mestre", cujas coisas boas e más constituem o único patrimônio da humanidade, ressalta não sermos mais do que o resultado do passado.

Sendo assim, atribuindo a crise brasileira a fatores como a "violência governamental, fraude criminosa, covardia dos fracos e o suborno dos desonestos", indica, à semelhança de Lima Júnior, que sobretudo a "mentalidade do homem" deveria melhorar, e "não se educa um homem num dia, muito menos um país". Finalmente, desvela-se o espírito idealista e evolucionista de Moacyr Pereira, que confia na consciência quanto ao passado, "tão humano com suas falhas e virtudes", para a conquista de um futuro "brilhante para a Juventude brasileira". Sobressai sua atitude ponderada, que não quer "nem o Conservantismo rotineiro, nem o radicalismo exótico e incoerente".

Confirmando o espírito de inquietação da Novidade com os problemas do seu tempo, não só nacionais, em “O Acordo Naval” (N 7, p. 12) Moacyr Pereira mostra-se preocupado com a situação de conflito mundial - e de fato em poucos anos se iniciaria a 
Segunda Guerra. Considerando que a Conferência de Desarmamento estava marcada para 1932 e que já havia um impasse entre a França e a Itália, questiona se o mundo, com complexos interesses em jogo, chegaria a um acordo quanto à limitação de suas armadas.

\section{Em “Uma idéia maluca - A propósito da divisão territorial” (N 6, p. 5), Lauro}

Jorge critica a combinação de dois chavões da época: o "conceituoso estribilho" segundo o qual o Brasil vivia "o seu mais sério e grave momento político", por razões financeiras, e as "fórmulas de salvação" do país, propostas por seus muitos acácios. Dentre essas fórmulas, rejeita como a mais desastrada e inócua a de se modificar a nossa divisão administrativa, anexando aos grandes Estados as consideradas pequenas unidades da Federação.

Lauro Jorge considera que essa anexação traria sérias perturbações, afinal os pequenos não admitiriam a tutela, até porque poderiam possuir maior patrimônio moral, histórico e/ou econômico do que os grandes. Além de ofensa aos brios dos pequenos Estados, a sugestão ventilada representaria um atentado à estabilidade do país. Em seu exemplo particular, Lauro Jorge nega a anexação de Alagoas a Pernambuco, com o argumento, entre outros, de ser a área territorial de seu Estado maior que a de vários países da Europa. Denotando embora certo bairrismo até exagerado, sua atitude traduz a defesa da tradição regional.

Sobretudo, Lauro Jorge enfatiza faltar a Alagoas o mesmo que aos demais Estados: "homens-administradores-estadistas". Então, ao defender o fundamento da Revolução, desnuda, com vocabulário bastante expressivo da familiaridade nacional com a prática dos acordos pessoais escusos e do nepotismo, um problema de todas as regiões do país: a necessidade de extinguir "a política dos cambalachos e das mamãezadas".

Em “Alberto Torres e a Constituição” (N 8, p. 5), Paulino Jorge destaca Alberto Torres como talvez o mais legítimo revolucionário do Brasil: foi o primeiro a revoltar-se contra a desorganização política do país, sem programa e orientação, alheia às necessidades do povo e à realidade do meio físico e social brasileiro. Segundo Paulino, diferentemente da dispersividade e confusão mental de respeitáveis expressões de nossa cultura, perdidas em duelos estéreis de oratória, em torno de preconceitos de escolas e divagações doutrinárias, a obra de Alberto Torres foi de autêntico revolucionário. Consubstanciava-se num "plano homogêneo de política social e econômica, subordinada à funda reforma constitucional". 
Ao resgatar o percurso do sociólogo e pensador de "espírito poderoso", afeito a investigar as causas dos fenômenos sociais, Paulino Jorge projeta o caminho de seriedade que desejava para a Segunda República. Alberto Torres tivera de insurgir-se contra "errôneos preconceitos" radicados nas esferas do governo, para apreender, nas nossas tendências étnicas e vida social, o sentido exato dos problemas do Brasil e traçar o seu plano de organização nacional. Assim, representava um exemplo para a situação vivida pelo país nos anos 1930, que Paulino confiava ser propícia à criação de uma nova consciência coletiva e contrária ao "surto das ambições pessoais" e ao "mandonismo usurpador".

$\mathrm{O}$ artigo de Paulino comprova a necessidade de divulgar-se a obra de Alberto Torres, para quem todos os problemas do país, agravados pela "inquietação universal", confluíam para o problema da cultura do homem brasileiro, prejudicada pela sua pobreza de instrução, voltada para um trabalho explorado. Contra esse "edema orgânico da nacionalidade", Torres propunha a "terapêutica de uma política governamental de cultura econômica e social”, da qual a revisão constitucional seria a pedra angular.

Com senso crítico, Paulino desnuda que a reforma da Constituição vinha sendo "um belo tema falaz, chavão obrigatório das plataformas de governo". Sem se ocuparem de fato com o nível da cultura e da vida social brasileira, proclamavam os políticos, "evidentemente antes de se instalarem no poder", a urgência de procederem às reformas da nossa lei fundamental, segundo o desenvolvimento da sociedade.

Já Alberto Torres, livre das injunções de nossos núcleos partidários personalistas, dedicara-se ao problema da revisão da Constituição, para que fosse verdadeiramente nacional, aparelhada para retificar os erros de nossa formação histórica e atenuar os defeitos da nossa incultura. Perfeita como lei formal, a nossa Constituição se compunha de transplantações jurídicas alheias, quando deveria ser um roteiro político para o progresso nacional, ditado pela natureza de sua terra e de seu povo, evitando o arbítrio.

Portanto, Paulino Jorge ansiava por que o mesmo espírito de "organização e renovação política" do jurista e sociólogo brasileiro inspirasse os legisladores constituintes, na futura assembléia nacional, a dirigirem mais o pensamento e a sensibilidade para o Brasil.

Também centrado na necessidade de uma nova Constituição é o artigo "Por que não a Constituinte?" (N 12, p. 3), de Edmilson Falcão. Por um lado, o autor demonstra sua consciência quanto à "fase histórica" vivida pelo país, a qual, em lugar de expectativa, 
exigia ação eficiente, colaboração ampla, crítica e discussão. Edmilson Falcão compraz-se com o combate ao "profissionalismo político" e com o horizonte da restauração nacional. Ao mesmo tempo, transparece em seu tom e vocabulário uma exaltação algo excessiva da Revolução, que incluiu componentes militares e pretensamente patrióticos. Por exemplo: ele declara que era o momento de renovação e organização de todos os brasileiros libertos, "pelo Exército, do jugo infamante dos partidos políticos, chefes e chefetes de partidos". E sublinha que, "sob o pálio revolucionário", todos aqui eram "filhos da mesma família civil e soldados do mesmo credo cívico: a salvação do Brasil".

Nessa combinação entre idealismo nacionalista exagerado e consciência crítica dos problemas do país, o autor se faz porta-voz do anseio de todos: Quando teremos a Constituinte? Seu texto é revelador do quadro de crise econômica generalizada, que abalava então o mundo inteiro, e do agravamento desse quadro no Brasil por causa de uma "herança de erros sistematizados". Com lucidez, Edmilson Falcão cobra da administração do país que persiga na restauração financeira e no "saneamento" dos hábitos sóciopolíticos. À semelhança de Lima Júnior e de Moacyr Pereira, retoma a imagem do país doente, "organismo roto e enfermado", ampliando-a com a de "maquinismo gasto e enferrujado". Igualmente, reconhece a necessidade de tempo para "reajustar as peças" desse maquinismo, de tempo e de uma "larga visão de estadistas".

Sendo assim, observando que o povo brasileiro jamais se amoldara por muito tempo ao regime da autoridade absoluta, Edmilson Falcão reclama que, decorridos oito meses da vitória da Revolução, ainda não se dera um passo no sentido das prerrogativas constitucionais. Por entender que a nova Constituição era um desejo coletivo e garantiria reformas radicais, voltadas para a "grandeza do Brasil", incita os leitores ao movimento pró-constituinte.

Recordando os nove anos da Revolta do Forte de Copacabana, em "5 de julho" (N 13, p. 5), Edmilson Falcão evoca o gesto épico da mocidade de 5 de julho de 1922: em sua revolta contra os responsáveis pela decadência do país, vinte e quatro "heróis" Siqueira Campos e seus bravos - resistiram ao ataque de milhares de soldados do governo.

Com acentuada retórica patriota, o autor credita ao "Sonho Ardente" e martírio desses jovens a base do idealismo revolucionário brasileiro. Se sobressai sua consciência histórica ao resgatar o acontecimento de 1922 e valorizar o espírito de rebelião dos jovens contra desmandos e violências, a um tempo é exagerada sua forma de conceber a data 
como página inicial de uma "epopéia gigante, cheia de esplendores cívicos, expressão de um dramático sopro idealístico, que foi a Revolução brasileira".

A presença de um texto de tom retórico como esse de Edmilson Falcão, na Novidade, pode soar paradoxal, à medida que destoa dos propósitos apreendidos da revista, sobretudo dos editoriais. No entanto, como já se notou, ele partilha do mesmo horizonte de crítica aos problemas político-sociais do país, de desejo de renovação e de cobrança de uma nova Constituição. Além disso, é preciso compreender o caráter vivo do semanário, disposto a trazer os vários matizes de reações aos acontecimentos políticos e sociais do momento, possibilitando formar-se uma postura crítica ante a realidade. Vejam-se os lemas que aparecem na revista: "Novidade acolhe diversidade", "Os colaboradores de NOVIDADE têm absoluta independência de idéias" (N 9, p. 7; N 11, p. 3; N 13, p. 10); "NOVIDADE não é essencialmente literária nem essencialmente política. NOVIDADE acolhe o pensamento de todos, para interessar a todos" (N 13, p. 3; N 14, p. 4; N 16, p. 11 etc.).

Síntese precisa do momento pós-revolução de 30 está nesta passagem das Notas da Semana da Novidade 6, provavelmente escrita por Valdemar Cavalcanti:

O Jornal de Alagoas publicou um tópico, há dias, muito justo, sobre o uso de carros oficiais para serviço particular, uma coisa que os revolucionários à outrance tanto criticaram nos governos da outra República.

Curta mas de teor crítico incisivo, esta nota desvela o personalismo e a retórica como marcas da política brasileira: acusa a velha prática de apropriação particular de bens públicos e, a um tempo, a sua continuidade na chamada República Nova, cujas promessas de renovação não passavam de discursos.

Também a nota "Guerra à luz" (N 7, p. 4) desmascara a falta de transformações após a Revolução de 1930. Denunciando os aumentos nas taxas das escolas pagas e no imposto sobre os isqueiros, conclui ironicamente que o governo sofre de um "horror de morcego" pela luz nacional:

E isso é, no entanto, pouco elogiável, porque é contrário ao programa revolucionário.

Vejam os srs. da Segunda República que o regime traçado era o de trazer para o Brasil uma vida completamente às claras... 


\section{A MAIOR CRIAÇÃO DE TRAÇAS DO NORTE: VIVA A BIBLIOTECA ALAGOANA!}

\section{O ambiente agressivo para as letras}

A Novidade procurou subsistir à precariedade da esfera da educação e cultura letrada em Alagoas, denunciando-lhe os fatores político-econômicos, oferecendo bons textos críticos e artísticos, dando espaço para se expressarem escritores em formação.

Uma nota do número 9 refere-se à idéia de $O$ Diário de se organizar em Alagoas uma "Associação de imprensa". Por um lado, conforme seu empenho por resistir ao ceticismo, a Revista apóia a idéia de uma Associação, acreditando que, "cuidadosamente estudados por todos, em conjunto", os obstáculos poderiam ser vencidos. No entanto, a princípio a proposta é recebida com descrença, reveladora da estreiteza cultural do ambiente:

(...) É que lhe falta [à Imprensa alagoana] um pouco de cada coisa. Cada periódico aqui luta com uma dificuldade diferente justamente por não possuirmos uma associação que nos crie a solidariedade profissional.

O meio é absolutamente agressivo para isso de letras, de modo que não há jornal que se possa manter sem uma enorme quantidade de esforços.

"É uma situação miserável a do homem pobre que cai na literatura e quer se dar ao delicioso contato com os livros". Assim se inicia "Um salão de leitura", tópico da Novidade 7 (p. 16), que também acusa a falta de interesse e o descaso pelas letras no país.

Mesmo que os leitores pobres quisessem livros, o acesso a eles mostrava-se muito difícil: o preço dos nacionais e, mais ainda, dos estrangeiros era elevado e não havia em Maceió um salão de leitura. Ao relatar-se que o governador Álvaro Paes visitara a Biblioteca Pública do Estado, a imagem que a define causa risos por desvendar de forma tão realista o nível crescente de corrosão a que as letras estão relegadas no país:

(...) o sr. Álvaro Paes meteu os pés na Biblioteca Pública do Estado, que era, pela falta de cuidado que lhe dispensavam, a maior criação de traças de todo o Norte.

Então, assumindo a corrosão crítica da realidade, os intelectuais da Revista cobravam que o Instituto Arqueológico franqueasse a sua rica biblioteca ao público, para dar "uma finalidade mais humana às suas centenas e mais centenas de livros". Como já salientado, os meninos impossíveis criaram em 1932 a Liga contra o Empréstimo de 
Livros, e somente em 1938 a Biblioteca Municipal de Maceió foi inaugurada, graças sobretudo a Aurélio Buarque de Holanda.

Chamando criticamente o país de "terra dócil do analfabetismo", o médico, farmacêutico e professor Álvaro Dória ironiza que a "revolução purificadora", origem de um "Brasil novo, logo tão parecido com o pai", incluiria "A Reforma do Ensino" (N 7, p. 3), "sensacional e ultramoderna".

Aponta que o ministro Francisco de Campos, após se inteirar da pedagogia da época e da sociologia moderna, retornou "aos cânones sentimentais do empirismo e à retórica conservadora do medievalismo". Ou seja, a propagandeada revolução pedagógica mostrou-se reacionária e antiquada.

Sublinhando que o mais odioso da reforma era o alto custo da aprendizagem, Álvaro Dória desmascara como retórica interesseira os discursos em prol da educação do povo brasileiro: por fim, resumiram-se numa "seleção grotesca de ricos e pobres". Questiona se "terão querido fazer do ensino uma fontezinha de renda" e alude com humor ao Ministro José Américo de Almeida, que reduzira as taxas postais; tal medida seria inútil, pois não haveria a quem escrever futuramente.

Assim, Álvaro Dória condena que se procurasse elitizar o estudo com taxas proibitivas, cerrando-se as portas das escolas às vocações verdadeiras de um já existente proletariado universitário-ginasial, para abri-las aos "enfants gatés que podem comprar bedéis e vender frivolidades". Reagindo às críticas contra o bacharelismo, esclarece que o índice cultural brasileiro ainda era o doutor - o médico, o promotor, o engenheiro -, sobretudo o pobre, que levava um pouco de claridade aos confins do país. Observa que em todo o mundo havia forte migração para a medicina, mas sem barreiras tributárias à conquista do "pergaminho hipocrático".

Por fim, expressa sua confiança em que os estudantes brasileiros adquirissem consciência universitária e fossem representados nas congregações, nos conselhos, nas administrações. Cientes de suas necessidades e aspirações, eles conseguiriam autonomia intelectual: "o ensino não é mais um benefício do Estado ou somente uma sua obrigação. Ele deve ser uma propriedade dos que estudam, auxiliados pelos que ensinam”. 


\section{Direções provisórias da instrução pública em Alagoas.}

Na seção “As nossas enquetes" ( $\mathrm{N}$ 4, p. 8), foi escolhido o dr. Miguel Baptista para falar sobre a educação no Estado. Diretor da Instrução Pública em Alagoas, o dr. Miguel Baptista é apresentado como estudioso e técnico dos problemas pedagógicos alagoanos, de visão percuciente quanto à deficiência didático-cultural brasileira.

Para ele, a escola tem por finalidade preparar o homem para a vida e facilitar-lhe a adaptação ao meio social. Deve levar em conta as condições de saúde, de vida e desenvolvimento físico das crianças e a natural inquietude do espírito infantil. Então, Miguel Baptista enfatizava existir um vasto programa educacional a empreender-se em Alagoas. Lamentava que fosse ínfimo o orçamento do Estado, não permitindo manter-se a quantidade desejável de escolas. Atribuindo essa penúria econômica ao fato de haver $80 \%$ de analfabetos e $78 \%$ de homens sem ofício, entendia que o defeito era exclusivamente de educação.

Por considerar que o brasileiro deveria ser educado para o trabalho, o diretor da Instrução Pública defendia que se instituísse em Alagoas a educação rural, com a criação de cursos em que o aluno aprenderia a necessária cultura regional, incluindo o plantio e o combate das pragas da lavoura e do gado. Além dessa educação regional, a criança teria no curso rural a necessária educação literária e entraria em contato direto com as ciências físicas e naturais.

Miguel Baptista via no curso rural a vantagem de fixar o homem no solo, despertando-lhe amor às coisas da terra e evitando o problema dos retirantes. Como Valdemar Cavalcanti faria no editorial 7, Baptista usa a expressão "tantalismo urbanista", evocando que este foi "tão belamente tipificado no Lucien de Rubempret, de Balzac, no Nantas de Emile Zola e no Último Tântalo da Chave de Salomão do célebre escritor Gilberto Amado". Segundo a mitologia grega, Tântalo testou a onisciência dos deuses e foi condenado ao suplício de, desejando saciar sua fome e sede, ter próximos os frutos das árvores e a água, porém inalcançáveis. Analogamente, oprimidos pelas secas por causa da "desorganização econômica", os retirantes-tântalos fugiam para as cidades. Contra fatalismos ideológicos, em "A propósito de seca" ${ }^{3}$, de 1937, Graciliano Ramos também condena os "processos rotineiros na agricultura", a "exploração horrível do trabalhador rural", "a carência de administração" - causas da fome no Nordeste, mais do que a seca. E

\footnotetext{
${ }^{3}$ RAMOS, Graciliano. A propósito de seca (1937). In: Linhas tortas. cit., pp. 128-130.
} 
sabemos a direção de Fabiano, de Vidas secas: sem a provisão de alimentos, trabalho e estudo no sertão, sonhando escolas para os filhos no Sul.

Quanto ao ensino profissional, o entrevistado aponta soluções para o problema: a montagem da secção de oficinas do Instituto Gabino Besouro, em Penedo; a montagem de escolas-agrícolas-pastoris em Palmeira dos Índios e em S. Luiz do Quitunde; de postos zootécnicos em Sant'Anna do Ipanema, em Paulo Afonso; a criação de uma escola de pesca em Coruripe ou Barra de S. Miguel. Finalmente, Miguel Baptista trata da diferença entre escola ativa (por exemplo, de artífices, apenas de homens), escola mista e educação sexual.

Assim, a entrevista chama a atenção para graves problemas da realidade nordestina e brasileira, como o analfabetismo, o desemprego e o "tantalismo urbanista", enfatizando a necessária educação - sobretudo rural e profissional, também literária e de ciências.

As Notas da Semana da Novidade 5, de 09 de maio de 1931, informam que Miguel Baptista havia pedido demissão de diretor da Instrução Pública para trabalhar como juiz de direito, já tendo sido nomeado para substituí-lo o sr. Osman Loureiro. Este, referido nas Memórias do cárcere, viria a ser governador de Alagoas de 1934 a 1940, com uma interrupção em 1935. Lembre-se que a diretoria da Instrução Pública, ocupada em 1931 por Miguel Baptista, era a "profissão" de Graciliano Ramos de 1933 a 1936, quando foi demitido e preso. Segundo ele relata, nos dois anos anteriores, oito pessoas haviam passado pelo cargo. Graciliano também se espantava de ter agüentado ali mais de três anos, contra a iniqüidade, o pistolão, a impotência em meio à rotina. Certamente descontentara “incapacidades abundantes", sobretudo por não ter a "habilidade necessária de prestar serviços a figurões" e por querer aproveitar "elementos dignos, mais ou menos capazes", como a professora mulata transferida para a cidade a fim de dirigir um grupo escolar. E, outro exemplo contra os preconceituosos, conseguira que 600 meninos pobres, calçados e vestidos pela caixa escolar, ingressassem na escola dirigida por d. Irene, para em seguida quatro deles, negros, obterem as melhores notas nos exames.

Curiosa e significativamente, ao ser preso, nas primeiras estações rumo ao Recife, após encontrar o usineiro José da Rocha, que o chamou com asco de comunista, foi com a "nobreza de Miguel Baptista, exposta num rápido cochicho", que Graciliano Ramos deparou. Conforme narra em Memórias do cárcere, correspondera-se, quando prefeito de Palmeira dos Índios, com Miguel Baptista, que, diretor da Instrução Pública, fazia o recenseamento da população escolar. 
(...) Agora, juiz de direito no interior, viajava [Miguel Baptista] para a sua comarca. Entrou no carro, abraçou-me em silêncio e foi sentar-se a pequena distância, de costas para mim. Não me olhou uma vez. No ponto de desembarque, entregues os pacotes ao carregador, veio abraçar-me de novo:

- Adeus, Fulano. Até a volta. Confundi-me, gaguejei:

- Não, Baptista, eu não volto.

- Volta, sim. Isso é um equívoco, não tem importância. Dentro de uma semana tudo se esclarece. Adeus, seja feliz.

Foi pouco mais ou menos o que ele disse - e isto dissipou negrumes, hoje me dá uma recordação amável daquele dia. Na ausência de Baptista, indaguei-me. Se os nossos papéis estivessem trocados, haveria eu procedido como ele, acharia a maneira conveniente de expressar um voto generoso? Talvez não. Acanhar-me-ia, atirar-lhe-ia de longe uma saudação oblíqua, fingir-me-ia desatento. Essas descobertas de caracteres estranhos me levam a comparações muito penosas: analiso-me e sofro. ${ }^{4}$

Do encontro dos dois diretores da Instrução Pública, resgatado pela memória escrita de Graciliano, sobressai a significação de ética. À medida que analisa o próprio comportamento se estivesse no lugar do outro, sofre, pois a comparação lhe revela que seria incapaz de um "voto generoso". Assim, Graciliano se empenha por perceber as diferenças entre as pessoas, conhecendo-lhes as limitações e os gestos de nobreza (em geral raros, como o de Miguel Baptista), o que configura o verdadeiro sentido de compreensão.

\section{A CIDADE MENDIGA}

\section{Multidão sob o relento e a seca}

As notas e tópicos da Novidade chamam a atenção reiteradamente para o problema social dos menores abandonados, dos sertanejos retirantes e dos mendigos. A tal matéria deram forma literária os escritores do semanário, como Carlos Paurílio, com os seus órfãos, e Graciliano Ramos, desde a primeira criação, "O pequeno pedinte" 5 , depois com

\footnotetext{
${ }^{4}$ RAMOS, Graciliano. Memórias do cárcere. cit., v. I, cap. 5, pp. 39-40.

${ }^{5}$ Em 1904, aos onze anos, Graciliano publicou o conto "O pequeno pedinte" no jornal $O$ Dilúculo, fundado por ele mesmo, em Viçosa. Conforme revela em Infância, o poeta e professor Mário Venâncio modificara seu texto. Mas note-se que já estava em questão o drama dos meninos de rua:

"Tinha oito anos. / A pobrezinha da criança sem pai nem mãe, que vagava pelas ruas da cidade pedindo esmola aos transeuntes caridosos, tinha oito anos. / Oh! Não ter um seio de mãe para afogar o pranto que existe no seu coração. / Pobre pequeno mendigo. / Quantas noites não passara dormindo pelas calçadas exposto ao frio e à chuva, sem o abrigo do teto. / Quantas vergonhas não passara quando, ao estender a pequenina mão, só recebia a indiferença e o motejo. (...)". (RAMOS, Graciliano. O pequeno pedinte. $O$
} 
Fabiano e várias figuras de mendigos, como Nicolau Varejão e os índios degenerados em Caetés, Seu Ivo, Evaristo e os muitos vagabundos de Angústia, e ainda o Venta-Romba, de Infância.

Logo no primeiro número da Revista, dentre as Notas da Semana, destacam-se "Escola de Gazeteiros" (p. 12), assinado V (Valdemar Cavalcanti), e "Louvado Seja N. S. Jesus Cristo" (p. 12), com a indicação A (Alberto Passos Guimarães). A primeira nota louva a iniciativa do sr. Manoel Candido, que recém-inaugurara a Escola de Gazeteiros. "Obra de um sentido admirável de humanitarismo", esse orfanato afastaria da fome, da sede, do frio e de uma "criminosa ignorância" os meninos abandonados. E a segunda nota aponta a fusão do problema dos sem-trabalho com o da mendicância. Ressaltando que "Maceió já não pode mais com tantos mendigos", compara a magreza destes a "criações doentias de um desenhista hoffmânico" e sua tragédia a romances russos. E conclui que os governantes não poderiam permanecer surdos a "esse pungente Louvado Seja Nosso Senhor Jesus Cristo" 6 .

Nas Notas da Semana da Novidade 6, o título "Meninos pobres" alerta para o "espetáculo triste" do abandono de menores - pobres-diabos que muito cedo se perdiam no "horror da luta pela vida". Agasalhando-se nos vãos de portas de casas comerciais, "esses onze e treze anos miseráveis" caminhavam para o vício e para o crime. O tom dramático da nota acentua a crueza da realidade, com o propósito de persuadir o leitor quanto à necessidade de se cuidar do problema. Sugere-se, a exemplo do Rio, a criação de albergues, para não mais expor tantas "almas em formação" a um "destino negro".

Então, revelando o caráter dinâmico e solidário da Novidade, uma nota do número 8 (p. 4) indica que o Jornal de Alagoas secundou o "nosso apelo às autoridades policiais no sentido de arranjarem um abrigo para os meninos pobres”.

Mas o tópico “Ao relento" (N 11, p. 15) reitera que os poderes públicos precisavam atentar para a "verdadeira multidão" de garotos abandonados. Após ironizar que não

Dilúculo. n. 1, 24 de junho de 1904. Apud MORAES, Dênis de. O velho Graça: uma biografia de Graciliano Ramos. cit., p. 18).

${ }^{6}$ Recordem-se estes versos de "G.W.B.R.", poema de Jorge de Lima em louvor à estrada de ferro Great Western, sua "primeira mestra de paisagem": "e os aleijados vêm aos vagons mendigar; / entram homens sem nariz dos cartazes do Elixir, / mulheres sem manga, / meninos sem pai. / Pobrezinhos! / Uns vêm vestidos de feridas, / outros expõem ventres inchados, / colunas vertebradas de clown, / beiços de boxeadores vencidos no último round... / - Louvado N. S. Jesus Cristo; (...) / - Perdão de Deus! / As moscas fazem uma manifestação de apreço aos pobrezinhos. / O condutor quer dar uma esmola: / Não tem troco; / e uma menina do Recife não vai almoçar / porque olhou o homem sem nariz. / Coitado!”. (LIMA, Jorge de. Poemas, 1927. In: Obra completa. Org. de Afrânio Coutinho. v. I - Poesia e ensaios. Rio de Janeiro: José Aguilar, 1958, pp. 242-8). 
constituiria sacrifício para o Estado conseguir um abrigo noturno para essa "gente infeliz", chama a responsabilidade de todos:

Devemos olhar com mais desprendimento para esses que não tiveram, como nós, quem lhes preparasse uma vida de comodidades.

Igualmente abandonados a um “pungente 'seja o que Deus quiser', sem roupa, sem teto, sem dinheiro, sem nada de seu que não seja uma desgraça imensa", eram os muitos retirantes; obrigados a exilarem-se de sua terra, enchiam a cidade. Note-se a veemência com que o tópico "A seca" (N 5) descreve a situação trágica dos sertanejos pobres: sua vida era uma "paisagem dolorosa", tinham apenas sua "desgraça imensa". Com consciência do valor de romances como A bagaceira, reveladores do quadro da seca, esse tópico aponta, no entanto, a necessidade de ações governamentais efetivas de combate ao problema sócio-político por ela representado. A um tempo, cobra a solidariedade de todos para com as vítimas da seca. Lembre-se que, sofrendo entre o ímpeto solidário e os limites da esfera política, o próprio José Américo de Almeida empenhou-se, como escritor e governante, por minorar a miséria de sua região.

Tem uma cor mesmo de tragédia esse quadro terrível. Uma cor que não será somente a boa vontade do sr. José Américo de Almeida que conseguirá nuançar.

(...)

Precisamos repartir o nosso pão com esses pobres forasteiros, nossos irmãos. (Tópicos, N 5, p. 2).

Curta, também uma nota da Novidade 5 aponta o drama, real, dos retirantes. E o enfatiza chamando-os de "mártires", com o intuito de despertar a atenção dos leitores para a questão da seca:

A cidade está cheia de pobres retirantes do interior, vítimas do horror das secas nordestinas. É preciso que acudamos esses mártires das secas. (Notas da Semana, N 5, p. 7).

Assim, confirma-se como motor do semanário o interesse pelos problemas sociais de seu tempo, da região e do país. 


\section{Os rostos de dez mendigos}

Página singular do último número da Novidade, "A cidade mendiga, a cidade que sofre", de autoria anônima, traz no título a palavra "mendiga" em sua ambigüidade gramatical, como a pedir a atenção do público. Adjetivo ou verbo, a palavra "mendiga" sinaliza uma face da cidade que, silenciada por inação e indiferença, é gritante: a miséria. Intencionalmente sem assinatura, essa espécie de crônica apresenta dez tipos de mendigos, singularizando cada um em quadros narrativo-descritivos. Veja-se que o texto trata esses tipos sociais como pessoas, diferenciando-os em suas características particulares. Ao singularizar poeticamente vários rostos de uma mesma tragédia social, quer instaurar um sentido ético.

O primeiro, velho mendigo negro, expõe a perna ferida e - num despropósito ante sua condição degradada - lê notas políticas ou reportagens sociais no jornal, interrompendo a leitura às vezes para "lançar o pedido simples: / - Mocinho...".

"É a imploração indiferente, quase compassiva da indiferença alheia". Sintética, essa definição do mendigo negro, ao inverter o sentido da compaixão, do pobre-diabo para o espectador do sofrimento, naturaliza ironicamente a cruel realidade de indiferença pelos mendigos, revelando serem os insensíveis também miseráveis. Assim, expressa de forma contundente a miséria como problema social de responsabilidade coletiva.

A segunda mendiga é Maria dos Chapéus, "a miséria enfeitada", conhecida em toda a Maceió pelos seus chapéus com flores ou plumas, não por ser aleijada. Ri de sua própria situação porque lhe falta consciência quanto ao tamanho de sua desgraça. Aqui, a miséria física se soma à social, e a familiaridade com o pitoresco da figura convive com a indiferença pela mulher, redundando numa dramática alienação: "É a tragédia de uma consciência em trevas abafando a tragédia de um corpo de aleijada".

Seguem-se o velho cego, filósofo guiado pela "claridade sobre-humana de seu espírito de resignação" e por um menino, e a pedinte mulata, louca e insistente, "a demência a serviço da caceteação".

A quinta figura é o cego que assovia como sabiá. Pede "ao menos cem mil-réis" não para a sua desgraça, mas talvez pela "alegria efềmera de imitar um passarinho". Aqui o leitor da Novidade, além de reconhecer essa "espécie de cartão de visitas" da cidade, recorda o lirismo do vendedor de apitos do contista Leônidas Barletta ${ }^{7}$.

\footnotetext{
${ }^{7}$ Cf. Poesia para todos: Leônidas Barletta, no capítulo 6 da tese.
} 
A tuberculosa é a florista única da cidade, que enfeita com um cravo a lapela das almas caridosas, em troca de dois tostões. O cronista vê algo de romanesco nessa intérprete do papel de "mártir de sua resistência física", "alma encantadoramente dolorosa e abatida pelo outono melancólico". Os cravos que a pobre distribui valem as palavras abafadas pela terrível asma.

Ao aleijado pedinte, cujas faces denunciam "verminose e fome muita", um perverso recomenda que vá tratar-se com "aquela miséria do Padre Cícero". E o miserável sai arrastando seu "trapo de corpo", benzendo-se com terror.

Sobressai dramaticamente o ar espalhafatoso de outra mendiga, "a degenerescência feita miséria, a miséria feita ridículo". A cara pintada feito um palhaço, um sorriso parvo, coque postiço no alto da cabeça, o balançar dos ombros e dos braços, cobertos pelo vestido "bem católico", - todos esses traços parecem compor, segundo a ironia tecida pelo cronista, um "anúncio desajeitado da mendicância em Maceió", semelhante aos dos cinemas de segunda linha. Completando esse anúncio que, embora singelamente trágico, não desperta a compaixão do público, a mendiga puxa os esses e erres: “- Faz o obséquio de me dar um auxiliozinho...".

O mulato delicado é um "exemplo pitoresco de ruína de uma aristocracia". Roupas escuras e discretas de casimira, ar imponente, esse cavalheiro pede níqueis com "uma elegância de quem dá dinheiro". Pitoresco, o descompasso entre a vida degradada e os modos elegantes esconde um drama: "Pede de chapéu na mão e de sorriso nos lábios: / - O cavalheiro podia ter a gentileza de dar-me duzentos réis?...”.

O décimo "tipo popular", conhecido de toda a cidade, é a Curió: bagaço de cara, chapéus e vestidos a contrastar vivamente, qual numa "terrível caricatura à elegância provinciana da terra". Como em relação às demais figuras destacadas, o cronista se aproxima dessa mendiga, ao atacar os privilegiados da sociedade, pretensamente bemvestidos e civilizados, porém deselegantes, inclusive porque indiferentes aos miseráveis. E, comicamente, de fato a mendiga Curió atacava os privilegiados ao pedir-lhes o tostão. Em seus "métodos pouco aconselháveis", ameaçava os transeuntes com a sombrinha suja: "Cadê o meu tostão, hein? Me dê um tostão...”.

Cercado pelos dez quadros de miséria, o cronista explicita, no centro da página, que é porta-voz da "cidade mendiga". A intenção da Novidade era chamar a atenção para o número muito grande de pessoas sem pão nem teto que viviam amargamente "dentro da cidade pacata, pequenina e burguesa”. 
"É o infinitamente desgraçado dentro da constante alegria do cotidiano feliz". Com tal frase incisiva, o cronista se revolta contra a convivência de realidades sociais tão contrastantes dentro de um mesmo espaço, sem que os "epicuristas" reparassem nos famintos, esfarrapados, aleijados, nos andarilhos pobres, resignados, sofredores. Enfatiza que a "cidade mendiga" trazia a miséria na "mais shakespeariana das representações", contudo uma representação crua, no palco das ruas, "sem maquilagem e sem diretores de cena".

Por fim, ironiza a falta de compaixão e de consciência crítica da sociedade alagoana: os mendigos, iguais em sua "infelicidade coletiva", tinham apenas o "socialismo igualitário dos mártires obscuros". Questionando essa sociedade fechada em seus privilégios, indiferente aos miseráveis, fecha o texto com a mesma expressão que o abriu: a denúncia da agonia da cidade mendiga "dentro da cidade pacata, pequenina e burguesa".

Assim, a Novidade traz à tona um impasse mascarado em Maceió e no país: haver figuras tão conhecidas em sua exterioridade degradada e, ao mesmo tempo, desconhecidas na especificidade de suas histórias trágicas e alvos da indiferença coletiva. A miséria surge comum a todos na "cidade mendiga", que identificam as feições de seus pobres-diabos e os conservam em sua degradação; mas a iniqüidade social generalizada naturaliza o que poderia chamar-se crueldade.

Paradoxalmente, ao serem vistos os mendigos como tipos sociais, apontam-se até como pitorescas algumas de suas particularidades, o que deixa ver a singularidade, abafada sob a face grotesca, dessas pessoas que foram privadas de seus direitos. E exatamente nos limites entre tipos sociais e pessoas, escritores como Graciliano Ramos apreendem o drama dessas figuras e configuram a força artística de suas personagens.

\section{LAMPIÕES E SANTAS: INDÚSTRIA DE MISÉRIAS}

Vinculada às insuficiências nas esferas de política e de educação, a atuação de duas figuras no Nordeste reitera-se como assunto da Novidade: Lampião e as santas milagreiras. Eles surgem em várias notas da revista (“O aventureiro do cangaço", "Lampião em cena”, "A industrialização do milagre", "A Santa de Tigipió", a "Santa de Coqueiros" etc.) e, como temas discutidos em seu aspecto problemático, no editorial "Lampião", de Valdemar Cavalcanti, numa entrevista criada no número 6 ("Lampião entrevistado por Novidade") e nas crônicas "Lampião" e "Milagres”, de Graciliano Ramos. 
A presença de Lampião era tão marcante nos anos 30, que na Revista Nova (19311932) de São Paulo, dirigida por Mário de Andrade, Paulo Prado e Antônio de Alcântara Machado, Mário escreveu, sob o pseudônimo de Leocádio Pereira, o "Romanceiro de Lampeão" 8 . Note-se que, contemporânea da Novidade, como esta a Revista Nova se voltava contra a literatura como retórica, desejo de brilhar pelas palavras, e contra o “imenso atraso intelectual" brasileiro ${ }^{9}$.

Com base na mesma atmosfera social da Novidade, Jorge de Lima, no romance Calunga (1935) ${ }^{10}$, utilizou-se das figuras de Lampião e de um santo milagreiro para denunciar a miséria dos trabalhadores da lama. Esses temas tão presentes no semanário alagoano também aparecem em obras literárias posteriores como, por exemplo, o quadro "Feira de cabeças" (1938), de Aurélio Buarque de Holanda, os romances Coiteiros (1935), de José Américo de Almeida, Pedra bonita (1938) e Cangaceiros (1953), de José Lins do Rego, Seara vermelha (1946), de Jorge Amado, e a peça Lampião (1953), de Rachel de Queiroz ${ }^{11}$. Conforme indica Alfredo Bosi, são livros anteriores sobre o banditismo "como efeito da miséria, dos latifúndios, das secas, das migrações": O cabeleira (1876), de Franklin Távora, A fome (1890) e Os brilhantes (1895), de Rodolfo Teófilo, O rei dos jagunços (1899), de Manuel Benício, Os cangaceiros (1912), de Carlos D. Fernandes ${ }^{12}$.

Pensando-se na formação da obra de Graciliano Ramos, note-se que os problemas relacionados a Lampião e às santas milagreiras ganharam forma artística nos romances do escritor, não por meio da representação direta dessas figuras, e sim de dramas advindos do mesmo fator político-econômico. Já em suas crônicas publicadas na Novidade (1931), apreendem-se o espírito crítico característico dos colaboradores da revista e a

\footnotetext{
${ }^{8}$ Cf. ANDRADE, Mário de. Romanceiro de Lampeão. In: $O$ baile das quatro artes. São Paulo: Martins, 1963.

${ }^{9}$ Cf. KREINZ, Glória Aparecida Rodrigues. Revista nova: contribuição para o estudo do modernismo brasileiro. Dissertação de mestrado. São Paulo, FFLCH-USP, 1979.

${ }^{10}$ Cf. LIMA, Jorge de. Calunga. $4^{a}$ ed. rev. Rio de Janeiro: Civilização Brasileira, 1997.

${ }^{11}$ Cf. FERREIRA, Aurélio Buarque de Holanda. Feira de cabeças. In: Dois mundos: contos, retratos e quadros. $2^{a}$ ed. rev. e aum. Rio de Janeiro: O Cruzeiro, 1956, pp. 273-281. Também em Melhores contos: Aurélio Buarque de Holanda. Seleção de Luciano Rosa. São Paulo: Global, 2007 (Coleção Melhores Contos), pp. 195-200. ALMEIDA, José Américo de. Novelas. 1. Reflexões de uma Cabra. 2. O Boqueirão. 3. Coiteiros. $3^{a}$ ed. Prefácio de Leandro Tocantins. Rio de Janeiro: Civilização Brasileira, 1979; REGO, José Lins do. Pedra bonita: romance. $9^{a}$ ed. Prefácio de Paulo Rónai. Rio de Janeiro: José Olympio, 1979; Cangaceiros. Rio de Janeiro: José Olympio, 1953; AMADO, Jorge. Seara vermelha. São Paulo: Martins, 1970; QUEIROZ, Rachel de. Mapinguari; Lampião; A beata Maria do Egito. Obra reunida - v. 5. Rio de Janeiro: José Olympio, 1989.
}

${ }^{12}$ BOSI, Alfredo. História concisa da literatura brasileira. São Paulo: Cultrix, 1975, p. 146. 
expressividade irônica singular do romancista, que busca compreender as tensões dos indivíduos marcados por estereótipos sociais.

\title{
Nada de heróis no mundo de Lampião
}

\author{
Essa questão de cangaço, \\ Não é tal como se pensa, \\ Depende do nosso povo, \\ Sua estrução, sua crença, \\ Faltam escolas, hospitais, \\ São os pontos principais, \\ Sem eles não há quem vença. \\ "As lágrimas de Antônio Silvino por \\ Ventania", cordel. ${ }^{13}$
}

Assinados V. (Valdemar Cavalcanti), os tópicos "O aventureiro do cangaço" (N 2, p. 2) e "Lampião em cena" (N 4, p. 2), embora curtos, revelam os vários impasses que constituem o problema do cangaço. Esses tópicos noticiam que, à época, o bandoleiro estava em Sergipe e temia-se que passasse para o sertão de Alagoas. Um dos impasses relativos ao cangaço, a que a Novidade buscou responder de maneira crítica e auto-irônica, é que a presença de Lampião na ordem do dia, como perigo iminente no sertão e objeto diário da imprensa, reforçava sua imagem de herói de romance. Valdemar Cavalcanti enfatiza que, na imaginação do povo, a vida aventureira do "herói do cangaço" tinha muita força de realidade. Segundo ele, Lampião estava à espera de um escritor ágil, que apreendesse do "grande tipo nordestino a figura representativa da raça". Porém, Valdemar conhecia o risco de a imprensa promover com sensacionalismo a naturalização da violência e a mistificação da realidade. Observa criticamente que os jornais todo dia vinham "cheios das façanhas do grande facínora, dando um gasto enorme à sua tiparia de sensação".

Então, nos tópicos da Novidade, ao apontar o "fulgor épico" de Lampião, bandido tido como invencível, Valdemar Cavalcanti procura desvelar o seu caráter trágico, decorrente de fatores econômicos e psicológicos. Ainda que nesses breves tópicos não aborde a motivação política do problema, descreve Lampião como o "representativ man",

\footnotetext{
${ }^{13}$ Cf. DIÉGUES JÚNIOR, Manuel. O romance do cangaço. O Jornal. Rio de Janeiro, 6 dez. 1953. Apud COUTINHO, Eduardo F.; CASTRO, Ângela Bezerra de. (Orgs.) José Lins do Rego. Coleção Fortuna Crítica. Rio de Janeiro: Civilização Brasileira; Paraíba: Edições Funesc, 1990, pp. 456-9.
} 
o "tipo mais característico" de uma terra agressiva, marcada pela seca, "o verdadeiro personagem desse doloroso conflito do homem com a gleba". Ao referir-se às tragédias da existência do bandido, sugere a raiz psicológica da sua vida desgraçada: o desejo de vingar a morte do pai. Assim, compreende o trágico da vida de Lampião que, abandonado pelo mundo, se abandonou a si próprio: o seu "destino de pária, de esquecido do mundo e de todas as virtudes, dá-lhe alguma coisa (...) do infinitamente humano do drama shakespeariano".

Contudo, a face trágica do pária não se dissociava do traço facínora de Lampião, que vitimava tanto famílias ricas quanto pobres. E, com seu empenho realista, a Novidade não podia deixar de noticiar o terror provocado em Alagoas pela aproximação dos "lampionistas", que saqueavam, matavam e estupravam. Por isso, o tópico "Lampião" (N 5 , p. 2) reconhece a luta do governador Costa Rego por desarmar os cangaceiros e cobra a sua continuidade, em consonância com os "ideais revolucionários". Se Costa Rego não era o criador do banditismo, ao contrário de acusações injustamente imputadas a ele, fato é que o cangaço integrava sérios problemas políticos, econômicos e sociais, para os quais os chamados revolucionários de 1930 precisavam atentar.

Esses problemas são a enorme desigualdade social, a concentração fundiária, a ausência de justiça, controlada pelo poder local, e o analfabetismo, conservado segundo os interesses dos proprietários de terra. Em Cangaceiros e fanáticos ${ }^{14}$, Rui Facó aponta-os como causas do cangaço, entrevendo neste uma "reação primária" da classe "potencialmente revolucionária", porém fatalista, contra o domínio do latifúndio. Desprovidos de terra, de ocupação certa, explorados em seu trabalho, os sertanejos só poderiam ser revoltados.

Desse modo, se os cangaceiros, vítimas e assassinos, não eram heróis, tampouco o eram o governo e a polícia. Matar os bandoleiros não significaria eliminar o cangaço, já que ainda subsistiriam os problemas sociais da realidade alagoana. No editorial 7 , Valdemar Cavalcanti desmascara alguns deles, por meio da figura de "Lampião". Ao evocar o pânico do interior ante os boatos da aproximação do "terrível caolho", desnuda

\footnotetext{
${ }^{14}$ FACÓ, Rui. Cangaceiros e fanáticos. Rio de Janeiro: Civilização Brasileira, 1963, p. 45. Dentre as muitas obras sobre o cangaço, confiram-se: QUEIROZ, Maria Isaura Pereira de. Os cangaceiros. São Paulo: Duas Cidades, 1977; Idem. História do cangaço. $5^{\text {a }}$ ed. São Paulo: Global, 1997; CHANDLER, Billy Jaynes. Lampião, o rei dos cangaceiros. Tradução de Sarita Linhares Barsted. Rio de Janeiro: Paz e Terra, 1980; ARAUJO, Antonio Amaury Correa de. Assim morreu Lampião. $3^{\mathrm{a}}$ ed. Santos: Editora Traço, 1982; MELLO, Frederico Pernambucano de. Guerreiros do sol: violência e banditismo no Nordeste do Brasil. Prefácio de Gilberto Freyre. São Paulo: A GIRAFA Editora, 2004; GRUSPAN-JASMIN, Élise. Lampião, senhor do sertão: vidas e mortes de um cangaceiro. Tradução de Maria Celeste Franco Faria Marcondes e Antonio de Pádua Danesi. São Paulo: Edusp, 2006.
} 
um perigo que deveria exigir maiores cuidados do interior: "o lampionismo semicivilizado". Acusa os acordos escusos, as maroteiras, fuxicos e politicagem, próprios de uma sociedade pretensamente civilizada, contudo violenta ("o senhor promotor que faz política e o boticário que machuca reputações como lenços de assoar"). Aqui se reencontra a sociedade de Caetés, com seus Valérios, Barrocas, Castros, Neves: com "uma tênue camada de verniz por fora", não passam de selvagens que derrubam os outros a favor de interesses particulares.

A seguir, Valdemar ironiza os determinismos geográficos e genéticos, as falsas justificativas e soluções para a miséria do sertão. Afirma que, com a presença de mulheres no bando, Lampião, tipo representativo de raça forte, realizaria a formidável obra de povoamento do sertão por uma espécie que viria a ser capaz de lutar com a "agressividade climatológica da terra". Segundo a ironia, Lampião estaria realizando "viagens de experiência”, para a escolha de mulheres produtivas; e, como o homem fraco não resiste ao sertão, seria medida eficiente o bandoleiro castrar os covardes encontrados no caminho. Quanto aos covardes, ou melhor, aos que resistem a entrar no banditismo, é relevante que Valdemar, citando "a literatura do sr. Álvaro Paes" e à semelhança de Miguel Baptista, chame o impasse vivido pelos retirantes de "tantalismo urbanista". Sofrendo fome e sede, impedidos de uma vida digna pela má administração, esses tântalos migravam para as cidades. Assim, compreendendo que a necessidade de sobreviver transformava os sertanejos em Lampiões ou em retirantes, Valdemar Cavalcanti não só critica a opção pela violência, como também desmistifica a idéia de ser a seca o obstáculo fatal dos retirantes.

Ao fim do editorial, a ironia é extrair dessa mesma "obra patriótica" (o povoamento do sertão por homens fortes) o crepúsculo de Lampião: as mulheres que ele carregava provavelmente seriam o único meio de estragar-lhe a carreira ("caboclas quentes e excitantes, que amoleçam o temperamento de aço do célebre cafuzo"). E aqui também a ironia se volta contra o apego excessivo da imprensa à figura do bandido, tornado herói: a literatura diária dos jornais sufocaria "a sua extraordinária personalidade de herói de romance".

\section{Novidade: uma entrevista com Lampião.}

"No próximo número: uma entrevista de Lampião à NOVIDADE". Tal anúncio, confirmado na Novidade 6, dá a medida do interesse do público pela figura do cangaceiro e 
da aposta da revista. A intenção do diálogo imaginário ${ }^{15}$ era relativizar a mistificação do herói, procurando entrevê-lo como pessoa e compreender as tensões sociais por ele representadas.

A entrevista com Lampião é uma das páginas mais sugestivas da Novidade, por reunir traços de ficção, crítica social e auto-ironia. Sublinhando que o cangaceiro estava na ordem do dia, a apresentação salienta-lhe a fama, o "prestígio terrível": nome nacional, ele já entrara no folclore, na poesia e no romance. O tom auto-irônico da apresentação começa a ganhar forma ao declarar-se que a entrevista, negócio rendoso, visava a agradar aos fregueses e amigos do semanário. A ironia prossegue na menção a um hipotético pedido de auxílio a oficiais da polícia, os quais, por modéstia, teriam recusado o contato com o bandido, alegando não serem repórteres. Eis que, auto-ironia máxima, confessa-se a artimanha utilizada para contornar a impossibilidade de um encontro com o "notável salteador": "um dos nossos redatores, antigo sócio de centros esotéricos, deitou-se, acendeu um cigarro, fechou os olhos e conseguiu, por via telepática, a seguinte entrevista".

Assim, angariando a simpatia do leitor por meio do riso, a Novidade desmascara a polícia como covarde, arbitrariamente violenta contra os fracos, e brinca com a face comercial da imprensa e com sua capacidade "telepática", de criar verdades expondo os fatos segundo seus interesses.

O diálogo imaginário com Lampião é marcado por humor, fruto de extrair-se da imagem cruenta do cangaceiro a visão auto-irônica da covardia do entrevistador. Pontuando a própria inverossimilhança, a entrevista inicia-se com a descrição da hospitalidade do bandoleiro, expressão material de uma realidade violenta e precária: Lampião recebeu o representante de Novidade "com o punhal na mão direita e o rifle na esquerda" e ofereceu-lhe uma pedra para descansar.

Ao apresentar-se o entrevistador para o cangaceiro, o nome da revista provoca a contrariedade deste, configurando-se uma passagem cômica e realista, em que a linguagem, viva, expressa a simplicidade, a cautela e a imediatez de violência desse sertanejo: avesso a novidades, desconfiado de traições, preocupava-se com sua sobrevivência, dispondo-se logo a matar o polícia ou espião e inspirando terror.

\footnotetext{
${ }^{15}$ De fato, Lampião concedeu uma entrevista em 1926 a um médico do Crato, quando foi a Juazeiro a convite do padre Cícero, para integrar o Batalhão Patriótico no combate à coluna Prestes. Trechos dessa entrevista estão em: SOARES, Mariana Cysneiros Cavalcanti. Lampião: a marca que vende o Nordeste. Recife: Ed. do Autor, 2007, pp. 86-97.
} 
- Novidade? Pois eu não quero saber de novidades. Aqui ninguém conta novidades. Foi por causa das novidades que o Sabino levou o diabo. E não gosto de gente que assunta. O senhor é macaco ou bombeiro?

Sentimos um baque no peito.

- Deixe disso, capitão, não se afobe. NOVIDADE é um jornal.

$\mathrm{Na}$ entrevista, concessão da palavra ao bandido porém com a mediação escrita de outrem, está contido o impasse dos intelectuais em relação ao cangaço. A expressão do pânico do entrevistador sinaliza sua recusa da violência como solução contra injustiças; ao mesmo tempo, a consciência de que muitos jornais imprimem tapeações alerta para a necessidade de os periódicos serem sérios e úteis, abandonarem a covardia e combaterem injustiças por meio da palavra escrita.

- Um jornal?

- Sim, senhor, um papel com letras para embromar os trouxas. Mas o nosso é um jornal sério, um jornal de bandidos. É por isso que estou aqui. Um jornal sisudo. Temos colaboradores entre as principais figuras do cangaço alagoano, temos correspondentes...

Desse modo, segundo a estratégia ficcional da entrevista, a intenção de persuadir Lampião a falar possibilita à Novidade declarar-se um "jornal de bandidos", voltado a desmascarar as iniqüidades da ordem estabelecida, resistindo criticamente a ela. Com autoironia, depois de aludir ao "lampionismo em literatura", o jornalista esclarece para o cangaceiro que entrevista é uma "tapeação" em que nem sempre os interlocutores precisam encontrar-se: "O senhor larga umas lorotas eu escrevo outras e no fim dá certo". Recordese, de Infância, a desconfiança do pai de Graciliano em relação aos livros, porque "papel agüenta muita lorota" (“A vila"): traduz o potencial e os limites da palavra escrita e, portanto, o imperativo ético de quem se dedica a ela.

Significativamente, a entrevista versa sobre questões sociais gritantes à época, enumeradas na manchete: os direitos de propriedade, o progresso, a justiça, os coronéis, o cangaceirismo. Caracterizando Lampião com linguagem e opiniões simples e diretas e qualificando-o como "amável facínora", a Novidade entrevê, no tipo do cangaceiro cruel, o rosto de um sertanejo sofrido, devoto do padre Cícero. Permite compreender-se que a proximidade com a natureza delineia o homem "amável”, simples, e o tipo "facínora", o qual abafa o primeiro. O sentido de propriedade para Lampião evidencia a naturalidade da violência em seu mundo. Em sua "vida agreste", para usar a expressão de Graciliano referente a Paulo Honório, aprendeu que o sujeito é dono daquilo que "agadanha" para si. Com franqueza, acha besteira essa história de propriedade: "Isso por aqui é nosso: gado, cachaça, mulher, tudo. É de quem passar a mão, entende?”. 
Analogamente, entende que, forma mais usada e infalível, a justiça é tocar fogo no inimigo. Aprecia também a justiça dos autos, por conhecê-la demorada e feita da maroteira de promotores e jurados.

Das respostas de Lampião apreende-se seu modo de ser simples e um egoísmo próprio de quem enfrentava luta brutal pela sobrevivência. Não tinha queixa da civilização, desde que the favorecesse, e apreciava os prazeres proporcionados pelo progresso. Sertanejo, não usava sapatos, mas bebia conhaque e gostava de vitrolas. Não reclamava dos doutores, pois nunca the haviam feito mal; considerava-os uns inocentes, que "estudam nos papéis e falam muito". E aqui se nota a ironia da revista em relação à retórica bacharelesca e à prática de arranjos pessoais dos advogados.

Numa crítica feroz contra a ordem social, mantida à custa da miséria alheia, a Novidade, por meio de Lampião, alveja a carestia e a exploração do trabalho no campo. $\mathrm{O}$ cangaceiro declara que seus roubos não the davam lucro, afinal não havia o que roubar; nem o povo apreciava ter tanto dinheiro, tão cara estava a vida. Porém, ele explicita enfaticamente que, "nem pelo diabo", deixaria o cangaço para trabalhar na enxada.

Em sua comicidade, a queixa do bandoleiro quanto à falta de objetos roubáveis denuncia a miséria no sertão, em que a propriedade de terra é o grande valor, de poucos. Faz lembrar as anedotas a respeito do pessimismo de Graciliano Ramos, como o diálogo sobre o custo de vida. Depois de José Lins do Rego declarar que, “desse jeito, vamos acabar pedindo esmolas", Graciliano teria respondido: "A quem?" 16.

Ao fim da entrevista, ao se confirmar o egoísmo de Lampião, certamente cruel, configura-se no entanto um realismo desmistificador. $\mathrm{O}$ bandido se afirma indignado com os cidadãos que, sem nunca terem visto o sertão, falavam deste. E, sob a ótica de seus interesses, ao apontar que tinha boas relações com um bando de coronéis, pondera haver alguns "metidos a bestas" e outros "pessoas direitas". Assim, surpreendem-se na entrevista imaginária com o cangaceiro alguns posicionamentos críticos que viriam a embasar os romances de Graciliano: a necessidade de observação dos fatos, de compreensão do "fator econômico" nas ações humanas e a relativização das verdades.

\footnotetext{
${ }^{16}$ Cf. MORAES, Dênis de. O velho Graça: uma biografia de Graciliano Ramos. cit., p. 173.

Segundo outra versão, a conversa imaginária teria sido entre Graciliano e Carpeaux; este, embora confirmasse o pessimismo do escritor, negou haver protagonizado o diálogo. (Cf. RESENDE, Otto Lara. Graciliano Ramos e Otto Maria Carpeaux: A quem, meu Deus, a quem? In: O príncipe e o sabiá e outros perfis. Organização de Ana Miranda. São Paulo: Companhia das Letras: Instituto Moreira Salles, 1994, pp. 245-6; CARPEAUX, Otto Maria. Amigo Graciliano. In: Teresa revista de Literatura Brasileira 2. São Paulo: Editora 34 / USP, 2001, pp. 145-6). Agradeço a Hélio de Seixas Guimarães a indicação de $O$ príncipe e $o$ sabiá e outros perfis.
} 


\section{O bandido com a palavra}

Depreendem-se do editorial de Valdemar Cavalcanti, das notas e da entrevista os vários impasses que constituem o problema do cangaço: a imagem de heroísmo, a violência naturalizada, sua motivação econômica, os dilemas da imprensa, o "lampionismo semi-civilizado".

Esses impasses ganharam elaboração crítica singular na crônica "Lampião", de Graciliano Ramos, que, significativamente, é o primeiro texto da Novidade, após o "Cartão de visita" e o expediente com seus tópicos. Essa crônica figura em Viventes das Alagoas: quadros e costumes do Nordeste (1962), livro póstumo que reúne crônicas publicadas pelo escritor nos anos 1940, em sua maioria na revista Cultura política.

Então, é esclarecedor, tanto para a compreensão do semanário de 1931 quanto da obra do romancista, saber que "Lampião" foi escrita em Alagoas nos anos 1930. À medida que traz os impasses de um intelectual em relação aos problemas de sua realidade, a crônica concentra a matéria e a busca de um olhar crítico a partir das quais se constituíram a revista Novidade e o trabalho artístico de Graciliano. No último capítulo, analisarei mais detidamente como esse texto apresenta temas a que ele deu forma nos romances, inclusive a frase "apanhar do governo não é desfeita", que aparece em Vidas secas.

Orientação representativa do semanário e do futuro escritor, a intenção da crônica não é julgar o indivíduo Lampião, mas compreender o lampionismo.

Graciliano começa por desmistificar o heroísmo dos cangaceiros, apontando que sofreram no início da vida muitas injustiças e violência. "Herói de arribação bastante chinfrim", Lampião foi explorado como trabalhador de enxada, preso injustamente, maltratado na cadeia da vila, porém resignado às vontades do coronel.

$\mathrm{Na}$ seqüência, o escritor explica que a fome, podendo converter os sertanejos em retirantes, rumo ao Acre, a São Paulo, muitas vezes fazia-os apelar para a violência: “o que transformou Lampião em besta-fera foi a necessidade de viver”. Assim, desnuda criticamente o problema da naturalização da violência: com fome, o sertanejo, como "bicho montado", passou a matar e roubar; era natural que se vingasse do soldado e do delegado que o haviam pisado e do proprietário "que lhe deixava a família em jejum”.

Com sensível e aguda compreensão da realidade terrível dos cangaceiros, Graciliano mostra que a sobrevivência os obrigava a serem cruéis e a manterem vivo o sentimento de terror que inspiravam. Vivendo perto da natureza, não se impressionavam com as violências que indignam "criaturas civilizadas". 
Lampião é cruel. Naturalmente. Se ele não se poupa, como pouparia os inimigos que lhe caem entre as garras? Marchas infinitas, sem destino, fome, sede, sono curto nas brenhas, longe dos companheiros, porque a traição vigia...

Imagine-se como essa análise de Graciliano, revelando o impasse da naturalização da violência e desmascarando-lhe os fatores econômicos, foi recebida na época. Essa compreensão de um fato que aterrorizava a todos era certamente uma novidade: permitia partilhar-se a perplexidade ante a violência tornada lugar-comum e tinha o potencial de criar consciência crítica quanto a um problema político e social.

No passo seguinte, como se cobrasse de si próprio e dos leitores uma reação ao estado de coisas, Graciliano acusa a covardia dos pretensamente civilizados, que, diferentemente da realidade crua de Lampião, recebem ordenado, depositam dinheiro no banco, escrevem em jornais. Angustia-se com sua inutilidade de intelectual, subserviente diante dos professores, dos chefes e dos jornais. Por fim, reconhecendo-se próximo de Lampião na revolta contra o mundo, ironiza que talvez tenha a energia do cangaceiro, porém adormecida "pela verminose e pelos adjetivos idiotas" que lhe ensinaram na escola. Desse modo, reage contra as instituições que, representantes da ordem estabelecida, conservam a miséria e a ignorância de muitos.

\section{Homens sem cabeça: onde a "ética do rosto"?}

Graciliano Ramos dedicou seis crônicas ao problema do cangaço, todas reunidas em Viventes das Alagoas, e tratou também do assunto em dois textos de Linhas tortas. Diferentemente de "Lampião", publicada em 1931 na Novidade, as demais foram escritas no Rio de Janeiro após 1937, ano em que o escritor saiu da cadeia: "Virgulino" (27 de janeiro de 1938), "Cabeças", "O fator econômico no cangaço", "Dois cangaços" (posteriores a 28 de julho de 1938, dia em que Lampião foi morto), "Corisco" (posterior a 25 de maio de 1940, morte desse cangaceiro), além de "A propósito de seca" (1937) e "Desordens" (sem indicação de data).

Atendendo a uma necessidade vivida em seu presente - compreender o fenômeno do banditismo no Nordeste -, essas crônicas partem do pressuposto assentado nas reflexões feitas em "Lampião": seu objeto não é o indivíduo Lampião, mas o lampionismo, que angariava muitas pessoas, vítimas da miséria. 
Nas crônicas "O fator econômico no cangaço", "Dois cangaçoo" e "A propósito de seca" ${ }^{17}$, Graciliano explica que, até o começo do século XX, os bandos, pequenos, incluíam homens necessitados, mas eram chefiados por pessoas de consideração e surgiam por questões de honra ou brigas políticas. O cangaço constituía um fenômeno social, agravado por fatores econômicos. Depois, tornou-se um fato mais sério e monstruoso, originado de dificuldades econômicas dos sertanejos, conseqüentes da falta de administração, da agricultura atrasada, indústria precária, exploração do trabalhador rural. A "democratização do cangaço" decorreu do aumento da população numa terra muito pobre: em época de seca, a fome obrigava grande massa de sertanejos a bandearem-se para junto dos criminosos. Nesse sentido, à semelhança de Alberto Passos Guimarães na Novidade, Graciliano ataca a frase feita que enaltece a fecundidade da terra, otimismo nacional mistificador, cego à incapacidade dela e de seus administradores para alimentar tanta gente. E condena as violências das forças volantes contra matutos indefesos, mais uma injustiça a levá-los ao cangaço.

Graciliano detém-se também na história de Corisco, neto de senhor de engenho e filho de um coronel que, fanático pelo Padre Cícero, se arruinou com as viagens a Juazeiro. Após a usina comer o engenho, passou a obedecer a Lampião e à "lei da necessidade". Conforme o escritor revela em "Corisco" 18 , no Nordeste havia indivíduos muito em cima, outros muito embaixo e alguns, como o cangaceiro que nomeia a crônica, no meio e obrigados a descer, por fim "degenerados pela miséria".

Desmascarando como origem do cangaço a miséria de uma terra muito povoada, aponta na crônica "Virgulino", de janeiro de $1938{ }^{19}$, as falsas verdades construídas pela imprensa em torno da desejada morte de Lampião. Desvenda que, distante de uma visão romântica de herói cavalheiresco, atribuída aos cangaceiros antigos porque eram amigos da propriedade, Lampião era uma besta-fera, não um homem que desmanchava injustiças. Não possuindo bens, os bandoleiros nada tinham a poupar a não ser suas vidas, inúteis. Sobretudo, Graciliano recusa a ingenuidade de se supor que a morte do cangaceiro significaria o desaparecimento das "monstruosidades" da vida no Nordeste resumidas nele, como se essa morte acabasse com a seca e a com a miséria. E a ênfase do cronista nesses

\footnotetext{
${ }^{17}$ RAMOS, Graciliano. O fator econômico no cangaço; Dois cangaços. In: Viventes das Alagoas. São Paulo: Martins, 1962, pp. 123-9; pp. 147-152; A propósito de seca. In: Linhas tortas. cit., pp. 128-130.

${ }^{18}$ Idem. Corisco. In: Viventes das Alagoas. cit., pp. 144-6.

${ }^{19}$ Idem. Virgulino. In: Viventes das Alagoas. cit., pp. 137-140.
} 
problemas revela criticamente a política do Estado Novo, mais interessado em glorificar-se com o combate ao bandido.

Em "Desordens" ${ }^{20}$, Graciliano ironiza o sensacionalismo da imprensa em relação à violência e, a um tempo, combate o estereótipo da índole pacífica do povo brasileiro. Mostra necessário conhecer-se que a realidade de violência não derivava apenas dos “discípulos de Lampião", mas principalmente dos proprietários, dos policiais e do governo, mantenedores da pobreza de muitos. Os poderosos da região não queriam a morte de sertanejos de ordinário maltratados covardemente, pois significava perderem trabalhadores e eleitores. Conforme se lê na ambigüidade criada por Graciliano, as autoridades eram tão violentas quanto os cangaceiros, sujeito oculto nesta passagem:

(...) Felizmente o prefeito e outros cavalheiros de influência (...), depois da saída dos cangaceiros, foram procurá-los na zona das operações, onde não os encontraram, naturalmente.

Prejuízo considerável: consta que mataram gente, surraram homens pacatos, roubaram dinheiro e jóias. Os bandidos, é claro. Com certeza levaram pouco dinheiro e muito poucas jóias, que Lagoa da Areia e Canafístula são pobres demais. Talvez até nem tenham achado jóia nenhuma e as mencionadas no telegrama figurem nele como enfeite, para dar brilho e importância a esses vagos lugarejos. [grifos meus]

Dessa forma, como na entrevista de Lampião na Novidade, Graciliano desmascara inverdades da imprensa e uma realidade de miséria, em que faltavam para os sertanejos objetos roubáveis, entretanto lhes sobrava a violência, do cangaço, da polícia, dos patrões, do governo.

"Cabeças" ${ }^{21}$ exige atenção. Aprofunda dois motivos fundamentais de "Lampião" e da entrevista. O primeiro é a consciência auto-irônica do intelectual, de que a palavra pode ser manipulada para construir verdades, tanto para criar e enaltecer heróis, como para desmistificá-los. O segundo é a busca do rosto do homem por trás do tipo social, a compreensão para com o sertanejo simples a quem a necessidade de viver e os maus tratos recebidos do patrão e do soldado transformaram em besta-fera.

Mas em "Cabeças" a consciência auto-irônica do intelectual é dramática. Porque precisa escancarar que a palavra pode ser usada para tentar justificar a barbárie. E desvelar

\footnotetext{
${ }^{20}$ Idem. Desordens. In: Linhas tortas. cit., pp. 199-200.

${ }^{21}$ Idem. Cabeças. In: Viventes das Alagoas. cit., pp. 141-3.
} 
que esse discurso vem do mesmo poder covarde e arbitrário, acostumado a pisar nos sertanejos pobres.

Graciliano relata que o tenente Bezerra, após matar Lampião (em Angico, Sergipe, a 28 de julho de 1938) levou a Maceió uma "bela coleção de cabeças" e, recebido com festas como herói, declarou extinto o cangaço. O fato e a declaração imprudente, segundo observa o cronista, davam mostra da confusão dominante, ainda agravada pela insensatez da imprensa.

Tecendo o alcance crítico da crônica por meio de uma comparação, o exemplo evocado é o do jornalista que acrescenta informações inverídicas a um assunto, frívolo, como a lhe dar teor relevante. Um repórter atribuíra, à vencedora de um concurso de beleza, a leitura de uma lista de romances, habilmente insinuando para o público que ela era interessante não apenas devido à beleza física.

Com sua ironia, Graciliano acusa de um só golpe o repórter embelezador de notícias, a população de Sant'ana do Ipanema, capaz de festejar as cabeças, e o tenente Bezerra, que, matador e degolador de cangaceiros, era metido a orador patriótico. Mordaz, o escritor critica que o "brioso agente da ordem" fizesse concorrência desleal a tantos politiqueiros que falam muito sem dizer nada. Após armar emboscadas no sertão com a ajuda de coiteiros e ter a "honra de decapitar o próximo", o tenente ainda queria justificar o injustificável. Além de desmascarar a covardia e a desumanidade do policial tido como herói, Graciliano rejeita o discurso do tenente, justificativa que destoa, como as leituras atribuídas pelo jornalista à moça do concurso.

A ironia de Graciliano é máxima contra a barbárie e sua naturalização, promovida em muito pelo discurso do poder, pronto a justificá-la. Desmontando o cinismo do discurso dos tenentes assassinos, insinua que pessoas muito sensíveis não suportariam a fotografia de cabeças fora dos corpos e precisariam de uma explicação. Assim, desnuda o horror de um homem ser perito na "arte de cortar cabeças" e querer justificar-se.

(...) Cortar cabeças nem sempre é barbaridade. Cortá-las no interior da África, e sem discurso, é barbaridade, naturalmente; mas na Europa, a machado e com discurso, não é barbaridade. $\mathrm{O}$ discurso nos aproxima da Alemanha. Claro que ainda precisamos andar um pouco para chegar lá, mas vamos progredindo, não somos bárbaros, graças a Deus.

Desse modo, em "Cabeças", Graciliano ironiza a um tempo a barbárie da Alemanha nazista e a dos dominantes no Brasil, condenando por inaceitáveis suas ações desumanas, o preconceito e os discursos de pretensa civilização. 
Segundo relata Élise Gruspan-Jasmin ${ }^{22}$, no quadro das relações de colaboração entre a Alemanha nazista e o governo Vargas, um instituto de Berlim chegou a solicitar o crânio de Lampião para estudos. De fato, as cabeças dos cangaceiros tornaram-se peças do Museu de Antropologia Criminal do Instituto Nina Rodrigues da Bahia (e foram enterradas somente em 1969). Élise pondera que, se a mutilação das vítimas pelos cangaceiros estava enraizada nos procedimentos de uma sociedade pastoril, por outro lado a profanação de cadáveres e a ausência de sepultura eram tidas como sacrilégio no sertão. Como se sabe, a população sofria com a violência do cangaço e também das forças volantes. Nesse sentido, o extermínio de Lampião representou um alívio, mas, por outro lado, conforme aponta Élise Gruspan, serviu para a glorificação do Estado Novo pela imprensa a serviço da ditadura. A estudiosa relembra, ainda, a tradição do país de origem colonial e escravocrata de arrancar cabeças: Zumbi (1695), Tiradentes (1792), o negro Lucas da Feira (1854), Antônio Conselheiro (1897), Lampião (1938).

Sendo assim, desde "Lampião" até o horror máximo de "Cabeças", Graciliano desvenda uma sociedade em que a violência era lugar-comum a igualar a todos, em especial coronéis, policiais, governantes, jornalistas e cangaceiros. Por isso - retomando-se aqui as expressões de Carpeaux e de Lévinas, respectivamente, e a interpretação de Sem novidades no front -, em oposição à realidade, Graciliano revela necessários o "desmascaramento do heroísmo" e a "ética do rosto": a compreensão de serem os homens a um tempo frágeis e fortes em sua singularidade, o que deveria redundar no respeito às diferenças e na impossibilidade de matar.

\section{Irrecusavelmente}

A postura crítica e ética marca vários intelectuais da geração da Novidade. Face ao mesmo fato da exposição das cabeças de Lampião, de Maria Bonita e de mais nove cangaceiros, Aurélio Buarque de Holanda, que ainda vivia em Alagoas em 1938, viu-se obrigado a escrever "Feira de cabeças" ${ }^{23}$.

\footnotetext{
${ }^{22}$ GRUSPAN-JASMIN, Élise. Lampião, senhor do sertão: vidas e mortes de um cangaceiro. cit., pp. 289348 .

${ }^{23}$ FERREIRA, Aurélio Buarque de Holanda. Feira de cabeças. In: Dois mundos: contos, retratos e quadros. $2^{\mathrm{a}}$ ed. rev. e aum. Rio de Janeiro: O Cruzeiro, 1956, pp. 273-281. Também em Melhores contos: Aurélio Buarque de Holanda. Seleção de Luciano Rosa. São Paulo: Global, 2007 (Coleção Melhores Contos), pp. 195-200.
} 
Paradoxo possibilitado pela seleção e combinação de palavras, esse texto atinge beleza ao presentificar a insensibilidade de um público frente a cadáveres, de criaturas ávidas por ver rostos fora dos corpos. Ao compor seu "quadro", Aurélio capta a ironia terrível do próprio ambiente, a que não faltam a ave-maria do sino da igreja, o estrugir de foguetes, o burburinho da multidão curiosa, a fala do orador (o tenente Bezerra), a claridade tíbia do luar, a aragem misturada ao cheiro da decomposição de restos humanos.

De forma sutil, o escritor concentra no advérbio irrecusavelmente a crueza da realidade:

O sino toca a ave-maria. Dilui-se-lhe a voz no sussurro espesso da multidão curiosa, nos acentos fortes do orador, que, terminando, refere a vitória contra Lampião, irrecusavelmente comprovada pelas cabeças ali expostas. [grifo meu]

Para o tenente, as cabeças eram provas irrecusáveis de seu heroísmo, considerando-se inclusive que, desde 1930, governos do Nordeste ofereciam recompensa em dinheiro pela cabeça de Lampião. Aterrador, conforme mostra Aurélio: as cabeças eram irrecusáveis para a multidão ali presente, ansiosa pelo "prazer do espetáculo". Hotéis, casas particulares e ruas estavam entupidos por causa daquela "feira horrenda".

Vendo confundirem-se o trágico e o grotesco, Aurélio confessa que esperou até aplausos da assistência, que incluía crianças e, evidentemente, repórteres e fotógrafos. Espanta-o que o trágico não arrancasse lágrimas e que nenhuma fisionomia se contraísse de horror. "Os lenços são levados ao nariz: nenhum aos olhos".

Assim, "Cabeças" denuncia como os policiais se igualavam em barbárie aos cangaceiros e como são perigosos os discursos do poder. Comprovando isso, "Feira de cabeças" acusa que grande parte da população não se diferenciava dessa violência banalizada, antes a incorporava. Desde o primeiro parágrafo, Aurélio é incisivo para desmascarar a inconsciência da multidão, daquele bando de autômatos que se espremiam para ver imagens de arrepiar. O problema expressivamente revelado era a generalizada ausência de cabeças, o perigoso "apaixonamento das massas" ${ }^{24}$, violência e irracionalismo que significavam a anulação do indivíduo.

De latas de querosene mãos negras de um soldado retiram cabeças humanas. O espetáculo é de arrepiar. Mas a multidão, inquieta, sôfrega, num delírio paredes-meias com a inconsciência, procura apenas alimento à curiosidade. $\mathrm{O}$ indivíduo se anula. Um desejo único, um único pensamento, impulsa o bando autômato. Não há lugar para a reflexão.

\footnotetext{
${ }^{24}$ Cf. LIMA, Raul. De Recife. Novidade 12, p. 12.
} 
Por fim, Aurélio parece resgatar da primeira crônica de Graciliano na Novidade o sertanejo que, após sofrer humilhação e fome, se fez bicho, tendo vida e morte trágicas. Reconstitui na imaginação a humanidade do cangaceiro, que, em horas como aquela, noite alta, deveria atenuar os pensamentos ferozes e olhar enternecido para Maria Bonita. Do lirismo o escritor passa à pergunta dramática pelo paradeiro dos corpos dissociados daquelas cabeças. Eis que, da imagem do olho cego de Lampião, agora morto, cabeça arrancada do corpo, Aurélio apreende um olhar que, apelo contra a desumanização, é expressão feroz da totalmente recusável ausência da "ética do rosto".

Onde andará o corpo da amada de Lampião? A cara arrepiadora, que mal entrevejo à luz pobre do crescente, não me responde nada.

E Lampião? Sereno, grave, trágico. O olho cego, velado pela pálpebra, fita-me.

Com sensibilidade, consciência crítica e apuro lingüístico, Aurélio deu uma configuração dramática à matéria histórica em que ocorreu o cangaço. Caminho análogo está na base da plenitude artística de S. Bernardo, Angústia e Vidas secas. No último capítulo, em ensaios de análise e interpretação dos romances, procurarei compreender a arte com que eles representam e expressam os problemas sociais e morais das personagens num mundo de violência.

\section{Progressos da miséria}

Graças à combinação de análise sócio-econômica, interpretação ética e força expressiva, os textos dos escritores da Novidade sobre o cangaço constituem contribuição valiosa para a vasta bibliografia do assunto. Quanto às santas milagreiras, o semanário também traz material relevante, difundido nas notas e tópicos e, em especial, nas reflexões de Raul Lima e de Graciliano Ramos.

As Notas da Semana da Novidade 4 (p. 4) destacam que a santa de Coqueiros, de Minas Gerais, estava na ordem do dia em 1931: muita gente se impressionava com seus milagres. Eles tinham eco muito forte até em Maceió, e a Noite, do Rio de Janeiro, ia mandar uma comissão de peritos estudar o caso. Aqui já se entremostram os vários componentes da questão das "santas": uma população miserável e de pouca instrução que, ávida de cura para seus males, se entrega ao fatalismo ou crê em superstições e em milagres; "peritos" prontos a estudar as santas, caminho para se justificarem os 
interessados em combater o povo de fanáticos; a imprensa sensacionalista, cobiçosa por vendas milagrosas de jornais; a exploração da miséria e da crendice do povo por charlatães, falsos milagreiros.

Sinalizando que o progresso material muitas vezes não se dissocia da miséria, antes a carrega, a Novidade 6 (p. 6) retransmite a notícia de que a Central do Brasil aumentara o número de vagões para atender à freguesia da santa de Coqueiros. O título da nota, "A concorrente", sintetiza seu tom bem-humorado, crítico em relação à mentalidade comercial, à divisão entre as profissões e à crise vigente, em que cada um buscava tão-só seus lucros e o próprio bem-estar. A santa representava ameaça no terreno profissional, tanto que um médico do Rio se queixara da propaganda que a imprensa fazia da concorrente. Conforme a Novidade ironiza, na época de dificuldades então vivida, "ninguém deixaria de recorrer a um milagre para se aventurar nas mãos dos médicos". Num materialismo de efeito cômico, sublinha que, mesmo não se sabendo tratar-se ou não de um fenômeno, a santa contribuía para um bem: o barateamento das consultas médicas. Outro resultado prático das romarias foram os reparos nas estradas de rodagem, promovidos pelos proprietários de terras vizinhas de Coqueiros (Notas da Semana, N 6, p. $5)$.

Desde seu título, o tópico “A industrialização do milagre” (N 6, p. 2) traduz bem a falsidade das santas, que proliferavam, surgindo a cada dia em outra região do Brasil; condensa também o interesse financeiro em nome do qual as milagreiras se criavam, como uma profissão, e os impasses entre modernização e conservação da miséria e do fanatismo religioso. Esse tópico revela que a santidade se tornara profissão lucrativa. O "negócio" iniciara-se com a mulata de Coqueiros, outra sobressaía em Recife (Tigipió) e já se antevia despontar em Alagoas alguém com a graça divina, o que de fato aconteceu, segundo se indica no número 8 do semanário. Insinuando ser Deus incapaz de imperfeições, o tópico ironiza como desarrazoada a crença em santas que corrigiriam os defeitos da obra de Deus. Afinal, era sempre a mesma história: cegos, surdos e mudos recobravam os sentidos, aleijados abandonavam muletas. "Tudo como sempre. E o dinheiro pingando...". Assim, a Novidade aponta criticamente que não havia nada de novo, e sim a exploração comercial de pessoas pobres por oportunistas. Daí a sugestão de criar-se para as milagreiras uma taxa no imposto de indústria e profissão.

Também com ironia uma nota do número 5 da revista (p. 7) anuncia a morte da Santa de Coqueiros: seus fiéis estariam contristados, e a conclusão seria que, nos tempos então vividos, nem valeria a pena ter-se santidade. 
Por outro lado, o tópico "A Santa de Tigipió" (N 7, p. 16) ressalta a força da religiosidade popular, da fé na "bondade ilimitada de Deus", como forma de reação à realidade do país, em que cada vez mais se perdia a crença de tudo. Mas o semanário também dá notícia de certo emaranhado de poder entre as milagreiras da religiosidade popular e os representantes institucionais da religião: Manoelina de Jesus, a santa de Coqueiros, recusava-se a abençoar seus devotos que não trouxessem autorização do vigário da freguesia $(\mathrm{N} 9, \mathrm{p} .4)$.

Embora essas milagreiras estivessem na ordem do dia no Brasil em 1931, não é fácil reconstituir a história delas. Em Introdução ao estudo do folk-lore brasileiro, Joaquim Ribeiro ${ }^{25}$ aproxima Manoelina Maria de Jesus e Antonio Conselheiro, afirmando ser o brasileiro um povo místico. Conta que ela nasceu entre 1906 e 1911 em Retiro Velho, Coqueiros. Trabalhou na lavoura, mas logo, devido à sua debilidade, passou aos afazeres domésticos. Em outubro de 1930, caiu doente e foi desenganada pelo médico. Passados alguns dias, levantou-se do leito em que jazia, para a admiração de todos. Revelou à sua mãe que um anjo em sonho the aparecera anunciando que Deus lhe confiara a missão de prestar caridade. Difundido esse segredo entre o povo, iniciou-se a vida mística da Santa Manoelina, como a chamavam os que buscavam suas curas e milagres.

Joaquim Ribeiro traz informações complementares às presentes na Novidade. Como acorriam romeiros de toda parte, a Estrada de Ferro Central do Brasil organizou trens especiais para a Estação João Ribeiro, da qual se ia a Coqueiros. Tamanho era o prestígio da Santa, o Bispo de Mariana, D. Helvécio, repreendeu-a por realizar bênçãos públicas à multidão que cercava a cabana de Retiro Velho.

Segundo narra o estudioso, em maio de 1931 Manoelina novamente caiu doente, foi desenganada e, para a sensação dos romeiros, ergueu-se curada. Agravou-se seu conflito com o clero e, humilde, ela anunciou que sua missão findaria no mês de maio. De fato morreu em seguida, conforme se lê na Novidade 5, de 9 de maio.

Assim, Joaquim Ribeiro deixa ver que a "santa" era também vítima da miséria e do fervor religioso ${ }^{26}$. Acrescenta, ainda, que em torno de Manoelina de Jesus se criou vasto

\footnotetext{
${ }^{25}$ RIBEIRO, Joaquim Brás. Introdução ao estudo do folk-lore brasileiro: ensaio. Rio de Janeiro: Alba, s/d.

${ }^{26}$ Recorde-se aqui, do romance Fronteira (1935), de Cornélio Penna, a figura de Maria Santa, cujo corpo era espetado por uma multidão ansiosa de milagres. Sobressai da obra, conforme revela muito bem André Luis Rodrigues, a superposição do arcaico com o moderno e o que há de estranheza, desamparo e incompreensão entre as pessoas. Cf. RODRIGUES, André Luis. Fraturas no olhar: realidade e representação em Cornélio Penna. Tese de doutorado. São Paulo, FFLCH-USP, 2006.
} 
espólio de poesias, lendas e milagres, divulgado devido à repercussão sensacional na imprensa do Rio de Janeiro. Zé Vicente, poeta popular paraense, publicou em 1932 A santa de Coqueiros, em que narra esse caso de misticismo.

Quanto à santa de Tigipió, Raul Lima traz informações nos números 10, 12 e 14 da Novidade, sempre à página 12. Ele escrevia na revista a coluna "Sociedade", sob o pseudônimo Ramil. Como foi estudar na Faculdade de Direito de Recife, tornou-se correspondente da Novidade a partir do número 8, de 30 de maio de 1931, assinando a seção "De Recife", rica em observações críticas a partir dessa capital nordestina nos anos 1930.

Desmascarando que a "santa" de Tigipió era "uma trapaçaria, um caso de polícia", Raul Lima comenta como fôra difícil, e prejudicial à popularidade do governo, convencer desse charlatanismo uma multidão crédula. Afirma que nunca tivera interesse de ver o arraial de dona Isabel, a qual já se encontrava presa. E questiona um jornal alagoano que dera trabalho à polícia de Minas e à de Pernambuco e quisera arranjar também uma santa em Alagoas. Expondo um pitoresco na verdade revelador de uma sociedade em que coexistiam pobreza, falta de perspectivas de vida concretas, algum progresso técnico e sonhos de superação, Raul Lima conta que o prestígio da santa fôra abafado pelo da Rádio Club de Pernambuco, e esse talvez perdesse apenas para o jogo do bicho. Segundo o cronista, as pessoas só se serviam da inteligência para o "malabarismo diário dos números". Ao se escapar de um atropelamento, interessava logo o número da chapa do automóvel, esperança de bom palpite.

“E pega pra linchar, e o diabo!”. Essas palavras integram outro caso referido por Raul Lima, em que também alerta para o perigo do "apaixonamento das massas", “entidade desabusada". O povo acreditava que o cidadão Júlio Moura tivesse criado um aparelho de captação de eletricidade da atmosfera. Conforme a utopia vigente, este ajudaria a saldar todos os débitos do país. Por isso, ao ver fracassar a experiência do "gênio", o povo enfurecido acusava o governo de estar mancomunado com a Tramways, que perderia muito com o invento.

Na Novidade 14, Raul Lima conta que, ao contrário do III Salão de Belas Artes de Pernambuco, exposição no prédio da Biblioteca do Estado que estivera aberta à “indiferença pública”, a Santa de Tigipió, o senhor Júlio Moura e, então, um homem imitando boneco de cera, propaganda da Paulista (rede de lojas espalhadas pelas cidades 
alagoanas ${ }^{27}$ ), tinham a atenção de todos em Recife. Desse modo, reivindicando a formação e o envolvimento cultural das pessoas, Raul Lima lamentava a existência delas como massa, sua exploração comercial e a atmosfera restrita dominante, de boatos e extremismo público.

\section{Milagres para o mundo: Novidade na pena irônica de Graciliano}

Incluída em Linhas tortas (1962, publicação póstuma) sem indicação de data, a crônica "Milagres" destaca-se por sua atualidade crítica. Porém, cumpre saber que, escrita nos anos 1930, expressa singularmente um olhar crítico em relação a vários problemas do contexto nordestino e brasileiro da época, como uma recolha das questões tratadas na Novidade, em cujo número 14 saiu. Graciliano desvela com ironia que só milagres trariam novidade frente aos problemas do Brasil e do mundo, concentrando assim sua lucidez crítica e seu desejo de mudanças, de uma realidade outra, o qual o moveu a escrever os romances.

A crônica inicia-se aludindo a um fato que estava na ordem do dia, conforme mostra a Novidade: a profusão de superstições do povo, que acreditava em profetas, na santa de Coqueiros, no padre Cícero etc., e o excesso de notícias sobre essas figuras. A princípio, Graciliano confessa seu desgosto ante o povo supersticioso e os jornais sensacionalistas. Em seguida, já revelando sua postura ética, de buscar compreender a si e aos outros, considera que todos temos superstições. Observando que, frágeis, todos precisamos crer em algo, ironiza que os deuses podem ser imateriais ou os do progresso técnico. Passa, então, a analisar as superstições, necessidade humana reforçada muitas vezes por motivações econômicas, apontando, a partir daí, carências do Brasil de 1930.

Cartomantes, quiromantes, profetas, espíritas, adivinhos de toda a casta, a santa de Coqueiros e o padre Cícero. Quando um desses está em evidência, os jornais aumentam a tiragem. Lemos as notas, bocejamos, sentimos desgosto. Realmente o povo é supersticioso.

Pensando assim, afastamos por um momento as nossas superstições e censuramos com azedume as superstições alheias. Depois voltamos às nossas.

Adoramos vários deuses, uns imateriais, outros de ferro, movidos por água ou alimentados a carvão e a gasolina. É necessário que alguém nos salve, a Divina Providência ou Henrique Ford.

\footnotetext{
${ }^{27}$ Cf. Nota 11 do volume de Cartas de Graciliano Ramos.
} 
Com veemência, Graciliano recusa que, faltando-lhes muitas coisas, as pessoas não se esforçassem por consegui-las e ficassem à espera de que caíssem do céu ou viessem de fora do país. O escritor insinua que só poderia haver mudanças com o desejo e o empenho de se buscar um caminho e, mesmo sendo penoso, percorrê-lo.

Faltam-nos muitas coisas, e o pior é não nos esforçarmos por obtêlas. Esperamos que elas nos venham de fora: do céu, da Rússia, dos Estados Unidos ou da Itália.

É possível reconhecer como alvos do inconformismo do cronista os políticos e os intelectuais acomodados ao status quo. Recordem-se, da Novidade, as críticas à inação dos pretensos revolucionários de 30, logo afeitos à política personalista. Graciliano partilhava dessa visão crítica, conforme sintetizou ao fim da "Pequena História da República", escrita no Rio em $1940{ }^{28}$. Condena que faltasse a tais revolucionários um programa e ironiza que pensassem em importá-lo e desistissem disso ante a peculiaridade do país, de regiões muito diferentes. Lamenta que a opção por firmarem-se na realidade brasileira tenha redundado em arranjos pessoais. Contudo, salienta que, embora tornada lugar-comum em artigos, a realidade brasileira foi a melhor das "fórmulas de 1930". Isso quando os problemas nacionais eram objeto de estudos sérios, feitos com observação e paciência - e aqui, de modo relevante, incluem-se os trabalhos do romancista e de vários intelectuais da Novidade, como Aurélio Buarque, Diégues Júnior, Alberto Passos Guimarães, Valdemar Cavalcanti, Santa Rosa.

A perspectiva crítica de Graciliano em relação à chamada revolução de 1930 também está na crônica "Bagunça" (Rio, 19 de agosto de 1941) 29 . "Nenhuma novidade": significativamente, assim o cronista descreve a ausência de barulho que precedeu e marcou a queda do governo. Houve os súbita e temporariamente dispostos a defendê-lo e os "moderadamente revolucionários". A tautologia "- Governo é governo", expressão da

\footnotetext{
28 "Realmente faltava um programa. Como seria possível fazer uma revolução sem programa? Derrubar para quê? Conversa fiada, tempo gasto à toa, perdas e vida e fazenda - e no fim, conquistado o poder, ficarem todos olhando uns para os outros, indecisos. Os homens de 1930 não tinham um programa. E justificaram-se. Como teriam podido arranjar isso? Importar? Que é que deviam importar? Vivíamos num país onde os lugares se diferençavam muito uns dos outros. (...)

Assim, os revolucionários deram uma explicação razoável ao público: tencionavam firmar-se na realidade brasileira. E como essa realidade tudo podia comportar, houve aqui um saco de gatos: inimigos ferozes se juntaram, idéias contraditórias tentaram harmonizar-se.

Tudo se separou, naturalmente. A realidade brasileira, badalada em artigo e discurso, virou lugar comum. É inegável, porém, que das fórmulas de 1930 foi esta a melhor. Sem mencioná-la, várias pessoas se ocupam com os problemas nacionais, em estudos sérios que exigem observação e paciência." (13 jan. 1940). RAMOS, Graciliano. 1930. Pequena História da República. In: Alexandre e outros heróis. cit., p. 176.

${ }^{29}$ Idem. Bagunça. In: Viventes das Alagoas. cit., pp. 71-4.
} 
obediência que o personagem Fabiano, de Vidas secas (1938), crê dever-se às autoridades, ressurge em "Bagunça", para sinalizar a manutenção do poder vigente, que prescinde de autoridade ética, de coerência ideológica: deputados alagoanos em 1930, otimistas e sem nenhum desejo de luta, não acreditavam numa revolução que alterasse a ordem estabelecida. Depois, conforme Graciliano ironiza (à semelhança de Lima Júnior na "Carta a um antigo correligionário político"), esses políticos escondiam seus lencinhos encarnados nos bolsos ou os ostentavam, ao sabor dos acontecimentos. Também nesse texto, o cronista se queixa dos "moços verbosos" que, falando muito na realidade brasileira, buscavam em países distantes "receitas convenientes aos males nacionais". E se ri dos conservadores, arrepiados ante o materialismo de alguns dos novos.

Assim, retomando "Milagres", entende-se o inconformismo do escritor contra a inação dos políticos, cujo empenho reformador seria um milagre, improvável, ou seja, não existia. Ao mesmo tempo, revolta-se com a apatia, o resignado sofrer de explorações da maioria da população, de condição financeira precária ou instável. Por um lado, o cronista compreende que, em suas muitas necessidades, como pagar o aluguel e controlar gastos de acordo com o câmbio, as pessoas acreditassem no governo como fonte de soluções. Por outro lado, desejaria o fim dessa paralisia, sintetizada na frase nominal "Milagres.".

Milagres. Quem reduzirá o aluguel das casas e elevará o câmbio? O governo, provavelmente.

A espera de milagres incluía a ânsia por heróis. Representante exemplar de uma postura comum aos intelectuais do semanário alagoano, Graciliano rejeita o culto a heróis. Ironicamente, afirma crucial ao país um super-homem e pergunta onde estaria ele. Percebese sua ressalva a mistificações da realidade, em particular a pretensos heróis da chamada revolução de 30. No editorial da Novidade posterior, Valdemar Cavalcanti questionaria os "técnicos da Segunda República", que se haviam alardeado reformadores, médicos especialistas, para alcançar o poder, porém não enfrentavam os problemas do Brasil. Graciliano repete o chavão da época, de existirem muitos talentos a serem aproveitados, e desmascara que o entusiasmo por eles logo esfriava, ao ler-se o que escreviam.

O essencial é que o país tenha um homem, ou antes um superhomem, um herói. Enquanto ele não chega, contentamo-nos imaginando alguns. (...)

Há por aí numerosos talentos. Deveriam ser aproveitados. Acreditamos neles, oh! temos grande confiança neles. Um dia lemos o que eles escrevem - e o entusiasmo encolhe-se. 
Então, retoma um forte estereótipo do herói nacional, para renegá-lo: “Meu Deus! Por que foi que o Rui Barbosa morreu? Um cavalheiro que produziu tantos discursos que a gente admirava sem perigo!". Com mordacidade, Graciliano critica a retórica empolada, própria de advogados e políticos defensores da propriedade, da ordem estabelecida, e atesta o perigo de haver adeptos sem reflexão do palavreado excessivo. A crítica à retórica bacharelesca cultivada e cultuada no Brasil é marca da Novidade. Como se viu, Valdemar Cavalcanti e José Lins do Rego, em especial, voltaram-se contra os Aristarcos, as pseudointelectualidades feitas antes de pose e excesso verbal do que de conhecimento e compreensão. No repúdio de Graciliano e de Valdemar aos hinos com seus entusiasmos verbais, estava a recusa de emburrecer e dominar as pessoas.

Rui Barbosa (Salvador, 1849 - Petrópolis, 1923), conforme sintetizou Alfredo Bosi, "testemunhou quase miticamente o modo de pensar das elites brasileiras que construíram a República" ${ }^{30}$. Com sua oratória eloqüente e prolixa, a vasta erudição reduzida a exemplos para suas teses, defendia a democracia jurídica, englobando a liberdade de expressão e o direito de propriedade. Desagradava a Graciliano Ramos a idolatria por Rui Barbosa: fato conhecido é que, por volta de 1919, em Palmeira dos Índios, gostava de declarar o orador "um fóssil", mudando para "um gênio" após verificar o assombro e censura de muitos. ${ }^{31}$

Conhecendo-se alguns episódios da vida de Rui Barbosa, representativos da tendência, na história brasileira, à improvisação, à retórica oca e ao personalismo políticos, compreende-se a ironia incisiva de Graciliano ao lamentar que Rui estivesse morto e, sendo assim, faltasse ainda a nova Constituição. A força da ironia dimensiona a necessidade de "Milagres".

Se ele [Rui Barbosa] ainda vivesse, a constituição estaria pronta. A constituição e uma réplica.

A constituição, sim, senhor, é o que vai fazer milagres.

Antes pragmático do que especulativo, Rui, monarquista, foi o improvisador e organizador da República no Brasil. Coube-lhe a revisão do projeto da primeira Constituição republicana do país, de 1891, inspirada na norte-americana. Ministro da Fazenda, seu plano de especulações financeiras (Encilhamento) acarretou inflação e crise. ${ }^{32}$

\footnotetext{
${ }^{30}$ Cf. BOSI, Alfredo. História concisa da literatura brasileira. cit., pp. 285-9.

${ }^{31}$ Cf. LIMA, Valdemar de Sousa. Graciliano Ramos em Palmeira dos Índios. Brasília: Livraria-Editora Marco, 1971, pp. 110-1.

32 Cf. CRUZ COSTA, João. Contribuição à História das Idéias no Brasil. Rio de Janeiro: José Olympio, 1956, p. 336; FAUSTO, Bóris. História do Brasil. 10ª ed. São Paulo: Edusp, 2002, p. 249.
} 
Quando Graciliano insinua que Rui Barbosa já teria escrito a constituição e uma réplica, refere-se a uma polêmica de 1902. Veja-se que, na Novidade, o período é: "a constituição estaria pronta. A constituição e uma réplica."; já na edição de Linhas tortas, que demanda revisão, aparece: “A constituição é uma réplica.”. Cumpre, pois, conhecer a história da Réplica.

Em 1899, o jurista Clóvis Bevilaqua redigiu o Código Civil brasileiro em apenas seis meses, conforme os interesses do governo Campos Sales de que fosse aprovado ainda em seu quatriênio, até 1902. Como os artigos sofreram emendas mas não foram reescritos em 1901, foi pedida a revisão, com prazo exíguo, para o filólogo Ernesto Carneiro Ribeiro.

Eis que Rui Barbosa, ressentido por não ter sido sequer consultado e desde o início insatisfeito com a realização, às pressas e por uma só pessoa, de trabalho jurídico tão relevante, escreveu o Parecer do senador Rui Barbosa sobre a redação do projeto da Câmara dos Deputados. Impressiona tratar-se de 217 folhas manuscritas (561 páginas editadas pela Imprensa Nacional), apresentadas depois de somente três dias e incidindo não sobre questões legislativas, mas de purismo gramatical. Por conseguinte, Rui angariou a um tempo a hostilidade de juristas e de escritores; críticos literários como José Veríssimo e Medeiros e Albuquerque também se manifestaram sobre o Parecer. Ante as respostas de Clóvis Bevilaqua e de Carneiro Ribeiro, Rui Barbosa escreveu a Réplica, que lhe rendeu a imagem de gramatiqueiro, defensor de uma língua convencional e inumana, personificação de um modelo contra o qual o modernismo se voltaria. ${ }^{33}$

Assim, a primeira Constituição da República e a polêmica relativa ao Código Civil brasileiro, incluindo o Parecer e a Réplica de Rui Barbosa, revelam que, desde o início, o âmbito jurídico-político da República no Brasil se pautou em improvisação, prolixidade e defesa de interesses pessoais e vaidades. Se o Código Civil não deveria ter sido feito às pressas tão-só para garantir o poder de alguns, também a resposta de Rui Barbosa, com sua verbosidade gasta em questões menores, era movida por objetivos particulares.

Diante de tal tradição de seriedade administrativa, risível porém de efeitos trágicos, ergue-se a ironia de Graciliano: "A constituição, sim, senhor, é o que vai fazer milagres". Se pareceria já um milagre a existência de leis no papel, milagre mais incrível seria que os políticos as fizessem vigorar de forma a minorar os problemas da realidade brasileira.

\footnotetext{
${ }^{33}$ Cf. BROCA, Brito. A vida literária no Brasil - 1900. $5^{\mathrm{a}}$ ed. Rio de Janeiro: José Olympio / Academia Brasileira de Letras, 2005, pp. 271-7. Brito Broca observa que, segundo San Tiago Dantas, ao fazer da Réplica um caso gramatical, Rui Barbosa tinha o objetivo político de retardar a votação do projeto.
} 
Ao inserir ironicamente a Constituição entre os milagres aguardados, Graciliano problematiza outro lugar-comum da época. Recordem-se, da Novidade, os artigos "Por que não a Constituinte?", de Edmilson Falcão, e “Alberto Torres e a Constituição", de Paulino Jorge. Este desmascarava que a reforma da Constituição não passava de "tema falaz" dos políticos, chavão para atingirem o poder. Nesse sentido, Graciliano desnuda que, ao tratarem a Carta Magna em polêmicas a respeito de tamanho e linguagem, contribuíam para generalizar-se a falta de conhecimento e de reflexão sobre as leis.

Como será a constituição? Comprida ou curta? semelhante à primeira ou diferente dela? escrita em português ou em brasileiro? Ninguém sabe, e inspira por isso um imenso respeito.

Sintetiza-se, nessa passagem, uma idéia central de "Milagres", caminho para apreenderem-se na matéria histórica da Novidade problemas de dimensão individual e social e, portanto, para compreender-se a criação de personagens como Fabiano de Vidas secas. "Ninguém sabe, e inspira por isso um imenso respeito": o desconhecido, a precariedade de vida e a falta de horizontes podem levar à crença em milagres e em heróis, à obediência cega ao governo como autoridade, à criação de mitos. É preciso perceber-se que a ignorância significa exploração; contudo, num paradoxo produtivo, significa o desejo de uma abertura possível para o necessário conhecimento e autonomia.

Na seqüência, Graciliano critica a idéia despropositada de divisão territorial do país e a imitação de modelos estrangeiros; aproveita para acusar a limitação da mentalidade norte-americana, exclusivamente voltada para o seu capitalismo:

Mas o milagre que nos convém será gramatical ou geográfico? Projetaram estraçalhar o mapa e cosê-lo de novo. Improvisaram uma divisão encrencada, com estados, províncias e territórios. Como ficaria essa manta de retalhos? Os pedaços seriam irregulares, como em toda a parte, ou quadrados, como na América do Norte, onde a própria terra é quadrada?

Já se observou em "Uma idéia maluca - A propósito da divisão territorial”, de Lauro Jorge, que uma das "fórmulas de salvação" do Brasil nos anos 1930 era anexar pequenas unidades da Federação aos grandes Estados. Ele a rejeitava, apontando faltarem ao país administradores sérios, não afeitos à prática de acordos escusos.

Consciente da quantidade e gravidade dos problemas do Brasil, Graciliano entende ironicamente que o milagre necessário deveria ter a dimensão territorial do país. Deseja também um milagre grande o bastante para o mundo, marcado por incertezas após o conflito de 1914 e a crise da bolsa de Nova York de 1929. 
De qualquer modo desejamos um milagre de oito milhões de quilômetros para o Brasil e outro muito maior para o resto do mundo.

Na composição da crônica, sobressai o tom coloquial, de horizonte crítico, com que o escritor pergunta pelos milagres: parecendo ironizar uma imagem comum na época, ele é como um médico a tatear uma receita para a cura do país. Por meio de uma dessas indagações, revela as opções restritas de ascensão dos indivíduos da classe média: uns sonham com uma democracia social, outros se vergam à lógica de favores e interesses pessoais e buscam um protetor.

(...) Democrático ou aristocrático? Quem sabe lá? Uns querem um governo popular, outros apelam para os figurões.

Com ironia máxima, o escritor mostra a gravidade de dois problemas interligados, objetos centrais da reflexão da Novidade: a falta de instrução e a realidade de violência. Enuncia a necessidade de um milagre ou de um decreto que concedesse, depressa, todas as línguas e conhecimentos possíveis para as pessoas; e sugere a importância da extinção "repentina" do cangaço e das secas.

E a instrução, é bom não esquecer a instrução. (...)

Também seria importante a supressão repentina dos bandidos do Nordeste e o desaparecimento das secas.

A instrução já se afigurava problema incontornável, pois demanda um exercício de mediação pelas palavras e um tempo de amadurecimento incompatíveis com uma realidade de violência, perpetuada pela miséria.

Como se viu, na Novidade Álvaro Dória contestava que a propalada reforma do ensino não passasse de cobrança de taxas elevadas, conservando o país como "terra dócil do analfabetismo". O semanário cobrava a existência de salões de leitura, denunciava a violência dos Lampiões e apontava a indiferença para com os muitos mendigos da cidade.

Por fim, Graciliano se ri do milagre malogrado do pernambucano que quis agarrar a eletricidade do céu, caso também referido por Raul Lima na Novidade. Melancolicamente, com a lucidez de sua crítica, sabe que se criarão, para fracassarem, outros milagres.

E o milagre gorou.

É conveniente que se arranjem outros.

Desse modo, "Milagres" condensa o olhar crítico do semanário em relação ao nada de novo: o mundo do pós-guerra de 1914 assistia aos bastidores de mais um conflito mundial e, em particular, o Brasil depois da revolução de 1930 continuava com os mesmos 
problemas. Tal crônica concentra os temas e a perspectiva da revista, além de já patentear a maestria do estilo do escritor: é síntese perfeita dos impasses que faziam necessária a Novidade. Graciliano desmascara como falsos milagres os vários chavões que estavam na ordem do dia após a revolução de 1930, alardeados como novidades que curariam os males do país: a reforma política, a nova Constituição, a divisão territorial, a instrução, o fim das secas e do cangaço.

\section{O SENTIMENTO PARA ALÉM DO PERIÓDICO: O SEMBLANTE ÉTICO DA NOVIDADE}

"A cidade mendiga, a cidade que sofre" e "Lampião entrevistado por Novidade", já analisados, são textos que, embora anônimos, configuram uma face da Novidade, por combinarem traços ficcionais, expressão irônica e perspectiva crítica ante problemas graves da realidade alagoana, como a mendicância e a violência. Igualmente nãoassinados, outros textos da revista merecem atenção especial, dada a sua expressividade mordaz frente a aspectos da precariedade, ainda atual, do país.

Em “Salve-se quem puder" (N 7, p. 7) e em "Impostos" (N 9, p. 9), acusa-se o sistema tributário brasileiro de ser o pior do mundo, por favorecer as classes defensáveis e atingir as indefesas. São atacados os governos "revolucionários", porque os impostos continuavam a recair com força no consumidor pobre, cobrados não proporcionalmente à riqueza de cada um, mas em paralelo à miséria de todos. É notável a impetuosidade crítica dos moços da Novidade: sem meias-palavras, apontavam a falta de inteligências e, portanto, de perspectivas no Brasil:

Infelizmente nada nos resta senão chorarmos a tristeza de ser o Brasil um país onde as inteligências hão de chegar com a utilidade das autópsias: quando nada se puder corrigir.

No número 17 , p. 5 , utiliza-se uma imagem para definir muitos dos "homens novos", vindos da revolução de Outubro: “águas paradas". Tinham, dos espelhos, a fidelidade no reproduzir e o brilho superficial. Porém, não conseguiam que ninguém neles se mirasse e não enxergavam que uma simples pedrinha podia desmanchar-lhes o descanso. A imagem "águas paradas", crítica à estagnação, continha o desejo de mudanças efetivas: "Aí então as águas se mexeriam e ondas impelidas por uma força central poriam tudo à margem". 
No já citado "Nós, os descendentes de Deodoro e Floriano" (N 20, p. 7), acusa-se que, enquanto jornais do Rio e de Pernambuco trataram da exoneração, em Alagoas, do doutor Freitas Melro e da conseqüente substituição na Interventoria Federal, os próprios alagoanos pouco se interessavam por sua política, pelas quedas e ascensões da Segunda República. Ao contrário, um fuxico sobre o adultério da mulher de um fulano correria unânime pela cidade.

Mas um caso político é, para nós, um 'simples' caso político. Para um povo doméstico somente têm importância as questões domésticas.

Opondo caso político a caso doméstico, os jovens da Novidade revelam forte insatisfação com a generalizada falta de consciência crítica em Alagoas. Demonstram conhecer bem sua realidade, em que, apesar do indiferentismo e ignorância políticos, depois se reclama das ações tomadas à revelia dos alagoanos, da hegemonia exercida pelo sul, da falta de atenção do governo. Desejam, embora com a consciência de estar num horizonte remoto, o dia em que se compreenderá a política como dever de todos em beneficio de todos, e não privilégio de doutores nem de ninguém. Nesse dia, eles, os "afamados herdeiros" de Deodoro e Floriano, teriam vergonha do "passado de lesmas" que legavam às gerações futuras.

Em "Luz e outras coisas" (N 14, p. 7) e “Escuridão" (N 18, p. 7), sobressai o elemento moderno mergulhado nas trevas em Maceió: denuncia-se a precariedade dos serviços de iluminação elétrica e de telefonia e a resignação das pessoas ante essa falta de conforto. Critica-se a Companhia Força e Luz Nordeste do Brasil, empresa estrangeira que, substituindo a antiga, não melhorou os serviços, ao contrário do imaginado por todos. A ironia atinge sobretudo a empresa estrangeira, mas também "os indígenas inocentes", que aguardavam por ela, e a companhia antiga, nacional. Esta era ruim, porém muitas vezes deixava às escuras uma rua só. Já a nova apagava as luzes da cidade inteira: sequer tinha "a delicadeza de escolher noites de lua" e fazia as pessoas, ao saírem de lugares de "civilização", mais ou menos iluminados, como cinemas e cafés, jogarem "cabra-cega com os postes inúteis". Também os telefones, quando chovia, tinham a regularidade de não funcionar.

Vejam o que ela [Companhia Força e Luz Nordeste do Brasil] nos deu. 'Vejam' é um modo de dizer. Quem pode ver nada com a escuridão que nos fornecem quase diariamente por um preço exagerado? 
Assim, a revista ironiza o descaso da Companhia de Luz para com a população, enfatizando necessário, embora reconhecesse inútil, o protesto contra aquela indignidade. A ironia por fim se dirige a um melhoramento nos transportes: a implantação de um bonde amarelo com enfeites coloridos. Tão belo, parecendo a bandeira da República ou um grande papagaio, agradaria, mais do que qualquer conforto, a um povo afeito a coisas pintadas.

Realmente a Companhia Força e Luz Nordeste do Brasil não nos tem dado confortos excessivos, que não merecemos, mas é injustiça dizer que ela nos trata mal. Estamos bem servidos. Para que mais? Temos um bonde com pintura nova. E nós gostamos de coisas pintadas.

Síntese crítica para esse impasse da modernidade estrangeira na Maceió de 1931 está em "Luz sem força”, de Juão Jurubita (pseudônimo de Octacílio Maia), na N 22, p. 4. A pedidos de assinantes e amigos da revista, esse "velho e hábil manejador da pilhéria" inaugurara no número anterior uma seção humorística. Numa linguagem próxima da fala popular, brinca com a inexistência das melhorias tecnológicas prometidas: a companhia estrangeira de energia elétrica não fez do bonde aeroplano, não eliminou os defeitos na telefonia nem na iluminação, não garantiu bons salários aos trabalhadores.

$$
\begin{aligned}
& \text { (...) O povo então cumessou } \\
& \text { a coisa profetisá } \\
& \text { "Agora sim - istrangêro } \\
& \text { As coisa vão miorá } \\
& \text { Im vez de bonde, - iroplano } \\
& \text { Im vez de tição, - luz solá". } \\
& \text { (...) } \\
& \text { Enquanto a mióra vem } \\
& \text { Do contrato qui se fez } \\
& \text { Os telesfome só fala } \\
& \text { Quando conhece o freguez } \\
& \text { De sumana im sumana } \\
& \text { Iscuridão uma vez } \\
& \text { Sem se contá cum as greve } \\
& \text { Qui agora é uma pur mez. }
\end{aligned}
$$

Aqui, pensando-se na configuração artística da passagem do mundo dos lampiões de gás para o da energia elétrica, evoca-se "O acendedor de lampiões". Apesar de alexandrinos, esses versos de Jorge de Lima já se movem por uma inquietação própria da poesia moderna: o olhar para o cotidiano, a preocupação com o trabalhador humilde.

Triste ironia atroz que o senso humano irrita: -

Ele [o acendedor de lampiões] que doira a noite e ilumina a cidade, Talvez não tenha luz na choupana em que habita.

Tanta gente também nos outros insinua 
Crenças, religiões, amor, felicidade,

Como este acendedor de lampiões da rua!

Capaz de criar um artifício que imita a harmonia da natureza, o homem inventou o lampião, que lhe permite "parodiar o sol e associar-se à lua". Ao mesmo tempo, falta "senso humano", pois o conforto levado pelo acendedor de lampiões não existe para todos, nem para ele próprio. Porém, há quem sofra com essa situação paradoxal e, aproximandose dos acendedores de lampião por meio das palavras, busque iluminar consciências com a sugestão da solidariedade.

Observe-se que "O acendedor de lampiões" foi composto em 1907, quando Jorge de Lima tinha catorze anos. Publicado em 1914 em XIV Alexandrinos, saiu num jornal de Alagoas em 1921, para consagrar o "Príncipe dos poetas alagoanos". Ao lado do soneto, segundo relata Carpeaux, figurava a tela $O$ acendedor de lampiões da rua, do pintor José Paulino, realçando para os leitores o colorido regional da personagem e do ambiente. Nesse sentido, o crítico Manuel Anselmo ressalta no soneto a facilidade verbal e a atitude de solidariedade humana, que depois se verificariam, por exemplo, nos poemas negros e no romance Calunga. Não aceita chamar de parnasianas as primeiras experiências poéticas de Jorge de Lima, e sim de clássicas e tradicionalmente líricas. ${ }^{34}$

Desse modo, o poema de Jorge de Lima e o de Jurubita mostram como, mesmo com as luzes do desenvolvimento humano, permanecem os impasses do cotidiano, como a precariedade da vida de muitos trabalhadores, que não dispõem de serviços básicos e, no entanto, os garantem a outrem, aos mais ricos.

Em “Um urubu pousou na nossa sorte" (N 22, p. 7) e em "Otimismo" (N 23, p. 7), já os títulos sintetizam a atitude auto-irônica dos colaboradores do semanário para com a realidade alagoana. Ante tantos problemas sociais e políticos, viviam a tensão entre sua fragilidade para conseguir mudanças e a necessidade de seu empenho crítico. Devido à situação precária e à falta de perspectivas de mudança, evocando o urubu de Augusto dos Anjos e o corvo de Poe, os autores comparam Alagoas a uma caixa de mágico: "nada de um lado, nada do outro", um soldado desconhecido saindo de dentro, após se "dar um jeitinho".

\footnotetext{
${ }^{34}$ Cf. CARPEAUX, Otto Maria. Notas e variantes; ANSELMO, Manuel. Nota preliminar. In: LIMA, Jorge de. Obra completa. cit., p. 1151; pp. 179-182.
} 
A crítica é veemente contra os "adjetivos excessivos" do otimismo patriótico das comemorações do aniversário da independência de Alagoas: apesar de seus "altos feitos", Floriano, Deodoro e o Barão de Penedo eram incapazes de reduzir a pobreza, a ignorância e a verminose dos alagoanos. Os escritores da Novidade cobram a formação, no interior do Estado, de uma classe que pense e trabalhe bem. E ironizam os cavalheiros mal-formados da elite, que "impingiam" discursos vangloriando-se de serem descendentes de figuras ilustres e de possuírem alguma terra, muito embora habitada por "mais de um milhão de mendigos, graças a Deus”.

Não era melhor que tivéssemos menos vaidade e pensássemos um pouco em açudes e outras coisas semelhantes?

A escolha vocabular e a mordacidade irônica com que se atacam os oradores patrioteiros, cheios de um otimismo mistificador da realidade, e se cobram soluções práticas para a pobreza, a ignorância e a verminose deixam ver a pena de Graciliano Ramos na composição provavelmente coletiva desses artigos ${ }^{35}$. Presume-se serem esses os "editoriais" que Graciliano escreveu para a revista além dos artigos assinados, segundo relata Valdemar Cavalcanti ${ }^{36}$. Ele recorda essa "época dourada" da vida intelectual alagoana, em que conviviam "uns grandes”, como Graciliano, José Lins e Santa Rosa, com os "meninos de Maceió", conforme José Lins do Rego os chamava, a ele Valdemar, a Aloísio Branco, Carlos Paurílio, Mário Brandão, Aurélio Buarque de Holanda, Diégues Junior e Raul Lima. Enfatiza que viviam a curiosidade e perplexidade frente ao presente e ao futuro, de Maceió, de Alagoas, do Brasil e do mundo, e cuidavam sobretudo de literatura, pensando em termos da literatura brasileira. Relembra que fundaram a revista Maracanã, de um número só, e a Novidade, semanário de seis meses, Alberto Passos Guimarães e ele na direção, "sofrendo o diabo mas resistindo até não poder mais". Revela que Graciliano, embora considerado um esquivo, lidou com os jovens na Novidade. E estes, mesmo que discordassem das idéias do Velho, respeitavam-no "como a ninguém”.

$\mathrm{Na}$ homenagem aos 50 anos do romancista, Francisco de Assis Barbosa ressalta que, tendo Graciliano largado a prefeitura de Palmeira dos Índios no início de 1930, trabalhou até o fim de 1931 em Maceió como diretor da Imprensa Oficial do Estado e era

\footnotetext{
${ }^{35}$ Em "Sertanejos" e em "Lampião", do primeiro número da Novidade, vê-se o inconformismo de Graciliano por andarem os sertanejos carregados de "adjetivos idiotas", "muita verminose" e "muita ignorância".

${ }^{36}$ Cf. Artigo de Valdemar Cavalcanti no Jornal de Alagoas, 21 de abril de 1978. Apud RAMOS, Clara. Mestre Graciliano: confirmação humana de uma obra. Rio de Janeiro: Civilização Brasileira, 1979, pp. 70-2.
} 
como "o cabeça do grupo de Alagoas": cercava-o uma "turma jovem e inteligente", "os seus amigos, verdadeiros companheiros de letras" 37 .

Tal sociabilidade do grupo de 1930 ganha contornos também no relato de Clara Ramos, filha de Graciliano: por volta de quatro e meia da tarde, buscavam o diretor do Diário Oficial e se dirigiam ao Bar do Alemão; depois seguiam para o Ponto Central, o bar do Cupertino ${ }^{38}$, em frente ao Relógio Oficial, onde papeavam até dez da noite. Clara salienta a agitação da atmosfera intelectual, promovida pelo grupo do bar do Cupertino: discutia-se literatura na mesa do bar, nas praças, reuniões de arte, nas redações dos jornais; realizaram-se a grande venda de livros usados, organizada pela Liga contra o Empréstimo de Livros, e a $1^{\text {a }}$ Exposição de Santa Rosa.

Dessas reuniões no Cupertino, Raul Lima guardou boas recordações, até olfativas em relação a Graciliano: "costumava ele derramar um pouco de açúcar no mármore da mesa e incinerá-lo com o cigarro aceso, disso resultando um cheiro gostoso de engenho, enquanto Santa Rosa fazia desenhos com que exercitava distraído a grande arte que lhe deu renome" 39 .

É interessante que, das conversas do pai, Ricardo Ramos relembre um fato sobre a composição de editoriais, que ele presume do Jornal de Alagoas, nos anos 30. Como Graciliano escrevia lentamente, José Lins do Rego o instava a encerrar logo o artigo. Um dia, aproveitando que o amigo fôra ao banheiro, Zé Lins concluiu depressa o texto e obteve a aprovação do escritor exigente. Então, podiam ir à Helvética ou ao Cupertino, para beber, conversar e tomar conta dos jovens Valdemar e Paurílio, que bebiam demais. Assim, é possível supor-se que vários artigos não-assinados da Novidade tivessem autoria coletiva, já que o grupo se encontrava com freqüência, certamente partilhando perspectivas sobre literatura e política. Nascido em 1929, Ricardo Ramos evoca da memória de criança os encontros dominicais em sua casa, na rua da Caridade, na Maceió "centro literário de importância” de 1934. Observa que o pai gostava desses encontros, pois continuaram no

\footnotetext{
${ }^{37}$ BARBOSA, Francisco de Assis. 50 anos de Graciliano Ramos. In: SCHMIDT, Augusto Frederico et alii. Homenagem a Graciliano Ramos. Rio de Janeiro: Alba, 1943, p. 48.

Graciliano foi diretor da Imprensa Oficial de Alagoas, que hoje tem seu nome, de 31/5/1930 a 26/12/1931.

${ }^{38}$ O Bar do Alemão pertencia ao vienense M. Goldenberg, o outro era de Manuel Cupertino Loureiro, sempre de roupa branca, que viveu 104 anos. (Cf. VASCONCELOS FILHO, Marcos. Marulheiro: viagem através de Aurélio Buarque de Holanda. Maceió: Edufal, 2008).

${ }^{39}$ Cf. citação de Raul Lima apud RAMOS, Clara. Mestre Graciliano: confirmação humana de uma obra. cit., p. 72.
} 
Rio de Janeiro, durariam toda a sua vida. Porém, revivendo as gargalhadas então ouvidas, pondera que, naquela época, "talvez fossem mais alegres" 40.

E aqui, para compreender a significação da Novidade, interessa a experiência de Carlos Drummond de Andrade, que em 1978 refletiu sobre sua atuação em A Revista, de 1925. Embora enjoado pelo que escrevera havia mais de cinqüenta anos, reconhece-a como documento modernista revelador da atmosfera intelectual dos anos 1920. O elemento que Drummond destaca do periódico vale também para se pensar na Novidade: refletia "aquilo que os moços têm de melhor, e é pena que a vida tire depois, da maioria deles: a insatisfação, geradora do novo" ${ }^{41}$.

Nesse sentido, Abelardo Duarte, em O periodismo literário nas Alagoas, chama a Novidade "exemplo magnífico da força e do idealismo da mocidade", realçando necessários o idealismo, próprio da juventude, e a resistência, em nome da expressão dos desejos e insatisfações ante a realidade. Sendo raras as referências à revista alagoana de 1931, surpreende a existente nesse livro, mesmo considerando que seu autor nela publicou "Brinquedos" (N 2, p. 11), "Sobre desenhos infantis" (N 5, p. 3) e "Notas sobre o problema da criança brasileira" (N 19, p. 10).

Abelardo a vê como "um ponto alto no panorama lítero-cultural provinciano de 1931 pela publicação de escritos (poesia e prosa) e pelos nomes que os assinam" ${ }^{42}$. Segundo ele conta, os exemplares da Novidade eram disputados, à porta da livraria Vilas Boas, nas tardes de sábado; nenhuma outra revista se impusera tanto e tão depressa à acolhida do público. Apesar disso, como a falta de condições financeiras provavelmente foi o fator determinante para o desaparecimento do semanário, o autor pondera que a evolução cultural então verificada ainda não era suficiente para manter aquela iniciativa.

Mas Abelardo Duarte enfatiza que a Novidade realizou a ambição de seus idealizadores: de fato "agitaram", "abalaram por algum tempo os ares provincianos com as suas crônicas e artigos de reação contra a pasmaceira literária". Relembrando os nomes de alguns de seus colaboradores, que se notabilizaram nas letras e na arte - Graciliano Ramos,

\footnotetext{
${ }^{40}$ RAMOS, Ricardo. Graciliano: retrato fragmentado. São Paulo: Siciliano, 1992, pp. 40-2.

${ }^{41}$ ANDRADE, Carlos Drummond de. A Revista, de novo. Interessa? In: Folha de S.Paulo, São Paulo, 21 set. 1978. Apud SILVA, Margaret Abdulmassih Wood da. Revista: contribuição para o estudo do modernismo em Minas Gerais. Dissertação de mestrado. São Paulo, FFLCH-USP, 1985, p. 274.

${ }^{42}$ DUARTE, Abelardo. O periodismo literário nas Alagoas. Maceió: Departamento Estadual de Cultura, 1961, pp. 33-5 (Caderno III, Série Estudos Alagoanos).
} 
Jorge de Lima, José Lins, Santa Rosa, Murilo Mendes, Álvaro Lins, Ademar Vidal, Mauro Mota $^{43}$-, sublinha que o periódico oferece um "precioso documentário", cada vez mais relevante ao longo do tempo.

Percebe-se, graças à Novidade, que em 1931 em Maceió já não havia grande crença na revolução de 1930; mas essa descrença alimentava os escritores a combaterem os chavões revolucionários, disfarces para uma política personalista, e a se dedicarem a uma literatura crítica dos problemas do país. A revista acolhia tendências diversas, desde homens ligados ao integralismo, como Arnóbio Graça, até militantes comunistas, como Alberto Passos Guimarães, divisão que se acirraria nos anos seguintes. Os nomes mais conhecidos, como Graciliano, Aurélio, Valdemar Cavalcanti e Santa Rosa, eram preocupados com questões sociais, com a cultura e a arte, mas não panfletários.

Sobressai, portanto, o idealismo e o espírito crítico do grupo de Alagoas, que se dedicou ao semanário como reação à realidade de violência, miséria e ignorância. Mais do que isso, cumpre perceber, também com Drummond, que o semblante de uma revista ultrapassa o seu sumário e os textos publicados:

O sumário de uma revista não esgota o seu semblante, que tem linhas ocultas à imagem visível. Se julgarmos nosso mensário exclusivamente pelos artigos, notas e poemas que ele publicou, estaremos omitindo um elemento não verbalizado, e que conta muito na raiz das coisas: o sentimento com que elas são feitas. ${ }^{44}$

Dessa forma, o semblante da Novidade compõe-se do sentimento de afeto e afinidade intelectual entre seus principais colaboradores, cuja amizade e empenho ético de trabalhar contra o lugar-comum, na arte, na política, na vida, se prolongariam no Rio de

\footnotetext{
${ }^{43}$ Merecem futura análise os textos destes escritores na Novidade: "O repórter atrás da grade", "A namorada do pintor", poemas de Murilo Mendes; "Vida das ruas, um cronista russo etc", crônica, "Infầncia", poema, "Renúncia", conto, de Álvaro Lins; "Mamanguape", poema de Ademar Vidal; "Flirt", poema de Mauro Mota.

${ }^{44}$ Cf. ANDRADE, Carlos Drummond de. Valeu a pena? Valeu. In: Folha de S.Paulo, São Paulo, 26 set. 1978. Apud SILVA, Margaret Abdulmassih Wood da. Revista: contribuição para o estudo do modernismo em Minas Gerais. cit., pp. 279-280. Vale a pena também ler a seqüência:

"Mas ressalvo e salvo o espírito de feliz aventura, de que nos impregnamos durante um semestre de vida - o tempo de duração da Revista. Éramos despreocupados e preocupados, vivíamos o que Eduardo Frieiro chamou de 'ilusão literária' e, mal ou bem, nos engajamos num movimento de revisão de conceitos estéticos que até hoje alimenta a criação no Brasil, pela liberdade que conquistou e ofertou aos novos que a consideram peça de museu. Revisão que ajuda a negar o modernismo servindo-se de sua herança de livre experimentação. No terreno do tratamento brasileiro da língua comum, parece evidente a libertação. E esse tratamento não era simples reivindicação gramatical, mas o processo que se utilizou para chegar a uma expressão nacional de sensibilidade brasileira perante o meio, a natureza, o dia-a-dia e o mundo.

(...) Sim, fomos ridicularizados, fomos xingados e xingamos também, acreditamos na literatura desacreditando seus deuses de barro ou que nos pareciam tal. Foi um momento feliz. Ainda se fala nele. Perduram suas consequiências. A Revista teve o seu cantinho no salão. Valeu a pena, amigos."
} 
Janeiro, no decorrer de suas existências. Partilharam de necessidades comuns, como a busca de emprego fora de Maceió, reveladora também de um problema do país: vários acabaram por migrar para o Rio (Graciliano preso), trabalharam no IBGE, escreveram para a Revista do Brasil e publicaram pela editora José Olympio.

Assim, relativiza-se a imagem de um Graciliano isolado e se percebe o valor do periódico alagoano como reunião de um grupo de intelectuais que permaneceriam ligados afetivamente e por propósitos culturais semelhantes. Se a Novidade não teve uma plataforma, particularmente em termos estéticos, constituiu um agrupamento de escritores com interesses comuns, que reconheciam os mesmos problemas sociais, políticos e culturais e desempenharam papel singular na cultura do país. Eles contribuiriam para a ficção brasileira, a poesia, a crítica literária, o jornalismo, a filologia, as artes plásticas: Graciliano Ramos, José Lins do Rego, Jorge de Lima, Carlos Paurílio, Aloísio Branco, Willy Lewin, Valdemar Cavalcanti, Alberto Passos Guimarães, Aurélio Buarque de Holanda, Santa Rosa ${ }^{45}$. Já se entende melhor também a presença marcante de Graciliano na Livraria José Olympio nos anos 40.

Importa, pois, delinear os perfis de alguns desses escritores, atentando para sua singularidade e inserção no grupo, a fim de melhor apreender o semblante da Novidade.

\footnotetext{
${ }^{45}$ Cf. RAMOS, Clara. Mestre Graciliano: confirmação humana de uma obra. cit., p. 70.
} 


\section{CAPÍTULO 6 - NOVIDADE LITERÁRIA: O RESGATE DE PESSOAS}

\section{Willy Lewin: a biblioteca de Cabral}

Willy Lewin (1909-1971) ${ }^{1}$, poeta bissexto e crítico literário, trabalhou como pagador da Secretaria da Fazenda de Pernambuco; no Rio de Janeiro, no Instituto de Pensões e Aposentadoria dos Servidores do Estado, IPASE; e, a partir do fim dos anos 60, como articulista de $O$ Estado de S. Paulo.

Colaborou, de Recife, com a Novidade e, ao lado de Joaquim Cardozo, Gilberto Freyre, Luís Jardim, Ascenso Ferreira e Manuel Bandeira, dentre outros, com a Revista do Norte, publicação significativa do modernismo e do regionalismo em Pernambuco.

Publicou, em 1936, Caminhos da poesia, volume de ensaios em edição restrita, e Quinze poemas, apenas em edição especial da revista cultural Renovação. Tempos depois, publicou Ensaios de circunstância (Rio de Janeiro: Ministério da Educação e Saúde, Serviço de Documentação, 1952) e Alguns ingleses, seleção de artigos que escreveu para o jornal $O$ Estado de S. Paulo.

Embora não tivesse uma obra volumosa, Lewin influenciou toda uma geração de intelectuais pernambucanos, freqüentadores do Café Lafayette, no centro de Recife, como o pintor Vicente do Rego Monteiro, Gastão de Hollanda, Ledo Ivo e João Cabral de Melo Neto. Em busca de território próprio, reagindo contra o predomínio do romance nordestino de 1930, alguns rapazes do círculo de Lewin (salvo Cabral) preferiam ler obras de fundo intimista, de Cornélio Penna, Octávio de Faria e Adonias Filho, até se centrarem na poesia.

Destaca-se o papel de Willy Lewin na formação intelectual de João Cabral de Melo Neto: franqueou-lhe sua biblioteca, possibilitando ao amigo, onze anos mais novo, descobrir Pirandello, os surrealistas, os cubistas, a moderna poesia francesa (Le Corbusier, Mallarmé, Valéry, Pierre Reverdy). Sobretudo, por intermédio de Lewin, Cabral conheceu a poesia de Carlos Drummond de Andrade (Brejo das Almas) e depois, no Rio, conheceu pessoalmente Murilo Mendes.

Prova de amizade e admiração, quando convidado por Décio de Almeida Prado, no fim dos anos 60, para ser resenhista de literatura inglesa do Suplemento Literário de $O$

\footnotetext{
${ }^{1}$ Cf. CASTELLO, José. João Cabral de Melo Neto. O homem sem alma \& Diário de tudo. Rio de Janeiro: Bertrand Brasil, 2006, pp. 44 e ss.
} 
Estado de S. Paulo, João Cabral sugeriu o nome de Lewin. E este lá trabalhou como articulista até o fim da vida.

Cabral dedicou a Lewin seu primeiro livro, Pedra do Sono (1942), cuja primeira edição foi por este prefaciada. Escreveu para o amigo, morto em 1971, este poema, desdobrando da dor da perda o valor de um mestre verdadeiro, capaz de testemunhar, com respeito crítico, o entusiasmo e as tensões da formação da identidade do outro:

\author{
A WILLY LEWIN MORTO \\ Se escrevemos pensando \\ como nos está julgando \\ alguém que em nosso ombro \\ dobrado, imaginamos, \\ e é o primeiro que assiste \\ ao enredado e incerto \\ que é como no papel \\ se vai nascendo o verso, \\ e testemunha o aceso \\ de quem está no estado \\ do arqueiro quando atira, \\ mais tenso que seu arco, \\ foste ainda o fantasma \\ que prelê o que faço, \\ e de quem busco tanto \\ o sim e o desagrado.
}

João Cabral de Melo Neto ${ }^{2}$.

\title{
O moderno e lírico na província: contra o standard, ruído da barbárie
}

São colaborações de Willy Lewin na Novidade: a crônica em forma de notas "Recife" (N 1, p. 4); os poemas "Fuga" (N 1, p. 6), "Solidão" (N 5, p. 6) e "O laboratório de imagens" (N 15, p. 11); a crítica de cinema em forma de notas "Branco e preto" (N 12, p. 11); as narrativas-crônicas “T. G. 13” (N 7, p. 6) e "Manhã” (N 6, p. 4); a crítica literária-crônica “Os últimos poemas do sr. Paulo Torres” (N 21, p. 10).

Veja-se como não é fácil estabelecer o gênero dos textos de Lewin: eles se definem pela construção fragmentária de formas poético-narrativas críticas, que sempre mesclam a

\footnotetext{
${ }^{2}$ MELO NETO, João Cabral de. A Willy Lewin morto. Museu de tudo (1966-1974). In: Obra completa. Rio de Janeiro: Nova Aguilar, 1994.
} 
crônica mundana da modernidade com a expressão de uma voz pessoal, de apelos líricos. Esse gênero indefinível traduz bem a contradição entre o desejo pelas modernidades que vêm de fora e a desconfiança em relação a esse progresso, reforçada pelo apego à simplicidade e às tradições locais.

$\mathrm{Na}$ Novidade 15 figura o poema em que Willy Lewin mais abusa do verso livre e da apropriação crítica das línguas francesa e inglesa. É “O laboratório de imagens”, em que constrói uma experiência poética a partir da ambigüidade da palavra estrelas: são as atrizes cobiçadas do cinema hollywoodiano, signo máximo do artifício da modernidade; são as luzes extintas do céu, signo da natureza singela, ameaçada de desaparecer.

Por um lado, Lewin evidencia seu deslumbramento com a mudança dos tempos, com o que há de integração do mundo inteiro por meio do cinema. Por outro lado, tem a percepção crítica de que as opiniões se tornaram "standard" e as relações pessoais estão escancaradamente mercantilizadas.

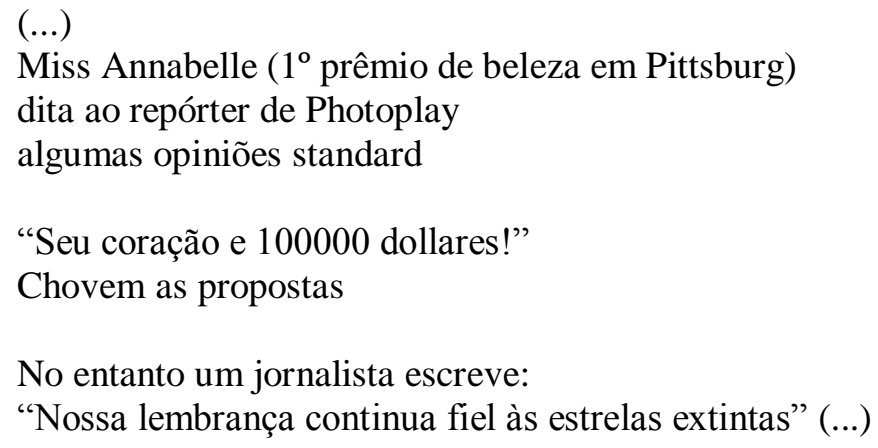

Assim, Lewin revela o caráter paradoxal e problemático do mundo moderno, em que as afirmações românticas provocam "comentários desencontrados". Conforme a imagem que abre o poema, a bebida predileta, embora tudo tenha mudado, ainda é a ilusão real do cinema, "Orangeade": a natural laranjada, artificial.

O poema "Fuga" traça a busca de identificação lírica do sujeito, aos olhos da amada e em meio à solidão e à frieza da cidade. Romântica e criticamente, ele apresenta uma "pequena flor" - "chama de lirismo" -, opondo-a a elementos da modernidade edifícios, anúncios de cinema e de sabonetes. Ao convocar tais elementos em versos livres, com direito à próclise modernista "me dissolvo", entrega-se ao "habitual" e ao "alucinado" da cidade grande provinciana e, a um tempo, os recusa.

Teu coração vermelho voa sobre os desertos.

Esta pequena flor é uma chama de lirismo no gelo das calçadas paralelas, 
edifícios enormes,

cartazes de cinema,

réclames de sabonetes.

Sou eu, Bellá!

Caminho entre anjos invisíveis

na tarde habitual.

Deformo todos os volumes.

Me dissolvo

nas alucinadas perspectivas.

A leitura de "Solidão" confirma a tensão do eu poético, entre a entrega ao "tumulto alegre" da cidade e a insatisfação íntima. Sendo o poema bastante simples, destaca-se o significativo emprego da segunda pessoa do plural para dirigir-se à interlocutora - a cidade. Embora plural, esta não acolhe com solidariedade as tristezas do outro. A linearidade do poema, enumeração da aposta nos gritos e luzes da cidade, quebra-se com a adversativa do final, que sinaliza como o traço de exterioridade do mundo urbano é hostil à interioridade do sujeito. De fato, a atração pela cidade, marcada por verbos no tempo passado, redunda na desilusão do presente e assim se projeta para o futuro: o eu-lírico se vê isolado, mesmo dentro da agitação alegre da cidade. Tal oposição se completa por meio de imagens: a metonímia das janelas, homens indiferentes aos desejos e pensamentos alheios; o contraste entre as luzes de néon e o escuro da solidão em que o sujeito se recolhe.

\section{Solidão}

acreditei em vós, cidade,

no consolo efêmero do vosso tumulto alegre!

Atordoei-me com os vossos gritos, enchi meus olhos das vossas luzes, esperei que de vós me viesse o esquecimento para as minhas [tristezas quotidianas,

desejei que as vossas janelas estivessem eternamente abertas para espreitar os meus pensamentos mais íntimos mas não me destes nunca a vossa solidariedade. Continuo sozinho, continuo no escuro, perdido nas noites de gás Néon.

Exatamente as contradições de uma capital brasileira provinciana, apreendidas por um cronista mundano e poeta, transparecem em "Recife". Ao longo dos dez segmentos dessa crônica-poema, Willy Lewin oscila entre os sentimentos de atração e de recusa anti- 
ilusionista tanto em relação às novidades técnicas do mundo moderno, que carregam ruídos de barbárie, quanto em relação ao lirismo de sua província, que carrega traços tacanhos.

Logo o primeiro segmento expõe a combinação, na Recife de 1931, entre signos da modernidade construída pelo homem (“3000 e poucos automóveis, dois pequenos arranhacéus de oito andares, serpentinas luminosas de gás néon”) e o elemento natural, o rio Capibaribe, referido como "fonte inesgotável de poesia". Contudo, tanto o entusiasmo pela modernidade como a resistência humana a seus artifícios surgem relativizados: os arranhacéus são pequenos e o lirismo inclui a frase-feita.

Nesse mesmo sentido, louva-se o cinema, diversão de "toda província que se preza"; porém, lamenta-se a "febre de som", a multiplicação dos hits musicais dos filmes nos "altifalantes das inumeráveis casas de vitrolas". Willy Lewin reclama do pouco respeito de Recife pela sensibilidade dos ouvidos alheios, que perde apenas para o Rio. Só se compraz de que os cinemas não usem sirenes para anunciar os inícios e fins de sessões. (Ao contrário de Maceió, como já se observou).

O cronista-poeta flagra com lirismo e alguma crítica o sabor pitoresco da convivência de modernidade com provincianismo. O cenário se transforma com a "radiomania": todos os tetos recebem antenas, e as instalações Telefunken trazem vaidade além de boa música. Ouviam o programa de Rudy Vallée, que cantava por meio de um megafone em várias línguas ${ }^{3}$. Um pitoresco gracioso assoma dos anúncios do comércio local nos jornais, bem como dos nomes de ruas (Becos das Almas, Rua dos Sete Pecados, Rua Lírica). A maquillage é obrigatória para as moças debruçarem-se às janelas às sete da manhã; a boa pronúncia inglesa mostra-se necessária para ostentar-se o garçon do american bar do Hotel Central.

“Manhã" reúne duas pequenas narrativas: a primeira é como um poema em prosa; a segunda, uma crônica poética. Na primeira, o eu-lírico estabelece uma construção sinestésica: caminha pelos desertos, imerso no orvalho da madrugada, no aroma de flores e nos sons de sinos. Então, entrega-se às "alucinações em disponibilidade": cria uma imagem de mulher que se transforma em violino, em violoncelo de grande orquestra sinfônica e que, no entanto, se recusa a ensinar-lhe os "caminhos do infinito". Assim, a arte, concentrando formas de beleza infinitas, revela as limitações da realidade.

\footnotetext{
${ }^{3}$ O cantor Rudy Vallée atuou desde os anos 30 no cinema e, mais tarde, na Broadway; foi o primeiro a gravar "As time goes by", treze anos antes de ter sido feito o filme Casablanca.
} 
Na segunda narrativa, a multidão ocupada ("As horas empurraram todos os ponteiros de relógios") é interrompida pela fala de um homem estranho, "de olhos doces e voz enérgica", que anuncia "grandes cousas" a ocorrer. Entretanto, logo um almofadinha, atribuindo tal fala a uma entrevista do Interventor de Pernambuco, dissolve em blague a agitação daquela "terra pequena e fútill"; mas sem perturbar o homem simples, que lhe sorri com piedade. Note-se como, com poucas palavras, Willy Lewin cria uma cena em que a oposição entre a vontade do povo, doce e enérgica, e a blague do almofadinha, cortante, desvela a manutenção do quadro político, avesso a sucederem "grandes cousas".

Justamente o almofadinha - de "cabelos engominados, olhos lânguidos e pulseirinha de ouro" - é a imagem exterior de Paulo Torres, cuja poesia também provoca aversão em Willy Lewin. Na crítica “Os últimos poemas do sr. Paulo Torres”, relata que, num encontro literário no Rio de Janeiro, provavelmente em 1923, esse poeta agrediu o público com a idéia sinistra de declamar sua Hora da neblina. De calças curtas, aos 13 ou 14 anos, incomodado ao ouvir imagens como a da mulher que parecia uma "silhueta esguia de pavão", Lewin já percebera que o almofadinha buscava um "lugarzinho entre a literatura 'bizarra' e exaltadamente requintada, tipo Géraldy ou Sarment”.

A ironia é o tratamento concedido por Willy Lewin tanto ao "vanguardista" Paulo Torres quanto "aos 'modernos' de Pernambuco (Inojosa \& Cia.)", que noticiaram amplamente a visita de Torres ao salão de conferências do Diário de Pernambuco em 1924 ou 25. Na ocasião, o poeta-almofadinha apresentou seu segundo livro, Bailados brancos, e ameaçou a todos com seus originais datilografados.

Lewin lembra que Paulo Torres, após ter desaparecido por um tempo, ressurgiu como redator principal de uma revista espírita, para em seguida sumir novamente. À pergunta irônica “Teria morrido o requintadíssimo poeta?", a resposta é o terceiro livro do almofadinha, Poemas proletários. Então, Willy Lewin explicita que não se poderia levar Paulo Torres a sério, “nem acreditar na sua 'evolução' de pulseirinha de ouro para o teórico overall proletário".

Desse modo, como existiam diferenças sob a mesma denominação de modernismo - entre os artistas e intelectuais, incluindo diversos níveis quanto às tendências regionalistas, de crítica social e de empenho estético -, não é conveniente generalizar-se o sentido da literatura moderna, de São Paulo, de Pernambuco, de Alagoas. O polemista Joaquim Inojosa vangloriava-se como introdutor do modernismo paulista de 1922 em Pernambuco. No entanto, segundo o exemplo ora apresentado, levou ao Nordeste figuras 
como o "vanguardista" Paulo Torres, cuja poesia Lewin julga antes um requinte almofadinha.

Já os textos de Willy Lewin, com sua liberdade formal entre crônica e poesia e com seu entusiasmo pelas inovações técnicas, como o rádio, o cinema, aproximam-se mais de um ideal de modernismo paulista. Ao mesmo tempo, com seu apego pelo lirismo do ambiente provinciano, resistente à modernidade como ruído, aproxima-se da ênfase concedida por Gilberto Freyre à tradição regional. Evoque-se também o analisado "T.G.13": é a narrativa curta que combina o olhar crítico para os problemas do seu tempo - a guerra e os falsos patriotismos, europeu e brasileiro - com o lirismo dos sonhos juvenis.

Conforme se lê em "Branco e preto", a atualização da inteligência desdobra-se no fascínio de Lewin pelo cinema e seu ritmo milagroso, impresso pelo close-up. (O crítico se deliciava lendo Epstein). Lewin saúda o cinema por expressar o mundo do sonho e vê no close-up uma forma de exceder a trechos de romances de Green e de Joyce. Em meio ao "simultaneísmo de Divoire", ao "sobre-realismo de Breton", à "complexidade de planos", ele vive os "torturantes esforços poéticos" da ânsia por novas formas, que esbarra sempre nos "limites dos meios de expressão".

Assim, Lewin louva soluções artísticas obtidas pelo cinema, como o close-up. Contudo, sinalizando que a mesma "marcha do progresso" que permitiu o close-up acarreta males às pessoas, observa que muitos filmes acompanham a "marcha do mau gosto humano". 


\section{“Meus livros são teus livros": Santa Rosa}

Sintetizar um texto de valor artístico conservando e até lhe enfatizando a poesia é tarefa difícil. No entanto, movida pelo desejo de partilhar da singular construção ensaística de um artigo de Otto Maria Carpeaux de 1953, arrisco-me aqui a retomar as imagens por ele então criadas, inspiradas num conto de Mark Twain.

No ano 9000, arqueólogos descobrem, em meio a ruínas do Rio de Janeiro, restos de livros. Surpreendentemente, na capa de todos, figura o mesmo "hieróglifo misterioso": "SR". Estupefactos, concluem os estudiosos que toda a literatura brasileira da época teria sido escrita por apenas um homem.

Então, debruçados sobre a questão, novos arqueólogos verificam que o "misterioso SR" contara com colaboradores, os quais, no entanto, necessitavam de várias páginas para construir um sentido que "SR" conseguia sintetizar por meio de um desenho na capa.

E tais desenhos garantiram o estudo da literatura brasileira dessa época remota. Por exemplo, os arqueólogos compreenderam A bagaceira, de José Américo de Almeida, e $O$ quinze, de Rachel de Queiroz, graças às imagens do cacto e dos retirantes nas capas. Conheceram, ainda, os negrinhos e meninos impossíveis do Nordeste de Jorge de Lima. Também apreciaram a chaminé "solitária e melancólica", símbolo de Usina, do colaborador José Lins do Rego, que permitiu a "SR" criar um ciclo de obras sobre sua região.

Como se vê, é altamente poética a forma como Carpeaux apresenta aos leitores o papel fundamental do pintor Santa Rosa para a literatura brasileira de sua época. Impossível não transcrever, em especial, duas passagens do ensaio. A primeira é a síntese em que se encontram as artes do crítico Carpeaux, do ilustrador Santa Rosa e do romancista Graciliano Ramos:

Outra vez, "SR" se revelou através do personagem complexo de Graciliano Ramos, ao qual foi dado sonhar com brutalidades terríveis, angústias tremendas, idílios trágicos, produtos de imaginação de um grande intelectual isolado no deserto; escreveu Insônia, e logo "SR" desenhou um relógio em meio da escuridão noturna. ${ }^{4}$

A segunda passagem é o momento em que Carpeaux aclara o "hieróglifo misterioso", desvendando, inteligente e sensível, o nome do pintor da poesia de Drummond:

\footnotetext{
${ }^{4}$ CARPEAUX, Otto Maria. Significação de 'SR' (de Retratos e leituras, 1953). In: Ensaios reunidos 19421978, v. I. cit., pp. 633-6.
} 
E numa hora triunfal que emergira das trevas "SR" desenhou a Rosa do povo, de Carlos Drummond de Andrade, o grupo de populares em torno da rosa que desabrocha no asfalto da rua: a "santa rosa" do povo.

Otto Maria prossegue com a sátira aos arqueólogos do ano da "graça ou desgraça" de 9000, apontando a falta de perspicácia da especialização científica: como se dera em relação a Homero, nem acreditavam na existência de um artista enciclopédico como "SR". O crítico ressalta a riqueza da singularidade do pintor: "um artista plástico de cultura literária, capaz de interpretar os mais diferentes estilos e personalidades", "mistura encantadora de talento, inteligência, coração e impontualidade". Relembra que "SR" pintou os cenários de Vestido de noiva e que homéricos foram seus esforços para criar uma escola de artes gráficas.

Por fim, Carpeaux destaca outra descoberta dos arqueólogos: simbolizada por uma palmeira e assinada por "SR", a coleção Documentos brasileiros, da "época de José Olympio", tinha por autores Lúcia Miguel Pereira, Octávio Tarquínio de Sousa, Álvaro Lins, Gilberto Freyre, Afonso Arinos de Melo Franco e Sérgio Buarque de Holanda.

Assim, de modo comovedor, Carpeaux expressa toda a sua simpatia por "SR", símbolo do Brasil. Revela como a arte de Santa Rosa foi o "denominador comum das aspirações artísticas da sua geração" - o que denota a significação cultural do grupo da Novidade.

É de um companheiro da Revista o artigo "Santa" 5, publicado em livro em 1961, também impregnado de poesia e de uma afetividade já contida no título. Valdemar Cavalcanti, inconformado com a morte do amigo Santa Rosa (1909, Paraíba - 1956, Índia $^{6}$ ), imagina que ele logo entrará em sua casa para retomarem uma conversa de mais de vinte anos, cheia então de reminiscências. À medida que faz desfilarem essas recordações, Valdemar presentifica aos olhos do leitor gestos de uma amizade e momentos significativos de um percurso intelectual e artístico, partilhados desde os anos $1930 \mathrm{em}$ Alagoas.

A lembrança inicial surge sobre a mesa de trabalho de Valdemar, num monte de papéis e livros, e ele crê que o amigo gostará de vê-la, pois talvez nem se recorde mais dela. Trata-se de seu primeiro ensaio de pintor, uma pequena tela a óleo feita ainda em

\footnotetext{
${ }^{5}$ CAVALCANTI, Valdemar. Santa. In: Jornal literário. cit., pp. 143-7.

${ }^{6}$ Em 1956, Santa Rosa foi para a Índia, participar da Conferência Internacional de Teatro, em Bombaim, e, como observador, da Conferência Geral da Unesco para a Educação, a Ciência e a Cultura, em Nova Délhi.
} 
Maceió, “dia de domingo em quarto de pensão, como um derivativo para o seu tédio miúdo de funcionário do Banco do Brasil”.

Tendo Valdemar acompanhado o tédio de funcionário e o entusiasmo de criador de Santa Rosa, revê a primeira exposição deste no Instituto Histórico de Alagoas: os quadros que pregaram juntos à noite, a desconfiança e surpresa dos convidados, a palestra em que apresentava o pintor aos meios artísticos da província, prognosticando-lhe o êxito, com a "arrogância própria dos jovens".

A integração do paraibano Santa Rosa com o grupo em Maceió ocorreu em fevereiro de 1932, por intermédio de Diégues Júnior. A exposição rememorada por Valdemar Cavalcanti integrou a Festa de Arte Moderna, promovida pela Liga contra o Empréstimo de Livros, ambas já aqui referidas ${ }^{7}$. Diégues Júnior falou na abertura da exposição sobre música moderna. Valdemar Cavalcanti, em lugar dos anunciados Alberto Passos Guimarães e José Lins do Rego, apresentou Santa Rosa numa palestra sobre o modernismo na pintura.

A recordação seguinte de Valdemar tem sabor especial neste meu trabalho:

Por falar em Maceió, mostrar-lhe-ei [Valdemar Cavalcanti a Santa Rosa] a coleção, que possuo, do semanário Novidade, onde publiquei poemas seus.

Se a poesia de Santa Rosa Júnior com palavras permaneceu restrita a Alagoas, a poesia dos desenhos expandiu-se do Rio de Janeiro a partir de julho de 1932. Após a exposição modernista de Maceió, ele decidiu deixar o emprego no Banco do Brasil, no qual recebia dois contos de réis, e embarcou para o Rio, onde dividiu um quarto simples com José Lins do Rego. De 1932 é Cacau, de Jorge Amado, publicado pela Ariel, de Gastão Cruls, com capa e ilustrações de Santa Rosa, as primeiras do desenhista que revolucionaria os livros brasileiros.

Valdemar Cavalcanti revela a grandeza humana e técnica do pintor, cuja atuação no cenário artístico brasileiro foi marcada por simplicidade e inteligência, traços de um observador compreensivo. Valdemar imagina novo diálogo sobre soluções artísticas para a capa de um livro: mais uma vez, o amigo ensinaria o que é uma discussão intelectual, não movida por vaidade, mas pelo gosto do exercício da inteligência. $O$ crítico valoriza que Santa Rosa soubesse discutir com tranqüilidade, sem querer impor suas idéias, antes

\footnotetext{
${ }^{7}$ Cf. CAPÍtulo 3 - A terRa dos meninos ImpossíveIS. Cf. SANT'ANA, Moacir Medeiros de. História do modernismo em Alagoas (1922-1932). cit., pp. 235-6; BARSANTE, Cássio Emmanuel. A vida ilustrada de Tomás Santa Rosa. Rio de Janeiro: Fundação Banco do Brasil: Bookmakers, 1993, p. 17.
} 
predisposto a aceitar as idéias dos outros. Conforme se evidencia em "Das estátuas" 8 , desagradavam visceralmente a Valdemar as "estátuas ou bustos", pessoas marcadas por imobilidade intelectual e por orgulho ou soberba. Ao contrário destas, o desenhista era "unidade humana extremamente sensível", cuja personalidade se definia pela "ânsia de amar e de compreender, [pel]o espírito de pesquisa e de entendimento, [pel]a gratuita generosidade".

Então, Valdemar Cavalcanti pensa que diria ao amigo - e efetivamente diz aos leitores - como o nome de Santa Rosa, com as famosas iniciais S.R., está de forma definitiva vinculado à história do livro no Brasil, ilustrado ou não, graças a seu papel de inovador. Ressalta que ele impôs aos livros em geral uma "renovação em matéria de bom gosto tipográfico". Destaca a excelência da apresentação gráfica das publicações oficiais brasileiras, conquista dos esforços do pintor junto aos serviços do Ministério da Educação e Cultura e também do Ministério das Relações Exteriores.

Por fim, essencial, a referência às capas criadas pelo desenhista para as "velhas edições José Olympio": a primeira fôra a de Bangüê, de José Lins do Rego, em 1934; e, ao todo, 220 capas para a editora. Os amigos folheariam as primeiras edições de José Lins, as de Graciliano, de Lúcio Cardoso, de Jorge Amado, também de Alencar e Dostoievski e de várias coletâneas de poesia.

Até que, noite alta, Santa resolva ir embora e me diga (é assim que sempre faz): 'Vai lá no meu atelier ver as coisas que estou fazendo agora'.

Depois que ele sair, estou certo de que a casa ficará como neste momento, impregnada de sua voz, de seu espírito de compreensão e de sua grandeza humana como a indestrutível presença.

Dessa forma, os retratos pintados por Carpeaux e Cavalcanti expressam o valor humano de Santa Rosa, síntese de sensibilidade e "espírito de compreensão", sublinhando a importância desse artista para a cultura do país, principalmente para a história do livro no Brasil. Poeta na revista alagoana em 1931, como criador das capas da José Olympio Santa Rosa condensou o espírito da literatura brasileira dos anos 30 e 40, o que sinaliza o valor da geração da Novidade no quadro intelectual e artístico brasileiro.

\footnotetext{
${ }^{8}$ CAVALCANTI, Valdemar. Das estátuas. In: Jornal literário. cit., pp. 30-1.
} 


\section{Santa, a flor do suor}

Na Apresentação d' A vida ilustrada de Tomás Santa Rosa, de Cássio Emmanuel Barsante ${ }^{9}$, Rachel de Queiroz sublinha como o desenhista era adorado e respeitado por todos. Professor de estética, era "mestre nos vários ofícios que lhe demandassem talento e informação", "homem de pensamento e estudo, de opiniões brilhantes e inovadoras".

E do retrato de Santa Rosa traçado pelo amigo e inspirador Portinari, a quem auxiliou no acabamento de vários murais, sobressai a conjugação de talento e trabalho, voltados para a renovação cultural brasileira:

Foi o renovador do livro nacional como de nossa cenografia, dando às edições literárias e ao teatro a contribuição do seu talento e bom gosto. Na pintura, na ilustração e na crítica, Santa Rosa foi sempre o trabalhador honesto e infatigável. Como crítico, destacou-se pela maturidade e segurança de seus juízos, mantendo-se à altura de um homem empenhado, honradamente, em servir à arte e à nossa cultura. ${ }^{10}$

Esse talento avultou logo aos nove anos: finda a I Guerra, Santa Rosa homenageou os aliados desenhando as bandeiras dos países. Impressionado, o governador da Paraíba propôs pagar-lhe os estudos na Europa, porém a mãe do menino teve de recusar, não querendo longe o único filho homem vivo. Aos doze anos, mesmo sem educação artística formal, ele ganhava dinheiro pintando bandeiras para procissões religiosas. ${ }^{11}$

Trabalhador "honesto e infatigável”, Santa Rosa fundou em 1938 o grupo teatral Os Comediantes, do qual foi cenógrafo, pintor, diretor artístico e coordenador; e, em 1944, integrou o Teatro Experimental do Negro. Primeiro cenógrafo moderno brasileiro, foi premiado pela Associação Brasileira dos Críticos de Arte pelos cenários das peças Vestido de noiva (1943, Nelson Rodrigues, direção de Ziembinski), A morte do caixeiro viajante (1951, Arthur Miller, direção de Esther Leão, Companhia de Comédias Jaime Costa) e Senhora dos afogados (1954, Nelson Rodrigues, direção de Bibi Ferreira, para a Companhia Dramática Nacional).

Segundo Álvaro Lins, sem a colaboração de Santa Rosa e de Ziembinski, Vestido de noiva não teria o enorme êxito que alcançou. O crítico destaca Santa Rosa como "artista puro" e também "homem de ação na vida artística": era o centro vital do grupo Os

\footnotetext{
${ }^{9}$ BARSANTE, Cássio Emmanuel. A vida ilustrada de Tomás Santa Rosa. cit.

${ }^{10}$ Idem, p. 9.

${ }^{11}$ Idem, p. 15. Cf. também HALLEWELL, Laurence. O livro no Brasil: sua história. Tradução de Maria da Penha Villalobos e Lólio Lourenço de Oliveira. São Paulo: T.A. Queiroz, Edusp, 1985, pp. 377-8.
} 
Comediantes, empenhado somente pela seriedade na arte, dedicado a criar um autêntico teatro brasileiro ${ }^{12}$.

Em 1945, Santa Rosa trabalhou como crítico de arte para o Diário de Notícias. Imaginou para Sérgio Porto o pseudônimo Stanislaw Ponte Preta, inspirado no personagem Serafim Ponte Grande, de Oswald de Andrade ${ }^{13}$. Em 1946, dirigiu o curso de artes gráficas na Fundação Getúlio Vargas, onde Fayga Ostrower estudou. Lecionou ainda na Escola Nacional de Belas Artes e no Museu de Arte Moderna do Rio de Janeiro, onde também dirigiu o Departamento de Teatro. Entre 1952 e 1954, integrou a Comissão Nacional de Belas Artes, dirigindo o Conservatório Nacional de Teatro.

Além da obra teatral, foi considerado o maior produtor gráfico de livros do Brasil, "responsável, quase sozinho, pela transformação estética do livro brasileiro nos anos 30 e 40" ${ }^{14}$. Conforme Hallewell, autor de O livro no Brasil, o desenhista exerceu uma "influência tríplice": a contribuição como produtor gráfico e ilustrador, sobretudo para as editoras Schmidt e José Olympio; a revolução no aspecto físico das publicações do governo federal, principalmente do Serviço de Documentação do Ministério da Educação; a influência como professor de artes gráficas.

Santa Rosa deixou inéditas as ilustrações para o livro infantil $O$ pinto pelado, velho conto popular. Em 1939, venceu o concurso do Ministério da Educação com o livro $O$ circo. Em carta a Heló́sa, de 3 de março de 1937, passado exato um ano de sua prisão, Graciliano elogia as ilustrações desse livro:

Depois do almoço caí no ramerrão diário. Fui à livraria, encontrei Zélins, Santa, Jardim. Fomos ao Ministério levar os álbuns de figuras dos dois últimos e os contos de Bárbara [Julieta Bárbara, mulher de Oswald de Andrade]. Os desenhos de Santa, um circo de cavalinhos, estão maravilhosos, mas também gostei dos de Jardim, uma história de bichos muito engraçada. José Olympio acha isso admirável, o que já se fez de melhor para crianças no Brasil. ${ }^{15}$

\footnotetext{
${ }^{12}$ LINS, Álvaro. Momento de plenitude: 'Os Comediantes' (Janeiro de 1944). In: Os mortos de sobrecasaca. (1940-1960). Rio de Janeiro: Civilização Brasileira, 1963, pp. 301-9.

13 "Por que Stanislaw Ponte Preta? Ele mesmo contou, em crônica publicada no jornal do Rio Última Hora, a 4 de dezembro de 1956 - crônica de homenagem à memória de Santa Rosa -, que partiu desse artista admirável a idéia da criação desse tipo literário. Na redação do Diário Carioca ele um dia disse a Sérgio Porto: 'Vamos criar um personagem novo, um tipo cabotino, para comentar notícias sofisticadas, uma mistura de crítica teatral e café society'. E diz Sérgio Porto que Santa Rosa se tomou do maior entusiasmo pelo tipo, fazendo ilustrações para as crônicas e até escrevendo alguns tópicos". CAVALCANTI, Valdemar. Dados biobibliográficos do autor. In: PONTE PRETA, Stanislaw. O melhor de Stanislaw: crônicas escolhidas. Seleção e organização de Valdemar Cavalcanti. $5^{\text {a }}$ ed. Rio de Janeiro: José Olympio, 1994, p. viii.

${ }^{14}$ HALLEWELL, Laurence. O livro no Brasil: sua história. cit.

${ }^{15}$ RAMOS, Graciliano. Carta a Heloísa de Medeiros Ramos. Rio, 3 de março de 1937 (n. 95). In: Cartas. cit., p. 184.
} 
Mas a amizade entre Graciliano e o desenhista iniciou-se nos anos 30 em Maceió, tanto que Caetés (1933) lhe foi dedicado, bem como a Jorge Amado e a Alberto Passos Guimarães. Impossível não citar esta saborosa narrativa de Jorge Amado, em que se descobre outro motivo por que Santa Rosa foi fundamental para a literatura brasileira:

O poeta e desenhista Santa Rosa, risonho mulato paraibano recémchegado ao Rio - via Maceió, onde servira no Banco do Brasil - trouxera notícia de um literato alagoano, ex-comerciante, ex-prefeito de cidade do interior, por fim funcionário público, na ocasião, se não me engano, Diretor da Imprensa Oficial. Os textos dos extraordinários relatórios, apresentados por ele ao deixar a Prefeitura de Palmeira dos Índios, circularam de mão em mão no limitado território literário da então capital da República e das letras pátrias (Maceió, 1933 - visita). ${ }^{16}$

Unindo as pontas da vida de Graciliano, veja-se como a história de Santa Rosa se prende também à da Livraria José Olympio. Como já dito, fez 220 capas para a editora, na qual não só ilustrava como paginava, diagramava e escolhia os tipos de letras. Partilhando do pensamento de outros companheiros da Novidade, desagradavam-lhe os excessos do modernismo: julgava que a abolição da letra maiúscula em títulos e nomes próprios redundava numa "socialização dos caracteres, sem gosto e sem engenho". ${ }^{17}$

$\mathrm{Na}$ crônica "A livraria José Olympio" ${ }^{18}$, Graciliano desnuda-a como matéria excelente para um romance. O escritor destaca que, desaparecidas as fronteiras sociais, havia camaradagem, um ar de família entre os críticos, ficcionistas, sociólogos, ensaístas e pintores que se encontravam à rua do Ouvidor 110. Fervilhavam discussões no fundo do estabelecimento, que reunia homens de diferentes crenças e partidos, "em carne e osso" ou nas paredes cobertas de livros. Com sua expressão compreensiva e crítica, Graciliano reconhece a importância do editor "liberal" José Olympio, que publicava livros da esquerda, da direita e do centro e acolhia amigavelmente "pessoas de cores diferentes ou sem nenhuma cor". Realça os nomes de Santa Rosa e Portinari, além de Otávio Tarquínio, Amando Fontes, José Américo, Lins do Rego, Gilberto Freyre, Rachel de Queiroz, Lúcio Cardoso, Luís Jardim, Murilo Mendes. Não mencionados por Graciliano, os amigos de Alagoas Valdemar e Aurélio também freqüentavam a livraria.

\footnotetext{
16 AMADO, Jorge. Navegação de cabotagem: apontamentos para um livro de memórias que jamais escreverei. $3^{\text {a }}$ ed. Rio de Janeiro: Record, 1994, p. 24.

${ }^{17}$ Cf. ROSA, Santa. Sobre a arte do livro. In: Roteiro de arte. Os cadernos de cultura. Rio de Janeiro: Serviço de Documentação, Ministério da Educação e Saúde, 1952, p. 37; BARSANTE, Cássio Emmanuel. A vida ilustrada de Tomás Santa Rosa. cit., p. 118.

${ }^{18}$ RAMOS, Graciliano. A livraria José Olímpio. In: Linhas tortas. cit., pp. 118-9.
} 
Desse modo, o percurso de Santa Rosa é revelador de uma história de amizades iniciadas no grupo de Maceió nos anos 1930 e continuadas no Rio de Janeiro nos anos 40, especialmente na Livraria José Olympio. A capacidade do pintor de ser amigo e de condensar a literatura brasileira nas capas dos livros, flagrada por Carpeaux e Valdemar Cavalcanti como a "indestrutível presença" inscrita nas iniciais "SR", foi também sintetizada pela poesia de Drummond, de que recolho estes versos:

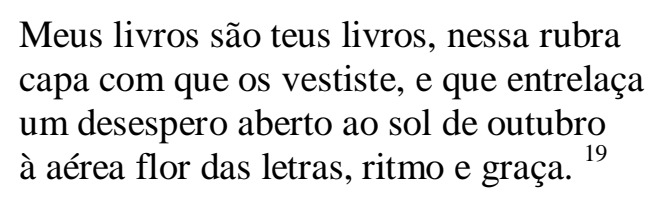

Ideal seria apreender o estilo de Santa Rosa analisando conjuntamente as capas e o teor dos livros por ele ilustrados. Constituiria inspiração para esse estudo a leitura que Antonio Candido fez da capa de Caetés. O crítico percebeu como o desenhista exprimiu graficamente as ambigüidades que estruturam o romance, decorrentes da "ironia criadora" de Graciliano. ${ }^{20}$

No entanto, nos limites deste trabalho, o caminho trilhado foi descobrir a trajetória do pintor por intermédio de ensaios poéticos de Carpeaux e de Valdemar Cavalcanti e de “depoimentos" de Rachel de Queiroz, Jorge Amado, Portinari, Graciliano Ramos e Drummond.

Delineado o perfil do desenhista, é muito instigante ler na Novidade o poeta Santa Rosa Júnior: "Bucólico" (N 11, p. 11); "Momento", "Memória” (N 9, p. 11).

"Bucólico" é bem o poema de um pintor, atraído pelas cores e luzes da natureza, e de um jovem da Novidade, dotado de olhar crítico para as incongruências do mundo.

A vocação inserida no poema, Santa Rosa parece desenhar com as palavras um quadro, em que ressalta, desde o título - "Bucólico" -, a integração feliz do eu-lírico com a natureza. Tal desejo pelo pictórico e harmonioso se confessa em primeira pessoa nos versos iniciais:

Esse gosto bom dos sentidos!

Acho daqui a paisagem completa.

\footnotetext{
${ }^{19}$ ANDRADE, Carlos Drummond de. A um morto na Índia. (A vida passada a limpo). In: Obra completa. Rio de Janeiro: Aguilar, 1964, pp. 297-8.

${ }^{20}$ Cf CANDIDO, Antonio. No aparecimento de Caetés. In: Ficção e confissão: ensaios sobre Graciliano Ramos. cit., pp. 92-101.
} 
A frase nominal exclamativa anuncia a plenitude estética do observador que frui satisfeito a paisagem.

Eis que, entre parênteses, o poeta imagina uma combinação de movimentos cujo brilho reforçaria a completude da paisagem: ante o alarido de cores de um trem passando, os homens que trabalhavam ao sol ergueriam seus corpos reluzentes.

(Se o trem passasse agora

os caboclos empinariam os torsos lustrosos

brilhando no sol!)

Entretanto, sendo o trem desejo do poeta, o que seus olhos acompanham é a placidez do contorno verde dos morros, que se encontram com o branquejar das casas. Tal panorama luminoso mas estático, de montanhas e casas, somente em cujo fundo estão caboclos suando com enxadas, proporciona uma "alegria campestre" ao eu-lírico. Novamente em primeira pessoa, ele se declara encantado pela claridade do verde. Veja-se a seqüência de versos:

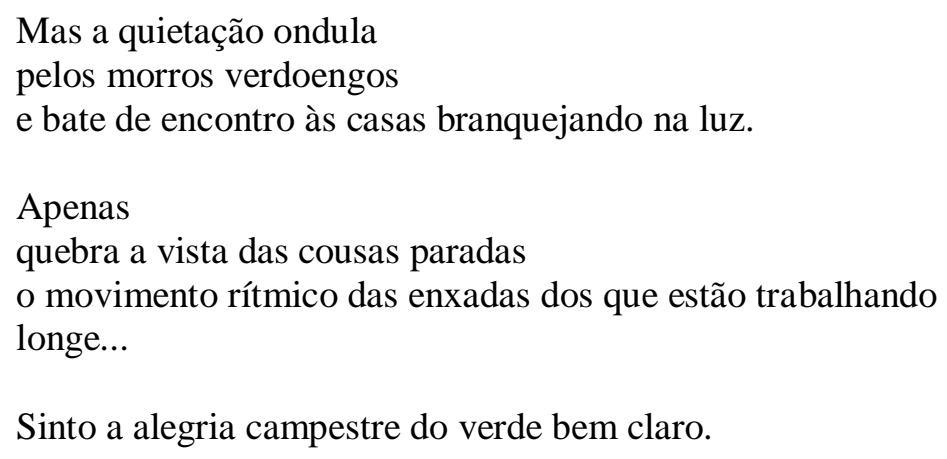

Finalmente, na última estrofe, vem a síntese dessa composição pictórica, com verdadeira pincelada de lirismo. Inebriado da feliz comunhão com a paisagem, o poeta pisa sem querer nas "flores pequeninas". Ao gesto involuntário de ferir o belo da natureza, o tempo todo visceralmente apreciado, sucede um vocativo a Deus - singelo desejo de redenção de um inocente que então se culpa:

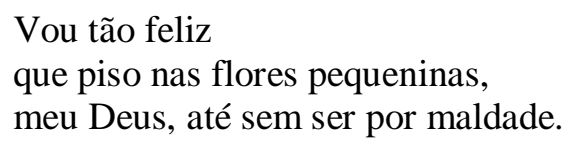

Sensível e crítico, Santa Rosa expõe o dilema dos artistas que, na busca pelo Belo, não podem ignorar as mazelas da realidade. Mais do que isso, seu poema condensa como a potencialidade da beleza e a consciência dos limites / da fragilidade compõem a força da arte. Paradoxo da poesia, o "gosto bom dos sentidos" carrega as "flores pequeninas" pisadas. 
Nesse sentido, é possível reler a imagem dos caboclos, identificando a tensão nela contida, que quebra o quadro bucólico. Traduz o apreço do artista pela beleza plástica - a luminosidade solar, refletida nos corpos suados - e, a um tempo, a sensibilidade crítica do poeta quanto aos conflitos dos trabalhadores. Ele se aproxima deles, ávidos de distração, de fuga ("Se o trem passasse agora / os caboclos empinariam os torsos lustrosos / brilhando no sol!”), mas sabe que permanecem trabalhando ao longe, maquinalmente (“o movimento rítmico das enxadas").

Assim, a marca de Santa Rosa parece ser uma tensão entre a satisfação pictórica, com as cores e formas da natureza, e o pesar pelos seres pisados, pela fragilidade da vida. E os versos de Drummond o confirmam:

Essa alegria de criar, que é tua explanação maior e mais tocante, fica girando no ar, enquanto avulta, em sensação de perda, teu semblante. ${ }^{21}$

Entre o entusiasmo de criador e o tédio de funcionário de banco, Santa Rosa Júnior também escreveu "Memória" e "Momento". Igualmente o motor desses poemas, versos livres que flagram cenas cotidianas, é a inquietação entre a amplitude da natureza e os limites humanos. Em "Memória", é no "azul feliz do céu indiferente" que a lembrança do amor distante "palpita". Essa oposição entre o "espaço imenso" da natureza, feito de brandura e paz, e a "terra cansada" dos homens se reencontra em "Momento".

O poeta passeia "ao largo" pelos campos que "se estiram sem fim", acompanhado da tarde "calada" e de um "perfume de rosas bem perto, / bem perto...".

\author{
Momento (Especial para NOVIDADE) \\ Passeio ao largo! \\ A tarde me acompanha calada. \\ Nem há rumores aqui. \\ Somente \\ um perfume de rosas bem perto, \\ bem perto... \\ Os campos se estiram sem fim,
}

\footnotetext{
${ }^{21}$ ANDRADE, Carlos Drummond de. A um morto na Índia. (A vida passada a limpo). cit.
} 
A combinação entre o silêncio largo do ambiente e a proximidade afetiva do perfume das flores - sugerindo o misto de indiferença e generosidade da natureza - leva à imagem central do poema, que vem entre parênteses: o apagar da árvore grande quando do retorno do eu-lírico.

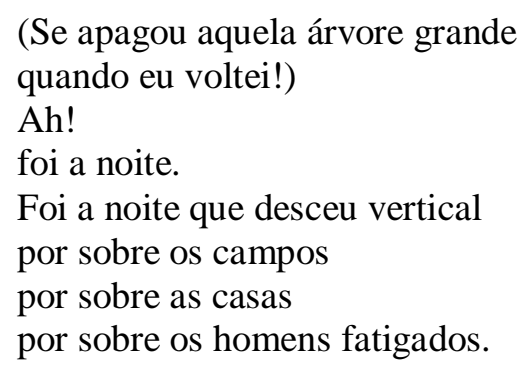

Novamente aqui se entrevêem no poeta o pintor e o intelectual crítico. Com o fechamento dos parênteses, ele cria o efeito da escuridão sobre a árvore; e, com a corriqueira e modernista próclise pronominal e o verbo "apagar" tendo por objeto uma árvore, parece desenhar um abajur e insinuar o que há de artificial no hábito moderno de se conceber a luz como elétrica.

Então, reconhecendo a primazia da natureza (“Ah! / foi a noite"), ele tece a verticalidade da noite por sobre os campos e as casas, por meio de um movimento anafórico que culmina em "por sobre os homens fatigados". Desse modo, revela a profundidade do anoitecer como o apagar-se, oferta temporária - e definitiva - de descanso para os homens, consumidos em seus trabalhos. Mais uma vez, o artista se curva à natureza, dadivosa e indiferente, e se inquieta com a sorte dos homens, pequeninas flores pisadas. Mais uma vez, Santa Rosa defronta o impasse de criar beleza conhecendo as fragilidades da vida.

\section{A geração da Novidade: o empenho pela arte, contra preconceitos}

Publicado em 1952, o Roteiro de arte ${ }^{22}$, de Santa Rosa, confirma-o um artista enciclopédico, empenhado em aprimorar sempre sua cultura literária e sua técnica, para ser autenticamente ilustrador, ou seja, um intérprete sensível, capaz de encontrar a "ressonância expressiva" do espírito dos textos. Seu roteiro inclui a busca do novo, atento

\footnotetext{
${ }^{22}$ ROSA, Santa. Roteiro de arte. cit. Cf. os capítulos "Sobre a arte da ilustração", pp. 25-33, e "Sobre a arte do livro", pp. 34-44.
} 
às necessidades do presente, ao valor da tradição e à formação cultural das crianças e dos jovens do país.

Combatendo o preconceito segundo o qual a ilustração seria uma arte subordinada à verdade alheia, Santa Rosa defende-a como arte autônoma e autêntica, paralela à literatura. Sublinha que o desenhista deve fixar o tema sugerido no livro com a força de sua personalidade. Sua difícil tarefa é captar, no tumulto das frases, as imagens plásticas que correspondam ao mesmo sentimento. Às vezes, tem de ir às fronteiras da imaginação e até esclarecer certos mistérios das palavras.

Lamentando que o gosto pelo livro ilustrado fosse quase inexistente no Brasil, julga enorme a tarefa dos "artistas intérpretes, sugestionadores do leitor transeunte". Alerta para as diferenças entre prosa e poesia, que devem estabelecer modos diversos de se conceber a imagem, expressão da substância do texto. Enquanto o desenho pode apreender da prosa minúcias, uma visão mais concreta das coisas ou a expressão do rosto das personagens, a poesia se afirma por meio de "cristalizações do espírito" em imagens sensíveis, imponderáveis e indiretas. Explica que, para o ilustrador, o que conta não é o descritivo do poema, do conto, do romance, mas a atmosfera espiritual em que se movem os personagens, os ritmos, os sentimentos. Como um cineasta, busca o ângulo em que o assunto mais avulta, melhor se define. Em seu trabalho de análise, cerca os personagens de um romance, para lhes transpor com verdade o caráter e a força e conquistar-lhes a psicologia.

Santa Rosa explicita todo o seu amor aos livros, que para ele são um "milagre da continuidade, da preservação, da comunhão de idéias e sentimentos, chamas vivas do espírito humano" (p. 35). Inquieta-o a baixa qualidade dos livros para crianças e a despreocupação com os meios de trabalho, com as técnicas da ilustração. Critica que os ilustradores trabalhem sobre fotografias, como nos estúdios norte-americanos, o que mata a imaginação e debilita a arte de ilustrar. Considerando a letra uma das mais belas entre as formas criadas, preocupa-se com a escolha dos caracteres, com a necessária harmonia nas capas dos livros, que representam um convite para o leitor.

Dessa forma, enfatiza a necessidade de se encarar seriamente o papel do ilustrador: ao lado da aprendizagem do desenho e das técnicas gráficas, a sua questão prioritária deve ser o "não muito simples problema da cultura". Como cabe ao artista interpretar as obras, precisa aplicar-se e se identificar profundamente com as suas essências. Seu guia mais seguro é desenvolver o gosto literário. Assim, Santa Rosa julga que o bom ilustrador deve ser de certa forma um literato e traduzir com sua arte somente as obras com as quais tiver 
afinidade, para que suas criações possuam equivalente força expressiva. Significativamente, sua principal eleição artística foram as obras de Graciliano Ramos e de José Lins do Rego.

Conforme já salientado, a José Olympio permitiu à sociabilidade do grupo da Novidade reencontrar-se e se enriquecer com outros artistas e intelectuais no Rio de Janeiro, a partir de meados dos anos 1930 e sobretudo dos anos 40. É necessário então registrar que vários escritores da Novidade estavam próximos também como colaboradores da Revista do Brasil, em sua terceira fase. Esta durou de 1938 a 1943, com um total de 56 números. Assis Chateaubriand a relançou e entregou sua direção ao historiador Octávio Tarquínio de Sousa. Resgataram-se características da primeira fase (113 números, de 1916 a 1925, adquirida em 1918 por Monteiro Lobato), como a diversidade de assuntos e a preocupação com os problemas nacionais, encarados sob perspectiva ampla ${ }^{23}$.

Na seção “Artes plásticas” desse periódico, no número 8, de fevereiro de 1939, Santa Rosa expõe sua atitude crítica contra vários "Preconceitos" comuns no Brasil ${ }^{24}$. A princípio, combate os preconceitos voltados aos artistas que buscam inspiração no lirismo da vida popular ou nos aspectos vivos da terra. Denuncia a recomendação, sempre feita na ocasião de convites para mostras de arte fora do país, de não se enviarem trabalhos cujo tema fosse a vida do povo, por conterem, conseqüentemente, negros e mulatos.

Ironiza esse "refinado escrúpulo" nacional de não incluir quadros com motivos de negros em amostras de arte destinadas ao estrangeiro. Repudia tal preconceito, reputando-o um "requinte de culpados", de quem deseja "encobrir uma verdade das mais simples". Enfatiza-o incompreensível sobretudo num salão de arte e ressalta a grandeza de caráter da música e da poesia dos negros.

Relata uma anedota terrível: o Brasil não figurou com obras de arte na Exposição Internacional de Paris, porque estava entre as telas destinadas ao evento o Café, de

\footnotetext{
${ }^{23}$ Cf. DE LUCA, Tania Regina. A Revista do Brasil: um diagnóstico para a (N)ação. São Paulo: Fundação Editora da UNESP, 1999; Idem. Revista do Brasil (1938-1943): um projeto alternativo? In: DUTRA, Eliana de Freitas; MOLLIER, Jean-Yves. (Org.). Política, nação e edição: o lugar dos impressos na construção da vida política no Brasil, Europa e Américas nos séculos XVIII-XX. São Paulo: Annablume, 2006, pp. 315334.

${ }^{24}$ ROSA, Santa. Preconceitos. Revista do Brasil, fev. 1939, ano II, $3{ }^{a}$ fase, n. 8, pp. 96-7.
} 
Cândido Portinari. A recusa pelos próprios brasileiros decorreu de o quadro trazer a representação de negros no rude trabalho de produzir a riqueza nacional ${ }^{25}$.

Expressando justa indignação, Santa Rosa desmascara ser esse preconceito freqüente entre os administradores do Brasil. Considera-os homens de semi-educação, cujas boas maneiras disfarçam enormes lacunas de conhecimentos, de cultura. Condena que esses sejam os destinados a superintender questões de arte, mesmo desconhecendo sua importância e até os pormenores mais simples. Alheios à natureza da obra de arte, esses administradores, com seu padrão arbitrário de julgamento, trazem consequiências desmoralizantes para os artistas.

Então, Santa Rosa indaga por que os próprios artistas, que conhecem os duros momentos do seu trabalho, o seu valor e as suas necessidades, não são chamados para resolverem seus problemas. Com consciência crítica quanto ao papel dos intelectuais e artistas, reclama já ser tempo de se unirem para conquistar seus postos.

Mais um preconceito condenado pelo ilustrador é o dos críticos de arte que, para enaltecer um artista, o afirmam isento de influências. Santa Rosa contesta que exista na história da arte um artista descompromissado com quaisquer escolas. Entende que sempre houve mestres e discípulos, os quais se tornaram mestres carregando muito de seus antecessores. Para ele, o descompromisso decorreria de ignorância e insensibilidade, já que a influência começa na admiração.

Outro preconceito que Santa Rosa combate é a rígida separação entre arte antiga e arte moderna. Segundo entende, não há antigos nem modernos. Existem os estagnados em preconceitos, paralisados em fórmulas que não se ligam com o passado nem com o presente. E há os que, numa "pesquisa incessante", levam a arte para o futuro, criam obras com os motivos e as formas de seu tempo, com um "espírito de universalidade comunicativo e amplo".

Em agosto de 1939, Santa Rosa publica um artigo em que retoma o de fevereiro, para comemorar, já no título, “A derrota dos preconceitos" ${ }^{26}$. Após recordar o absurdo veto a telas que incluíssem gente negra, como as de Portinari, conta que esses preconceitos sofreram uma "derrota espetacular" na Exposição do Riverside Museum, de Nova York. O propósito dessa exposição era dar, em seu conjunto, uma idéia da arte nos países latinoamericanos.

\footnotetext{
${ }^{25}$ E essa obra recebeu um prêmio muito honroso para a arte brasileira na Exposição do Instituto Carnegie, em Pittsburg, um dos mais famosos centros de arte do mundo.

${ }^{26}$ Idem. A derrota dos preconceitos. Revista do Brasil, ago. 1939, ano II, 3 a fase, n. 14, pp. 95-6.
} 
Em busca de triunfo, não foi escolhido para o evento nenhum modernista brasileiro, e sim um grupo homogêneo, de arte muito comedida e bem educada, intérprete da nossa natureza, "com os seus amarelos de cromo e os seus céus de cobalto, os amantes das belezas do Corcovado e da Lagoa Rodrigo de Freitas, dos flamboyants incendiados, das naturezas-mortas com presunto e tachos de cobre". Santa Rosa ironiza a crença equivocada desses expositores: enfim, a pintura seria muito bem representada "pelos artistas do Salão, pelos conquistadores, em lutas de café, dos valiosos diplomas que conferem medalhas de ouro e de prata". E imagina suas falas preconceituosas, convictas de êxito em sua ignorância: "eles iam ver, esses pintores de monstros, de gente suja, do morro!”.

Contudo - para o regozijo, embora de origem melancólica, de Santa Rosa -, ao contrário do que esperavam os expositores, as obras receberam severas críticas: foram chamadas de falsas, convencionais, fora de seu tempo, imitadas do academismo francês, “escolhidas por um taberneiro míope".

Santa Rosa revela que um crítico do New York Herald elogiou a arte da Argentina, do Chile e de Cuba, em contraste com a amostra brasileira, e explicou não se tratar de deficiência dos nossos artistas, porém dos administradores que fizeram a seleção. E foi um crítico do Time quem criticou a seção brasileira, imitação do academicismo europeu, afirmando-a escolhida por um "myopic bartender" - "taberneiro míope", segundo a pitoresca tradução de Santa Rosa. O crítico expressou toda a sua decepção por não constar da exposição a obra de Portinari, cujos murais do Rio de Janeiro já conhecia.

Santa Rosa partilha com os leitores o entusiasmo dos críticos de Nova York em relação à arte de Portinari e ao "caráter bem brasileiro" que ela lhes revelou. Rejubila-se com a "excelente lição" dada a um meio onde avultam os preconceitos de arte. Agrada-lhe que, enquanto a arte oficial "empalidecia e desafinava a representação do Brasil", a música de Villa-Lobos, a arquitetura de Oscar Niemeyer e Lucio Costa e a pintura de Candido Portinari conquistavam seu merecido lugar de relevo. Ressalta que Portinari recebera no Museu de Arte Moderna, ao lado de Cézanne, Renoir, Degas e Picasso, as homenagens que no seu próprio país lhe haviam sido recusadas.

Well, well, well! Candido Portinari, o renegado, o pintor dos morros, das festas populares, dos jogos da infância, do café, dos pretos e mulatos, marcou, felizmente, para o Brasil, o único ponto, revelando bem alto, com a sua arte recusada, o nível real da nossa cultura artística.

Assim, esses artigos de Santa Rosa formalizam uma inquietação determinante para a geração da Novidade: a consciência crítica quanto à necessidade da arte de combater 
estereótipos, conciliando a busca de novas formas de expressão com a representação dos problemas brasileiros.

Reprovando a arte interessada em encobrir as realidades da vida, o ilustrador se solidariza com Portinari, com os "pintores de monstros, de gente suja, do morro". Impossível não recordar aqui a crônica "Norte e sul", de abril de $1937^{27}$, na qual Graciliano Ramos ironiza os defensores do "espiritismo literário", incomodados com a revelação da miséria pelos romances nordestinos:

(...) Vamos falar mal de todos os romancistas que aludem à fome e à miséria das bagaceiras, das prisões, dos bairros operários, das casas de cômodos. Acabemos tudo isso.

E a literatura se purificará, tornar-se-á inofensiva e cor-de-rosa, não provocará o mau humor de ninguém, não perturbará a digestão dos que podem comer. Amém.

Agora se entendem melhor as imagens dos trabalhadores ao sol e das flores pisadas, responsáveis pela poesia de Santa Rosa. Sua felicidade com a criação pictórica não se desvinculava do olhar sensível e culpado em relação aos sofrimentos dos homens. Freqüente em sua pintura era o tema dos trabalhadores, como os pescadores. Para ele, eram fundamentais e indissociáveis a arte e a denúncia de misérias. Daí a veemência com que defendeu o Café, de Portinari. Nesse contexto, vêm à mente as palavras de Graciliano Ramos numa carta de fevereiro de 1946 justamente a Portinari, cuja tela Retirantes é de 1944:

A sua carta chegou muito atrasada, e receio que esta resposta já não o ache fixando na tela a nossa pobre gente da roça. Não há trabalho mais digno, penso eu. Dizem que somos pessimistas pois exibimos deformações; contudo as deformações e a miséria existem fora da arte e são cultivadas pelos que nos censuram.

O que às vezes pergunto a mim mesmo, com angústia, Portinari, é isto: se elas desaparecessem, poderíamos continuar a trabalhar? Desejaremos realmente que elas desapareçam ou seremos também uns exploradores, tão perversos como os outros, quando expomos desgraças? (...). ${ }^{28}$

A um tempo, Graciliano demonstra consciência crítica quanto a seu papel de artista, de apontar as misérias da realidade, e sofre o impasse de dedicar a vida a dar forma estética às desgraças que afligem os homens. Santa Rosa partilhava das angústias do romancista.

\footnotetext{
${ }^{27}$ RAMOS, Graciliano. Norte e sul. In: Linhas tortas. cit., pp. 131-2.

${ }^{28}$ Carta de Graciliano Ramos a Cândido Portinari. In: RAMOS, Clara. Mestre Graciliano: confirmação humana de uma obra. cit., pp. 130-1.
} 
Ele o confessa num pequeno mas significativo bilhete de outubro de 1942, por ocasião do aniversário de cinqüenta anos do escritor:

\section{Graça querido:}

Senti muito não ir ao jantar que os amigos te ofereceram. Não estive entre eles, mas estou entre os que mais te estimam. Esse meio século que cobriste ontem, sei o que te vale, de lutas, sofrimento e angústia. Sinto bem tudo isso e talvez esteja mais perto de ti, por isso mesmo.

Hoje, te envio o meu abraço, nesse começo de posteridade a que já chegaste.

Recebe-o como o do verdadeiro amigo

Santa Rosa

$28 / 10 / 1942^{29}$.

Por fim, novamente recorro às palavras de Drummond, que definem o Santa, a existência da arte e da amizade verdadeiras, a felicidade em meio aos sofrimentos da vida.

Por outro lado, não se tratava [a Casa José Olympio] apenas de uma loja simpática. Era também uma editora revolucionária, que lançava com ímpeto nomes conhecidos de pouca gente ou de ninguém. Apresentava um livro diferente e elegante, formato padronizado, capa desenhada por Santa Rosa (o que nem sempre era fácil de conseguir, pois o Santa, como a felicidade, não estava onde o procurassem, ou nunca o procuravam onde poderia estar), e o aspecto gráfico e o prestígio da casa acendiam nos escritores o desejo de figurar em seu catálogo.

Carlos Drummond de Andrade. ${ }^{30}$

\footnotetext{
${ }^{29}$ Correspondência passiva - Arquivo Graciliano Ramos - Instituto de Estudos Brasileiros, IEB - USP.

${ }^{30}$ ANDRADE, Carlos Drummond de. A Casa. (Fala, amendoeira). In: Obra completa, cit., pp. 740-1.
} 


\section{Claro e denso, o horizonte das palavras: Aurélio}

\section{Ninharias e ninhos: as palavras. Aurélio e Graciliano}

Sintaxe e bom gosto não são incompatíveis. Sobretudo nos tempos atuais, quando ambos se tornam raros, tal idéia, que une os amigos e escritores Graciliano Ramos e Aurélio Buarque de Holanda, merece ser partilhada por todos.

Ao ler Dois mundos (1942), Graciliano aplaude-o porque esse volume de contos de Aurélio dissolve o preconceito contra a escrita correta, tornado corrente pelos "reformadores da literatura indígena" ${ }^{31}$. Segundo o romancista, estes condenaram algumas obras fracas, porém, sem a devida observação, reputando-as bem escritas, o que provocou uma generalizada recusa de textos bem escritos. Agudamente Graciliano alerta contra o perigo das generalizações, indispensáveis para se defenderem teses equivocadas. A do preconceito contra textos bem escritos levou, de um lado, à injusta desconsideração de obras relevantes e, de outro, a pretexto de liberdade, redundou em exagero, na limitação de se escrever contra as normas.

Então, oferecendo ao leitor uma lição de crítica e de composição literária, Graciliano identifica as virtudes do livro de Aurélio, das quais partilha: "simplicidade e clareza obtidas com esforço". Reconhece no conterrâneo a combinação fecunda entre o professor de gramática e o escritor admirável. Valoriza-lhe o cuidado com as palavras em busca de precisão semântica e adequação sintática, sem se ater a gírias gratuitas ou a pedantismos aristocráticos. Enfatiza também o trabalho lúcido e paciente de construção de histórias "simples e claras" - humanas - e, por isso, sublimes. Com consciência crítica, revolta-se contra práticas decorrentes da nossa "pequenina revolução", como a concepção de histórias em "estado de sonambulismo" e a aceitação de solecismos, caminho para anfibologias.

Procedeu [Aurélio] assim com método, pesando, medindo, comparando, levando a literatos avançados em demasia a convicção de que um professor de gramática não é necessariamente imbecil, produtor de lugares-comuns. Suas histórias (...) são admiravelmente simples e claras.

\footnotetext{
${ }^{31}$ RAMOS, Graciliano. Dois mundos. In: Linhas tortas. cit., pp. 264-6.
} 
Ao apontar as "figuras admiráveis" de Dois mundos - Molambo, João das Neves, o otimista Gonçalo, Maria Araquã -, aos olhos de Graciliano avulta D. Cândida Rosa: "grande velha, personagem que ficaria bem numa literatura sólida". Conforme analisarei adiante, essa sua avaliação do "Retrato de minha avó" é perfeita, tanto que o incluiu na sua Seleção de contos brasileiros ${ }^{32}$.

Por fim, Graciliano destaca as três bases que asseguram a arte das histórias escritas por Aurélio: ele usa muita observação, muita imaginação e também o dicionário. Ironizando os "espíritos superiores e emancipados", que crêem dispensável o dicionário, ressalta-o fundamental para quem se dedica ao ofício de escrever. Para os "sapateiros da literatura", conhecer o valor semântico e sintático das palavras é saber lidar com facas e "ficar na tripeça, cosendo, batendo, grudando": embora "armas insignificantes", as palavras são "armas" 33 .

O dicionário, em certos meios, é tão desconsiderado como os palavrões obscenos que a crítica pudibunda repele. Contudo não poderíamos trabalhar sem ele, como não poderíamos trabalhar sem couro ou tijolos se fôssemos sapateiros ou pedreiros.

Significativamente, o papel imprescindível do dicionário para os escritores é central na nota crítica de Graciliano sobre os contos de Aurélio. O trabalho de dicionarista se definiria na vida do alagoano a partir de 1941, no Rio de Janeiro. E, confirmando a teia de amizades entre os nossos grandes intelectuais e artistas nos anos 1930 e 40, foi Manuel Bandeira o responsável por que Aurélio se tornasse lexicógrafo.

Conforme conta em entrevista de 1949 a Homero Senna ${ }^{34}$, foi indicado por

\footnotetext{
${ }^{32}$ Idem. Seleção de contos brasileiros. $1^{\circ}$ v. (Norte e Nordeste). Rio de Janeiro: Edições de Ouro, s/d. Justamente, é Aurélio Buarque o autor da "Explicação" de abertura desse volume. Após declarar que a literatura brasileira deve a Graciliano contos dignos de antologia, relata que, embora o romancista jamais se incluísse ou se deixasse incluir na Seleção, por ser póstuma deveria apresentar um conto de sua autoria. Então, a pedido de Ricardo Ramos, Aurélio escolheu o dolorosamente belo "Minsk".

${ }^{33}$ Cf. RAMOS, Graciliano. Os sapateiros da literatura. In: Linhas tortas. cit., pp. 183-4.

${ }^{34}$ SENNA, Homero. Como se faz um dicionário. In: República das letras: entrevistas com vinte grandes escritores brasileiros. cit., pp. 261-274. Além dessa entrevista a Homero Senna, as referências biográficas de Aurélio aqui reunidas constam de: PEREZ, Renard. Escritores brasileiros contemporâneos. $2^{\mathrm{a}}$ série. 22 biografias, seguidas de antologia. $2^{a}$ ed. rev. e atualizada. Rio de Janeiro: Civilização Brasileira, 1971, pp. 6579; RÓNAI, Paulo. Cronologia e Bibliografia de Aurélio; O homem atrás do dicionário. In: FERREIRA, Aurélio Buarque de Holanda. Seleta em prosa e verso. Rio de Janeiro: José Olympio; Brasília: INL, 1979, pp. ix-xxiii; RÓNAI, Paulo. Um idioma ganha o seu dicionário (1975). In: Pois é: ensaios. Rio de Janeiro: Nova Fronteira, 1990, pp. 275-8; SANT'ANA, Moacir Medeiros de. História do modernismo em Alagoas (19221932). cit., pp. 91-3. Em 2008, quando eu já havia escrito este ensaio, saiu Marulheiro: viagem através de Aurélio Buarque de Holanda, de Marcos Vasconcelos Filho. (Maceió: Edufal, 2008). Pude então completar com algumas informações os perfis de Aurélio e de outros meninos impossíveis, pois esse premiado livro do jovem pesquisador alagoano Marcos Vasconcelos é muito rico para se conhecerem o filólogo (sua biografia e obra, inclusive os sonetos e poemas modernos) e vários intelectuais da Novidade.
} 
Bandeira à Editora Civilização Brasileira para fazer a parte de brasileirismos na terceira edição do Pequeno dicionário brasileiro da língua portuguesa. No entanto, minucioso e dedicado, Aurélio reviu todo o dicionário, acrescentando-lhe inúmeras palavras de uso geral. Foi chamado para preparar a nova edição, que, devido às muitas tiragens, acabou sendo a sexta, totalmente revista e bastante aumentada, sobretudo quanto aos brasileirismos. A seguinte foi a nona edição (1951), em que procedeu a várias alterações, transposições e aprimoramentos no dicionário, para torná-lo mais útil aos consulentes. $\mathrm{E}$ então se dedicaria à obra lexicográfica: o Vocabulário ortográfico brasileiro saiu em 1969, a primeira edição do Novo dicionário da língua portuguesa é de 1975.

A “obstinação concentrada” de Graciliano Ramos, nas sucessivas emendas textuais, no "arranjo de ninharias" 35 para construir as personagens de seus romances, irmana-se com o apreço do dicionarista Aurélio a seu "trabalho dos diabos".

Contra a moda dos apressados (generalizada entre 1922 e 1930), Graciliano concebia como dever do romancista diminuir pacientemente suas imperfeições. Vivia preso a miudezas "horrivelmente chatas", surgidas na aula primária e alongadas em "complicações". Mas sabia também que dessas "pequenas arrumações de insignificâncias"36 vem o pensamento, a possibilidade de distinguirem-se os homens dos animais. Nesse sentido, emendar defeitos dos textos impunha-se para ele junto com a necessidade de minorar as mazelas sociais, como a espoliação dos mendigos, dos retirantes; veja-se como ele atingia a raiz das palavras emenda e mendigo, a qual tem o significado de defeito.

Paralelamente, o trabalho de Aurélio necessita mais do que cultura e largo conhecimento da língua: exige paciência e bom senso. E ele viveu em função do dicionário: seus 140.000 verbetes, salienta Paulo Rónai em 1975, foram "pesados, examinados e definidos um por um”. Muitos passos constituíram sua tarefa: na relação e definição dos verbetes, partindo da obra dos antecessores, estabeleceu métodos pessoais para ordenar assuntos, corrigiu o que julgava imperfeito, efetuou escolhas, transposições, supressões. Tendo montado uma equipe interdisciplinar, Aurélio multiplicou o número de verbetes e de subverbetes, preocupou-se com a contextualização das palavras e dedicou-se à inclusão de brasileirismos, gírias, estrangeirismos, termos científicos, além de copiosa sinonímia, informações gramaticais e etimológicas. E gostava de seu trabalho, visto que

\footnotetext{
${ }^{35}$ As expressões são de "Manhã", Infância.

${ }^{36}$ RAMOS, Graciliano. Uma palestra (fev. 1952). In: Linhas tortas. cit., pp. 267-270.
} 
também fala à imaginação: deparava com palavras desusadas mas pitorescas, outras recordavam vozes da infância, dava a algumas vida nova ao transpô-las da língua falada, geral e regional, para a letra de fôrma. Em síntese, era-lhe prazerosa a tarefa de "lidar com as palavras - defini-las, grupá-las, dar-lhes sinônimos", porque vinculada à profissão de escritor. E, dessa forma, concretizou um projeto fundamental para a cultura brasileira.

Assim, aproximam-se Graciliano e Aurélio no empenho paciente por clareza e precisão e na capacidade de "sentir a miséria alheia" (citando aqui Caetés, analisado por Aurélio no Boletim de Ariel logo em 1933) ${ }^{37}$. Desde meninos, concentraram-se nas palavras, ninharias (etimologicamente, criancice) mas que lhes permitiram acolherem-se no mundo e o povoarem criticamente, originando trabalhos de sentido social, cultural e artístico. Alguns fatos semelhantemente marcaram a formação de ambos: o precário ensino escolar e, por conseguinte, a força pessoal de superação, movida pelo desejo de decifrar as palavras e entender a realidade.

Nascido em Passo do Camaragibe, Alagoas, a 3 de maio de 1910, as cidades onde Aurélio cresceu, Porto de Pedras e Porto Calvo, eram muito pobres, e - ele mesmo o compreende - seus professores não podiam ser bons. Recorda-se advir dessa época a preocupação e a curiosidade com as palavras. Porém, escapava-lhe o sentido de muitas: os professores não lhe explicavam quase nada do que almejava saber e não possuía em casa um dicionário. Desconhecendo embora a significação de vários vocábulos, chegou até a decorar o poema "Velhice e mocidade", de Gonçalves Dias, incluído no Quarto livro de leitura, de Felisberto de Carvalho.

O único dicionário da casa, de Simões da Fonseca, a irmã levara ao se casar. Então, o menino sonhava "com a delícia de possuir um livro dessa espécie", entretanto sem saber como o poderia adquirir, pois o pai se queixava sempre da crise. Mais tarde, descobriu no cartório do tabelião de Porto Calvo, parente da família, o dicionário de Jaime de Séguier.

Aí então fartei-me. Quando queria decifrar o sentido de alguma palavra, corria ao tabelião - e o gordo volume desvendava-me os mistérios vocabulares.

Relata Aurélio que o pai, apesar de homem simples, era uma espécie de leitor municipal em Porto de Pedras. Conforme figura no conto "Dois mundos", à noite ou nas "tardes vazias de domingo", o Sr. Manuel lia romances (de Alexandre Dumas, Xavier de

${ }^{37}$ Cf. VASCONCELOS FILHO, Marcos. Marulheiro: viagem através de Aurélio Buarque de Holanda. cit., p. 206. 
Montepin, Victor Hugo, Perez Escrich) para os amigos, caprichando para dar às frases inflexões dramáticas ou cômicas. Contudo, o dicionarista atribui antes à intuição do que à herança paterna seu gosto pelo estudo da língua. Aprendera a ler com a mãe, aos seis anos, e pouco nas escolas, tendo demorado a adquirir o hábito da leitura. Aos 13 anos, já em Maceió, o professor de Português obrigou-o ao suplício de analisar estrofes d'Os Lusíadas, sem mostrar aos alunos a beleza do poema. Fato semelhante ocorrera com Graciliano, porém aos sete anos, tendo permanecido até os nove quase analfabeto: não bastassem os "cipoais escritos" dos livros de leitura do Barão de Macaúbas, "infligiram" Camões, em manuscritos borrados, ao menino, que, ignorante da língua, teve de adivinhálo e odiá-lo ${ }^{38}$.

Em 1925, aos 15 anos, Aurélio precisou abandonar os estudos e empregar-se no comércio, para ajudar os pais. Em 1926 e 27, publicou vários sonetos e crônicas no Jornal de Alagoas e n'O Semeador, como fazia Valdemar Cavalcanti, que se tornou seu grande amigo. O pesquisador Marcos Vasconcelos transcreve e comenta esses sonetos e outros poemas ainda medidos: "Mãe", "O mendigo", "Brasil", "Um ébrio", "Exortação", "Esperança", "Ilusão". Neles se nota, já pelos títulos, certa grandiloqüiência verbal da tradição, ao lado de temas sociais como o dos miseráveis.

Aurélio passou a dar aulas particulares de português, aritmética e inglês para os colegas, até que, em 1927, foi convidado a ensinar no Ginásio de Maceió. Nesse ano, juntou-se a outros jovens intelectuais no Grêmio "Guimarães Passos" e, em junho de 1928, divulgou a Festa da Arte Nova e publicou na revista Maracanan seu primeiro poema modernista, "Árvore humana", dedicado a Valdemar Cavalcanti. Recebendo a influência de José Lins e de Jorge de Lima, a própria transformação para o verso livre foi um "abalo dos diabos" para ele. Mas logo publicou no jornal a seqüência de crônicas "Poetas às carradas", em que atacava tanto os parnasianos como os futuristas.

Escreveu vários poemas modernos em 1930, nos quais, conforme enfatiza Marcos Vasconcelos, rompia com os sobrados pedantes a favor das casinhas tristes e humildes: "Noturno", "A casinha pobre de minha rua", "Praça abandonada", "Poema que eu faria si tivesse uma namorada bonita que me desse presentes caros no dia do meu aniversário...",

\footnotetext{
${ }^{38}$ As palavras enfáticas de Graciliano ante semelhante disparate gravam-se na memória: "Aos sete anos, no interior do Nordeste, ignorante da minha língua, fui compelido a adivinhar, em língua estranha, as filhas do Mondego, a linda Inês, as armas e os barões assinalados. Um desses barões era provavelmente o de Macaúbas, o dos passarinhos, da mosca, da teia de aranha, da pontuação. Deus me perdoe. Abominei Camões. E ao barão de Macaúbas associei Vasco da Gama, Afonso de Albuquerque, o gigante Adamastor, barão também, decerto." (Infância, p. 123).
} 
"Patos", "Poema da noite alta", "Província I, II, III", "Dois poemas para Miss Alagoas", "O aleijadinho", "Cantiga de sapos" (publicados alguns no Jornal de Alagoas e outros, a convite de Willy Lewin, em Pr'a você, revista modernista de Recife). Com influência de Manuel Bandeira, esses versos marcavam-se por lirismo ingênuo e preocupação com os menos favorecidos.

Em 1930, Aurélio se tornou amigo de Graciliano Ramos, recém-chegado da prefeitura de Palmeira dos Índios, para trabalhar em Maceió como Diretor da Imprensa Oficial. Na entrevista a Homero Senna, Aurélio recorda o notável grupo, "como outro talvez nunca mais se reúna em pequena capital de província”, que então se juntava em torno de Graciliano, no seu gabinete na Imprensa ou no "Ponto Central". Aponta que participavam das conversas literárias as figuras de primeiro plano que residiam em Maceió nesse tempo - Graciliano, José Lins do Rego, Jorge de Lima, Rachel de Queiroz, Santa Rosa -, mas também jovens escritores, como Valdemar Cavalcanti, Carlos Paurílio, Alberto Passos Guimarães, Raul Lima, Barreto Falcão, Diégues Jr. e Aloísio Branco. Observa que vários dos mais importantes livros da moderna literatura brasileira foram escritos nos anos 30 em Maceió: Angústia, de Graciliano; Menino de engenho, Doidinho, Bangüê, parte de Moleque Ricardo, de José Lins. E leu S.Bernardo antes da publicação.

Feitos os preparatórios em 1930 e 1931, no ano seguinte Aurélio ingressou na Faculdade de Direito de Recife. Mas durante o curso continuou morando em Maceió, já que conseguira um emprego no Orfanato São Domingos. A figura generosa do professor do Orfanato inspirou Carlos Paurílio a compor os contos "Orfanato" (escolhido por Graciliano Ramos para figurar no volume "Norte e Nordeste" da antologia de contos brasileiros) e "O caso pungente do 17" (N 3, p. 6). Neste, Aurélio figura nominalmente como personagem, conforme Paurílio inclusive esclarece em rodapé:

Aurélio Buarque de Holanda contou, a mim e a Aloysio Branco, o caso do 17. Ele leciona português e outras matérias no Orfanato São Domingos. Àqueles meninos infelizes, que não têm alguém por si, preferia antes ensinar a suportar a solidão.

Após os poemas para a Novidade, de 1931, a seguir analisados ("Silêncio" e "Noite"), ele compôs em 1932 "O menino órfão", dedicado a Paurílio. No poema, combinava suas recordações de infância com a imagem do mesmo aluno infeliz do conto do amigo: o "orfãozinho" doente sonhava um horizonte a unir céu e terra. Publicou ainda 
"Solidão" (1932) e "Retalhos" (1938), em Alagoas, além de "Soneto" (em 1944, à futura esposa Marina Baird) e "Sonetilho a M.S.B." (a Mário da Silva Brito), no Rio de Janeiro.

A exemplo de vários companheiros alagoanos, em 1933 Aurélio viajou para o Rio de Janeiro, mas no início do ano seguinte retornou a Maceió. Em 1936, formou-se em Ciências Jurídicas e Sociais e foi nomeado professor do Liceu Alagoano, onde lecionou português, francês e literatura. Ainda em Alagoas, trabalhou como secretário da Prefeitura (1934), diretor e organizador da Biblioteca Municipal de Maceió e diretor do Departamento de Estatística e Publicidade (1937/38). A Biblioteca foi inaugurada a 13 de maio de 1938 graças, sobretudo, ao empenho e entusiasmo de Aurélio, que obteve, junto a amigos, livrarias e editoras, cerca de 4000 volumes em menos de um ano ${ }^{39}$. Eis que, seguindo os conterrâneos migrados para o sul, foi para o Rio em 1938, a fim de estagiar no Instituto Brasileiro de Geografia e Estatística, e lá se fixou.

Aurélio "cultivava palavras": ao ler livros, revistas e anúncios, anotava muitas em tiras de papel, que carregava nos bolsos (como fizera com os próprios poemas no passado). Além de empregar essas palavras nos contos, teriam lugar no dicionário, conforme indica poeticamente Marcos Vasconcelos: “colheria sementes de um projeto futuro?". Homero Senna salienta que Aurélio Buarque reunia duas qualidades nem sempre verificáveis juntas: "conhecedor da língua e escritor". "Autodidata como quase todo brasileiro", sua intuição filológica, sua cultura, bom gosto literário e paixão da minúcia e da exatidão tornaram-no, desde que chegou ao Rio, inigualável como consultor e mestre de escritores e nos trabalhos de organização de antologias, apuração de textos, confecção de dicionários, traduções, edições críticas.

De fato, com uma atuação muito variada, Aurélio Buarque contribuiu enormemente para o país. De 1939 a 1943, a convite de Otávio Tarquínio de Sousa, secretariou a Revista do Brasil ( $3^{\mathrm{a}}$ fase). Foi professor de Português do Colégio Pedro II, de 1940 a 1969, e professor de Ensino Médio do Estado do Rio de Janeiro, de 1949 a 1980. Trabalhou como revisor do Correio da Manhã, tendo deixado o emprego em 1947, indicando para seu lugar Graciliano Ramos ${ }^{40}$. Se Memórias póstumas de Brás Cubas, de Machado de Assis, foi o

\footnotetext{
${ }^{39}$ Cf. DIÉGUES JÚNIOR, Manuel. Evolução urbana e social de Maceió no período republicano (Rio, novembro de 1939). In: COSTA, Craveiro. Maceió. cit., p. 210.

${ }^{40}$ Ricardo Ramos relata que o alagoano Costa Rego, diretor do Correio da Manhã, se espantou quando Aurélio indicou Graciliano para substituí-lo como copidesque do jornal. Para a surpresa então de Aurélio, Costa Rego julgava rico o romancista, afinal era o único alagoano que não lhe havia pedido emprego no Rio. Mas Graciliano precisava muito do emprego e a ele se dedicou de 1947 até as vésperas da morte. (RAMOS, Ricardo. Graciliano: retrato fragmentado. cit., pp. 86-8).
} 
primeiro livro adquirido por Aurélio na vida, depois fez a revisão dos três volumes d' $A$ Semana da Editora Jackson, preparando-lhes 130 notas, e também de Várias histórias. Nos anos 1950, foi nomeado professor de Português do curso de preparação à carreira diplomática do Itamaraty. Esteve na Europa e, contratado pelo Itamaraty, lecionou na Universidade Autônoma do México, no curso de Estudos Brasileiros (1954-5). Realizou conferências sobre cultura brasileira no México, nos Estados Unidos, em Cuba, na Guatemala e na Venezuela. Em 1961, foi eleito para a Academia Brasileira de Letras.

Evidentemente merece ênfase sua atividade de lexicógrafo. Como já dito, em 1941 Aurélio começou a colaborar no Pequeno dicionário brasileiro de língua portuguesa, organizado por Hildebrando de Lima e Gustavo Barroso e revisto na parte geral por Manuel Bandeira e José Baptista da Luz. Graças a seu trabalho, a nona edição (1951) foi inteiramente revista e consideravelmente aumentada, sobretudo na parte de brasileirismos. E o nome Aurélio já se tornava sinônimo de dicionário.

Mas o "sonho tornado realidade" ${ }^{41}$ foi o Novo dicionário da língua portuguesa, publicado em 1975 (Nova Fronteira, $3^{\text {a }}$ ed., revista e ampliada, em 1999; 6 ${ }^{a}$ reimpressão, Curitiba, 2004, $1^{\text {a }}$ reimpressão Positivo, acompanhada de CD-ROM). Publicou também Vocabulário ortográfico brasileiro (1969); Minidicionário da língua portuguesa $\left(1977,6^{\text {a }}\right.$ ed. em 2004, Editora Positivo, com CD-ROM); Dicionário Aurélio básico da língua

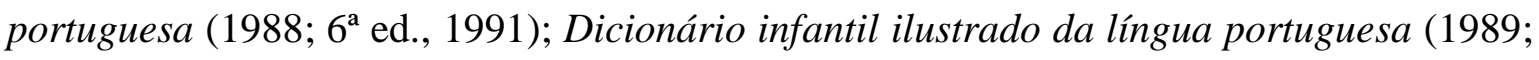
$4^{\mathrm{a}}$ reimpressão, 1999; Aurelinho - Positivo, 2005); Microdicionário Aurélio. Nova Fronteira, 1992 (Aurélio Mirim - Dicionário ilustrado da língua portuguesa. Positivo, 2005).

Vencedor do prêmio Afonso Arinos, da Academia Brasileira de Letras, é de 1942 o livro de contos Dois mundos, publicados no Diário de Notícias, O Jornal, O Cruzeiro e na Revista do Brasil. Esse volume acaba de sair, integralmente, na Coleção Melhores Contos, da Editora Global, incluindo o conto "O escritor Alberto Barros", que havia sido suprimido pelo autor na segunda edição ${ }^{42}$. Em 1947, Aurélio iniciou no Suplemento Literário do Diário de Notícias a seção "O conto da semana", que durou até 1960 e, a partir de 1954, contou com a colaboração de Paulo Rónai (1907-1992). Os dois amigos, que se conheceram na redação da Revista do Brasil, dedicaram-se a publicar a coleção Mar de histórias, antologia do conto mundial (dez volumes, de 1945 a 1989).

\footnotetext{
${ }^{41}$ RÓNAI, Paulo. Um idioma ganha o seu dicionário (1975). In: Pois é: ensaios. cit.

${ }^{42}$ Cf. HOLANDA, Aurélio Buarque de. Melhores contos: Aurélio Buarque de Holanda. Seleção de Luciano Rosa. São Paulo: Global, 2007 (Coleção Melhores Contos).
} 
Destacam-se também as suas obras: Linguagem e estilo de Eça de Queirós, 1945; Contos gauchescos e lendas do sul, de Simões Lopes Neto, edição crítica com introdução, variantes, notas e glossário (1949); O romance brasileiro (de 1752 a 1930), história literária, 1952; Roteiro literário do Brasil e de Portugal (Antologia da língua portuguesa), em colaboração com Álvaro Lins, 1956; Território lírico (ensaios), 1958; Enriqueça o seu vocabulário, filologia (1958); Discurso de posse na Academia, 1964; Discursos de posse e de recepção (na Academia Brasileira, recebendo Marques Rebelo; recebendo Ciro dos Anjos), Separata, 1972; O chapéu de meu pai, edição revista e reduzida de Dois mundos (1974). São suas traduções, dentre outras: Pequenos poemas em prosa, de Baudelaire, Poemas e prosas, de Oscar Wilde, Poemas de amor, de Amaru. Aurélio Buarque de Holanda Ferreira morreu no Rio de Janeiro, a 28 de fevereiro de 1989.

\section{O poeta combalido da miséria silenciada}

Ao publicar "Silêncio" na Novidade (14, p. 11), Aurélio contava 21 anos. Jovem, com grande segurança vocabular, enfrentava no poema a questão dos limites humanos corporificando-a em imagens concretas e remetendo à sua dimensão metafísica.

Dada a precisão na escolha dos adjetivos, os dois versos da estrofe inicial parecem sintetizar o todo do poema:

Ao silêncio religioso da hora avançada, há no tique-taque do relógio uma intenção humana de profanação.

Perturbam o eu-lírico os artifícios criados pelo homem, como o relógio, que fragmenta o tempo em segundos ("há no tique-taque do relógio uma intenção humana de profanação"). Tal insatisfação se ergue em contraste com um desejado sentido totalizador, de integração no absoluto ("silêncio religioso"), no mistério da morte ("hora avançada").

Porém, na sequiência, a revolta contra o artifício mecânico (o tique-taque) se estende também à natureza indiferente, por meio da metonímia do tempo ("pêndula incansável e insensível"). A metafísica assume a concretude da angústia, à medida que o poeta quer parar o ruído do relógio, implacável, para dar voz aos lamentos dos homens sofridos, inaudíveis na ordem do mundo. Assim, a segunda estrofe faz-se de versos longos, em que o eu-lírico repete o verbo ouvir para se aproximar dos insones, dos miseráveis, das prostitutas, dos tísicos e doentes dos hospitais. 


\begin{abstract}
Vem-me um desejo de parar esta pêndula incansável e insensível, para mais profundamente ouvir as queixas dos insones, ouvir a respiração ofegante dos miseráveis que dormem, ouvir os soluços abafados das pobres mulheres que debalde esperam o dinheiro do amor impuro, ouvir o desespero dos tísicos que se despedaçam numa tosse convulsa, ouvir os gemidos, os gritos, as imprecações escapadas de milhares de peitos nos hospitais,

ouvir os estertores dos que partem, a estas horas...
\end{abstract}

O ritmo pesado, com excesso de palavras, quer figurar os estertores de moribundos, para realçar-lhes o silêncio, de pessoas marcadas pela privação - do sono, do amor, de uma vida digna. Esse paradoxo trágico entre gritos de dor e silêncio condensa-se no verso seguinte, isolado:

Todos esses ruídos aumentam a gravidade do silêncio.

Eis que, em outro verso desgarrado, diretamente em primeira pessoa, surge a imagem do balido de uma simples ovelha - intensidade lírica para a construção de um silêncio denso de sofrimentos:

Ouço perto o balido de uma ovelha.

Agora sujeito da estrofe, cujos versos encurtam, a pêndula resolve o paradoxo dos gritos cheios de silêncio: à força do tempo, os lamentos se repetem até se extinguirem. Sendo a pêndula insensível tanto às dores dos homens quanto ao seu fim, reconhece-se a angústia do poeta em relação aos movimentos, mistérios e perdas da vida.
A pêndula multiplica todos os lamentos, apressa a extinção de todos os lamentos, continua insensível a sua monótona viagem, indiferente às viagens que começam com os lamentos extintos...

Retomada, a imagem do balido da ovelha, ao ganhar os qualificativos "insistente" e "magoado" e ressurgir desdobrada em duas construções sintáticas nominais, desvela-se expressão pungente máxima dos desamparados:

O balido da ovelha, insistente, magoado...

- As lágrimas dos que ficam sós...

Então, num novo olhar para o texto, entrevê-se o poeta, solitário e insone na "hora avançada" da noite, preencher o silêncio por meio das palavras. A criação da imagem da ovelha a balir aproxima-o dos homens pobres e sofridos, num enraizamento social da dor que fala também da condição humana. As "lágrimas dos que ficam sós" irmanam os que 
vivem e morrem desamparados e os taciturnos que sofrem por suas perdas. Na estrofe que fecha o poema, a expressão para designar o tempo é "pancadas simbólicas". O mesmo soar das horas corta o tempo, numa "pancada" dolorida, e prolonga-o, em eco místico.

Três pancadas simbólicas que se prolongam indefinidamente tornam o silêncio absolutamente místico.

Desse modo, expressando uma angústia metafísica e social, "Silêncio" quer ouvir os miseráveis, preocupação da Novidade. Ainda que se ressinta de certo excesso verbal, o poema possui a marca de Aurélio Buarque na coerência de sua construção e na verdade humana que o move: a compaixão pelos que sofrem e o misto de atração e temor ante os mistérios da vida.

\section{Taciturno menino, o mundo a definir}

Além de "Silêncio", Aurélio publicou na Novidade (3, p. 7) o poema "Noite" (tendo já escrito "Noturno" e "Poema da noite alta"). Desde os títulos, aludem à esfera do calado, do taciturno, do que guarda segredos. Verso que abre o poema e nele se repete, é "na solidão calada da noite" que se define a atitude ambígua do eu-lírico, entre o medo e a entrega ao desconhecido.

O sentimento de temor desenvolve-se a partir de várias imagens, a começar da "solidão calada da noite", que congrega desamparo, silêncio e escuridão, nos limites do pleonasmo. Construído concisa e enfaticamente esse cenário sombrio, o poeta experimenta nas três primeiras estrofes sensações de estranhamento nos planos visual, auditivo e táctil: espia becos e vê figuras do "outro mundo" em qualquer vulto humano; as conversas ao longe são "indistintas"; sente doer-lhe no rosto o vento frio da praia como um "inimigo invisível".

Na solidão calada da noite os meus olhos espiam todos os becos

Qualquer figura humana ao longe me parece do outro mundo.

Ouça conversas longínquas indistintas na solidão calada da noite.

$\mathrm{O}$ vento frio da praia que me dói no rosto dá-me a impressão dum inimigo invisível 
O movimento central da quarta, quinta e sexta estrofes é declararem-se o pavor da noite e o remorso de ter saído, por oposição ao sossego da casa. A sugestão de ser o lar um aconchego feliz define o medo e o arrependimento de entregar-se à escuridão da noite. Nela, figura ambiguamente a voz atraente do mar, com "fundos soluços" de inquietação, que podem quebrar o sossego da casa. Essa imagem do mar evoca em seu infinito superstições, mistérios, perigos, sintetizados na expressão “inimigos invisíveis”. E a noite contém também sinais de perdas, causadores de arrepio: a ameaça da presença de ladrões e o inesperado cantar de um galo, como um dobre de sino. Assim combinadas, a imagem da realidade concreta e violenta (o ladrão) e a imagem insólita (o galo noturno) reforçam a atmosfera de mau agouro da noite.

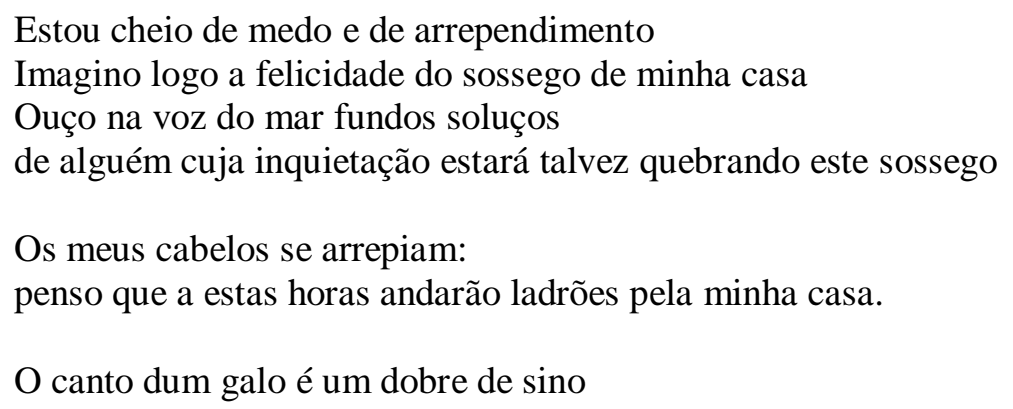

Finalmente, nas três últimas estrofes, rendido ao temor da solidão na noite, o eulírico sente dentro de si o mesmo estranhamento do mundo e deseja regressar para casa. Buscando o velho conhecido caminho de volta, identifica-o qual via crucis, numa imagem contundente, em que dá adeus ao próprio horizonte, crescida a distância até o lar por causa do pavor.

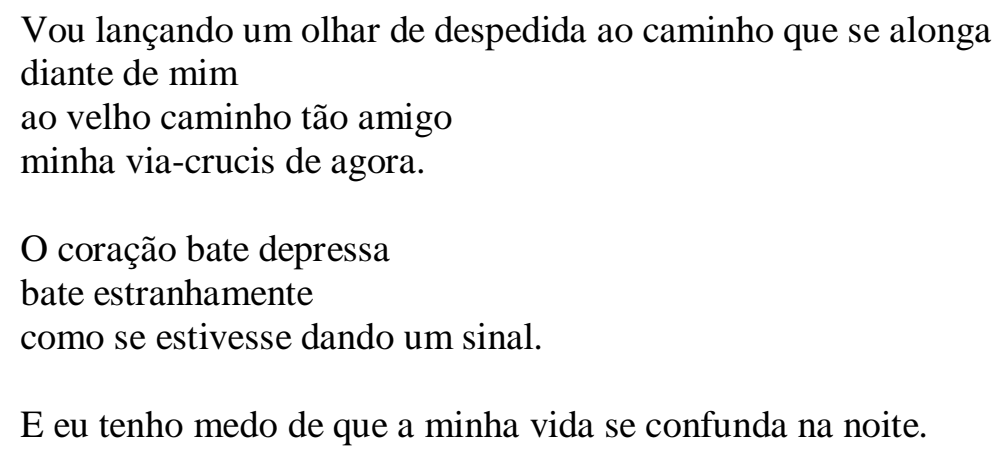

E eu tenho medo de que a minha vida se confunda na noite.

Dessa forma, entregue à criação poética, o movimento do jovem Aurélio é de aproximação e afastamento frente à "solidão calada da noite" e ao sossego da casa. Exatamente entre o "outro mundo" e o lar do menino, fontes de insatisfações e de prazeres, constrói-se o universo artístico de "Dois mundos". Escrito entre 1939 e 1941 e publicado 
no livro homônimo em 1942, esse conto parece um desenvolvimento do poema "Noite", de 1931, e permite alargar a sua compreensão.

“Dois mundos" 43 revive uma experiência marcante do menino Aurélio aos oito, nove anos. Aos domingos, ia com o pai, Manuel, à casa de campo de Seu Domingos e de D. Marinheira. Enquanto o pai lia com entusiasmo romances para os amigos, sentados os três em círculo no alpendre ante a rua sossegada, o menino, desinteressado da leitura, buscava ávida e melancolicamente os mistérios do mar.

Por um lado, a narrativa do adulto dá forma à poesia que então reconhece no gesto do pai: enfatiza como Manuel vibrava ao partilhar com os amigos a leitura de romances de Escrich. Com um pitoresco rico em cores e afeto, o narrador reconstitui o modo como o pai e seus ouvintes viviam as histórias intensamente, de diferentes maneiras: D. Marinheira, mais prática, seguia com certa distância a "coisa inventada", já Seu Domingos tentava abafar a comoção, e o pai de Aurélio enxugava as lágrimas.

No entanto, embora o pai lesse com alma, ator singular a exaltar-se e entristecer conforme as alegrias e infortúnios dos heróis dos romances, o narrador observa que, em menino, lhe faltava paciência para ouvir a leitura, tendo só aos 16 anos conhecido o primeiro romance. Ele "ouvia, sem escutar, pedaços das narrações", frases dispersas incompreensíveis como as "conversas longínquas indistintas" que compõem a atmosfera do poema "Noite". Pondera o adulto que, se ouvisse mais do que fragmentos das histórias e tivesse a experiência da "gente grande", deveria comover-se também.

Então, por outro lado, a narrativa delineia o mundo para o qual se voltava o menino enquanto o pai lia alto. Entristecia-se com o mar e o sossego da rua, observava as pessoas dos casebres pobres e os meninos que brincavam na areia. Numa passagem especialmente poética, o futuro dicionarista recorda que, menino afeito à bondade da professora Paulina, resignara-se à definição de horizonte dada na aula de geografia, segundo a qual este tão-só parece unir o céu e a terra. Contudo, preferia a ela a história contada pelo amigo Zeca: afastando-se a jangada de um menino pescador até "junto-junto do céu", ele o furou com a vara de pesca, porém o horizonte ficou intacto. E poeticamente garantido pelas palavras de Aurélio: "não houve nada, não, felizmente, porque São Pedro, muito habilidoso, fez um remendo muito bem feito, com sabão".

\footnotetext{
${ }^{43}$ FERREIRA, Aurélio Buarque de Holanda. Dois mundos. In: Dois mundos: contos, retratos e quadros. $2^{\mathrm{a}}$ ed. rev. e aum. Rio de Janeiro: O Cruzeiro, 1956, pp. 111-122.
} 
Assim, o horizonte do garoto, o "outro mundo" que lhe interessava, era a contemplação do céu. O narrador recria esse mundo - a solidão saborosa de acompanhar o crepúsculo. Não lhe pesava a proibição, pelo pai, de brincar com as outras crianças na praia: sua felicidade residia, antes, em sentir a doçura do anoitecer, que lhe abrandava aos ouvidos até a voz do pai nas passagens impetuosas da narrativa.

$\mathrm{O}$ mar, cada vez mais preguiçoso, dir-se-ia querer escutar. $\mathrm{O}$ vento soprava mais frio - e o pôr-de-sol me apertava, numa indefinida tristeza, o coração de menino. Enfiava os olhos compridos pela paisagem crepuscular. Sem que o pudesse exprimir, sentia, vagamente, o ar de meditação que parecia imobilizar os coqueiros e tornar mais doce o murmúrio do mar. Um tom violáceo coloria o céu. Fugia o sol. Nas casas de palha, luzes acesas. Os meninos recolhiam-se para a ceia. Mães chamavam retardatários: (...).

Como no poema "Noite", instaura-se uma atmosfera lírica por meio da personificação da natureza: o mar, com preguiça e desejo de escutar as histórias, murmura docemente, o vento sopra frio, os coqueiros parecem imobilizar-se num "ar de meditação". Também aqui essa personificação converge para a imagem do "inimigo invisível”. Porém, o anoitecer é fonte de uma "indefinida tristeza" para o menino, tomando o medo a forma de um respeito supersticioso pelo "mistério fundo" da noite.

Boca da noite. A noite encerrava um mistério fundo. Eu ouvia sempre dizer que 'cada noite tem seu dono'. Um ser fantástico, invisível, reinava sobre a noite.

No passo seguinte, reiterando marcar-se o menino pela solidão contemplativa, o narrador desvenda nessa postura a curiosidade da criança, seu desejo de entender a realidade observando-a e confrontando-a com as lições da escola. Preferia deixar-se ficar no alpendre, para "gostosamente" envolver-se pela sombra e ouvir o cricrilar dos grilos, a acompanhar os adultos, que entravam na casa para prosseguir a leitura. Almejava compreender as "vozes da noite" e equacionar os mistérios do mar, tão tranqüilo diante de seus olhos, incompatível com o "oceano terrível” de Gonçalves Dias, presente em seu livro de leitura.

Então, o narrador deixa ver seu traço de observador desde pequeno. Depois de relatar que, já na sala, estudava fisionomias e gestos dos adultos, ressalta o valor das comidas e hábitos regionais, como a obediência à recomendação da mãe, de não comer exageradamente na casa dos outros, nem o delicioso pé-de-moleque.

Eis que se mostra relativizado o distanciamento em relação ao Sr. Manuel e aos demais adultos. O filho confessa que, se lhe desagradava ser chamado de "menino" pelo 
pai, adorava que ele lhe acarinhasse a cabeça. E a importância do pai se concretiza na metonímia da "mão poderosa", fonte de afeto, puxões de orelha, vinténs para gulodices e da bênção diária. A mesma presença da figura paterna impõe-se comovedoramente no desenvolvimento metonímico de "O chapéu de meu pai”, conto de 1939 (Dois mundos).

Esmerando-se na escolha de expressões coloquiais para a construção dos diálogos, o contista a um tempo caracteriza pai e filho. Quando o Sr. Manuel chamava Aurélio traquina "de marca maior", a reação do amigo, de espanto, confirma ser a introspecção o caráter da criança: “- Traquina? - estranhava Seu Domingos. - Um menino calmo desse jeito!". Mas o pai tinha prazer em exagerar a peraltice e também o ar de sonso e a sabedoria do filho, causando satisfação a este especialmente ver elogiada a sua memória, sinal de inteligência.

Por fim, iluminando os significados do título do conto, o narrador recorda o retorno para casa à noite, ao lado do pai. Distantes embora em seu silêncio, aproximam-se graças à poesia com que Aurélio flagra a intensidade do universo psicológico de cada um deles, em seus passos partilhados na noite enluarada. O pai, calado, continuava vivendo o mundo do romance, carregado debaixo de seu braço. Já o menino se voltava para "outro mundo": o "imenso mistério da natureza", que incluía a voz do mar, soturna, a dos coqueiros ao vento, dos sapos, dos grilos. Para ele, o mistério do mar residia em ser tranqüilo, sem lendas de naufrágios, de afogamentos, de peixes-monstros, e o vento nas palmas do coqueiral trazia "escuras mensagens". Qualificado como sentimental, esquisito, tristonho, contemplativo, o garoto fitava o mar e a lua errante no céu. Sabia que, invisível, o "dono da noite" rondava.

Papai continuava mudo, vivendo todas aquelas vidas, o volume do romance sob o braço, como quem conduzisse um mundo. Meus sentidos se abriam, como uma flor, para outro mundo, estranho, imenso, misterioso.

'Cada noite tem seu dono...'

Desse modo, o leitor reconhece os "dois mundos": o do pai, livro no braço, realidade intensamente vivida por meio dos romances; o do filho, fora da realidade, solidão meditativa frente à noite e ao mar. E sobressai a permeabilidade entre esses dois mundos, de um adulto e de uma criança singulares: acompanhada do gosto vital do pai pela literatura, a introspecção do menino continha sede de poesia e ânsia de entender a realidade. Na formação de Aurélio, a curiosidade por invenções, personagens, descobertas, própria das crianças, cedo se combinou com o pendor à concentração observadora e reflexiva, próprio da maturidade, - o que resultou no trabalho de contista, crítico, revisor e, sobretudo, lexicógrafo, sempre apaixonado pelas palavras. 
Pensando no título Dois mundos, Álvaro Lins ${ }^{44}$ depreende do livro um sentido mais de tempo que de espaço e um conteúdo antes psicológico do que físico. Vê em Dois mundos um memorialismo da família literária de Machado de Assis, no qual a distância temporal carrega de amadurecimento as "sensações entrecruzadas do menino e do adulto".

Saúda Aurélio como exemplo de "honestidade intelectual e consciência literária". Isso porque seu livro, constituído de contos, "quadros" e "retratos", revelava um trabalho de concepção e de forma. O crítico ressalta que, ao contrário de muitos autores apressados da época, o alagoano cedo compreendeu não ser a literatura uma tarefa fácil, mas agonia constante, "luta pelo domínio da natureza, das idéias e das palavras". Álvaro Lins observa que, sendo desigual o valor dos contos, marcam-se todos, no entanto, por linguagem e estilo admiráveis. Destaca a originalidade d' "O chapéu de meu pai" e julga todos os "quadros" e "retratos", sobretudo o de D. Cândida Rosa, "páginas magistrais de arte literária".

Sublinhando embora a verdade humana de compreensão e reconstituição histórica e psicológica dos contos, o crítico aponta uma limitação de Aurélio, a qual termina por qualificá-lo muito bem: é antes escritor do que ficcionista, contista de sensibilidade mais do que de imaginação ou ação. Então, como Graciliano Ramos e Homero Senna, Álvaro Lins enfatiza a raridade de um gramático escrever com beleza artística, congregando correção de filólogo com estilo de escritor. Numa aula de crítica, deixando ver as dimensões de representação social, expressão pessoal e construção técnica que configuram as obras literárias, enumera as virtudes do contista: poder de observação, sensibilidade, arte da composição, senso psicológico e recursos de expressão (mistura entre a língua dos clássicos e a do povo). Ao final de seu artigo, Álvaro Lins confia em que Aurélio se imponha a ambição de tornar-se "um dos melhores escritores da língua".

Traço marcante da literatura de Aurélio, muito bem apreendido por Álvaro Lins, é a primazia da sensibilidade sobre a imaginação. A tendência à observação e à evocação lírica aproxima poemas, contos, quadros, retratos e também discursos. O elemento confessional do conto "Dois mundos" retorna comovidamente em "Agradecimentos à terra natal" 45 , discurso de posse de Aurélio na Academia Brasileira de Letras, em 1961. O discurso é revelador de sua poética, das dimensões regional e social do lirismo de Aurélio.

\footnotetext{
${ }^{44}$ LINS, Álvaro. Jornal de crítica. $3^{\text {a }}$ série. Rio de Janeiro: José Olympio, 1944 (9, 16 e 23 jan. 1943).

${ }^{45}$ FERREIRA, Aurélio Buarque de Holanda. Agradecimentos à terra natal. In: Seleta em prosa e verso. cit., pp. 174-7.
} 
Declara de saída que sua memória se marcou pela presença do mar alagoano de Porto de Pedras, terra de seu pai, onde viveu dos oito meses aos dez anos. Experiente, afirma ser a contemplação do mar "incentivo e limitação": sua beleza e mistério atraem o mergulho dos aventurosos, contudo barram a fantasia dos tímidos, encaramujando-os ainda mais em seu microcosmo, amedrontados ante o desconhecido. Reconhecendo-se nesse pendor ao ensimesmamento, confessa seu antigo temor ao mar terrível do livro de leitura, o qual the sugeria o outro mundo - o céu. Nessa auto-análise, identifica que fôra uma criança timidamente contemplativa, devido a uma disposição de espírito favorecida pelo ritmo de vida modorrento da cidadezinha. Também a natureza - os coqueiros altos, balançados pelo vento, e o mar, tão próximo - impelira-o ao hábito meditativo.

Então, indica a forma como o mistério tomou conta de seu coração de menino. Relembra que o pai e amigos contavam histórias de Trancoso à noite na calçada de sua casa, ao luar, propício aos sonhos. Sugerindo a procedência da imagem do "inimigo invisível", do "dono da noite", recorrente em sua literatura, faz referência também às figuras do folclore que lhe assombraram a infância: a Caipora, o Lobisomem, o FogoCorredor, o João-Galafoice.

Conforme Câmara Cascudo ${ }^{46}$, João-Galafoice em Alagoas é um "preto velho, de surrão clássico", que, nas trevas da noite, ronda as casas para raptar os meninos que estejam fora da defesa doméstica. A lenda de João-Galafoice vincula-se à luminosidade da água do mar. Designado João Galafuz em Pernambuco, é uma espécie de duende que emerge à noite das ondas do mar como um facho luminoso e multicor, prenúncio de tempestade e de naufrágio. Seria a alma penada de um caboclo que morreu pagão.

Revelando o salto de sua formação, Aurélio explica que, ao crescer o mistério, aumentava o "desejo precoce" de decifrá-lo. Como as palavras são o veículo dos pensamentos e sua própria matéria, firmou-se seu interesse e amor por elas.

Desse prazer de interrogar o mistério e da ânsia de esclarecê-lo me há de ter vindo o interesse por um novo mundo - o mundo vocabular. Entrei a amar as palavras, ferramenta do ofício das idéias e porventura chave de enigmas. Daí viria a desabotoar, com o volver dos anos, o aprendiz de lexicografia, o interessado pelo exame dos textos, pela exegese poética, o estudante e curioso da língua.

\footnotetext{
${ }^{46}$ CASCUDO, Luís da Câmara. Dicionário do folclore brasileiro. $11^{\mathrm{a}}$ ed. - edição ilustrada. São Paulo: Global, 2002. Essa superstição existe também em outros estados, como em Sergipe, com os nomes Juan de la Foice, fogo-fátuo, Fogo-Corredor ou boitatá (chama azulada vista saindo dos túmulos como alma do outro mundo; cobra-de-fogo que reside na água e protege os campos contra os que os incendeiam).
} 
O final do discurso de Aurélio condensa os pendores regional, social e universal de sua obra. Ele estende à sua terra o agradecimento dirigido aos Acadêmicos, destacando suas paisagens sólidas e líquidas, os habitantes míticos e os reais. Evoca em especial o escuro de tantas noites de sua infância, "tão gratas ao João-Galafoice, à Caipora, ao Lobisomem, e a companheiros de seu fabuloso universo". E, sublinhando que não abusa do "odioso eu", enfatiza dar voz às suas Alagoas - "tão desqueridas e desassistidas", como todo o Nordeste.

Esse aspecto social sobressai em Dois mundos, principalmente no excepcional quadro "Feira de cabeças", já analisado, e nos contos "Zé Bala", "Molambo" e "João das Neves e o condutor". Esses textos revelam muito bem Aurélio como escritor da geração da Novidade, semanário voltado para a literatura e para questões sociais. Dentre os contos mencionados, que trazem figuras marcantes de pobres-diabos, destaca-se "Zé Bala", que dá forma artística ao empenho da Novidade de combater os estereótipos e a violência. Num mundo de assassinos e homens jurados de morte, ninguém acredita que Zé Bala, preguiçoso e cachaceiro, de fato matou o conhecido que lhe cobiçou a mulher.

\section{Senhores e cativos do território lírico}

Nos poemas e no conto aqui analisados, Aurélio, construindo poeticamente a imagem dos mistérios da noite, expressou o temor às assombrações do folclore alagoano, a angústia ante a natureza indiferente, a solidariedade aos desassistidos, de sua terra e em geral, e também o prazer estético ante o crepúsculo.

Devido a esse talento literário, em 1957 José Lins do Rego expressou sua revolta contra o fato de Aurélio, seu amigo desde os anos 30 em Maceió, desperdiçar a vocação exercendo atividades de erudição lexicográfica e estilística. Como explica Paulo Rónai, numa das introduções de textos da Seleta em prosa e verso ${ }^{47}$, José Lins não chegou a conhecer o dicionário Aurélio, que o faria perdoar ao amigo o aparente desvio em relação à literatura.

Em "O homem atrás do dicionário" ${ }^{48}$, Rónai esclarece que a obra de Aurélio, embora relativamente pequena, é bastante multifacetada, incluindo poesia lírica, contos,

\footnotetext{
${ }^{47}$ RÓNAI, Paulo. O contista e o retratista. In: Seleta em prosa e verso, cit., pp. 3-4.

${ }^{48}$ Idem. O homem atrás do dicionário. Ibidem, pp. xv-Xxiii.
} 
exegese estilística, comentário filológico, tradução de prosa e de poesia, além da produção lexicográfica. Então, analisa os fatores que obstaram a Aurélio uma obra literária mais larga - todos reveladores de seu amor às palavras.

Um deles é o perfeccionismo minucioso, que levava o escritor a burilar sempre seus textos. Pode-se conjecturar que, junto com o esmero da escrita, o teor confessional de seus contos e a tendência antes à literatura de sensibilidade do que de imaginação - apontada por Álvaro Lins - impedissem uma produção literária maior.

Além disso, Rónai, muito grato, relata que o alagoano se ocupava demais com a revisão de livros de amigos, como os dele próprio. E não recusava ser revisor anônimo para colegas, cujos livros ganhavam valor graças a ele. Ironizando esse trabalho de "Hércules-Pitangui", Drummond, no cinqüentenário de Aurélio, também lamentou que este se desviasse de sua literatura, mas realçou que o motor do generoso "consultor secreto" era tão-só impedir "novas ofensas à literatura e à gramática" 49.

Ao lado de Paulo Rónai, outro grande amigo a quem Aurélio auxiliou a escrever em português e fazendo revisões - e que contribuiu extraordinariamente para a cultura no país - é Otto Maria Carpeaux. A sólida base de latim e os conselhos de Aurélio permitiram-lhe em pouco tempo escrever em português, pois já havia aprendido a língua lendo ${ }^{50}$.

Identificavam-nos o talento e o empenho hermenêutico, como se lê em "Entendimento da poesia" ${ }^{51}$, ensaio de Carpeaux sobre o Território lírico, reunião dos artigos de crítica estilística de Aurélio ${ }^{52}$. Compreendendo o título do livro, Carpeaux desvela ser a poesia, como a música, a mais misteriosa das "paisagens do espírito", a um tempo tão familiar e muito remota: o "território lírico" abriga nossas emoções, mas se situa num mapa enigmático. Por isso, cabe ao crítico enfrentar a "necessidade de entender qualquer expressão alheia, provinda de um coração igual ao nosso e no entanto imperscrutável para sempre”.

\footnotetext{
${ }^{49}$ Citado por Paulo Rónai. Idem, p. xix.

${ }^{50}$ SENNA, Homero. A literatura brasileira vista por um europeu. In: República das letras: entrevistas com vinte grandes escritores brasileiros. cit., pp. 293-303.

${ }^{51}$ CARPEAUX, Otto Maria. Entendimento da poesia. (de Livros na mesa, 1960). In: Ensaios reunidos 19421978. v. I. cit., pp. 863-6.

${ }^{52}$ Cf. FERREIRA, Aurélio Buarque de Holanda. Território lírico. Rio de Janeiro: O Cruzeiro, 1958. Com prefácio de Augusto Meyer, o livro traz, dentre outros, ensaios sobre a "Canção do exílio", de Gonçalves Dias, o "Rondó dos cavalinhos" e "Andorinha", de Manuel Bandeira, a "Pobre velha música!", de Fernando Pessoa.
} 
Então, Carpeaux ressalta que Aurélio se debruçou sobre esse "problema do Entendimento" em seu livro de crítica. Território lírico traz a verdadeira análise estilística, empenhada em reconhecer, no caminho entre uma palavra, uma frase e uma página, o sentido de um poeta e de sua obra. Carpeaux chama de "filologia moral" a honestidade do procedimento analítico de Aurélio, de aplicar toda a sua inteligência nos textos. Distingueo como escritor, dono de sensibilidade e de gosto em sentido autêntico - não como impressionismo irresponsável e sim como critério literário. É o gosto na dupla acepção de tato: regra de bom comportamento na sociedade, de não ofender os sentimentos íntimos alheios, e fonte de percepção estética.

Dessa forma, Carpeaux mostra como Aurélio apreendeu o mundo com integridade e assim se formou, aplicando-se todo aos textos - o que identifica "território lírico" a "território humano". Desvenda o segredo profissional de Aurélio: sua inteligência é “inteligência do coração".

Agora se compreendem melhor as imagens centrais do "território lírico" criado por Aurélio: o balido da ovelha e o tique-taque do relógio, sons tão próximos do sujeito em seus poemas, aludem aos estertores de todos os desamparados e à morte; o mar sereno, familiar, remete aos mistérios da superstição regional e imemoriais.

E considerando o humano território lírico de Aurélio, a um tempo familiar e remoto, não se pode esquecer D. Cândida Rosa - o "Retrato de minha avó", logo chamado de antológico por Álvaro Lins e de fato incluído por Graciliano na Seleção de contos brasileiros. A sensibilidade do escritor constrói a personagem Cândida Rosa como dona de um lirismo áspero. Delineando a expressão psicológica da velha de quase noventa anos, aponta como sua peculiaridade os modos intratáveis, para desvelar, sob eles, uma mulher sofrida.

Ao aproximar-se da avó definindo-lhe os traços físicos e psicológicos, o esmero da construção sintática e vocabular, que soma correção de escrita e coloquialismo, extrai força estética das debilidades humanas da velha senhora. As marcas negativas do tempo vivido compõem o difícil encanto da personalidade dura da avó. Enxerga apenas de um olho, e nele há um "lampejo onde raro se entremostra a simpatia humana". Repare-se, nas palavras escolhidas por Aurélio - lampejo, raro, entremostrar -, a brecha de humanidade da velha e, por conseguinte, a ambigüidade do neto, entre a admiração afetuosa por ela e o distanciamento ante uma aspereza que quase não fazia concessões. 
São muitos os exemplos dessa aspereza. D. Cândida Rosa dava gritos na empregada, em todos da casa, até em bisnetos de dois anos. Sobretudo rogava praga em quem lhe perturbasse o bem-estar, prognosticando um castigo para esse ou "o outro mundo". Aurélio procura evocar a história pessoal da avó, para compreender-lhe a rudeza. Então, garantindo a força dessa crônica da memória, sua construção funde a expressão psicológica de D. Cândida Rosa e a representação histórico-social do Brasil dos inícios do século XX.

Filha de proprietário rural, senhor de escravos, tinha uma ignorância "bem sólida": nunca freqüentou escola, não conhecia dinheiro. Aurélio flagra de saída a "mágoa funda" que ela guardou desde o casamento, imposto sem amor. E o retratista se compraz ante a incorreção de linguagem e a sintaxe bem pessoal, rica em pitoresco, da avó. Considera-a preciosa fonte para estudos linguísticos, dados os numerosos pontos de contato entre a língua das classes incultas e a dos clássicos ${ }^{53}$.

Sobressai, por seu valor histórico, o realismo com que Aurélio representa a crueza da velha em relação aos negros. Não hesita em afirmar que ela os descompunha, batia neles e até queimou um com tição em brasa. O contista revela criticamente que o preconceito contra os negros estava tão naturalizado, que a avó, ignorando a Abolição, sempre os destratava, votando-lhes uma "birra entranhável".

O negro, a seu juízo, é o escravo. Fora daí, não pode compreendê-lo. ${ }^{54}$

Em seu orgulho, só aceitava ser tratada no diminutivo - Sinhá Candinha ou D. Candinha. Contudo, além de não dar a ninguém tratamento igual a esse, gostava de deturpar os nomes alheios. Em especial, chamava de "Garrota", por vingança, a negra Carlota, com quem seu marido mantivera relações ilícitas.

Traçadas a origem social e a psicologia de D. Cândida Rosa, marcante complexidade a define. Graciliano Ramos a viu agudamente como uma personagem que ficaria bem numa "literatura sólida". Depois de caracterizar o gênio forte da avó, Aurélio nega que ela fosse uma fera como parecia. No entanto, ao apontar-lhe os momentos de delicadeza, a ressalva é superlativa: eram "muitíssimo raros".

\footnotetext{
${ }^{53}$ Cf. FERREIRA, Aurélio Buarque de Holanda. Notas sobre a linguagem de D. Cândida Rosa. Revista do Brasil, mai. 1939, ano II, $3^{\text {a }}$ fase, n. 11, pp. 41-5.

${ }^{54}$ Na primeira edição de Dois mundos, base para a versão do conto presente na antologia organizada por Graciliano, vinha na seqüência desse trecho a significativa frase: "A abolição não se fez, para D. Cândida Rosa". Ao se cotejar a primeira com a segunda edição, em geral se verifica como os cortes e emendas feitos por Aurélio tornaram ainda melhor o texto, o que talvez não tenha ocorrido nessa passagem.
} 
O contista partilha com o leitor as peculiaridades, inclusive lingüísticas, que faziam da velha uma criatura a um tempo tão intratável e especial. Nas horas de "mansidão absoluta", ela pedia cigarros "pra acendê", nunca "para fumar". Tendo o estômago por relógio, anunciava segundo sua fome a manhã, o meio-dia ou "as carranca da noite" e, terrível, exigia a refeição bem antes do horário devido. Gostava de doces feito uma criança, adorava comidas pesadas como feijoada e abusava do café.

Em meio ao caráter rude e rabugento de D. Cândida, Aurélio surpreende a singeleza de sua caduquice, capaz de despertar bem-humorada piedade. Embora despreocupada com a higiene, a velha mantinha "curiosos requintes de vaidade". Dedicava-se a "tarefas ociosas": alisava o rosto em frente ao espelho, numa tentativa inútil de suavizar as rugas, e costumava arrancar cabelos brancos, tendo já toda embranquecida a cabeça. E reagia com violência quando a chamavam de velha.

Como outros contos de Dois mundos, também o "Retrato de minha avó" se adensa à medida que, presentificando a velhice, traz a indagação pelo "outro mundo". Se o contista trata com humor a recusa da avó quanto a ir para o outro mundo conversar com os pais dela, já se apieda ao expressar que a afligiam os temores da solidão e da morte.

Por fim, condensa-se para o leitor o território lírico de D. Cândida Rosa, encontrado pelas palavras de Aurélio. Como se observou, a avó se mostrava hostil, imagem de "insensibilidade mineral"; ele nunca a havia visto chorar. Entretanto, confirmando a mágoa funda que a marcara no passado, desvela não terem restado lágrimas a ela, do muito que chorou. Então, emerge a familiaridade da emoção, a nos aproximar a todos de D. Cândida Rosa. Aurélio recorda que, quando lhe morreu o pai, filho dela, foi difícil fazê-la alcançar a realidade. Ante tamanha falta de sentido, desvaneceu-se em D. Cândida o exagerado apego à vida. E o neto soube acompanhá-la apreendendo-lhe o sabor lingüístico e a intensidade da comoção:

- Meu fio, tu morresse hoje... Vem amanhã ou despois me buscá pra tua companhia.

Tremia-lhe a voz: D. Cândida devia sofrer.

Finalmente, cumpre evocar o retrato de Aurélio traçado por Graciliano em 1942, quando recebeu a já mencionada homenagem pelo conjunto de sua obra ${ }^{55}$. Migrante

\footnotetext{
55 Aurélio organizou o almoço da homenagem, a 27 de outubro de 1942, no restaurante Lido, em Copacabana. Dentre os 93 presentes, estavam Valdemar Cavalcanti, Raul Lima, Jorge de Lima, José Lins do Rego, Jorge Amado, Drummond, Bandeira, Portinari, Lúcia Miguel Pereira, Álvaro Lins, Carpeaux, Paulo Rónai, Amando Fontes, Joel Silveira, Marques Rebelo, Murilo Miranda, Augusto Frederico Schmidt, José
} 
forçado pela prisão, o romancista identifica sua trajetória com a de alguns amigos. De procedências variadas, jamais suporiam "juntar-se e auxiliar-se" no Rio de Janeiro: dez anos antes, nas universidades européias, Otto Maria Carpeaux e Paulo Rónai não pensavam que um dia, expulsos pela guerra, estudariam a terra e a literatura brasileiras; em 1930, José Lins do Rego escrevia artigos em Maceió, mas se surpreenderia se lhe dissessem do Ciclo da Cana de Açúcar; Aurélio Buarque de Holanda também não imaginaria seu futuro no Rio de Janeiro. Cativo de D. Cândida Rosa, Graciliano relembra desde o professor e poeta dos anos 1930 em Alagoas, até o colaborador de dicionário e contista dos anos 1940 no Rio:

Aurélio Buarque de Holanda, quase criança ainda, trabalhava no Orfanato São Domingos, acumulava livros na sua casinha da Cambona e redigia poemas que se machucavam, em pedaços de papel, por todos os bolsos, e voltavam da lavadeira completamente ilegíveis. (...) Aurélio Buarque de Holanda possuía uma avó indefinível - D. Cândida Rosa. Aurélio definiu-a em dois trabalhos, fixou-lhe rigorosamente a língua e a figura. E D. Cândida Rosa começou a viver. D. Cândida Rosa concebeu Aurélio, Aurélio concebeu D. Cândida Rosa. Não tenho culpa desse absurdo. Na verdade ele realizou muitas outras coisas. Publicou um livro de contos, ensinou português no Pedro II e consertou um dicionário, mas tudo foi determinado por D. Cândida Rosa. E aí temos a guerra, os engenhos e D. Cândida Rosa influindo na existência de alguns indivíduos, fazendo que eles imaginassem deliberar conhecer de perto Copacabana e a rua do Ouvidor. ${ }^{56}$

Olympio. (Cf. VASCONCELOS FILHO, Marcos. Marulheiro: viagem através de Aurélio Buarque de Holanda. cit., pp. 203-4).

${ }^{56}$ Discurso de Graciliano Ramos. In: SCHMIDT, Augusto Frederico et alii. Homenagem a Graciliano Ramos. cit., grifos meus. 


\section{Carlos Paurílio, um moderno pungente}

\section{Poesia para todos: Leônidas Barletta}

Para apresentar a poética de Carlos Paurílio, contista e poeta praticamente desconhecido da historiografia literária brasileira, um bom começo pode ser conhecer-lhe as simpatias intelectuais. Manifestou-as num ensaio de crítica publicado na Novidade 18 (p. 6): "Simpatias" traz a comparação entre os contistas Hernandez Catá e Leônidas Barletta, que despertaram o gosto estético de Paurílio na época.

Ele sabia tão-só que os dois eram sul-americanos: de Hernandez Catá lera o livro Os sete pecados ${ }^{57}$, de Leônidas Barletta apenas contos esparsos em jornais e revistas argentinas. Com clareza crítica, abre o artigo sintetizando as semelhanças de temperamento e as diferenças de fontes criadoras entre eles: o caráter trágico marcava a ambos, porém um era atormentado pela imaginação e o outro pela sensibilidade. Imaginativo, Hernandez Catá idealizava paisagens absurdas, fora de si mesmo. Já o sensibilista Leônidas Barletta era um evocador de paisagens íntimas, passeava pelas almas dos homens e pela sua própria.

Conforme Paurílio, a Hernandez Catá importava antes o fato, o heroísmo praticado, do que o indivíduo, o herói. Fixava bem o ambiente em que as personagens agiam muito depressa. Por isso, não sendo um bom retratista de almas, tinha mais qualidades de contista que Leônidas Barletta. Em seus contos ("Limite", "Conto de amor"), cobria de mistério e fantasia as histórias mais cotidianas e reservava surpresas dolorosas para os desfechos. Com um trabalho de cerebralismo, preparava o leitor para os efeitos trágicos, levando-o “insensivelmente a um abismo por um suave declive". Seu fatalismo fazia as personagens agirem como autômatos, sem consciência e sem alma, arrastados a um fim calculadamente previsto.

Interessa-me atentar para a caracterização de Leônidas Barletta, visto que "O vendedor de apitos", conto de sua autoria, teve uma tradução especial para a Novidade (talvez por Paurílio) no número 22. Inversamente aos tipos criados por Catá, os de Barletta não traem pressa de realizar o que irá talvez suceder: não sabem o que os espera na jornada

\footnotetext{
57 Alfonso Hernández Catá (1885, Aldeadávila, Espanha - 1940, Rio de Janeiro): viveu em Cuba, onde se dedicou à literatura (contos, romances, periodismo, teatro) e à carreira diplomática. O livro de contos Los siete pecados foi publicado em 1920.
} 
e há sempre um talvez que os torna confiantes. Passam mansamente, saboreando a própria "miséria e desencanto de seus destinos quebrados". Paurílio destaca o "lirismo quase místico" com que o escritor lhes anuvia os olhos, para não verem os perigos da estrada. Identifica-se com suas personagens que, como nós, sentem e vivem: um palhaço que passa por um episódio triste, um maquinista desesperado como sua locomotiva "cega e trepidante", um marinheiro "de olhos gastos de mirar todas as distâncias". O ritmo das histórias segue as emoções que oprimem essas figuras, até que um coração pare, cansado, no fim do conto. Paurílio explicita agradar-lhe nas criações de Leônidas Barletta a naturalidade dos desfechos, movidos pelo cansaço das personagens e por não haver mais o que contar.

A leitura d' "O vendedor de apitos", de Leônidas Barletta, desperta de fato simpatia intelectual por seu autor e, por conseguinte, pelo leitor sensível Carlos Paurílio. Ele apreendeu muito bem o lirismo com que as personagens do contista argentino persistem confiantes em suas trajetórias miseráveis, até o cansaço de não haver mais o que narrar. No conto traduzido para a Novidade, o ritmo poético acompanha o pregão do bom velho de voz áspera, vendedor do mais modesto apito, brinquedo de flandres com um galozinho na extremidade, que serve "para que aprenda a cantar o canário e ao mesmo tempo se divirta o menino”. Evocando algumas vezes esse pregão, o conto se tece pela oposição entre a singeleza do objeto oferecido pelo vendedor - que remete ao belo e lúdico da natureza e da infância - e o desencantamento do mundo dito civilizado, urbano, dominado por desejos e ambições.

Definidas metonimicamente as pessoas da cidade, dessa fragmentação interessa ao escritor surpreender os rostos e sua expressão nada serena. Flagra que o pregão do vendedor de apitos põe uma nota incerta no ir e vir das "frontes cheias de preocupações", das "caras fatigadas, ensombrecidas pela ambição ou mordidas pelos ácidos do desejo".

Como num poema, repetindo o advérbio ali, o narrador parece desenhar concretamente as marcas civilizadas e mercadológicas da cidade: o templo, os bancos, as grandes lojas, as livrarias, as companhias de vapores, os advogados, os restaurantes. Tudo para fazer ouvir-se na mesma esquina, por contraste, a poesia do canário e do menino, entoada pelo vendedor. Com consciência crítica, Barletta desnuda que, nas livrarias, as pilhas de tomos podem trazer "uma partícula da sabedoria ou da estupidez humana". E acusa os restaurantes de exporem "sem pudor aos olhos do faminto e do farto o peito insolente dum peru ou um leitão de orelhas rosadas com uma folha de alface no rabo". 
Em meio a esta confusão “de cousas, de vozes, de apetites e intenções”, a voz rouca do velho surge como disparatado refrão. “Custa acreditá-lo!”: com tal concisão, o contista expressa a obstinação singela do vendedor, cuja confiança no brinquedo de flandres com um galozinho na extremidade desafiava a indiferença do mundo. Muito bem apreendido por Paurílio, esse é o "lirismo quase místico" com que Barletta, comovendo o leitor, anuviava os olhos das suas personagens para que não vissem os perigos da estrada.

Criação lírica de Barletta, o vendedor de apitos com o pregão do canário, tão familiar e remoto na cidade, sensibiliza a todos. Ninguém deixa de sorrir ao escutá-lo: ele tem o dom de abrir uma brecha na "teia de ambições e interesses que agitam a multidão". Como por um "artifício mágico", o pregão ( "para que aprenda a cantar o canário e ao mesmo tempo se divirta o menino") alude ao próprio canário e transporta metaforicamente as pessoas a um jardim, a uma ideal comunhão com a natureza. E os rostos, de ordinário fechados pelas lutas cotidianas, são tomados por um sorriso melancólico.

O narrador sublinha que o vendedor, em sua pretensão insignificante, escolheu o mais modesto apito: não era nem o de aviso de incêndios ou de partida de trens, nem o apito matreiro dos caçadores. Doce imitação do gorjeio do pássaro, a contrastar com a voz rouca do velho, o som do apito evocava uma "palavra definitiva, limpa do prejuízo e do interesse". O trinado do canário apontava o egoísmo das pessoas, encerradas na grande cidade, a cobrir de sombras o espírito e a empobrecer o coração. Enfaticamente, o contista desvela desconcertante a presença do ancião na esquina da cidade: seu apito sobrepunha-se à mesquinhez dos homens, de cujas mãos as horas escapavam, preocupados tão-só em "encher os bolsos, e nada mais que os bolsos".

Acusa-nos porque não sentimos a necessidade de ver uma ave e de ouvir o seu chilreio e de viver permanentemente abstraídos por esse triste afã de amontoar os bolsos.

Assim, com a construção lírica de uma figura singela em meio aos rostos empedernidos da multidão, Leônidas Barletta desmascara desumanizadora a ânsia de acumulação capitalista, para dar voz à necessidade de ver e ouvir uma ave, à necessidade da poesia. Lutando por meio do pregão de palavras, confia em seu vendedor de apitos e no arremedo de trinado que oferece, simples, "dum canozinho em cuja extremidade avança, não se sabe por quê, a petulância dum galozinho de flandres”.

No conto, percebe-se a tendência de Barletta à criação poética de olhar crítico contra as desigualdades sociais. Opondo-se aos poetas de torre de marfim, aproxima-se das 
criaturas simples, deixadas à margem pelo poder capitalista. Nascido em Buenos Aires, Leônidas Barletta (1902-1975) ${ }^{58}$ foi um dos fundadores do grupo de Boedo, em 1920, com Elías Castelnuovo, Lorenzo Stanchina, Roberto Mariani e Alvaro Yunque, entre outros. Boedo era o bairro popular em que se reuniam esses autores, simpatizantes do realismo crítico, influenciados por escritores como Dostoiésvski, Tolstoi, Gorki, Anatole France.

Seu principal órgão de expressão foi a revista Claridad - Tribuna del pensamiento izquierdista, editada desde 1926 pelo socialista espanhol Antonio Zamora. A princípio, desde 1922, a revista chamava-se Los Pensadores, destinada a difundir, a preços baixos, clássicos da literatura realista e da biblioteca socialista, para a formação intelectual dos leitores. De maneira irregular, Claridad durou até 1941, como importante empreendimento cultural de esquerda não partidário. Seu horizonte era contribuir para a ascensão social dos setores populares por meio do acesso à alta cultura. Provavelmente Paurílio leu os contos de Barletta na revista Claridad.

Segundo escreveu Leônidas Barletta em 1967, o Boedo buscava "a arte para a revolução”. Já o grupo oposto - Florida (Oliverio Girondo, Jorge Luis Borges, Norah Lange, Francisco Luis Bernárdez, Leopoldo Marechal, entre outros) -, dedicado sobretudo à poesia, queria a "revolução para a arte", tendo como revista a Martín Fierro (19241927). O grupo se denominava Florida por causa do bairro central de Buenos Aires cujos cafés freqüentava.

Barletta enfatiza os benefícios da disputa: os de Boedo se empenharam por escrever cada vez melhor e os de Florida compreenderam que não poderiam permanecer alheios à política. Assim, as duas correntes, com suas tendências de literatura social ou de vanguarda, possibilitaram surgir uma literatura argentina e uma massa de leitores até então inexistentes (p. 420).

Destaca-se que, em 1930, por iniciativa de Barletta, foi fundado o Teatro do Povo, primeiro teatro independente argentino. Seu propósito era a difusão de bons textos, com conteúdo social e estético, para o povo, sem fins comerciais. Ele também dirigiu duas revistas na área de teatro: Metrópolis (15 números entre maio de 1931 e agosto de 1932) e Conducta (27 números entre agosto de 1938 e dezembro de 1943).

\footnotetext{
${ }^{58}$ Cf. JITRIK, Noé; GRAMUGLIO, María Teresa. Historia crítica de la literatura argentina: el imperio realista. Buenos Aires: Emecé, 2002, v.6. (Em especial: EUJANIÁN, Alejandro; GIORDANO, Alberto. Las revistas de izquierda y la función de la literatura: enseñanza y propaganda, pp. 395-415; ASTUTTI, Adriana. Elias Castelnuovo o las intenciones didácticas en la narrativa de Boedo, pp. 417-445; TRASTOY, Beatriz. El movimiento teatral independiente y la modernización de la escena argentina, pp. 477-494).
} 
"Los destinos humildes. Sepulturero" é outra publicação de Barletta no Brasil, na revista Festa, $2^{\text {a }}$ fase, ano I, n. 8, p. 5, de maio de $1935^{59}$. Barletta publicou 37 livros, dentre os quais: Canciones agrias, 1923 (poesia); Cuentos realistas, 1925; Los pobres, 1927; Vigilia, por una pasión, 1932; La vida, 1933; Relatos de otros tiempos y de estas tierras, 1936; Cómo naufragó el capitán Olssen, 1942; La señorita Enriqueta y su ramito, 1943; La felicidad gris, 1945; Pájaros negros, 1946; La flor: Cuento de hadas: La mesa, 1954; Cuento del hombre que daba de comer a su sombra, 1957; Nuevos cuentos, 1961 (volumes de contos); María Fernanda, 1924; Vidas perdidas, 1926; Royal circo, 1927; Vientres trágicos, 1933; La ciudad de un hombre, 1943; De espaldas a la luna, 1964; Aunque llueva..., 1972; Historias de perros, 1972; El señor de levita: novela del barrio Norte, 1972 (romances); Odio (teatro), 1933; Viejo y nuevo teatro: crítica y teoría, 1956; Boedo y Florida. Una versión distinta, 1967 (ensaio).

\section{Descoberta de lirismo na cidade}

Das narrativas de Carlos Paurílio, "Descoberta de um jardim na Cidade Qualquer" (N 15, p. 10), em especial, confirma sua simpatia pelo vendedor de apitos de Barletta. Como um poema em prosa, revela a face crítica do lirismo de Paurílio, ao expressar a resistência ao aspecto reificador generalizado nas grandes cidades e a busca de comunhão com a natureza. Porém, diferentemente de Barletta, Paurílio em seus contos configura a questão das injustiças sociais de forma mais indireta, à medida que se centra no abandono dos indivíduos.

Nessa pequena narrativa, a princípio o alagoano demonstra o gosto de andar numa metrópole desconhecida, por isso chamada de "Cidade Qualquer": parece um convite à liberdade e à aventura desbravadora. Contudo, logo o contista, por meio de frases concisas, aflige-se com o artificialismo opressivo da grande cidade e suas máquinas.

Mas a sensibilidade revolta-se no ambiente mecânico. Fere-se com esses bueiros de fábricas soprando fumaças grossas.

Então, todo o movimento do texto se faz do contraste entre o presente, de insatisfação na "Cidade Qualquer", e os momentos de evocação do passado na "minha

\footnotetext{
${ }^{59}$ Cf. DOYLE, Plínio. História de revistas e jornais literários. Rio de Janeiro: Ministério da Educação e Cultura / Fundação Casa de Rui Barbosa, 1976.
} 
cidadezinha”. Esta se delineia como espaço e tempo de segurança e plenitude afetivas, tanto que as recordações da terra natal vêm protegidas entre parênteses.

(Em minha cidadezinha eu podia caminhar de olhos fechados ou imaginando poemas).

Afeito à sua cidadezinha, conhecida e aberta a seu lirismo, o poeta se assusta com a "fúria de velocidade" dos ônibus, automóveis e bondes da cidade grande. Para o ritmo da sensibilidade de Paurílio, eles surgem desumanos: teriam pressa de chegar a algum lugar "fora do espaço ou do tempo" e haveriam escolhido por trajeto o do "fim do mundo". Aqui, no susto do homem ante as conquistas modernas dos grandes centros urbanos, flagra-se o componente desumanizador que acompanha muitas inovações tecnológicas naturalizado face às vantagens que elas trazem.

Mais uma vez entre parênteses, por oposição ao ritmo infernal dos transportes da grande cidade, o poeta se recorda do "monótono itinerário de paraíso" dos bondes "cochilantes" de sua cidadezinha. A imagem mesma criada por Paurílio enfatiza que a lentidão dos bondes era favorável à poesia: a seus olhos infantis, as paisagens marginais sucediam-se "como as estampas coloridas dum álbum que se folheia devagar". Poeticamente, ganha expressão um viés de crítica à velocidade moderna: esta limita os sentidos de observação, fruição de paisagens e a mediação da realidade pelo folhear de livros.

Sobretudo perturbam o escritor os "rostos anônimos" perdidos na multidão. O malestar de que se queixa - ser acotovelado e machucado pela turba - é físico e também social e psicológico: ao ser empurrado pela multidão, percebe não possuir uma meta definida. Assim, o contista sente o perigo da massificação, da perda de identidade das pessoas na Cidade Qualquer. Embora reconheça a atração exercida por vitrinas, anúncios e luzes das grandes cidades, destaca, por meio de uma metonímia feita de negatividade, o achatamento e desnorteio de seus habitantes:

Mas a turba comprime-se e eu sou uns pequenos pés sem rumo.

Por fim, o narrador confessa seu alívio: conseguiu esgueirar-se num beco, respirar e se encontrar consigo mesmo, depois de ter vagado como ausente de si em meio à multidão. Eis que, à semelhança do território lírico criado por Barletta com o canário e o menino, Paurílio "abandona-se às crianças": mostram-lhe um sorriso e um brinquedo, arrebatam-no "no vôo" e, quando ele abre os olhos, vê-se num jardim, a que fôra por elas conduzido. 
Dessa forma, embora hoje possa carecer de originalidade a perspectiva crítica ante a coisificação dos homens nas grandes cidades, ela ainda é muito atual. E o texto de Paurílio sobressai pela sinceridade e força crítica com que recusa por desumana a velocidade moderna, para defender a sua província, aberta à poesia. Mas sobressai também porque ele deseja a poesia da grande cidade, configurando-a no encontro com as crianças e na descoberta do jardim.

\section{Rostos anuviados de órfãos-números}

Conhecido o apreço de Paurílio pelo teor poético que singulariza a natureza e a infância, por oposição à correria vã e ao anonimato dos grandes centros urbanos, compreende-se como o sensibilizava e o movia à criação artística o tema da infância infeliz. Esse é o cerne d" "O caso pungente do 17" (N 03, p. 6) e de "Orfanato", escolhido por Graciliano Ramos para a Seleção de contos brasileiros. Como uma continuação do primeiro, este apresenta maior elaboração ficcional.

Traço marcante dos contos de Paurílio é expressarem sentimentos dolorosos fincados em situações do cotidiano. Nas Notas da Semana de vários números da Novidade vê-se como o abandono dos meninos pobres em Maceió afligia os escritores da revista ${ }^{60}$. Queriam despertar a consciência de seus leitores para esse problema social, apelavam às autoridades para que arranjassem um abrigo para os menores e também criaram a Liga contra o empréstimo de livros, com o objetivo de aumentar o acesso da população aos livros e de arrecadar fundos para se construir um orfanato.

“O caso pungente do 17" (N 3, p. 6) trata de um menino abandonado, mas não da rua. Conforme Paurílio explica em nota, escreveu esse conto com a colaboração de imagens criadas por Aló́sio Branco, a partir de um fato verídico relatado por Aurélio Buarque de Holanda. Tal fato sucedeu no Orfanato São Domingos, onde este lecionava português e outras matérias.

Embora o conto tenha algo de simples registro de acontecimento da pequena cidade, transparece nele o trabalho formal de seu autor. A apresentação e o desenrolar da

\footnotetext{
60 "Escola de Gazeteiros" (Notas da Semana, N 1, p. 12), "Meninos pobres" (Notas da Semana, N 6, p. 6), "Ao relento" (Tópicos, N 11, p. 15). Cf., neste trabalho, a seção 3 - A CIDADE MENDIGA, do CAPítULO 5 NOVIDADE POLÍTICA: O RESGATE DOS SEM-LUGAR.
} 
história estruturam-se com tamanhas concisão e carga dramática, que alcançam a pungência anunciada no título.

À medida que condensa o motivo do conto, o primeiro parágrafo permite compreender-se a significação da palavra pungência. Definem o 17, interno do orfanato, expressões de robustez e grandeza: diária e incansavelmente, ele tocava com entusiasmo e quase orgulho uma tuba imensa, o "maior" instrumento da banda, inchando (comicamente embora) as bochechas. Em síntese, evidencia-se corresponder a vida do 17 ao "ardor musical" pela tuba. Então, antes inimaginável, desponta expressão máxima de pungência: exatamente o mesmo instrumento que lhe despertava o entusiasmo musical fez mal aos seus pulmões delicados de tísico. Numa dramática aproximação afetiva com o menino, o narrador, por meio de adjetivos e diminutivo, deixa de se referir a um número, para falar metonimicamente de "uns pobres pulmõezinhos", para os quais a tuba sempre significara a saúde. Com um terrível jogo de palavras, expressa que a saudade da tuba doeria mais à criança do que a saúde debilitada.

No segundo parágrafo, a doença toma corpo, fazendo do 17 um sopro fraco. Afinando-se, os ombros vergados e o garbo mudado "num ar aflito de sacrifício", não tem forças para carregar o enorme instrumento. Trágico desenvolvimento metafórico, o som do sopro, cavo e trêmulo sai "triste e fatal como um sintoma. Como um revelador som de tosse".

O terceiro parágrafo traz a indignação e a mágoa do 17 , obrigado pelo diretor a ceder a tuba querida a um colega robusto: não tocaria mais.

Bem no fundo de seu coração, qualquer cousa doía, ao pensar que não sairia mais na parada de sete de setembro, em que decerto iria fazer uma bela figura.

"Bem no fundo do coração" doía-lhe a perda da tuba, da própria identidade: o sofrimento da personagem se origina do mesmo ponto do qual the provinha a alegria. $\mathrm{O}$ mesmo ardor musical de tocar a tuba que garantia a existência do 17 decretou o seu fim, por intensificar-lhe a tísica. Assim, provocando a comoção do leitor, o conto parece definir a pungência, pontada no coração.

Na etimologia de pungência, estão o verbo latino pungo ('picar, atormentar, pungir, mortificar, afligir') e o particípio punctum ('picada, ponto, instante; pontada, estocada'). E pungir também tem por significado estimular, cuja origem é a mesma de estilo. Sendo assim, a pontada que mortifica pode incitar à criação escrita. 
Nesse sentido, Paurílio obedece a uma necessidade de sua consciência e sensibilidade ao centrar-se no tema da criança órfã e doente. Embora propício a sentimentalismos, este lhe permite expressar a verdade do sofrimento cotidiano, flagrante no caso representado. Longe de banalizar a dor do menino, o conto a singulariza, em especial ao configurar a perda da vontade de brincar, e, assim, atinge força humana. De modo comovedor, Paurílio esmera-se na construção das imagens do recreio do 17 no pátio do orfanato, as quais presentificam o desamparo do menino. Isolado e pensativo, como a procurar recordações, esticava os olhos para os colegas que saltavam e jogavam. Padecia de uma inveja dos camaradas sadios que era antes nostalgia precoce e mendicância dos bons momentos dos órfãos e de sua própria infância estreita:

Parecia estar recolhendo com o olhar uns restos de brinquedo para a sua infância miserável.

Com tosse e febre, o 17 sofria a impossibilidade de ser criança, isolava-se e, portanto, já se despedia da vida. O narrador identifica-se com ele, compartindo de sua solidão, que, maior à noite, aumentava-lhe a tosse. Com a colaboração de Aloísio Branco (que, segundo Paurílio enfatiza, deveria assinar também o conto), cria esta imagem, em que parte da natureza se solidariza com o órfão: as árvores carinhosas do pátio ofereciamlhe sombras maternais.

Se a pungência é a marca do conto, ela só ganha forma porque se assenta sobre a perspectiva realista de Paurílio. Certamente o impressionara o relato de Aurélio, sobretudo quanto à partida do menino para o hospital quando piorara. Com apurado senso de observação e de crítica, o contista revela as reações do professor, dos colegas e do próprio enfermo quando de sua saída.

Preocupado em encorajar o doente a curar-se para voltar a tocar a tuba, Aurélio contraria o absurdo hábito do orfanato de identificar as crianças por números. Comovido, pela primeira vez chama o 17 pelo nome, Júlio. E Paurílio flagra a surpresa da criança ao ouvir seu próprio nome. Ao recobrá-lo, o frágil enfermo revela a força de sua humanidade: agradece suavemente ao professor a consideração e as palavras de estímulo e demonstra a clarividência trágica de que o nome lhe era restituído porque estava doente.

O 17 ficara admirado ouvindo o seu próprio nome. Já não era um número. Agradeceu ao professor [Aurélio] com um olhar doce, depois interrogou:

- Professor, para o senhor eu era sempre o 17. Por que me chama agora pelo nome? Será porque estou doente? 
Paurílio lamenta a impiedade dos colegas, que caçoavam da perna fina do 17. Tragicamente, compreende-os incapazes de perceber que deveriam despedir-se do menino, pois talvez aquele "passeio até o hospital continuasse depois até o cemitério". Como no caso do soldado desejoso das botas do companheiro ferido em Sem novidades no front, Paurílio desvela a lógica egoísta dos homens: aponta a naturalidade com que os colegas demonstram interesse de ocupar a carteira deserta do 17. Mas o contista enfatiza a atitude de Aurélio, que os repreende. E ele próprio repreende o menino robusto, substituto do doente na banda, por resmungar que o colega não retornaria do hospital. Chama-o de "boca de mau agouro", preparando o desfecho do conto, com a morte de Júlio.

Uma semana depois, "dolorosamente" Aurélio apagou o nome - Júlio Maria da Conceição - de todos os livros do 17, de gramática, geografia, aritmética, para dividi-los entre os outros meninos. Aqui, a partir da situação cotidiana da aula, o conto materializa o sofrimento do professor ao encarar a ausência da criança morta. Ao mesmo tempo, deixa ver o problema do difícil acesso aos livros e da falta de convívio com eles no país. "Mas era como se estivesse apagando uma coisa maior, até a saudade": se em vida o nome do menino já não era lembrado, menos o seria a sua memória. Solidarizando-se com essa dura realidade dos abandonados, Paurílio dá voz ao desejo do professor Aurélio: preferia ensinar aqueles "meninos infelizes, que não têm ninguém por si”, a suportarem a solidão. Assim, a um tempo, expressa sua compaixão pelo desamparo das crianças órfãs e representa a precária realidade social e educacional do país.

Vinculado a "O caso pungente do 17", o conto "Orfanato" ${ }^{61}$ retoma várias de suas imagens e, sobretudo, fixa a figura das mães ausentes, para melhor delinear o espaço solitário em que viviam as crianças. E esse espaço se revela ao longo das quatro pequenas partes que compõem o conto, centradas em: o órfão Antenor; os professores, em especial o de português; o dormitório; o pátio.

A princípio, Carlos Parílio detém o olhar no menino Antenor, que viera para o orfanato após a morte da mãe e que do pai, marinheiro, tinha raras notícias. Poeticamente, desenha-se a situação desalentadora do pequeno órfão: a memória cansada trazia-lhe apenas um vestido roxo de sua mãe, "fantasma sem fisionomia e sem palavras". Quando lança o olhar para o portão gradeado, "que abria mais para se entrar que para se sair" -

${ }^{61}$ PAURÍLIO, Carlos. Orfanato. In: RAMOS, Graciliano. Seleção de contos brasileiros. $1^{\circ}$ v. Norte e Nordeste. Rio de Janeiro: Edições de Ouro, s/d. 
imagem de angústia recorrente em "Orfanato" -, avista na estrada uma pessoa com uma bandeja de rosas; deseja o domingo e, com ele, o consentimento para levar flores à sepultura de sua mãe. Como no primeiro conto, a natureza serve de conforto à criança: sentava-se debaixo de um cajueiro do orfanato, cuja sombra tinha "a tepidez de um colo".

E mais uma vez o contista descerra criticamente o mau costume de atribuir números aos meninos, prática a qual, se colaborava para a organização do orfanato, redundava em prejuízo para a formação pessoal dos meninos. São muito expressivas as imagens da solidão e falta de perspectivas de Antenor, o número 6: ficava a medir o largo pátio do orfanato a passos miúdos, e "o seu corpo curvado e magro ia tomando o jeito de um 6". Enquanto fixava insistentemente na cabeça o gorro branco com o 6 vermelho, escrevia o seu nome num papel e o repetia diversas vezes, "como se o quisesse decorar ou para não o esquecer".

Observando com afeto as crianças, resta ao contista brincar comovidamente com elas, ou seja, com imagens relativas a numerais. Dos meninos enfileirados em silêncio na aula de ginástica, os números vermelhos nos gorros brancos, apreende uma "soma alucinante". Ao se iniciarem os exercícios, lê no baralhar dos números um cálculo profético dos destinos dos órfãos. Mas se os vê como "números vivos", não se esquece do 17, que morreu tísico e para quem não veio substituto.

Paurílio analisa a relação entre os professores e os alunos. Mais temível é o de ginástica, cuja neurastenia de solteirão "encontra no orfanato muitos filhos para castigar". A maioria dos demais professores - de aritmética, de geografia, de música - ensinam aos meninos tudo o que vem nos livros. No entanto, conforme ressalta o narrador, embora exerçam perfeitamente o oficio, não se lembram de ensinar também aos órfãos como suportar a solidão. E aqui o leitor reconhece o motor desses contos de Paurílio, que traduzem o desejo generoso de Aurélio Buarque quando professor do Orfanato São Domingos: defender a formação não só intelectual mas também afetiva dos meninos abandonados.

No primeiro conto sobre o orfanato, confessamente baseado na realidade alagoana, surgia o próprio Aurélio como professor de português. Já no segundo, Paurílio representa o amigo por meio da figura do sr. Estanislau. Apesar de muito jovem, marcava-se por um ar paternal e concentrava o interesse dos alunos, em muito porque dizia frases que não eram da lição. Assim, o conto sugere como a atenção dedicada aos alunos por esse professor, evidenciando sua sensibilidade e integridade, acrescia valor às lições baseadas nos livros. E aponta que os conteúdos escritos só têm importância se vinculados à vida humana. Por 
isso, segundo a pungente imagem reiterada por Paurílio, quando morria um aluno do orfanato, os livros a serem divididos iam além das palavras escritas:

Um de seus [do professor de português] dias mais melancólicos é quando tem que dividir com os alunos os livros de um ausente ou de um morto. As gramáticas tornam-se quase humanas, são a presença dos que partiram, nas quais não se devia tocar.

Então, sobressai a forma como o professor de português se consolava da morte de um aluno e oferecia outro mundo ao universo de solidão dos órfãos. Propunha-lhes que escrevessem cartas ao pai desconhecido, à irmã inexistente. Na expressão do contista, o sr. Estanislau iludia-os com "temas mentirosos". Ou seja, estimulava-os à ficção, a criarem vida por meio da imaginação e da composição escrita.

A aproximação de Paurílio com os órfãos confirma seus motivos literários: a solidão e o problema da identidade e das diferenças entre as pessoas. Assim como the desagradava o nivelamento de todos os indivíduos na Cidade Qualquer, a multidão de "rostos anônimos", repudia que as crianças fossem rotuladas por números. Acompanha a tristeza de Antenor, que se apegava a retalhos da lembrança da mãe e precisava rabiscar o próprio nome para constituir-se como pessoa, ter uma memória. E destaca como a necessidade afetiva dos meninos do orfanato redundou na escrita de cartas, povoando-lhes o mundo com famílias imaginárias.

Também ao focalizar o dormitório dos internos, o contista apreende a falta de horizontes e o tracejar de sonhos que lhes marcavam as existências. Sensível, observa que as camas de ferro enfileiradas e a brancura das paredes e dos lençóis faziam o quarto assemelhar-se a um hospital. Ao mesmo tempo, é capaz de ver que, nessa brancura, "os sonhos dos meninos desenha[va]m arabescos". Porém, figuras sem fisionomia humana, os arabescos eram como os fantasmas das mães ausentes. Nas paredes brancas, ecoava o medo provocado por uma tosse: embora abafada, repercutia qual uma "advertência de desastre". Os olhos se arregalavam com a inquietação e pavor de quem convivera com a doença do 17. Assim, Carlos Paurílio configura o drama de faltarem às crianças órfãs desde o nome até a saúde e o carinho necessários à formação de uma pessoa.

Ao final do conto, a solidão do orfanato ganha contundente forma poética, ao expressar-se em imagens da natureza. A atmosfera carregada de tristeza sem saída parece prolongar-se até o céu, cujas "nuvens cinzentas" são errantes, fecham-no. Anúncios de tempestade, impressionam o contista-poeta os galhos das árvores sacudidos pelo vento. 
Vendo-os como braços agitados, adivinha neles o desespero das mães que perdem os filhos. E então volta o olhar para os filhos separados para sempre das mães:

A meninada anda pelo pátio tristemente. A tarde gris é um contágio. Perde-se o jeito de brincar. Até os professores se sentem abandonados, com medo de que o portão de grades não se abra mais para eles.

Observe-se nesse trecho como as orações coordenadas figuram o abandono das crianças: sem pais a quem amar e obedecer, vagam pelo pátio, subordinadas tão-só ao céu cinzento, tristeza que as contagia e mata. A palavra contágio, presentificando a carga de dor do ambiente, evoca a figura do 17. A comovedora passagem em que, tísico, ele recolhe como migalhas as brincadeiras dos colegas retorna aqui com uma concisão muito expressiva: "perde-se o jeito de brincar". O teor da frase é de extrema pungência: as crianças que não sabem mais brincar deixaram de existir. E essa falta, a inação das crianças órfãs, formalizase sintaticamente: elas são o oculto agente da passiva em "perde-se o jeito de brincar".

Paurílio é incisivo ao revelar a atmosfera de tristeza em que viviam os meninos. Ela se estendia aos professores, que também se sentiam abandonados e presos no orfanato, temerosos de que o portão de grades não se abrisse mais nem para eles. E ao fechar-se o conto, a construção imagética das nuvens cinzentas, materializando o abandono e a intensidade do pesar dos órfãos, configura em sua plenitude a poética do escritor: a presentificação subjetiva dos afetos ausentes.

As nuvens passam tão baixo que se refletem cinzentamente numa bacia velha e imprestável, no fundo do pátio. Também se anuviam os rostos dos meninos.

O professor Estanislau olha o céu. Daria um soneto o que sonha nesse momento. As nuvens errantes são os fantasmas das mães ausentes.

O cinzento das nuvens incide no fundo do pátio, numa bacia velha e "imprestável": para os seres do orfanato, que se sentem desimportantes, o único céu é o desalento. Como bacias inúteis e abandonadas nas quais refletem as nuvens cinzentas, os meninos têm seus rostos anuviados. E a associação de imagens se enriquece quando o professor querido dos alunos olha o céu cinzento e sonha um soneto: melancólico ante o clima opressivo do internato, deseja formas harmoniosas que estancassem os sofrimentos dos órfãos. Contudo, as nuvens nos rostos dos meninos são os fantasmas sem fisionomia das mães mortas. Os órfãos carregam nos rostos a dor da perda de seus pais e da falta de identidade e de perspectivas. 
Dessa forma, a escolha do adjetivo "anuviados" para os rostos das crianças concretiza liricamente a tristeza delas, já que as mães ausentes foram figuradas como nuvens errantes de chuva a refletir sobre os abandonados. Assim, os "rostos anuviados" dos órfãos parecem condensar a poética de Paurílio, de corporificar por meio de palavras distâncias intransponíveis.

\section{O poético dos impossíveis}

Em vez de dobrar, seguiu reto. Sabia que o itinerário ficava mais comprido, porém já estava habituado. Até era uma nova maneira de passear, quando ia a caminho do escritório.

Nesse parágrafo, início do conto "Olhos verdes", do primeiro número da Novidade (p. 5), pode-se entrever uma síntese da busca de Paurílio: premido pelos limites do cotidiano, deseja experienciar as distâncias para extrair seu caminho lírico particular.

Escolhido pelo protagonista, o caminho mais distante até o escritório era o que incluía a visão de uma loura pálida, de olhos verdes. E o conto expressa exatamente a angústia do moço apaixonado no dia em que, em lugar dos olhos verdes à janela, avistou de longe um pequeno caixão branco no meio da sala.

“Talvez fosse ela...". Repetida, tal frase de dúvida permite ao narrador delinear o caráter tímido e contemplativo do protagonista e, a um tempo, a figura da mulher adorada à distância. A princípio, a imagem do nevoeiro nos olhos, recorrente na literatura de Paurílio, caracteriza o homem tolhido pela timidez que, sentindo as pernas pesadas devido à suspeita da morte da amada, não pôde aproximar-se da casa dela. Depois, os olhos ficam nublados do choro de quem a crê morta. Porém, mesmo aflito, ele é incapaz de bater à porta para inquirir quem havia falecido. Percorrendo sempre o caminho entre a sua casa e o escritório, bastava-lhe ver a moça a distância. Assustava-se com a palidez dela e já lhe parecia amar a uma defunta, cujos olhos verdes, opacos, miravam coisas longínquas.

Então, note-se que esse esboço de um amor romântico, adolescente, eivado de medo, não se aparta de uma base realista. Sobressai a tensão do rapaz, que não se iludia com sonhos irrealizáveis, tinha consciência da impossibilidade de seu amor.

Felizmente não tinha sonhos impossíveis. Não se enganava com o pensamento de que os dois se pudessem encontrar de mãos dadas algum 
dia. Mesmo, a palidez da moça lhe dava susto, como se já estivesse querendo uma defunta.

Sua vida marcava-se pela obediência ao patrão: extraía faturas no escritório e, à noite, escondido qual criminoso, ficava entre os livros e compunha versos. Condenando a poesia, o patrão, "homem gordo e vermelho", já amassara um jornal por estampar um soneto na primeira página. Por isso, os olhos verdes da moça, atração longínqua, já se haviam materializado numa quadrinha (“Olhos verdes, bom dia!”) que, no entanto, o funcionário, receoso do patrão, jamais publicaria, a não ser com pseudônimo.

A caracterização dos tormentos do pequeno funcionário, cujo ambiente opresso lembra o que afligiria Luís da Silva (Angústia), ganha maior força estética na passagem em que ele necessita ir ao enterro da moça. A imagem dos ponteiros do relógio ${ }^{62}$, convertidos em chumbo, sinaliza o terror de quem, sofrendo já a incerteza quanto à morte da amada, precisava decidir-se a inventar uma mentira e pedir ao chefe permissão para sair mais cedo do emprego. Sobretudo se destaca sua transformação súbita e passageira em meio à movimentação da cidade, quando a caminho do enterro: por instantes, é capaz de atropelar os outros, sua ansiedade derrota os modos de ordinário tímidos e humildes.

(...) Disparou para a rua, quase correndo, sem medo de atropelar os outros. Ele que era tão prevenido em andar sempre encolhido, roçando as paredes, parando a cada passo para dar passagem a transeuntes mais apressados. Mas, agora, dir-se-ia que a sua grande timidez compreendia a pressa de sua própria ansiedade. E essa pressa, esse arrojo de passos e expressões eram tão estranhos nele que o rapaz chegava a respeitá-lo como se fosse nos outros. Agora, nenhum transeunte poderia ser mais apressado do que ele.

Assim, o conto ganha forma à medida que combina a expressão de angústia do homem solitário, atordoado pela possível perda da mulher sonhada, com a representação de seu cotidiano estreito de pequeno funcionário, cerceado pelo patrão. E toda a construção se desencadeia desde o título: os "Olhos verdes" são o amor conscientemente longínquo, inconfesso e não publicado do funcionário tímido, o qual contudo se grava no papel, na sua literatura particular. Ao final do conto, irradiam esperança ao poeta: imagina que, sendo o morto um irmãozinho da amada, ele a reencontraria absorta à janela no dia seguinte e lhe recitaria balbuciando a quadrinha. Entretanto, mais uma vez buscando presentificar as distâncias intransponíveis, teme que precisará emendar a quadrinha para: "Olhos verdes,

62 "Começou a olhar insistentemente o relógio. (Era tão despreocupado das horas, antes!) Os ponteiros pareciam pregados num lugar fixo, como se fossem de chumbo e não tivessem força bastante para se mover". 
boa viagem!". Desse modo, como o narrador se aproxima simpaticamente do protagonista, um apelo romântico e a consciência de seu sem-lugar, dados os limites da realidade, constituem a singeleza do conto.

Fato a salientar é que "Olhos verdes", além de figurar no primeiro número da Novidade, de abril de 1931, foi republicado na seção "O conto brasileiro" da Revista do Brasil, em janeiro de 1941, com o título alterado segundo o fim do conto: "Olhos verdes, boa viagem!". E A. B. de H. (Aurélio Buarque de Holanda) assina uma pequena mas valiosíssima introdução em que apresenta o contista e poeta Carlos Paurílio aos leitores. Contribuem também para se compor o perfil do escritor as já citadas obras de Moacir Medeiros e de Simone Cavalcante, o dicionário ABC das Alagoas, a Antologia de contistas alagoanos, de Romeu de Avelar, e o ensaio "Da arte do conto em Carlos Paurílio", de José Augusto Guerra ${ }^{63}$.

Nascido em Maceió a 21 de agosto de 1904, Carlos Malheiros da Silva nas primeiras produções era Carlos Silva. O pseudônimo Paurílio talvez seja homenagem ao pai, Hipólito Paurílio da Silva, aplaudido musicista alagoano. Fez o curso científico no Liceu Alagoano e aos 20 anos publicou Reflexos (1923), poemas quase parnasianos, e entrou para a Academia dos Dez Unidos. Do Jornal de Alagoas de 1924 são seus mais antigos contos, "Dona Saudade" e "O homem que perdeu o chapéu".

A 3 de julho de 1927, como Carlos Silva, fundou o semanário O Nordeste, que se dizia "porta-voz da geração moça". Dirigia esse periódico, redigido por Joaquim Maciel Filho e Rocha Lima ${ }^{64}$. Em setembro de 1927, elegeu-se sócio efetivo do Cenáculo Alagoano de Letras; em abril de 1929, foi empossado no Grêmio Literário "Guimarães Passos".

Em 1928, escreveu o primeiro poema modernista, "A rosa", e participou ativamente da Festa da Arte Nova e da criação da revista Maracanan. Outros títulos de poemas, referidos por Moacir Medeiros: "Noite de São João" (com a dedicatória "Para Jorge de Lima este meu esforço modernista"), "Coqueiro do Sobral", "Um poente vermelho", "Bandeira", "As minhas mãozinhas travessas de criança", "Elogio a uns olhos azuis", "Poema a uma aleijadinha", "Mudança", "Lírica", "Só aquele harmonium triste" e

\footnotetext{
${ }^{63}$ Cf. AVELAR, Romeu de. Antologia de contistas alagoanos. Maceió: Departamento de Ciência e Cultura, 1970, p. 113; GUERRA, José Augusto. Da arte do conto em Carlos Paurílio. In: Testemunhos de crítica. Recife: Universidade Federal de Pernambuco, 1974.

${ }^{64}$ Cf. SANT'ANNA, Moacir Medeiros de. Efemérides alagoanas. cit.
} 
“Abandono". Também em 1928 seguiu para São Paulo e o Rio de Janeiro, levando o número único de Maracanan, presente da geração nova de Alagoas. Homem da província, contrariando o costume da época, permaneceu pouco tempo fora de Alagoas, voltou no mesmo ano. Fundou o panfleto Nordeste e dirigiu o Boletim Casa Ramalho, órgão literário e bibliográfico mensal, fundado em setembro de 1931.

Já referidos, "Notas" e "Um professor de estupidez" ${ }^{65}$, artigos de crítica de Paurílio publicados no Jornal de Alagoas em 1929, sobressaem, à medida que neles se reconhecem as vertentes modernista e irônica do escritor, a amizade com Aloísio Branco e com Valdemar Cavalcanti e sua autodenominação como meninos impossíveis. Desejando registrar seu gosto pelos Novos poemas, de Jorge de Lima, Paurílio ataca João Caçamba, pseudônimo de um crítico que alardeara haver Jorge "estragado" os jovens com seu "futurismo". Ciente da resistência de alguns conterrâneos à poesia moderna, Paurílio enfatizava que a admiração pela poesia de Jorge de Lima não significava retrocesso nem imitação subserviente.

Segundo Aurélio Buarque, mesmo com a adesão ao modernismo, o verdadeiro caminho da poesia e também da prosa de Paurílio, indicado pelo feitio de sua sensibilidade, era a feição penumbrista:

Sua obra em geral - verso ou prosa - é toda ela banhada de uma doce meia-luz. Nada de gestos arrebatados, gritos de entusiasmo ou desespero: a alegria - quando surge - é discreta, como se temesse suscetibilizar os tristes; a tristeza, que é a nota habitual, chega sempre receosa, humilde, gemendo em surdina a sua desolação. ${ }^{66}$

Carlos Paurílio é autor de Solidão, reunião de 14 contos, dentre os quais "Olhos verdes, boa viagem!", e da novela A idade dos passos perdidos, ambos de 1933. Aurélio revela uma das curiosas manias dessa "figura estranha": criar contos que tivessem todos o mesmo número de linhas, de palavras e às vezes até de letras. Sublinhando seu espanto, conta que, numa das habituais noites de boêmia, Paurílio perdeu os originais de outro livro de contos, Sarampo, e relatou o fato com "uma serenidade de quem se acostumou a perder coisas mais sérias na vida". O filólogo ressalta que marcavam o amigo o riso baixo, um sorriso velado, de sofrimento, a vida atormentada. Mesmo quando já lhe tremia a mão,

\footnotetext{
${ }^{65}$ PAURÍLIO, Carlos. Notas. Jornal de Alagoas, 30 ago. 1929, p. 3; Idem. Um professor de estupidez. Jornal de Alagoas, 6 set. 1929, p. 3. Apud SANT’ANA, Moacir Medeiros de. (pesquisa e seleção). Documentário do modernismo. cit., pp. 132-5.

${ }^{66}$ HOLANDA, Aurélio Buarque de. Pequena introdução a O CONTO BRASILEIRO. "OLHOS VERDES, BOA VIAGEM!”, de Carlos Paurílio. Revista do Brasil, jan. 1941, ano IV, $3^{\text {a }}$ fase, n. 31, p. 46.
} 
devido à boêmia fatal, Paurílio escrevia muito e em qualquer parte: na banca de revisor (atividade que exerceu por um tempo na Imprensa Oficial), na mesa de botequins, em casa. E, compondo versos ou contos, era sempre o poeta, a extravasar "a maré viva de uma sensibilidade das mais vibráteis" que Aurélio conhecera. Quanto à face boêmia, conforme relatado, Graciliano e José Lins, nos encontros na Helvética e no bar do Cupertino, "tomavam conta" de Carlos Paurílio e de Valdemar Cavalcanti que, "muito jovens, bebiam demais" 67 .

Paurílio faleceu aos 37 anos em Maceió, a 30 de dezembro de 1941. Deixou inéditos: Fantasias, prosa; A cartilha do sonho, Medalhão, Os motivos ternos, Carícias, Infância, Natura, poemas; Ressurreição, A irmã, romances; Julião apavorou uma criança, contos. Publicou na Novidade: os ensaios e crônicas "Retrato de Manoel Maia Júnior", "Sobre o gesto", "Descoberta de um Jardim na Cidade Qualquer", "Simpatias", "Jornalismo de outrora"; os contos "Olhos verdes", "O caso pungente do 17", "Carta de Amor", "Ausência", "História de Mosca", "Os gêmeos"; e os poemas "Névoa e silêncio", "A Encantadora", "Muro de cemitério", "Repouso", "Na Noite", "Sobral" e "Urbano". Segundo encontrei, saíram na Revista do Brasil estes poemas de Paurílio: "Sindbad" (em agosto de 1940); "Elegia” e "Tempestade” (publicação póstuma, em fevereiro de 1942).

Depreendeu-se dos contos analisados aqui, em especial da imagem dos rostos anuviados, a feição penumbrista da literatura de Paurílio, já apontada por Aurélio. Ele também foi certeiro ao perceber que o conterrâneo era sempre o poeta, cujos contos, de "sobriedade quase ascética", praticamente não têm história, ou são, "tão eles, a mesma história de um incompreendido". Aurélio identificou os vários solitários que povoam a criação de Paurílio: um tímido, um enfermo, um enteado, um namorado infeliz, um destino mutilado, "uma vida em pedaços - pedaços donde por vezes escorre sangue" 68.

Já se partilhou da simpatia de Paurílio pelo enfermo, o órfão Júlio (o 17). Em "Olhos verdes", ele dá voz ao tímido, ao namorado infeliz. Esse conto se aproxima de "Carta de amor" e de "Ausência": curtos, os três figuram amores impossíveis por meio de efabulações que atraem o leitor, baseadas em fatos do cotidiano e contendo elementos que

\footnotetext{
${ }^{67}$ Cf. RAMOS, Ricardo. Graciliano: retrato fragmentado. cit., p. 42.

${ }^{68}$ Também José Augusto Guerra sublinha na literatura de Paurílio o sentido de inadaptação à realidade e a ausência do espetaculoso. Entende que ao estilo "rememorativo" do escritor importa a esfera dos afetos e da imaginação, porém não lhe falta a marca da época, as características urbanas de Maceió. Nas palavras do crítico: Paurílio "acreditava na literatura. E não creio que acreditasse em mais nada". ("Da arte do conto em Carlos Paurílio". In: Testemunhos de crítica. cit.).
} 
lembram passagens de contos machadianos (a atração do adolescente por uma mulher mais velha; a figuração física de fenômenos imateriais).

“Carta de amor" (N 11, p. 5) responde à necessidade de um jovem de 18 anos de confidenciar a uma senhora a sua paixão. Ele escreve a D. Mathilde para explicar-lhe por que deixara de visitá-la, depois de freqüentar-lhe muito tempo a casa, em especial a rica biblioteca de seu falecido esposo. Eis que o leitor surpreende votar o rapaz amor a uma menina de quem conhecia tão-só o retrato, guardado dentro de um livro da viúva. E a poesia da construção do conto decorre de o jovem, de modo semelhante ao funcionário de "Olhos verdes", também apegado aos livros e de "coração anacrônico", ter-se apaixonado por uma menina inacessível, que não mais existia. Ao fim do conto, ele revela que a pequena defunta a quem adorava era a própria D. Mathilde aos 12 anos.

Uma comparação poética sobressai na composição do "enevoado idílio" do remetente da carta: encantado com aquele rosto, buscava com desespero a fotografia dentro do livro, que era como o "pequeno túmulo dessa menina de outros tempos". A força do conto é fazer o mesmo impulso de vida do moço, de conhecer a identidade da amada, coincidir com a descoberta da ação do tempo sobre ela. Ele se encorajou para perguntar à viúva quem era a menina, pois desejava trazê-la do sonho à realidade, aproximá-la de sua época, ver outras expressões de seu rosto. Então, ao sabê-la uma D. Mathilde sem rugas, sem cabelos grisalhos e sem os olhos apagados, a esperança desapareceu, porém se exaltou seu "amor póstumo".

$\mathrm{Na}$ construção do conto, a definição do amor primordial pela menina é singelamente ambígua: ele "já a tinha visto ou já a amava ou já a esperava", os olhos doces dela prometiam-lhe um "amor longínquo e impossível, do outro lado da vida". De fato, esse sentimento amoroso intenso, ao reencontrar-se como ternura filial por D. Mathilde, redunda num impasse lírico: a presença da senhora amiga, embora devesse ser reconfortante, significa a distância temporal que tornou impossível para ele o amor da menina.

O tempo é um grande inimigo e eu sou um tolo rapaz enamorado dos velhos retratos.

Apenas as palavras da carta, com a confissão do amor à própria menina - que não o é mais - e o retrato, que ele lhe pede, preenchem, poeticamente, a distância que o separa dela. 
Desculpe-me a sinceridade destas linhas, ia dizer, desta carta de amor. E rogo-lhe, por piedade, que me ofereça esse rosto de menina. Está na estante D, página 80 do "Jocelyn" de Lamartine. Eu saberei amá-lo com doce melancolia, como se ama uma pequena morta.

Seu jovem amigo A.

Veja-se que a referência de Paurílio ao criar o melancólico apaixonado é a poesia romântica francesa do século XIX. Em Jocelyn (1836), de Alphonse de Lamartine, primeira parte de uma "imensa epopéia espiritualista sobre o destino humano" ${ }^{69}$, há motivos inspiradores da "Carta de amor": o jovem renuncia tragicamente à sua paixão (para ordenar-se sacerdote), as duas almas apaixonadas buscam-se ao longo dos tempos.

“Ausência" (N 14, p. 6), como "Olhos verdes" e "Carta de amor", traz a pungência de um amor impossível, votado a uma mulher que não existe mais. Entretanto, aqui a impossibilidade nasce de uma base mais real do que idealizada: esse conto expressa o sofrimento do viúvo ante a perda da esposa. Confirmando o estilo de Paurílio, de surpreender no cotidiano grandes distâncias (obstáculos à realização do sujeito) e confiar na criação poética como forma de mediá-las, "Ausência" figura o sentimento de saudade, por meio da experiência dolorosa do homem aturdido por uma debilitação física dos olhos.

Novamente surge a imagem do nevoeiro nos olhos, índice de tristeza. Contudo, a concretude desse mal irremediável é à primeira vista algo cômica, pois impelira o protagonista a consultar um médico. Na construção do conto, combinam-se a falta de um diagnóstico categórico para o problema, desafio para todas as leis físicas, e a abertura para o poético. Uma das hipóteses é que o protagonista não via com nitidez os objetos próximos e enxergava tão-só os distantes, por sofrer de presbitismo. No entanto, ele a descarta, afinal o que via estava fora de seu horizonte visual, eram distâncias. Fugiam-lhe os olhos para uma praça com crianças, por ele freqüentada desde a infância, e se sentia pintado na paisagem, desprovido de contorno e de relevo. Embevecido por um perfume e por diálogos musicais, percebia haver um "semblante ideal" a esperá-lo "nos longes". E aqui o leitor relembra a imagem da adorada a distância, de "Olhos verdes", e o rosto querido da menina do retrato antigo, de "Carta de amor".

Eis que Paurílio descerra o choque da realidade moderna sobre a subjetividade sensível do personagem: com a promessa de um exame oftálmico mais detido no dia

\footnotetext{
${ }^{69}$ Cf. LANSON, G. Histoire de la Littérature Française. Remaniée et complétée pour la période 1850-1950 par Paul Tuffrau. France: Librairie Hachette, 1955, pp. 948-953.
} 
seguinte, ele desce qual sonâmbulo do consultório e quase é atropelado. Então, aclarandose o título do conto, desvela-se ao leitor o mal do doente: a "Ausência" da mulher provocara um desajuste interior no viúvo, marcara-o com um "ar ausente".

A turba acotovelara com indiferença esse rapaz de ar ausente, cujas calças, o paletó, o chapéu, atônitos dentro do emaranhante quotidiano, moviam-se desajeitadamente nas ruas geométricas. Mas uns conhecidos cochicharam que era o Luciano Borges, funcionário dos Correios, viúvo, morava na Rua dos Jasmins; meio maluco com a morte da sua Hilda.

E Paurílio apieda-se também desse pobre-diabo, por fim identificado como Luciano Borges, funcionário dos Correios. De andar desajeitado, contava com a indiferença da turba e com a crueldade dos que o apontavam como maluco. Abandonado numa poltrona no quarto, sofria a impossibilidade de fugir com o corpo para as "distâncias inconcebíveis onde pairavam os olhos em aéreo passeio".

Segundo o crítico Carlos Moliterno, contemporâneo de Paurílio, no livro Solidão existe uma "permanente identificação do autor com a paisagem dos nossos subúrbios. Foi um fixador seguro de retalhos da vida" ${ }^{70}$. Algo insólito para um escritor moderno, há um pendor romântico na construção dos contos de Paurílio, que redunda em criações poéticas, na expressão de pungência fincada em situações do cotidiano.

No conto “Os gêmeos" (N 20, p. 5), o autor mais uma vez acompanha um pobrediabo: Francisco, que, desde o acolhimento pela parteira, foi preterido a favor de seu irmão, Paulo. Este contou com maior carinho da mãe e das amas, coube-lhe um padrinho rico, sua adolescência foram os esportes, as moças, a predileção de Julieta, enquanto a de Francisco teve paludismo, poesia e desilusão amorosa.

Enfatizando as diferenças entre os gêmeos, a princípio iguais nas roupas e nos cabelos encaracolados, Paurílio caracteriza a injustiça que separa dois ambientes sociais. Com boa herança do padrinho, Paulo tornou-se comerciante e pôde ostentar a "barriga burguesa e cheia". Já o irmão, cada vez mais magro e pálido, porque sofria de paludismo e reumatismo, vivia esperançado num emprego público e trabalhava como revisor num jornal, colaborando com versos aos domingos.

\footnotetext{
${ }^{70}$ Apud AVELAR, Romeu de. Antologia de contistas alagoanos, cit.
} 


\section{Os sonhos das moscas}

Destaca-se "História de mosca" (N 17, p. 6), singela construção ficcional na qual se assiste aos sonhos e amores, aos receios e desventuras da mosquinha Zizi, até se presenciar seu fim trágico, resultado de flit e piparote. Nesse conto convergem todas as faces, interligadas, da poética de Paurílio: a presença das crianças como motivo de resistência à reificação moderna; a necessidade de preencher com palavras as distâncias provocadas por amor e morte; a simpatia pelos pobres-diabos. E sobretudo "História de mosca" traz o acréscimo de leve ironia, capaz de atenuar de forma graciosa o matiz romântico, sem diminuir a aproximação afetiva com os sofredores.

A protagonista do conto, iniciado com "Era uma vez”, é uma pequena mosca. Em primeira pessoa, o narrador faz questão de intrometer-se no próprio relato, até então em terceira pessoa, para batizar sua personagem: Zizi. Mostrando simpatia por ela e brincando com a consciência de escritor zeloso das palavras, defende ser indecoroso chamá-la de mosca, nome criado pelos homens, e indecente repeti-lo muito na narrativa.

Ao personificar o inseto, o contista demonstra o respeito devido a todos os seres, por mais insignificantes que pareçam. Por isso, caracteriza muito bem a mosca, sublinhando que o pequeno ser, na sua linguagem, era capaz de poesia. Zizi recebeu esse nome por causa do leve zumbido de suas pequenas asas: impertinente para o velho Fonseca, dono da casa, era deleitoso para ela, "era a sua maneira de compreender a música". Integrante de uma sociedade de mosquinhas "desportivas e alegres", Zizi às vezes ensaiava vôos atrevidos até o quintal, atraída pela "caixa de surpresas", a lata do lixo. Não tendo o pecado da gula, buscava antes a colorida toalha da mesa, boa para brincar, do que as comidas.

Então, central no conto, é a relação entre Zizi e Alice, filha do sr. Fonseca. A mosca adorava pousar nos cabelos louros e no rosto claro e corado da menina, a qual parece concentrar os atrativos das figuras femininas dos demais contos. Mais do que isso, a preferência da mosca pela cabeça da criança configura a possibilidade de os pobres-diabos sonharem com uma vida de plenitude, mesmo fracassando logo ante tantos limites.

Mas se avistava [Zizi] a menina Alice, então ia rápida pousar em seus cabelos louros ou na tez de leite e rosa. Aí demorava um tempo longo, como num país ideal, desmemoriada de sua condição ínfima, sonhando com cousas brancas e suaves. Até que se desvanecia o sonho aos piparotes da mão enorme da menina Alice. 
Nessa passagem, sobressai a poesia de Paurílio: entrevê, na cabeça da pequena Alice, um "país ideal", maravilha onde os seres de condição ínfima podem, por pouco tempo embora, esquecer-se disso e sonhar.

No entanto, num percurso comum aos protagonistas de Paurílio, os sonhos de Zizi se desvaneciam com os piparotes da "mão enorme" da menina. O conto acompanha, a um tempo, as vidas da mosca e dos donos da casa - o velho Fonseca, d. Graça e a filha Alice -, feitas todas de sonhos, alguns prazeres e muitos sustos, até o piparote final. Revela poeticamente o susto de Zizi quando, pousada no rosto da criança, viu-a, como por magia, abrir os lábios com uma "voz trovejante". Mas depois a mosca se acostumou: não era uma tempestade, tão-só Alice conversando com os pais.

Ao apresentar um dos prazeres de Zizi, o contista desnuda um problema social alagoano, também criticado nas notas e tópicos da Novidade: a falta de condições de higiene ${ }^{71}$. Com antipatia pelo sr. Fonseca, a mosca e suas amigas de traquinagem faziam acrobacias num "trapézio escarlate", o nariz do pai de Alice. Indignado, ele bradava cobrando os mata-mosquitos, anunciados pela política pública, e ameaçava trazer um tubo de flit. Da cozinha, a mulher "acomodava", pedindo-lhe paciência. E Zizi já se refugiara, provavelmente no quadro da Ceia Larga, seu esconderijo favorito.

No intervalo em que o flit foi ameaça incompreendida pela mosca e esquecida pelo homem, Paurílio não privaria Zizi de viver um "idílio de asas". Estava na cabeça loura de Alice, "fantasiando cousas inexplicavelmente macias", quando encontrou seu par. Mais uma vez, o escritor realça a singularidade dos seres e o desejo de transpor distâncias, possibilitado pelo sentimento amoroso:

\footnotetext{
${ }^{71}$ Nas Notas da Semana da Novidade 7, p. 4, lê-se:

"Os mata-mosquitos continuam a cometer abusos, pondo petróleo nos potes de água de beber, quartinhas etc. / É preciso reprimir esse abuso".

E um tópico do número 8 da revista apresenta esta narrativa, cujo pitoresco aparente na verdade traz um problema grave de "Higiene pública" (p. 16):

"- Esta água aqui tem larvas!

E o funcionário de roupa cáqui retira de dentro do pote uma lanterna funcionando na mão de higiene absolutamente discutível.

Fecha o registo da lanterneta, coça a cabeça como para matar um problema e resolve ditatorialmente:

- Tem larvas e vamos logo botar a água fora.

O outro funcionário de roupa cáqui revoga a disposição em contrário, com prudência e serenidade:

- Não, bota-se petróleo.

E faz o servicinho, sem ouvir pedidos nem desaforos da dona da casa, comovida sem dúvida pela sabedoria inflexível.

Põem petróleo também numa quartinha inocente deixada à janela para esfriar. Ameaçam de multa os queixosos e saem com um ríspido até-logo.

Chama-se a isso higiene pública.

E o povo chama os rapazes de mata-mosquitos...”.
} 
E não se perdiam nunca. Apesar de serem todas aparentemente iguais e facilmente confundíveis sobre a toalha colorida, Zizi e a outra se buscavam dos ângulos opostos da sala de jantar. Do mesmo modo se achariam e se reconheceriam se estivessem distantes uma da outra nos confins do mundo.

Por fim, Paurílio relata a morte das moscas enamoradas, que, tentadas pela comida à mesa, foram atingidas pelo flit. Num tom solene, irônico em relação ao caráter ínfimo das personagens, anuncia ter havido "a grande catástrofe, a dolorosa hecatombe de todas as moscas". Atingindo os exageros românticos, a ironia se prolonga quando o flit é chamado de "veneno voluptuoso e fulminante", perfume amargo como o amor e a morte. Ao mesmo tempo, o leitor, com simpatia por Zizi, reconhece um aspecto trágico na ironia de caber à menina Alice o último piparote na mosquinha e de esta tombar de asas enlaçadas com seu amor.

Então houve a grande catástrofe, a dolorosa hecatombe de todas as moscas. Um grosso tubo surgiu no ar expelindo um líquido finíssimo que entontecia e matava. Zizi e a outra foram as primeiras alcançadas pelo veneno voluptuoso e fulminante. Era o Flit, perfume jamais sentido, amargo como o amor e a morte. E por epitáfio, a mão enorme da menina Alice enxotou com um último piparote, lá para debaixo da mesa, os cadáveres das duas, que tombaram de asas enlaçadas.

\section{Relíquias de palavras}

Os poemas de Carlos Paurílio são versos livres que dão forma à mesma temática depreendida dos contos. A escrita lírica da solidão e do apego às distâncias, materialização do amor e da plenitude impossíveis para o sujeito, configura-se por meio de imagens recorrentes, como a neblina nos olhos, o marinheiro infeliz.

Destaca-se "Névoa e silêncio": desde o título, exprime a incomunicabilidade do eulírico, que sente "grossa parede", "uma ausência de cem anos" a distanciá-lo da amada. Ele almeja ouvir até o pio de uma coruja solitária, que inspiraria seu amor a dar um grito. Porém, no centro do poema, a adversativa - "Mas todos os rumores se dispersaram em ecos longínquos" - confirma que as palavras de amor, perdidas no interior do sujeito, não conseguem expressar-se. Resta-lhe apenas a companhia do vento a agitar as ramagens, como um gesto do silêncio.

O leitor reencontra aqui, sobretudo na imagem das "bocas caladas e os olhos cheios de bruma", o protagonista do conto "Olhos verdes", que também padecia por causa do 
amor inconfesso e da perda de sua adorada. A dicção poética de Paurílio expressa uma sensibilidade que se reconhece na dor de ver perdidas as palavras de amor dentro de si e de ter a amada como uma distância intransponível. Dada a universalidade do sentimento figurado, e também devido às imagens da coruja, do silêncio e do vento, é instigante pensar, apesar de todas as evidentes diferenças, que o poema, expressando uma sonhada libertação quanto à "vida agreste", poderia dar voz a um conterrâneo: ao sofrimento de Paulo Honório (S. Bernardo) ante o desencontro e a ausência, irreversíveis, de Madalena, tão-só atenuados pela escrita de sua história.

\section{Névoa e silêncio $(05$, p. 6.)}

todas as palavras de amor se perdem dentro de mim...

Na paisagem enevoada seriam também perdidas...

Coração! perdoe as bocas caladas e os olhos cheios de bruma!

Se ao menos o pio duma pobre ave solitária

- não importa fosse uma feia coruja agourenta varasse essa grossa parede de névoa e silêncio, então o meu amor teria também um grito.

Mas todos os rumores se dispersaram em ecos longínquos.

E um leve sopro de vento cego tateando na névoa agita as ramagens, mas tão lentamente, que parece um gesto do próprio silêncio.

Essa névoa nos distancia a antípodas inconcebíveis...

Esse silêncio põe uma ausência de cem anos entre nossos rostos...

Também o poema "Na noite" (N 21, p. 11) é a espera do amor e da noite por um eu-lírico que quer dirigir "palavras tateantes" à amada. Num paradoxo lírico, imagina que terá mais consciência da proximidade dela quando, envolvida por sombras, estiver "perdida de vez".

E ansiosamente, palpitantemente,

Esperamos na sala o amor e a noite.

As sombras virão deslizando dos ângulos,

Se amontoarão em roda de ti.

Tu serás perdida de vez...

A combinação romântica entre amor e medo explicita-se no poema "A Encantadora" (N 9, p. 11). O eu-lírico compara a amada a Nossa Senhora e, temendo 
ultrajá-la, fecha os olhos. Novamente a distância é a aproximação que permite à poesia do amor realizar-se: "Os olhos fechados serão o único beijo".

“Urbano" (N 24, p. 7) traz o eu-lírico solitário na tarde chuvosa, a caminhar sem rumo pela cidade vazia. Parecendo-se com o funcionário de "Olhos verdes", lamenta não haver uma "mocinha pálida à janela" a esperá-lo. Sob o peso do silêncio, ressentindo-se da ausência de vida (amores, jornais, meninos), suas alternativas de passeio, a estação ou o cemitério, incluem sempre ver gente partindo. Por fim, seu desejo ambíguo é encontrar-se com a poesia simbolista francesa, representada pelo "defunto Laforgue num beco triste" (que morreu aos 27 anos).

Vinculando-se a "Urbano", o poema "Muro de cemitério" também figura o gosto de freqüentar lugares de "tristeza permanente". Sua riqueza poética constrói-se a partir do sentido de relíquia. Revela a combinação paradoxal entre inutilidade e importância afetiva dos mortos, guardados no cemitério "avaramente dos olhos do mundo", e dos objetos pessoais estimados, que podem sobreviver a quem os possui.

O eu-lírico deseja despojar-se dos objetos da memória mas, como sempre, mostrase presa dos afetos distanciados pelo tempo, tanto que conjuga os verbos no futuro do pretérito. Os objetos que guardaria no muro gelado representam momentos significativos que, de valor subjetivo intenso, permaneceriam para ele. Referem-se à iniciação da criança e do jovem na vida ("o registo de minha primeira comunhão", "a caderneta militar"), às amizades do adulto ("minhas cartas") e, principalmente, aos exercícios do artista ("os cadernos de poemas", as promessas de pintor).

Assim, a poesia - recolha das experiências pela memória e sua reunião no "Muro de cemitério", em versos, - é a condição do sujeito, relíquia inútil poderosa, que lhe possibilita dispensar as relíquias concretas:

\footnotetext{
Vou a passeio aos lugares de tristeza permanente e penso idéias esquisitas vendo esse muro cinzento de cemitério onde os mortos se guardam avaramente dos olhos do mundo como se fossem relíquias.

Também eu tenho pequenas relíquias inúteis que poderia guardar dentro desse muro gelado: o registo de minha primeira comunhão, os cadernos de poemas, a caderneta militar, minhas cartas, até uma paisagem medíocre que pintei quando era menino
} 
e que na sala ainda está a prometer o artista.

Dentro do muro cinzento e gelado do cemitério

deixaria todas essas cousas que talvez ainda continuem existindo depois de mim.

E voltaria para casa com as mãos vazias.

Publicado junto com "Muro de cemitério" na Novidade 13, "Repouso" merece especial atenção. Evidencia também o desejo impossível do eu-lírico, de livrar-se da memória: ele almeja esquecer-se das tensões da vida para entregar-se à brandura da natureza. Paurílio criou imagens expressivas da liberdade do homem em comunhão com a natureza, como de uma morte serena: deitado na extensão da relva, o rosto e os braços abertos para o céu, sentindo a brisa nas faces e o crepúsculo baixar como um "crepe fúnebre" sobre seu rosto, velas ao longe como lenços de despedida e os passarinhos a mariscar bem próximos.

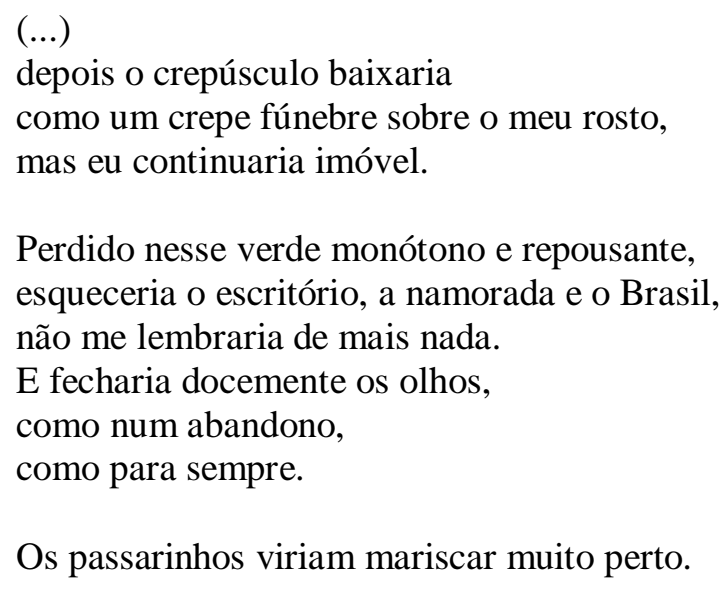

Os passarinhos viriam mariscar muito perto.

Nota-se nessas criações a tendência de Paurílio ao penumbrismo, da atmosfera comum do Decadentismo europeu (fins do século XIX e início do XX), com influências de Laforgue, de Francis Jammes (cujo conto "O cachimbo" foi traduzido na Novidade 7). Nas palavras de Ítalo Bettarello ao tratar dos italianos Corazzini, Gozzano, marcava-se a poesia crepuscular pela "intimidade humilde dos motivos cotidianos", pela "incapacidade de aderir ao ritmo vivo da existência". Incluía uma "ânsia de canto" com potencial artístico, mas implicava falta de compromisso ${ }^{72}$.

\footnotetext{
${ }^{72}$ BETTARELO, Ítalo. A poesia italiana atual. Tradução, notas e apresentação de Elvira Rina Malerbi Ricci. Boletim n. 15 (Nova Série), Faculdade de Filosofia, Letras e Ciências Humanas, USP, 1977, pp. 66-8.

Dessa tendência de transição, entre simbolista e moderna, destacam-se (indico alguns títulos de obras): na prosa, Gonzaga Duque (Mocidade morta, romance, 1900; Horto de mágoas, contos, 1916) e Lima Campos (Confessor supremo, 1904); na poesia intimista, Ribeiro Couto (Jardim das confidências, 1921; Poemetos de ternura e melancolia, 1924), o primeiro Manuel Bandeira (A cinza das horas, 1917), Mário Pederneiras (Rondas noturnas, 1901; Ao léu do sonho e à mercê da vida, 1912), Álvaro Moreyra (Elegia da bruma,
} 
Então, veja-se que a face crepuscular da literatura de Paurílio se acompanhava de compromisso com questões sociais: no poema "Repouso" (mesmo de forma atenuada) e sobretudo em alguns contos. Em "Repouso", o recorrente gesto de inadaptação do funcionário à realidade ganha um tom crítico mais vital, ao incluir o país entre os fatores de sua insatisfação. No futuro do pretérito, anuncia que o repouso sonhado, porém inatingível para a sua consciência inquieta, abarcaria as esferas do seu trabalho, das relações amorosas e do país: "esqueceria o escritório, a namorada e o Brasil / não me lembraria de mais nada".

Por fim, em "Sobral" (N 23, p. 11) - considerado por Aurélio Buarque um dos mais belos poemas de Paurílio -, o eu-lírico, ante a plenitude da natureza, constitui-se como inventor de um silêncio com que se identifique. Personifica a natureza, nela incorporando limites humanos: o ritmo das ondas inclui perdas, o farfalhar dos coqueiros são acenos nostálgicos.

Diante das ondas barulhosas e dos coqueiros farfalhantes invento um silêncio que fale a mim mesmo.

As ondas vão e vêm em ritmos perdidos e os coqueiros nostálgicos acenam aos navios.

Então, com consciência de sua efemeridade, humana, vê projetarem-se o belo da natureza e o da arte. No horizonte do poeta, o verde dos olhos de uma jovem artista pinta uma marinha (à semelhança da machadiana figura de Fidélia, do Memorial de Aires).

Traço pensamentos graves na areia para ter consciência de que sou efêmero.

Ali, uma senhorita, com o verde dos seus olhos, Junto ao cavalete, pinta uma marinha.

Finalmente, aprofundamento das imagens criadas, em que se fundem as esferas humana e natural - a nostalgia dos coqueiros, os pensamentos de efemeridade traçados na areia, o verde dos olhos, da marinha e da pintura -, surge a mais lírica: o crepúsculo que afunda no mar e faz mais tristes os afogados. Levado por esse lirismo, desejoso de

1910), Filipe D’Oliveira (Vida extinta, 1911; Lanterna verde, 1926), Ronald de Carvalho (Poemas e sonetos, 1919), Guilherme de Almeida (Nós, 1917; A dança das horas, 1919), Olegário Mariano (Evangelho da sombra e do silêncio, 1913; Destino, 1931), Rodrigo Otávio Filho (Alameda noturna, 1922), entre outros. (Cf. BOSI, Alfredo. História concisa da literatura brasileira. cit., pp. 376-7; O pré-modernismo. São Paulo: Cultrix, 1973, p. 38; OTÁVIO FILHO, Rodrigo. Sincretismo e transição: o penumbrismo. In: COUTINHO, Afrânio (dir.). A literatura no Brasil. Rio de Janeiro: São José, 1959, v. III, t. 1, pp. 311-372; GOLDSTEIN, Norma Seltzer. Do penumbrismo ao modernismo. São Paulo: Ática, 1983). 
esquecer os limites, o poeta se entrega aos sonhos, embarcando na plenitude da criação artística.

O crepúsculo afunda-se no mar os afogados vão ficar mais tristes.

Esqueço-me a soltar os sonhos como barcos

e a sacudir o coração para pescar poemas.

Sua sensibilidade, guardando os impasses da consciência, precisa vitalmente conquistar uma arte bela e simples como a natureza - "pescar poemas". 


\section{"Se o Aloísio Branco consentir": um inquieto em busca dos sentidos.}

Desconhecido hoje, o nome de Aloísio Branco é recorrente nas páginas da Novidade. Desperta a atenção a diversidade de seus poemas e ensaios de crítica literária na revista, sinalizando a um tempo a necessidade e a dificuldade de interpretá-los. Talvez um caminho seja partir da singeleza de "Viagem" (N 04, p. 5), descobrindo-lhe as tensões, até chegar à sua configuração mais dramática, em "Berceuse para embalar o mundo".

\section{Viagem}

No último barquinho de papel que eu soltei aos doze anos na enxurrada da sarjeta partiu para sempre uma estranha e doce passageira.

Partiu envolvida em calendários velhos e levando em sua bagagem os meus brinquedos o meu pavor à mãe-d'água as minhas calças curtas e o meu encanto pelos livros de Julio Verne cuja maravilhosa ciência de navegação de nada serviu a ela que ainda hoje se acha perdida no mar abstrato do tempo aonde às vezes vão desaguar os rios infantis das sarjetas.

"Viagem" é bem o poema de um "menino impossível": no mundo solitário, temia a mãe-d'água e, buscando povoá-lo, lia Julio Verne e lançava barquinhos nos rios da sarjeta. No entanto, a "maravilhosa ciência de navegação" dos livros de Verne não impediu a "estranha e doce passageira" do barquinho de perder-se no "mar abstrato do tempo". E o ritmo dos versos livres, feito de enumerações e seqüência de orações adjetivas, parece acompanhar o movimento do barquinho afastando-se na enxurrada.

Aloísio Branco constrói liricamente a imagem da infância perdida: cara ao poeta, ela é a passageira que viaja no barquinho feito por ele menino, mas rumo ao longínquo indefinido, aos mistérios da vida. Note-se que, já na plenitude da infância, paradoxalmente há a marca da insatisfação: introspectivo e sonhador, o menino parecia inquietar-se com o universo e o tempo, visto que demandava a criação de formas, como a literatura e o barquinho de calendários velhos lançado ao mundo. 
O mesmo poeta que compôs um barquinho lírico, para resgatar no "mar abstrato do tempo" os "rios infantis das sarjetas", escreveu poemas de blague, ironizando até a Saudade, ou melhor, o emprego vago das palavras, desvinculado de uma experiência concreta.

\section{Saudade}

Ao Manoel Ramalho

Os aviões da Laté, da Nyrba e da Condor vão acabar com a saudade juntando como bairros duma só cidade as terras bem distantes.

Então as malas postais ficarão muito mais leves e muito menos dolorosas.

Mas eu juro que Alberto de Oliveira ainda achará um jeito de ficar com saudade da Saudade.

Nesses bem-humorados versos livres, está representada uma mudança de sensibilidade propiciada pela tecnologia dos transportes: o poeta expressa sua admiração ante os aviões, que de fato possibilitaram diminuírem muito as distâncias entre as pessoas. Aloísio Branco exagera que os aviões extinguiriam a saudade, para ironizar, com um juramento coloquial em primeira pessoa, a alienação dos parnasianos em relação à realidade e seu apego a moldar-se a fórmulas fixas: "Mas eu juro que Alberto de Oliveira ainda achará um jeito / de ficar com saudade da Saudade”.

Sob o título "7 Poemas", "Saudade" foi publicado na Novidade 06 (p. 13), ao lado destes, todos de blague: "Garanhuns", a Marietinha Pragana; "Freud", ao Alberto Passos Guimarães; "Concurso de beleza", ao Luiz Ramalho; "Fenômeno", ao Théo Brandão; "Geografia", ao Willy Lewin; "Portugal", ao Manoel Lubambo. E anunciava-se que pertenciam a um livro inédito de Aloísio Branco, Blagues entre amigos.

Como a fundir o apelo nostálgico à memória, de "Viagem", com o desejo modernista por velocidade e liberdade antiparnasiana, de "Saudade", destaca-se "Viajante" (N 22, p. 11):

A minha lembrança acompanha o trem, sem cansaço.

Mas que viajante tão solitário é a minha lembrança para quem não existe o encanto dissipador das paisagens, o ingênuo pitoresco das estações.

A minha telegráfica, elétrica lembrança zomba da distância exaustiva dos caminhos, ri do esforço ridículo da locomotiva para produzir mecanicamente o vácuo abstrato e inferior da ausência. 
A minha lembrança leva a bagagem dum corpo querido de mulher.

Mas essas fugas da minha lembrança, acompanhando os trens vagabundos, saberão encher o vazio da tua ausência com tantas coisas suaves de ti que eu me julgarei fazendo também doces viagens de idílios em misteriosos veículos invisíveis.

E depois será inútil a peregrinação mensageira das cartas.

Embora contendo a dor pela amada distante, sobressai a confiança do eu-lírico no poder de sua lembrança e, logo, de sua poesia, capazes de "encher o vazio" da ausência da mulher. Isso porque, na criação poética de Aloísio Branco, a lembrança, à medida que acompanha o trem, levando na bagagem um "corpo querido de mulher", é telegráfica e elétrica. Porém, se o poeta parece incorporar a velocidade moderna, a um tempo, incansável viajante solitário, zomba dela, pois o poder das palavras lhe permite ultrapassála.

Enquanto a locomotiva faz um "esforço ridículo" para produzir mecanicamente ausências, o eu-lírico pode supri-las com a lembrança, criando poeticamente "misteriosos veículos invisíveis" para "doces viagens de idílios". Se em "Saudade" a tecnologia dos aviões, por possibilitar a aproximação entre as pessoas, dispensava o correio, aqui a própria memória inutiliza as cartas, à medida que se exerce como mediação poética das distâncias. Mais eficaz do que locomotivas, a memória carregada de lirismo alimenta afetivamente o presente com imagens remotas.

De maior fôlego, tendendo à prosa, em "Véspera de Ano Novo" (N 12, p. 11) reencontram-se os traços da poética de Aloísio Branco até aqui apreendidos. Como em "Saudade", o espírito de blague surge no poema, em especial na ironia à vaidade das mulheres que, temerosas do efeito da velhice em seus rostos, se fiam nos "milagres dos Institutos de Beleza", passageiros. Contudo, esse traço de humor está integrado à tensão predominante, já notada em "Viagem", entre o desejo de plenitude, de entregar-se ao novo (como o barquinho dos sonhos infantis), e a consciência dos limites, da passagem do tempo. E, diversamente de "Viajante", em que o potencial da memória e da poesia garante altivez ao poeta, em "Véspera de Ano Novo" certo tom melancólico deixa ver a insegurança do eu-lírico em relação ao futuro.

Os dois versos iniciais do poema concentram o dilema que o move: a despeito de ser véspera de um novo ano, este surge ao eu-lírico como iminência de morte. 
Os ponteiros dos relógios irão bater meia noite com um som lúgubre de dobre a finados.

$\mathrm{Na}$ seqüência, por um lado, o poeta quer acolher com simpatia as pessoas que depositam confiança no calendário: "mãos sonhadoras" que pregam às paredes "folhinhas intactas", cujos números dos dias "multiplicam felicidades". Por outro, além de concebêlas em sua fragmentação metonímica, o eu-lírico dirige o olhar para "o sorriso cético" dos chefes de família, cujo cansaço e preocupações desmistificam o aspecto falso das promessas de prosperidade no novo ano.

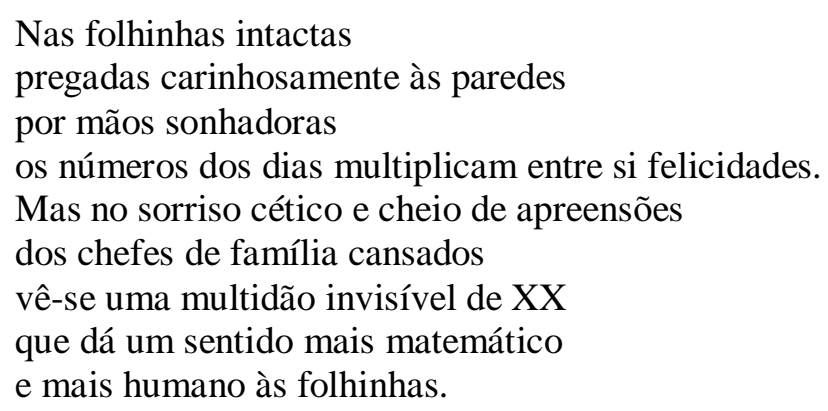

Assim, a poesia de Aloísio Branco nasce de sua sensibilidade à experiência cotidiana, em que busca alguma singeleza e renovação (os sonhos do Ano Bom) e a consciência crítica quanto aos problemas sociais (a aflição dos pais de família), recusando o mascaramento da realidade.

Ao mesmo tempo, os limites da vida em termos metafísicos movem sua poesia, redundando numa revolta expressa em associações de imagens de base concreta. Vendo nas folhas brancas do calendário uma ameaça de velhice, compara-as a futuras cãs e deseja arrancá-las:

Tenho vontade de arrancar uma a uma todas essas folhas brancas que marcam os dias vindouros como se arrancasse futuros cabelos brancos.

Nesse contexto, tem lugar também na poesia de Aloísio Branco um ímpeto religioso: este parece ligado a uma sensação de acolhimento maternal da cidade pequena (“a voz carinhosa dos sinos das igrejas"), mas não descarta a consciência de ser a natureza indiferente aos homens ("no eterno / onde esse medo ao tempo desconhecido / faria as estrelas darem boas gargalhadas").

No fim do poema, também se conjugam imagens da realidade concreta e abstratas: uma "canção indiferente" de bêbado irrompe na rua, o poeta anseia que o Anjo da Guarda dê corda em seu relógio protegendo-o de "horas de desdita" no ano vindouro. As 
preocupações com o outro social e consigo próprio confluem sob a mesma "ameaça de morte", reiterada no poema, apesar de ser anúncio de um ano novo.

E mais provocadora é a última combinação de imagens, em que o tom de blague não elimina, antes realça, o de melancolia.

\section{Amanhã passarei telegramas de feliz ano-novo \\ a todos os burros de carroça da cidade \\ e à alma duma namorada minha que morreu.}

Reconhece-se nesses versos o poeta solitário, para quem, paradoxalmente, só os seres desprezados e mortos (os animais explorados e a amada falecida) têm significação no ano-novo. Ao mesmo tempo, a apreensão quanto ao futuro, patente em "Véspera de Ano Novo", dá a dimensão das contradições sentidas nos anos 30 pelos moços da Novidade. Mesmo que Aloísio condene o atraso da cidade (com seus burros de carroça), ele vê o anonovo como continuação da véspera, lúgubre. Dessa forma, percebe-se ser a inquietação, em termos pessoais, coletivos e metafísicos, a marca de Aloísio Branco.

\section{Mundo menino ninando?}

Os dois primeiros versos de "Berceuse para embalar o mundo" (a Murilo Mendes, N 18, p. 11) desvelam Aloísio Branco como um poeta que traz excessivamente dentro de si uma inquietação com o mundo. Ao imprecar a este em segunda pessoa, pedelhe que descanse um pouco, porém logo se vê que não se trata de exterioridade, o mundo e seu cansaço estão dentro do poeta. Tamanho o peso de tal fusão lírica, o sujeito precisa que o mundo fuja de dentro dele, necessidade que move a "Berceuse":

Descansa um pouco tu que estás dentro de mim, mundo!

Foge de dentro de mim, mundo!

No entanto, antes de elucidar por que se aflige com o mundo, ao enfatizar que essa preocupação dominava seu espírito o poeta deixa ver que sua inquietação tinha uma face pessoal, concernente à esfera dos desejos amorosos não realizados.

E eu sinto que no deserto do meu ser físico a fuga do mundo não deixou o vestígio sequer da saudade dos seios durinhos de uma menina que eu não bolinei. 
Então, percebe-se que a angústia do poeta é incorporar os desejos espalhados por "todas as vozes" que vibram na "geografia universal", desde o frêmito capitalista norteamericano até o ideal revolucionário russo, passando pelo silêncio dito selvagem africano, o misticismo asiático e as ideologias políticas européias. Diante dessa diversidade das “cousas terrestres" e seus ruídos, o eu-lírico quer recolher-se em seus "ouvidos religiosos". Almeja apartar-se das modernidades telegráficas, que dissolvem a beleza e plenitude próprias dos mitos, como das sereias.

O rumor dinâmico de New York, o silêncio selvagem da África, os ritmos místicos da Ásia, as ideologias políticas européias, a memória demoníaca de Lenine, as revoluções argentinas, todas as vozes, todos os rumores que andam vibrando na geografia universal

morreram neste momento para os meus ouvidos religiosos porque este meu desejo súbito de fuga das cousas terrestres cortou todos os arames de telégrafo todos os cabos submarinos que vivem enredando os corpos das sereias.

$\mathrm{Na}$ composição do poema, repare-se que, em meio aos versos livres e longos, a repetição deste - "porque este meu desejo súbito de fuga das cousas terrestres" - esclarece a tensão indicada desde os dois primeiros versos: liricamente, expandindo-se e se angustiando em palavras, o poeta absorve o mundo mas se distancia dele, sofre com suas insuficiências.

Porque este meu desejo súbito de fuga das cousas terrestres ordenou aos anjos maus que levassem para a solidão ardente do inferno todas essas músicas dos cabarets de Broadway e todos esses manifestos de Staline que as ondas artesianas sacodem pelo espaço.

Ao tempo em que o atraem, "as músicas dos cabarets de Broadway" e "todos esses manifestos de Staline" revelam desejos insatisfeitos.

Eis que, reforçando-se a intensidade de sua tensão entre o apego ao mundo e a recusa dele, o poeta se define por seus anseios, passando da expressão "este meu desejo" a "sou um desejo".

Sou um desejo que sobe que vara as nuvens e que encontra lá muito no alto a alma de Saint-Romain ouvindo com saudade o ruído dos aviões atrevidos que tornam menos doloroso o exílio dos aviadores mortos. 
Fugindo das vozes da geografia universal, o eu-lírico com seus "ouvidos religiosos" parece buscar a ligação com outra esfera, não terrestre, mas além das nuvens. Ao mesmo tempo, mostra-se como seu ideal não uma plenitude abstrata, e sim o apaziguamento dos sofrimentos concretos de sua realidade. Veja-se que a imagem da alma de Saint-Romain, no céu, saudosa dos "aviões atrevidos", capazes de atenuar o sofrimento pelos aviadores exilados e mortos, alude ao sonho de libertar-se do peso da dor carregada pela guerra. A referência de Aloísio é o escritor francês Romain Rolland (1866-1945), autor do romance Jean-Christophe (dez volumes, entre 1904 e 1912), que recebeu o prêmio Nobel de Literatura em 1916. Romancista, dramaturgo, ensaísta, crítico, estudioso de música, biógrafo (de Beethoven, Michelangelo, Tolstoi, Gandhi), foi um dos maiores pacifistas do século XX.

Assim, nos anos 30, Aloísio Branco sente a perda da experiência num mundo em crise após a guerra, em que tantos deixaram para sempre suas casas. Tamanha a aspiração do poeta por um mundo diferente, cria mais uma imagem rica para denunciar a degradação dos sentidos autênticos do seu tempo. Buscando solidarizar-se com o mundo exilado, acalentar-lhe as dores, ele quer exilar-se de si próprio e da terra. Dramaticamente, fica como um cego desprovido também de tato, olfato, audição e paladar. Mais do que uma situação individual de um cego, a oração adjetiva polissêmica - "que procurasse em vão o resto dos sentidos" - qualifica a baixa da experiência mundial no pós-guerra, que logo se tornaria entreguerras.

Sou um desejo que abandonou o meu corpo todas as minhas raízes com que deixou o meu corpo desolado como um cego a terra que procurasse em vão o resto dos sentidos.

Encarnando o desejo de fugir do mundo, com suas ambições, guerras, revoluções, o horizonte do poeta é viajar pelo azul e livrar-se até da memória. Significativo paradoxo, na intenção de afastar-se do cotidiano, surpreende-se o homem afeito à literatura e às conversas de café, autofiguração de Aloísio Branco no grupo da Novidade, freqüentador da Helvética e do bar do Cupertino, o Ponto Central, junto com Aurélio Buarque, Valdemar Cavalcanti, Alberto Passos Guimarães, Carlos Paurílio, Barreto Falcão, Raul Lima, Diegues Júnior, José Lins do Rego e Graciliano Ramos. Mas o poeta não quer carregar lembranças de suas ambições e amizades literárias, nem de seus desejos amorosos. Talvez conserve apenas a recordação dos "seios mornos" da amada, porém como o "ambiente casto" do pequenino crucifixo, e aqui novamente se insinua o ímpeto religioso de Aloísio: 
Sou um desejo puro gótico nu que não leva na sua viagem pelo azul nem lembrança da literatura nem das conversas de café que talvez só leve a lembrança dos seios mornos da amada como do ambiente casto em que caía o seu pequenino crucifixo de marfim preso ao pescoço por uma volta de oiro.

Finalmente, vem a adversativa, a indicar que se frustrou o desejo do eu-lírico, de embalar-se a si e ao mundo e varar as nuvens, acalentando uma realidade outra. Incansável de perturbações, o poeta permanece premido pelas contingências do mundo, "exilado no chão", como "O albatroz" de Baudelaire. Se almejara as alturas, por fim se reconhece um desejo sem forças e "sem rumo", derrotado: é o pássaro bêbedo que teve as asas cortadas pelo diabo no inferno e caiu, definitivamente desolado. E aqui a tradição poética evocada é "O corvo", de Poe, a repetir o sombrio "Nunca mais". Melancolicamente, o eu-lírico expressa que, mantendo-se inquieto em relação à realidade, agora descrê de encontrar um sentido integrador para o mundo. Sua aflição se traduz à medida que se refere a si mesmo como um pássaro, "um desejo fraco", mas na terceira pessoa, não mais na primeira. $\mathrm{O}$ ritmo, feito o tempo todo de encadeamentos sem muitas pausas, torna-se ainda mais sufocante. E o emprego do advérbio "monstruosamente" e do adjetivo "decorativa" caracterizam a sua sofrida descrença num caminho religioso católico, o qual se mostrava exterior e convencional. Lembrando aqui o "Cartão de visita" da Novidade, numa linha de continuidade apesar das diferenças entre o avô Renan e o neto Psichari, Aloísio ansiava por valores autênticos e não decorativos.

\footnotetext{
Mas agora eu já sou um pássaro tão doido tão bêbedo um desejo fraco que voou tão sem rumo tão desequilibrado que aproximou do inferno sem querer e o diabo cortou as asas dele e o deixou de repente cair na terra sobre o túmulo de Renan acreditando monstruosamente que os pequeninos crucifixos de marfim têm apenas uma função decorativa entre os seios mornos das mulheres morenas.
}

Desse modo, vivendo com intensidade seu cotidiano, a um tempo atraído pela modernidade técnica e angustiado pela preocupação com o outro social e pela busca religiosa e metafísica, Aloísio Branco empenhou-se sempre, a partir da memória e da criação poética, em acalentar o mundo, à procura do "resto dos sentidos". 


\section{Fora da terra, com a guerra dentro}

Para se compreenderem melhor a "Berceuse para embalar o mundo", a poética de Aloísio Branco, o grupo da Novidade e a história da publicação de Caetés e de $S$. Bernardo, contribuem em especial algumas cartas de Graciliano Ramos.

Como se leu na "Berceuse", vitais para Aloísio eram a literatura e as conversas de café. Na correspondência escrita em Maceió para Heloísa, Graciliano deixa ver que tinha apreço pelo jovem poeta, ávido por livros e por discussões sobre literatura, mas considerava excessivo o apego do moço. Nestas cartas, de 26 de setembro e 4 de outubro de 1930, alude às visitas de Aloísio, que o impediam de terminar Caetés:

Se não surgirem complicações, como dizia o dr. Liberato [médico, personagem de Caetés], julgo que darei o trabalho concluído em fim de outubro. Se não aparecerem complicações... e se o Aloísio Branco consentir.

À noite, se o Aloísio consentir, vou mexer num capítulo [de Caetés], a ver se mando logo para o Rio aquela encrenca [os originais do romance para Schmidt publicá-lo]. ${ }^{73}$

Observe-se que, a 27 de setembro de 1931, Aloísio Branco e Jorge de Lima se mudaram para o Rio de Janeiro, este provavelmente por causa de perseguições políticas (sofrera um atentado à bala). Moacir Medeiros entende que a viagem dessas "duas maiores figuras do Modernismo em Alagoas" praticamente encerrou a fase mais importante do movimento ali ${ }^{74}$. Fato é que a Novidade deixou de ser publicada em setembro e, nos dois últimos números, trouxe os tópicos “Um jantar” (N 23, de 19 de setembro, p. 4) e "O jantar a Aloísio Branco" (N 24, de 26 de setembro, p. 15). Nessas notas, anunciava-se que a revista iria patrocinar, no Bar Alemão, um "jantar cordial” de homenagem a ele. Essa festa de despedida na véspera de sua viagem para o sul do país foi oferecida por um grupo de amigos e admiradores da "inteligência viva e inquieta" de Aloísio Branco, dentre os quais Jorge de Lima, Graciliano Ramos, Carlos de Gusmão, José Lins do Rego, Barreto Falcão, Raul Lima, Valdemar Cavalcanti e Aurélio Buarque de Holanda. A este caberia o discurso de adeus da gente moça de Alagoas a Aloísio.

Então, a 2 de outubro, já no Rio de Janeiro, Aloísio escreveu a Graciliano perguntando-lhe se recebera as provas tipográficas de seu livro (Caetés). O poeta

\footnotetext{
${ }^{73}$ RAMOS, Graciliano. Cartas a Heloísa de Medeiros Ramos. Maceió, 26 de setembro de 1930; Maceió, 4 de outubro de 1930. In: Cartas. cit., p. 111; p. 115.

${ }^{74}$ Cf. SANT’ANA, Moacir Medeiros de. História do modernismo em Alagoas (1922-1932). cit., pp. 233-4.
} 
encontrava-se na Livraria Católica, de Augusto Frederico Schmidt, junto de Rômulo de Castro, secretário deste ${ }^{75}$. Confirmando ter sido Aloísio um provinciano muito inquieto e inclinado a vôos metafísicos e poéticos, ele próprio aponta a Livraria Católica como refúgio para seus nervos, que estranhavam o "tumulto carioca"; e relata que ainda não resolvera nada sobre seu "caso prático" (provavelmente uma colocação no Rio, com a ajuda de José Américo de Almeida).

Meu caro Graciliano:

Estou the escrevendo da Livraria Católica em cujo ambiente calmo procuro um refúgio quase terapêutico para os meus nervos não habituados com esse tumulto carioca. Estou junto da bondade larga do Rômulo, que, neste momento mesmo, me fala, com um tom doce de nortista na voz, sobre os seus autores queridos e pede para você telegrafar a ele, ou ao Schmidt, se recebeu ou não as provas tipográficas do seu livro. Estas, segundo o Rômulo me disse, já foram enviadas de São Paulo há muitos dias. O grande sucesso literário do momento aqui é o romance de José Geraldo Vieira: A mulher que fugiu de Sodoma. Dizem que é um romance muito moderno, cheio de cousas à Conrad e à Proust. Só li deste livro um capítulo, que achei cheio de força humana, embora um pouquinho convencional. Até agora não resolvi nada sobre o meu caso prático.

Amanhã irei ter com o José Américo de Almeida. Rômulo e Schmidt mandam-lhe um abraço. Você abrace toda a turma boa daí.

Do amigo

Aloysio

Rio, $2-10-31^{76}$.

Num tom de ironia bem-humorada, a resposta de Graciliano Ramos denota seu afeto pelo jovem Aloísio. Como este não enviara seu endereço do Rio, obrigara o romancista a adivinhar a "região intermediária" em que se achava o destinatário, ou seja, a Livraria Católica. Nessa brincadeira muito pertinente, Graciliano define com precisão o temperamento do moço, de quem se afasta por não ser religioso, mas se aproxima no

\footnotetext{
${ }^{75}$ Observe-se que a Livraria Católica, no Rio de Janeiro, era de Jackson de Figueiredo. Em 1929, foi comprada por um grupo de amigos liderados por Alceu Amoroso Lima e entregue a Augusto Frederico Schmidt para que a administrasse. Em 1930, já como Schmidt Editora, publicou O país do Carnaval, de Jorge Amado, A mulher que fugiu de Sodoma, de José Geraldo Vieira, e João Miguel, de Rachel de Queiroz. Lançou em seguida, dentre outros: Caetés, de Graciliano Ramos, Casa grande \& senzala, de Gilberto Freyre, Oscarina, de Marques Rebelo, Maquiavel e o Brasil, de Octávio de Faria, Maleita, de Lúcio Cardoso. (Cf. MEY, Letícia; ALVIM, Euda. Quem contará as pequenas histórias? Uma biografia romanceada de Augusto Frederico Schmidt. São Paulo: Globo, 2005, p. 99, p. 122).

${ }^{76}$ Aloísio Branco. Correspondência passiva de Graciliano Ramos. (Arquivo Graciliano Ramos - Instituto de Estudos Brasileiros, IEB-USP).
} 
desejo de eliminar / emendar o mundo (como revelou Carpeaux): Aloísio vivia "fora da terra", mexendo em livros e almejando uma guerra que causasse o fim das máquinas, o sofrimento dos homens e, por conseguinte, a salvação.

Assim, reencontram-se na carta traços marcantes do poeta da "Berceuse", conhecidos por Graciliano Ramos: o amigo era religioso, distraído, totalmente envolvido pela literatura e absorto pelos problemas mundiais e dores humanas. Também se identifica na carta o pendor de crítico de Aloísio, interessado em dialogar com o Velho Graça sobre o sucesso literário de então, A mulher que fugiu de Sodoma, de José Geraldo Vieira. Mesmo tendo lido apenas o primeiro capítulo do romance, considerado por todos muito moderno, reconhece como valor sua força humana e lastima sua face convencional.

Ironizando que a velocidade moderna e o linotipo serviam a finalidades católicas, Graciliano se ri do temor do jovem provinciano ante a modernidade carioca, cobra-lhe por fim um abraço e desconfia das promessas de Rômulo e do editor Schmidt. A carta é reveladora do início da escrita de S. Bernardo: desanimado porque demoravam a chegar as provas de Caetés, Graciliano abandonara "os trabalhos rurais" e os estudos sobre gado em que estava envolvido ("Oito capítulos perdidos e mais a leitura dumas coisas sobre zootecnia para descobrir o Schwitz e o Caracu").

Surpreende-se também na resposta a Aloísio o cotidiano de Graciliano em Maceió: as queixas devido ao excesso de café e às escassas e pouco interessantes leituras (apenas duas obras sobre a Rússia); as conversas sobre literatura com os amigos, como o jovem Aurélio, insatisfeito com um diálogo do citado livro de José Geraldo Vieira.

Aloysio:

Desejo que Nosso Senhor o ilumine sempre com a sua divina graça.

Você não me mandou endereços, naturalmente porque vive fora da terra. Infelizmente o carteiro não vai a esses lugares por onde você anda - e eu sou forçado a escolher uma região intermediária, a Livraria Católica. Está o meu amigo agora lá, mexendo nos livros e desejando que uma guerra das brabas espatife todas as máquinas e traga aos homens a quantidade de sofrimento necessária à salvação que procuramos.

Nós aqui continuamos a achar bom o automóvel, pelo menos para levar com rapidez confissão e absolvição a um doente que quer morrer depressa. E pensamos que o linotipo e os navios nos oferecem publicações católicas sem atraso e numerosas.

A propósito de linotipo, ainda não me vieram as provas. Mas recebi uma carta de São Paulo com a notícia de que a composição está concluída. O resultado dessa demora é que fiquei desanimado e abandonei os trabalhos rurais a que me vinha dedicando. Oito capítulos perdidos e mais a leitura dumas coisas sobre zootecnia para descobrir o Schwitz e o Caracu. Deixei isso. 
O café abundante continua a arrasar-me os nervos. Nenhuma leitura, além de duas obras sobre a Rússia, pouco interessantes. Vi esse livro de que você falou: o Aurélio esteve a cacetearme com um pedaço de diálogo muito mal feito.

Adeus, meu caro Aloysio. Desejo-lhe felicidades. Abrace o Rômulo e o Schmidt. E abraceme também.

Graciliano

Maceió $-16-10-1931^{77}$.

\section{O quarto de livros, gaiola azul}

Não apenas Graciliano viu em Aloísio o rapaz digno de atenção e amizade, que mexia nos livros e sonhava com uma guerra capaz de levar os homens à salvação. José Lins do Rego, no artigo "Um poeta menino" (Jornal de Alagoas, 25 jan. 1928), assegurava existir no "menino irrequieto" que lhe invadia a casa para dizer tolices e mexer nos livros "um verdadeiro poeta". Para ele, os poemas de Aloísio Branco traziam "a frescura e graça" duma coisa em cuja companhia a gente se sente bem. O "Poema à velha cidade de Alagoas", provavelmente sua primeira composição moderna, foi considerado por José Lins "duma tocante beleza, sobretudo porque o menino como que perdia ali todo o seu pernosticismo". Sobressai a imagem de Aloísio como jovem inquieto e muito apegado à literatura:

Fala [Aloísio Branco] por vício. Ninguém o pode aturar com as suas perguntas, os inquéritos e sua desgraçada literatura. (...) A literatura, porém, não o deixa. Literatura em tudo, até no andar desarticulado como um boneco engonço. ${ }^{78}$

E nas "Notinhas" do Jornal de Alagoas de 1 de fevereiro de 1928, apostando na força da poesia de Aloísio Branco, Jorge de Lima afirmava que as criações deste se diferenciavam do "caldo insosso" que as "bodegas do modernismo" ofereciam pelo país. Apontava a inegável influência de José Lins, que "desempenou o nosso poeta caçula" e iria disciplinar seu talento, verdadeiro.

\footnotetext{
77 "Primeira carta de Graciliano Ramos ao poeta Aloísio Branco, menos de três semanas após a viagem deste ao Rio de Janeiro, em companhia de Jorge de Lima, em 1931". O manuscrito aqui transcrito está em ROCHA, Tadeu. Modernismo e regionalismo. Maceió: Departamento Estadual de Cultura, 1964, p. 72.

${ }^{78}$ REGO, José Lins do. Um poeta menino. Jornal de Alagoas, 25 jan. 1928, p. 3. Apud SANT'ANNA, Moacir Medeiros de. (pesquisa e seleção). Documentário do modernismo (Alagoas, 1922/31). cit., p. 40.
} 
(...) Zé Lins desempenou o nosso poeta caçula e vai por certo disciplinar muita coisa de seu talento que é talento verdadeiro, que já não é mais esperança de asas, porém asas de alumínio forradas de seda. Ele já sobe alto como um avião. Ele subirá muito mais ainda. Conheço todos os seus poemas, toda a sua poesia que absolutamente não tem o gosto de muito caldo insosso que as bodegas do modernismo andam a nos dar a beber...

(...) Mas por que será que eu não esqueço o Aloísio? ${ }^{79}$

A força e a singeleza do jovem poeta alagoano insinuam-se nesta curiosa imagem fixada por Mário de Andrade, em carta a Jorge de Lima de 1929:

Em Maceió, Jorge de Lima... Em Maceió, Lins do Rego uma espécie de galinho-de-campina bem decente, com a vermelhidão por dentro, numa alvura de gente. Aloísio Branco quando aparece é assim uma espécie de estrela-do-mar branca e até transparente bem. Botando ele de pé numa paisagem, não sei se você pôs reparo, ele não atrapalha nada, a gente enxerga tudo da mesma maneira... ah, Maceió... (...) Jorge de Lima, não se amole com esta minha franqueza de lembrar. ${ }^{80}$

"O maior talento da geração": assim Manuel Diégues Júnior considerava Aloísio, oferecendo também informações sobre ele.

Também tinha suas raízes em engenho Aloísio Branco, grande inteligência de poeta e prosador, larga cultura em sua idade, o maior talento da geração, morto na casa dos trinta anos. ${ }^{81}$

As informações biográficas a que tive acesso sobre Aloísio Branco são poucas ${ }^{82}$, provavelmente porque ele morreu jovem e sem ter publicado nenhum livro. Aloísio Machado Branco Bezerra nasceu em São Luiz do Quitunde, a 6 de janeiro de 1909, e faleceu em Maceió, a 4 de fevereiro de 1937. Em 1924, era David d'Alcobaça, prosador e poeta lírico de 15 anos e membro da Academia "Olavo Bilac". Na Gazeta de Notícias escreveu arrebatados versos parnasianos a Mathilde d'Ávila, atriz da Companhia de Operetas e Revistas Colyseu dos Recreios, que se apresentava no Teatro Deodoro.

\footnotetext{
${ }^{79}$ LIMA, Jorge de. Notinhas. Jornal de Alagoas, 1 fev. 1928, p. 3. Apud SANT'ANNA, Moacir Medeiros de (pesquisa e seleção). Documentário do modernismo (Alagoas, 1922/31). cit., p. 43.

${ }^{80}$ ANDRADE, Mário de. Carta a Jorge de Lima. 19 de maio de 1929. In: 71 cartas de Mário de Andrade. Ed. prep. por Lygia Fernandes. Rio de Janeiro: Livraria São José, 1968, pp. 120-1.

${ }^{81}$ DIÉGUES JÚNIOR, Manuel. O bangüê nas Alagoas. $3^{\mathrm{a}}$ ed. Maceió: Edufal, 2006, p. 284.

${ }^{82}$ Cf. SANT'ANA, Moacir Medeiros de. História do modernismo em Alagoas (1922-1932). cit., pp. 101-3; CAVALCANTE, Simone. Literatura em Alagoas: ensino médio e vestibular. cit., pp. 59-61; BARROS, Francisco Reinaldo Amorim de. ABC das Alagoas: dicionário biobibliográfico, histórico e geográfico das Alagoas. 2 v. cit.; MORAES, Dênis de. $O$ velho Graça: uma biografia de Graciliano Ramos. cit., pp. 241-2; VASCONCELOS FILHO, Marcos. Marulheiro: viagem através de Aurélio Buarque de Holanda. cit., pp. 735 .
} 
Influenciado por José Lins e por Jorge de Lima, em 1928 Aloísio compôs seus primeiros poemas afeitos ao modernismo. Como já dito, em outubro de 1931 foi com Jorge de Lima para o Rio. Estudou Direito em Niterói, tendo concluído o curso em Recife, junto com Aurélio Buarque, em 1936. Colaborou em diversos periódicos, como Jornal de Alagoas, Gazeta de Alagoas, A Província (Recife) e Boletim de Ariel (Rio de Janeiro). Aloísio trabalhou como foca de revisão no Correio da Manhã, que teve como editorialistas Otto Maria Carpeaux e Álvaro Lins (e, na cúpula da redação, nos anos 1940, os alagoanos Costa Rego, Aurélio - depois Graciliano - e Rodolfo Motta Lima). Foi idealista do integralismo e, de volta a Alagoas, oficial de gabinete do governador Osman Loureiro. Pretendia seguir a carreira diplomática, mas morreu aos 27 anos.

Além dos poemas da Novidade, Aloísio publicou: "O elogio lírico do vento" (em Maracanan, 1928), "Inverno” (1929), “Conflito”, “A canção lírica da chuva” (1930), "Ascetismo lírico" (1931), "O pária” (1932), "Poema da mulher transatlântica" (1936), "Dia de finados" (1937).

Encontrei na Revista do Brasil de fevereiro de $1940{ }^{83}$ estes poemas, publicados postumamente: "Oração de escravo fugido", "Obediência", "Raiozinho de luar", "Poema em louvor do telefone". Comentários breves já evidenciam que tais poemas merecem leitura cuidadosa. Em "Oração de escravo fugido", com linguagem coloquial e afetiva, partindo da cumplicidade brasileira com os santos, desvenda criticamente a dor dos africanos, exilados, explorados e sem rumo por causa da escravidão. Dá voz ao escravo fugido, que pede para São Benedito, o Negro, ensinar-lhe o caminho de Luanda, ameaçando-o de denunciá-lo ao ioiô do engenho como "negro fujão" também.

"Obediência" se faz de imagens singelas: o mar doce, "mais manso do que um menino / que não leva castigo na escola", vela o sono dos "filhinhos dos pescadores"; as velas brancas das jangadas, "casto rebanho", lembram ao poeta seu carneiro de nome Jasmim.

Em "Raiozinho de luar", a carga afetiva ante a brecha de luz que lhe invade o quarto, para beijar-lhe a testa, combina-se à ironia com que lastima a infelicidade dos "poetas ricos como Oswald de Andrade", desprovidos do "raiozinho" em seus "palacetes bem forrados".

\footnotetext{
${ }^{83}$ Revista do Brasil, fev. 1940, ano III, $3^{\text {a }}$ fase, n. 20, pp. 41-3.
} 
No "Poema em louvor do telefone", o objeto concreto, da modernidade, fascina o poeta por trazer-lhe a "voz longínqua" da Amada, servindo a seu amor platônico. E assim Aloísio Branco critica seu "século mecanicista", que descarta mensagens afetivas.

Confirmadores de sua inquietação literária e de seu empenho pela "atualização da inteligência artística brasileira", Aloísio Branco escreveu para a Novidade ensaios de crítica sobre escritores estrangeiros e sobre cinema: "A Poesia de Jean Cocteau", "Oscar Wilde", "Notas sobre o espírito de Dostoiewski" e "A Filosofia de Ramon Novarro". Embora todos mereçam leitura minuciosa, comentarei em particular os dois primeiros mencionados, em que Aloísio estabelece vínculos entre a literatura estrangeira e a literatura e crítica brasileiras. Também demandam atenção os ensaios de crítica que Aloísio Branco publicou no Jornal de Alagoas nos anos 1930, como "Jorge Amado chez Le sururu" ${ }^{84}$. Nas palavras de Aurélio Buarque em entrevista a Homero Senna, Aloísio Branco, "morto aos 27 anos, foi uma das mais brilhantes promessas de ensaísta que já tivemos" ${ }^{\text {} 85}$.

No ensaio "A Poesia de Jean Cocteau" (N 03, p. 11), Aloísio Branco parte da percepção de que a "estranha poesia" deste vivia dramático conflito entre seu ideal de arte e sua realização até então. Não se tratava da busca impotente de perfeição, mas de o poeta libertar-se dos deleites literários que o perseguiam, lutando com seus próprios defeitos. Segundo entende Aloísio, derivada de uma espécie de ascetismo platônico, a arte de Cocteau era "agudamente voluptuosa no sentido abstrato das cousas". Mesmo considerando que a poesia moderna demanda um acordo entre leitor e poeta, o crítico alagoano temia que a arte de Cocteau atingisse um "despotismo lírico": suas imagens do concreto se tornariam incompreensíveis, de tão abstratamente deformadas.

Então, importa ver como a crítica ao poeta francês integra a preocupação de Aloísio Branco com a literatura brasileira. Para ele, Cocteau incorrera no erro comum a nossos grandes poetas, como Bilac, Cruz e Souza e Alphonsus de Guimaraens. Mais do que isso, Aloísio tinha-o como o erro de quase toda a história da literatura brasileira: a submissão do sentimento à "camisa de força dos requintes intelectualistas", o excesso de confiança em construções da inteligência.

\footnotetext{
${ }^{84}$ Agradeço a obtenção desse texto a César Braga-Pinto, estudioso da obra de José Lins do Rego.

${ }^{85}$ Cf. SENNA, Homero. Como se faz um dicionário. In: República das letras: entrevistas com vinte grandes escritores brasileiros. cit., p. 265.
} 
É que a vitória sobre o sentimento só vale, a meu ver, quando é alcançada no seio do próprio sentimento, e não fora dele. Quando um sentimento profundo vence e substitui um sentimento frívolo.

Tal defesa da verdade lírica contra o falseamento da realidade se reitera no ensaio "Oscar Wilde" (N 21, pp. 3, 12). Observando que a obra de arte mais fascinante deste foi a vida, Aloísio Branco defende que estudar seus livros sem levá-la em conta oferece uma visão incompleta de sua obra. Então, procura caracterizar alguns fatos da vida de Wilde, detendo-se em especial no episódio da prisão.

Pondera que há temperamentos concentrados, sem encanto ao falar, mas de escrita admirável; e outros, como Wilde, brilhantes no falar, porém inferiores no escrever. Relata que Gide passava horas a ouvir o irlandês narrar belas fantasias. Destaca que Wilde fôra chamado com razão "Le Roi de la Vie" em Paris: passeava pelos boulevards sua figura de gentleman com uma grande flor na mão. Sempre foi gentleman, sobretudo quando o levaram para a cadeia e ele quis pagar seu coche.

Aloísio Branco se compadece da prisão do escritor, confundido com criminosos e obrigado a mover com suas "mãos espirituais e femininas" as rudes máquinas da oficina do cárcere. Ressalta que, ao sair Wilde da cadeia, faltaram-lhe dinheiro e um amigo que simpatizasse com a sua desgraça; seu tormento era pior que o do leproso. ${ }^{86}$

O crítico brasileiro crê que Wilde tivesse desejado, por pura imaginação, ser também um pouco criminoso. Aponta-lhe o "diletantismo da canalhice", mas admira seu esforço por "aguçar o pecado em alegria artística". Ao mesmo tempo, com sua compreensão religiosa, Aloísio julga que Wilde deve ter passado amargos instantes de ateu meio doloroso.

Contudo, na seqüência do ensaio, Aloísio Branco substitui a compaixão por uma gargalhada: acusa a covardia de Wilde, que teria sido sempre o maior inimigo do real. Mudou de nome, deixou o instinto de conservação vencer o instinto de beleza e chegou a um grotesco desespero.

Então, Aloísio Branco se volta para a recepção da obra de Oscar Wilde no Brasil, destacando os nomes de Elísio de Carvalho e de João do Rio. Chama-os de "dois grandes maníacos", acusando a incapacidade deles de escreverem um bom ensaio crítico e uma boa

\footnotetext{
${ }^{86}$ Por infringir a lei que proibia práticas homossexuais, Oscar Wilde foi condenado a dois anos de reclusão e trabalhos forçados, tendo ficado no cárcere de Reading, não muito longe de Londres. Cf. VIZIOLI, Paulo. Introdução a WILDE, Oscar. A balada do Cárcere de Reading. Tradução de Paulo Vizioli. Edição bilíngüe. São Paulo: Nova Alexandria, 1997.
} 
biografia do ídolo. Cobra-lhes um "controle fortemente analítico" que explicasse os motivos da "obsessão" por Wilde, para que não se tornasse apenas "ridícula".

Aloísio observa criticamente que, para Wilde, escrever um livro interessante era mais uma "função do dândi que do escritor", preocupado igualmente com a escolha de uma gravata e de um paradoxo ${ }^{87}$. Recorda um comentário de Jorge de Lima, segundo o qual o "snobismo de Wilde" era como uma terrível arma da estupidez contra a inteligência. Mas Aloísio reconhece que o escritor, com medo ou vergonha de entregar-se todo à figura de Dorian, repartiu o espírito com Lord Henry e o pintor Basil. Só deu o corpo a Dorian, que não pensava: apenas guardava as reflexões "bizarras" do seu amigo, "a diabólica teoria do seu epicurismo".

Por fim, associando a vida de Oscar Wilde a um gabinete de fotógrafo, Aloísio Branco a critica pelo excesso de poses. E atribui à sugestão do "pecado à meia-luz" o fato de a figura de Wilde permanecer tão grata à imaginação burguesa e popular.

Dessa forma, nos ensaios, Aloísio Branco condena a falsidade dos requintes de inteligência dos escritores e críticos, em especial brasileiros, para erigir como valor a verdade dos sentimentos, cuja expressão atenderia conjuntamente à necessária representação da realidade brasileira. Imerso sempre nos livros e nos problemas nacionais e mundiais, movia o ensaísta a necessidade de refletir criticamente sobre as obras de arte e seu sentido no mundo.

Jorge de Lima escreveu "Elegia e notícias da terra para Aluísio Branco", publicado no Diário da Manhã de Recife, a 20 de novembro de $1938^{88}$. Com saudade e admiração, dirige-se ao jovem poeta, morto em fevereiro de 1937, reiterando a apóstrofe "Ó jovem cristão". A força das imagens desse poema de Jorge ilumina os traços de Aloísio depreendidos aqui, da análise de sua obra e dos comentários críticos sobre ele: a face católica, as "mãos inquietas", os "gestos ainda infantis", "as insônias" e "as noites de infindáveis conversas / transformadas em hastes floridas", o abrigar em seu corpo as "asas de raros pássaros”.

\footnotetext{
${ }^{87}$ Lima Barreto também criticara a admiração (de Gastão Cruls) por Wilde, condenando-lhe a falta de "senso da vida", de "força de execução" das obras e as "poses de artista requintado". (BARRETO, Lima. À margem de Coivara, de Gastão Cruls. A.B.C., Rio, 23 jul. 1921. Impressões de leitura. Crítica. Prefácio de M. Cavalcanti Proença. São Paulo: Brasiliense, 1956, pp. 86-91).

${ }^{88}$ LIMA, Jorge de. Elegia e notícias da terra para Aluísio Branco. Poemas dispersos. In: Obra completa. cit., pp. 973-4.
} 
Denotando a tendência religiosa e a inquietação de Aloísio ante as "horas inseguras" da vida, em termos político-econômicos e existenciais, Jorge de Lima transmite singelamente as "notícias da terra" ao amigo morto:

Jovem cristão,

aqui a vida continua tímida e provisória.

E a "Elegia", ao lamentar a ausência do poeta nos serões, confirma o entusiasmo de Aloísio pelas conversas literárias e seu desejo de fugir do mundo mecânico e desumanizado, que corta asas aos albatrozes:

Os nossos serões estão vazios sem ti

e a ventania dos nossos coqueirais aprendeu o uivo dos homens.

(...)

Ontem um gladiador veio marchando

e afugentou os pássaros.

Mas fizemos tremular tua bandeira

sobre o mastro da nau.

Jorge de Lima definiu com precisão a força da poética de Aloísio Branco, que expõe a fragilidade humana ante o tempo e sente o cansaço do mundo, decorrente dos muitos rumores da "geografia universal".

Compreendes a sem-importância

do tempo e a fragilidade das grandes nações da terra

e visto como eras forte e como eras grande

com teus poemas e com tua fraqueza!

Sobressaem algumas imagens criadas por Jorge de Lima, em que se refletem sua própria poética - marcada por variadas faces, como a cristã - e a figura de Aloísio morto. Este menino impossível sofreu com as contingências do mundo e transformou sua insatisfação em formas poéticas, acolhendo múltiplos prismas. Sua ânsia por realidades outras só sossegava na inquietação infinita de prender-se ao quarto de livros, "gaiola azul".

Jovem cristão, coroado de espinhos, transformados em flores, teu rosto

sereno

se multiplicou em mil prismas celestes,

e o cubo sossegado de teu quarto de livros

pende de tua mão como uma gaiola azul.

E a imagem da "gaiola azul" traduz bem a condição paradoxal dos intelectuais e artistas num mundo de violência, presos e libertos pelas palavras. 


\section{Elegia e notícias da terra para Aluísio Branco}

Ó jovem cristão, a morte apurou tuas feições

e cerrou tua barba tênue, e transmitiu majestade às tuas mãos inquietas

e deu serenidade a teus passos, a teus gestos ainda infantis.

Pertences agora à grande raça,

e te imprimiste a bela face solene do Mestre!

ó jovem cristão,

a tua boca desmaiada que sabia poemas

e o orfeão de João Crisóstomo.

$E$ as tuas insônias e as tuas noites de infindáveis conversas

transformadas em hastes floridas pendem agora sobre os ouvidos das musas.

Sabes signos secretos; e tua estatura imponente e teus

cabelos de ramos em flor entrelaçados abrigam

asas de raros pássaros que ninguém avistou!

Compreendes a sem-importância

do tempo e a fragilidade das grandes nações da terra

e visto como eras forte e como eras grande

com teus poemas e com tua fraqueza!

Jovem cristão, coroado de espinhos, transformados em flores, teu rosto sereno se multiplicou em mil prismas celestes,

e o cubo sossegado de teu quarto de livros

pende de tua mão como uma gaiola azul.

Vives a existência inúmera e reservada das montanhas

sobre que planam as imensas constelações de Deus.

Jovem cristão,

aqui a vida continua tímida e provisória,

e os suicídios aumentam,

e cada tarde vermelha é um prenúncio de horas inseguras

em que sentimos o hálito da morte disfarçado entre as rosas.

Os nossos serões estão vazios sem ti

e a ventania dos nossos coqueirais aprendeu o uivo dos homens.

Só os negros ainda riem

entre um saxofone e dois banjos.

Ontem um gladiador veio marchando

e afugentou os pássaros.

Mas fizemos tremular tua bandeira

sobre o mastro da nau.

Jorge de Lima

(Novembro de 1938). 


\section{A literatura central dos homens da província}

Passados dois anos da morte do jovem Aloísio Branco, Valdemar Cavalcanti escreveu para o Diário de Notícias (Rio de Janeiro, 08 jan. 1939) "Lembrança do poeta", artigo em que recompõe afetivamente a figura do amigo, de forma a colaborar para o leitor de hoje conhecê-lo ${ }^{89}$.

De saída, uma informação relevante: Aloísio morreu de tifo em Maceió. E logo o leitor acompanha a comoção de Valdemar Cavalcanti que, pelas ruas, cafés e livrarias do Rio de Janeiro, ante todo jovem magro e pálido, de "olhar vivo e gestos desengonçados", revia Aloísio Branco.

$\mathrm{Na}$ caracterização do poeta, Valdemar delineia um tipo singular e parece definir os meninos impossíveis: é o migrante de origem provinciana, em busca de realizar-se como intelectual e artista, sem vergar de sua base ética. Identifica-o com os rapazes do norte que estampam na fisionomia a enorme bagagem de ilusões trazidas da terra natal. Aloísio seria o tipo de romântico que, encolhido em suas "qualidades essenciais", resiste às deformações do meio, numa luta dramática com a realidade.

Impregnando de poesia suas palavras, Valdemar distingue, no tumulto da cidade grande, o "quixotismo" que floresce em certos homens da província: são as "figuras cinzentas das pensões modestas - Aloísios Brancos multiplicados”, cujo desejo era "conservar a sua candura e a limpidez de suas intenções". Não seduzidos pela vaidade do mundo, nem tangidos pela ambição das altas rodas, conservavam-se "simples e leais", resguardando "com um fervor desesperado a sua expressão original de vida".

Valdemar Cavalcanti reconhece que, evidentemente, alguns cediam às tentações do ambiente e se deformavam em "caricaturas de si mesmos". Após um tempo nas bancas de jornal ou de academia, instalavam-se em empregos rendosos e, segundo ele enfatiza, mudavam "mais de temperamento que de posição social", mais por dentro que por fora. Vendiam a sua personalidade, renunciavam ao subúrbio em favor de Copacabana ou do Leblon e enchiam "a boca de ss e rr como se fosse de dentes de ouro".

Entretanto, conforme a experiência observada e vivida por Valdemar, muitos permaneciam retraídos em seu canto, inflexíveis a qualquer processo de assimilação. A maioria de seus conhecidos e amigos, como Aloísio Branco, continuavam, no Rio, vivendo

${ }^{89}$ CAVAlCANTI, Valdemar. Lembrança do poeta. Diário de Notícias, Rio de Janeiro, 08 jan. 1939. Agradeço a Leonardo Cunha, da Biblioteca da Fundação Casa de Rui Barbosa, do Rio de Janeiro, a gentileza de ter-me prontamente enviado esse artigo, presente na Coleção Jorge de Lima. 
à sua maneira, sem fazer concessões que implicassem condescendência com modos de ser diversos dos seus.

A Aloísio cabe até a censura de Valdemar, porque o amigo levara ao Rio muitos projetos literários, porém nenhum de vida prática. Não se lançara à aventura da viagem visando a uma situação financeira definida, e sim pelo gosto de experimentar ambientes e emoções novas, de descobrir tipos. "Não pensava em emprego, mas em romances e poesia".

Com espírito compreensivo, Valdemar sublinha que, num meio onde prevaleciam os interesses materiais, Aloísio só poderia sofrer “muita decepção cruel”. Contudo, realça que o poeta procurou resistir a tudo, com sua "camada grossa de idealismo", com sua literatura. Mais que simples devoção, para Aloísio Branco a literatura era uma mística.

Chega a impressionar o modo como Valdemar Cavalcanti atribui à literatura a maneira natural de ser do amigo, "naqueles 27 anos vividos sem disciplina". Explica que um mero afastamento do perímetro da literatura representava para Aloísio a ausência de si mesmo. Considera que a literatura era "toda a sua impertinência": a seus olhos, coisas e homens tinham sempre relevos literários, só sabia examinar o cotidiano em relação com o romance e sob o ponto de vista da poesia. A perspectiva literária constituía um "exclusivismo de visão que não estava na sua têmpera combater; era uma força imperialista que agia sobre o seu espírito".

Poderia o mundo movimentar-se em sentidos diferentes e ele [Aloísio Branco] tomaria conhecimento das coisas através das novidades de livraria. A vida, para esse extremista da literatura, não era bem a que se via nas ruas, se apresentava nos campos ou se encontrava dentro das casas, mas a que se expunha nos volumes que ele devorava como um glutão. E talvez por tudo isto, por essa mania de sentir as realidades pelos seus reflexos, talvez por isto chegasse a experimentar, ao contato com a vida, o gosto de monotonia do já visto e já sentido, e os homens de carne e osso supusesse uma fraca e mole representação dos heróis criados pela imaginação humana.

Eis que, descobrindo o poeta como um "extremista da literatura", glutão dos livros, Valdemar ajuda a entender um sentido da criação poética desse menino impossível: a insatisfação e angústia ante a monotonia da vida.

E o crítico relembra outros escritores que testemunharam o valor vital da literatura para Aloísio Branco: José Lins do Rego, Jorge de Lima, José Américo de Almeida, Ademar Vidal, Gastão Cruls, Agripino Grieco. Destaca os nomes de José Geraldo Vieira e Barreto Filho, amigos com quem o poeta tinha grande afinidade e se comunicou muito. 
Valdemar Cavalcanti observa que até o amor para Aloísio passava pelo filtro literário: ele descobria traços de lirismo e gestos de beleza romântica em criaturas sem saliência, de "um cinzento de vida quase desolador". Sua última amada foi uma violinista, que provavelmente o atraíra por causa da música, "voz de que a Amada se servia para melhor se comunicar com o meu pobre amigo".

Por fim, apontando-lhe a "estranha exuberância de imagens", Valdemar transcreve o poema "Véspera de Ano Novo", da Novidade. Vinha de reler, na revista de Maceió de 1931, "muitas das coisas extraordinárias” que Aloísio Branco nos deixou. 


\section{CAPÍTULO 7 - GRACILIANO RAMOS E A NOVIDADE}

O próximo que me obseda é já rosto, a um tempo comparável e incomparável, rosto único e em relação com rostos, precisamente visível na preocupação da justiça.

Emmanuel Lévinas. ${ }^{1}$

(...) se possui como traço distintivo o dom de exprimir-se a seu jeito, de acordo com o seu temperamento, o escritor contrariará sempre em alguma coisa os rumos gerais de seu tempo. Mas, vinculando-se a este mais do que o comum dos homens, pela sensibilidade mais viva, mais pronta a captar-lhe os influxos, em muitos pontos lhe dá de seguir e evidenciar as diretrizes.

Lúcia Miguel Pereira. $^{2}$

(...) Desgraçadamente não sei matar ninguém direito, mesmo no papel, e isto é uma vergonha para um sujeito mais ou menos perigoso.

(...) O meu bárbaro pensamento é este: um homem, uma mulher, dois meninos e um cachorro, dentro de uma cozinha, podem representar muito bem a humanidade. E ficarei nisto, enquanto não me provarem que os arranha-céus têm alma.

Graciliano Ramos. ${ }^{3}$

\footnotetext{
1 "Le prochain qui m'obsède est déjà visage, à la fois comparable et incomparable, visage unique et en rapport avec des visages, précisément visible dans le souci de justice". LÉVINAS, Emmanuel. Autrement qu'être ou Au-delà de l'essence. M. Nijhoff, 1978, p. 201. Apud ABENSOUR, Miguel. L' extravagante hypothèse. Rue Descartes, n. 19, 'Emmanuel Lévinas'. Paris: Presses Universitaires de France, février 1998, p. 82.

${ }^{2}$ PEREIRA, Lúcia Miguel. Cinqüenta anos de literatura, 1952. In: A leitora e seus personagens: seleta de estudos publicados em periódicos (1931-1943). Rio de Janeiro: Graphia Editorial, 1992, p. 251.

${ }^{3}$ RAMOS, Graciliano. Cartas a Benjamín de Garay: Rio de Janeiro, 22 de abril de 1937 [VII]; 13 de dezembro de 1937 [XVII]. In: Cartas inéditas de Graciliano Ramos a seus tradutores argentinos Benjamín de Garay e Raúl Navarro. Introdução, ensaios e notas de Pedro Moacir Maia; organização e apresentação de Fernando da Rocha Peres. Salvador: EDUFBA, 2008, p. 45; p. 69. Agradeço à Prof ${ }^{a}{ }^{a}$ Yêdda Dias Lima a indicação desse livro.
} 


\section{Caetés: novidade para o sem novidades}

"Seria uma felicidade para mim, de certo, a morte de Adrião". Esse desejo da morte do outro abre o capítulo XXIV de Cahetés, de Graciliano Ramos, publicado no número 9 do semanário alagoano, a 6 de junho de 1931. Aparecia como "página do romance que Schmidt Editor lançará brevemente no sul, escolhida especialmente para Novidade". O livro foi escrito entre 1925 e 1928 e reescrito até 1930. Anunciado embora para breve, saiu apenas no final de 1933, quando o romancista já havia terminado S.Bernardo, que viria a público em 1934. A recepção crítica primeira de Caetés, conforme relata Antonio Candido, coube a Santa Rosa, Valdemar Cavalcanti e Aurélio Buarque, para o Boletim de Ariel ${ }^{4}$. Esses meninos impossíveis exercitaram-se como críticos com o Velho Graça.

Por que Graciliano escolheu o capítulo 24 de Caetés para figurar no semanário? O leitor de hoje reconhece que esse capítulo concentra questões centrais do romance. Dele apreendem-se os dois caminhos de ascensão do protagonista João Valério: amante de Luísa, esposa do patrão (Adrião Teixeira), queria ocupar o lugar deste também na firma comercial e desejava ser autor de um romance histórico sobre os caetés, nativos de sua região (Palmeira dos Índios).

A composição desses elementos no capítulo, por dotá-lo de certa autonomia, era capaz de atrair o público da revista. Constituía novidade a construção irônica por meio da qual o escritor, repetindo o "nada de novo sob o sol" do Eclesiastes, desvendava criticamente as limitações de João Valério, arrivista leviano, e do seu ambiente, fincado na conservação de desigualdades sociais. Se no Eclesiastes se lê que tudo é vão, sendo iguais os homens porquanto mortais, de saída o leitor da Novidade ficaria intrigado com um narrador que diferenciava algumas mortes como mais importantes. Ansioso pelo desaparecimento do enfermiço Adrião, lamentava a imperícia do médico: este não impedira a morte da jovem e bela filha do prefeito, porém deixava viverem seres "inúteis", como Adrião e a mulher do sapateiro, pobre e tísica. Desse contraste de caracteres, ressalta o interesse egoísta como motor do protagonista: desejava apoderar-se do lugar do patrão para obter melhor posição financeira. Exatamente no capítulo 24 vem esta síntese da

\footnotetext{
${ }^{4}$ Cf. CANDIDO, Antonio. No aparecimento de Caetés. In: Ficção e confissão: ensaios sobre Graciliano Ramos. cit.
} 
leviandade afetiva, intelectual e moral do protagonista, que permite aproximá-lo do aspecto negativo da "cordialidade" brasileira conforme analisada por Sérgio Buarque de Holanda:

Em todo o caso nunca ousei descobrir a mim mesmo o fundo do meu coração. Não chegaria a pedir aos santos, se acreditasse nos santos, que abreviassem os padecimentos do Teixeira. Tergiversava. As minhas idéias flutuavam, como flutuam sempre. (Caetés, capítulo $24^{5}$ ).

Nesse sentido, recorde-se uma imagem recorrente em Caetés: a Bíblia, em especial o Eclesiastes, era o cofre de João Valério. Tal imagem sinaliza expressivamente que, para ele, segundo a lógica comercial vigente e seu desejo de ascensão, a prioridade era o dinheiro, fator a diferenciar as pessoas.

Note-se que o Eclesiastes é um texto bíblico de interpretação especialmente contraditória. Nele lateja um dilema em relação à fé, ao afirmar-se que tudo é vão, já que $a$ semelhança entre homens e brutos, entre sábios e estultos, é caminharem todos para a morte. ${ }^{6}$ No capítulo 24 de Caetés também ecoa esse questionamento do Eclesiastes quanto ao sentido da sabedoria. Pretenso escritor, João Valério pondera que, para compor o romance sobre os caetés, precisaria estudar história. No entanto, observa não ter paciência para viver curvado sobre os livros e logo descarta sua proximidade intelectual com o médico Liberato e com o tabelião Miranda. Mais do que isso, desfaz da necessidade de um tabelião em Palmeira dos Índios ser "tão instruído". De fato, em seu percurso, João Valério prefere à prática de escritor a lógica comercial de Adrião, que incluía arranjos e maroteiras, e ascende socialmente. Nada de novo: movido por uma ambígua ambição ambiente ${ }^{7}$, ele reitera em sua trajetória o círculo fechado de sua cidade, em termos intelectuais, sociais e

\footnotetext{
${ }^{5}$ RAMOS, Graciliano. Caetés. (Introdução de Antonio Candido, "Ficção e confissão"). $5^{\mathrm{a}}$ ed. Rio de Janeiro: José Olympio, 1955.

${ }^{6}$ Ao mesmo tempo, a interpretação do Eclesiastes pode abrir caminhos para a religiosidade, ao se ressaltar a força da criação divina, em especial a possibilidade do cultivo da inteligência pelos homens, que os diferencie e eleve perante Deus. (Cf. Torá - a Lei de Moisés. Ed. Jairo Fridlin. Tradução e comentários de Meir Matzliah Melamed. São Paulo: Editora e Livraria Sêfer, 2001; Qohélet = : O-que-sabe: Eclesiastes: poema sapiencial. Transcriado por Haroldo de Campos. Colaboração especial de J. Guinsburg. São Paulo: Perspectiva, 1990).

${ }^{7}$ Considerando-se que no romance estão representadas as ambigüidades da ambição do protagonista, que não ultrapassa a passividade do seu ambiente (ele cerca o que o cerca), é sugestivo observar que os substantivos ambição, ambigüidade e ambiente se vinculam em sua etimologia. 'Ambição' deriva do verbo ambire, 'rodear, cercar por todas as partes'; ambicionar um objeto implica cercá-lo até consegui-lo. Já 'ambigüidade' vem de ambigere, 'rodear, cercar, duvidar'. E o particípio presente ambiens, entis, 'que rodeia', originou 'ambiente'. Todas essas palavras têm seu sentido decorrente do elemento comum de composição ambi-, cujo significado é 'em volta, de ambos os lados'. (Cf. CRETELLA JR, José \& ULHÔA CINTRA, Geraldo de. Dicionário Latino-Português. $3^{\mathrm{a}}$ ed. São Paulo: Companhia Editora Nacional, 1953).
} 
econômicos. Após o suicídio do patrão, descoberto o caso com Luísa, Valério ocupa o lugar dele na firma, tendo abandonado a mulher e também o projeto de escritor.

Importa observar aqui uma marca da composição do romance: a caracterização das personagens se faz por meio de muitas comparações, das quais se depreende a ironia do autor. Sendo assim, elas ganham singularidade e, a um tempo, tece-se a representação crítica da realidade. A partir da caracterização do pseudo-escritor e arrivista leviano, constrói-se a crítica ao ambiente social e intelectual restrito, tendo por substrato a tensão própria do Eclesiastes, entre sabedoria e brutalidade.

Se o "nada de novo sob o sol" representado pela trajetória de João Valério atende à consciência realista do escritor, a construção irônica do romance alerta para o perigo da indistinção de valores provocado pelas generalizações. No último capítulo, o narradorprotagonista rememora as marcas de leviandade de seu percurso e se reconhece um caeté "com uma tênue camada de verniz por fora". Por um lado, confirma-se o "nada de novo", o homem como um selvagem, movido pelo egoísmo para vencer os demais. Ao mesmo tempo, a ironia que reponta desse final, recaindo sobre a falta de consistência intelectual, afetiva e ética do guarda-livros arrivista, prova a diferenciação entre o humano e o bruto.

Essa inconsistência evidencia-se ante a morte do patrão. Na expressão lapidar de Graciliano, o personagem, "incapaz de sofrer muito tempo" (capítulo 30), teve "explosões súbitas de dor teatral, logo substituídas por indiferença completa..." (capítulo 31). Tal leviandade interesseira, de quem tomou Luísa por amante para abandoná-la após a morte de Adrião, sintetiza-se no período que fecha o romance: "Tenho passado a vida a criar deuses que morrem logo, ídolos que depois derrubo - uma estrela no céu, algumas mulheres na terra...” (capítulo 31). Significativamente, ao ironizar esse comportamento pautado em bajulação e rasteiras, o escritor tem em mira também práticas políticas como as do bacharel e deputado Evaristo Barroca. Com espírito crítico, verificado também na Novidade, contra um meio afeito à retórica e ao personalismo político em detrimento de uma formação cultural e autonomia reflexiva, sobressai a ironia ao despreparo intelectual de João Valério:

Não há ninguém mais crédulo do que eu. E esta exaltação, quase veneração, com que ouço falar em artistas que não conheço, filósofos que não sei se existiram! (capítulo 31).

Chamando a consciência histórica do leitor, a crítica ao ambiente marcado por falta de instrução e subserviência à cultura estrangeira revela, nas entrelinhas, os males 
provenientes da origem colonial do país e da manutenção da ordem dominante. Nesta, há os usurpadores e retóricos que vencem, porém às custas de muitos miseráveis, como os índios remanescentes. Por isso, Graciliano combate generalizações: João Valério por fim se diz um caeté; contudo, ele venceu com sua preguiça e inconstância, estereótipos atribuídos aos índios que, ao contrário, foram derrotados no passado por resistirem ao trabalho escravo.

Repare-se, finalmente, como o contexto histórico de Caetés é melhor compreendido ao se conhecer a Novidade. Preocupações do semanário, a conservação da ordem social iníqua, a mendicância, a falta de instrução e o personalismo político são os problemas sociais a que Graciliano deu forma no romance. Não lhe falta nem a referência, embora periférica, a uma multidão de pessoas pobres que, adoradoras de um cajueiro com dois galhos formando uma cruz, eram exploradas por espertalhões. A expressão "lampionismo semi-civilizado", de Valdemar Cavalcanti, define bem o ambiente de Caetés. Nele despontam: o farmacêutico Neves e o tabelião Miranda, que tesouravam a vida alheia, em especial o adultério de Luísa; Manuel Tavares, o assassino que prestava serviços ao político Barroca; o bacharel Castro, que, por ser parente de Barroca, ocupava o cargo de promotor público para facilitar-lhe as falcatruas e era presidente da junta escolar sem jamais ter visitado uma escola.

Exemplar do "lampionismo semi-civilizado" é a cena do capítulo 11 em que o tabelião Miranda, com a concordância velada de Valério, se mostra favorável à intervenção da polícia contra os mendigos. Miranda fala em eutanásia, 'boa morte' para os indigentes, que considera "gente sem préstimo". Enquanto isso, o jornalista Pinheiro e o guarda-livros pretenso escritor ignoravam o significado da palavra eutanásia. Num livro que remete, desde o título, aos índios dizimados, já se vê a ironia criada por Graciliano, voltada contra a conservação da miséria e da ignorância, contra a barbárie envernizada de civilização.

Dessa forma, depreendem-se de Caetés não só eixos temáticos, como também movimentos composicionais da formação da obra de Graciliano Ramos. A força irônica da comparação entre personagens, em especial entre o protagonista e os caetés, comprova a necessidade ética de atentar-se para as semelhanças e diferenças entre os seres, combatendo estereótipos. Como resultado, firma-se para o escritor o propósito de representação crítica da realidade social, do ambiente em que o poder se mantém por meio de maroteiras. E, a um tempo, do embate entre caracteres e da representação das desigualdades sociais, em busca de uma forma artística mais depurada para combater 
estereótipos, cria-se para o romancista a necessidade de expressar os impasses subjetivos aí envolvidos em sua tragicidade, conforme se veria a partir de S. Bernardo.

É relevante considerar o Eclesiastes - pensando-se em especial na vanidade de tudo e na tensão entre ser homem e ser bicho - também para compreender os dramas de Paulo Honório, Luís da Silva e Fabiano, os quais serão o centro de ensaios analíticointerpretativos neste capítulo. Em S.Bernardo, Paulo Honório afirma que realizou atos bons que lhe deram prejuízo e cometeu crimes lucrativos. Sobretudo, recorde-se o terrível "para quê?" do proprietário ante a morte da professora e tardiamente reconhecida como sua amada Madalena. "Para quê?" também pergunta o vaqueiro e retirante Fabiano, de Vidas secas, diante de sua realidade seca, desejoso e descrente ante a instrução de Seu Tomás da Bolandeira. Igualmente, em Angústia, o funcionário público e intelectual frustrado Luís da Silva anseia pelos sentidos, pois ter matado Julião Tavares não eliminou as injustiças do mundo nem sua dor.

\section{Novidade: os romances dos anos 1930}

Como se viu, escrito entre 1925 e 1928, Caetés tece uma crítica ao ambiente intelectual e social restrito de Palmeira dos Índios e teve um capítulo publicado na Novidade, periódico nascido contra essa estagnação cultural. Significativamente, saber que o capítulo 24 do romance saiu nessa revista foi caminho para conhecer que Maceió nos anos 1930 reuniu um grupo notável de intelectuais e escritores responsáveis por ela, muitos dos quais, migrados para o Rio de Janeiro, seriam grandes expressões da cultura e da arte.

Aqui é produtivo evocarem-se os sentidos de romance e de provinciano, apreendidos de Ortega y Gasset, válidos para a compreensão da literatura como da vida. Avaliando que o romance europeu nos anos 1920 estava em decadência, o crítico espanhol a atribui à falta de temas. Resgata, argutamente, da palavra espanhola novela (em português, romance) a sua alma desgastada pelo uso: o traço semântico de novidade. Entretanto, por considerar que as melhores obras são criações das decadências, devido à experiência acumulada, o crítico ainda acredita no romance. Para além da trama, entende importar para o leitor a "invenção de almas interessantes". Segundo Gasset, mais do que em horizontes vastos, o romance deve centrar-se na representação da "vida provinciana", pequeno horizonte hermético que, dotado de vitalidade, desperta o interesse do leitor. 
Embora o microcosmos e o macrocosmos se diferenciem pelo tamanho do raio, para quem vive dentro de cada um eles são igualmente cosmos, têm o mesmo tamanho absoluto. Daí Gasset extrai uma lei vital, que na ordem estética torna possível o romance: "a relatividade entre horizonte e interesse", ou seja, "que todo horizonte tem seu interesse". ${ }^{8}$

Em termos da compreensão das relações humanas, é iluminador relativizar-se o sentido pejorativo atribuído à palavra provinciano. Perspectiva crítica, senso de humour e conhecimento de "certas gradações de valores" (Manuel Bandeira ${ }^{9}$ ) constituem o bom provincianismo, de vitalidade central. É o caso dos meninos impossíveis da Novidade: formados criticamente ante a realidade alagoana dos anos 30, contribuíram muito com a cultura do país, residindo depois, em sua maioria a partir do fim dos anos 30, no Rio de Janeiro. Mas essa transferência para a capital federal, além de refletir o desejo de experienciar lugares outros e mais ricos em possibilidades, fala também do mau provincianismo do país, das injustas condições de vida, que obrigam as pessoas a emigrarem para os grandes centros econômicos.

Quanto à compreensão do romance, é também iluminador vê-lo como criação da "vida provinciana". Tal concepção é próxima à de Paul Ricoeur, para quem a mediação pela literatura oferece ao leitor uma "proposição de mundo" que rompe com a linguagem cotidiana e abre novas possibilidades de ser no mundo. Compreender significa compreender-se diante da proposição de mundo do texto, "expor-se ao texto e receber dele um si mais amplo" ${ }^{10}$, potencializando-se a metamorfose do sujeito e a do mundo.

Também Susan Sontag ${ }^{11}$ defende o alcance moral do romance, narrativa completa de uma história humana num mundo com "calculado encolhimento" de espaço e de tempo. Ela não apenas combate a idéia de que o romance nos moldes realistas não faria mais sentido (generalizada a partir das reflexões de Walter Benjamin no contexto do pós-guerra de 1914), como desvela o papel ético dessa forma artística: ao centrar-se num espaço

\footnotetext{
${ }^{8}$ ORTEGA Y GASSET, José. Novela: como 'vida provinciana'. La deshumanización del arte e Ideas sobre la novela (1925). In: Obras completas. $2^{\mathrm{a}}$ ed. t. III (1917-1928). Madrid: Revista de Occidente, 1950, pp. 407-10.

${ }^{9}$ Cf. BANDEIRA, Manuel. Um belo exemplo que A Província está dando, 1928. Crônicas inéditas I, 19201931. Organização, posfácio e notas de Júlio Castañon Guimarães. São Paulo: Cosac Naify, 2008, p. 148.

${ }^{10}$ Cf. RICOEUR, Paul. Interpretação e ideologias. Organização, tradução e apresentação de Hilton Japiassu. $4^{a}$ ed. Rio de Janeiro: Francisco Alves, 1990, pp. 54-9. (Na reedição, Hermenêutica e ideologias, pp. 63-9).

${ }^{11}$ SONTAG, Susan. Ao mesmo tempo: O romancista e a discussão moral. Conferência Nadine Gordimer. In: Ao mesmo tempo. Ensaios e discursos. Tradução de Rubens Figueiredo; organização de Paolo Dilonardo e Anne Jump; introdução de David Rieff. São Paulo: Companhia das Letras, 2008, pp. 220-240.
} 
determinado, o romance, nos limites da imaginação, atinge universalidade e cria solidariedade; cria a simultaneidade com a "dor dos outros", resistindo à simultaneidade habitual no mundo contemporâneo, de desgraças recebidas com indiferença.

Desse modo, com base em Gasset, em Ricoeur e em Sontag, entende-se o potencial de novidade da ficção, como também da poesia, formas artísticas que oferecem uma "proposição de mundo" e possibilitam a flexibilização do leitor. Logo, considerando-se o contexto brasileiro dos anos 1930, percebe-se como eram uma novidade singular as criações então apresentadas ao público, no geral romances de valor artístico, contrários à ênfase retórica e dedicados à representação da realidade social do país, das misérias sofridas pelo homem. No grupo de intelectuais que se encontraram em Maceió nos anos 1930 e tiveram na Novidade um de seus meios de expressão, estavam Graciliano Ramos e José Lins do Rego, futuros escritores desse romance novo brasileiro. Os três primeiros de Graciliano foram escritos em Alagoas (Caetés, 1933; S.Bernardo, 1934; Angústia, 1936), bem como os de José Lins (Menino de engenho, 1932; Doidinho, 1933; Bangüê, 1934).

No inquérito de 1942 aqui apresentado (capítulo 3), Graciliano Ramos destacou que, se o modernismo de 1922 falhou quanto à prosa, após 1930 "começou um trabalho de criação dos mais brilhantes, até 1936". Em "Decadência do romance brasileiro" (1941) ${ }^{12}$, observa que o Modernismo e a Revolução de Outubro, cuja importância é ora muito ampliada, ora negada, desobstruíram caminhos, cortaram amarras, exibiram coisas até então não enxergadas. Enfatiza que em 1930 surgiram desconhecidos de vários pontos, que escreveram numa língua próxima à do cotidiano, embrenharam-se pela sociologia e pela economia e revelaram a vida de trabalhadores e de vagabundos, as cadeias da roça, as bagaceiras, os canaviais, as fábricas. Entende que os melhores representantes do romance nordestino, Rachel de Queiroz, Jorge Amado, José Lins do Rego e Amando Fontes, tendo

${ }^{12}$ RAMOS, Graciliano. Decadência do romance brasileiro. Literatura, Rio de Janeiro, ano I, n. 1, set. 1946. Apud GARBUGLIO, J.C. et alii. Graciliano Ramos. São Paulo: Ática, 1987, pp. 114-6. Antes de sair no Brasil, esse artigo, cujo manuscrito data de 20 de outubro de 1941, foi publicado no Uruguai (Decadencia de la novela brasileña. Nueva Gazeta, Montevidéo, n. 11, dez. 1941. Cf. CARPEAUX, Otto Maria. Pequena bibliografia crítica da literatura brasileira. Rio de Janeiro: Edições de Ouro, 1968, p. 256) e também na Argentina, no início de 1942 (segundo carta de Graciliano a Nelson Werneck Sodré, de 2 de outubro de 1942, que consta do site da Biblioteca Nacional). Descobri essas informações junto com Erwin Torralbo Gimenez, cujo estudo atual se centra nas tentativas de romance de Graciliano nos anos 40.

Considerando que Graciliano se inquietou com a decadência do romance brasileiro a partir de 1935, as reflexões de Ortega y Gasset sobre a questão no contexto europeu ajudam a compreender a força de Infância, forma primorosa da verdade do viés subjetivo e do estilo do autor. Obra iniciada em 1937 e publicada em 1945, é a invenção artística, por meio da escrita da memória, de uma "alma interessante" numa realidade hostil e incongruente. 
vivido na província, "miúdos e isentos de ambição", alcançaram êxito porque foram muito "sinceros" ao contar o que viram e ouviram: eram "observadores honestos" e "bons narradores". Revelando sua concepção de literatura, forma em que pesa a verdade da matéria e da perspectiva pessoal do escritor, Graciliano atribui a decadência, a perda de novidade dos romances a partir de 1935, à não representação das coisas vistas pelo sujeito, das "pequenas verdades, essas que são nossas conhecidas" 13 .

Rachel de Queiroz, celebrando em 1972 os quarenta anos de Menino de engenho, relembra o tempo em que José Lins e ela estrearam com seus "romancinhos". Segundo afirma, ela causara espanto sobretudo por ser uma escritora garota, de dezoito anos, ao publicar $O$ quinze, em 1930, trazendo os retirantes famintos da seca de 1915. Já o amigo, na casa dos trinta anos e conhecido até no Rio por seus artigos e ensaios de crítica, surpreendia porque seu livro "era um marco, uma voz nova e clara a dar o seu recado como ainda não se dera, - e ao mesmo tempo fazendo obra de arte e da melhor". Rachel observa terem sido eles, os da "chamada 'geração de 30", os grandes beneficiários da "luta travada e afinal vencida pelos heróis da Semana de Arte Moderna". Passado o período de contestação e conquistado o direito à liberdade, também não eram necessárias estripulias com a língua, pois podia exprimir-se o falar brasileiro. ${ }^{14}$ Repare-se que, nos romances mencionados, a novidade artística advinha da representação da realidade social do país, da qual não se dissociava um viés intimista - a expressão dos confrontos subjetivos da professora Conceição, em $O$ quinze, e da memória do descendente de senhores de engenho Carlos de Melo, em Menino de engenho. ${ }^{15}$ É interessante notar que, em 1934, a escritora também residia em Maceió, após ter-se casado com José Auto da Cruz Oliveira, que publicou poemas na Novidade.

Nesta, a preocupação com o romance brasileiro evidencia-se num artigo de José Lins do Rego: "O último livro do sr. Plínio Salgado" (N 6, p. 12). Após ler O esperado, publicado exatamente em 1931, José Lins recusa-lhe a abundância de palavras e de pessimismo: "Não é, portanto, um livro real, um livro onde a gente leia o drama que anda

\footnotetext{
${ }^{13}$ RAMOS, Graciliano. O fator econômico no romance brasileiro, 1937. In: Linhas tortas. cit., p. 252.

${ }^{14}$ QUEIROZ, Rachel de. Menino de engenho: 40 anos. In: REGO, José Lins do. Menino de engenho. $17^{\mathrm{a}}$ ed. Rio de Janeiro: José Olympio, 1972. Apud COUTINHO, Eduardo F.; CASTRO, Ângela Bezerra de. (Orgs.) José Lins do Rego. Coleção Fortuna Crítica. Rio de Janeiro: Civilização Brasileira; Paraíba: Edições Funesc, 1990, pp. 238-241.

${ }^{15}$ Cf. BUENO, Luís. Uma história do romance de 30. São Paulo: EDUSP; Campinas: Editora da UNICAMP, 2006, pp. 156-7.
} 
apontando por todo canto do Brasil". O crítico lamenta que um dos heróis dessa obra se revolte contra o medo dos novos escritores brasileiros em relação ao excesso verbal e faça uma apologia deste. Comentando O estrangeiro (1926), observa que a ênfase do escritor paulista na descrição de cenários obsta a construção de uma verdade pungente, apenas esboçada por meio de suas personagens.

Mais do que criticar a abundância de palavras e de imagens de Plínio Salgado, José Lins rejeita-lhe a "vaidade doentia", a ambição de criar "o livro nacional". Citando Dostoiévski e depois Cervantes, entende que um romance só sobressai quando o autor entra na alma de seu povo e se dedica ao trabalho mental, o que exige recolhimento modesto.

Ora, o romance que se há de fazer do Brasil precisa é de um homem mais modesto, mais recolhido sobre ele mesmo.

Muitas vezes o tal livro que será todo um povo sai, como o de Cervantes, de um fundo fedorento de cárcere, cheio de humildade, e de uma riqueza que não se esgotará nunca.

Assim, é como se José Lins do Rego antecipasse um julgamento crítico que caberia à futura obra de Graciliano Ramos: a universalidade de um livro nasce em geral da concretude da vida precária e dos sofrimentos humanos nele figurados, a partir da "obstinação concentrada" ${ }^{16}$ do escritor, homem mais modesto e recolhido sobre si mesmo. Ao contrário, conforme prognosticava Zé Lins, autores ávidos da glória da eternidade morrem numa geração. E incluía entre esses Plínio Salgado, sufocado pelo peso de chumbo de sua retórica.

Finalmente, cumpre dimensionar o caráter problemático dessa novidade representada pelos autores e temas do chamado romance nordestino. Como a Novidade, essa ficção de 30 surgiu ante uma realidade cujo lugar-comum era a miséria, a violência do cangaceirismo, a falta de instrução, a política personalista. Por isso, a novidade dessa literatura, em especial a de Graciliano Ramos, é carregada da densidade dolorosa de um mundo velho, cujas injustiças combate. Sua autenticidade é construir artisticamente juntos o "problema moral" e o "problema social" da gente do país, conforme revela Otto Maria Carpeaux numa interpretação iluminadora:

\footnotetext{
${ }^{16}$ A expressão é de Graciliano Ramos em "Manhã", Infância.
} 
O romance brasileiro moderno não é, como parecem acreditar os leitores estrangeiros, o de um mundo novo em eclosão, mas o de um mundo velho em decomposição. Satisfaz à definição de Lukács: 'O romance é uma expressão de sem-abrigo transcendental, epopéia de um mundo que Deus abandonou'. Essa definição faz transparecer o problema moral dentro do problema social (ou vice-versa). Por isso, o romance brasileiro moderno já se elevou, em raros momentos, como em Angústia, à altura da tragédia. É o critério de sua autenticidade, como monumento da terra e da gente do Brasil. ${ }^{17}$

\section{Pena dos inteligentes}

Publicada na Novidade 8 e não incluída nos volumes de crônicas do romancista, "Chavões" destaca-se pela veemência irônica de sua crítica contra o lugar-comum. A um tempo revela o empenho crítico partilhado com os jovens do semanário e a singularidade da escrita de Graciliano Ramos.

É preciso perceber a complexidade da ironia construída pelo escritor: decorre de sua recusa de uma realidade cujas insuficiências ele necessita apontar; porém, ao mesmo tempo é a afirmação dessa realidade por uma consciência que, conhecendo como a ordem dominante se conserva, não quer enganar-se.

De saída, as entrelinhas deixam ver que, sendo o lugar-comum naturalizado por conveniência, quem se volta contra ele, como Graciliano e seus pares, não tem lugar no mundo, é novidade a ser dissolvida.

Atacam por aí o lugar-comum. Não sei por quê. Sendo comum, deve ser conveniente ao público, e não valem contra ele as opiniões de alguns cavalheiros que não são comuns.

Como a traduzir a configuração de seu estilo, Graciliano desenvolve a ironia contra o lugar-comum por meio da comparação entre escrita, literatura / estrada, viagem, para ressaltar nelas o sentido de dificuldades, patente nas imagens de atoleiro, pedra, curvas fechadas. Num discurso aparentemente linear, afirma preferir os clichês, cômodos, aos caminhos sertanejos, espinhosos e cheios de perigos. Contudo, já se vê que, irônico, o

17 CARPEAUX, Otto Maria. Autenticidade do romance brasileiro. Livros na mesa. In: Ensaios reunidos 1942-1978, v. I. Organização, introdução e notas de Olavo de Carvalho. Rio de Janeiro: UniverCidade \& Topbooks, 1999, p. 884 (grifos meus). 
caminho de Graciliano é tortuoso: sua "literatura encrencada" identifica-se com as veredas do sertão, entremeadas de adversidades e de sofrimentos.

Se me dão licença, declaro que tenho predileção especial pelos clichês. E a minha razão está aqui: é mais cômodo viajar em automóvel por uma estrada de rodagem sem buracos que percorrer os caminhos sertanejos cheios de surpresas de espinho rasga-beiço.

Comparando mal (ou comparando bem, como quiserem), a literatura encrencada dos homens de talento é como as veredas de minha terra: tem curvas fechadas, rampas que escangalham um carro, tocos prejudiciais aos pneumáticos, pedras, atoleiros, riachos, precipícios, a [ilegível] e ramos indiscretos que batem na cara da gente.

Tudo isso é desagradável e produz abalos e interrupções freqüentes na viagem ou na leitura.

O escritor mostra que, na estrada como na literatura, o comum é optar-se pelo caminho mais fácil, conveniente aos interesses particulares, livre de obstáculos. Planas e batidas, rodovias bem conservadas e crônicas literárias inofensivas são percorridas com velocidade, sem que o viajante ou leitor sinta necessidade de entendê-las. Assim, por meio do paralelo entre "o artigo campanudo" e a estrada, Graciliano ironiza essa literatura plana, que, sem o tempo de mediação intelectual, não se abala com os impasses de sua realidade. A um tempo, denuncia a insuficiência dos leitores, afeitos antes à preguiça do que ao "trabalho penoso" de buscar compreender as linhas escritas, mesmo que em sua maioria elas não tragam pensamentos consideráveis nem expressos com clareza. Embora tenha efeito cômico, a ironia guarda teor trágico:

Imaginem a maçada de estar um cristão a catar pensamentos em todas as linhas que encontra. (...) Por isso lemos com imenso prazer os escritores que não dizem nada. Excelentes criaturas. Têm boas intenções e portam-se decentemente.

Gritantes, a inabilidade de leitura do público e a vacuidade de muitos escritos fazem incisiva a crítica de Graciliano ao generalizado despreparo intelectual. O artigo da Novidade esclarece o contexto de Caetés, em que o protagonista João Valério confessa ter uma "inteligência confusa, pronta a receber sem exame o que lhe impingem" (capítulo 31). Pretenso escritor, utilizava palavras ouvidas cujo significado desconhecia. E pensava que deveria aprender um pouco de história para concluir seu romance histórico, contudo não desejava estudar.

Também alvo de crítica é o apego da personagem à retórica balofa, embora ele até cortasse depois adjetivos: "Admiração exagerada às coisas brilhantes, ao período sonoro, 
às miçangas literárias, o que me induz a pendurar no que escrevo adjetivos de enfeite, que depois risco..." (capítulo 31). Em especial, a retórica dos políticos, pretensamente voltada para o coletivo, porém movida por interesse pessoal, é desmascarada por Graciliano. Ao compor a figura do bacharel Evaristo Barroca, cujo traço retórico e repugnante antecipa o Julião Tavares de Angústia, encena suas estratégias oratórias, como repetir três vezes a mesma idéia e improvisar discursos com "abundância de chavões sonoros" (capítulo 4). Arrivista político de trajetória paralela à do protagonista, Barroca também criou ídolos para depois derrubá-los: publicou textos de encômio ao prefeito, recheados de "adjetivos fofos" como a estimular a ação deste no município, mas para eleger-se deputado e então lhe dar uma rasteira.

Justamente a repulsa a essa retórica balofa, à prática encomiástica e aos falsos valores erigidos por elas é central em "Chavões". Voltada contra "os escritores que não dizem nada", a ironia, bastante mordaz, recai sobre a figura de Graça Aranha, que, “coberto de glória", "resolvera" então morrer (a 26 de janeiro de 1931), "perda irreparável para a sua excelentíssima família e para a Academia Brasileira de Letras”. Graciliano critica também um doutor que, tendo-se entusiasmado havia vinte e tantos anos com Canã̃ (1902) como era costume, compôs o necrológio do "ilustre diplomata" 18.

O contexto brasileiro de academismo e estagnação intelectual do início do século XX foi sintetizado por Graciliano em "Decadência do romance brasileiro" (1941). Após apontar a generalizada ignorância quanto aos fatos do país, o gosto por brilho e a prática de imitação (como se viu, figurados em Caetés), o escritor revela sua rejeição pelo romance de Graça Aranha:

Tínhamos, porém, vivido numa estagnação. Ignorância das coisas mais vulgares, o país quase desconhecido. Sujeitos pedantes, num academismo estéril, alheavam-se dos fatos nacionais, satisfaziam-se com o artifício, a imitação, o brilho do plaquê. Escreviam numa língua estranha, importavam idéias reduzidas. As novelas que apareceram no começo do século, medíocres, falsas, sumiram-se completamente. Uma delas, Canaã, que obteve enorme êxito, dá engulhos, é pavorosa. ${ }^{19}$

\footnotetext{
${ }^{18}$ Graça Aranha (José Pereira da): nasceu em São Luís do Maranhão, a 21 de junho de 1868, e faleceu no Rio de Janeiro, a 26 de janeiro de 1931. De família rica, formou-se em Direito pela Faculdade do Recife, foi juiz municipal (no Espírito Santo) e diplomata. Participou da Semana de Arte Moderna e rompeu com a Academia Brasileira de Letras em 1924, após a conferência "O espírito moderno".

Publicou: Canaã (1902), Malasarte (1911), A estética da vida (1921), Machado de Assis e Joaquim Nabuco - comentários e notas à correspondência entre estes dois escritores (1923), Espírito moderno (1925), Futurismo. Manifesto de Marinetti e seus companheiros (1926), A viagem maravilhosa (1929), O meu próprio romance (1931). Cf. BOSI, Alfredo. História concisa da literatura brasileira. cit., pp. 365-372.

${ }^{19}$ RAMOS, Graciliano. Decadência do romance brasileiro. Literatura, Rio de Janeiro, ano I, n. 1, set. 1946. Apud GARBUGLIO, J.C. et alii. Graciliano Ramos. cit., p. 115.
} 
De fato, Canaã teve grande êxito. Carpeaux relata que Anatole France, embora sem ler português, elogiara-o como o "romance da América". E observa também que o forte sabor regionalista e as discussões do romance sobre os problemas e sobre o futuro da nação ainda impressionavam, nos anos 1960, muitos jovens da província. No entanto, Carpeaux sublinha que não caberia sequer considerá-lo "romance do Brasil", sobretudo depois das obras de escritores como José Lins, Graciliano, Guimarães Rosa. Segundo o crítico, o romance de Graça Aranha "só convence leitores inexperientes", pois é um "mosaico de estilos diferentes": início descritivo, excesso de ensaios dialogados, reportagem sobre a colonização alemã, passagens naturalistas, final simbolista. Carpeaux critica as idéias vagas e o simbolismo retórico de Graça Aranha, sem base real: a colonização alemã no Espírito Santo se distanciava do quadro progressista esboçado pelo autor. ${ }^{20}$

Nesse mesmo sentido, devem ter desagradado muito a Graciliano a ênfase retórica, o pendor abstrato e o academismo de Graça Aranha, ambiguamente associado aos modernistas ${ }^{21}$. Na crônica "Bahia de Todos os Santos", refere-se à tradução para o espanhol de dois romances "inteiramente inofensivos": um de Graça Aranha, o outro de Paulo Setúbal, escritores "notáveis, acadêmicos e mortos". A eles, opõe os livros de Jorge Amado, os quais, traduzidos para o francês, revelariam os "pretos e farrapos" do país até para os finos "leitores indígenas" importadores da mercadoria nacional ${ }^{22}$.

Em "Chavões", desvelando o aspecto convencional, conservador e adequável às circunstâncias do tal necrológio de Graça Aranha, Graciliano ironiza a capacidade de muitos literatos de escreverem sobre qualquer assunto sem dizer nada. O necrológio não passava da adaptação a uma fórmula: “com pequenas modificações no tipo, no título e em alguns adjetivos", servia perfeitamente "para defender o divórcio, para fazer declarações de amor e para insultar a Rússia". Sobressai o repúdio de Graciliano a tantos chavões patrioteiros, que, exaltando a natureza e as instituições brasileiras, surpreendem por sua inutilidade:

\footnotetext{
${ }^{20}$ CARPEAUX, Otto Maria. Canaã revisitada. Livros na mesa. In: Ensaios reunidos 1942-1978, v. I. cit., pp. 895-7.

${ }^{21}$ Cf. 1922 - Itinerário de uma falsa vanguarda - os dissidentes, a Semana e o Integralismo (São Paulo: Brasiliense, 1983), em que Antonio Arnoni Prado aponta criticamente a "modernidade ambígua" de Graça Aranha e o caminho dos "dissidentes" da Semana, intelectuais que nela figuraram e confluíram para o Integralismo.

${ }^{22}$ RAMOS, Graciliano. Bahia de Todos os Santos. In: Linhas tortas. cit., pp. 114-5.
} 
Têm minas de ouro, cachoeiras, florestas, a pátria, a bandeira, o céu, o mar, um grande número de instituições consideráveis que a gente lê pensando na vida, pensando no câmbio, ou não pensando em coisa nenhuma. É admirável.

Por oposição a esses artigos desprovidos de perspectiva crítica, repetidores de chavões, Graciliano destaca os capítulos de Oliveira Vianna, por trazerem a história do Brasil colonial, com seus latifúndios, a nobreza rural, a mineração, os governadores gerais $^{23}$. Então, como a arrematar a ironia segundo a qual preferiria estradas planas e batidas, afirma ótima a maioria dos artigos publicados na época: tinham tudo, ou seja, nada, não perturbavam as "ocupações ordinárias" dos leitores e se adaptavam "admiravelmente" às "condições interiores" deles. Ao sugerir que esses artigos poderiam ser lidos no banho, em cima de uma bicicleta ou junto a um tabuleiro de xadrez, Graciliano configura, para seu leitor, a distinção entre textos inofensivos, descartáveis, e textos densos e críticos, movidos pelos problemas dos homens e capazes de atingir-lhes a sensibilidade e a consciência.

Assim, "Chavões" diagnostica e condena com veemência o nada de novo em termos estéticos e político-sociais, o predomínio de literatos "imbecis", repetidores de fórmulas de louvor à natureza e às instituições da pátria. Por isso, o conselho de Graciliano na Novidade, de uma ironia terrível, é a desistência de escrever:

Apresento uma sugestão aos homens inteligentes: deixem de escrever e entreguem a pena aos imbecis.

Essa sugestão para os inteligentes não escreverem, desejo de silenciar que cala fundo no leitor até hoje, expressa a consciência angustiada de Graciliano, de que o caminho possível da literatura num mundo de chavões é um atoleiro.

Desse modo, "Chavões" tem um sentido de formação de leitores e escritores críticos: evidencia a necessidade de se buscar, com esforço, uma expressão pessoal e a dificuldade de o fazer num mundo estagnado em lugares-comuns. Seu horizonte, a um

\footnotetext{
${ }^{23}$ Oliveira Viana (Francisco José de): nasceu a 20 de junho de 1883 e faleceu a 28 de março de 1951, no Rio de Janeiro. Bacharelou-se pela Faculdade de Direito de Niterói, foi professor, membro da Academia Brasileira de Letras desde 1937 e ministro do Tribunal de Contas da União (1940).

Publicou, dentre outras obras, Populações meridionais do Brasil (1920), Pequenos estudos de psicologia social (1921), Evolução do povo brasileiro (1923), O ocaso do Império (1925), O idealismo na Constituição (1927), Problemas de política objetiva (1930), Raça e assimilação (1932), Problemas de Direito Corporativo (1938), Instituições políticas brasileiras (1949). Cf. PAIM, Antônio. Oliveira Viana e o pensamento autoritário no Brasil. Introdução a VIANA, Oliveira. Instituições políticas brasileiras. Brasília: Conselho Editorial do Senado Federal, 1999.
} 
tempo ético e estético, são caminhos outros que os ordinários, na literatura e nas relações humanas. Desde a comparação entre a escrita e a estrada, nota-se como Graciliano compreende indissociáveis a vida e a literatura: volta-se contra o não-enfrentamento de pedras e atoleiros pelos homens, contra a conservação de muitas dores sob chavões.

\section{Contra os chavões: os astrônomos do inferno}

(...) Daí também o privilégio da palavra poética, que revela a invenção significativa fazendo brotar a diferença a partir do mesmo, a metáfora como a surpresa que as velhas palavras escondem.

(...) O esquecimento da história das palavras é condição primária da mistificação. Esta é a razão pela qual a linguagem 'política' a que estamos habituados constitui-se quase exclusivamente de clichês apenas reiteradores de estímulos sonoros e visuais que remetem a sentidos estereotipados e desvinculados de um contexto social interativo.

$$
\text { Franklin Leopoldo e Silva }{ }^{24}
$$

Meu pai determinou que eu principiasse a leitura. Principiei. Mastigando as palavras, gaguejando, gemendo uma cantilena medonha, indiferente à pontuação, saltando linhas e repisando linhas, alcancei o fim da página, sem ouvir gritos. Parei surpreendido, virei a folha, continuei a arrastar-me na gemedeira, como um carro em estrada cheia de buracos. ("Os astrônomos" ${ }^{25}$ ).

"Como um carro em estrada cheia de buracos": à semelhança de "Chavões", em "Os astrônomos" surge a imagem do texto escrito como uma estrada penosa a ser percorrida obstinadamente, neste caso pelo menino ainda analfabeto aos nove anos, guiado pelas mãos de ordinário rudes do pai. Note-se como a gradação de gerúndios, sinalizando supressões e repetições de sílabas e de linhas, expressa o difícil caminho do garoto para conseguir ler, feito de terror e desejo de acertar ("Mastigando as palavras, gaguejando,

\footnotetext{
${ }^{24}$ SILVA, Franklin Leopoldo e. A dimensão ética da palavra. Tempo social: revista de sociologia da USP. São Paulo, v. 8, 1996, pp. 56, 61, 62.

${ }^{25}$ RAMOS, Graciliano. Os astrônomos. In: Infância. Memórias. $3^{\text {a }}$ ed. Rio de Janeiro: José Olympio, 1953, pp. 189-194.
} 
gemendo uma cantilena medonha", "saltando linhas e repisando linhas"). Sofrida embora, essa leitura não interrompida por repreensões o surpreendeu: habitual era o ambiente opressivo e raros os momentos de satisfação. Da escola, ele fixara a imagem terrível dos alunos como mortos sentados nos bancos, com moscas a lhes roerem o canto dos olhos. Junto a isso, a palmatória, usada pelo pai e pela maioria dos professores, e a imposição de obras inadequadas para introduzir as primeiras letras (Os Lusíadas e as cartilhas do Barão de Macaúbas) haviam definido o contato do menino com os livros como momento de alteridade máxima.

No entanto, essa mesma atmosfera angustiante levava a criança a sonhar personagens de um mundo outro, a "engenhar bonecos de barro". Já se surpreendera certa vez, quando o pai, "Tentador, humanizado", o consultara sobre aprender a ler - dominar "armas terríveis". Mas desconfiara da "excelência do papel impresso", pois os "traços insignificantes" em três colunas de um folheto não pareciam perigosos feito armas; além disso, era-lhe um "inferno" distinguir as letras e, a um tempo, entender diferenças e semelhanças entre maiúsculas e minúsculas, "maldades grandes e pequenas" ("Leitura"). Eis que, tempos depois, o pai (negociante que certamente naquele dia "recebera uma dívida perdida") abriu para o menino de nove anos o encontro com o mundo dos livros, para fechá-lo (aparentemente) logo em seguida. Assim, configurando as tensões e o prazer dessa mediação da distância entre o pequeno leitor e o texto escrito, o capítulo "Os astrônomos" delineia os passos da formação da sensibilidade e da consciência de Graciliano Ramos em relação às palavras e ao outro social.

O narrador adulto dialoga consigo mesmo revivendo a "noite extraordinária" em que o pai o chamou, menino de nove anos quase analfabeto, para ler um romance, explicando-lhe do que tratava, traduzindo-lhe "em linguagem de cozinha" as expressões literárias. Animada, a criança reconhecia que havia "alguma coisa no livro", entretanto difícil de entender totalmente: "E uma luzinha quase imperceptível surgia longe, apagavase, ressurgia, vacilante, nas trevas do meu espírito". Alheio a brinquedos e à escola, viveu com as personagens do livro, que, perseguidas por lobos, lhe agitaram o sono: a literatura ajudava-o a habitar o mundo.

Contudo, depois de mais uma noite de "leitura emperrada, mal-entendidos, explicações”, o pai passou a esquivar-se, até abandonar aquele hábito das noites, causandolhe mágoa terrível: 
Nunca experimentei decepção tão grande. Era como se tivesse descoberto uma coisa muito preciosa e de repente a maravilha se quebrasse. E o homem que a reduziu a cacos, depois de me haver ajudado a encontrá-la, não imaginou a minha desgraça. A princípio foi desespero, sensação de perda e ruína, em seguida uma longa covardia, a certeza de que as horas de encanto eram boas de mais para mim e não podiam durar. (pp. 191-2).

Supondo remediável aquele mal, o menino recorreu à prima Emília. Inesquecível o retrato desse "anjo", lição para minorar desgostos. Com "rosto sereno" e "ar de seriedade", Emília "não era deste mundo"; só se zangou com o primo quando, tuberculosa, o viu beber água no copo dela. Instada a ajudá-lo a ler, ela lhe sugeriu que se arriscasse a tentar a leitura sozinho. O argumento da menina, metafórico, desenha a tarefa hermenêutica: Emília fez o primo observar que, se os astrônomos lêem o céu, enxergam "coisas tão distantes", não haveria motivos para ele não conseguir "adivinhar a página aberta diante de [seus] olhos", se ele distinguia as letras e sabia reuni-las em palavras.

Observe-se que a idéia de fazer-se astrônomo e conseguir ler parece inalcançável para aquela criança que falava pouco e se habituara, seguindo a opinião da própria mãe, a julgar-se "uma besta", inferior às outras, de mente fraca. Combatendo a mentira desse estereótipo, a sugestão da prima condensa a possibilidade de o menino construir, com base no desejo e no esforço, a significação do texto literário e, por conseguinte, de formar-se como sujeito. E, realizando essa possibilidade do círculo hermenêutico, ele pôde viver com intensidade o mundo do romance:

E tomei coragem, fui esconder-me no quintal, com os lobos, o homem, a mulher, os pequenos, a tempestade na floresta, a cabana do lenhador. Reli as folhas já percorridas. E as partes que se esclareciam derramavam escassa luz sobre os pontos obscuros. Personagens diminutas cresciam, vagarosamente me penetravam a inteligência espessa. Vagarosamente. (pp. 193-4).

Dobrando-se ao texto, o menino Graciliano tornou-se outro, à semelhança dos astrônomos: libertou-se da paralisia que lhe causava o estigma de "bruto em demasia" e elegeria em seguida a biblioteca do tabelião Jerônimo Barreto sua "provisão de sonhos", seu meio de habitar o mundo. No entanto, não eliminaria a distância máxima, não seria astrônomo do céu: sabia que haveria sempre incompreensões e incongruências a serem enfrentadas, para receberem alguma luz. A identificação que lhe marcaria a obra era com os homens perseguidos como os do mundo daquele livro da infância. Essa identificação se 
realizaria enquanto consciência e mediação pela linguagem, de um escritor preso à terra, preso e livre pelas palavras.

Os astrônomos eram formidáveis. Eu, pobre de mim, não desvendaria os segredos do céu. Preso à terra, sensibilizar-me-ia com histórias tristes, em que há homens perseguidos, mulheres e crianças abandonadas, escuridão e animais ferozes. (p. 194).

Numa realidade de violência, em que a criança era vítima de maus tratos, a descoberta da mediação intelectual, o esforço por iluminar o incompreendido, fez de Graciliano astrônomo do inferno. E o escritor se dedicaria aos seres pisados pelo soldado, pelo patrão e pelo governo, os quais sofriam o inferno da sede e fome no ciclo entre "Mudança" e "Fuga". Na hermenêutica singular de Graciliano Ramos, o apagado encontra alguma luz aos poucos, os abandonados falam à sensibilidade.

Em especial com o retirante, realizou-se o astrônomo do inferno: Graciliano foi capaz de configurar a descoberta pelo vaqueiro rústico da poesia dentro de si, conforme revela a "Imagem de Fabiano",26, primorosa interpretação de Alcides Villaça. Analisando o capítulo "O mundo coberto de penas", de Vidas secas, Alcides ressalta o "instante de felicidade" de Fabiano após a "atividade interior" que lhe permitiu compreender a imagem criada por sinha Vitória. $\mathrm{O}$ vaqueiro se ilumina ao entender a fala expressiva da mulher: as arribações iam matar o gado, ou seja, beberiam a água, e o gado morreria de sede, anúncio de seca. Mais do que isso, como a partilhar com o narrador "a transfiguração de um novo olhar sobre a paisagem", Fabiano prolonga a imagem em metáfora, vendo as arribações, pousadas no mulungu ressecado, como folhas e flores a enfeitá-lo.

Assim, se o lugar-comum é a violência, a estagnação intelectual e a retórica como a do Barão de Macaúbas, ainda pode haver o esforço pela singularidade poética, a extraordinária descoberta de ler as palavras, reuni-las em romances e, portanto, apreender a vitalidade presente nas histórias dos abandonados. Figuração da poética, essencialmente ética, de Graciliano Ramos, central em "Chavões" e em "Os astrônomos" é a imagem do caminho penoso, palmilhado aos solavancos por um sujeito que, experienciando dificuldades e embates, busca compreender a si e aos outros. Tendo enfrentado o estigma de ser "bruto em demasia", Graciliano constituiu seu olhar desconfiado e crítico quanto à própria brutalidade e à do mundo, o que lhe permitiu expressar as tensões entre ser intelectual e ser bruto, numa realidade de violência, por meio de um estilo de rigor,

\footnotetext{
${ }^{26}$ VILLAÇA, Alcides. Imagem de Fabiano. Estudos avançados, São Paulo, v. 21, n. 60, 2007, pp. 235-246.
} 
empenhado sempre pela perfeição artística. E assim criou Fabiano, descobrindo nele a possibilidade de poesia, de pensamentos e, como se mostrará adiante, de ética.

\title{
Sertanejos no espelho
}

\section{A pena sertaneja de tipos entrevê pessoas: cartucheira e molambos por dentro}

\author{
O estereótipo nos é transmitido com tal força e autoridade que pode \\ parecer um fato biológico. (...) \\ $O$ repouso no estereótipo, nas explicações dadas pelo poder, conduz a uma \\ capitulação da percepção e a um estreitamento do campo mental. (...) \\ A consciência se enfraquece quando se dobra à realidade sem tensão; é \\ preciso despregar a verdade das coisas por um esforço. (...) \\ Mas só merece de nós um esforço aquilo que amamos. \\ (...) Tudo começa numa afinidade, numa simpatia do sujeito da percepção \\ e da ação pelo seu objeto. \\ Para alcançar esse alto grau de tomada de consciência da vida em si, há \\ um momento de recusa do que foi estabelecido sem a nossa aquiescência e \\ experiência. Isto se dá sempre que nós queremos habitar plenamente as coisas do \\ mundo.
}

\section{Ecléa Bosi ${ }^{27}$}

“Sertanejos" e "Lampião", do primeiro número da Novidade, parecem acompanhar os bastidores da criação literária de Graciliano, que apreende nos tipos sociais os dramas pessoais que singularizam suas personagens. O escritor rejeita generalizações, para revelar, na especificidade do fator econômico em que surge o tipo, as situações e problemas vividos por diferentes pessoas, em especial as impedidas de o ser devidamente em seus direitos.

Em "Sertanejos", Graciliano revela o modo como o habitante do litoral, a gente da cidade, via o sertanejo, de acordo com o lugar-comum apresentado em jornais e livros: não passaria de um tipo pitoresco, "mistura de retirante, beato e cangaceiro, enfeitada com um patuá, duas alpercatas e muitas figuras de retórica". O estereótipo do sertanejo soma traços do retirante, do beato, do índio (conforme aparece em Caetés) e do cangaceiro: ele surge

\footnotetext{
${ }^{27}$ BOSI, Ecléa. Entre a opinião e o estereótipo. O tempo vivo da memória: ensaios de psicologia social. São Paulo: Ateliê, 2003, pp. 117, 118, 123, 125.
} 
faminto, esfarrapado, com um rosário de contas enorme, devoto do Padre Cícero; meio selvagem, é falso, preguiçoso e vingativo; com chapéu de couro e faca de ponta, sem morada fixa, desloca-se do Juazeiro para o bando de Lampião, abandona "facilmente" a família, bebe cachaça e "furta como rato".

Então, Graciliano contesta esse estereótipo, criando uma imagem que adensa a exterioridade pitoresca: afirma que os homens de sua terra podem ter "a cartucheira e os molambos", mas "por dentro", pois exteriormente são criaturas comuns. Sem nenhum pitoresco, a cartucheira e os molambos por dentro sinalizam a miséria dos sertanejos, sua revolta abafada ou transformada em violência na luta por sobreviver. Sendo assim, o cronista apresenta ao leitor caminhos possíveis dessas criaturas comuns, apontando elementos econômicos, políticos e culturais de seu ambiente.

Refere-se aos retirantes que, após extraírem borracha no Norte ou plantarem café no Sul, regressaram com dinheiro, ostentando-se sabidos e desconhecendo os amigos ${ }^{28}$. Os que haviam apanhado na cadeia tornaram-se soldados e se vingaram. Os que adquiriram alguma propriedade passaram a explorar o trabalho alheio. E aqui o leitor entrevê a mesma matéria histórica de injustiças e maus tratos que seria a base dos caminhos dos sertanejos configurados nos romances de Graciliano: mesmo tendo padecido na cadeia, Fabiano foi incapaz de vingar-se por meio de violência; após exploração no eito, sede e fome, Paulo Honório matou e se fez proprietário explorador, até sofrer o sem-sentido de tudo, com o suicídio de Madalena.

Porém, os sertanejos referidos na crônica não são apenas os miseráveis, retirantes e trabalhadores, que serviriam de matriz a personagens como Fabiano e Paulo Honório. Há também os lampiões semi-civilizados, pertencentes às classes média e alta, dentre os quais o leitor reconhece várias figuras de Caetés: o farmacêutico, o tabelião, o redator da folha

\footnotetext{
${ }^{28}$ Em crônica para o Jornal de Alagoas de 27-5-1933, Graciliano Ramos apresenta o "Comandante dos burros". Além do cangaço, aponta "três saídas" para os sertanejos pobres: a morte por fome, a emigração para o sul ou a farda de polícia. Enfatiza que, habituados a apanhar - dos pais e familiares, do proprietário, do cangaceiro -, aceitavam com resignação, quase com indiferença, as surras na prisão; afinal, na expressão também nesse texto escolhida por Graciliano, "apanhar do governo não é desfeita".

Eis que alguns sertanejos sentem vontade de vingar-se: pedem um cartão do juiz de direito, vão para a capital e voltam transformados. Com uniforme cáqui e "terrivelmente bestas", desconhecem os amigos e os nomes das coisas mais comuns, dormem demais, vão aos batuques e provocam brigas, pisam os pés dos indefesos, batem nas prostitutas, bebem junto com o inspetor e o subdelegado. Graciliano ironiza a importância desses horríveis preguiçosos, alguns dos quais têm por encargo tomar conta dos burros que haviam sido usados para afugentar Lampião quando esteve em Palmeira dos Îndios: são os "comandantes de burros". Cf. RAMOS, Graciliano. Comandante de burros. In: Revista do Instituto de Estudos Brasileiros, n. 35. Publicação do IEBUSP. São Paulo, 1993, pp. 207-9.
} 
semanal, os comerciantes que podem viver cochilando ou tesourando a vida alheia, os doutores, os políticos arrivistas.

Desse modo, Graciliano desmonta o estereótipo de "Sertanejos" para desvelar as várias faces da realidade de sua terra. Seu propósito é chamar a atenção para as incongruências e sofrimentos decorrentes das desigualdades sociais: rodovias, estradas de ferro, luz elétrica, cinema, praças com jardins, filarmônicas, máquinas de escrever e pianos surgem-lhe como "necessidades exorbitantes", porque "faltam escolas e hospitais". Incisivamente críticas, as palavras do cronista decerto eram inspiradoras no contexto do primeiro número da Novidade: "Por isso, os sertanejos andam carregados de muita verminose e muita ignorância”.

Graciliano aponta com lucidez que o país vivia encantado com os signos norteamericanos de um progresso que aqui era fachada sob a qual havia uma realidade de pobreza. Por meio de uma imagem contundente, tece sua crítica a esse progresso epidérmico, que quer encobrir a fragilidade estrutural do país:

Numa casa velha de taipa arranjam uma sala bonita e metem dentro quadros, cortinas, penduricalhos.

Desmascara que os sertanejos semi-civilizados "trabalham pouco, pensam pouco", desejam o progresso que admiram no cinema americano e adotam, no comércio e na política, as ladroeiras e o blefe do pôquer. Condena que incorporassem esse "bando de coisas de nomes esquisitos", como o bluff, o charleston, o jazz, o foot-ball, o motor USA, e deixassem de cultivar "o terço, o reisado, o pastoril, a quadrilha, a cavalhada, o bozó pelo Natal, as sortes em noites de São João". Mas veja-se que tal repúdio à importação do elemento estrangeiro tem uma base realista: significa a defesa da tradição regional, da identidade e também da integridade do povo, segundo o fator econômico:

(...) Isto é nosso e é barato. O resto é dos outros e caro.

Dentro em pouco estarão todos no sertão falando inglês. Mas nós não somos ingleses...

Assim, Graciliano parece apresentar os sertanejos aos sertanejos, para que aqueles metidos a ingleses, alienados, desviassem os olhos das fitas e costumes importados e dos estereótipos estampados nos jornais e atentassem para a seca e a falta de trabalho e de perspectivas dos homens pobres de sua região.

Entretanto os rios estão secos, o gado morre, a lagarta rosada deu no algodão. Tudo tão pobre... 
Desse modo, em "Sertanejos", já o título no plural denota que, contrário a estereótipos, Graciliano considerava as várias possibilidades dos habitantes de sua região, não só as classes sociais, mas também as diferenças dentro delas. Havia os lampiões semicivilizados, dentre os quais os exploradores, os encantados com modernidades importadas. Enquanto isso, a maioria eram homens comuns explorados: trabalhadores e retirantes resignados; no entanto, alguns deles se tornavam cangaceiros, outros passavam a opressores de sertanejos pobres no papel de soldados ou de proprietários. A percepção dessas diferenças entre os sertanejos pobres, bem como da violência que permite a mobilidade deles, mostrando os limites da noção de tipos sociais, é a base para a construção dos dramas de personagens como Fabiano, de Vidas secas, e Paulo Honório, de

\section{S.Bernardo.}

E tal percepção seria expressa, com toda a angústia quanto aos limites, intersecções e prevalências entre elementos típicos de classe social e de formação pessoal, nas Memórias do cárcere. Questionando-se sobre até que ponto perspectivas e ações obedecem ao enquadramento social e/ou a motivações de ordem subjetiva e cultural dos indivíduos, relativiza certezas. Após ter sido duramente tachado de burocrata por um estivador, estando ambos na prisão, Graciliano sofre e traduz o impasse do intelectual num mundo de violência e de estereótipos. Deixa ver que tanto patrões como trabalhadores braçais ou de gabinete podem marcar-se por atitudes de arrogância autoritária, bem como de revolta, resignação e, raramente embora, por senso de justiça. Ao mesmo tempo, sabe o peso que têm, fora do cárcere, a posição e a imagem sociais.

(...) Evidentemente as pessoas não diferiam por se arrumarem numa ou noutra classe; a posição é que lhes dava aparência de inferioridade ou superioridade. Evidentemente. Mas evidentemente por quê? A observação me dizia o contrário. Homem das brenhas, afeito a ver caboclos sujos, famintos, humildes, quase bichos, era arrastado involuntariamente a supor uma diversidade essencial entre eles e os patrões. $\mathrm{O}$ fato material se opunha à idéia - e isto me descontentava. Uma exceção rara, aqui, ali, quebrava a monotonia desgraçada: o enxadeiro largava o eito, arranjava empréstimo, economizava indecente, curtia fome, embrenhava-se em furtos legais, chegava a proprietário e adquiria o pensamento e os modos do explorador; a miserável trouxa humana, batida a facão e a vergalho de boi, resistente ao governo, à seca, ao vilipêndio, resolvia tomar vergonha, amarrar a cartucheira à cinta, sair roubando, incendiando, matando como besta-fera. Essas discrepâncias facilmente se diluíam no marasmo: era como se os dois ladrões, o aceito e o réprobo, houvessem trazido ao mundo a condição inelutável: pequenas saliências no povo imóvel, taciturno, resignado. Naquele instante a aspereza do estivador me confirmava o juízo. Lá fora sem dificuldade me reconheceria num degrau acima dele; sentado na cama estreita, rabiscando a lápis um pedaço de papel, cochichando normas, reduzia-me, despojava-me das vantagens acidentais e externas. ${ }^{29}$

\footnotetext{
${ }^{29}$ Idem. Memórias do cárcere. cit. v. II, capítulo 8, pp. 66-7.
} 


\section{Lampião de palavras}

Cumpre retomar a análise de "Lampião"30, agora com vistas a refletir sobre a formação da obra do romancista. O motor da crônica é a ambivalência de Graciliano entre o sentimento de revolta contra as injustiças, que o faz identificar-se com a figura do bandoleiro, e, ao mesmo tempo, a consciência dilacerada de ser inútil como escritor, pois o universo letrado o distancia da ação do cangaceiro. Esse movimento de ver-se próximo e distante do outro, de Lampião nesse caso, condensa o caminho ético do romancista. Assemelha-se à comparação de João Valério com os índios no último capítulo de Caetés, em que, diferentemente da crônica, desponta a ironia, afinal a situação do protagonista era bem diferente da dos caetés, destruídos, vistos como estereótipos.

Ao identificar-se com Lampião, o escritor explicita a condição social dos sertanejos famintos, alguns dos quais se fazem Lampiões: o sofrimento de injustiças, a exploração do trabalho no eito, as humilhações pelo soldado, a prisão, o fatalismo resignado ante o coronel e o governo.

No começo da vida sofreu [Lampião] numerosas injustiças e suportou muito empurrão. Arrastou a enxada, de sol a sol, ganhando dez tostões por dia, e o inspetor de quarteirão, quando se aborrecia dele, amarrava-o e entregava-o a uma tropa de cachimbos, que o conduzia para a cadeia da vila. Aí ele agüentava uma surra de vergalho de boi e dormia com o pé no tronco.

As injustiças e os maus-tratos foram grandes, mas não desencaminharam Lampião. Ele é resignado, sabe que a vontade do coronel tem força de lei e pensa que apanhar do governo não é desfeita. ("Lampião").

Como não ver, nessa caracterização, a "vida agreste" de Paulo Honório, protagonista de S. Bernardo (1934), que "sofreu sede e fome" antes de assumir a "profissão" de "explorador feroz" ${ }^{31}$ dos trabalhadores do eito como ele o fôra?

Até os dezoito anos gastei [Paulo Honório] muita enxada ganhando cinco tostões por doze horas de serviço.

(...) Sofri sede e fome, dormi na areia dos rios secos, briguei com gente que fala aos berros e efetuei transações comerciais de armas engatilhadas. (S. Bernardo, cap. 3, pp. 14-5).

\footnotetext{
${ }^{30}$ Idem. Lampião. In: Novidade 1, Maceió, 11 de abril de 1931, p. 3. (Também em Viventes das Alagoas. cit, pp. 130-3).

${ }^{31}$ Idem. S. Bernardo. $6^{\text {a }}$ ed. Rio de Janeiro: José Olympio, 1955. As referências são dos capítulos 19, 3, 2 e 36.
} 
E, sobretudo, o quadro de miséria e opressão que transforma pobres-diabos em bestas-feras anuncia a situação de Fabiano, protagonista de Vidas secas (1938), que, depois de preso injustamente e espancado, chega a sonhar-se um cangaceiro e pensa que "apanhar do governo não é desfeita”.

Então porque um sem-vergonha desordeiro se arrelia, bota-se um cabra na cadeia, dá-se pancada nele? Sabia [Fabiano] perfeitamente que era assim, acostumara-se a todas as violências, a todas as injustiças. E aos conhecidos que dormiam no tronco e agüentavam cipó de boi oferecia consolações: - 'Tenha paciência. Apanhar do governo não é desfeita'. ("Cadeia", Vidas secas ${ }^{32}$ ).

A ponte entre a crônica sobre Lampião e os romances de Graciliano traz elementos para se compreender melhor a construção das personagens Paulo Honório e Fabiano e de seus dramas. Para Lampião, segundo a crônica, a única saída foi a violência: resistir vivo era vingar-se contra o mundo dos proprietários, queimando fazendas, inspirando terror. Já Paulo Honório, após sofrer sede, fome e exploração, vingou-se, mas contra si mesmo, conforme tarde percebe: roubou, matou e fez-se proprietário dominador, até sentir a impotência de não haver compreendido Madalena e ter-lhe causado o suicídio. Quanto a Fabiano, seu "arrivismo" (do francês arriver, à rive, 'chegar à margem, ao rio') é ser retirante, sobreviver fugindo às secas. Sofre com o desejo de se tornar um cangaceiro, capaz de vingar-se do soldado amarelo que o humilhara: tem a família e o temor de prejudicar-se ainda mais se desrespeitar a autoridade.

Assim, além de conhecer "Sertanejos", importa para o leitor de Graciliano Ramos saber que "Lampião", publicada em Viventes das Alagoas, é de 1931. Ambas as crônicas, do número inicial da Novidade, mostram como o escritor apreendeu, da matéria histórica de seu presente, alguns caminhos possíveis dos sertanejos pobres: integrarem-se à violência como cangaceiros ou como soldados; roubarem e matarem até se fazerem proprietários de terra; sobreviverem como retirantes, sofrendo as injustiças promovidas pelo patrão, pelo soldado e pelo governo. Observados tais caminhos, construiu seus romances, articulando a representação dessas relações sociais pautadas pela violência com a expressão dos conflitos subjetivos carregados por ela. Por combinar consciência histórica e sensibilidade, Graciliano foi capaz de conceber personagens para além de estereótipos: criou as figuras de Madalena e da família de Fabiano e, assim, presentificou os dramas do

\footnotetext{
${ }^{32}$ Idem. Cadeia. In: Vidas secas. $59^{\mathrm{a}}$ ed. Rio de Janeiro: Record, 1989, p. 33.
} 
enxadeiro que se torna explorador de enxadeiros e do retirante que, apesar das tantas injustiças, resiste a ser cangaceiro e a vingar-se do soldado de quem apanhou.

Ao fazer do remorso o motor para um sertanejo pobre tornado proprietário escrever um romance e ao vislumbrar no homem mais rebaixado à condição de bicho o mais humano - ao lado da cadela Baleia, necessária e tragicamente morta por ele -, Graciliano combate estereótipos. É sua forma de enfrentar, por meio da arte, o impasse do intelectual num mundo de violência, em que parece vedada a possibilidade de mediações.

No segundo momento da crônica "Lampião", Graciliano lastima exatamente a sua covardia de sujeito letrado, se comparada à força do bandoleiro. Deixa entrever-se o impasse do intelectual brasileiro, que tem sentimento de culpa por sua impotência em meio às iniqüidades do mundo. Tal impasse ganhou formalização plena em Angústia (1936) ${ }^{33}$, em que o funcionário e intelectual Luís da Silva se pretendeu um cangaceiro e matou o bacharel e negociante Julião Tavares. Irmanando-se a milhares de "figurinhas insignificantes" ${ }^{34}$, dentre as quais os cangaceiros (como Cirilo de Engrácia, morto), desejou vingar-se das humilhações que lhe imputavam os donos de dinheiro e de propriedades: perdeu Marina para o rico Julião, escrevia nos jornais obedecendo às idéias e aos interesses alheios. Contudo, a vingança contra um só proprietário não dissolve e sim intensifica a angústia de Luís da Silva.

Ao fim da crônica "Lampião", do movimento de identificação e distância em relação ao cangaceiro, Graciliano insinua que a vingança contra as injustiças sociais, perpetrada pelo bandoleiro por meio da violência, talvez seja possível também pela literatura, pela educação, desde que autênticas. Aqui, inevitavelmente eu me remeto a Infância, logo ao primeiro capítulo.

\footnotetext{
33 Segundo Ricardo Ramos, grande foi a alegria de Graciliano por ter lido, numa revista americana, a compreensão de haver em Angústia a "crônica da condição do intelectual nos países subdesenvolvidos da América Latina”. (RAMOS, Ricardo. Graciliano: retrato fragmentado. cit., p. 110).

${ }^{34}$ RAMOS, Graciliano. Angústia. $7^{\mathrm{a}}$ ed. Rio de Janeiro: José Olympio, 1955.
} 


\section{Laranjas e pitombas: as esferas ética e estética da obra de Graciliano Ramos}

\section{Nuvens: sombras e clarões}

Em carta de Maceió, a 28 de janeiro de $1936{ }^{35}$, Graciliano revela à esposa Heloísa alguns títulos de capítulos para um livro que planeara escrever. Era a idéia original de Infância, obra a que ele se dedicaria de 1937 a 1945, mas no Rio de Janeiro, após a prisão. Dentre esses títulos, destaca-se "Sombras", que depois Graciliano significativamente mudaria para "Nuvens", nome do primeiro capítulo.

Pensando nessas imagens, vale recordar o depoimento do escritor a João Condé sobre a origem de Paulo Honório. Graciliano concebera esse personagem em 1924, em Palmeira dos Índios, num momento de angústia intensa que o exercício literário logrou aplacar. Passados alguns anos, foi prefeito e, após deixar o cargo, mudou-se para Maceió. Era o tempo da Novidade, em que trabalhava e discutia literatura na Imprensa Oficial. Depois, demitiu-se por causa da "bagunça revolucionária de 30" e voltou para Palmeira dos Índios, com os filhos pequenos, "sem ofício nem esperanças, enxergando em redor nuvens e sombras" ${ }^{36}$. Eis que, para desanuviar-se novamente da aflição, retomou a história do criminoso e compôs S.Bernardo.

Articuladas em sua dimensão de fenômenos físicos, nuvens e sombras são carregadas de sugestivo potencial poético, ambíguo entre negatividade e abertura para o novo. Parece-me fecundo acompanhar em Vidas secas como as imagens das sombras e nuvens, positivas porque raras no sertão, desenham a combinação de esperança e desalento dos retirantes, revelando suas tensões e combatendo quaisquer estereótipos.

Fabiano (...) espantou-se: uma sombra passava por cima do monte. Tocou o braço da mulher, apontou o céu, ficaram os dois algum tempo agüentando a claridade do sol. Enxugaram as lágrimas, foram agachar-se perto dos filhos, suspirando, conservaram-se encolhidos, temendo que a nuvem se tivesse desfeito, vencida pelo azul terrível, aquele azul que deslumbrava e endoidecia a gente.

(...)

Miudinhos, perdidos no deserto queimado, os fugitivos agarraramse, somaram as suas desgraças e os seus pavores. O coração de Fabiano bateu junto do coração de sinha Vitória, um abraço cansado aproximou os

\footnotetext{
${ }^{35}$ Idem. Carta a Heloísa de Medeiros Ramos. Maceió, 28 de janeiro de 1936 (n. 88). In: Cartas. cit., p. 161.

${ }^{36}$ Idem. Paulo Honório. In: Revista do Instituto de Estudos Brasileiros, n. 35. cit., pp. 204-6, grifos meus.
} 
farrapos que os cobriam. Resistiram à fraqueza, afastaram-se envergonhados, sem ânimo de afrontar de novo a luz dura, receosos de perder a esperança que os alentava. ("Mudança").

Anúncio indeciso da necessária chuva no sertão, as nuvens muitas vezes tão-só passam. Mas, ao projetarem no inferno da seca uma sombra bem-vinda, configuram a resistência dos retirantes à fraqueza, e a arte de Graciliano delineia o "abraço cansado" de Fabiano e sinha Vitória, os corações unidos e os farrapos, encolhidos junto aos filhos numa soma de desgraças e pavores.

A recusa do romancista à animalização e reificação dos homens ganha força à medida que ele expressa poeticamente os sentimentos dos sertanejos, suas dores mas também seus lampejos de felicidade. As nuvens passam, e Fabiano fica "sombrio". Tragicamente, tem de arrancar à unha a água da terra para matar a sede. Saciado, iluminase por alguns instantes, ao adivinhar no céu de estrelas e cirros um aceno de plenitude para sua família. No entanto, o escritor conhece que as nuvens que "ensombram" o vaqueiro são o soldado, o patrão, o governo.

Fabiano (...) encaminhou-se ao rio seco, achou no bebedouro dos animais um pouco de lama. Cavou a areia com as unhas, esperou que a água marejasse e, debruçando no chão, bebeu muito. Saciado, caiu de papo para cima, olhando as estrelas, que vinham nascendo. Uma, duas, três, quatro, havia muitas estrelas, havia mais de cinco estrelas no céu. O poente cobria-se de cirros - e uma alegria doida enchia o coração de Fabiano.

Pensou na família, sentiu fome. Caminhando, movia-se como uma coisa, para bem dizer não se diferençava muito da bolandeira de seu Tomás. (...) ("Mudança").

$\mathrm{O}$ vaqueiro ensombrava-se com a idéia de que se dirigia a terras onde talvez não houvesse gado para tratar. (...) Encarquilhou as pálpebras contendo as lágrimas, uma grande saudade espremeu-lhe o coração, mas um instante depois vieram-lhe ao espírito figuras insuportáveis: o patrão, o soldado amarelo, a cachorra Baleia inteiriçada junto às pedras do fim do pátio. ("Fuga").

$\mathrm{Na}$ gênese de Infância, a alteração do título "Sombras" para "Nuvens" parece conjugar o aspecto entre fugidio, impreciso e perdido da memória, com o seu potencial de resgatar e criar formas. Nas nuvens adivinham-se figuras, o esfumaçado ganha contornos, essa a lição dos astrônomos. E a poesia de Infância advém em muito de Graciliano, ao evocar suas memórias e compor a narrativa, reconstituir a descoberta do mundo pela criança - com suas perplexidades, pavores e descobertas -, revelando a formação da sensibilidade e da consciência do adulto. 


\section{O sabor amar-amaro de saber laranjas e pitombas}

Criando formas a partir das "Nuvens" 37 da memória, a primeira recordação, nebulosa, de Graciliano é um vaso de pitombas escondido atrás de uma porta. Sensível ao mecanismo da memória, o escritor evoca como a lembrança se fixou, entre a sensação de um sonho e a confirmação por outras pessoas a quem falou da imagem. Mas o vaso se presentifica porque desaguou num caso marcante: as pitombas remetem às frutas vistas no pátio da escola que servira de pouso na sua viagem com os pais e as duas irmãs para o sertão de Pernambuco; eram laranjas, erroneamente chamadas de pitombas pelo menino.

Inculcaram-me nesse tempo a noção de pitombas - e as pitombas me serviram para designar todos os objetos esféricos. Depois me explicaram que a generalização era um erro, e isto me perturbou. ("Nuvens").

Bela síntese da poética, essencialmente ética, do escritor: a repreensão por considerar pitomba todo objeto esférico rendeu-lhe o aprendizado de avaliar com respeito as semelhanças e as diferenças entre as palavras, entre os seres: "a generalização era um erro". Conhecer, respeitar o sentido das palavras e dos seres carrega sempre tensão e dificuldades, mas significa um ganho de consciência. Pensando no contexto das memórias de um exímio observador das relações entre presente e passado, é relevante considerar a etimologia de respeitar: de re- e specio, mesma raiz de espelho, especialista, introspecção e perspectiva, é 'olhar com atenção para trás', o que pressupõe o difícil e fecundo tempo de mediação para compreender as palavras, a si e o outro, as diferenças.

Significativamente, entre as "nuvens espessas" que o cobriam, a primeira recordação nítida de Graciliano são "muitas caras, palavras insensatas” presenciadas nessa escola. Marcou-o ouvir, numa sala de aparência enorme (depois reduzida pela observação do adulto à sua dimensão real), a soletração das crianças, que "se esgoelavam" diante de um velho barbado, o professor. A lembrança dessa primeira aula, obviamente breve e intensa de incompreensão para o menino, suscita-lhe um sentimento combinado de opressão e fascínio. Com seu impacto, réstia de luz nas sombras, a aula de bê-á-bá aparece logo no primeiro capítulo, como a concentrar a trajetória de Infância: imensos obstáculos e contentamentos raros formaram Graciliano no aprendizado de ler e entender a realidade,

\footnotetext{
${ }^{37}$ Idem. Nuvens. In: Infância. cit., pp. 7-18.
} 
combatendo estereótipos, de soletrar e escrever o mundo sabendo que era perder-se o querer remediá-lo ${ }^{38}$.

Assim, no meio do caminho de Graciliano para o sertão de Pernambuco havia uma escola. Nela, para desagrado e surpresa do menino de dois ou três anos, corrigiram-lhe as pitombas, reveladas as laranjas. Tal descoberta das palavras e coisas acompanhou-se do conhecer as letras, num misto de insatisfação e prazer. Daí o desejo do escritor incontentável: ter consciência do valor de cada palavra e de cada ser, tratá-los com rigor perfeccionista. O sofrimento obstinado de emendar os textos e a confiança no potencial de transformação pelas palavras revelam-se nestas alterações feitas por Graciliano no capítulo "Nuvens", da versão publicada em 1941 na Revista do Brasil (indicada entre chaves) para a de Infância (1945):

(...) Em escolas primárias da roça ouvi cantarem a soletração de várias maneiras. Nenhuma como aquela, e a toada única, as letras e as pitombas [dão-me a certeza] convencem-me de que a sala, as árvores, [que eram laranjeiras] transformadas em laranjeiras, os bancos, a mesa, o professor e os alunos existiram. Tudo é bem nítido, muito mais nítido que o vaso. $(\ldots)$

(...)

Positivamente havia pitombas e um vaso de louça, esguio, oculto atrás [dum] de um móvel a que a experiência deu o nome de porta. Surgiram repentinamente a sala espaçosa, o velho, as crianças, a moça, bancos, mesa, árvores, sujeitos de camisas brancas. E sons estranhos também surgiram: letras, sílabas, palavras [desconhecidas] misteriosas. Nada mais. ${ }^{39}$

Observe-se que, imposto embora pela convenção alheia, o conhecimento das palavras transforma as coisas: "as árvores, transformadas em laranjeiras". Estranheza a desafiar os astrônomos, as palavras, mais que desconhecidas, são misteriosas.

Em "Nuvens", o escritor recompõe sua perplexidade de menino não só ante as letras, as palavras e as coisas, mas também ante as pessoas e o ambiente. O mundo cedo foi percebido por Graciliano como "incongruente". Seu caminho, de astrônomo do inferno, condensa-se em belas imagens da "hibernação", da "inércia", da "letargia", "raramente perturbada por estremecimentos": "tecido negro" com "rasgões", sombras "quase

\footnotetext{
38 "Todos os homens voltam para casa. / Estão menos livres mas levam jornais / e soletram o mundo, sabendo que o perdem". (ANDRADE, Carlos Drummond de. "A flor e a náusea", A rosa do povo. In: Obra completa. cit., p. 140).

${ }^{39}$ RAMOS, Graciliano. Nuvens. In: Infância. cit.; Revista do Brasil, Ano IV, $3^{\mathrm{a}}$ fase, n. 33, Março de 1941.
} 
impenetráveis", "cortadas por vagos clarões". Algumas dessas brechas de luz eram fragmentos de pessoas: os brincos e a cara morena de Sinha Leopoldina, o gibão de Amaro Vaqueiro, os dentes alvos de José Baía.

$\mathrm{Se}$ as pessoas surgiam a princípio para o menino como "figuras indecisas" e o espaço onde se desenvolveu como um "pequeno animal" eram "pontos nebulosos", aos poucos sua sensibilidade e consciência se aguçaram, frente ao sentimento de medo. A "ordem dos acontecimentos" era a violência e o pavor, raramente interrompidos por bom tratamento - o "doce parêntese" ${ }^{40}$, na expressiva formulação do astrônomo Graciliano. Assim, sob o pavor, entrecortado por "vagos clarões", o menino apreendeu os caracteres dos pais e percebeu as necessidades de seu ambiente, em que avultaram a tempestade, a construção do açude e a vazante das abóboras, a falarem, por contraste, dos rios secos, que lhe marcariam a alma.

Meu pai e minha mãe conservavam-se [grandes e temerosos, acima do meu conhecimento] grandes, temerosos, incógnitos. Revejo pedaços deles, rugas, olhos raivosos, bocas irritadas e sem lábios, mãos grossas [e pesadas] e calosas, finas e leves, transparentes [, calosas]. (...) [Estremeci, dominado pelo medo.] Medo. Foi o medo que me orientou nos primeiros anos, pavor [contínuo]. Depois as mãos finas [e leves] se afastaram das grossas [e pesadas], lentamente se delinearam dois seres que me impuseram obediência e respeito. Habituei-me a essas mãos, cheguei a gostar delas. [As finas e brancas nunca] Nunca as finas me trataram bem, mas às vezes molhavam-se de lágrimas - [e diante daquela fraqueza os meus receios esmoreciam] e os meus receios esmoreciam.

O leitor de Graciliano conhece que, diversamente do convencional, as recordações da infância do escritor recompõem uma realidade de violência, em que os momentos de abrandamento desta, de descoberta intelectual e reconforto afetivo constituíam novidade. Veja-se então como, afiando o seu "meio de expressão", ele gastou "uma eternidade no arranjo de ninharias" ${ }^{41}$ para melhor presentificar o seu sentimento de menino atemorizado e compreensivo ante os pais. As emendas garantiram à segunda versão a escolha concisa e precisa do adjetivo "incógnitos" para os pais. Após a sua caracterização como "grandes" e "temerosos" também por meio das metonímias do corpo, com destaque para os "olhos raivosos", o máximo de concisão expressiva é a frase nominal "Medo". Igualmente, antepondo o advérbio nunca para a abertura da frase, enfatiza a dureza da mãe; ao mesmo

\footnotetext{
40 “Manhã”, Infância.

41 “Manhã”, Infância.
} 
tempo, tece a proximidade afetiva com ela, graças à poesia do ritmo mais incisivo da frase e à força metonímica das mãos molhadas de lágrimas, omitida a locução adverbial em que aparece a palavra fraqueza: "[As finas e brancas nunca] Nunca as finas me trataram bem, mas às vezes molhavam-se de lágrimas - [e diante daquela fraqueza os meus receios esmoreciam] e os meus receios esmoreciam".

Quanto à caracterização inicial do seu ambiente, surpreenderam o menino a tempestade, a construção do açude e a vazante das abóboras. Momento incomum de agitação da natureza, da tempestade ele fixou as "nuvens de poeira" em briga, a escuridão e o barulho (que significativamente compõem a figuração do abandono em Angústia), além do desespero da mãe ao fechar uma porta em meio à ventania e machucar um dedo.

Ao recordar a construção do açude, Graciliano revela sua curiosidade primeira quanto ao trabalho dos homens: que propósito teria o precipício cavado com suor por aquelas formigas? E essa admiração se prolongaria diante do açude pronto, "maravilha, água infinita" onde patos e marrecos eram capazes de viver. "O mundo era complicado": além de nunca ter visto aquelas aves, nem tanta água, com dificuldade o menino identifica o precipício cavado pelas formigas àquele "enorme vaso metido no chão". A recriação poética da infância oferece ao leitor a descoberta do valor do trabalho, da água e dos açudes no ambiente nordestino.

A vazante das abóboras, que rendeu uma "safra inútil", é resgatada da memória porque constituiu para a criança uma "bela calçada movediça" de frutas e, a um tempo, como reconhece o adulto, um dos primeiros sinais da realidade nordestina de seca, fome e falta de planejamento agrícola.

Dentre os vagos clarões que iluminaram Graciliano, um foi proporcionado pela mãe: embora rude, ela gostava de "matracar" contos. Perseguem o adulto expressões imprecisas de um desses contos que a mãe lhe legou da tradição oral ${ }^{42}$. Lentamente ele reconstitui seus versos: tratavam de um garoto pobre acolhido por um padre amancebado. Para evitar indiscrições, o vigário dizia-se chamar Papa-hóstia, Folgazona a amante, o gato era papa-rato e o fogo, tributo. Crendo-se resguardados, o padre e a mulher passaram a maltratar o menino. Porém, ele se vingou. Pôs fogo no rabo do gato e fugiu, gritando:

\footnotetext{
${ }^{42}$ Cf. O menino sabido e o padre. In: CASCUDO, Luís da Câmara. Contos tradicionais do Brasil. $12^{\mathrm{a}}$ ed. São Paulo: Global, 2003, pp. 234-5.
} 
Levante, seu Papa-hóstia,

Dos braços de Folgazona.

Venha ver o papa-rato

Com um tributo no rabo. ("Nuvens", p. 17).

Note-se que o primeiro movimento do menino Graciliano, vítima também de maustratos, foi admirar o menino pobre, capaz de um ímpeto vingativo de herói. No entanto, logo vem a ponderação de que não saberia agir mediante violência. Aula de precisão vocabular, estas emendas feitas pelo escritor, ao chamarem pelo nome a violência, indicam que ser forte significa mais do que exercer a vingança:

(...) Ouvindo a modesta epopéia, com certeza desejei exibir energia e ferocidade. [Por desgraça,] Infelizmente não tenho jeito para [semelhantes ações] violência. Encolhido e silencioso, agüentando cascudos, limitei-me a aprovar a coragem do menino [forte] vingativo.

Fechando o primeiro capítulo, o adulto reflete sobre a necessidade de se relativizar o valor do heroísmo, numa sugestão de que as ações enérgicas, vingativas, de grande ostentação, muitas vezes escondem maior covardia. Esse pensamento, de implicações políticas e educacionais, corresponde à sua ética como artista da palavra escrita, para a qual importa construir imagens literárias que expressem a revolta contra injustiças. Mas ele sabe que, tal qual na historieta contada por sua mãe, as associações criativas entre palavras e imagens podem promover engano ou libertação. A valentia de Graciliano foi, tendo experienciado injustiças desde criança, combatê-las por meio da dedicação aos romances, da "obstinação concentrada" no "arranjo de ninharias", atitude contrária a populismos e proselitismos de partidos políticos.

Mais tarde, entrando na vida, [sempre calado e sempre esquivo, ] continuei a venerar a decisão e o heroísmo, quando isto [aparece] se grava no papel e os gatos se transformam em papa-ratos. De perto, os indivíduos capazes de amarrar fachos nos rabos dos gatos nunca me causaram admiração. Realmente são espantosos, mas é necessário vê-los a distância, modificados.

$\mathrm{Na}$ versão de Infância, o escritor eliminou o aposto tão autodefinidor "sempre calado e sempre esquivo". Porém, esse sentido de introspecção e recusa ao mundo violento fica condensado nas confissões de quem, "encolhido e silencioso", ao "entrar na vida" preferia as ações enérgicas convertidas em imagens literárias "gravadas no papel".

Assim, conhecendo-se o afastamento de Graciliano em relação a vinganças violentas como a do menino do conto, tem-se nova luz sobre as diferenças que o separam 
de Lampião. Precisava compreender-lhe os motivos da violência e então vê-lo à distância. Mais do que transformar a besta-fera Lampião na imagem do homem injustiçado que se vinga, Graciliano moveu-se pelo sentimento de culpa ante o mesmo mundo do sertanejo faminto: vingou-se no papel, com suas armas insignificantes e terríveis de Lampiãoastrônomo, construindo os dramas de Paulo Honório, Luís da Silva e Fabiano. Em Infância está o sentido de vingança em que se formou o romancista. Preso à realidade de violência, a fuga para a imaginação, o esforço de decifração das letras e a mediação pela literatura foram sua vingança, no sentido etimológico de libertação ${ }^{43}$. Do diálogo do adulto com as perplexidades, impressões e pensamentos do menino, sobressaem os componentes dessa vingança pela literatura: a sensibilidade, a consciência histórica e a potencialidade crítica de construir mundos reunindo palavras.

Dessa forma, o primeiro capítulo de Infância concentra a poética, essencialmente ética, de Graciliano, ao figurar o aprendizado do menino sobre as diferenças e semelhanças entre as palavras e entre os seres, junto com sua percepção sobre a violência do mundo e resistência a ela. Em "Nuvens", surgem a primeira aula de bê-á-bá por ele ouvida, o erro fecundo de chamar laranjas de pitombas e a historieta contada por sua mãe sobre o menino vingativo. Nesse capítulo, a condensar o percurso de Infância, delineiam-se as enormes dificuldades e os ganhos raros que formaram Graciliano, no aprendizado de distinguir as letras, as palavras, as frutas, as coisas, as pessoas, as metáforas, a violência e a possibilidade de mediação pela literatura.

Infância (1945) é a construção literária da compreensão do mundo pelo escritor. Tece a representação do olhar da criança que depara com a complexidade física e social do sertão nordestino, com as contradições inerentes às relações sociais, em casa, na escola, no trabalho, deixando entrever-se a formação da identidade do romancista, de sua auto-estima e de sua consciência crítica quanto a questões centrais - a educação, a política, a justiça, a literatura. Com a força expressiva da comoção sem derramamentos, revela como foi tenso o encontro de Graciliano menino com as letras: em meio à contínua apreensão - o pavor da

\footnotetext{
${ }^{43}$ Vingança, de vingar e -ança, da raiz vindic-, vindicare: 'vingar, castigar, pôr em liberdade'; vindicta, ae: 'varinha com que o lictor dava um pequeno toque sobre a cabeça do escravo enquanto o pretor pronunciava a fórmula de alforria; defesa, proteção, vindita, castigo, punição'. Se o lugar-comum de vingança é aludir à violência, a palavra guarda um sentido de liberdade, de reivindicar; e vingar significa também 'resistir vivo, medrar, sair vencedor'. (CRETELLA JR, José \& ULHÔA CINTRA, Geraldo de. Dicionário LatinoPortuguês. cit.; HOUAISS, Antonio e VILLAR, Mauro de Salles. Dicionário Houaiss da Língua Portuguesa. Rio de Janeiro: Objetiva, 2001).
} 
palmatória, a cegueira maltratada ${ }^{44}$, o sofrimento de injustiças -, surpreendiam-no os inesperados momentos de satisfação, o entreabrir de descobertas cognitivas e afetivas. Assim, Infância dá a medida dessas incongruências que parecem definir o mundo, apreendidas pelo olhar do adulto em sensível e aguçado diálogo com o do menino.

\section{Homens no papel, modificados}

Evocando-se os significados de "Nuvens", desde a soletração na escola nordestina até o conto sobre o menino vingativo, reencontra-se o impasse apreendido de "Lampião" e formalizado nos romances de Graciliano: o lugar da educação, da literatura, no mundo de violência.

Contra o lugar-comum em termos éticos e estéticos, a atitude hermenêutica, o movimento de aproximar-se e afastar-se dos outros por meio da elaboração com as palavras, afigura-se meio possível para o intelectual vingar-se, ou seja, resistir nesse mundo. Pensando-se na formação da obra de Graciliano, aqui se entroncam a Novidade e as crônicas de 1931 com os seus romances e memórias. Segundo o leitor confirma ao deparar com a verdade do viés subjetivo de Infância, Graciliano se vingou no papel, por intermédio de Paulo Honório, Luís da Silva e Fabiano, superando estereótipos na construção de seus dramas, até atingir a mais plena formalização do foco narrativo no livro de memórias. Retomando o problema a cuja reflexão dei início no mestrado, da superação formal na passagem de Caetés para S. Bernardo e Angústia, note-se que a vingança de Paulo Honório e de Luís da Silva foi narrar a própria trajetória. Diferentemente de João Valério, eles escrevem porque têm necessidade de libertação, oprimidos em seus sofrimentos: configuram-se narradores depois e justamente em virtude das experiências por eles vividas, em que provocaram as mortes de Madalena e de Julião Tavares, respectivamente.

S. Bernardo é a narrativa do proprietário que fora pobre mas que, dono da visão retrospectiva do todo de sua trajetória que culminou na morte de sua mulher, está

\footnotetext{
${ }^{44}$ Conforme se lê nos capítulos "Cegueira" e "Chico Brabo", o menino Graciliano sofreu com uma doença de olhos que o mergulhava periodicamente na sombra: as pálpebras inflamadas grudavam-se; a mãe lhe dava os apelidos horríveis de bezerro-encourado e cabra-cega; perseguia-o a imagem dividida do vizinho Chico Brabo, amável na rua, mas de quem ouvia urros e agressões ao criado na sala de jantar. Ao mesmo tempo, nas palavras do escritor-astrônomo: "Na escuridão percebi o valor enorme das palavras".
} 
insatisfeito e é impelido a escrever. Assim, o segundo romance de Graciliano retoma em outra direção o princípio da tensão formal de Caetés, em que João Valério, satisfeito, não tem motivos para escrever quando se torna sócio-proprietário da firma.

Também Angústia concentra o aperfeiçoamento formal de Graciliano a partir de Caetés. O narrador-protagonista João Valério contém em germe, a um tempo, Paulo Honório e Luís da Silva. Se Paulo Honório é proprietário, desenvolvimento da condição de João Valério ao fim de seu percurso, Luís da Silva é o pequeno funcionário, órfão de aristocracia decadente, mas que, ao contrário do guarda-livros de Caetés, representa um intelectual crítico da ordem do mundo. Narra o fracasso de sua vida amorosa e de escritor, marcada pelo sentimento de impotência porque matar o bacharel e proprietário comercial Julião Tavares não redimiu, antes aumentou, sua miséria, a qual compartilha, em sua consciência angustiada, com milhares de "figurinhas insignificantes".

Desse modo, no centro dos romances S.Bernardo e Angústia, está o impasse de sobreviver num mundo de violência e a potencialidade de resistir a ele por uma atitude hermenêutica, de compreensão das palavras, do outro, de si, da realidade. Na medida em que as narrativas decorrem de os protagonistas experienciarem o sofrimento alheio e o próprio e, portanto, a compaixão, apreende-se a ética da literatura de Graciliano Ramos. Segundo ensina Schopenhauer, a compaixão depende de "o animal espectador identificarse com o animal que sofre", constituindo "a própria motivação moral" ${ }^{45}$. Recorde-se a "ética do rosto", nos termos de Lévinas: um rosto, "exposição de um ser à sua morte, o sem defesa, a nudez e a miséria de outrem", significa um pedido e uma ordem, um imperativo à misericórdia e à responsabilidade do outro ${ }^{46}$.

Os ensaios a seguir buscam a compreensão dos romances de Graciliano levando em conta a Novidade. Serão analisados momentos centrais em que os protagonistas se defrontam consigo mesmos após se verem como causadores da morte do outro. Nestes momentos configuram-se artisticamente, juntos, o "problema social" e o "problema moral" das personagens, constituindo a "autenticidade do romance brasileiro" (Carpeaux). Minhas leituras do escritor se acompanharam de sua fortuna crítica, sobretudo dos textos indicados na Bibliografia.

\footnotetext{
${ }^{45}$ Cf. SCHOPENHAUER, Arthur. Sobre o fundamento da moral. Tradução: Maria Lúcia Mello Oliveira Cacciola. $2^{a}$ ed. São Paulo: Martins Fontes, 2001, p. 167, p. 186.

${ }^{46}$ POIRIÉ, François. Emmanuel Lévinas: ensaio e entrevistas. cit., p. 85 (Entrevistas realizadas entre abril e maio de 1986).
} 


\title{
Parado, o coração de Madalena Paulo Honório toca.
}

\section{Lembrança com propósito despropositado: S.Bernardo}

\begin{abstract}
Aproximei-me, tomei-Ihe as mãos, duras e frias, toquei-lhe o coração, parado. Parado. (...) Comecei a friccionar as mãos de Madalena, tentando reanimá-la. (capítulo $31^{47}$ ).
\end{abstract}

Madalena morta. Tardio o propósito de Paulo Honório de salvá-la, conhecer Madalena morta move todas as linhas de S. Bernardo.

$\mathrm{Na}$ recordação do momento imediatamente anterior ao suicídio da mulher, destacase o eixo dramático da "carta" (capítulo 31): uma construção de imagens ligadas à visão e à cegueira figura a dificuldade de Paulo Honório para fazer-se astrônomo e compreender os outros e a si, surgindo imbricadas a representação da pobreza inicial dele e de Madalena e a expressão da angústia do sertanejo que, pobre, se tornou assassino, ladrão e proprietário, enfim narrador, responsável pela morte de outras pessoas, sobretudo da mulher reconhecida tardiamente como o seu amor. Partindo da imagem do protagonista cego, diante da propriedade, da mulher e, síntese trágica, diante da carta a ele destinada, a arte do capítulo é fazer convergirem os seus problemas social e afetivo-moral, o seu completo abandono.

Acompanhe-se, então, a construção de imagens ligadas à visão e à cegueira. $\mathrm{Na}$ composição do capítulo, o primeiro movimento é, do alto da igreja, a visão do proprietário satisfeito diante de sua fazenda enorme. Enquanto o empregado Marciano eliminava corujas na torre, mas não augúrios de desgraça, Paulo Honório se comprazia de seu poder: possuía plantações e rebanhos numerosos, as casas de seus trabalhadores, o respeito e talvez até o amor desses dependentes, dispunha da vida de seus inimigos. Diante de tal poderio, pareceu-lhe insignificante Madalena a escrever no escritório, "uma boneca traçando linhas invisíveis num papel apenas visível”.

Contudo, essa convicção de fortaleza se abalaria ante as palavras desconhecidas de uma folha escrita pela mulher, trazida pelo vento. Não suportando que nada, nem as palavras nem Madalena, lhe escapasse ao domínio, Paulo Honório, ao desconfiar de carta dirigida a homem, é incapaz de lê-la.

\footnotetext{
${ }^{47}$ RAMOS, Graciliano. S. Bernardo. $6^{\mathrm{a}}$ ed. Rio de Janeiro: José Olympio, 1955, p. 172.
} 
Lia a folha pela terceira vez, atordoado, detendo-me nas expressões claras e procurando adivinhar a significação dos termos obscuros.

- Está aqui a prova, balbuciei assombrado. A quem serão dirigidas estas porcarias?

(...)

Afinal a noite caiu, não enxerguei mais as letras.

Sim senhor! Carta a homem!

No papel "apenas visível", perduravam "invisíveis" as linhas. A dificuldade de Paulo Honório para fazer-se astrônomo e ler a carta tem por contraparte sua reação violenta de ciúme. Movimento central do capítulo e do livro, desvelam-se cegas as certezas do proprietário: sertanejo que "sofreu sede e fome" e, na luta pela vida, acostumado a roubar e matar, elevou-se socialmente a fazendeiro, não sabia ler bem, não soube compreender os "bons propósitos" de Madalena, nem seu intuito de se matar. Tragicamente, a mesma carta, por meio da qual ela se despedia de Paulo Honório e de uma vida de sofrimentos acirrados pela obsessão de posse do proprietário, incitou ainda mais a cegueira daquele ciúme.

E voltei furioso, decidido a acabar depressa com aquela infelicidade. Zumbiam-me os ouvidos, dançavam-me listras vermelhas diante dos olhos. Ia tão cego que bati com as ventas em Madalena, que saía da igreja.

- Meia-volta, gritei segurando-lhe um braço. Temos negócio.

- Ainda? perguntou Madalena.

E deixou-se levar para a escuridão da sacristia. Acendi uma vela (...). (grifos meus)

À visão de onipotência do proprietário ante sua fazenda segue-se o ciúme violento, culminando na cegueira máxima ao “- Ainda?” perguntado pela professora, expressão temporal do trágico descompasso entre Paulo Honório e Madalena. Contrariamente às "violências desmedidas" que nele ferviam, a mulher aparentava tranqüilidade; certo o seu propósito de se matar, ela se sabia fora do tempo de Paulo Honório, do tempo insuportável de pessoas sujeitadas a negócios. Assim, figurando-se em arte o imperativo ético e, conjuntamente, a história social violenta e a necessidade de amor de Paulo Honório, seu ímpeto ciumento de matar Madalena pára diante do rosto dela, cuja impassibilidade ele necessita compreender, sem conseguir.

O que me espantava era a tranqüilidade que havia no rosto dela. Eu tinha chegado fervendo, projetando matá-la. (...)

À medida, porém, que as horas se passavam, sentia-me cair num estado de perplexidade e covardia. 
As imagens de gesso não se importavam com a minha aflição. E Madalena tinha quase a impassibilidade delas. Por que estaria assim tão calma?

(...)

As minhas mãos contraíam-se, moviam-se para ela, mas agora as contrações eram fracas e espaçadas.

Para além de um estereótipo de proprietário sertanejo cruel, é comovedora a tensão de Paulo Honório entre o pulsar e o abafar de sentimentos amorosos nesse momento que, sabemos com o narrador, precedia o suicídio de Madalena. Inconsciente do tempo, dividindo o olhar entre a mulher e os santos do oratório, sente raiva, angústia, cansaço, sucedidos por perplexidade e covardia. Ele se adivinha imerso num equívoco que a mulher poderia esclarecer; no coração, "coices desesperados" querem convencer-se da inocência dela. Quando esta se anuncia e ele quase exprime "palavras de arrependimento", sufoca-as movido por um "orgulho estúpido"; e o proprietário-narrador exprime a dor desse erro irreparável evocando a concretude de sua profissão: "Muitas vezes por falta de um grito se perde uma boiada".

Tendo em mente o desencontro de Paulo Honório e Madalena, note-se a etimologia da palavra propósito: 'pôr diante', do verbo propor. Sem enxergar o que estava diante de seus olhos - as "linhas invisíveis" da mulher, que logo se mataria -, o fazendeiro prático, sensibilidade abafada, chama a conjectura dela de morrer repentinamente de "lembrança fora de propósito". Desse modo, condensando o drama do proprietário, sua fúria de matar Madalena encontra o despropósito do suicídio dela, reação contra todas as formas de apagamento dos outros, praticadas por ele em nome de seus propósitos materiais. Por ser Madalena uma professora sensível e preocupada com a "questão social”, embora juntos, era como se ela e o proprietário tivessem vivido tempos diferentes; porém, iguais na miséria de que partiram e na desgraça a que chegaram, encontram-se tragicamente por meio da memória escrita de Paulo Honório, na bela criação de Graciliano. Embora tarde, ele compreenderia as "linhas invisíveis" dela e as transmitiria.

$\mathrm{Na}$ cena analisada, surgem as últimas palavras de Madalena. Os olhos fitos na vela e no agitar de sombras nas paredes, ela reconhece o desamparo de sua vida, casada com o dono da fazenda, explorador dos outros: recorda-se do seu esforço de estudar, a despeito e por causa da miséria, em busca de condições de vida dignas. Chamando a atenção de Paulo Honório para a vida precária dos trabalhadores de S. Bernardo, a professora pede também por ele, que se constituíra de crimes e brutalidade na luta contra a origem igualmente 
pobre. Ao se aproximar dos trabalhadores e se afastar do caminho do proprietário, Madalena aponta para o problema social representado pela trajetória dele.

Percebe-se o pressuposto hermenêutico, ético, de Graciliano na construção das personagens, atento à realidade, às semelhanças e diferenças entre os seres. Como se viu, em "Sertanejos" e em "Lampião", o escritor depreende os caminhos possíveis dos sertanejos e, dentre eles, a história social do enxadeiro que se torna explorador de enxadeiros. A partir dela, criou o drama de Paulo Honório: arrependido por haver provocado o suicídio de Madalena, tendo sufocado sua sensibilidade como assassino, ladrão e explorador, ele se aflige por não conseguir modificar-se de sua "profissão". Ao figurar o sofrimento deste proprietário incapaz de mudar sua "alma agreste" enraizada pela "vida agreste", Graciliano desnuda o impasse contido na naturalização da violência. Na poesia trágica que antecede o suicídio de Madalena, a natureza, indiferente, se humaniza, mas o homem demora, indiferente: "o vento se cansou de gritar à toa", e, quando Paulo Honório acordou na sacristia, a vela já estava apagada, o relógio parado, Madalena morta.

Dessa forma, fazendo sobressair o desamparo social, afetivo e moral de Paulo Honório, a arte de S.Bernardo comove e cria consciência crítica. Repare-se como surgem imbricados na trajetória do personagem os mesmos problemas da realidade dos anos 1930 acusados pela Novidade - a miséria, ignorância, violência, política personalista e de conchavos. Ele sofreu sede e fome, aprendeu a ler na prisão e, para fazer um empréstimo, tirou o título de eleitor, atendendo aos interesses do voto de cabresto. Ascendeu matando e roubando e, proprietário explorador, era contra a instrução para os trabalhadores; só quis a escola na fazenda, cuja professora veio a ser Madalena, para obter vantagens pessoais, correspondendo às intenções eleitoreiras do governador. Assim, o impasse entre violência e hermenêutica move a escrita de S. Bernardo: sufocada sua sensibilidade, o trabalhador pobre roubou, matou e chegou a proprietário; faltando-lhe mediações com a realidade e consciência crítica, teve dificuldade para fazer-se astrônomo - ler a carta de Madalena, compreender os bons sentimentos dela -, o que redundou na perda da mulher; paradoxo trágico, só então Paulo Honório percebeu o sem-sentido de sua vida de proprietário e, necessitando reagir a essas faltas, dedicou-se à arte de escrever sua história. 


\section{Mortos vivos em Angústia: ódio e compaixão aos vencedores vencidos (o cangaceiro, o funcionário, o bacharel proprietário)}

(...) A obsessão ia desaparecer. Tive um deslumbramento. O homenzinho da repartição e do jornal não era eu. Esta convicção afastou qualquer receio de perigo. Uma alegria enorme encheu-me. Pessoas que aparecessem ali seriam figurinhas insignificantes, todos os moradores da cidade eram figurinhas insignificantes. Tinham-me enganado. Em trinta e cinco anos haviam-me convencido de que só me podia mexer pela vontade dos outros. Os mergulhos que meu pai me dava no poço da Pedra, a palmatória de mestre Antônio Justino, os berros do sargento, a grosseria do chefe da revisão, a impertinência macia do diretor, tudo virou fumaça. Julião Tavares estrebuchava. Tanta empáfia, tanta lorota, tanto adjetivo besta em discurso - e estava ali, amunhecando, vencido pelo próprio peso, esmorecendo, (...) amortalhado na neblina. ${ }^{48}$

Essencial em Angústia, este é o momento raro de "deslumbramento" e "alegria enorme" de Luís da Silva ao matar Julião Tavares. Impulsionava o assassino uma perturbação interior indissociável do fator econômico, de sua miséria social. Descendente de aristocracia decadente, levara vida de cigano por fazendas, como mestre de meninos, experienciara a caserna, a mendicância, empregos miúdos e a banca de revisão. Já em Maceió, após curvaturas em busca de um pistolão, tornou-se pequeno funcionário de repartição e jornal, literato de aluguel. Noivo de Marina, contraiu muitas dívidas com presentes para ela, que, no entanto, o preteriu em favor de Julião Tavares. Carregando o peso de tantas humilhações, essa perda para um bacharel rico, de retórica oca ("Linguagem arrevesada, muitos adjetivos, pensamento nenhum"), fez o pobre-diabo concentrar no rival todo o ódio pelos donos de "dinheiro e propriedades". Por isso, ao matá-lo, crendo-se livre da "obsessão", Luís da Silva se sente transformado: não era mais o "homenzinho da repartição e do jornal". Capaz de estrangular um homem cheio de empáfia, vê-se forte, não submisso. Nesse momento, como se as dissolvesse, evoca as muitas humilhações e violências a ele impingidas, pelo pai, pelo professor, pelo sargento, pelo chefe da revisão, pelo diretor.

Contudo, a obsessão permanece: preso em sua rotina miserável, e ainda mais mortificado por saber-se assassino, Luís da Silva precisa reconstituir sua história por meio da escrita. A tragédia de Angústia, apontada por Carpeaux, advém exatamente de o "problema social" do protagonista estar dentro de seu "problema moral" ou vice-versa.

\footnotetext{
${ }^{48}$ RAMOS, Graciliano. Angústia. $7^{\mathrm{a}}$ ed. Rio de Janeiro: José Olympio, 1955, p. 210.
} 
Para entender essa fusão, cumpre ressaltar o momento anterior ao estrangulamento de Julião Tavares, em que avultam em Luís da Silva certa autoconfiança e piedade, sentimentos que, após o crime, se reverterão em angústia. Ele se vê forte socialmente, porque o homem rico, espreitado, surge como seu dependente. E, base de seu posterior tormento, é forte eticamente, no instante em que enxerga o outro como seu igual no desamparo e sente a piedade por Julião substituir o ódio.

(...) Para que seguir o homem odioso que tinha tudo, mulheres, cigarros? (...) A idéia de que nos íamos separar me desesperava. Ali era como se ele dependesse de mim. (...) De repente senti uma piedade inexplicável, e qualquer coisa me esfriou mais as mãos. Julião Tavares era fraco e andava desprevenido, como uma criança, naquele ermo, sob ramos de árvores dos quintais mudos. Uma hora, meia hora depois, passaria pelo guarda adormecido junto a um poste, seria forte, mas ali, debaixo das árvores, era um ser mesquinho e abandonado. (Grifos meus, pp. 205-6).

Morto o bacharel, junto com a acirrada penúria afetiva e econômica de Luís da Silva, o vivo remoer desse momento de compaixão é constitutivo da sua angústia, porque, sinalizando o abandono comum, aponta a fraqueza da sua ação. Como sentiu em Julião o desamparo de uma criança desprotegida, Luís da Silva chegou por instantes a identificar-se com ele, surpreendentemente suprimidas as barreiras que os separavam. Conforme sublinha Schopenhauer, a compaixão, apesar de constituir um mistério, é o motor da moral, quando um animal espectador de outro que sofre se identifica com ele. ${ }^{49}$ Assim, embora inexplicável a piedade humana para com a dor alheia, ainda mais de um rival, uma parte da angústia do intelectual pobre-diabo advém de ter deixado o ódio prevalecer, ferindo o fundamento da moral: além de ser irrelevante socialmente, sabe-se assassino, não suporta as suas mãos sujas, "estragadas". Expressando o impasse entre a culpa de matar um homem e o sentimento da necessidade social de eliminar proprietários canalhas, é enorme o potencial ético de sua narrativa: Luís da Silva exprime os seus sofrimentos e revela a miséria de muitos trabalhadores pobres, mendigos, vagabundos e assassinos, com a qual se identifica, mesmo se confessando distante deles (dado terem um nível econômico e intelectual inferior ao seu) e impotente para minorá-la ${ }^{50}$.

\footnotetext{
${ }^{49}$ SCHOPENHAUER, Arthur. Sobre o fundamento da moral. cit., p. 163.

${ }^{50}$ Erwin Torralbo Gimenez desvela muito bem o modo como o protagonista de Angústia "encarna" o pobrediabo: espremido entre o povo, que o olha com desconfiança, e as elites dominantes, que o exploram, Luís da Silva cria sua consciência de "fracassado", esbarrando sempre "na inércia sem poder comunicar com os demais". Cf. GIMENEZ, Erwin Torralbo. Graciliano Ramos - O mundo coberto de penas. Tese de doutorado. São Paulo, FFLCH-USP, 2005, p. 156.
} 
Ainda no momento precedente ao crime, veja-se que é noite mal-iluminada e o ódio sobrepuja a compaixão: o assassino não enxerga o rosto nem a roupa da vítima. Que melhor maneira para representar o assomo de coragem do funcionário humilhado frente ao proprietário desprezível e, a um tempo, figurar o imperativo ético, substituído pela raiva irracional? A presença de Julião como sombra deixou em suspenso a "resistência ética" 51 de Luís da Silva.

$\mathrm{O}$ desejo de fumar levava-me ao desespero. $O$ acesso de piedade sumiu-se, o ódio voltou. Se me achasse diante de Julião Tavares, à luz do dia, talvez o ódio não fosse tão grande. Sentir-me-ia miúdo e perturbado (...). Afastar-me-ia precipitadamente, como um bicho inferior. Agora tudo mudava. Julião Tavares era uma sombra, sem olhos, sem boca, sem roupa, sombra que se dissipava na poeira de água. A minha raiva crescia, raiva de cangaceiro emboscado. Por que esta comparação? Será que os cangaceiros experimentam a cólera que eu experimentava? (Grifos meus, p. 207).

Como na crônica "Lampião", nota-se aqui também a comparação do intelectual com o cangaceiro, mas integrada à situação dramática de Luís da Silva. Sempre se sentira covarde: preso à sua "tendência para os impressos", herdada do pai, e sem dinheiro, era subserviente, a camisa amassada, curvado desde os tempos da escola até o presente de revisor e redator de artigos elogiosos a políticos. Ressalta como se afastara do avô, capaz no passado de soltar um cangaceiro da prisão. Porém, em sua revolta de ordem pessoal e social, Luís da Silva desejou ser um bandoleiro e matou o homem rico, o que o distingue dos intelectuais, lampiões de palavras; ao mesmo tempo, diferenciando-se da violência naturalizada dos cangaceiros, remorde em sua consciência a raiva e a culpa. ("Tudo isto é absurdo, é incrível, mas realizou-se naturalmente. A corda enlaçou o pescoço do homem, e as minhas mãos apertadas afastaram-se", p. 210).

No tormento de analisar-se e aos outros, compreendendo e recusando as ações violentas, o narrador de Angústia deixa ver, nos diferentes matadores, necessidade, ódio, crueldade tornada habitual e até inocência. Reconhece-se próximo e distante não só dos bandoleiros, como do matador José Baía. Por um lado, deseja a inocência deste, que não teria uma crise de ódio semelhante à sua, nem remorso. Como matava forçado pela necessidade, obedecendo à ordem do patrão, rezava pelo defunto e provavelmente ficava

\footnotetext{
51 "Há uma relação, não com uma resistência muito grande, mas com alguma coisa de absolutamente Outro: a resistência do que não tem resistência - a resistência ética. A epifania do rosto suscita a possibilidade de medir o infinito da tentação do assassínio, não como uma tentação de destruição total, mas como impossibilidade - puramente ética - dessa tentação e tentativa". LÉVINAS, Emmanuel. Totalidade e infinito. cit., p. 178.
} 
sossegado. Evocando José Baía como irmão, com saudades de suas conversas infantis e histórias simples, Luís da Silva se indaga se o infeliz, velho, já teria morrido em tocaia ou continuaria na prisão. Por outro lado, rejeita José Baía como irmão, lembrando-se dele como um estranho a apodrecer na cadeia por homicídio.

Desse modo, o repisar das muitas humilhações sofridas e do ódio pelo bacharel rico que lhe roubou a noiva, a rememoração do instante de piedade por ele e a comparação com os cangaceiros e com José Baía revelam Luís da Silva um homem torturado pelos sentimentos simultâneos da culpa por ser assassino e da necessidade de seu ato. Se, antes de matar o rival, não lhe distinguiu o rosto, depois é perseguido pela recordação da "cara balofa" de Julião Tavares. Imagem repugnante do proprietário e bacharel bem-nutrido, desgraçador de Marina e de outras moças pobres, invasivo, sem consistência e de palavrório adjetivoso que Luís da Silva precisava matar, e, a um tempo, da pessoa de quem de fato tirou a vida, esse rosto figura as dimensões social e moral da angústia do funcionário assassino.

Essas dimensões social e moral do tormento do protagonista ganham forma por uma obsessiva rede de imagens associadas, que engloba a miséria de muitas "figurinhas insignificantes". Angústia tece a representação de um "ambiente de miséria e humilhação e tristeza infinita" e, "obra-prima de introspecção psicológica", é, "pelo estilo e pela composição, um romance-poema, ou romance poemático", segundo a percepção fecunda de Otto Maria Carpeaux ${ }^{52}$. Assim, encadeadas a partir da presença viva da "cara balofa" do defunto na mente de Luís da Silva, sobressaem na composição do romance várias figuras de mortos vivos e metonímias de humilhações, que assombram o cotidiano dele e o mortificam.

Como the falta inocência, ele se esforça por tornar-se criança e mistura coisas do presente e do passado. A caminho da repartição, pensa em defuntos. Não tendo onde cair morto, imagina o próprio cadáver, defunto pobre num caixão barato. Destacam-se as sombras dos defuntos antigos, que o importunam. Remetendo-o a um inverno passado, a chuva alude a instantes de alegria, mas sobretudo à tortura dos banhos no Poço da Pedra com cobras, em que o pai lhe provocava o medo de afogar-se. Raros no sertão, trovões e relâmpagos, que obrigavam os bichos a abrigarem-se no copiar da fazenda, firmaram na memória de Luís da Silva o grito de Quitéria. Ante aquele temor de desamparo, a ex-

52 CARPEAUX, Otto Maria. Realismo mágico, novamente. In: Tendências contemporâneas na literatura. Um esboço. Rio de Janeiro: Edições de Ouro, 1968, p. 254. 
escrava com quem o avô de Luís da Silva teve muitos filhos bastardos, espalhados pelo mundo, exclamava: "Misericórdia!". Surgindo esta frase nominal com seu teor de pedido cheio de pungência nessa cena, ela retorna em situações que falam do abandono do protagonista e de todo vivente (misericórdia, o coração contrito ante a miséria).

Quando pensa na morte do pai, Camilo Pereira da Silva, de pés magros, sujos e "desgovernados", Luís se lembra de que sentiu pena de si mesmo, sozinho no mundo. Se enterrar o morto constituiu "obra de misericórdia", no dia seguinte os credores bateram os pés com força e levaram as mercadorias e os móveis, indiferentes ao menino órfão, "bichinho abandonado". Novamente Quitéria se encolheu, gemendo: "Misericórdia!". Também esta tinha sido a reação dela diante da cobra enrolada qual uma corda no pescoço do avô Trajano. Sombras da decadência de sua família, o pequeno funcionário se lembra da avó, que xingava escravas inexistentes, e do avô anos depois, bêbado e amparado por um ex-escravo, chamando pela mulher morta. No romance, as metonímias dos pés - sujos, descalços, pisados, apertados - e das cobras remetem a humilhações (de etimologia ligada a rastejar, sepultar), pavor e morte. E as imagens de cobras aludem à corda, presente do pedinte Seu Ivo que seria o instrumento da vingança e conseqüente angústia (etimologicamente: estreiteza, estrangulamento, aperto) de Luís da Silva.

Assim, eco e resposta ao grito de Quitéria, os sentimentos de desamparo e de misericórdia do narrador de Angústia fazem várias imagens de defuntos, os antigos, os recentes e os vivos, perturbarem-no: os animais sob o trovão; o avô, Trajano Pereira de Aquino Cavalcante, senhor de terras decadente; o pai, "reduzido" a Camilo Pereira da Silva, preguiçoso e violento com ele; o órfão pobre, ele próprio, que se tornaria o homenzinho da repartição, literato de aluguel e assassino; os pedintes como Seu Ivo e Seu Evaristo; as grávidas pobres e abandonadas como Marina; os cangaceiros como Cirilo de Engrácia; os vagabundos como o que lhe deu um cigarro na cena do crime; e, perfazendo a força artística do romance, o bacharel rico enforcado.

Dentre as imagens que atormentam Luís da Silva, aludindo ao seu desejo de mudança social e à sua culpa moral, destaca-se a de Seu Evaristo. A história trágica de miséria deste certamente compungia o pequeno funcionário, compondo o fermento de sua ânsia de matar os donos de dinheiro; e, sobretudo para quem desejou e conseguiu estrangular Julião Tavares, a imagem de Seu Evaristo enforcado causava pavor. Desnudando a necessidade de um salto para outro mundo social, é muito viva de 
inconformismo a figuração dos passos finais desse defunto em pé. Após ter sido um trabalhador sério, na velhice passou fome ao lado da esposa: "olhou os quatro cantos e não encontrou amparo" (p. 165). Teve de pedir esmola, foi maltratado. Enforcou-se. Encontraram-no morto, levantado, balançando, com os pés no chão como se ameaçasse dar um salto.

"Defunta em pé": após fazer o aborto do filho de Julião Tavares, assim Marina surge aos olhos do ex-noivo. Desprezado por não ser rico, julgando a escolha de marido por dinheiro a "pior espécie de prostituição", ele a insulta. Porém, desgostoso ante o fatalismo dela, usada e abandonada sem reagir contra o bacharel abastado, apieda-se, sabendo-a uma desgraçada sem rumo, de pés "metidos na areia". Condoído da sorte da mulher e da sua própria, soma enjôo e ódio, palavras de mesma raiz (in-odio), numa idéia que inutiliza qualquer outra e o confirmará também defunto em pé: matar Julião Tavares.

Impossível não recordar aqui uma imagem que, na construção do romance, anuncia a gravidez de Marina: andando como um cego em meio à multidão hostil, no mundo "empastado e nevoento", o funcionário deu um encontrão numa grávida muito pobre, que trazia a barriga enorme, os pés apertados em sapatos furados e uma criança pelo braço. Ele viu um pedaço da cara dessa mulher, que lhe dirigiu um olhar cheio de ódio e de sofrimento. Esse rosto, aludindo metonimicamente à degradação de Marina, sinaliza uma acusação de culpa e um pedido de misericórdia. Condensando a modernidade de Angústia, romance poemático de um mundo abandonado por Deus e tragédia da gente do país, marcou Luís da Silva esse choque com a grávida pobre na multidão: parecia haver um ventre a gestar misérias que se alargavam por todos.

\section{- Puta!}

Marina ouviu isto sem se revoltar. Apenas ficou mais branca, estirou o beiço quase chorando.

(...)

Dizia-lhe o insulto, mas estava cheio de piedade. Não sentia cólera, o que sentia era desgosto.

Marina estava como uma defunta em pé. Pensei em Cirilo de Engrácia, visto dias antes em fotografia - um cangaceiro morto, amarrado a uma árvore. Parecia vivo e era medonho. O que tinha de morto eram os pés, suspensos, com os dedos quase tocando o chão. Os pés de Camilo Pereira da Silva, ossudos, magros, eram assim desgovernados. Os de Marina estavam metidos na areia. E Marina parecia morta. (Grifos meus, p. 192).

Outros mortos vivos que perseguem Luís da Silva são os cangaceiros. Como se viu, especialmente nas crônicas de Graciliano, eles não se poupavam nem aos outros, vivendo 
emboscados, entre matar ou morrer, depois de a necessidade de sobreviver tê-los arrastado para os bandos. Se o funcionário desejou ter a crueldade naturalizada dos cangaceiros para assassinar Julião, identificava-se com esses sertanejos pela condição social, "heróis de arribação bastante chinfrins".

Observe-se que a metáfora de mortos vivos enforma o romance, aproximando suas várias figuras, sobretudo Julião Tavares, Marina e o próprio narrador-protagonista, delineadas em sua singularidade a partir das sombras da memória atormentada deste. Quando vê que perderá a noiva para o homem rico, Luís da Silva sente um embotamento generalizado, as idéias truncadas, pressente uma guerra na Europa. No diálogo com Moisés, apontam-se as iniqüidades e sofrimentos impingidos aos judeus, perseguidos na Europa, e aos nordestinos, fatalistas. Assim, por apreender criticamente o contexto de miséria e violência dos anos 1935, em que fermentavam ditaduras e se anunciavam os horrores da Segunda Guerra ${ }^{53}$, Angústia pôde incorporar a imagem de origem factual de um cangaceiro "defunto em pé".

Quando completava a escrita do romance, Graciliano deve ter visto nos jornais uma fotografia medonha de Cirilo de Engrácia, chefe de um subgrupo de Lampião, morto a 5 de agosto de 1935 em Mata Grande, Alagoas. Acompanhando as cartas de 1935 do escritor ${ }^{54}$, percebe-se como, durante a gênese de Angústia, sua inquietação era a criação artística, mas indissociável da culpa ante os problemas social e moral da miséria do país e da guerra no mundo. Mais preocupado com a literatura, se ele acusa sua "sensibilidade excessiva" de escritor, esta incluía aguda visão da realidade e rigorosa postura ética:

(...) O Estado está pegando fogo, o Brasil se esculhamba, o mundo vai para uma guerra dos mil diabos, muito pior que a de 1914 - e eu só penso nos romances que poderão sair dessa fornalha em que vamos entrar. Em 1914-1918 morreram uns dez ou doze milhões de pessoas. Agora morrerá muito mais gente. Mas pode ser que a mortandade dê assunto para uns dois ou três romances - e tudo estará muito bem. Por aí vê você que eu sou um monstro ou um idiota. (...)

Carta a Heloísa. Maceió, 3 de abril de 1935 (n. 77, p. 146).

\footnotetext{
53 "Publicado em 1936, um ano depois da revolta militar da Aliança Nacional Libertadora e um ano antes da implantação do Estado Novo, portanto, esse romance traduz incomparavelmente, no seu psicologismo sombrio, o clima de sufoco que se iria seguir". PAES, José Paulo. O pobre-diabo no romance brasileiro. In: A aventura literária: ensaios sobre ficção e ficções. São Paulo: Companhia das Letras, 1990, p. 48. Também em Armazém literário: ensaios. cit., pp. 59-60.

${ }^{54}$ Cf. RAMOS, Graciliano. Cartas. cit., pp. 140-163; Cartas inéditas de Graciliano Ramos a seus tradutores argentinos Benjamín de Garay e Raúl Navarro. cit., pp. 21-30.
} 
Sabe-se que, por volta de 20 de março desse ano, Graciliano retomou a composição de Angústia, cuja origem remota era um conto, "Entre grades", e que estava abandonada desde outubro de 1934; a obra contava 95 páginas. Incentivavam-no a escrever Rachel de Queiroz e o marido José Auto, para os quais ele apresentava os novos capítulos. Em cartas de 10 de abril e da Páscoa de 1935, Graciliano revela a Heloísa estar detido nos encontros de Marina com Julião Tavares no teatro, e atrapalhado em busca de uma corda para matar este, "que não vale uma corda"; sobressai a auto-ironia de confessar-se sem jeito para assassino, na qual se entrevêem a ética do escritor e o drama do protagonista. Em carta provavelmente do fim de abril, o romancista conta à mulher que José Olympio queria editar a obra. Como menciona a gravidez de Marina e a dificuldade do assassinato, supõese que estivesse avançada a narrativa, buscando o escritor arrematar a formalização do desfecho, carregado dos impasses essenciais dela. Em julho de 1935, José Lins do Rego, que lera alguns capítulos, já havia anunciado o livro em jornais do Rio, segundo Graciliano comenta em carta de agosto ao editor argentino Benjamín de Garay.

Porém, o autor previa a publicação para o fim do ano ou para o ano seguinte. Sublinha a Garay que o "romance encrencado" ainda não estava escrito, pois sua vida era “embrulhadíssima". Já se depreende o seu empenho de emendar o texto, evidenciado nas demais cartas conhecidas desse ano. A 30 de setembro, indica a Garay que terminaria o livro por aqueles meses. A 13 de dezembro, sugere ao argentino publicar em El Hogar um capítulo de Angústia, a que estava "agarrado com unhas e dentes". Já em meados de dezembro, como permanecia "consertando" o livro, substituindo e cortando palavras, pondera para a esposa que não o publicaria no ano seguinte, embora José Olympio pretendesse fazê-lo logo em janeiro. Mas a 17 de janeiro de 1936, 204 páginas de Angústia estavam emendadas, e o autor acreditava-o concluído e datilografado em um mês, conforme pediam José Lins e Jorge Amado. A 28 de janeiro, precisava endireitar umas 80 folhas. No dia de sua prisão, 3 de março de 1936, entregou à datilógrafa as últimas páginas do livro, que saiu em agosto, com o escritor no cárcere.

Em carta do Rio, de 1945, confirmando ter vivido muitas inquietações enquanto compunha Angústia, Graciliano relata a Antonio Candido que "matou” Julião Tavares em 27 dias e arranjou o delírio final em uma noite. Embora ele concorde com as ressalvas do crítico às repetições excessivas e às "partes corruptíveis" do romance, sua queixa é sobretudo não haver revisado suas provas, pois estava preso. Segundo escreve para o crítico Cassiano Nunes, a 20 de junho de 1945, entende que tais falhas talvez contribuam 
para a "aparência de realidade" da história; com rigorosa autocrítica, afirma que alguns capítulos do livro não the "parecem ruins". O fim do romance, em que aproveitou os seus delírios no hospital anos antes (como nos contos "O relógio do hospital" e "Insônia"), não lhe parece "completamente mau", conforme confessava em carta de 1937 a Garay. Nas Memórias do cárcere, Graciliano conta que compôs Angústia "aos arrancos, com largos intervalos"; por duas vezes o deixara de lado e passara um ano sem vê-lo. Afirma que certas passagens não lhe desagradavam, porém considerava necessário condensar "observações espalhadas", eliminar "pelo menos um terço" do romance. E reitera que, apesar dos 27 dias de esforço e "razoável gasto de café e aguardente", o assassinato lhe surgia falso: "realmente eu era um assassino bem chinfrim" 55.

Assim, apreende-se que, completada uma primeira versão da narrativa (mais da metade provavelmente estava pronta em julho de 1935), Graciliano se dedicou a emendar a obra, cujas repetições são constitutivas do drama de Luís da Silva. Significativamente, infere-se que, a partir de agosto de 1935, o trabalho de depuração estilística empreendido pelo escritor se acompanhou da inserção, no romance, da imagem de Cirilo de Engrácia, então morto e fotografado. Surgindo apenas três capítulos antes do difícil enforcamento de Julião Tavares, a figura do cangaceiro, cadáver vivo, integra a construção imagética, a representação social e a expressão de conflitos de Angústia. Impressionando o romancista, o horror da foto é Cirilo no centro, em pé, cabelos compridos e cartucheira pendurada, ladeado simetricamente por dois pares de homens; porém, morto, amarrado a uma tábua, os olhos fechados e os pés suspensos, cercado de seus assassinos. ${ }^{56}$

\footnotetext{
${ }^{55}$ RAMOS, Graciliano. Carta a Antonio Candido. Rio de Janeiro, 12 de novembro de 1945. In: CANDIDO, Antonio. Prefácio a Ficção e confissão: ensaios sobre Graciliano Ramos. cit., pp. 7-9.

Idem. Carta a Benjamín de Garay. Rio de Janeiro, 13 de maio de 1937 [XVI]. In: Cartas inéditas de Graciliano Ramos a seus tradutores argentinos Benjamín de Garay e Raúl Navarro. cit., p. 54.
}

NUNES, Cassiano. Duas cartas de mestre Graciliano. In: A Tribuna. Santos, 18 de janeiro de 1992. Apud GIMENEZ, Erwin Torralbo. Graciliano Ramos - O mundo coberto de penas. cit., p. 155.

RAMOS, Graciliano. Memórias do cárcere. cit., v. I, capítulo 2, pp. 16, 18 e 19.

${ }^{56}$ Diz-se que Cirilo, bêbado, importunou a noiva do irmão Antônio numa festa e o matou, tornando-se um "pária entre os párias da lei". Integrado ao bando de Lampião em 1928, na Bahia, Cirilo era chamado de Ponto Fino, o mesmo apelido de Ezequiel, irmão de Lampião cuja morte os bandoleiros queriam disfarçar. Conta-se que Cirilo foi morto por um subdelegado e por civis armados pelo governo ou por passageiros de um caminhão que resistiram ao seu assalto. A fotografia saiu no Diário de Pernambuco de 28 de agosto de 1935, a primeira de um cadáver de cangaceiro publicada naquele Estado. Confiram-se: MELLO, Frederico Pernambucano de. Guerreiros do sol: violência e banditismo no Nordeste do Brasil. cit., p. 217, e JASMIN, Élise. Cangaceiros. Apresentação de Frederico Pernambucano de Mello. São Paulo: Terceiro Nome, 2006, 
Não à toa, a figura de Cirilo é recorrente no delírio de Luís da Silva, falando do seu drama social e moral num mundo de desigualdade econômica e generalizadas violência e impunidade, desde o governo, os proprietários exploradores até os sertanejos pobres:

(...) Cirilo de Engrácia, carregado de cartucheiras e punhais, encostava-se a uma árvore, amarrado, os cabelos cobrindo o rosto, os pés com os dedos para baixo. (...) Cirilo de Engrácia, esticado, amarrado, marchando nas pontas dos pés mortos que não tocavam o chão, vinha deitar-se na minha cama. (pp. 250-1).

Gerando insônia, não se distinguem força e fraqueza: o sertanejo pobre se faz cangaceiro, mata proprietários e é morto pela polícia; por meio da imprensa, os agentes do governo, pretensa autoridade, exibem barbaramente o cadáver como se estivesse vivo, numa covarde ostentação de poder. Essa ambigüidade entre fraqueza e força é determinante no drama de Luís da Silva: tendo vivido e reconhecido nos outros as experiências de pobreza, humilhação e injustiças, entregou-se com ódio à vingança contra o proprietário; contudo, aflito entre a consciência da manutenção da ordem social iníqua e os sentimentos de revolta, piedade, impunidade e culpa, torturam-no as certezas da necessidade e da inutilidade do seu crime.

Dessa forma, concentrando os impasses de ser intelectual / ser cangaceiro, a construção de Angústia, sobretudo por meio das imagens de defuntos em pé, configura de forma indissociável o plano da representação social e a expressão dos conflitos éticos, existenciais do protagonista.

"Nenhuma novidade". Repetida duas vezes no capítulo que antecede o delírio de Luís da Silva, essa formulação traduz seu espanto diante da ausência de "qualquer acontecimento extraordinário" após a pretensa façanha de ter matado o proprietário Julião. Sua condição social de desamparado não se modificou e ainda mais se evidencia quando remorde o assassínio: continuaria sendo o pequeno funcionário e redator de artigos subserviente aos interesses alheios, descrente de revoluções sociais. Igualmente a condição humana de desamparado se sobreleva em sua mente, ratificando para ele a inutilidade do crime: “- Todos os dias nasce gente, morre gente. Isso não tem importância” (p. 231). Em

pp. 106, 145, livros em que se pode ver a foto; CHANDLER, Billy Jaynes. Lampião, o rei dos cangaceiros. cit., p. 251; FONTES, Oleone Coelho. Lampião na Bahia. $4^{\text {a }}$ ed. Petrópolis: Vozes, 2001, p. 327; ARAÚJO, Antônio Amauri Correia de. Moça, de Cirilo de Ingrácia. In: Lampião: as mulheres e o cangaço. São Paulo: Traço, 1985, pp. 154-161. 
sua consciência obsessiva, ele se distingue da maioria, para mais ainda se reconhecer inútil, igual a todos.

Reencontrado aqui o sem novidades próprio do Eclesiastes, é marcante a passagem em que o narrador, pontuando a força da engrenagem social que aparta o pedinte Ivo do bacharel Julião Tavares, não deixa de aproximá-los como inúteis, defuntos em pé:

Talvez houvesse também alguma inteligência perdida por detrás daqueles olhos mortos pela cachaça. Um sujeito inútil, sujo, descontente, remendado, faminto [Seu Ivo].

O outro sujeito inútil que nos apareceu era muito diferente. Gordo, bem vestido, perfumado e falador, tão falador que ficávamos enjoados com as lorotas dele. Não podíamos ser amigos. Em primeiro lugar o homem era bacharel, o que nos distanciava. (...) Tudo nele era postiço, tudo dos outros. [Julião Tavares]. (p. 50, 52).

"Nenhuma novidade". Também aflige Luís da Silva a demora para o acusarem pelo enforcamento do homem rico. Tenso, ele acompanha à janela os transeuntes, e novamente a metonímia dos pés lhes diferencia a condição social. Quando teme a vinda de um agente da polícia, é surpreendido por um pedinte à porta. "- Onde vamos parar com tantos mendigos? Isso tem jeito?” (p. 235). A essa pergunta, marcante também na Novidade, sucede o xingamento do angustiado narrador aos canalhas e preguiçosos, que, Graciliano Ramos bem o insinua, não são apenas os mendigos.

Preocupado com a opinião pública a respeito de seu ato, Luís da Silva ressalta o embotamento geral, o lugar-comum de indistinção entre um crime e uma ação boa. Como os jornais obedecem a ordens, alguns estariam do seu lado por ter matado Julião Tavares, outros o condenariam. E aqui se fundem o peso realista do Eclesiastes, da vanidade de tudo, com a crítica à generalizada falta de ética, em especial do governo e da imprensa, afeitos à violência, a tapeações. Nesse sentido, Angústia escancara o horror de se apagarem as pessoas e as singularidades delas e de seus atos. E esse horror se estampava na fotografia tirada de Cirilo de Engrácia, cangaceiro que parecia vivo mas era um cadáver. Outro bandoleiro referido no livro é Fabrício, o primeiro homem assassinado que Luís da Silva viu. Ressaltando sua agonia ante o corpo daquele, "cosido de facadas", o redator e revisor de jornal desnuda que depois se tornou insensível aos defuntos, tanto se habituara a vê-los. Percebe-se a forte crítica à sociedade e à imprensa, que mais promovem do que recusam a naturalização da violência. Impossível não lembrar aqui "Cabeças”, a crônica de Graciliano posterior à decapitação dos cangaceiros em 1938. 
Sendo assim, garantindo a força do romance poemático, a rede de defuntos vivos se potencia no delírio final de Luís da Silva (pp. 240-251), uma retomada, em turbilhão, de figuras e de cenas de sua vida. Tombado na cama como um morto, tudo era nevoeiro. No tempo sem horas, em meio à "escuridão cheia de pancadas", acompanhava uma réstia na parede como uma lagartixa e depois caía. Febril, "sem memória", chorava; sentia-se sozinho, morrendo à míngua, com sede. Dada sua miséria moral e social, perturbavam-no criaturas indistinguíveis e muitos infelizes seus conhecidos, que se confundiam: tipos de caras esquisitas, todos iguais, de bocas negras e enormes línguas escuras; um homem sem rosto que falava muito, mas numa língua que parecia estrangeira; três corpos juntos com rostos iguais, ou um corpo com três cabeças; o pai morto, com uma nódoa vermelha cheia de moscas no lugar da cara; o avô com a cobra enrolada no pescoço; o pedinte Ivo, que lhe deu a corda e teria recebido a roupa do dia do crime ("talvez fosse tudo um sonho"); a prostituta da Rua da Lama; a grávida pobre na multidão; o cego do bilhete de loteria; a empregada Vitória, que enterrava moedas e se preocupava com o movimento dos navios sem nunca ter embarcado.

Dentre várias outras imagens do delírio, destaca-se mais uma da miséria alagoana, representativa também do folclore da região (defendido por Graciliano na crônica "Sertanejos"): os reisados com seus pedintes, "feixinhos de lenha" que, depois de baterem à porta de um Seu Batista importante, voltariam a suar no eito. Segundo a monografia de Théo Brandão, folclorista que colaborou na Novidade, esse folguedo era o de maior prestígio entre a população mais humilde das zonas suburbana e rural de Alagoas. Por isso, na mente de Luís da Silva, que temia a visita de policiais e não suportava a de mendigos, não poderia faltar o coro dos defuntos vivos do reisado, que assim cantavam na "Abrição de porta":

Aqui 'tou em vossa porta

Feito um feixinho de lenha

Esperando pela resposta

Que de vossa boca venha.

(...)

Aqui 'tou em vossa porta

De cóca (cócoras) como raposa;

Esperando pela resposta

De lá venha quarqué coisa.

Aqui 'tou em vossa porta

Meio vivo, meio morto; 
Esperando pela resposta

Cumo navio no porto.

Aqui 'tou em vossa porta

Com a mão na fechadura;

Esperando que abra a porta

Coração de pedra dura. ${ }^{57}$

Se, no momento de matar o bacharel, Luís da Silva julgou todos ao redor desimportantes, agora, no delírio, reconhece-se uma "figurinha insignificante" como essas milhares que iam para a sua cama: os pedintes, os cangaceiros, Cirilo de Engrácia, "esticado, amarrado, marchando nas pontas dos pés mortos que não tocavam o chão", os vagabundos, o assassino e inocente José Baía.

Pensa que cairia da cama e, aberto o chão, rolaria "pelos séculos dos séculos fora disto". Ao repetir a frase do Gênesis - "O espírito de Deus boiava sobre as águas" -, parece ter um desejo de criação, mas pressupondo um abandono, a destruição de tudo o que existe. $\mathrm{O}$ amigo Moisés lia para ele, atormentavam-no histórias de revoltas na China, a figura de Fernando Inguitai, desconhecido, e palavras incompreensíveis. Nas paredes, vê letreiros subversivos, "lágrimas pretas de piche", recolha de imagens do passado e projeção de um futuro sombrio, com desejo de réstias. Assassino, imagina que as riscas de piche formavam grades. Literato, indignara-se com a ausência de vírgula e de traço na inscrição subversiva "Proletários, uni-vos.", feita de piche na parede do bairro onde Marina fizera o aborto e meninos abandonados pediam esmola. Como intelectual, distante dos vagabundos e dos proprietários, não poderia acreditar numa revolução sem vírgulas e sem traços; sofria porque seu conhecimento da palavra escrita parecia não ter valor no mundo. Drama das letras, drama das "figurinhas insignificantes".

\footnotetext{
${ }^{57}$ Cf. BRANDÃO, Théo. O reisado alagoano. ( $1^{\circ}$ Prêmio no $4^{\circ}$ Concurso de Monografias sobre o Folclore Nacional, instituído em 1949 pela Discoteca Pública Municipal, do Departamento de Cultura, da Prefeitura do Município de São Paulo). Separata da Revista do Arquivo n. CLV. São Paulo: Departamento de Cultura, 1953, p. 13, p. 36. Na nova edição: BRANDÃO, Théo. O reisado alagoano. Maceió: EDUFAL, 2007, p. 11, p. 34. Segundo Théo Brandão, o reisado alagoano inclui pedidos de entrada, louvações aos donos das casas e ao presépio ou ao templo, danças de personagens míticos, fragmentos de autos, danças e cantos variados. São seus figurantes principais: o rei, o secretário de sala, o contramestre, os mateus, a catirina, o palhaço. Muitas representações dramáticas constituem os "entremeios" do reisado: o boi, a burrinha ou cavalo-marinho, o sapo, o lobisomem, cangaceiro e soldado, o morto-vivo etc.
}

Conforme Câmara Cascudo, o reisado pode ser o cortejo de pedintes ou o auto popular profano-religioso, de músicos, cantadores e dançadores que, de porta em porta, anunciam a chegada do Messias e homenageiam os três Reis Magos. Cf. CASCUDO, Luís da Câmara. Dicionário do folclore brasileiro. $11^{a}$ ed., ilustrada. São Paulo: Global, 2002, p. 581. 
Devido à tendência de Luís da Silva para os impressos, a face do intelectual ganha forma junto com a angústia social e moral: vê letras com cara de gente, algumas com ferocidade de cobras; os letreiros são constituídos por pessoas, pelas "figurinhas insignificantes". E elas formam um grande clamor na parede. Com consciência aguda de um tempo de generalizado embotamento, de homens reduzidos a letreiros degradados, deseja, sabendo-a remota, a possibilidade de compreensão, de terem as letras e as pessoas seu valor respeitado; queria que os números da sorte se acertassem e todos se reconfortassem em colchões de paina.

Afligindo o leitor a inópia de tantas figurinhas insignificantes, ressalta de Angústia, da consciência obsessiva de Luís da Silva, que quer compreender a todos, uma sensação de "eqüidade opulenta", a "noção dos seres iguais". Essas são palavras de Mário de Andrade, integrante do júri que em 1937 premiou o romance como o melhor do ano. Ele observou como Graciliano, revalorizando o "pensamento com os botões", mostrou que o operário inculto, o filósofo requintado e o amanuense pensam, com a "mesma violência e a mesma insolubilidade vital" ${ }^{58}$. Nesse mesmo ano, o romancista daria expressão aos pensamentos de outro tipo sem importância: Fabiano.

\footnotetext{
${ }^{58}$ Mário de Andrade, Aníbal Machado e Álvaro Moreyra compunham o júri da Revista Acadêmica que outorgou a Angústia o Prêmio Lima Barreto. A citação apresentada, da justificativa do voto de Mário no romance de Graciliano, saiu na revista em maio de 1937 e está transcrita em: ANDRADE, Mário de. Cartas a Murilo Miranda (1934-1945). Rio de Janeiro: Nova Fronteira, 1981, p. 45.
} 


\section{Fabiano, panela fervendo: mataria os que mandam.}

Então porque um sem-vergonha desordeiro se arrelia, bota-se um cabra na cadeia, dá-se pancada nele? Sabia perfeitamente que era assim, acostumara-se a todas as violências, a todas as injustiças. E aos conhecidos que dormiam no tronco e agüentavam cipó de boi oferecia consolações: - "Tenha paciência. Apanhar do governo não é desfeita."

Mas agora rangia os dentes, soprava. Merecia castigo?

$-\mathrm{An}$ !

E, por mais que forcejasse, não se convencia de que o soldado amarelo fosse governo. Governo, coisa distante e perfeita, não podia errar. O soldado amarelo estava ali perto, além da grade, era fraco e ruim, jogava na esteira com os matutos e provocava-os depois. O governo não devia consentir tão grande safadeza. (“Cadeia”, pp. 33-4 ${ }^{59}$ ).

“Apanhar do governo não é desfeita". Como nas crônicas "Lampião", de 1931, “Comandante dos burros", de 1933, e "A propósito de seca", de 1937, este lugar-comum de resignação dos sertanejos pobres é combatido nessa passagem de Vidas secas, que figura o drama de Fabiano a partir do episódio de sua prisão. Trata-se de um momento muito significativo: cheio de injustiças, o vaqueiro se volta contra a atitude habitual dele próprio e de muitos de curvarem-se aos poderosos. A adversativa "mas agora" sinaliza que, no presente, preso e espancado pelo arbítrio do soldado amarelo, questiona como errado o pretérito mais-que-perfeito em que se "acostumara" a todas as violências e injustiças. Coerente com sua subserviência aos donos e com sua resistência a aceitar um soldado agressor de matutos, ganha forma sua definição de governo: "coisa distante e perfeita, que não podia errar". É como se Fabiano resgatasse a palavra em seu significado original, de uma entidade organizadora da harmonia coletiva, e se opusesse ao uso degradado, ao governo como perpetuação de privilégios e de misérias.

Assim, no capítulo "Cadeia", acompanha-se, com o narrador ${ }^{60}$, o questionamento do sertanejo quanto a si mesmo e à sua realidade social. Delineia esse drama de Fabiano, agitado em emoções e pensamentos, a imagem da panela fervente em sua cabeça.

\footnotetext{
${ }^{59}$ RAMOS, Graciliano. Cadeia. In: Vidas secas. $59^{\mathrm{a}}$ ed. Rio de Janeiro: Record, 1989.

${ }^{60}$ Nesse trecho, o narrador acompanha o movimento, em seus limites, da consciência crítica do vaqueiro contra o governo. Com base na análise reveladora de "Céu, inferno", de Alfredo Bosi, percebe-se como o foco narrativo de Vidas secas inclui "aproximação com a mente do sertanejo" e distanciamento em relação à consciência dele. "O perto se faz longe": da passagem "A caatinga ressuscitaria...", Bosi apreende e potencia a poesia do modo condicional com que o realismo de Graciliano figura criticamente os desejos de Fabiano. (BOSI, Alfredo. Céu, inferno. In: Céu, inferno. cit., pp. 19-50).
} 
São muitos os seus fermentos de indignação, e tinha um fio de idéia a engrossar. $\mathrm{Na}$ feira, com as notas amarradas na ponta do lenço, temeroso de ser enganado, comprou mantimentos. Contudo, sendo aguado o querosene e cara a chita desejada por Sinha Vitória, não os adquiriu logo, nem depois: bebeu cachaça batizada e perdeu o dinheiro ao jogar trinta-e-um com um soldado amarelo. Furioso com a derrota e o prejuízo, com a necessidade de obter os produtos e com o problema de justificar-se para a mulher, saiu sem se despedir do soldado.

Além de faltar-lhe dinheiro para iluminar a casa e de descontentar Vitória, só cresceria a indignação de Fabiano: o mesmo soldado amarelo que lhe batera familiarmente no ombro e o convidara para o jogo empurrou-o e o insultou, porque ele não se despedira; querendo puxar questão mas falto de pretexto, o soldado pisou-lhe o pé e, xingado por Fabiano, mandou-o para a cadeia. "- Faça lombo, paisano": a lâmina do facão feria o homem simples junto com a incompreensão da ordem arbitrária que o prendeu e tratou como animal.

Eis que, moído mas duvidando daquela desgraça, preocupado com a casa sem pai nem querosene, às escuras, aos poucos Fabiano tece uma reflexão sobre si mesmo e seus vínculos com o soldado amarelo, o governo e a família.

Comparando-se com o soldado, distingue-se daquele covarde, "escarro de gente" que fazia mal a um pai de família e jamais enfrentaria um cangaceiro na caatinga. Vendo a ambos como desgraçados, percebe que o problema não era tão-só o amarelo: não o atacava por causa dos "homens que mandavam". Revolta-o que o governo não agisse de maneira correta, e sim com safadeza.

Após experienciar tantas injustiças, sentindo que "estava tudo errado", pergunta pelos culpados da sua brutalidade. Afinal, trabalhava como escravo num casco de fazenda sem valor, vivia agarrado aos bichos, nunca vira uma escola, nem sabia falar direito, à semelhança do papagaio, morto para saciar a fome da família quando fugiam da seca. Aflige Fabiano a dificuldade de se explicar para o soldado e de pensar. Sofre por se diferenciar de Seu Tomás da Bolandeira, homem bom e aprendido (porém igualmente pobre, vagando pelo mundo), que saberia contar tudo. Atordoa-o assemelhar-se com os outros presos: os homens acocorados em torno de um fogo, a rapariga da vida e o bêbedo de fala desconexa feito a sua. Precisa gritar que ele e os demais eram "uma lástima", não serviam para nada, a não ser para "agüentar facão". E o fogo que enchia o cárcere de fumaça mais lhe lembra a falta do querosene, a mulher e os meninos na escuridão. Panela 
chiando, a imagem da família, já sofrida da seca e da fome e então desamparada junto à trempe de pedras, ocupa a sua mente:

Pobre de sinha Vitória, cheia de cuidados, na escuridão. Os meninos sentados perto do lume, a panela chiando na trempe de pedras, Baleia atenta, o candeeiro de folha pendurado na ponta de uma vara que saía da parede.

(...)

Pobre de sinha Vitória, inquieta e sossegando os meninos. Baleia vigiando, perto da trempe. Se não fossem eles... (“Cadeia”, p. 35, 37).

Assim, entre fermentos de indignação, o pensamento de Fabiano, difícil, ganha luz: era enorme seu desejo de vingar-se do soldado, porém a existência da família o obstava de agir como um cangaceiro.

Agora Fabiano conseguia arranjar as idéias. $O$ que o segurava era a família. Vivia preso como um novilho amarrado ao mourão, suportando ferro quente. Se não fosse isso, um soldado amarelo não lhe pisava o pé não. O que lhe amolecia o corpo era a lembrança da mulher e dos filhos. Sem aqueles cambões pesados, não envergaria o espinhaço não, sairia dali como onça e faria uma asneira. Carregaria a espingarda e daria um tiro de pé de pau no soldado amarelo. (pp. 37-8).

É notável o paralelo do vaqueiro com um novilho: além de submisso ao "patrão invisível", preso e surrado pelo soldado, tem a família como cambões a impedi-lo de atirar-se contra ele. Desenhando a ebulição interior do personagem, entre ser bruto e ser homem, tal comparação ressalta a um tempo a animalização de Fabiano, subjugado aos poderosos, e sua força ética, fraco para violências porque sensível para com a família, para com outras vidas. Por isso, percebe no amarelo um infeliz seu igual, e a idéia que lhe "ferve" na cabeça, em luta com sua impossibilidade de realizá-la, é entrar no cangaço e matar os donos do soldado:

Não. O soldado amarelo era um infeliz que nem merecia um tabefe com as costas da mão. Mataria os donos dele. Entraria num bando de cangaceiros e faria estrago nos homens que dirigiam o soldado amarelo. Não ficaria um para semente. Era a idéia que lhe fervia na cabeça. Mas havia a mulher, havia os meninos, havia a cachorrinha. (p. 38).

Quanto mais se acirra seu desejo de insurgir-se contra o governo, fonte de injustiças e de safadezas, tanto mais o vaqueiro se sente impotente, incapaz de violência porque preso à família. Daí a imagem contundente da dor de cabeça, representação do problema social 
dos maus tratos contra os pobres e expressão do drama de Fabiano, entre revoltado e paralisado:

(...) Estava com a testa doendo, provavelmente em consequiência de uma pancada de cabo de facão. E doía-lhe a cabeça toda, parecia-lhe que tinha fogo por dentro, parecia-lhe que tinha nos miolos uma panela fervendo. (p. 37).

Desse modo, central no capítulo "Cadeia" é a imagem da panela fervendo na cabeça de Fabiano: caldo a fermentar vários motivos de indignação, engrossa-se num movimento de compreensão de si mesmo e do mundo. Ele se aquece e ilumina, em sua precariedade, com a priorização dos elos vitais, afetivos, e com a crítica aos donos do poder. A imagem da panela fervente dá materialidade à revolta de Fabiano contra uma sociedade iníqua que naturaliza a brutalidade dos homens. E expressa sua luta consigo mesmo, entre ser bruto e ser homem: embora sem condições dignas de vida, não-instruído, não era violento e sim digno pai de família, preocupado com os seus, resistentes à fome e à seca, submetidos à escuridão junto à trempe. Esta reúne a imagem dos três, a mulher e os dois filhos, mais a cadela, significando frágil mas seguro o único amparo de Fabiano: alimento e lareira escassos, um lar.

Assim, a construção do foco narrativo em terceira pessoa perfaz a expressão da interioridade de Fabiano e a representação social crítica, criando imagens-síntese como a trempe, o fio de idéia a engrossar em sua cabeça, panela fervendo. Por conseguinte, Vidas secas aponta os problemas contidos no estereótipo de brutalidade do sertanejo pobre: desvelando a origem social de sua condição de trabalhador explorado, privado de escola, exprime seus dilemas entre sobreviver como vaqueiro retirante, submisso aos poderosos, apegado à família, e sonhar-se cangaceiro ou soldado, capaz de façanhas. No "Inverno", aquecendo-se ao fogo, embora Fabiano contasse seus pretensos grandes feitos, o menino mais velho desconfiou das palavras indecisas do pai e deixou de considerá-lo herói: era "humano e contraditório". A narrativa confusa do vaqueiro servia para esquecer a desgraça da prisão, época em que fantasiara abandonar a família e matar o amarelo, o juiz, o promotor e o delegado.

No romance, desvendando o fator econômico-social da fala desconexa do vaqueiro, Graciliano Ramos lhe arruma o que tinha no interior, de forma a atacar não só os soldados agressores de "criaturas inofensivas", mas sobretudo os donos deles. Reencontra-se aqui o desejo do escritor, partilhado com o personagem, de distinguir o valor das palavras e dos 
seres: Graciliano recusa estereótipos em busca de entender a alma do retirante, sua história e contradições; e este queria ver o governo no sentido original da palavra, livre de safadezas.

Resgatar a história de gestos e de palavras é uma forma de devolver-lhes a alma, embotada pela convenção e pelo uso, e de ampliar a compreensão da realidade. E isso se descobre singularmente ao se acompanhar a reflexão de Ortega y Gasset ${ }^{61}$ sobre o cumprimento de dar e apertar as mãos. Hoje tal gesto constitui sinal de civilização, revelando amizade ou sociabilidade, seja de aparências ou autêntica. Percebe-se com Gasset que, inerente ao cumprimento, há sempre algo de mistério e perigo, "minúsculo drama", segundo as circunstâncias e os diferentes níveis de proximidade entre as pessoas. E, ao envolver esse "mútuo risco", próprio do encontro com o outro, o gesto de apertar as mãos guarda parte de sua significação de origem.

Uma hipótese de Gasset é que, ação interindividual com alma, dar as mãos ao outro era forma de os homens se garantirem mutuamente de que não carregavam armas nas mãos. Acrescentando a Spencer (Sociologia) observações filológicas, depreende o cumprimento como gesto de submissão a um superior. Ao refinar-se, o homem primitivo prefere escravizar a matar o inimigo, originando o romano manus dare, com o significado de entregar-se, render-se. De manus dare, colocar o inferior as mãos entre as do poderoso, advém o verbo mandar. Quanto ao gesto, num primeiro momento, o inferior toma a mão do superior e a beija. Depois, dada a democracia de aparências, o inferior puxa a mão do superior para beijá-la mas este a retira, resultando dessa luta o aperto de mãos.

Considerando essa etimologia do cumprimento e do verbo mandar, é notável como Graciliano parece reconstituí-la ao configurar a história da prisão de Fabiano. Num primeiro momento, o cumprimento do soldado parece aproximá-lo do vaqueiro: convida o "camarada" para o jogo, batendo-lhe familiarmente no ombro. Porém, este acata o convite por respeito à farda; obedece ao amarelo, que "era autoridade e mandava". Como após o jogo, indignado por somar apenas prejuízos, Fabiano não se despediu, o soldado tomou isso por desacato. Então, provocou o sertanejo pobre, pisou-o, foi xingado e ordenou que o prendessem. Fiando-se de que ser uma autoridade significa tão-só mandar, vingou-se do homem humilde que não lhe beijou as mãos.

\footnotetext{
${ }^{61}$ ORTEGA Y GASSET, José. Meditação sobre o cumprimento. O homem, animal etimológico. Que é um uso? In: $O$ homem e a gente: inter-comunicação humana. $2^{\mathrm{a}}$ ed. Nota introdutória e tradução de J. Carlos Lisboa. Rio de Janeiro: Livro Ibero-Americano, 1973, cap. X, pp. 227-253.
} 
Assim, fincada a hierarquia entre os dois sertanejos no fator social e político, marcando-se seu encontro por violência, pelo uso do poder com arbítrio, evidencia-se a etimologia do verbo mandar, vinculada à do cumprimento. Repetida no romance, a expressão de autoritarismo do soldado amarelo indicia a dificuldade de aproximação entre os homens, a ausência da devida ética, tão propalada pelos comandantes: "- Desafasta, ordenou o polícia. Aqui tem gente”.

Fabiano, força guardada:

\section{a ética do manso e a tautologia do governo}

Os olhos abertos contemplam; os olhos fechados, sem atender a coisa nenhuma, tipificam, julgam, decretam.

$$
\text { Alfredo Bosi }{ }^{62}
$$

Fabiano meteu-se na vereda que ia desembocar na lagoa seca, (...).

(...) Desembaraçou o cabresto, puxou o facão, pôs-se a cortar as quipás e as palmatórias que interrompiam a passagem.

(...) voltou-se e deu de cara com o soldado amarelo que, um ano antes, o levara à cadeia, onde ele agüentara uma surra e passara a noite. Baixou a arma. Aquilo durou um segundo. Menos: durou uma fração de segundo. Se houvesse durado mais tempo, o amarelo teria caído esperneando na poeira, com o quengo rachado. Como o impulso que moveu o braço de Fabiano foi muito forte, o gesto que ele fez teria sido bastante para um homicídio se outro impulso não Ihe dirigisse o braço em sentido contrário. A lâmina parou de chofre, junto à cabeça do intruso, bem em cima do boné vermelho. A princípio o vaqueiro não compreendeu nada. Viu apenas que estava ali um inimigo. De repente notou que aquilo era um homem e, coisa mais grave, uma autoridade. Sentiu um choque violento, deteve-se, o braço ficou irresoluto, bambo, inclinando-se para um lado e para outro. (“O soldado amarelo", pp. 99-100).

Essa situação criada no capítulo "O soldado amarelo" põe em xeque o pensamento difícil elaborado por Fabiano após sua prisão: face à possibilidade de matar o inimigo poderoso, de fato não o faria por causa da família? Já dessas primeiras linhas do capítulo se depreende que se confirmariam as tensões e a coerência do vaqueiro.

Numa fração de segundos, empunha a faca contra um intruso numa vereda e suspende o gesto. A partir dessa figuração de dois impulsos contrários da personagem,

\footnotetext{
${ }^{62}$ BOSI, Alfredo. O enigma do olhar. In: Machado de Assis: o enigma do olhar. cit., p. 36.
} 
Graciliano alcança amalgamar a representação social crítica e a expressão de conflitos subjetivos. Involuntário, o homicídio decorreria da brutalidade do homem que vivia perto da natureza, cortando obstáculos nas veredas e lidando com bichos. Voluntário, o homicídio seria, na seqüência, possibilidade de vingança que abala o vaqueiro. Após suster o braço, seu "choque violento" ao dar de cara com o soldado amarelo revela a um tempo sua força ética e fragilidade social. "Aquilo era um homem e, coisa mais grave, uma autoridade": a compaixão que o impede de matar outro ser combina-se com a submissão por ser o outro uma autoridade.

Esse reencontro com o algoz que o levara à cadeia constituía oportunidade para Fabiano cumprimentá-lo com o facão: o lugar-comum seria a violência, a vingança contra o soldado amarelo. No entanto, abre caminho para o narrador acompanhar as fortes inquietações do vaqueiro em relação a si mesmo, ao soldado e ao governo, quanto ao sentido de justiça e de falsa coragem.

Os dilemas de Fabiano ante o amarelo estampam-se nas variações de seu rosto. A princípio, com o olho arregalado de espanto, ficara indeciso: se tivesse atingido o soldado, seria valente; sentindo um medo absurdo, riu. Irritado diante daquele homem trêmulo, fechou a cara: o outro não o via incapaz de vingar-se? Embora desejasse tornar a ficar cego, readquirir o "instante de inconsciência" em que quase matara o amarelo, sabe que não conseguiria usar a arma; a cólera de se considerar impotente o faz avançar para o inimigo só por um minuto. Lembrando-se da surra e da noite na cadeia, prega nele os olhos ensangüentados: deveria mesmo acabar com o safado que só sabia, na cidade, maltratar os matutos. O rosto contraído, "mais feio que um focinho", rugas aprofundadas na testa, os pequenos olhos azuis muito abertos, Fabiano era uma "interrogação dolorosa": "Estava certo? Bulir com as pessoas que não fazem mal a ninguém. Por que?”.

Quando vê apenas um braço, uma perna e um pedaço da cara do policial, que estava escondido na catingueira, o retirante chega a temer a autoridade. Porém, o rosto daquele homem acuado, "os olhos arregalados, os beiços brancos, os dentes chocalhando como bilros", revela maior a infelicidade do vaqueiro: fôra insultado e preso por aquele covarde, em que se mirava e se sentia ainda mais miserável, para sempre submisso.

Assim, o impasse de Fabiano ante o policial indefeso cria um olhar crítico em relação a si mesmo, ao outro e ao governo. Vive um embate entre o desejo de vingar-se, para aparentar força, e a certeza de ser incapaz de violência, o que o diferencia da face agressiva e injusta do soldado. Desde sua prisão, não suporta a covardia do amarelo, que só 
espancava e prendia pessoas inofensivas. Confirmada agora essa covardia, mais ainda a deplora, porque ela lhe escancara a própria miséria e impotência. Fabiano percebe também que o amarelo, autoridade, devia sabê-lo inocente: a tolice de um matuto que perde a paciência e xinga não justifica surra e cadeia. Por descobrir medrosa e falha essa autoridade, o vaqueiro não poderia continuar julgando que "apanhar do governo não é desfeita". Não entendia por que o governo admitia safados como o amarelo: "Só se ele tinha receio de empregar tipos direitos". Numa conjectura plena de sentido ético e crítico, reconhecendo a inutilidade do amarelo e a insuficiência do governo, Fabiano chega a pensar-se soldado e conclui que não pisaria os pés dos trabalhadores: a farda não o tornaria ruim.

Desse modo, o sertanejo pobre mostra-se incapaz de matar outro homem e temeroso das autoridades. Ao mesmo tempo, revolta-se contra as incongruências destas, atordoando-se por ser submisso e ainda mais a um covarde; conforme a lógica de violência de seu ambiente, imagina que, se houvesse matado o policial, não sentiria remorso, seria um homem. No fim do capítulo, essas tensões da personagem culminam numa passagem marcante de lirismo e realismo, em que Fabiano está preso, a um tempo, à "ética do rosto" e à definição tautológica de governo.

Depois de pensar que por um segundo não matara o polícia, imagina-o caído, "as pernas abertas, os bugalhos apavorados, um fio de sangue empastando-lhe os cabelos, formando um riacho entre os seixos da vereda". Por um lado, essa imagem do inimigo morto, arrastado por ele à caatinga e entregue aos urubus, mataria a sede de vingança do sertanejo injustiçado, que não se sentiria mais um incapaz. Por outro lado, como ele busca em vão os olhos do soldado, que os desvia, percebe que não deveria matar um homem, nem precisava matar aquele covarde da polícia. Fabiano não quer inutilizar-se moralmente como responsável pela morte de outro ser, nem socialmente, muito menos por causa daquela "fraqueza fardada" que agredia os pobres. E então, carregada da história de sofrimentos de um homem que só queria estar com a família, em segurança junto à trempe, vem, concisa, a frase: "Guardava a sua força".

Aprumou-se, fixou os olhos nos olhos do polícia, que se desviaram. Um homem. Besteira pensar que ia ficar murcho o resto da vida. Estava acabado? Não estava.

(...) Mas para que suprimir aquele doente que bambeava e só queria ir para baixo? Inutilizar-se por causa de uma fraqueza fardada que vadiava na feira e insultava os pobres! Não se inutilizava, não valia a pena inutilizar-se. Guardava a sua força. (p. 107). 
Em nome da compreensão crítica e afetiva do outro, mediando o distanciamento intelectual em relação ao vaqueiro, o narrador apreende em Fabiano a resistência econômico-social e a "resistência ética". Com a singularidade de sua arte, Graciliano recria, da tradição da literatura brasileira, especificamente d' Os sertões, a imagem do sertanejo como "um forte" e dono de "retidão impensada e singela", usando aqui a expressão com que Antonio Candido aproxima o personagem de Vidas secas dos campeiros nordestinos do segundo capítulo do livro de Euclides da Cunha ${ }^{63}$. E essa retidão singela de Fabiano sobressai ao não matar o soldado, numa cena que ilumina o sentido da "ética do rosto", cunhada pelo filósofo Lévinas, e é por ela iluminada:

A impossibilidade de matar não tem uma significação simplesmente negativa e formal; a relação com o infinito ou a idéia do infinito em nós condiciona-a positivamente. $\mathrm{O}$ infinito apresenta-se como rosto na resistência ética que paralisa os meus poderes e se levanta dura e absoluta do fundo dos olhos, sem defesa na sua nudez e na sua miséria. A compreensão dessa miséria e dessa fome instaura a própria proximidade do Outro. ${ }^{64}$

Em sua força ética e fragilidade de espoliado, Fabiano poupa a vida do policial e permanece submisso, indicando-lhe o caminho em meio às veredas. Ele é manso (palavra cuja etimologia Ortega y Gasset desvela junto com a de mandar): 'acostumado à mão' dos donos. A tautologia "- Governo é governo" representa o sem-saída de sua obediência de homem pobre aos poderosos, para os quais tira o chapéu de couro e se curva ${ }^{65}$. Ao mesmo tempo, está pressuposta na tautologia a concepção ingênua e ideal, potencialmente crítica, de Fabiano, do governo como respeitável e incapaz de erro. Nesse sentido, "curvar-se e ensinar o caminho ao soldado amarelo" é a própria configuração do drama do personagem: apesar de apagado porque manso, guarda caminhos de senso crítico e de ética, a serem ensinados. Como se viu em "Nuvens" (Infância), a poética do escritor pressupõe o distanciamento em relação a violências (no conto popular, o menino se vinga) e a necessidade de respeitar-se o valor das palavras, das coisas e viventes: ser forte significa mais do que exercer a vingança.

\footnotetext{
${ }^{63}$ CANDIDO, Antonio. Ficção e confissão. In: Ficção e confissão: ensaios sobre Graciliano Ramos. cit., p. 45.

${ }^{64}$ LÉVINAS, Emmanuel. Totalidade e infinito. cit., p. 178.

${ }^{65}$ Como se viu no capítulo 5, a tautologia "- Governo é governo" aparece também na crônica de Graciliano "Bagunça" (1941), como crítica à manutenção do poder vigente após a chamada Revolução de 1930, sem autoridade ética nem coerência ideológica.
} 
Vacilou e coçou a testa. Havia muitos bichinhos assim ruins, havia um horror de bichinhos assim fracos e ruins.

Afastou-se, inquieto. Vendo-o acanalhado e ordeiro, o soldado ganhou coragem, avançou, pisou firme, perguntou o caminho. E Fabiano tirou o chapéu de couro.

- Governo é governo.

Tirou o chapéu de couro, curvou-se e ensinou o caminho ao soldado amarelo. (p. 107).

Assim, à medida que o vaqueiro não se vinga do soldado, critica-se a estrutura social que obriga o injustiçado a curvar-se aos poderosos. E revelam-se a ética e o impasse da sua realização, caminho a ser seguido que, difícil, soa como fraqueza num mundo de arbitrariedades. Nesse mundo, naturais o imediatismo e a violência, é raro ser manso no sentido de ir de "mãos dadas" com o outro.

\section{Baleia: misericórdia do manso}

(...) Sinha Vitória, embalando as crianças, enjoou-se da cadela achacada, gargarejou muxoxos e nomes feios. Bicho nojento, babão. Inconveniência deixar cachorro doido solto em casa. Mas compreendia que estava sendo severa demais, achava difícil Baleia endoidecer e lamentava que o marido não houvesse esperado mais um dia para ver se realmente a execução era indispensável. (“Baleia", p. 86).

A arte atinge beleza e comove ao revelar limitações. Porta-voz certeiro dos leitores, Otto Maria Carpeaux confessa que o capítulo da morte de Baleia o "comoveu intensamente" e apreende ser a alma de Graciliano "cheia de misericórdia e de simpatia para com todas as criaturas" 66 . Também considerando "Baleia" um dos "mais abaladores" capítulos da literatura brasileira, Anatol Rosenfeld assinala que é raro alcançar tão grande efeito, "incomparavelmente comovedor", a partir de tamanha sobriedade, como o emprego de um adjetivo ("o pequeno coração de Baleia") e de dois diminutivos ("a criaturinha", "sua cabecinha") ${ }^{67}$. Assim, acompanhando os dois críticos, um caminho possível para se

\footnotetext{
${ }^{66}$ CARPEAUX, Otto Maria. Visão de Graciliano Ramos. Origens e fins. In: Ensaios reunidos 1942-1978. cit., v. I, p. 447.

${ }^{67}$ ROSENFELD, Anatol. Graciliano Ramos como poeta da seca. In: Letras e leituras. Nanci Fernandes e Jacó Guinsburg (Orgs.). São Paulo: Perspectiva / Edusp; Campinas, SP: Editora da Unicamp, 1994, pp. 137147.
} 
compreender a arte do capítulo é ver como a composição da imagem da morte da cadela está carregada de misericórdia.

Se já despertaria a compaixão do leitor a figuração do sofrimento de uma cachorrinha, a de Baleia não se dissocia da formalização do drama social e, ainda mais agora, moral de Fabiano. O capítulo concretiza um procedimento caro ao escritor, na vida como na literatura: a compreensão / criação de cada caráter a partir da comparação com outros na sociedade, apreendendo traços em comum e diferenças. À cena da morte de Baleia comparecem simbolicamente, no doloroso embate da cachorra com o dono, os limites e possibilidades deste em relação ao governo, ao patrão invisível, ao soldado amarelo e à família. E aqui a compaixão se intensifica: estende-se para o vaqueiro submisso, matador do próprio animal de estimação; e o sentido da compaixão como fundamento da moral ganha força, à medida que depois ensombrará Fabiano a culpa ou a dúvida de haver matado um inocente sem o devido julgamento. Como se evidencia na passagem citada, Sinha Vitória, aflita, procurando suster os filhos, que "adivinhavam desgraça”, entendia que o marido poderia ter aguardado mais um dia para ver se era mesmo indispensável a "execução" da cadela.

Evocando-se os capítulos "Cadeia", "O soldado amarelo" e "Baleia", apreende-se um paradoxo trágico vivido por Fabiano. Por causa da família, não matou o soldado que o maltratara, nem se fez cangaceiro, embora desejasse combater seus opressores. No entanto, matou Baleia, também pela família, da qual a cadela fazia parte. Como ela estivesse à morte, imaginou-a com um "princípio de hidrofobia" e decidiu matá-la: não poderia deixar as crianças expostas a uma mordida. Sendo assim, verificado nos momentos da humilhação pelo policial e da opção pela família (comprovada na postura ética ao reencontrá-lo), o misto de fraqueza e força do retirante ganha expressão artística máxima no capítulo "Baleia". O sertanejo pobre, capaz de poupar os seus exploradores, teve o infortúnio de matar Baleia, que, como ele, vivia em função dos outros, submissa aos donos e presa afetivamente à família dele.

Trabalhando "como escravos" em nome dos familiares, é grande a identificação entre os dois. Por isso, tragicamente, o tiro que Fabiano dá em Baleia o faz depois crer-se algoz, como eram para ele o soldado amarelo e seus donos; e a faz crer, perdendo a visão, que é noite e não cumpriu suas obrigações diurnas para com o vaqueiro. Com a "grande escuridão" vem o susto ante os animais soltos, quando ouve o chocalho das cabras e sente o fartum do chiqueiro: a necessidade impotente de realizar suas funções a impede de 
perceber que, à morte, está "livre de responsabilidades". Fala mais alto para ela o impulso afetivo e cotidiano de proteger das cobras a família, sobretudo os meninos.

Baleia assustou-se. Que faziam aqueles animais soltos de noite? A obrigação dela era levantar-se, conduzi-los ao bebedouro. Franziu as ventas, procurando distinguir os meninos. Estranhou a ausência deles.

(...) Uma angústia apertou-lhe o pequeno coração. Precisava vigiar as cabras: àquela hora cheiros de suçuarana deviam andar pelas ribanceiras, rondar as moitas afastadas. Felizmente os meninos dormiam na esteira, por baixo do caritó onde sinha Vitória guardava o cachimbo. (pp. 89-90).

Muito da força artística do capítulo advém de Graciliano presentificar o momento da morte da cadela revelando-lhe a vida - feita de cuidados com Fabiano, Vitória e os meninos, - à qual ela se mantém agarrada, porquanto não sabe estar morrendo, ainda mais pelas mãos de Fabiano. A agonia da morte de Baleia, em que deixa fisicamente de existir, para ser simbolicamente, mais a aproxima de Fabiano-bicho e, a um tempo, mais a humaniza: sofre o "medo da roda", a "sede horrível", o não latido mas uivo baixinho, a perda de muito sangue, que a faz andar "como gente, em dois pés", o nevoeiro que a impede de se ver, a gradual perda dos sentidos. Bicho-gente, deseja morder o dono, porém é incapaz disso, tal qual Fabiano quando recua, pela família, do sonho de ser cangaceiro e matar os donos do soldado amarelo:

(...) Não poderia morder Fabiano: tinha nascido perto dele, numa camarinha, sob a cama de varas, e consumira a existência em submissão, ladrando para juntar o gado quando o vaqueiro batia palmas. (p. 89).

Se a arte atinge beleza revelando limitações, não à toa é tão comovedora a combinação de fragilidade e força de Baleia, e de Fabiano, na cena em que ela morre pelas mãos do dono. Dolorosamente bela a construção de imagens do capítulo, uma em especial insinua que o sertanejo, sempre vítima de uma estrutura social fincada em iniqüidade, talvez tenha cometido injustiça ao matar a cadela - e, ainda mais terrível, em nome da proteção dos filhos, que também a amavam. Mais uma vez, trata-se da imagem da trempe, porém a figuração da família agora terá a pedra fria.

A morte de Baleia e a possibilidade de ser uma injustiça de Fabiano surgem num pormenor de alta poesia: ainda percebendo na carne doente os espinhos de mandacaru, mas sendo tomada por "insensibilidade e esquecimento", Baleia sente o frio ao encostar a "cabecinha fatigada" na pedra do pátio; em seu delírio, julga ser a pedra da trempe da cozinha, cujas cinzas Vitória varria antes de se deitar. Esse lugar quente, onde a cadela costumava cochilar e encontrar os preás, é a origem da criação poética de Graciliano. 
Agora "a pedra estava fria", e a sensibilidade da cachorra, insciente da morte e presa à vida em família, crê conhecer o motivo disso:

(...) certamente sinha Vitória tinha deixado o fogo apagar-se muito cedo. (p. 91).

Comovedoramente, insinuando-se nos verbos empregados (deixar e apagar) e na intensidade da expressão de tempo (muito cedo), o fogo que Sinha Vitória deixou apagarse muito cedo, mais do que o da trempe, parece ser a própria cachorrinha. O citado pensamento de Baleia remete ao suspiro de Sinha Vitória antes da "execução": deixara o marido matar a cadela, embora julgasse precipitada a decisão.

As dúvidas quanto à justiça de Fabiano ao matar Baleia revelam os problemas inerentes às questões da eutanásia e da pena de morte. Quando ele sente a culpa de um algoz ${ }^{68}$, consolo possível é ter atirado na cachorra por "eutanásia": preocupado com a proteção da família, o vaqueiro carregou bem a espingarda para que a cadela não sofresse muito e a matou, porque ela estava doente e ele não podia arriscar a vida dos filhos. $\mathrm{O}$ leitor de Graciliano se lembrará da "eutanásia" criticada por meio de ironia em Caetés: João Valério, entre os dominantes de seu ambiente, recomendava descaradamente aos mendigos, "récua inútil”, a eutanásia ('boa morte', como o genocídio dos índios resistentes à escravização). No entanto, algoz de quem é Fabiano? "Criatura inofensiva" que sofre injustiças e não sabe falar nem se defender, Baleia é como ele, sempre a cair de fome pelo sertão com a família, a apanhar, impotente, do soldado amarelo, do patrão, do governo.

\footnotetext{
68 “(...) Desceu [Fabiano] o copiar, atravessou o pátio, avizinhou-se da ladeira pensando na cachorra Baleia. Coitadinha. Tinham-lhe aparecido aquelas coisas horríveis na boca, o pêlo caíra, e ele precisara matá-la. Teria procedido bem? Nunca havia refletido nisso. A cachorra estava doente. Podia consentir que ela mordesse os meninos? Podia consentir? Loucura expor as crianças à hidrofobia. Pobre da Baleia. Sacudiu a cabeça para afastá-la do espírito. Era o diabo daquela espingarda que lhe trazia a imagem da cadelinha. A espingarda, sem dúvida. Virou o rosto defronte das pedras do fim do pátio, onde Baleia aparecera fria, inteiriçada, com os olhos comidos pelos urubus".

“(...) Mas o coração grosso, como um cururu, enchia-se com a lembrança da cadela. Coitadinha, magra, dura, inteiriçada, os olhos arrancados pelos urubus". (RAMOS, Graciliano. O mundo coberto de penas. In: Vidas secas. cit., pp. 109 e 114).

“(...) Encarquilhou as pálpebras contendo as lágrimas, uma grande saudade espremeu-lhe o coração, mas um instante depois vieram-lhe ao espírito figuras insuportáveis: o patrão, o soldado amarelo, a cachorra Baleia inteiriçada junto as pedras do fim do pátio". (Idem. Fuga. In: Vidas secas. cit., p. 120).
} 
Quanto à questão da pena de morte ${ }^{69}$, da condenação sem o devido julgamento, é inevitável pensar-se no contexto pessoal vivido por Graciliano Ramos em 1937, quando escreveu Vidas secas: acabara de deixar o cárcere, em que fôra detido, ameaçado e marcado de morte, sem julgamento ${ }^{70}$. Necessitando de dinheiro para manter-se e à família, publicou na imprensa brasileira e argentina, a princípio como contos, os capítulos desse romance "desmontável" (segundo a conhecida expressão de Rubem Braga). Impagável, cobra leitura a ironia com que Graciliano, nesta carta a Garay, se refere à sua situação de preso sem processo e ex-detento do Estado Novo:

(...) É que ando aperreado, chateado, indignado com a obrigação de pagar casa, comida, bonde, roupa, café e outras inconveniências.

Eu vivia livre de todos esses aborrecimentos. O governo do meu país é um governo sábio e algumas vezes nos fornece mesa, cama, transporte e boas conversas, tudo de graça. Você não acha que é safadeza sustentar um cidadão durante um ano e de repente mandá-lo embora, desempregá-lo sem motivo? Foi o que me aconteceu. Eu estava quase habituado, considerava-me, com certa vaidade, hóspede oficial, membro de uma instituição respeitável e necessária ao preparo de eleições e outros jogos nacionais. Infelizmente a minha reduzida pessoa foi julgada inútil a essa trapalhada - e o governo, por economia, me cortou os meios de subsistência.

Agora preciso dar dinheiro à mulher da pensão e aumentar os lucros da Light. Para isso tenho de explorar alguém ou qualquer coisa e ser explorado pelo dono do jornal e pelo editor. Como não possuo bondes nem casas, lembrei-me de explorar um hospital, um médico, enfermeiros e a doença que me ia matando anos atrás. ${ }^{71}$

Nono capítulo, "Baleia" foi o primeiro conto, de 4 maio de $1937{ }^{72}$. Nele, Graciliano reviveu a lembrança de um cachorro sacrificado no interior de Pernambuco

\footnotetext{
${ }^{69}$ Essa questão surge discutida no ensaio "Tempos futuros", de Zenir Campos Reis. In: Revista do Instituto de Estudos Brasileiros, $\mathrm{n}^{\mathrm{O}}$ 35, cit., pp. 69-92.

70 “- Aqui não há direito. Escutem. Nenhum direito. Quem foi grande esqueça-se disto. Aqui não há grandes. Tudo igual. Os que têm protetores ficam lá fora. Atenção. Vocês não vêm corrigir-se, estão ouvindo? Não vêm corrigir-se: vêm morrer.

(...) Várias pessoas estavam ali sem processo, algumas deviam quebrar a cabeça a indagar por que as tratavam daquele jeito; não havia julgamento e expunham claro o desejo de assassiná-las. Não nos faziam ameaça vã, como notei depois. Atanazavam-me as palavras do caolho: todos iguais, nenhum direito, os soldados podiam jogar-nos impunemente no chão, rolar-nos a pontapés. E finar-nos-íamos devagar". RAMOS. Graciliano. Memórias do cárcere. cit., v. III, capítulo 12, pp. 80-1.

${ }^{71}$ RAMOS, Graciliano. Carta a Benjamín de Garay. Rio de Janeiro, 22 de abril de 1937 [VIII]. In: Cartas inéditas de Graciliano Ramos a seus tradutores argentinos Benjamín de Garay e Raúl Navarro. cit., p. 45.

${ }^{72}$ Depois vieram, por ordem de escrita: "Sinha Vitória", "Cadeia" e "O menino mais novo", em junho; "O menino mais velho", "Inverno", "Mudança", "Festa" e "Contas", em julho; "Fabiano" e "O mundo coberto de penas", em agosto; "O soldado amarelo", em setembro; "Fuga", em outubro. Repare-se que o capítulo do reencontro com o amarelo, antepenúltimo do livro, foi o penúltimo escrito, vários meses após "Baleia". (Testemunho de Graciliano sobre Vidas secas, escrito a pedido de João Condé no Rio em junho de 1944, para a sua seção "Arquivos Implacáveis", publicada na antiga revista $O$ Cruzeiro. In: Publicação fac-similar da primeira edição do romance Vidas secas, de Graciliano Ramos, que homenageia e comemora o cinqüentenário do seu lançamento. São Paulo, dezembro de 1988).
} 
(Maniçoba), tendo transformado seu avô Pedro Ferro em Fabiano, sua avó em Sinha Vitória e os tios pequenos nos dois meninos. Chamou de Baleia a cadela, como era Tubarão o cachorro de Paulo Honório e Moqueca a cachorra de Angústia e de Histórias de Alexandre, segundo o costume sertanejo de dar nomes de peixes aos cães para evitar a hidrofobia (recurso que, como o rosário de sabugos de milho queimados amarrado ao pescoço, não surtiu efeito para Baleia nem para a primeira Moqueca) ${ }^{73}$.

Por meio desse conto, logo articulado em romance com "Cadeia", "O soldado amarelo" e com os demais capítulos, o escritor que recém sofrera na colônia correcional tecia a representação crítica da realidade, marcada por miséria, violência, injustiças e arbitrariedade do governo, e a expressão dramática do imperativo ético. Valioso por si e "solidário" com o todo do romance, ao qual se liga por um "pensamento unificador" 74 , "Baleia" traz primorosamente juntos o problema moral e o problema social da gente do país: embora as "pupilas negras" da cadelinha impedissem Fabiano de atirar, ele a matou, no mais terrível gesto, porque, tendo poupado seus inimigos sociais, fez desaparecer um ser amado da família, igual a ele, tanto no desamparo de todo vivente, como na condição de submisso ao dono.

Tat twam asi ['Isto és tu']: Carpeaux retoma dos Vedas, com Schopenhauer, a visão para além do "princípio de individuação", a qual permite aos seres perceberem-se iguais enquanto sofredores e abrirem-se à compaixão do outro. Depreendendo a misericórdia tão compreensiva do "pessimista" Graciliano, em relação a si mesmo e a todas as criaturas (como Baleia e o "mudo assassino" Casimiro Lopes, capanga de Paulo Honório), Carpeaux destaca o desejo do escritor: a destruição deste mundo, para libertar todos os viventes; daí seu estilo conciso, centrado no essencial ${ }^{75}$.

\footnotetext{
${ }^{73}$ Cf. RAMOS, Clara. Cadeia. Rio de Janeiro: José Olympio: Secretaria de Cultura, 1992, p. 178.

${ }^{74}$ CANDIDO, Antonio. Ficção e confissão. In: Ficção e confissão: ensaios sobre Graciliano Ramos. cit., p. 44.

Em "Tempos futuros", Zenir Campos Reis agrupa os treze capítulos segundo a simetria temática entre eles: "Mudança", o primeiro, e "Fuga", o último; "Fabiano", o segundo, e "O mundo coberto de penas", penúltimo; "Cadeia", o terceiro, e "O soldado amarelo", antepenúltimo; "Sinha Vitória", o quarto, e "Contas", décimo; "O menino mais novo" e "O menino mais velho", quinto e sexto, e "Baleia", nono; "Inverno", o sétimo, e "Festa", o oitavo, no centro. (In: Revista do Instituto de Estudos Brasileiros, n. 35, cit., p. 77). Em seu estudo sobre Graciliano, Luís Bueno depreende muito bem a unidade ao longo dos capítulos do "romance desmontável" e retoma o artigo de 1973 do professor norte-americano Frederick G. Williams, que apontou a "relação especular" entre os capítulos de Vidas secas. (Cf. BUENO, Luís. Uma história do romance de 30. cit., pp. 641-664).

${ }^{75}$ CARPEAUX, Otto Maria. Visão de Graciliano Ramos. Origens e fins. In: Ensaios reunidos 1942-1978. cit., v. I, p. 447. Cf. SCHOPENHAUER, Arthur. $O$ mundo como vontade e como representação. $\mathrm{I}^{\mathrm{o}}$ tomo. Tradução, apresentação, notas e índices de Jair Barboza. São Paulo: Editora UNESP, 2005 (Livro quarto -
} 
Acostumada a viver pelo outro, Baleia, no momento de limite máximo, na morte, resiste viva, preocupada ainda com os seus. E, ao humanizá-la, Graciliano, como o menino de Tatipirun (A terra dos meninos pelados), dá lugar aos sonhos, imaginando para Fabiano um mundo com a fartura do que lhe falta:

Baleia queria dormir. Acordaria feliz, num mundo cheio de preás. E lamberia as mãos de Fabiano, um Fabiano enorme. As crianças se espojariam com ela, rolariam com ela num pátio enorme, num chiqueiro enorme. O mundo ficaria todo cheio de preás, gordos, enormes. (p. 91).

"No fundo todos somos como a minha cachorra Baleia e esperamos preás": a afirmação do escritor revela que, se necessitara enfrentar a dificuldade de "adivinhar o que se passa na alma duma cachorra" ${ }^{76}$, tinha consciência do alcance universal de sua construção literária. Lúcia Miguel Pereira observou exatamente que Graciliano, pondo à prova a sua técnica ao criar personagens que não sabiam analisar os próprios sentimentos, escolheu o caminho mais difícil, mas venceu: "viu criaturas humanas nesses retirantes. E as viu tão humanas, que até a cachorra Baleia foi humanizada com uma ternura que põe uns longes de poesia no livro" 77 .

Também destacando o "retrato interior de um primitivo" como "façanha" do romance, Rubem Braga ressalta a percepção a um tempo precária e aguda e a necessidade de pensar de Fabiano. Recorde-se a analisada imagem da panela fervendo na cabeça do personagem:

Como pensa esse homem que não sabe pensar! Sente as coisas de um modo grosso e ao mesmo tempo agudo, sente que é preciso pensar, entender as coisas. E pensa com esforço, penosamente, sentindo raiva dessa necessidade de pensar. ${ }^{78}$

Dessa forma, Graciliano desfaz o lugar-comum segundo o qual o sertanejo era um tipo pitoresco, "mistura de retirante, beato e cangaceiro", preguiçoso, falso, bêbado, ladrão e vingativo, capaz de se deslocar do Juazeiro para o bando de Lampião, de abandonar facilmente a família. Como se viu, na crônica "Sertanejos" (Novidade, 1931) já criticava

\footnotetext{
"Do mundo como vontade". Segunda consideração - "Alcançando o conhecimento de si, afirmação ou negação da Vontade de vida", § 63, pp. 448-455).

${ }^{76}$ RAMOS, Graciliano. Carta a Heloísa de Medeiros Ramos. Rio, 7 de maio de 1937 (n. 103). In: Cartas. cit., p. 201.

${ }^{77}$ PEREIRA, Lúcia Miguel. Um romance mudo como um filme de Carlitos: Vidas secas. In: A leitora e seus personagens: seleta de estudos publicados em periódicos (1931-1943). cit., pp. 121-2.

${ }^{78}$ BRAGA, Rubem. Vidas secas. In: Teresa revista de Literatura Brasileira 2. cit., pp. 127-8.
} 
esse estereótipo. E, confirmando a opção do escritor por embrenhar-se em "caminhos tortuosos", apresentada em "Chavões" (também da Novidade), o narrador em terceira pessoa de Vidas secas (1938), com consciência crítica do mundo exterior e proximidade afetiva de Fabiano, acompanha a interioridade do vaqueiro nas situações dramáticas por ele vividas. Revela como ele tinha, por dentro, "a cartucheira e os molambos": trabalhador e honesto, sofria por causa da miséria, da falta de instrução, das injustiças, entre a explosão e o abafamento da revolta, preocupado sempre com a família.

Assim, conforme a dimensão compreensiva de seu foco narrativo, o romance configura a desconfiança do vaqueiro quanto à justiça dos donos, o seu desejo de ser cangaceiro (para vingar-se dos poderosos, que reduzem homens à condição de escravos, de bichos) e a sua resistência ética. Vidas secas sobressai ao trazer à luz os dilemas, os sonhos e, em seus limites, a possibilidade de consciência crítica dos pobres-diabos como Fabiano. Em novembro de 1937, ao enviar o romance ao editor argentino Benjamín de Garay, Graciliano explica-lhe que, atendendo a seu pedido, o livro traz coisas regionais, porém diferentes da literatura existente, cheia de descrições-chavão de paisagens e cujos matutos eram inverossímeis, de fala difícil e errada artificialmente: ele buscava ver "por dentro" seus matutos, apreender o pensamento deles.

Os nossos matutos nunca foram observados convenientemente. Os que aparecem em romances pensam como gente da cidade e falam difícil, apenas deformando as palavras, suprimindo os ss, os 11 e os rr finais. (...)

Acho que os tipos que the mando são verdadeiros. Procurei vê-los por dentro e evitei os diálogos tolos e fáceis, que dão engulhos. Os meus matutos são calados e pensam pouco. Mas sempre devem ter algum pensamento, e é isto que me interessa. Não gastei com eles as metáforas ruins que o Nordeste infelizmente produz com abundancia. Também não descrevi o pôr-do-sol, a madrugada, a cheia e o incêndio, coisas obrigatórias, como você sabe.

Veja se essa gente lhe agrada. Se ela for metida em La Prensa, ficarei muito satisfeito. ${ }^{79}$

Graciliano conhecia que sua criação, contra o lugar-comum em termos estéticos e éticos, era novidade de valor universal:

Os meus cachorros não falam. E isto é interessante, porque todos os bichos que têm surgido na literatura falam. Donde se conclui que eles nunca foram bichos. Os meus matutos também não falam, e isto é um buraco. Vou ver se consigo adivinhar o que eles pensam, mas sem

\footnotetext{
${ }^{79}$ RAMOS, Graciliano. Carta a Benjamín de Garay. Rio de Janeiro, 18 de novembro de 1937 [XIV]. In: Cartas inéditas de Graciliano Ramos a seus tradutores argentinos Benjamín de Garay e Raúl Navarro. cit., p. 63.
} 
reproduzir a linguagem deles. Se isto não for novidade, macacos me mordam. Vai ser uma pequena coleção de Silvas, bípedes e quadrúpedes. ${ }^{80}$

Recuperando a percepção do amigo em comum Aurélio Buarque de Holanda, de que cada romance de Graciliano constituía experiência diversa, Otto Maria Carpeaux compreende que o escritor estava em busca da solução para um "problema vital".

Em S.Bernardo, contra estereótipos, a narrativa é do proprietário que, sertanejo pobre, após ascender fazendo-se ladrão e assassino, se afligiu com a inutilidade de sua trajetória, pois levou à morte a amada, compreendida por ele tardiamente. Também fugindo ao lugar-comum, em Angústia a narrativa é do intelectual pobre-diabo que, como um cangaceiro, matou o rival, proprietário e bacharel - ação inútil que lhe atormenta a consciência. Já em Vidas secas, a novidade da narrativa é surpreender a interioridade dramática dos matutos, em especial do retirante que, sofrendo miséria e falta de instrução, não matou o inimigo, no entanto levou à morte a cadela estimada.

Desse modo, ressaltam dos dramas dos três protagonistas a necessidade de compreensão do outro, compaixão e resistência ética, um sentido de vanidade de tudo, próprio do Eclesiastes, e, a um tempo, a crítica à ordem social iníqua e o impasse do intelectual num mundo de violência. As dúvidas do vaqueiro quanto à justiça, após ter sofrido o tiro em Baleia e as arbitrariedades da polícia e do governo no episódio de sua prisão, falam da detenção do próprio escritor. Se em 1931, inconformado com o predomínio de chavões na política e na literatura, Graciliano sugeriu numa crônica, com sábia ironia, que os homens inteligentes deixassem de escrever e entregassem "a pena aos imbecis”, em 1936, diretor sério da Instrução Pública e com dois romances publicados, ele foi preso. Culpado aos olhos de um governo tautologicamente personalista, a culpa que sentia era a impotência de sua arte, cuja beleza artística se nutriu das misérias reais.

Permanência trágica da "pequena coleção de Silvas" num mundo de injustiças, a imagem literária de Baleia não se apaga:

Uma chuva de faíscas mergulhou num banho luminoso a cachorra Baleia, que se enroscava no calor e cochilava embalada pelas emanações da comida.

(...) Baleia despertou, retirou-se prudentemente, receosa de sapecar o pêlo, e ficou observando maravilhada as estrelinhas vermelhas que se apagavam antes de tocar o chão. ("Sinha Vitória”, pp. 39-46).

\footnotetext{
${ }^{80}$ Idem. Carta ao filho Márcio. Rio, 22 de agosto de 1937. Apud RAMOS, Clara. Cadeia. cit., pp. 169-170.
} 
"Eqüidade opulenta" ${ }^{81}$ : os meninos impossíveis e o astrônomo do inferno

\author{
(...) \\ $\mathrm{O}$ rio de minha terra é o $\mathrm{ABC}$ \\ De minha meninice, o meu passado \\ a correr para o mar \\ com todas as pedrinhas com que eu criança \\ brincava a fingir que eram bois. \\ Em junho o rio enchia, em agosto secava \\ e refletia o rio nágua uma verde esperança \\ com a cabeça virada para baixo. \\ (...) \\ Um dia é o que me lembra, eu desci o meu rio, \\ Perguntaram-me: aonde vais? \\ - Vou descer! respondi \\ Desci! \\ e não subi nunca mais! \\ "Mundaú", Jorge de Lima ${ }^{82}$
}

Por fim, esboça-se um arco entre a Novidade dos meninos impossiveis, dos anos 1930 em Maceió, e A terra dos meninos pelados, de Graciliano Ramos, conto publicado em 1937 no Rio de Janeiro.

O primeiro "menino impossível”, Jorge de Lima, quebrou em 1927 os brinquedos complicados: preferia o faz-de-conta aplicado aos objetos simples do cotidiano. Brincava com pedrinhas brancas do rio, bois ou ovelhas desgarradas das quais se apiedava. Transformava tacos em cangaceiros, não em soldadinhos de chumbo. Recusando a cultura de importação, o parnasianismo, o poeta, por meio de formas livres, modernas, voltou seu olhar para a tradição regional, afetiva, e para criaturas injustiçadas da realidade social nordestina.

De 1926 a 1935 em Maceió, onde escreveria seus três primeiros romances, José Lins do Rego, o paraibano autor de Menino de engenho, apresentou a poesia nova de Jorge de Lima a alguns moços de vinte anos: Valdemar Cavalcanti, Alberto Passos Guimarães, Santa Rosa, Carlos Paurílio, Aloísio Branco, Aurélio Buarque, Willy Lewin, Raul Lima, Barreto Falcão, entre outros. Esses meninos impossíveis desejaram expressar-se e criticar a

\footnotetext{
${ }^{81}$ Já citada, a expressão é de Mário de Andrade a respeito de Angústia.

${ }^{82}$ LIMA, Jorge de. Mundaú. Poemas (1927). In: Poesia completa: volume único. cit., p. 231.
} 
paralisia de um mundo de misérias e estereótipos. Os dois primeiros fundaram e dirigiram em 1931 a Novidade, seminário interessado numa renovação cultural e política.

Com quarenta anos tal qual Jorge de Lima, no centro dos meninos impossíveis estava, agudez irônica a distanciar e aproximar, o "velho Graça", que conheceu menino o significado da palavra inferno. Como o poeta de "Mundaú", quase todos desceriam ao Rio de Janeiro, Graciliano numa migração forçada, para não subirem nunca mais.

O menino Santa Rosa, brincando de pintar paisagens com palavras em poemas para a Novidade, pisa as flores pequeninas e sofre por isso. Mas depois contribuiria para revolucionar o livro nacional, desenhando a interpretação da literatura brasileira nas capas para a editora José Olympio.

Aloísio Branco é o menino inquieto com o universo e o tempo, em termos pessoais, coletivos e metafísicos. Povoava o mundo lendo: em criança, Julio Verne; depois, vários escritores estrangeiros, como Oscar Wilde, Jean Cocteau, Dostoievski (sobre os quais escreveu na Novidade), além dos brasileiros. E povoava o mundo criando poemas, lançando barquinhos de calendários velhos para resgatar no "mar abstrato do tempo" os "rios infantis das sarjetas". Como um cego a buscar "em vão o resto dos sentidos", compôs a "Berceuse para embalar o mundo", no momento em que se saía de uma guerra e outra se anunciava. Sintetizando o traço de Aloísio Branco, apegado à literatura, e a condição paradoxal do intelectual e artista num mundo de violência, Jorge de Lima no poema dedicado ao amigo, que morreu jovem em Maceió, cria para o quarto de livros dele a imagem da "gaiola azul".

Paurílio é sempre o poeta e contista da solidão, afetivamente ao lado das criaturas abandonadas, como o órfão tísico. Fez da cabeça da pequena Alice um país ideal, onde a mosquinha Zizi pousava e podia sonhar, desmemoriada de sua condição ínfima, até se desvanecerem as fantasias com os piparotes da mão enorme da menina e depois com o terrível flit.

Aurélio, o menino professor das crianças do Orfanato São Domingos, curioso e taciturno, contemplativo do mar e do céu, era afeito a mistérios mas também interessado por decifrações. Prosador hábil em criar mundos de lirismo, carregados do peso da realidade, definiu-se por meio da áspera avó D. Cândida Rosa e seu pungente desejo de ir ao "outro mundo". Futuro dicionarista brasileiro, cedo o encantou a definição de horizonte: jangada longe, o "junto-junto do céu", furado com a vara pelo menino pescador e felizmente remendado com sabão por São Pedro. 
No horizonte, entre a terra e o céu, outro menino, o mais velho de Vidas secas, como o de Infância, também se inquietava com uma palavra: inferno ${ }^{83}$. O escritor conhece o desejo da criança, de que os vocábulos desconhecidos virem coisas, e o desapontamento de descobrir que uma palavra bonita designava um lugar ruim. A mãe não poderia "transformar" o inferno e, além disso, o presentifica quando destina cocorotes ao filho ao invés de explicações. Se Sinha Vitória se recusa a descrever o inferno de espetos quentes, narrador e leitor têm em mente que ela experienciou o tempo de seca e fuga, fome e sede, esquecido do menino. Para ele, havia apenas os lugares bons como o curral, o pátio, - o mundo onde viviam sua família e os bichos da fazenda.

Infeliz, enxotado pela mãe, o menino consola-se de sua "curiosidade funesta" partilhando da simpatia de Baleia, que "não podia sentir dor excessiva", e pensando no morro onde ela caçava preás. Graciliano criou bela imagem a partir desse refúgio imaginário do menino: na serra "distante e azulada", viviam pedras e plantas que "procediam como gente", compreendiam-se e se auxiliavam, vencendo as forças maléficas. À semelhança do menino impossível Jorge de Lima, ele transformava ossos e seixos nas figurinhas abandonadas que povoavam a serra, habitada também por cobras, segundo dizia Fabiano.

Já se vê que a harmonia desse mundo imaginário, estrela desejada pelo romancista astrônomo, está imersa na escuridão. Quando anoitece e não se distinguem serra e céu, o menino, surpreso, avista estrelas na serra: “como era possível haver estrelas na terra?". Sem encontrar resposta, entristece recordando a presença da mãe. Então, admitindo um inferno cheio de cobras, de habitantes submetidos a cocorotes, tenta em vão pensar nas estrelas "que se acendiam na serra": já estavam apagadas. Resta-lhe, sentindo-se "fraco e desamparado", olhar os braços magros, fazer "desenhos misteriosos" no chão e abraçar com força a cachorrinha. Mesmo reprovando essa "carícia excessiva", Baleia se encolhe para não magoar o amigo, enquanto sonha com um impossível osso graúdo.

Por meio do menino mais velho, Graciliano expressa seu desejo de resgatar o potencial poético das palavras, vivo aos olhos das crianças, que resistem ao convencional do signo lingüístico, ansiosas de sua motivação. Assim, critica a ordem social, fincada em fórmulas engessadas, conservadora: se uma palavra bela como inferno não poderia

\footnotetext{
${ }^{83}$ RAMOS, Graciliano. O menino mais velho. In: Vidas secas. cit., pp. 54-62; Idem. O inferno. In: Infância. cit., pp. 72-6.
} 
designar coisa ruim, também não era justa a realidade hostil de Fabiano e sua família, nem a inocência trágica do menino, que vivia num inferno sem conhecê-lo pelo nome.

Impossível e astrônomo, o menino mais velho, desalentado ante as palavras desconhecidas, isolado num mundo de maus-tratos, mas observador e ávido de aprender, sonhava com entes fantásticos como plantas e pedras que viviam em harmonia numa serra azulada, em cuja escuridão ele via estrelas acenderem-se e se apagarem. Seu nome bem poderia ser Raimundo, ou Pirundo, personagem d' A terra dos meninos pelados (1937) ${ }^{84}$.

$\mathrm{O}$ olho direito preto, o esquerdo azul e a cabeça pelada, Raimundo sofria com a zombaria dos outros garotos: fechava um olho, o outro, e "a cara ficava toda escura". Então, falava sozinho e desenhava na calçada as maravilhas de Tatipirun, terra onde não havia cabelo e todos tinham um olho preto, o outro azul. Ele visita esse país formidável e retorna saudoso para casa, mas ensinará a todos o caminho de Tatipirun.

Em lugar do rosto escuro de tristeza de Raimundo estigmatizado pelos vizinhos, no mundo iluminado pela menina-princesa Caralâmpia imperava o respeito entre os viventes: cada cara continha "os olhos de duas criaturas". Nessa imagem concebida por Graciliano, de rostos com um olho preto e outro azul, todo ser contém o olho de um diferente: criação incomparável, é a própria materialização da ética do rosto. E Tatipirun figura, portanto, a possibilidade de um mundo livre de estereótipos e preconceitos, que fervilhava na cabeça pelada do escritor, saído da prisão.

Note-se que o peso da realidade move essa criação imaginária. Ao contrário do mundo violento, em que Raimundo é inadaptado, na terra dos meninos pelados, prolongamento da serra azulada de Vidas secas, as plantas, as pedras, os troncos e os bichos são muito educados. As crianças conversam com eles, ouvem as histórias da Guariba, macaca sábia que já estava caducando, vestem belas túnicas tecidas pelas aranhas. Se o menino mais velho ensombrecia, maltratado pelos pais em consequiência da seca, ou seja, da má administração social, em Tatipirun a natureza é amiga: a serra de Taquaritu se abaixa e os rios se fecham biblicamente para as pessoas passarem e depois retornam, não faz calor nem frio, não chove, não há noite.

\footnotetext{
${ }^{84}$ Idem. A terra dos meninos pelados. Ilustrações de Roger Mello. $20^{\mathrm{a}}$ ed. Rio de Janeiro: Record, 1998. Também em Alexandre e outros heróis. cit., pp. 123-153. A primeira edição é de agosto-setembro de 1937 (Pan Infantil, Rio de Janeiro); a segunda, de 1939 (Porto Alegre, Livraria do Globo). Graciliano recebeu com o livro o prêmio "Literatura Infantil" do Ministério da Educação e Saúde (terceiro lugar). Cf. LIMA, Yêdda Dias; REIS, Zenir Campos (Coords.) Catálogo de manuscritos do Arquivo Graciliano Ramos. São Paulo: EDUSP / Instituto de Estudos Brasileiros, Universidade de São Paulo, 1992, p. 44.
} 
Nesse país sonhado por Graciliano, o progresso técnico se acompanha de civilidade autêntica, combatida a barbárie. Como todos os seres, também os automóveis, um olho preto e outro azul em lugar de faróis, não atropelam ninguém. A laranjeira oferece frutas aos meninos e lhes ensina a persistirem sempre em busca de um caminho pessoal: "Vá seguindo sempre. Todos os caminhos são certos". Essencial, esse não-dogmatismo combina-se com a não-violência de Tatipirun, onde os meninos não sabem o que é brincar de bandido e ninguém morde, nem as cobras, que enfeitam Caralâmpia como colares. Com generosidade e olhar crítico, a laranjeira indica que, sendo outros os costumes no passado, esse não-uso de espinhos foi uma conquista. Assim, destinada às crianças, a fabulação de $A$ terra dos meninos pelados, com certa aparência ingênua, carrega forte sentido ético, formador de adultos.

Uma imagem logra figurar não apenas a necessidade recíproca entre realidade e fantasia, como o movimento do escritor entre observação, introspecção, consciência insone e desejo de um "soninho sossegado" e de uma vida plena como sonhos: os meninos de Tatipirun, para descansar, fechavam um olho e mantinham o outro aberto, vendo tudo.

$\mathrm{O}$ peso da realidade, além de motivar a fantasia, está presente nela. Preocupado em voltar para casa, pois precisava estudar geografia, Raimundo ensina a geografia humana aprendida em Tatipirun, onde não cabiam preconceitos. Graciliano quis mostrar como valor em seu mundo sonhado a igualdade entre os seres, sobretudo o respeito ao diferente, o que não está livre de impasses a serem superados. Fringo, Talima, Sira, Pirenco, todas as crianças de Tatipirun eram igualmente calvas, um olho preto e outro azul, porém apresentavam diferenças: havia um sardento, um anão, um negro. Insatisfeito, o sardento projetava obrigar todos a terem manchas no rosto. Então, ante esse projeto, Raimundo compreende que não faria sentido as pessoas serem todas iguais, feito rapadura; e argumenta que gostavam do sardento como ele era. Recordem-se as laranjas e pitombas de "Nuvens", esféricas ambas, com sabores diferentes.

Fantasia dentro da fantasia, a falar também da realidade, Caralâmpia desperta incredulidade ao contar que visitou uma terra cujos guris possuíam duas cabeças, oito olhos, cinco braços e uma perna só. Para os relutantes a fugir de estereótipos, vem a pergunta, defesa das singularidades: "Por que é que não existem pessoas diferentes de nós?”. Ora, em Tatipirun as laranjeiras não têm espinhos, cada criatura traz no rosto dois olhos de cores diferentes, o olho do outro, a ética. 
De fato, ante o lugar-comum de embotamento e violência, causam estranheza as diferenças entre as pessoas e a possibilidade de haver misericórdia. Preso, Graciliano Ramos sofreu pavor e incompreensão: qual bandido perigoso, foi escoltado por um policial negro que lhe encostou uma arma nas costas; no porão, morto de sede, recebeu a generosidade de outro guarda negro ${ }^{85}$. Caminho difícil, o escritor buscava compreender as diferenças e, no mundo hostil, ver alguma luz:

(...) Precisamos viver no inferno, mergulhar nos subterrâneos sociais, para avaliar ações que não poderíamos entender aqui em cima. Dar de beber a quem tem sede. Bem. Mas como exercer na vida comum essa obra de misericórdia? Há carência de oportunidade, as boas intenções embotam-se, perdem-se. ${ }^{86}$

As palavras do menino que se fez astrônomo do inferno permanecem: "Como era possível haver estrelas na terra?".

\footnotetext{
${ }^{85}$ Marcante, extremamente expressiva do esforço necessário para se recusarem estereótipos e preconceitos, essa passagem das recordações da prisão foi muito bem analisada por Alfredo Bosi no ensaio "A escrita do testemunho em Memórias do cárcere". In: Literatura e resistência. São Paulo: Companhia das Letras, 2002, pp. 221-237.

${ }^{86}$ RAMOS, Graciliano. Memórias do cárcere. cit., v. I, capítulo 22, p. 166.
} 


\section{NOTAS BIOBIBLIOGRÁFICAS}

Os primeiros perfis são dos fundadores da Novidade, Valdemar Cavalcanti e Alberto Passos Guimarães. A seguir, em ordem alfabética, vêm as notas sobre outros escritores referidos ou analisados neste trabalho, com a indicação dos textos deles no semanário e de livros publicados.

VALDEMAR CAVALCANTI (Maceió, 29/03/1912 - Rio de Janeiro, 19/06/1982): jornalista e crítico literário. Seu gosto pelas letras e pelo jornal começou quando pequeno: acompanhava emocionado as personagens dos livros (Coração, de Amicis, O conde de Monte Cristo, de Dumas, Os miseráveis, de Victor Hugo) e fazia pequenos jornais à mão. Logo publicou pequenos contos e poemas humorísticos em $O$ Bacurau; aos 15 anos, tornou-se redator de O Semeador e, aos 18, do Jornal de Alagoas.

Foi um dos fundadores, em 1927, do Grêmio Literário "Guimarães Passos". Como outros meninos impossíveis, a princípio rejeitou o modernismo, condenando a "tapeação literária" de poetas apressados e sem talento surgidos com a arte nova. Contudo, com a publicação d' $O$ mundo do menino impossível, de Jorge de Lima, alterou-se o ponto de vista dos jovens literatos alagoanos Valdemar, Aurélio Buarque, Carlos Paurílio, Aloísio Branco, Diégues Júnior. Em 1928, promoveram a Festa da Arte Nova, vaia às coisas acadêmicas e desejo de uma literatura nova, atenta à tradição e às coisas brasileiras. Valdemar escreveu poemas modernos, dentre os quais "A grande descoberta lírica", "História simples de uns olhos lindos", "Poema de todos os dias", "Inteligência brasileira", "Poema que eu esqueci de oferecer a Papai Noel".

Condenava o modernismo "de superfície" (expressão de José Lins do Rego), opunha-se à "mania do novo", entendendo que passar "tinta nova em coisas velhas" era simples modificação do vício classicista de procurar palavras antigas nos sermões de Vieira ou nas conferências de Rui Barbosa. Insurgiu-se contra a Revista de Antropofagia (Alcântara Machado, Raul Bopp, Oswald de Andrade), Raça, de Guilherme de Almeida, e República dos Estados Unidos do Brasil, de Menotti del Picchia. De forma lúcida, apontou falhas no modernismo, que logo se encheu também de convencionalismos, porém lhe reconhecia o valor, de nos trazer "uma compreensão mais clara de beleza" e "um gosto bem bom pelas coisas brasileiras".

Ao escrever a biografia de Valdemar Cavalcanti, Renard Perez chama a atenção para esse período até 1932, muito significativo na vida cultural de Alagoas: a "ebulição intelectual" decorria da presença em Maceió de figuras que viriam a ter projeção nacional, como Graciliano Ramos, Jorge de Lima, José Lins do Rego e Santa Rosa. Perez destaca a fundação da Novidade em 1931, com Alberto Passos Guimarães: “essa publicação teve prestígio indiscutível, porque inseria - em primeira mão - colaboração de escritores de todo o Nordeste e mesmo do Sul" (p. 354). Além de 12 editoriais, muitos Tópicos e Notas da Semana, Valdemar publicou no semanário o esboço de novela "Raul Marques, proprietário de Rio Comprido" (N 18, p. 8), a crítica de Oscarina, de Marques Rebelo (N 23 , p. 9), e, conforme ele desvendou anos depois em "Uma Revista", vários artigos sob pseudônimos ${ }^{1}$.

\footnotetext{
${ }^{1}$ São artigos de Valdemar Cavalcanti na Novidade sob pseudônimos: "Paisagens" (N 09, p. 8), Cinema "Retrato de Nancy Carroll” (N 20, p. 11), por José Maria de Assumpção; "Clara Bow" (N 14, p. 8), "O 'Lírio Sinuoso' da Alemanha" (N 15, p. 9), Cinema - "Rosita Moreno", "Ann Harding" (N 22, p. 8), por Mário das Neves; "Relógio oficial" (N 17, p. 10), "Livros novos", sobre Um jogador, de Dostoiewski (N 18, p. 12), por Rubens Cardoso.
} 
O biógrafo também revela o papel de Valdemar, seu estímulo e dedicação à obra nascente do grupo: discutia literatura e lia poemas inéditos no consultório de Jorge de Lima, ouviu de José Lins do Rego a leitura dos originais dos primeiros romances e datilografou Menino de engenho, Doidinho e Bangüê, além de S. Bernardo, de Graciliano.

Aos 20 anos, atuou como chefe do gabinete do prefeito de Maceió (seu tio), mas continuava escrevendo para jornais. Vivia como dândi, gostava de dançar e, com o amigo José Lins do Rego, foi o introdutor do frevo em Alagoas. Em 1933, foi para o Rio de Janeiro, onde traduziu romances, trabalhou no Diário Carioca e se dedicou à crítica literária no Diário de Notícias, junto com Manuel Bandeira e depois com Rosário Fusco. Como Aurélio, Valdemar escreveu as primeiras leituras críticas sobre Caetés, publicadas em 1933 no Boletim de Ariel. No ano seguinte, foi para Recife, convidado a ser secretário do Diário de Pernambuco. Em 1936, de volta a Maceió, casou-se e se tornou redator-chefe da Gazeta de Alagoas. Era um dos "meninos pelados" a quem Graciliano, no Rio de Janeiro em 1937, saído da prisão, mandava lembranças nas cartas a Heloísa.

Em 1937, Valdemar Cavalcanti regressou ao Rio, convidado a trabalhar no recéminstalado Instituto Brasileiro de Geografia e Estatística (IBGE). Intensificou sua colaboração na imprensa, escrevendo crítica e crônicas no Observador Econômico $e$ Financeiro, na Revista do Brasil, em O Cruzeiro, Vamos Ler etc. e nos jornais Diário de Notícias, O Jornal, Diretrizes etc. Foi diretor do suplemento literário de $O$ Jornal e redator-secretário em A Manha, de Aparício Torelly, o Barão de Itararé. Na Folha Carioca, publicou por largo período a primeira coluna diária de informações literárias num jornal brasileiro.

Em 1953 o governo francês lhe concedeu o título de Oficial da Academia de França, pela difusão da cultura francesa. Em 1955, recebeu o Prêmio Prefeitura Municipal de São Paulo, pela cooperação constante à causa das letras no país. Foi membro da União Brasileira de Escritores do Rio de Janeiro e membro correspondente do Instituto Histórico de Alagoas.

Embora muito respeitado como crítico e autor de vários artigos esparsos, Valdemar Cavalcanti nunca desejou publicar livros. Na juventude escreveu um esboço de novela (provavelmente, "Raul Marques, proprietário de Rio Comprido", da Novidade), mas o rasgou, insatisfeito. Publicou alguns contos, sempre com pseudônimos. No entanto, enquanto viajava numa caravana cultural no Nordeste, sua mulher descobriu os originais de um diário crítico e os levou para José Olympio. Assim, em 1960, com apresentação do amigo Aurélio Buarque de Holanda, saiu o Jornal literário, crônicas sobre fatos da vida literária, na maioria publicadas na seção diária homônima de Valdemar em O Jornal. Com essa obra, conquistou os prêmios literários da Academia Brasileira de Letras e da União Brasileira de Escritores.

Valdemar Cavalcanti traduziu, para a Editora José Olympio: Ressurreição, de Leon Tolstoi; Vozes da França, de André Maurois; Vento leste, vento oeste, de Pearl Buck; Lei do cnut e contos, de Wladyslaw Stanislaw Reymont; Grinalda de Afrodite (Antologia de Poemas Gregos), de Ferdinand Herold; A princesa e a cigana, de Jean Rosmer; Sangue e volúpia (em colaboração com Raul Lima), de Vicki Baum, dentre outras obras. Publicou: Jornal literário (Rio de Janeiro: José Olympio, 1960), 14 poetas alagoanos. Poemas escolhidos. (Maceió: Departamento de Assuntos Culturais-SENEC, 1974), o ensaio "O enjeitado Adolfo Caminha" (In: HOLANDA, Aurélio Buarque de, org. O romance brasileiro. Rio de Janeiro: O Cruzeiro, 1952). Preparou para a José Olympio O melhor de Stanislaw, seleção de crônicas de Stanislaw Ponte Preta. 
ALbERTO PASSOS GUIMARÃES (Maceió, 16/04/1908 - Rio de Janeiro, 24/12/1993): autodidata, realizou trabalhos de economista, geógrafo e historiador, sempre segundo sua formação marxista. Viveu seus primeiros anos no casarão onde hoje funciona o Instituto Histórico e Geográfico de Alagoas. Iniciou os estudos no Colégio Diocesano, mas teve de abandoná-los para trabalhar.

Em 1931, fundou e dirigiu, com Valdemar Cavalcanti, a revista Novidade, alternando com ele a responsabilidade pelos editoriais. Financiador da revista, colaborou também, junto com Jorge Amado e com Santa Rosa, para a publicação de Caetés (1933), sendo-lhes dedicado o romance.

Desde jovem dedicou-se à militância política: aderiu em 1926 à Aliança Libertadora Nacional e, anos depois, ao Partido Comunista Brasileiro (PCB), tendo sido preso em 1932. Colaborou em O Estado, Jornal de Alagoas, A Vanguarda Proletária, que dirigiu a partir de janeiro de 1933. Segundo salienta Luís Bueno, Alberto Passos Guimarães foi conhecido intelectual comunista: em agosto de 1933, publicou no Boletim de Ariel uma crítica sobre Cacau, de Jorge Amado, em que enfatizava a importância do romance proletário. Defendendo os sentidos de engajamento, revolta e luta, considerava uma necessidade histórica a representação literária dos pobres e da crise do capitalismo.

Perseguido politicamente, Alberto Passos Guimarães viveu um tempo escondido em Maceió e, depois de 1940, na Bahia, sendo referência para os que se dispunham a lutar contra o Estado Novo. Ajudou a fundar o semanário progressista Momento (1945), colaborou para o Diário da Bahia e o Estado da Bahia e foi redator da revista A Seiva.

Em 1945, foi para o Rio de Janeiro. Ingressou no IBGE como redator, foi responsável pela coleção Retratos do Brasil e realizou vários estudos, entre eles o Primeiro Censo das Favelas do Rio de Janeiro, em 1950. José Paulo Netto ressalta o pioneirismo de Alberto ao tornar as favelas objeto de análise socioeconômica sistemática.

Nos anos 50, colaborou com projetos editoriais do Partido Comunista ou vinculados a ele: foi diretor de Hoje, da Imprensa Popular, do Editorial Vitória e da revista Paratodos, que fundou junto com Jorge Amado e Oscar Niemeyer. Quando da crise do PCB após a denúncia do stalinismo (1956), combateu o dogmatismo e o sectarismo do partido, buscando formular uma nova linha, ao lado de Giocondo Dias, Mário Alves, Jacob Gorender e Armênio Guedes. Redator de O Jornal e da revista Observador Econômico e Financeiro, foi, a convite de Antônio Houaiss, co-editor e responsável pelo setor de geografia da Enciclopédia Mirador.

Conforme Luiz Nogueira Barros e Simone Cavalcante destacam, Alberto Passos Guimarães, no livro Quatro séculos de latifúndio (São Paulo: Fulgor, 1963; Rio de Janeiro: Paz e Terra, 1989, 6 ${ }^{a}$ ed., com prefácio de Antonio Houaiss), desmistificou pela primeira vez "o processo de formação da estrutura fundiária brasileira", revelando como o latifúndio nasceu da violência escravocrata, contra os índios e depois contra os africanos. José Paulo Netto salienta ser essa obra até hoje "indescartável" para se refletir sobre a questão agrária brasileira, um dos cernes da atividade intelectual de Alberto Passos Guimarães, como pesquisador, publicista e militante da Associação Brasileira de Reforma Agrária. Ele também foi membro da Comissão Nacional de Defesa e pelo Desenvolvimento da Amazônia (CNDDA) e membro correspondente do IHGA.

Outras obras: Inflação e monopólio no Brasil: por que sobem os preços? (Rio de Janeiro: Civilização Brasileira, 1963); A crise agrária (Rio de Janeiro: Paz e Terra, 1978); As classes perigosas: banditismo urbano e rural. (Rio de Janeiro: Graal, 1981, reeditado em 2008). No prefácio dessa republicação, José Paulo Netto sublinha a atualidade do livro e a percepção de seu autor, atento aos fenômenos da violência urbana quando a 
intelectualidade acadêmica mal despertava para o problema. Lamentando a desmemória atual acerca de um representante valioso da "inteligência crítica brasileira", atribui-a à "operação borracha" empreendida pela ditadura de 1964 e à "pauperização cultural" verificada no país. Ao traçar a biografia de Alberto Passos Guimarães, também o pesquisador Luiz Nogueira Barros se queixa da falta de documentos que esclareçam seu perfil histórico de intelectual e militante político. Ressalta haver Alberto pertencido ao grupo que mudou a mentalidade dos escritores alagoanos, ao introduzir o gosto por uma literatura preocupada com o social.

ABELARDO DUARTE (Maceió, 18/5/1900 - Maceió, 7/3/1992): professor, jornalista, médico. Doutorou-se pela Faculdade de Medicina da Bahia (1926). Estudante, fundou, com Artur Ramos e outros, a Revista Acadêmica, dedicada à ciência e à literatura, publicada de 1923 até 1926. Médico do Serviço de Saneamento Rural, organizou o primeiro Serviço de Higiene Infantil. Concursado em 1930, tornou-se catedrático de Cosmografia no Liceu Alagoano e, depois, de Geografia do Brasil na Escola Normal. Foi chefe de Clínica Pediátrica do Hospital Infantil da Santa Casa de Maceió e Diretor-Médico do Instituto de Assistência e Proteção à Infância de Alagoas. Um dos fundadores da Faculdade de Medicina de Alagoas, professor de Clínica Pediátrica e Higiene Infantil nessa faculdade e também diretor (1954/57 e 1964/70).

Publicou na Novidade: - "Brinquedos". 2, p. 11;

- "Sobre desenhos infantis". 5, p. 3;

- "Notas sobre o problema da criança brasileira". 19, p. 10.

Algumas de suas publicações:

- Contribuição ao estudo dos grupos sanguíneos na Bahia (Tese - Faculdade de Medicina da Bahia, 1926);

- A mortalidade infantil em Maceió. Rio de Janeiro, Confederação Nacional de Proteção à Infância, v.V, 1933;

- "A língua, o povo e os escritores", Maceió, Casa Ramalho, 1951, discurso de posse na Academia Alagoana de Letras;

- Um folguedo do povo: o bumba-meu-boi. Maceió: Edições Caeté, 1957;

- Negros muçulmanos nas Alagoas: os Malês. Maceió: Edições Caeté, 1958;

- História do Liceu Alagoano: desde sua criação até o ano de 1960. Maceió: DEC, 1961;

- O periodismo literário nas Alagoas. Maceió: Departamento Estadual de Cultura, 1961;

- Folclore negro das Alagoas (áreas da cana-de-açúcar): pesquisa e interpretação. Maceió: Departamento de Assuntos Culturais, 1974;

- As Alagoas na Guerra da Independência. Maceió: Arquivo Público de Alagoas, 1974;

- "A realidade brasileira em Tavares Bastos". In: Tavares Bastos visto por alagoanos, coordenação de Moacir Medeiros de Sant'Anna. Maceió: Assembléia Legislativa Estadual, [IGASA], 1975, pp. 141-5;

- Dom Pedro II e dona Teresa Cristina nas Alagoas. Maceió: Instituto Histórico e Geográfico de Alagoas, 1975;

- Autores alagoanos \& peças teatrais: contribuição para a história do teatro das Alagoas.

Maceió: Fundação Teatro Deodoro, 1980.

- Colaborou no Jornal de Alagoas, na Gazeta de Alagoas, no Diário de Pernambuco. 
ÁLVARO DE MELLO DÓRIA (Alagoas, 1904-1975): médico, farmacêutico e professor, interessado por ciências sociais e jurídicas, religião e psicologia. Em 1925, defendeu a tese Transfusão de sangue. Em 1929, com as teses Estudo geral das regiões da África e Povos Africanos, assumiu a cadeira de Geografia no Liceu Alagoano, onde trabalharam também Jorge de Lima e Abelardo Duarte. Lecionou Cartografia na antiga Escola Normal. Na Bahia, no Instituto Médico-legal Nina Rodrigues, fundou a revista Arquivos do Instituto Nina Rodrigues, ao lado de Arthur Ramos e Estácio de Lima.

Na Novidade: "A Reforma do Ensino". 7, p. 3.

Pedro BARRETO FALCÃO (Viçosa, Alagoas, 14/05/1902 - Maceió, 5/09/1945): jornalista e estatístico, preparou ao lado de Aurélio Buarque o quadro histórico da estatística de Alagoas e do Brasil. Foi redator-chefe do Jornal de Alagoas em 1934. Requisitado pelo IBGE em 1939, foi nomeado Diretor de Estatística do Rio Grande do Sul, onde chefiou os trabalhos do recenseamento de 1940. Voltando para Alagoas, organizou e dirigiu o Departamento das Municipalidades. Faleceu em 1945, num desastre de avião.

Na Novidade: “O novo 'menù' político”. 4, p. 13.

Publicou: - O bangüê na formação econômica de Alagoas. Maceió, 1937;

- Uma interessante experiência de revitalização das células municipais. Rio de Janeiro, IBGE, 1943, 13 p. (Separata da Revista Brasileira de Estatística, n. 13, jan./mar. 1943);

- "O sentido nacionalista da obra de Tavares Bastos". In: Tavares Bastos visto por alagoanos, coordenação de Moacir Medeiros de Sant'Anna. Maceió: Assembléia Legislativa Estadual, [IGASA], 1975, pp. 195-202.

Manuel DIÉGUES JÚNIOR (Maceió, 21/09/1912 - Rio de Janeiro, 27/11/1991): professor, sociólogo, antropólogo. Em 1927, fundou o Grêmio Literário "Guimarães Passos", o "Grêmio dos Meninos Impossíveis". Em 1931, foi para Recife cursar a Faculdade de Direito e, até 1935, integrou o grupo de estudantes que se reuniam com Gilberto Freyre todas as tardes na Biblioteca Pública de Recife. Examinavam jornais velhos, em busca de "fatos socialmente significativos", em geral desprezados por historiadores voltados somente para os conhecimentos mais vistosos do passado político e militar do Brasil. Assim, Diégues Júnior pertenceu à primeira geração de cientistas sociais do Brasil junto com Gilberto Freyre.

Após concluir seu curso superior, em 1935, voltou a Maceió, onde lecionou História da Civilização, no Liceu Alagoano. Em 1939 foi convidado a trabalhar como assistente da Secretaria Geral do IBGE, no Rio de Janeiro. Em 1942, foi nomeado diretorgeral desse órgão em Alagoas, ingressou no Instituto Histórico e Geográfico e no ano seguinte fundou o Centro de Estudos Econômicos e Sociais, em Maceió.

Em 1945 radicou-se no Rio, como Chefe da Difusão Cultural do IBGE. Já tendo o seu trabalho reconhecido, atuou como diretor de vários Institutos de Ciências Sociais, de Assuntos Culturais e de Defesa do Folclore e, a partir de 1979, diretor estadual do Instituto do Patrimônio Cultural do Estado do Rio de Janeiro. Foi também professor de Antropologia na Pontifícia Universidade Católica do Rio, além de assessor da Delegação do Brasil nas Conferências Gerais da Unesco nos anos 1960 e 70. Sociólogo, antropólogo, 
folclorista, contribuiu para o estudo da cultura brasileira e publicou mais de trinta obras. Teve quatro filhos, um deles é Carlos José, o cineasta Cacá Diégues.

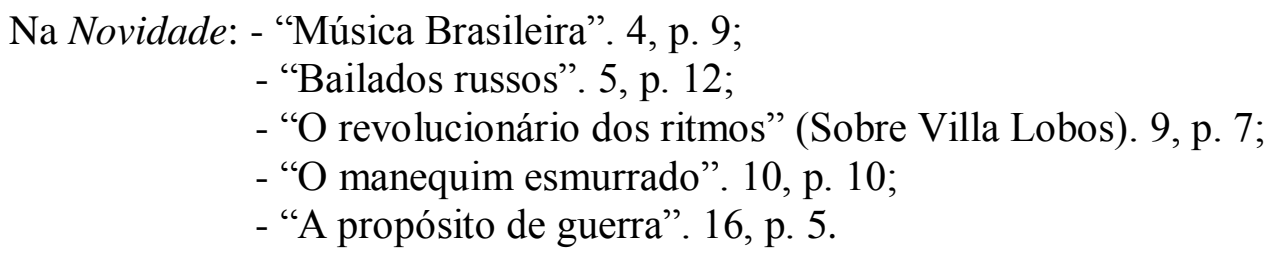

Algumas de suas publicações:

- Estudos e pesquisas de aculturação, um século de vida social. Maceió: Casa Ramalho, 1935 ;

- "Introdução do negro nas Alagoas". Revista do Brasil. Rio de Janeiro, ago. 1939;

- "Evolução urbana e social de Maceió no período republicano" (Rio, nov. 1939). In: COSTA, Craveiro. Maceió. Vinhetas de Santa Rosa. Rio de Janeiro: José Olympio, 1939.

- Variações sobre estudos regionais. Maceió: Imprensa Oficial, 1942;

- Alagoas e seus municípios, Diário Oficial de Maceió, 1944;

- O bangüê nas Alagoas: traços da influência do sistema econômico do engenho de açúcar na vida e na cultura regional. Pref. de Gilberto Freyre. Capa e vinhetas de Santa Rosa. Rio de Janeiro: Instituto do Açúcar e do Álcool, 1949; $3^{\text {a }}$ ed. Maceió: EDUFAL, 2006;

- O engenho de açúcar no Nordeste. Rio de Janeiro: Ministério da Agricultura, 1952; Maceió: EDUFAL, 2006 (Coleção Nordestina);

- Etnias e culturas no Brasil. Rio de Janeiro: Ministério da Educação e Cultura, Serviço de Documentação, 1952;

- População e açúcar no Nordeste do Brasil. Rio de Janeiro: Comissão Nacional de Alimentação, 1954;

- Regiões culturais do Brasil. Rio de Janeiro: Centro Brasileiro de Pesquisas Educacionais, INEP, Ministério da Educação e Cultura, 1960;

- Ocupação humana e definição territorial do Brasil. Rio de Janeiro: Conselho Federal de Cultura, 1971;

- Literatura de cordel: a literatura oral e sua tradição ibérica. Cadernos de Folclore n.2. Rio de Janeiro: DAC / MEC / Funarte, Campanha de Defesa do Folclore Brasileiro, 1975;

- A África na vida e na cultura do Brasil. Rio de Janeiro: Artes Gráficas Schulze, 1977, apresentado no $2^{\circ}$ Festival de Artes e Cultura Mundial, Lagos (Nigéria);

- Os santos de junho na tradição brasileira, Carta Mensal, Confederação Nacional do Comércio, 1981.

GRACILIANO RAMOS DE OLIVEIRA (Quebrangulo, Alagoas, 27/10/1892 Rio de Janeiro, 20/3/1953): Primeiro de 15 filhos, passou a infância em Buíque (Pernambuco) e em Viçosa (Alagoas). Estudou no Colégio Quinze de Maio, do professor Agnelo Marques Barbosa, não cursou faculdade. Residiu de 1910 a 1914 em Palmeiras dos Índios, onde o pai tinha a loja Sincera. Foi para o Rio de Janeiro em 1914, onde trabalhou como revisor no Correio da Manhã e em A Tarde. Retornou a Palmeira dos Índios em 1915, pois três irmãos e um sobrinho haviam morrido pela peste bubônica. Ajudava o pai na loja e se dedicava ao jornalismo (colaborava no jornal $O$ Índio, com os pseudônimos $\mathrm{J}$. Calixto e Anastácio Anacleto). Em 1920, sofreu a morte da esposa, Maria Augusta Barros, que o deixou com quatro filhos: Márcio, Júnio, Múcio e Maria Augusta. Em 1925 começou 
a escrever Caetés. Casou-se em 1928 com Heloísa de Medeiros, com quem teve os filhos Ricardo, Luísa e Clara. Entre 1928 e 1930, foi prefeito de Palmeira dos Índios; o estilo de seus relatórios sobre a prefeitura atraiu a atenção de Augusto Frederico Schmidt, que publicaria Caetés em 1933.

Em Maceió, de maio de 1930 até dezembro de 1931, foi diretor da Imprensa Oficial do Estado, época em que colaborou na Novidade. Voltou a Palmeira dos Índios, escreveu 19 capítulos de S. Bernardo na sacristia da igreja de Nossa Senhora do Amparo. Em 1933 regressou para Maceió, nomeado Diretor da Instrução Pública de Alagoas. Criou a Escola Profissional Feminina, a Escola Normal de Viçosa, a de Penedo e Juntas Escolares.

Em 3 de março de 1936, entregou os originais de Angústia para a datilógrafa e, conforme testemunhou nas Memórias do cárcere, foi preso como subversivo, sem provas nem julgamentos, e levado a vários presídios. Libertado a 13 de janeiro de 1937, continuou a escrever romances, contos e livros para a infância, sobrevivendo no Rio de Janeiro das publicações e colaborações para revistas. "Por volta dos fins da Guerra o seu nome já está consagrado como o do maior romancista brasileiro depois de Machado de Assis" 2. Em 1938, passou a trabalhar como inspetor de estabelecimentos de ensino secundário e na revista Cultura Política. Em 1945, ingressou no Partido Comunista Brasileiro. Em 1947, voltou para a revisão do Correio da Manhã. Tornou-se diretor responsável pelo jornal Partidários da Paz, publicado no Rio de Janeiro. Em 1951, foi eleito presidente da Associação Brasileira de Escritores (ABDE), reeleito em 1952. Nesse ano, viajou para a Checoslováquia e a União Soviética (Viagem).

A indicação das publicações de Graciliano consta da Bibliografia.

JORGE MATHEUS DE LIMA (União, Alagoas, 23/04/1893 - Rio de Janeiro, 15/11/1953): poeta, pintor, professor, médico, deputado estadual em Maceió (1919-20 e 21-22), vereador no Rio (1947-50). Estudou Medicina em Salvador e no Rio de Janeiro, diplomando-se em 1914, com tese sobre $O$ destino higiênico do lixo no Rio de Janeiro. Voltou para Maceió, passou a clinicar, foi Diretor Geral da Instrução Pública, professor e diretor do Liceu Alagoano, professor catedrático de História Natural e Higiene da Escola Normal de Alagoas (1922-30) e professor catedrático de Literatura Brasileira e Línguas Latinas do Ginásio do Estado (1927-30), tendo defendido uma tese sobre Proust e outra sobre o modernismo brasileiro.

Após sofrer um atentado, mudou-se para o Rio de Janeiro em 27/9/1931, onde montou consultório e foi professor de Literatura Luso-Brasileira na Universidade do Distrito Federal (1937-38) e professor de Literatura Brasileira na Universidade do Brasil (1940). Membro fundador da AAL (Academia Alagoana de Letras), sócio do IGHAL (Instituto Geográfico e Histórico de Alagoas) desde 1926. Em 1927, aderiu ao modernismo com "O mundo do menino impossível" e, em 1935, converteu-se a uma "forma dramática e moderna de Catolicismo" ${ }^{3}$. Em 1940, recebeu o prêmio Machado de Assis, da Academia Brasileira de Letras, pelo conjunto da obra.

Na Novidade: - "Nota religiosa". 3, p. 4;

- "Padre Feijó", uma página do livro inédito Notas sobre o sentimento religioso no Brasil. 5, p. 11.

\footnotetext{
${ }^{2}$ BOSI, Alfredo. História concisa da literatura brasileira. cit., p. 450.

${ }^{3}$ Idem, p. 503.
} 
- Poesia: XIV Alexandrinos (1914); O mundo do menino impossível (1927); Poemas (1927); Essa negra Fulô (1928); Novos poemas (1929); Poemas escolhidos (1932); Tempo e eternidade (com Murilo Mendes, 1935); A túnica inconsútil (1938); Poemas negros (1947); Livro de Sonetos (1949); Obra poética (organizada por Carpeaux, reúne a produção anterior e Anunciação e encontro de Mira-Celi, 1950); Invenção de Orfeu (1952); Castro Alves - Vidinha (1952).

- Romances: Salomão e as mulheres (1927); O Anjo (1934); Calunga (1935); A mulher obscura (1939); Guerra dentro do beco (1950).

- Ensaios: A comédia dos erros (1923); Dois ensaios ("Proust" e "Todos cantam sua terra", 1929); Anchieta (1934); Rassenbildung und Rassenpolitik in Brasilien (1934); Vida de São Francisco de Assis (1942); D. Vital (1945); Vida de Santo Antonio (1947).

- Álbum de fotomontagens: A pintura em pânico (1943).

- Inéditos para teatro: A Filha da Mãe d'Água, As Mãos, Ulisses, A volta de Ulisses.

- Argumento de filme: Os Retirantes.

- Publicou, nos Cadernos Mira Coeli: Les Iles, Antologia de sonetos; Sonetos em Francês; Antologia Católica; Ode ao Coxo Veloz, de Bernanos (segundo Raul Lima).

- Os melhores contos rústicos de Portugal. Rio de Janeiro: Edições Dois Mundos, 1943. Seleção e prefácio de Jorge de Lima.

- Traduções: Os Judeus, de Jacques Maritain, Paul Claudel e outros, 1938; Morte, onde está tua vitória?, de Daniel Rops, 1940; Aventuras de Malasarte, 1942 (literatura infantil, em parceria com seu irmão, Mateus de Lima, tradução e adaptação de várias obras alemãs sobre Til Eulenspiegel); Sol de Satã, de Georges Bernanos, 1947.

- Colaborou em diversos periódicos, entre eles: Autores e Livros, Boletim de Ariel, Dom Casmurro, Festa, Leitura, Revista do Brasil.

JOSÉ LINS DO REGO CAVALCANTI (Engenho Corredor, Pilar, Paraíba, 03/06/1901 - Rio de Janeiro, 12/09/1957): Formou-se em 1923 em Direito no Recife, onde se tornou amigo de José Américo de Almeida, de Osório Borba (com quem fundou então o semanário Dom Casmurro no Recife) e, em especial, de Gilberto Freyre, seu grande incentivador para o regionalismo na arte. Era o clima intelectual do modernismo regionalista do Nordeste. Nomeado promotor público em Manhuaçu (Minas Gerais) em 1925, transferiu-se no ano seguinte para Maceió, onde trabalhou como fiscal de bancos, conheceu o grupo de intelectuais que seriam seus amigos para toda a vida (Jorge de Lima, Graciliano Ramos e os vários meninos impossíveis, entre eles, Aurélio, Valdemar, Aloísio Branco, Paurílio) e escreveu seus três primeiros romances. Mudou-se em 1935 para o Rio de Janeiro. Em 1955, foi eleito para a Academia Brasileira de Letras.

Na Novidade: - "O último livro do Dr. Plínio Salgado”. 6, p. 12.

- "O Brasil precisa de Catolicismo". 11, p. 3.

- Ficção: Menino de engenho (1932); Doidinho (1933); Bangüê (1934); O moleque Ricardo (1935); Usina (1936); Pureza (1937); Pedra bonita (1938); Riacho doce (1939); Água-mãe (1941); Fogo morto (1943); Eurídice (1947); Cangaceiros (1953).

- "Mistério de Brandão (Glória)". In: Brandão entre o mar e o amor: romance (com Aníbal Machado, Jorge Amado, Graciliano Ramos e Rachel de Queiroz, 1942).

- Memórias: Meus verdes anos (1956).

- Literatura infantil: Histórias da velha Totonha (1936). 
- Crítica e crônica: Gordos e magros (1942); Poesia e vida (1945); Homens, seres e coisas (1952); A casa e o homem (1954); Presença do Nordeste na literatura brasileira (1957); $O$ vulcão e a fonte (1958); Dias idos e vividos (1981); Flamengo é puro amor (2002).

- Conferências: Pedro Américo (1943); Conferências no Prata ("Tendências do romance brasileiro", "Raul Pompéia", "Machado de Assis", 1946); Discurso de posse e recepção na Academia Brasileira de Letras: José Lins do Rego e Austregésilo de Athayde (1957).

- Viagem: Bota de sete léguas (1951); Roteiro de Israel (1955), Gregos e troianos (1957).

- Tradução: A vida de Eleonora Duse, de E. A. Rheinhardt (1940).

JURANDIR GÓES GOMES (Penedo, Alagoas, 26/3/1904 - Maceió, 1956): jornalista e funcionário público. Em 1925, foi nomeado Administrador da Recebedoria de Piassabuçu, seu primeiro cargo público. Fez carreira na Secretaria da Fazenda. Em 1940, tornou-se redator principal da Gazeta de Alagoas. Patrono da cadeira 46 do IGHAL, sócio da AAL.

Na Novidade: - "Yo, El-Rei”. 09, p. 12;

- "Impressões" (sobre Leonel Franca). 11, p. 8;

- "Impressões" (Tristão de Athayde). 12, p. 6;

- "Impressões" (Agrippino Grieco). 14, p. 10;

- "Crônica de deselegâncias". 15, p. 12; 17, p. 10;

- "All quiet...". 18, p. 12;

- “O imposto territorial no Norte”. 23, p. 3, conclusão na p. 10.

Publicou:

- Quadros da História de Alagoas - breves ensaios sobre a história pátria. Prefácio de Théo Brandão. Maceió: Casa Ramalho Editora, 1956;

- Silvestre Péricles e a opinião nacional (O homem público através das referências insuspeitas) 1947-1950. Maceió: Imprensa Oficial.

- "Notas sobre a história de Penedo", Revista do IGHAL, v. 24, pp. 71-3; "Outras notas sobre a história de Penedo", Revista do IGHAL, v. 25, ano 1947, Maceió, Imprensa Oficial, 1949, pp. 56-9.

Alfredo de Barros LIMA JÚNIOR (Passo de Camaragibe, Alagoas, 24/2/1894 Maceió, 26/3/1967): jornalista, poeta, deputado estadual, advogado, irmão de Raul Lima (também colaborador da Novidade). Diplomado em Direito pela Faculdade do Recife (1921), foi promotor em Passo do Camaragibe e secretário da Prefeitura de Maceió. Um dos fundadores e professor da Faculdade de Direito de Alagoas. Membro-fundador da AAL, deputado estadual (1927-28, 29-30 e 1935-37). Colaborou em vários jornais de Maceió, foi diretor do Jornal de Alagoas e redator principal do Diário do Povo. Publicou crônicas em $O$ Semeador com o título de "Moedas correntes".

Na Novidade: - “... de política”. 3, p. 4.

- "Sobre um Instituto de Advogados". 6, p. 3.

- "Carta a um antigo correligionário político". 9, p. 6.

- "Os Obscuros". 11, p. 10.

- “Uma mentalidade nova para o Brasil". 15, p. 3, continuação na p. 13. 
Publicou:

- Canções da Idade de Oiro (Poemas do Amor e da Natureza. Soneto da Vida e do Amor). Maceió: Tip. Fonseca, 1920;

- Acção de salários de empregado no comércio. Maceió: Tip. Alagoana, 1932;

- Apelação e sucessores do Cel. Carlos Benigno Pereira de Lyra a Usina Serra Grande S/A

e a Firma Carlos Lyra \& Cia. Recife: Of. do Jornal do Comércio, 1940;

- Alguns homens do meu tempo (Evocações e reminiscências). Maceió: DEC, Série Estudos Alagoanos, Cad. XX, 1963;

- Fim de tarde: poesia. Maceió: Imprensa Oficial, 1962;

- Velha nau: poesias simples. Maceió: 1968;

- "Jorge de Lima”, Revista da AAL, n. 12, p. 121-123;

- Enriquecimento sem justa causa (Actio de in rem verso). Recife: Oficina Gráfica do Jornal do Comércio, 1940, juntamente com Nehemias Gueiros, Esdras Gueiros, Mário Marroquim e Morse Lira.

A princípio, julguei tratar-se do alagoano Félix Lima Júnior (1901-1986), um dos fundadores da Academia dos Dez Unidos, integrante do Grêmio Literário "Guimarães Passos", historiador e autor de romances, crônicas, contos e de muitos relatos etnográficos, que se tornou nos anos 1950 membro do Instituto Histórico e Geográfico de Alagoas e da Academia Alagoana de Letras. No entanto, considerando os artigos assinados por Lima Júnior na Novidade, entendo que o colaborador da revista é Alfredo de Barros Lima Júnior, advogado além de escritor alagoano.

LOURENÇO PEIXOTO (Maceió, 3/7/1897 - 27/3/1984,6?): pintor, escultor, professor. Para ensinar Artes Plásticas criou, em 1925, o Instituto de Belas Artes de Alagoas, posteriormente Instituto de Belas Artes Rosalvo Ribeiro, responsável pela promoção de vários salões de arte nos fins da década de 1920. Participou da Festa da Arte Nova, em 17/6/1928, que incluiu uma seção literária e uma exposição de pintura, de alguns de seus trabalhos e de Manoel Messias e de Zaluar de Sant'Ana, que valorizaram temas regionais. Sua temática oscilou entre a fixação de tipos locais e paisagens. Foi um dos criadores, com Aloísio Branco, Carlos Paurílio, Valdemar Cavalcanti e Diégues Júnior, entre outros, do número único da Revista Maracanã.

Na Novidade: - "O Último Bailado", Fantasia de Abellard França, Xilogravura de Lourenço Peixoto. 2, p. 5.

- "Oração", Xilogravura. 4, p. 12.

- "Sertão", Xilogravura. 6, p. 8.

Antonio Saturnino de MENDONÇA JÚNIOR (Engenho Maranhão, Matriz de Camaragibe, Alagoas, 8/3/1908 - Rio de Janeiro, 24/10/1985): poeta, deputado federal, jornalista, professor, juiz, advogado. Fundou o Cenáculo Alagoano e integrou o Grêmio Literário "Guimarães Passos". Sua adesão ao modernismo foi em 1927, com o poemeto "Rosas tagarelas". Outros poemas: "Chromo", "Poema da vida simples", "O teu escravo", "Para o Natal de um pobrezinho", "Poema sem pé nem cabeça", "Mulherzinha fora de moda", "A jandaia de Iracema", "Poema pequenininho". Escreveu também contos e crônicas nos periódicos A Notícia, Maracanan e Novidade, sob pseudônimos como 
Domício Castelo Branco, Juvenal e Domício Braga. Promoveu em 1928 a Festa da Arte Nova. Ainda estudante, escreveu uma seção diária no Jornal de Alagoas, sob o pseudônimo Mênio d'Altamira. Em 1927 matriculou-se na Faculdade de Direito de Recife e concluiu o curso em Niterói, em 1932. No Rio, foi redator do Diário da Noite. Em 1933, em Minas Gerais, trabalhou como promotor de Justiça, professor de Geografia e História da Escola Normal e colaborou em jornais.

Em 1945, de volta a Alagoas, nomeado diretor-geral do Departamento de Imprensa e Propaganda, promoveu atividades culturais, como concursos de literatura, a publicação de uma antologia de poetas alagoanos. Foi diretor do Departamento de Cultura e presidente da Caixa Econômica Federal de Alagoas, do Centro de Estudos Econômicos e Sociais e do Conselho Regional de Desportos. Em 1950, assumiu e presidência da AAL e se elegeu deputado federal pelo PSD. Foi, ainda, professor da Faculdade de Direito de Alagoas e, no Rio de Janeiro, advogado da prefeitura do Distrito Federal. Membro da AAL e do IGHAL.

Na Novidade: - "A política brasileira na Segunda República". 2, p. 6;

- "Um homem feio", conto. 5, p. 4; "O estancieiro", conto. 8, p. 6;

- V. também "Solidariedade da geração" (Sobre o caso de Mendonça Júnior), 10, p. 7.

Publicou:

- O que eu queria dizer ao seu ouvido (poesia). Maceió: DEC, 1946;

- Jornal da Província, prefácio de Romeu de Avelar. Maceió: Imprensa Oficial, Tip. Menezes, 1948;

- Jornal de Alagoas (crônicas). Maceió: Casa Ramalho Ed., 1949;

- Dinheiro e mulher bonita (poesia). Maceió: DEC, 1964;

- Poemas fora de moda. Rio de Janeiro: Apex. Gráfica e Editora, 1971;

- Marcha nupcial (poesia). Rio de Janeiro: MAFC, 1977;

- O anel de brilhantes e outras estórias (contos). Brasília: Col. Machado de Assis, 1979;

- Tempo de falar. Discursos e conferências. Maceió: SERGASA, 1983;

- O último senhor de engenho (Gesta dos Mendonças no Vale do Camaragibe, romance póstumo). Maceió: EDUFAL, 1987.

MIGUEL ARCANJO BATISTA: professor, foi diretor da Instrução Pública de Alagoas e juiz de direito no interior. Obra: Autonomia do Direito Aéreo. Maceió: Imprensa Oficial, 1955 (Tese para professor de Direito Comercial da Faculdade de Direito de Alagoas).

Na Novidade: As nossas "enquetes" - A instrução pública em Alagoas, entrevista com Miguel Baptista. 4, p. 8.

MOACYR SOARES PEREIRA (Maceió, 10/12/1907 - Maceió, 19/3/2001): químico industrial pela Escola Politécnica do Rio de Janeiro (1927), bacharel pela Faculdade de Direito do Rio de Janeiro (1930). Catedrático, por concurso, de Física, do Liceu Alagoano (1927), ao lado de outros colaboradores da Novidade, como Aurélio Buarque de Holanda (professor de Português), Jayme d'Altavilla (História) e o médico, escritor e pesquisador Abelardo Duarte (Geografia). Em 1936 foi encarregado pelo 
governo estadual de fiscalizar, na Alemanha, a fabricação das estacas de aço utilizadas no porto de Maceió. Plantador de cana-de-açúcar, foi representante dos bangüezeiros na Comissão Executiva do IAA, por quatro mandatos, de 1940 até 1952, e, a partir de 1955, representante dos usineiros no mesmo instituto, por três mandatos consecutivos. Químico tecnologista do IAA, aposentado em 1966. Superintendente do Plano do Álcool do IAA, de 1943 a 1964, presidiu a comissão responsável pela construção da Destilaria Central de Alagoas, inaugurada em 1961.

Moacyr Pereira apresentou nova versão para o naufrágio em que morreu o bispo Sardinha. Inocentando os Caetés, indicou o litoral de Sergipe como o lugar do naufrágio e como antropófagos e devoradores do bispo Sardinha e de seus companheiros de viagem os Tupinambás, ali estabelecidos e inimigos dos Caetés. Segundo ele, teria havido inexplicável confusão e desconhecimento geográfico da região em que se localizavam as tribos, ou então uma fraude histórica, com o aproveitamento da morte do bispo para aniquilar os Caetés e apropriar-se de seus despojos materiais e humanos.

Na Novidade: - "O Acordo Naval”. 7, p. 12;

- "O voto proporcional". 10, p. 6;

- "Novos rumos". 13, p. 10.

Obras principais:

- O problema do álcool-motor. Prefácio de José Lins do Rego. Rio de Janeiro: José Olympio, 1942;

- A questão alcooleira. Rio de Janeiro: IAA, 1942;

- Política do álcool carburante (tese apresentada no $1^{\circ}$ Congresso Açucareiro Nacional, Petrópólis, 1948;

- Ventos do Norte. Maceió: Casa Ramalho, 1953;

- A origem dos cilindros na moagem da cana: investigação em Palermo. (Prefácio de Gil de Methodio Maranhão. Rio de Janeiro: Instituto do Açúcar e do Álcool, Serviço Especial de Documentação Histórica, 1955;

- Capitães, naus e caravelas da armada de Cabral. Lisboa: Junta de Investigações Científicas do Ultramar, 1979;

- A navegação de 1501 ao Brasil e Américo Vespúcio. Apresentação de Rachel de Queiroz. Rio de Janeiro: ASA Artes Gráficas, 1984;

- Naufrágio e morte de D. Pedro Fernandes Sardinha, primeiro bispo do Brasil: sua revisão histórica, publicado em 1996, em separata da Revista do Instituto Histórico e Geográfico Brasileiro (IHGB) e Os Índios Tupi-Guarani na Pré-História - suas invasões do Brasil e do Paraguai, seu destino após o Descobrimento. Maceió: EDUFAL, 2000;

- Publicou artigos em jornais e, em especial, na revista Brasil Açucareiro, relacionados a assuntos canavieiros, açucareiros e alcooleiros.

PAUlino DE ARAÚJO JORGE: membro da Academia do Comércio e funcionário do Banco do Brasil, também integrou a Academia dos Dez Unidos.

Na Novidade: - "Alberto Torres e a Constituição". 8, p. 5;

- "Do patriotismo brasileiro". 19, p. 6. 
RAUL DO REgO LIMA (Passo do Camaragibe, Alagoas, 3/12/1911 - Rio de Janeiro, 18/11/1985): jornalista, historiador, secretário de estado, professor, advogado. Funcionário da Intendência de Maceió aos 14 anos e depois escriturário da Prefeitura de Maceió, foi um dos membros do Grêmio Literário "Guimarães Passos". A partir de 1927, escreveu para o Jornal de Alagoas uma coluna diária, de comentários, sob o pseudônimo Ramil (o mesmo da Novidade). Utilizou também o pseudônimo Vivian, em uma página dedicada ao público feminino. Revisor na Imprensa Oficial, teve um chefe que, ao assumir o cargo, acabou com o acordo dos revisores de trabalharem apenas três vezes por semana: se desagradou a Raul perder a folga, apreciou a freqüência maior com que tal chefe, Graciliano Ramos, descia ao revisor "literatelho" e lhe falava de livros. Anos depois, Raul Lima afirmaria com precisão, a respeito da linguagem de Graciliano: "eleva a dignidade do uso da palavra escrita" (Graciliano Ramos, Fortuna Crítica).

Bacharel pela Faculdade de Direito de Recife (1935), foi promotor público, por concurso, de União dos Palmares e juiz de direito interino em Maceió. Fundou e foi redator-chefe da revista Alagoas Ilustrada e da Gazeta de Alagoas. Diretor do Jornal de Alagoas, colaborou também em $O$ Semeador e no Diário de Pernambuco.

Em 1940, transferiu-se para o Rio de Janeiro, onde dirigiu o Arquivo Público Nacional e o Suplemento Literário do Diário de Notícias, com o qual recebeu o prêmio Paula Brito, da Prefeitura do Distrito Federal. Colaborou também em A Noite. Técnico em estatística, trabalhou na Divisão de Publicidade do Serviço Nacional de Estatística do IBGE. No Ministério da Agricultura, dirigiu o Serviço de Estatística da Produção e foi assessor de ministro. Um dos diretores do Escritório Técnico de Agricultura - Missão Brasil - Estados Unidos, diretor-adjunto de Informação da União Pan Americana (OEA) e diretor de publicações da FGV. Secretário de Governo de AL (1965) e professor de Ética Jornalística da Universidade Católica do Rio de Janeiro (PUC).

Na Novidade: - "De Recife" - Correspondência especial. 8, p. 10;

- "De Recife" - Correspondência. 10, p. 12; 11, p. 12; 12, p. 13; 13, p. 12;

- "Memórias íntimas de Josephina Baker". 14, p. 5;

- "De Recife" - Correspondência. 14, p. 12; 15, p. 12; 16, p. 12; 17, p. 12;

- "A Revolução e o Álcool. Da influência da aguardente na evolução política do Brasil". 19, p. 11;

- "Maceió à distância". 22, p. 5;

- “Árvores". 24, p. 5.

Também na Novidade, escreveu a coluna "Sociedade", sob o pseudônimo RAMIL: "Sociedade" - "Mlle Creme de Baunilha", "Modas" (01, p. 13); "O culto do domingo" (02, p. 13); "A Valsa" (03, p. 12); "De música" (04, p. 13); "Noivas ideais" (05, p. 10); "Piropos" (06, p. 11); "Fan" (07, p. 13); "Recitativo" (09, p. 13); "O homem e a máquina" (12, p. 14); "Domingo" (13, p. 13); "Sociedade" (15, p. 13); "Minha ansiedade" (16, p. 13); "Bilhete" (17, p. 13); "Correio" (19, p. 13); "Saudade" (21, p. 13); "Telegrama" (22, p. 13); "Cosmopolitismo", "Indústria brasileira" (23, p. 13); "Sports" (24, p. 13). "Cinema" - "Luzes da cidade" (15, p. 80).

Obras principais:

- Tavares Bastos: prosa. Rio de Janeiro: Agir, 1957;

- Jornalismo e democracia. Rio de Janeiro: Ministério da Educação e Cultura, Serviço de Documentação, 1960; 
- Reforma agrária e desenvolvimento rural. Rio de Janeiro: S.N., 1963;

- Presença de Alagoas. Maceió: Departamento Estadual de Cultura, 1967;

- O fio do tempo. Recife: Universidade Federal de Pernambuco, 1970;

- A criação do Diário Oficial. Rio de Janeiro: Departamento de Imprensa Nacional, 1978;

- "A Abolição à luz de documentos", Revista IHGA, v. 38, Maceió, 1984, pp. 89-98;

- "Artur Azevedo funcionário público", Revista da AAL, n. 02, pp. 129-131;

- “Guimarães Passos - Uma revisão a fazer”, Revista da AAL, n. 12, p. 105-113;

- Com Valdemar Cavalcanti traduziu Sangue e volúpia, de Vicki Baum, editado pela José Olympio.

THÉO BRANDÃO (Theotônio Vilela Brandão) (Viçosa, Alagoas 26/1/1907 Maceió, 29/9/1981): folclorista, poeta, professor, médico, farmacêutico. Diplomado pela Escola de Farmácia da Bahia (1928). Colaborou na Gazeta de Viçosa, na qual publicou seus primeiros poemas modernistas, com o pseudônimo de joão guadalajara (em minúsculas). Professor de Higiene e Puericultura da Escola Normal, de Antropologia na Faculdade de Filosofia de Alagoas e de Puericultura e Clínica da Primeira Infância, na Faculdade de Medicina de Alagoas. Diretor do Instituto de Filosofia e Ciências Humanas da UFAL. Fundador e primeiro diretor do Museu de Antropologia e Folclore da UFAL, que hoje leva seu nome. Secretário de Interior, Educação e Saúde, no Governo de Osman Loureiro e Diretor do Departamento de Educação (1941-1942). Em 1942, criou a Sociedade Alagoana de Folclore.

Na Novidade: - "Folk-lore e Educação Infantil”. 8, p. 3;

- "Chupetas". 10, p. 3;

- "Dentição". 13, p. 3;

- Poemas - "Poema da Saudade No 1". 21, p. 11.

Obras principais:

- Folclore de Alagoas. Maceió: Casa Ramalho, 1949;

- Trovas populares de Alagoas. Maceió: Edições Caeté, 1951;

- O reisado alagoano. ( $1^{\circ}$ Prêmio no $4^{\circ}$ Concurso de Monografias sobre o Folclore Nacional, instituído em 1949 pela Discoteca Pública Municipal, do Departamento de Cultura, da Prefeitura do Município de São Paulo). Separata da Revista do Arquivo n. CLV. São Paulo: Departamento de Cultura, 1953; Maceió: EDUFAL, 2007;

- Folguedos natalinos de Alagoas; estudo introdutório e descrição: folclore. Maceió: Div. do Dep. Estadual de Cultura, 1961;

- Folguedos de Alagoas: desenho a bico de pena. Maceió: Universidade Federal de Alagoas, 1975;

- Folguedos natalinos. Maceió: Ufal, 1976. (Vários volumes: presépio, Taieiras, reisado maracatu, cavalhada, guerreiro, caboclinhos, quilombo, baianas, chegança, pastoril);

- Cavalhadas de Alagoas. Rio de Janeiro: Campanha de Defesa do Folclore Brasileiro, 1978;

- Quilombo. Rio de Janeiro: Ministério da Educação e Cultura, Departamento de Assuntos

Culturais, Fundação Nacional de Arte, Campanha de Defesa do Folclore Brasileiro, 1978;

- Folclore de Alagoas II. Maceió: Museu Théo Brandão-CEC-UFAL, 1982;

- Cadernos de exercícios de um aprendiz de poesia. Maceió: Museu Théo Brandão, 1983. 


\section{Referências bibliográficas:}

BARROS, Francisco Reinaldo Amorim de. ABC das Alagoas: dicionário biobibliográfico, histórico e geográfico das Alagoas. 2 v. Brasília: Senado Federal, Conselho Editorial, 2005.

BARROS, Luiz Nogueira. Alberto Passos Guimarães. In: Do sertão ao litoral. Maceió: Edições Catavento, 2000, pp. 124-134.

BEZERRA, Edson José de Gouveia. Sobre o Autor. In: LIMA JÚNIOR, Félix. Maceió de outrora: obra póstuma. Maceió: EDUFAL, 2001.

BOSI, Alfredo. História concisa da literatura brasileira. São Paulo: Cultrix, 1975.

BUENO, Luís. Uma história do romance de 30. São Paulo: EDUSP; Campinas: Editora da UNICAMP, 2006.

CAVALCANTE, Simone. Literatura em Alagoas: ensino médio e vestibular. Ilustrado por Iuri Ávila. Maceió: Scortecci / Grafmarques, 2005.

CAVALCANTI, Valdemar. Jornal literário. (orelha escrita por Aurélio Buarque e "Nota da Editora"). Rio de Janeiro: José Olympio, 1960.

DIÉGUES JÚNIOR, Manuel. O bangüê nas Alagoas. Pref. de Gilberto Freyre. $3^{\mathrm{a}}$ ed. Maceió: EDUFAL, 2006.

GUIMARÃES, Alberto Passos. As classes perigosas: banditismo urbano e rural. Apresentação de José Paulo Netto. Rio de Janeiro: Editora UFRJ, 2008.

HALLEWELL, Laurence. O livro no Brasil: sua história. Tradução de Maria da Penha Villalobos e Lólio Lourenço de Oliveira. São Paulo: T.A. Queiroz, Edusp, 1985.

LIMA, Raul. Sobre Graciliano. Presença de Alagoas. Maceió: Departamento Estadual de Cultura, 1967. Apud BRAYNER, Sônia. (Org.). Graciliano Ramos. Coleção Fortuna Crítica. Rio de Janeiro: Civilização Brasileira, 1978, pp. 134-144.

Maceió - 180 anos de história. Maceió: Instituto Théo Brandão, 1995.

PEREZ, Renard. Escritores brasileiros contemporâneos. $2^{\text {a }}$ série. 22 biografias, seguidas de antologia. $2^{a}$ ed. rev. e atualizada. Rio de Janeiro: Civilização Brasileira, 1971.

SANT'ANNA, Moacir Medeiros de. Efemérides alagoanas. Maceió: Instituto Arnon de Mello, 1992.

. História do modernismo em Alagoas (1922-1932). $2^{\mathrm{a}}$ ed. revista e aumentada.

Maceió: EDUFAL, 2003.

VASCONCELOS FILHO, Marcos Antônio Rodrigues. Centenário de Álvaro Dória. $O$ Jornal, Maceió, ano XI, n. 88, terça-feira, 14 dez. 2004, p. A2. Disponível em: http://www.mvfbv.com/centenario_de_alvaro_doria.htm 


\section{BIBLIOGRAFIA}

\section{- De Graciliano Ramos:}

A terra dos meninos pelados. Ilustrações de Roger Mello. 20ª ed. Rio de Janeiro: Record, 1998. Alexandre e outros heróis. $3^{\mathrm{a}}$ ed. São Paulo: Martins, 1966.

Angústia. $7^{\mathrm{a}}$ ed. Rio de Janeiro: José Olympio, 1955.

Caetés. (Introdução de Antonio Candido, "Ficção e confissão"). $5^{\text {a }}$ ed. Rio de Janeiro: José Olympio, 1955.

Cartas. $7^{\mathrm{a}}$ ed. Rio de Janeiro: Record, 1992.

Cartas inéditas de Graciliano Ramos a seus tradutores argentinos Benjamín de Garay e Raúl Navarro. Introdução, ensaios e notas de Pedro Moacir Maia; organização e apresentação de Fernando da Rocha Peres. Salvador: EDUFBA, 2008.

Chavões. Novidade 8, Maceió, 30 mai. 1931, p. 7.

Comandante de burros. In: Revista do Instituto de Estudos Brasileiros, n. 35. Publicação do IEB-USP. São Paulo, 1993, pp. 207-9.

Correspondência - Arquivo Graciliano Ramos. Instituto de Estudos Brasileiros, IEB-USP.

Infância. $3^{\mathrm{a}}$ ed. Rio de Janeiro: José Olympio, 1953.

Insônia. $4^{\mathrm{a}}$ ed. Rio de Janeiro: José Olympio, 1955.

Lampião. Novidade 1, Maceió, 11 abr. 1931, p. 3. (Também em Viventes das Alagoas).

Linhas tortas. $14^{\mathrm{a}}$ ed. Rio de Janeiro: Record, 1989.

Mário. In: Brandão entre o mar e o amor: romance. (com Aníbal Machado, Jorge Amado, José Lins do Rego e Rachel de Queiroz). $2^{\mathrm{a}}$ ed. Rio de Janeiro: Record, 1985.

Memórias do cárcere. 4 v. Rio de Janeiro: José Olympio, 1953.

Milagres. Novidade 14, Maceió, 11 set. 1931, p. 3. (Também em Linhas tortas).

Paulo Honório. Revista do Instituto de Estudos Brasileiros, n. 35. Publicação do IEBUSP. São Paulo, 1993, pp. 204-6.

Relatórios. Rio de Janeiro: Record, 1994.

S. Bernardo. $6^{\text {a }}$ ed. Rio de Janeiro: José Olympio, 1955.

Seleção de contos brasileiros. 3 v. (Norte e Nordeste; Leste; Sul e Centro-oeste). Rio de Janeiro: Edições de Ouro, 1966.

Sertanejos. Novidade 1, Maceió, 11 abr. 1931, p. 11.

Viagem. $2^{\text {a }}$ ed. Rio de Janeiro: José Olympio, 1955.

Vidas secas. 59ª ed. Rio de Janeiro: Record, 1989.

Viventes das Alagoas. São Paulo: Martins, 1962.

Tradução de: WASHINGTON, Booker T. Memórias de um negro. (Up from slaveryautobiography). São Paulo: Companhia Editora Nacional, 1940.

Tradução de G.R.: CAMUS, Albert. A peste (La peste, 1947). Rio de Janeiro: José Olympio, 1950; Rio de Janeiro: Opera Mundi, 1973. 


\section{- Sobre Graciliano Ramos:}

BOSI, Alfredo. A escrita do testemunho em Memórias do cárcere. In: Literatura e resistência.

São Paulo: Companhia das Letras, 2002, pp. 221-237.

. Céu, inferno. In: Céu, inferno. São Paulo: Duas Cidades; Ed. 34, 2003, pp. 19-50.

BRAYNER, Sônia. (Org.). Graciliano Ramos. Rio de Janeiro: Civilização Brasileira, 1978.

CANDIDO, Antonio. Ficção e confissão: ensaios sobre Graciliano Ramos. Rio de Janeiro: Ed.34, 1992.

CARPEAUX, Otto Maria. Visão de Graciliano Ramos. Origens e fins. In: Ensaios reunidos 1942-1978. Rio de Janeiro: UniverCidade \& Topbooks, 1999, v. I, pp. 443-450.

GARBUGLIO, J.C. et al. Graciliano Ramos. São Paulo: Ática, 1987.

GIMENEZ, Erwin Torralbo. Graciliano Ramos - O mundo coberto de penas. Tese de doutorado. São Paulo, FFLCH-USP, 2005.

LIMA, Yêdda Dias; REIS, Zenir Campos (Coords.) Catálogo de manuscritos do Arquivo Graciliano Ramos. São Paulo: EDUSP / IEB-USP, 1992.

LIMA, Valdemar de Sousa. Graciliano Ramos em Palmeira dos Índios. Brasília: Ed. Marco, 1971.

LINS, Álvaro. Valores e misérias das Vidas secas. In: Os mortos de sobrecasaca. (1940-1960). Rio de Janeiro: Civilização Brasileira, 1963.

MIRANDA, Wander Melo. Corpos escritos: Graciliano Ramos e Silviano Santiago. São Paulo: Edusp; Belo Horizonte: Editora UFMG, 1992.

MORAES, Dênis de. $O$ velho Graça: uma biografia de Graciliano Ramos. $3^{\text {a }}$ ed. Rio de Janeiro: José Olympio, 1996.

PINTO, Rolando Morel. Graciliano Ramos: autor e ator. Assis: FFCL, 1962.

RAMOS, Clara. Cadeia. Rio de Janeiro: José Olympio, Secretaria de Cultura, 1992. . Mestre Graciliano: confirmação humana de uma obra. Rio de Janeiro: Civilização Brasileira, 1979.

RAMOS, Ricardo. Graciliano: retrato fragmentado. São Paulo: Siciliano, 1992.

REIS, Zenir Campos. A revolta do parafuso: uma leitura de Angústia. In: Cadernos da Católica. Universidade Católica de Brasília - UCB. Brasília: Universa, 1996.

. S. Bernardo: o paradoxo da comunicação. In: MATOS, Edilene et al. (Org.). A presença de Castello. São Paulo: Humanitas: Instituto de Estudos Brasileiros, 2003.

Revista do Instituto de Estudos Brasileiros, n. 35. Publicação do IEB-USP. (Edição que contém ensaios sobre Graciliano Ramos, pelo centenário de seu nascimento). São Paulo, 1993.

ROSENFELD, Anatol. Graciliano Ramos como poeta da seca. In: Letras e leituras. Nanci Fernandes e Jacó Guinsburg (Orgs.). São Paulo: Perspectiva / Edusp; Campinas, SP: Editora da Unicamp, 1994, pp. 137-147.

SCHMIDT, Augusto Frederico et al. Homenagem a Graciliano Ramos. Rio de Janeiro: Alba, 1943. Teresa revista de Literatura Brasileira 2. São Paulo: Editora 34 / USP, 2001.

VILLAÇA, Alcides. Imagem de Fabiano. Estudos avançados, São Paulo, v. 21, n. 60, 2007, pp. 235-246. 
- Revista Novidade. (Direção de Valdemar Cavalcanti e Alberto Passos Guimarães). Maceió, Livraria Vilas-Boas, 1931, 24 números: 1 - 11 abr.; 2 - 18 abr.; 3 - 25 abr.; 4 - 02 mai.; 5 - 09 mai.; 6 - 16 mai.; 7 - 23 mai.; 8 - 30 mai.; 9 - 06 jun.; $10-13$ jun.; $11-20$ jun.; 12 - 27 jun.; 13 - 04 jul. 14 - 11 jul.; $15-18$ jul. $16-25$ jul. $17-01$ ago.; $18-08$ ago.; 19 - 15 ago.; 20 - 22 ago.; 21 - 29 ago.; 22 - 05 set.; 23 - 19 set.; $24-26$ set.

\section{- De alguns autores da Novidade:}

BRANCO, Aloísio. Poemas. Revista do Brasil, fev. 1940, ano III, $3^{\text {a }}$ fase, n. 20, pp. 41-3. BRANDÃO, Théo. $O$ reisado alagoano. ( $1^{\circ}$ Prêmio no $4^{\circ}$ Concurso de Monografias sobre o Folclore Nacional, instituído em 1949 pela Discoteca Pública Municipal, do Departamento de Cultura, da Prefeitura do Município de São Paulo). Separata da Revista do Arquivo n.

CLV. São Paulo: Departamento de Cultura, 1953. . O reisado alagoano. Maceió: EDUFAL, 2007.

CAVALCANTI, Valdemar. Dados biobibliográficos do autor. In: PONTE PRETA, Stanislaw. O melhor de Stanislaw: crônicas escolhidas. $5^{\text {a }}$ ed. Rio de Janeiro: José Olympio, 1994. . Jornal literário. Rio de Janeiro: José Olympio, 1960. . Lembrança do poeta. Diário de Notícias, Rio de Janeiro, 08 jan. 1939.

DIÉGUES JÚNIOR, Manuel. Evolução urbana e social de Maceió no período republicano (Rio, nov. 1939). In: COSTA, Craveiro. Maceió. Vinhetas de Santa Rosa. Rio de Janeiro: José Olympio, 1939, pp. 197-219. . O bangüê nas Alagoas. $3^{\mathrm{a}}$ ed. Maceió: EDUFAL, 2006.

. O romance do cangaço. O Jornal. Rio de Janeiro, 6 dez. 1953. Apud COUTINHO, Eduardo F.; CASTRO, Ângela Bezerra de. (Orgs.) José Lins do Rego. Coleção Fortuna Crítica. Rio de Janeiro: Civilização Brasileira; Paraíba: Edições Funesc, 1990, pp. 456-9. DUARTE, Abelardo. O periodismo literário nas Alagoas. Maceió: Departamento Estadual de Cultura, 1961 (Caderno III, Série Estudos Alagoanos).

FERREIRA, Aurélio Buarque de Holanda. Dois mundos: contos, retratos e quadros. $2^{\mathrm{a}}$ ed. rev. e aum. Rio de Janeiro: O Cruzeiro, 1956.

. Melhores contos: Aurélio Buarque de Holanda. Seleção de Luciano Rosa. São Paulo: Global, 2007 (Coleção Melhores Contos). . Notas sobre a linguagem de D. Cândida Rosa. Revista do Brasil, mai. 1939, ano II, $3^{\text {a }}$ fase, n. 11, pp. 41-5. . Novo dicionário da língua portuguesa. $2^{\mathrm{a}}$ ed. rev. e aum. $28^{\mathrm{a}}$ reimpressão. Rio de Janeiro: Nova Fronteira, 1986. . Pequena introdução a O CONTO BRASILEIRO. "Olhos verdes, boa viagem!”, de Carlos Paurílio. Revista do Brasil, jan. 1941, ano IV, $3^{\text {a }}$ fase, n. 31, p. 46. . Seleta em prosa e verso. Organização, estudo e notas do Prof. Paulo Rónai. Rio de 
Janeiro: José Olympio; Brasília: INL, 1979 (Coleção Brasil Moço).

GUIMARÃES, Alberto Passos. As classes perigosas: banditismo urbano e rural. Apresentação de José Paulo Netto. Rio de Janeiro: Editora UFRJ, 2008.

LIMA, Jorge de. Calunga. $4^{\text {a }}$ ed. rev. Rio de Janeiro: Civilização Brasileira, 1997.

. O mundo impossível do menino. Rio de Janeiro: S.N., 1927.

. Obra completa. Org. de Afrânio Coutinho. v. I - Poesia e ensaios. Rio de Janeiro: José Aguilar, 1958.

. Poesia completa: volume único. Org. Alexei Bueno; textos críticos: Marco Lucchesi et al. Rio de Janeiro: Nova Aguilar, 1997.

LINS, Álvaro. Jornal de crítica. $3^{\text {a }}$ série. Rio de Janeiro: José Olympio, 1944.

. Os mortos de sobrecasaca. (1940-1960). Rio de Janeiro: Civilização Brasileira, 1963.

PAURÍLIO, Carlos. Olhos verdes, boa viagem! Revista do Brasil, jan. 1941, ano IV, $3^{\text {a }}$ fase, n. 31, p. 46.

REGO, José Lins do. Cangaceiros. Rio de Janeiro: José Olympio, 1953.

. Dias idos e vividos. Seleção, organização e estudos críticos de Ivan Junqueira. Rio de Janeiro: Nova Fronteira, 1981.

. Ligeiros traços. Escritos da juventude. Seleção, introdução e notas de César Braga-

Pinto. Rio de Janeiro: José Olympio, 2007.

. Pedra bonita. $9^{a}$ ed. Prefácio de Paulo Rónai. Rio de Janeiro: José Olympio, 1979.

ROSA, Santa. A derrota dos preconceitos. Revista do Brasil, ago. 1939, ano II, $3^{\text {a }}$ fase, n. 14 , pp. 95-6.

. Preconceitos. Revista do Brasil, fev. 1939, ano II, $3^{\text {a }}$ fase, n. 8, pp. 96-7.

. Roteiro de arte. Os cadernos de cultura. Rio de Janeiro: Serviço de Documentação,

Ministério da Educação e Saúde, 1952.

\section{- Geral:}

ABENSOUR, Miguel. L' extravagante hypothèse. Rue Descartes, n. 19, 'Emmanuel Lévinas'. Paris: Presses Universitaires de France, février 1998, pp. 55-84.

ADORNO, Theodor W. Educação e emancipação. Tradução de Wolfgang Leo Mara. $2^{a}$ ed. São Paulo: Paz e Terra, 2000.

. Notas de literatura I. Tradução e apresentação de Jorge M. B. de Almeida. São Paulo: Duas Cidades; Ed. 34, 2003.

AMADO, Jorge. Navegação de cabotagem: apontamentos para um livro de memórias que jamais escreverei. $3^{\text {a }}$ ed. Rio de Janeiro: Record, 1994.

ANDRADE, Carlos Drummond de. A Revista, de novo. Interessa? In: Folha de S.Paulo, São

Paulo, 21 set. 1978; Valeu a pena? Valeu. In: Folha de S.Paulo, São Paulo, 26 set. 1978.

Apud SILVA, Margaret Abdulmassih Wood da. Revista: contribuição para o estudo do 
modernismo em Minas Gerais. Dissertação de mestrado. São Paulo, FFLCH-USP, 1985. . Obra completa. Rio de Janeiro: Aguilar, 1964.

ANDRADE, Fábio de Souza. O engenheiro noturno: a lírica final de Jorge de Lima. São Paulo: Edusp, 1997.

ANDRADE, Mário de. A lição do amigo. Cartas de Mário de Andrade a Carlos Drummond de Andrade. $2^{\mathrm{a}}$ ed. Rio de Janeiro: Record, 1988. . Aspectos da literatura brasileira. São Paulo: Martins, s/d. . Cartas a Murilo Miranda (1934-1945). Rio de Janeiro: Nova Fronteira, 1981. . Há uma gota de sangue em cada poema. In: Obra imatura. São Paulo: Martins, 1960. O empalhador de passarinho. $3^{\text {a }}$ ed. São Paulo: Martins; Brasília: INL, 1972. . Romanceiro de Lampeão. In: O baile das quatro artes. São Paulo: Martins, 1963. . 71 cartas de Mário de Andrade. Ed. prep. por Lygia Fernandes. Rio de Janeiro: Livraria São José, 1968. . Táxi e crônicas no Diário Nacional. Estabelecimento de texto, introdução e notas de Telê Ancona Lopez. São Paulo: Duas Cidades, Sec. da Cultura, Ciência e Tecnologia, 1976. ANDRADE, Mário de; ANDRADE, Carlos Drummond de. Carlos \& Mário: correspondência completa. Prefácio e notas de Silviano Santiago; org. e pesquisa iconográfica de Lélia Coelho Frota. Rio de Janeiro: Bem-Te-Vi, 2003.

AUERBACH, Erich. Mímesis. A representação da realidade na literatura ocidental. $4^{\mathrm{a}}$ ed. São Paulo: Perspectiva, 1998.

AVELAR, Romeu de. Antologia de contistas alagoanos. Maceió: Departamento de Ciência e Cultura, 1970.

BANDEIRA, Manuel. Poesia completa e prosa. Rio de Janeiro: José Aguilar, 1967. . Crônicas inéditas I, 1920-1931. Organização, posfácio e notas de Júlio Castañon Guimarães. São Paulo: Cosac Naify, 2008.

BARRETO, Lima. Impressões de leitura. Crítica. Prefácio de M. Cavalcanti Proença. São Paulo: Brasiliense, 1956

BARROS, Francisco Reinaldo Amorim de. ABC das Alagoas: dicionário biobibliográfico, histórico e geográfico das Alagoas. 2 v. Brasília: Senado Federal, Conselho Editorial, 2005.

BARROS, Luiz Nogueira. Do sertão ao litoral. Maceió: Edições Catavento, 2000.

BARSANTE, Cássio Emmanuel. A vida ilustrada de Tomás Santa Rosa. Rio de Janeiro: Fundação Banco do Brasil: Bookmakers, 1993.

BARTHES, Roland. Mitologias. Tradução de Rita Buongermino, Pedro de Souza e Rejane Janowitzer. $2^{\mathrm{a}}$ ed. Rio de Janeiro: Difel, 2006.

BENJAMIN, Walter. Magia e técnica, arte e política. São Paulo: Brasiliense, 1993. . Reflexões sobre a criança, o brinquedo e a educação. Tradução, apresentação e notas de Marcus Vinicius Mazzari. Posfácio de Flávio Di Giorgi. São Paulo: Duas Cidades; Ed. 34, 2002. BETTARELO, Ítalo. A poesia italiana atual. Tradução, notas e apresentação de Elvira Rina 
Malerbi Ricci. Boletim n. 15 (Nova Série), Faculdade de Filosofia, Letras e Ciências Humanas, USP, 1977.

BOSI, Alfredo. Brás Cubas em três versões. São Paulo: Companhia das Letras, 2006. . Céu, inferno. São Paulo: Duas Cidades; Ed. 34, 2003. . História concisa da literatura brasileira. São Paulo: Cultrix, 1975. . Literatura e resistência. São Paulo: Companhia das Letras, 2002. . Machado de Assis: o enigma do olhar. São Paulo: Ática, 1999. . O pré-modernismo. São Paulo: Cultrix, 1973. . O ser e o tempo da poesia. São Paulo: Cultrix, 1993. . Reflexões sobre a arte. $4^{\mathrm{a}}$ ed. São Paulo: Ática, 1991.

BOSI, Ecléa. O tempo vivo da memória: ensaios de psicologia social. São Paulo: Ateliê, 2003.

BRITO, Mário da Silva. História do modernismo brasileiro - I. Antecedentes da Semana de Arte Moderna. $2^{\mathrm{a}}$ ed. rev. Rio de Janeiro: Civilização Brasileira, 1964.

BROCA, Brito. A vida literária no Brasil - 1900. $5^{\text {a }}$ ed. Rio de Janeiro: José Olympio / Academia Brasileira de Letras, 2005.

BUENO, Luís. Uma história do romance de 30. São Paulo: EDUSP; Campinas: Editora da UNICAMP, 2006.

CANDIDO, Antonio. A educação pela noite \& outros ensaios. $2^{\mathrm{a}}$ ed. São Paulo: Ática, 1989. . Literatura e sociedade. Ensaios de teoria e história literária. São Paulo: Companhia Editora Nacional, 1965. . Teresina etc. Rio de Janeiro: Paz e Terra, 1980.

CANDIDO, Antonio e CASTELLO, José Aderaldo. Presença da literatura brasileira: história e antologia. II. Modernismo. 10 a ed. rev. Rio de Janeiro: Bertrand Brasil, 1997.

CARPEAUX, Otto Maria. As revoltas modernistas na literatura. Rio de Janeiro: Edições de Ouro, 1968.

. Ensaios reunidos 1942-1978. v. I. Organização, introdução e notas de Olavo de Carvalho. Rio de Janeiro: UniverCidade \& Topbooks, 1999.

Ensaios reunidos 1946-1971. v. II. Prefácio de Ivan Junqueira. Rio de Janeiro:

UniverCidade \& Topbooks, 2005.

. Introdução. In: LIMA, Jorge de. Obra poética; Org. Otto Maria Carpeaux. Rio de Janeiro: Ed. Getulio Costa, 1949.

. Pequena bibliografia crítica da literatura brasileira. Rio de Janeiro: Ed. de Ouro, 1968.

. Tendências contemporâneas na literatura. Rio de Janeiro: Edições de Ouro, 1968.

CASCUDO, Luís da Câmara. Contos tradicionais do Brasil. 12ª ed. São Paulo: Global, 2003.

. Dicionário do folclore brasileiro. 11ª ed., ilustrada. São Paulo: Global, 2002.

CASTELLO, José Aderaldo. A literatura brasileira: origens e unidade (1500-1960). v. II. São Paulo: Edusp, 1999.

. A pesquisa de periódicos na literatura brasileira. In: NAPOLI, Roselis Oliveira de. 
Lanterna Verde e o modernismo. São Paulo: Instituto de Estudos Brasileiros, 1970, pp. 5-12. . José Lins do Rego - Modernismo e regionalismo. São Paulo: Edart, 1961.

CASTELlO, José. João Cabral de Melo Neto. O homem sem alma \& Diário de tudo. Rio de Janeiro: Bertrand Brasil, 2006.

CAVALCANTE, Simone. Literatura em Alagoas: ensino médio e vestibular. Ilustrado por Iuri Ávila. Maceió: Scortecci / Grafmarques, 2005.

CAVALHEIRO, Edgard. Testamento de uma geração: 26 figuras da intelectualidade brasileira prestam seu depoimento no inquérito promovido por E. Cavalheiro. Porto Alegre: Globo, 1944.

CHANDLER, Billy Jaynes. Lampião, o rei dos cangaceiros. Tradução de Sarita Linhares Barsted. Rio de Janeiro: Paz e Terra, 1980.

COSTA, Luiz. A invenção do País pelo regionalismo nordestino. O Estado de S. Paulo, São Paulo, 14 out. 2001. Caderno 2.

COUTINHO, Afrânio (dir.). A literatura no Brasil. v. III, t. 1. Rio de Janeiro: São José, 1959.

COUTINHO, Eduardo F.; CASTRO, Ângela Bezerra de. (Orgs.) José Lins do Rego. Coleção Fortuna Crítica. Rio de Janeiro: Civilização Brasileira; Paraíba: Edições Funesc, 1990.

CRETELLA JR, José \& ULHÔA CINTRA, Geraldo de. Dicionário Latino-Português. $3^{\mathrm{a}}$ ed. São Paulo: Companhia Editora Nacional, 1953.

CRUZ COSTA, João. Contribuição à História das Idéias no Brasil. Rio de Janeiro: José Olympio, 1956.

DE LUCA, Tania Regina. A Revista do Brasil: um diagnóstico para a (N)ação. São Paulo: Fundação Editora da UNESP, 1999

EKSTEINS, Modris. Sagração da primavera: a grande guerra e o nascimento da era moderna.

Tradução de Rosaura Eichenberg. Rio de Janeiro: Rocco, 1991.

FACÓ, Rui. Cangaceiros e fanáticos. Rio de Janeiro: Civilização Brasileira, 1963.

FAUSTO, Boris. A Revolução de 1930. São Paulo: Companhia das Letras, 1997. História do Brasil. 10ª ed. São Paulo: EDUSP, 2002.

FLAUBERT, Gustave. Correspondance. Sixième Série (1869-1872). Paris: Louis Conard, 1930. FREYRE, Gilberto. Região e tradição. Prefácio de José Lins do Rego. Rio de Janeiro: José Olympio, 1941.

GAGNEBIN, Jeanne Marie. História e narração em Walter Benjamin. $2^{\mathrm{a}}$ ed. São Paulo:

Perspectiva, 1999. . Lembrar escrever esquecer. São Paulo: Editora 34, 2006.

GRUSPAN-JASMIN, Élise. Lampião, senhor do sertão: vidas e mortes de um cangaceiro.

Tradução de Maria Celeste Marcondes e Antonio de Pádua Danesi. São Paulo: Edusp, 2006. . Cangaceiros. Apresentação de Frederico Pernambucano de Mello. São Paulo: Terceiro Nome, 2006.

GUERRA, José Augusto. Testemunhos de crítica. Recife: Univ. Federal de Pernambuco, 1974.

HALLEWELL, Laurence. O livro no Brasil: sua história. Tradução de Maria da Penha 
Villalobos e Lólio Lourenço de Oliveira. São Paulo: T.A. Queiroz, Edusp, 1985.

HOBSBAWM, Eric J. Era dos extremos: o breve século XX (1914-1991). Tradução de Marcos Santarrita. Revisão técnica de Maria Célia Paoli. São Paulo: Companhia das Letras, 1995. HOLANDA, Sérgio Buarque de. O espírito e a letra. 2 v. Organização, introdução e notas de Antonio Arnoni Prado. São Paulo: Companhia das Letras, 1996. . Raízes do Brasil. Prefácio de Antonio Candido. $4^{\text {a }}$ ed. Brasília: Ed. Un.B, 1963.

HOUAISS, Antonio e VILLAR, Mauro de Salles. Dicionário Houaiss da Língua Portuguesa. Rio de Janeiro: Objetiva, 2001.

JITRIK, Noé; GRAMUGLIO, María Teresa. Historia crítica de la literatura argentina: el imperio realista. Buenos Aires: Emecé, 2002, v.6.

KREINZ, Glória Aparecida Rodrigues. Revista nova: contribuição para o estudo do modernismo brasileiro. Dissertação de mestrado. São Paulo, FFLCH-USP, 1979.

LAFETÁ, João Luiz. 1930: a crítica e o modernismo. São Paulo: Duas Cidades; Ed. 34, 2000. . A dimensão da noite. (Org. Antonio Arnoni Prado). São Paulo: Duas Cidades; Ed. 34, 2004.

LANSON, G. Histoire de la Littérature Française. Remaniée et complétée pour la période 18501950 par Paul Tuffrau. France: Librairie Hachette, 1955.

LEFÈVRE, Frédéric. Une heure avec... VI série. Paris: Flammarion, 1933.

LEITE, Dante Moreira. O caráter nacional brasileiro: história de uma ideologia. $6^{\text {a }}$ ed. rev. São Paulo: Editora UNESP, 2002.

LÉVINAS, Emmanuel. Entre nós - ensaios sobre a alteridade. Tradução de Pergentino Stefano Pivatto (coord). Petrópolis: Vozes, 2004.

. Ética e infinito: diálogos com Philippe Nemo. Tradução de João Gama. Lisboa: Edições 70, 2000.

. Humanismo do outro homem. Tradução de Pergentino S. Pivatto (coord). Petrópolis: Vozes, 1993.

. Totalidade e infinito. Tradução de José Pinto Ribeiro. Lisboa: Edições 70, 2000.

LIMA, Alceu Amoroso. Memórias improvisadas - diálogos com Cláudio Medeiros de Lima; prefácio de Antônio Houaiss. Petrópolis: Vozes, 1973.

LUKÁCS, Georg. A teoria do romance. Tradução, posfácio e notas de José Marcos Mariani de Macedo. São Paulo: Duas Cidades; Ed. 34, 2000.

MARTINS, Ana Luiza. Revistas em revista. São Paulo: EDUSP / FAPESP / Imp. Oficial, 2001.

MATOS, Olgária. Cerimônias da destruição. In: NOVAES, Adauto (Org.). Civilização e barbárie. São Paulo: Companhia das Letras, 2004, pp. 281-299.

MELLO, Frederico Pernambucano de. Guerreiros do sol: violência e banditismo no Nordeste do Brasil. Prefácio de Gilberto Freyre. São Paulo: A GIRAFA Editora, 2004.

MELO NETO, João Cabral de. Obra completa. Rio de Janeiro: Nova Aguilar, 1994.

MEY, Letícia; ALVIM, Euda. Quem contará as pequenas histórias? Uma biografia romanceada 
de Augusto Frederico Schmidt. São Paulo: Globo, 2005.

MORAES, Marcos Antonio de. Orgulho de jamais aconselhar: a epistolografia de Mário de Andrade. São Paulo: Edusp / FAPESP, 2007.

NAPOLI, Roselis Oliveira de. Lanterna Verde e o modernismo. São Paulo: IEB, 1970.

ORTEGA Y GASSET, José. O homem e a gente: inter-comunicação humana. $2^{\mathrm{a}}$ ed. Nota introdutória e tradução de J. Carlos Lisboa. Rio de Janeiro: Livro Ibero-Americano, 1973. Obras completas. $2^{\text {a }}$ ed. t. III (1917-1928). Madrid: Revista de Occidente, 1950.

PAES, José Paulo. Armazém literário: ensaios. Organização e apresentação de Vilma Arêas. São Paulo: Companhia das Letras, 2008.

PEREIRA, Lúcia Miguel. A leitora e seus personagens: seleta de estudos publicados em periódicos (1931-1943). Rio de Janeiro: Graphia Editorial, 1992.

PEREZ, Renard. Escritores brasileiros contemporâneos. $2^{\text {a }}$ série. 22 biografias, seguidas de antologia. $2^{\mathrm{a}}$ ed. rev. e atualizada. Rio de Janeiro: Civilização Brasileira, 1971.

PEYRADE, Jean. Psichari, maître de grandeur. Paris: Julliard, 1948.

POIRIÉ, François. Emmanuel Lévinas: ensaio e entrevistas. Tradução de J. Guinsburg, Marcio Honorio de Godoy e Thiago Blumenthal. São Paulo: Perspectiva, 2007.

PRADO, Antonio Arnoni. 1922 - Itinerário de uma falsa vanguarda - os dissidentes, a Semana e o Integralismo. São Paulo: Brasiliense, 1983.

. Trincheira, palco e letras. São Paulo: Cosac Naify, 2004.

PRADO, Paulo. Retrato do Brasil: ensaio sobre a tristeza brasileira. Organização: Carlos Augusto Calil. $9^{a}$ ed. São Paulo: Companhia das Letras, 1997.

Qohélet = : O-que-sabe: Eclesiastes: poema sapiencial. Transcriado por Haroldo de Campos. Colaboração especial de J. Guinsburg. São Paulo: Perspectiva, 1990.

QUEIROZ, Maria Isaura Pereira de. Os cangaceiros. São Paulo: Duas Cidades, 1977.

QUEIROZ, Rachel de. Menino de engenho: 40 anos. In: REGO, José Lins do. Menino de engenho. $17^{\mathrm{a}}$ ed. Rio de Janeiro: José Olympio, 1972.

REMARQUE, Erich Maria. Sem novidades no front - O regresso (Dois romances). Tradução de José Geraldo Vieira. Rio de Janeiro: José Olympio, 1951 (Coleção Fogos Cruzados). . Nada de novo no front. Tradução de Helen Rumjaneck. Porto Alegre: L\&PM, 2004.

RESENDE, Otto Lara. O príncipe e o sabiá e outros perfis. Organização de Ana Miranda. São Paulo: Companhia das Letras: Instituto Moreira Salles, 1994.

RIBEIRO, Joaquim Brás. Introdução ao estudo do folk-lore brasileiro. Rio de Janeiro: Alba,s/d. RICOEUR, Paul. Interpretação e ideologias. Organização, tradução e apresentação de Hilton Japiassu. $4^{\text {a }}$ ed. Rio de Janeiro: Francisco Alves, 1990. . Leituras 1 - em torno ao político. Tradução Marcelo Perine. São Paulo: Loyola, 1995. ROCHA, José M. Tenório. Théo Brandão: mestre do folclore brasileiro. Maceió: Edufal, 1988. ROCHA, Tadeu. Modernismo e regionalismo. Maceió: Dep. Estadual de Cultura, 1964. RODRIGUES, André Luis. Fraturas no olhar: realidade e representação em Cornélio Penna. Tese 
de doutorado. São Paulo, FFLCH-USP, 2006.

RÓNAI, Paulo. Um idioma ganha o seu dicionário (1975). In: Pois é: ensaios. Rio de Janeiro: Nova Fronteira, 1990.

ROUANET, Sergio Paulo. Mal-estar na modernidade. São Paulo: Companhia das Letras, 2003.

SALIBA, Elias Thomé. Grupo rejeitava literatura pitoresca. O Estado de S. Paulo, São Paulo, 14 out. 2001. Caderno 2.

SANT'ANA, Moacir Medeiros de. (pesquisa e seleção). Documentário do modernismo (Alagoas, 1922/31). Maceió: UFAL, 1978.

. Efemérides alagoanas. Maceió: Instituto Arnon de Mello, 1992.

. História do modernismo em Alagoas (1922-1932). $2^{\text {a }}$ ed. revista e aumentada. Maceió:

EDUFAL, 2003.

SCHOPENHAUER, Arthur. Sobre o fundamento da moral. Tradução de Maria Lúcia Mello

Oliveira Cacciola. $2^{\mathrm{a}}$ ed. São Paulo: Martins Fontes, 2001.

SCHWARZ, Roberto. Que horas são? São Paulo: Companhia das Letras, 1987.

Sem novidade no front (All quiet on the western front), 1930, filme com direção de Lewis

Milestone.

SENNA, Homero. República das letras: Entrevistas com vinte grandes escritores brasileiros. $3^{\text {a }}$ ed. rev. e atualizada. Rio de Janeiro: Civilização Brasileira, 1996.

SILVA, Franklin Leopoldo e. A dimensão ética da palavra. Tempo social: revista de sociologia da USP. São Paulo, v. 8, 1996, pp. 53-66.

SOARES, Mariana Cysneiros Cavalcanti. Lampião: a marca que vende o Nordeste. Recife: Ed. do Autor, 2007.

SONTAG, Susan. Ao mesmo tempo. Ensaios e discursos. Trad. Rubens Figueiredo; org. Paolo Dilonardo e Anne Jump; intr. David Rieff. São Paulo: Companhia das Letras, 2008.

TELLES, Gilberto Mendonça. Vanguarda européia e modernismo brasileiro: apresentação dos principais poemas, manifestos, prefácios e conferências vanguardistas, de 1857 a $1972.13^{\text {a }}$ ed. Petrópolis: Vozes, 1997.

Teresa revista de Literatura Brasileira 3. São Paulo: Editora 34 / USP, 2002.

Torá - a Lei de Moisés. Ed. Jairo Fridlin. Tradução e comentários de Meir Matzliah Melamed.

São Paulo: Editora e Livraria Sêfer, 2001.

VASCONCELOS FILHO, Marcos. Marulheiro: viagem através de Aurélio Buarque de Holanda. Maceió: Edufal, 2008.

VILLAÇA, Alcides. Passos de Drummond. São Paulo: Cosac Naify, 2006. 


\section{ANEXOS \\ Do CAPÍTULO 1 - “CARTÃO DE VISITA” DA NOVIDADE}

- NOVIDADE 1, Maceió, 11 abr. 1931 (em negrito os textos analisados na tese):

"Cartão de visita", Valdemar Cavalcanti.

Expediente. "Feminismo no Brasil", "Sirenes de Cinema", "Pilhérias a 20\$000",

"Última Flor do Lácio etc", $\boldsymbol{V}$.

"Lampião", Graciliano Ramos.

3.

"O voto feminino", L. Lavenére.

"Recife", Willy Lewin.

"Olhos verdes", conto de Carlos Paurilio.

4.

Poemas: "Fuga", Willy Lewin. "O Carteiro", José Auto.

Fotografias "Novidade na Rua...": Antes da Semana Santa.

6.

6.

Arte Fotográfica: Matando o tempo. Margem de Lagoa. Fotografias artísticas de Ismael Accioly.

Cinema: "Cinema alagoano", "Alvorada do amor", F. Marroquim Souza. Notas. 10.

"Sertanejos", Graciliano Ramos.

Notas da Semana: "Escola de Gazeteiros", "Os Boateiros", V. "Louvado seja

N. S. Jesus Cristo", A. Outras.

Sociedade: "Mille Creme de Baunilha", "Modas", Ramil.

"Registo de Aniversários", "Festas". 13.

Anúncios.

- "Vida, paixão e morte de Novidade" (1931), Valdemar Cavalcanti e Alberto Passos Guimarães.

- "Uma Revista" (Jornal literário, 1960), Valdemar Cavalcanti.

\section{Do CAPÍTULO 2 - SEM NOVIDADE NO FRONT}

- “All quiet...", Jurandir Gomes (N 18, p. 12).

- “T.G. 13" (Tiro de Guerra 13), Willy Lewin (N 7, p. 6).

- “A propósito de guerra”, Diégues Júnior (N 16, p. 5).

\section{Do CAPÍTULO 3 - A TERRA DOS MENINOS IMPOSSÍVEIS}

- De Jorge de Lima: "Nota religiosa" (N 3, p. 3), "Padre Feijó" (N 5, p. 11).

- “O modernismo morreu?" - Resposta de Graciliano Ramos ao Inquérito de Osório Nunes. In: Dom Casmurro. Rio de Janeiro, 12 de dezembro de 1942. Ano VI, n. 280, p. 3.

\section{Do CAPÍTULO 4 - ITINERÁRIO POLÍTICO E CULTURAL: OS EDITORIAIS}

- De Valdemar Cavalcanti: "Os técnicos da Segunda República" (N 15), "Nós somos mesmo do amor" (N 21).

- De Alberto Passos Guimarães: “...país essencialmente agrícola” (N 14), “A última geração de burgueses" (N 24). 


\section{Do CAPÍTULO 5 - NOVIDADE POLÍTICA: O RESGATE DOS SEM-LUGAR}

- "O novo menù político" (N 4, p. 13), Barreto Falcão.

- "Carta a um antigo correligionário político" (N 9, p. 6), Lima Júnior.

- "O voto proporcional" (N 10, p. 6), Moacyr Pereira.

- “Por que não a Constituinte?” (N 12, p. 3), Edmilson Falcão.

- As nossas "enquetes" - A instrução pública em Alagoas, entrevista com Miguel Baptista (N 4, p. 8).

- "Um salão de leitura", "A Santa de Tigipió" (N 7, p. 16).

- "A cidade mendiga, a cidade que sofre" (N 24, pp. 8-9).

- "Lampião entrevistado por Novidade", Xilogravura "Sertão", de Lourenço Peixoto (N 6, p. 7).

- "Lampião" (Editorial 7), Valdemar Cavalcanti.

- "De Recife" - Correspondência de Raul Lima (N 10, p. 12).

- Artigo não-assinado: “Águas paradas” (N 17, p. 5).

\section{Do CAPÍTULO 6 - NOVIDADE LITERÁRIA: O RESGATE DE PESSOAS}

- Willy Lewin: “O laboratório de imagens", poema (N 15, p. 11).

- Santa Rosa Júnior: "Bucólico”, poema (N 11, p. 11).

- Aurélio Buarque: "Silêncio", poema (N 14, p. 11).

- Carlos Paurílio: "O caso pungente do 17" (N 3, p. 6), "História de mosca" (N 17, p. 6), contos.

- Aloísio Branco: "Berceuse para embalar o mundo", poema (N 18, p. 11), "A Poesia de Jean Cocteau", ensaio (N 03, p. 11).

\section{Do CAPÍTULO 7 - GRACILIANO RAMOS E A NOVIDADE}

- De Graciliano Ramos: "Chavões" (N 8, p. 7),

"Milagres" (N 14, p. 3),

Cahetés - capítulo XXIV (N 9, p. 5).

("Lampião" e "Sertanejos" constam da N 1).

- De José Lins do Rego: “O último livro do sr. Plínio Salgado" (N 6, p. 12),

"O Brasil precisa de Catolicismo" (N 11, p. 3). 
Solsre essa geraçz̆to de hoje - uma geração de vinte annos desencantados - sobre a nova geração intellectual re Alagoas recae agora a responsabilidade de commetter lotcuras. De affirmar-se, đle ter convicções. E' preciso abafar o platonismo com que poderiamos ficar tecendo sonhcs côrAe-rosa, em detrimento das realidades da vida. Si é grande a ancia de novos deaes, maior deve ser esforço pcla sua conquista. A mocidade carce 13 áo somente de oĺhar a vida, mas viver a vida. Principalmente viver a vida. Porém com esse tracicional commodismo de attitudes e esse ro. mantismo mollenzo da heranca etluniéa, é que näo podemos

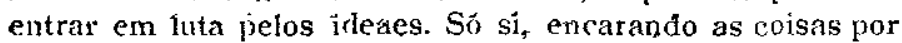
outro lado, levarmes em esata os jóeaes de burocraeia e de casamento.

A. outra geração já vae longe da nossa. Ella acreditavá em nilaǵres estitisfiens de Alencar e. Chateaubriand. Ctixava-se attrair pelo perigoso seepticismo remaniano. Olhava a vida com o mesmo a linroso monoculo' anatoliano de ironia, de amavel deserenca. Uma geraçäo para quen Darwin existiv.

A nrissatem $\mathrm{um}$ iectino a cumprir: vencer primeiramente os erros da ouiro e passar adiante; como no pro* gramma de Psichari, apurar os defeitos eas virtudes de nossos pars, buscando no exemplo do passado aquellas como que. marens de passos que Nabuco rizia ser dever dos bons paes ieixarem pela vida para orientar os fithos. $F$ - aproveitando a imagem admiravel clum ensaista brasileiro - jun tar, perlaço a pedaço, os rcatos do erucifixo quefrado pelo avô Renan.

Porém uma geraçáa moça de - Alignas ectá mas é abarando os seus gritos te irlealismo, de independencia, de vida mesmn, snb um assassino silencio de cavorna. Um sîlenrio tanto más criminoso quanto está sanguesugarido torlas essas energias tisnersais mis capazes. Com a auscrcia te um prrta-voz para os séus impulsos, accentúa-se entáo uma coisa a que podemos chamar o puror de tet vinta arnos.

De uma reflexăo assin sobre a situação dessa ganie moç (inclúo aqui, paradoxalmente talvez, muitos trinta. annos independentes, gente a quem os hitizontes novos fizeram exilar-se de sua propria geração), foi que Novidade nascen.

Nâo scrá apenas se rebolando de deleites intellectuaes por essa coisa attraente a que Flaubert chamava de "sacrosanta literítura" que $a^{*}$ nossa geraça cumpriál esse destino.

Novidade quer controlar os esforços dispersivos dirsses mocos que entre nós começam a evalir-se das condem nacōes do meio. $O$ que não quer dizer que se affastará dos maks velhos. Antes procutara ouvir-lhe a voz Mesmo que ella năo combine com o ruthmo desordenado da mócidade-um rythmo desordenado resultante dessa mossa nervosa procura de ordem. $O$ que vale éque essa voz não seja somente una cantiga sén o puro interesse das itćas.

Assim, Novidade vem preencher uma lacuna cm a .. .etc. cte. Por aqui é que iacemrȩar o artigo de fundo.

\section{Galdemar

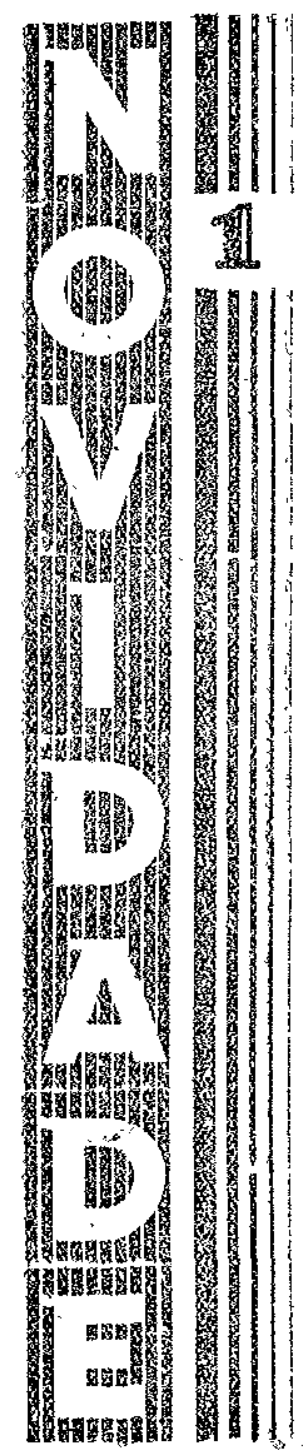




\section{femintsmo no}

Brasil

Parece que desta feita a muther emqulstara de todo 0 seu prestigio politico no Brasil, adquirindo, depois de tanto tempo de luta, o direito do voto. E' que desta vez a muther conquistou a apoio do Chefe do Governo Provisorio e de muitos dos seus auxillares, nãs esquecendo o nome da General Juarez Tavora. A voz da igreja faz eco com a dos pilotos da Nova Republica. Nis o que prarece é que $\dot{e}$ bem celo para se dar à mulher brisileira os mesmos direitos politicos do homem. Porquecom franqueza - resalvando uin pequenissimo numero de elite, ellas pouco teem dado de bim á literatura e á historia, e isso nos faz imaginar o angú poitico mexido por certas cabecas sle vento. Na literaturavejam só-apenas uma mulher cons $\rightarrow$ guiu dar um livro serin: 1). Carolina Nabuco. As ou. tras continuam a knlaquizar ns suas pouco apreciaveis $f(1$. mss sexuaes por moio de ver. sos em obras aliás q e devi. an levar o distico cinematographica: impropros para menores e senhoritas ou a desman ${ }^{2}$ har-se em frases feitas pe. las jor rats e revistas. Convenhamos que esca gente, ab. sorvida irremedavelmente com os ligurinos de elegancia e literatura de Paris, não podera rensar nunca sobre os prob'emas do pais. Uns tantos pro' blemas que teem trazido cans ás mais enrugadas experiencias. $-V$.

\section{Sirenes de \\ Cinema}

Em Maceió quando a tarde cae começam a gritar, como agolurentos passaros nocturnos, as sirenes dos cinemas. Dez ou doze sirenés, espalhadas até o mais afastado bairro, conspiram sovieticamente contra o sossegne a santa paz provinciana da nossa gente. Parece uma marinettica re crào contra os crepusculas Gritam uns gritos lancinantes, dolorosos, de carpideiras, crmo si lisstimassem a falta din gosto pelo cinema nustu pa "ifop pulaçio

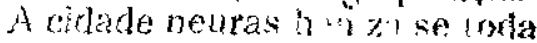
com a nevrose aguda das sire ness. Deuma impertinencia su.

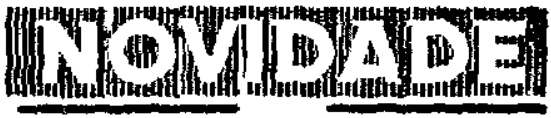

Semanario 1llustrado

Numero1 $11 * 4 * 31$
Direção de
Alherto Passos Guimarãos
$e$
Valdemar Cavalcanti

\section{Assignaturas}

Semestre ........

105000

Anno. 183000

Numero avalso.... $\$ 400$

Toda corespondentia para a Rua Gapao do stalaia, 33 .

As collaboracoses devem ser cbsolutamente ineditas.

Callaboraçăo especial de Jorge de Lima, Graciliano Ramos, Guedes de Miranda, Orjando Aranjo Arthur Accioly, Carlos de Gusmão, Lima Junior, José Lins do Rego, Manoel Lubambo, Jayme Sentos, Alvato Doria, Cravejro Costa, Awryno Mreiel, Luiz Lavenére, Jayme de Altavilla, Miguel Baptista, Abeflario Duarte Barreto Falcino, Fstras Gueiros, Jose Auto, Willy Lewin, Alnysio Branco, Mendonça Junicr, Carlos Paurilio Sebastiano Hora, Mendonca Braga, Itaul Lima, Aurelio Buarque, F, Marraquim Souaa, José Borba, Pautino Jorge, Moa. cyr Perpirn, Leăo Tavares Basto, Abrllard de Franca, outros mais.

perior á dos vendedores de $b^{\circ}$ Thetes de loteria, ellas annunciam os principios e fins de sessões. Si isso continuar por muito tempo, Maceíô ficará sen' doem breve «a cidade que so. ffre dos nervos $\ldots=V$.

\section{Pliherias a \\ $20 \$ 000$}

Un cidadào carioca, naturalmente engraçado por demais, foi protagonista dn mais curioso drama succerlido na novissıma éra da Historia do Brasil : cobraram-lhe uma mul. la de $20 \$ 1 n$ por uma pitheria atirada a certa senhora. Ora, nino vemos motivo para essi alta da pilheria. Só si querem valotizal-a por atravessarmos uma phase absoluta e politicamente seria Porém mesmo assim as do Procopio Ferreira cujo éfeito maravilhoso è estourar suspensorios e desatar delicadezas de ttoilette" inte rior feminina-.- as do Procopio continuam no entanto, a ser cobradas modieamente, a quast 58000 o cento, sendo que depois são repetidas de graça pelos admiradores delle. E uma pilheria, uma coisa tảo carioca, não es motivo para tanta zanga e tal recompensa. Isso é levar muito longe a honestidade auditiva, tăo susceptivel no cavo como a de uma go. vernante suissa. $E^{\prime}$ uma salyaçăo, em todo o caso, para as meninas faceiras que seacos tumaram ás malicias da aveni. da como a lugarescommuns. Pode dar certo como meio de vida. Por isso convem se precavenham os amatores de piadas galantes : uma traquinice de lingua thoje laga a peso de ouro. $=V$.

\section{ultima fiorde}

\section{Lacio, etc}

Agora está em fờco no Brasil a velba questão de uniformidade orthographica, a $\mathrm{ma}$ neira do que já fizeram no - jardim da Europa. . . Parece mesmo que desta vez a coisa vae. No entanto nós, brasileiros, nãก é com fácilifa: de que nos acostumaremos a graphia simplificada. Nossa gente, $\mathrm{cmm}$ o gosto das pala vras rechonchud $s$. das frases roliças -. gosto que tinto tes. esperava Verissimo - Bunca que se habitue rom essa muti lação geral. Uma pagina em orthographia portuguesa sem. pre me dá a desagradavel im. pressão de um hospital de in' validos, tal $n$ aspecto de alei jados que eu sinto nessas pala* vras decapitadas, meio mortas. Como que ellas tomam lune. cões differentes ou mesmo con" trarias com a simplificação. Depois, essa simplificaçãn tem sido a coisa mais complicada do mundo; em Portugal os es' etiptores ainda hoje asdam ás cabeçadas, tontos rom o $\mathrm{cnn}^{4}$ traste ras gracinhas do randi do de $F$ e o eruditiomo de Theophilo Braga Para quem

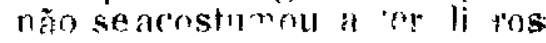
portugueses, rue ser un tabo serio- $V$. 
Lampião nasceu ha muitns annos, em todos os Estados do Nordeste. Não falo, está clàro, no individuo Lampiắa, que não poderia nascer em muitos $! u^{\text {* }}$ gares e é pouco interessante. Pela descripção publicada vemos perfeitamente que o salteador cafuso é um heroe de arribação bastante chinfrim Zarolho, corcunda, chamboqueiro, dá impressão má.

Refiro-me ao Lsmpionismo, e nas linhas que se seguem é conveniente que o leitor não veja allusões a um homem só.

Lampião nasceu, pois, ha muitos annos, mas está moço e de boa saude. Não é verdade que seja doente dos olhos: tem, pelo contrario, excellente vista.

$\mathrm{E}^{\prime}$ anaiphabeto. Não foi, porèm, a ignorancia que o levou a abraçar a profissão que exerce.

No começo da vida soffreu numerosas injusticas e supportou muito ernfurrão. Arrastou a enxada, de sol a sol, ganhan. do dez toctões por dia, e o inspector de quarteirào, quan. do se aborrecia delle, amarrava-o entregava-o a uma tropa de cachimbos, que o con duzia para a cadeia da villa. Ahi elle aguentava uma surra de vergallio de boi e rormia com o né no tronco.

As injustiças e os maus tratos f ram grandes, mas não decen aminhatam $\mathrm{l}$ a $\mathrm{m}$ p i ão. Elle é recignado, sobe que a vontade do coronel tem forca de lei e pensa que apanhar do governo nào é desteita.

O que transformou Lampião em besta-fera foi a necessidade de viver. Emquanto possuia um bocado de farinha $r$ rapa- dura, trabalhou. Mas quando vitu o alastrado morrer e em redor dos bebedouros seccos o gado mastigando ossos, quando já não havia no mato raiz de imbti ou caroço de mucunã, poz o chapeo de couro, o patuá com oraçóes da calıra preta, tomou o rifle e ganliou a capocira. Lá está como bir cho montido.

Conhecirlos delle, velhos, su. biram para o Acre; outros, mais moços, desceram para São Paulo. Elle não: foi an Joa seiro, confessou-se ao padre Cicero, pediu a bençam a Nossa Senhora e entrou a matar e roubar. E natural que procure o soldado que the pisava o pé, na feira, o delegado que the dava pancada, o promotor que o denunctou, o proprietario que the deixuva a fa. milia em jejum.

A's vezes utiliza outras vic. timas. Isto se dá porque precisa conservar sempre viwo o sentimento de terror que inspira e que é a nais efficaz das suas armas.

Queima as fazendas, E ama. anressado, um bando de mutheres. Horrivel. Mas cerlas vioIencias, que indignam criaturas civilizadas, não impressionam quem vive perto da natureza. Algumas amantes de Lampião se envergonham, realmente, $\mathrm{e}$ finam-se de cabeça baixa: outrus, portum, ficam até satisfeitas com a preferencia e com os aneis de missanga que recebem

Lámpião é crue!. Naturaimente. Se elle nãn se poupa, como pouparia os inimigos que the caem entre as garras? Marchas infinitas, sem destino, fome, sede, somno curlo mas brenhas, longe doe companhei- ros, porque a traição vigia ... $E$ de vez em quando a necessidade de sapecar um amigo que deíta o pé adiante da mão...

Não podemos razoavelmente esperar que elle proceda como os que têm ordenado, os que depositaram dinheiro no banco, os que escrevem em jornaes e os que fazem discursos. Quando a policia o apanhar, elle estará mettido numa toca, ferido, comend"s uma cascavel ainda viva.

Como somos differentes delle : Perdemos a coragem e perdemos a confiança que ti. nhamos em nós. Trememos diante dos professores, diante dos chefes e diante dos jornaes; e se professores, chefes e i rnaes adoecem do figado, não dormimos. Marcamos passo e depois ficamos em posição de sentido. Sabemos regularmente: temos o francez para os romances, umas palavras inglezas para o cinema, outras coisas emprestadas.

Apesar de tudo, muitas vezes sentimos vergonha da nossa decadencia. Effectivamente valemos pouco.

O que nos consola é a idéa de que no interior existem ban. didos como Lampiảo. Quando descobrirmos o Brasil, elles serão aproveitados.

E ja agora nos trazem, em momentos de optimismo, a esperança de que não nos conservaremos sempre inuteis.

Afinal somos da mesma raça. Ou das mesmas racas.

$\mathrm{E}^{\prime}$ possivel, pois, que haja em nós, escondidos, alguns vestigiós da energia de Lampiào. Tilvez a energia esteja apenas adormecida, abafada pela verminose e pelos adjecti. vos idiotas qu? nos ensinaram na recola. 
Não obstante at tendencia geral de abolir as leis que pos. sam impedir os surtos da imagunação na litteratura e nas artes, o desejo de extinguir privilegios, de libertar os málivi. duos do pezo das convencéos sociacs, a maioria dos homens giver ainda conservar a mulher e no uma boneca bem ves. uda, ou uma maceruinha pin. tada e nada mais.

Só the conecderam o direito de aliviar o peso dos vestidos.

$\Lambda$ mulher deve ter o direito de ser um individuo util á sociedade, não somente como esposat e mãe, porque aquelias que não chegaram a exerces essas funcções não hajo de continuar a ser, como etn tempos remotos, um ente frivolo, ignorante, incapaz. uma escrava to homen, um animal que não vivia sinäo para saciar os appetites do sell dono.

Podemis vir aqui mesmo que a mulher tem capacidado para trabalhar bem, como qualquet homem, em iguallade de

400.000 tubitantes, 3.000 e pouros automoveis, dois pequenos ar gynha-céts de oilo andares, ser. pentinas luminosas de gaz Néon $e$ a rio Capibaribe, forte inexgotlavel de poesia', conforme a opinião de um joven intellectual, correcto amigo das boas phrases e membro do um nuclea de letras.

$$
\text { * * }
$$

Diversões? Antes ${ }^{*}$ de quatquer outra, o ainema. Como em toda pro. vincia que si preza. Febre de som. Western Eletric, R. C. A. Weber, Fonocinex. Ein Recife, Diogenes nấo procuraria utm homem. Vararir os suburbios na pesquiza ansiosa de um oinema "without sound equipment. Isso se Diogenes fôsse um "fan" de bom gosto.

$$
\text { * }
$$

Os "hits" musicaes dos films mul. tipliaam-se nas boccas dos altifalantes als innumeravuis easas the victrolas. Depois do Rin, Recife é condições, pois que temos phar. maceuticas, dentistas, auxiliares do commercio, negrociantes. funccionarias nos Correios. nos 'Jelerraphos, ete.

rorque não podem essas mulheres dar um smples voto e citoral, quando homens muito inferiomente collocados, ntellectual e moralmente, sĩo eleitores e podem ser tamben votarlos?

Concordo que haja restri. cçócs, tanto para homens como para mulheres, no exercicio do direito do volo.

As praças de pret não derem votar ; as mulheres casadeis, sujeitas aus maridos, não votarian da mesma maneira.

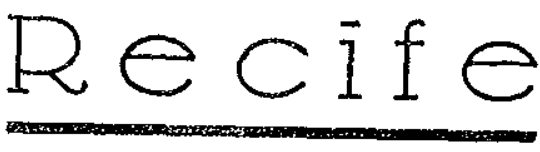

(Espocial paro NJVIDADE)

talvez a cidade brasileira que me nos respeita a sensibilidade dos ouvidos atheios. Folizmente os cinemas näo usam sirenes.

$$
\text { *** } *
$$

Os anmunoios jomalisticos do $a$. marinho "A Graciose": prginas inconfiondivess de literatura commer. cial.

$$
\text { *** }
$$

Radiomania. Antents em todos os tectos. Installaeñes "Telefunlev" no Radio Club de Pernambiteo, adus melhores alo Brasil, segundo os technicos e vamios baimistas extre mados. Depois das vinte e luas ho ras, as ondas antras aprinham Shennestralye Pitisbnor. Eo gente pode ouvir Rudy Irallée.

$$
* *
$$

Nomes pittorescos de ruas: Beceo das Almas. Rua dos Sele Pereados. Rua Lyrica.

$$
* *
$$

Buirro de S. José. A's sete horrus da manhä as pequenas fazem
Penso que ate os funccionarios publicos deveriam ser inperirlos de votar. Nas suas releções eom os chefes, $O$. funceionarios publicos achamscem situação in ferior à das mulheres casadas. Essas obedecem por amor, aquelles obedecom por medo de perseguição.

Avella historia de que a mulher éum entesinho fragil, uma pombinha sem fel, um bibilot que só serve para ser usado como joia, pintadinha, cheirosinha, e que só se d've occupar em brunir as unhas, $\hat{e}$ uma historia muito velha. Quando a muther se esquece de que pertence a sexo fraco, morde, arranha, mata, esfola, faz tudo que o mais perverso dos homens poderia fazer.

Dêem, pois, melhor educação á mulher; ensinem-lhe que o seu destino é tão nobre como o do homem ; concedam-lhe os mesmos direitos de que tanto abusamos.

"maquillage» eompleta e desbris. gam-se ats janellas com ligeiros in. tervallos alestimados as refeiguies.

$$
\text { *** }
$$

No "amerisan bar" do Hotel Central, um gargon malctio e pernostico insistena apologia do "Pink Roce Cocktail". Só perra mostrar a sua boa pronuncio inglèsa.

$$
\text { *** }
$$

O "alto circulo" atanse no Joekey. na APA, no Intencecional, no Club de Tennis eno British Conntry Clab. A inferionitade social dos outros clubs caracteriza-se pelo "Uranco a rigòr".

$$
\text { * } x
$$

Elte éo Recife ans chronistas mumdanos mais viciados. O Reaife dos poetas sstá no sìlencio catholico do Lango de São Pedro, nos becos nocturnos e na serenidade dos longos crepusculos quse adornsecem os mangues. 
Em vez de dobrat, seguiureato. Subia areo itinerario firata wats commido, porem in esiava hobi. tuario. Atê era uma nova mrapra de passear, quando ia a caminho do eseriptorio.

Adeante, quase pstrien, assustado. Alwos cripes arlejaram, ypmalurados a todas as jan llas daqualla casa: partida de aiguem para o céo. Contimuow androndo, devarar, reporando. Tru que trixăosinho brepeo no meio da subr. Seria uma crietrena? Talyos fôsse ella...

Distancion-se do rasa com as pernos diffices de arrostar, pesando. Estara ìndignado comsigo propriv, com a sua timidez que the parlibiti ver ludo claro que punha wh nevoeiro en quase todos os ensos de sua vide. Por que nûto parou port olhar melhor? Erra angustiante ir para o escriptorio com essa duviáa.

\section{**}

Taluez fosse ella... Era linfla com o seu rosto oval e paltido, stergindo entre os eabellos louros o lisos, como rema lur. Tão branca! Ta o triste ! Quem sabe si não teria noivo embarcado e perdido, on mesmo algum mal sem cura!

Wlle a queria huseto. Näo ena mu. moro. Outrem é quem fica á esquiria, horas a fio, ou passeia, para cá é para ló, em frente a ianella da namorada, incommodando os visinhos. Dile, năo. Demarom sempre em exsu oom os sens livrns. $A$. noite, trancado no quarto, escnv. dido como se estivesse a commeter a'gum erime hediondo,escrevia fatia versos. Si a paträo sousesel Fira um homem gordo e vernpliho. Um dirs, enfureado, wmarfanhou um jomal, soporque trazis am soneto logo na prigueire progina.

risso rapaz niñ erra como eskes, chetos ile atuiluiks que se approximatm immediatamente drs mocas. semicenimoniats, dizem-lhes palawras tornas, apertam-thes as minos tremulas, beojrm-lhes os aballus e as

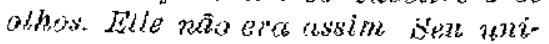
co desejo era vêta a janella, quando passava, na źla ou de volta do esoriptorin. Ape'sas, itm ocntemplativo om tialo.

fielizmente năo tinka sonhos inpostivese Náo se enganova com o persamento de que os dois se puiessem encontrar re inäos uadas algum dia. Mesmo, a pallidez da moęa the dava susto, como si já astimesse querendo a uma defuncta.

A moed nem ao menos the somria. Lemertata-se que wha vez ella the olhot iongrmente. mas dir-seria que nâs o via, que miraija coisas longinquers ... Sentiu ate vexame em anrofundar agnelles olinos que brilhnwam docemerste nomo de luz reflectida : enam dus serte ofsano, eomis o de cerlas alfures pzradas.

Do noite, sob a trompoda amiga. fremindo, inspirado, fea 1 kmirs quar drinhrs que intitulou: colhos ner. des, bom dia lis e que nâa publicrrianemed por onesa do chefe. So si fos 'e com yseudomyma.

$$
\text { ** }
$$

Chegou as escrintorio. Ya eqtrehinuto fncturas o wo mesmo tempo se querendo compucer que o crixão err pequentino remris porra ella qup allis so podia mosmo eaber uma crianca. Mus a incertezo persistia e,o que erre pebr, aisdia the fasta errar as retripas.

Comegon a olhar insistentemente - relogin. (Era tão despreoccupado das horas, antes!) Os ponteirospareciam pregados num lagar fixo, como si fossem de chumbo $e$ não tivessem force bastante para

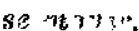

O enterroderta ser ás quatro horas, mais ou menos. Inventuria zma mentira. pedíria ao paträ́o pa rasahir antes do tempo regulamontar.

Finalmente, sonram as quatro. Parder ainda uma poroúa de minutos. indecis em falar no chefe. Como era a primeirc nez que desefava sahis cedo, rot attendido. Dis' paron para "rua, quasi correndo, sem medo de atropelar os outros. Elle que ora tão moverido em andar sempre encolhido noomdn as pasedes, parando a exala prasso parr dar pussayen a iranserntes mas apressadas. Mas, agora, dir-seret que a sua graxdo timidnz comprehendik a pressa de sua propria ansiedade. Es essa pressa, esse ryojo de prssos e expiessōes eram tüs estrrathos nelle phe o rnouz chegavo a respeital-o como si fosse nos ontros Agown, nenlezm tranganate, poderia ser mais apressado do que elle.

Qunse chegrave tarde. Nease minmento mesno, ans homens levaym o cairasosinto branes, alegrenente, e sem esfonço, porque clla deyia ser muito leve...

Como um avtomuto, juntouse ass que acompanhavam. deridido a ir atè ao remiforion. I'strüa demastrutrompite rotath e senith os nthos ardendo. enmm si quizessf whrus.

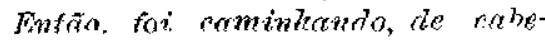
ca baira. Fgfara enveranthato. T: whre a impresano ave todo mundo botanf as olhos nelle.

A mution onsto, armisenon nimothry remith sirise do erixarosinhn, tontando medir-the o enmprimento Mas. sem sober nor anemesse instan-

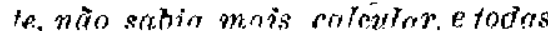
us eousas the nareciam arspropor cionndas, sem voiume sem tama nho rerto. E' que seus olhos estavam nublados, chorwam.

Deu mais algmus nassos, depois parou. $A$ inéa de que essa gente todr. o visse momando eo julgoisse aloum parente dx morta, tal. nez o seu noinn, atemorizerva- Não in to newiterio. noltava para casa nnde nodin fhorar $d$ rontade. sem dor enmfas a minnuem.

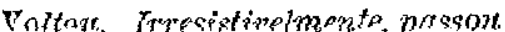

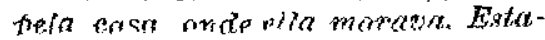
in, flo jumpllos fechrolas, no escuro dessionridrmente triste. Serita täo freil buter, pernomentror onem morreu! Mrs semmor nanmteria isto: nos casos mnis importantes $\mathrm{m}$ mais ur. rentes, ramilawa. A timinez tolhiathe of mowimentos. Afrytow-se a missos lentos, nensemdo esmorsumata mente no dia segurinte. Dir seia que os othos verdes della. patingessam reflectindo esneranra pm. sua alma.

I talvez nem fosse ella, fosta tirn irmãzinho seu .. De manha, gratudo viesse para o escriptorio, pedia sir, gue re escontra se de nowo á janella absòrta. Inncān, lambem podicz sur rue a ulasia fosse tano forte, que os seus labios se desymalassem, uma unira vez, e brbbuciassem timita mente o seu verilcifiro: "Olhos verdes, bon hial ". Was, bem no furto, tihha rectio ie ser preciso reformar. math tomde, assuas quadrinhas, assim "olhos werdes, boavirigen!"

NOVIDAUE dara em sel proxinu bumern uma muito mais amplat reportagim phom tographica, que por falta de espaço dejxul dro ser inserida hoj. 
$-6-$

\section{$\mathscr{F} \boldsymbol{u g} \mathbf{a}$}

\section{Especial para NOVBDADE:}

Teu coração vermeltho vod sobre os desertos.

Está pequena flor é uma chamma de lyrismo

no gêlo das calçadas parallelas "

edificios enormes,

cartazes de cinema,

réclames de sabonetes.

Sou eu, Bellá!

Caminho entre anjos invisiveis

na tarde habitual.

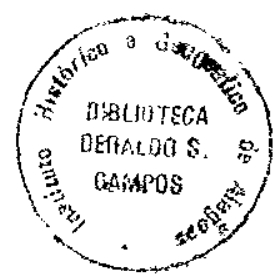

Deformo todas os volumes.

Me dissolvo

nas allucinadas perspectivas.

\section{Willy Lewin}

\section{o Carteiro}

\section{(Especial para NOVIDADE)}

O carteiro que á roite vende rosas a marafonas

e a adolescentes embriagados

durante o dia

entrega cartas de amor aos namorados

distribue emocoes commerciaes com os acambarcadares

mata as saudades dos que tem parentes varando as distancias azuis

leva pezanes ás familias mconsolaveis

Hontem elle me trouxe uma carta de mintha mäe:

mella havia noticias tristes

um pouco de lagrirnas beijos

- um leus te atuençôe no fim. 


\section{Tlovidade na Rua...}
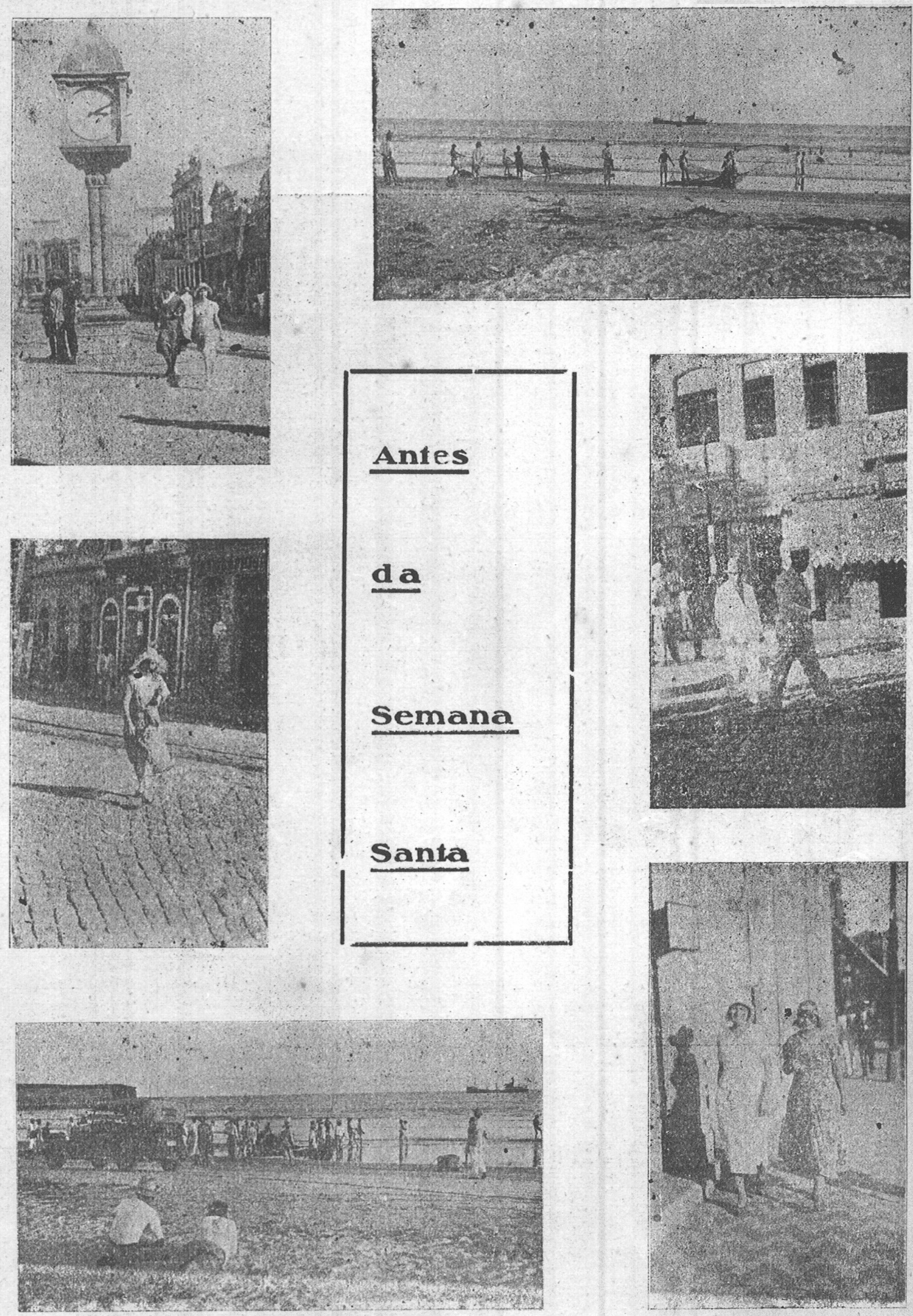


\section{$\mathbb{A} \mathbb{R} \mathbb{T}$ IPIIOT}

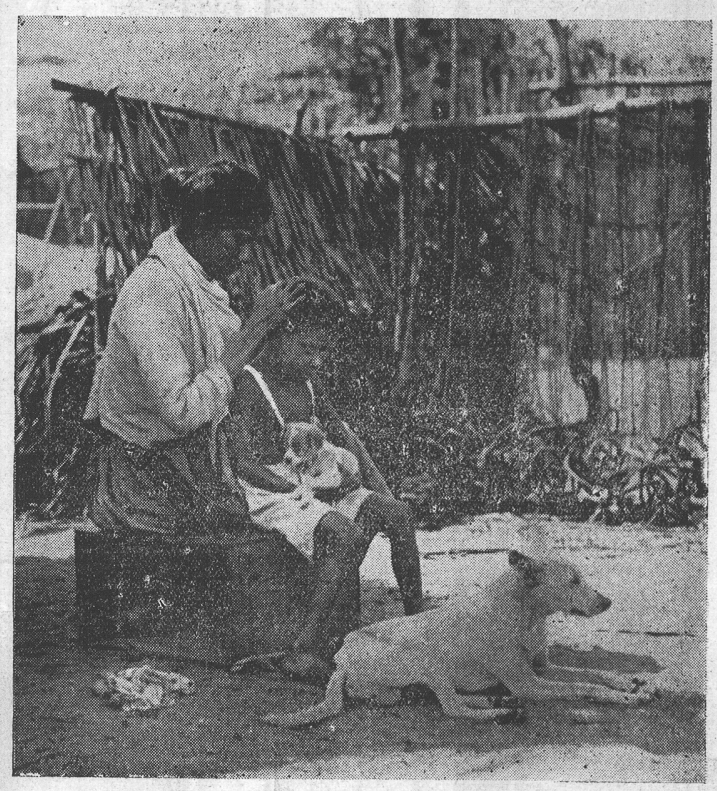

Matando o tempo...

\section{$D \in \mathbb{R} \mathbb{A} \mathbb{P} I I \mathbb{A}$}

Margem de Lagôa

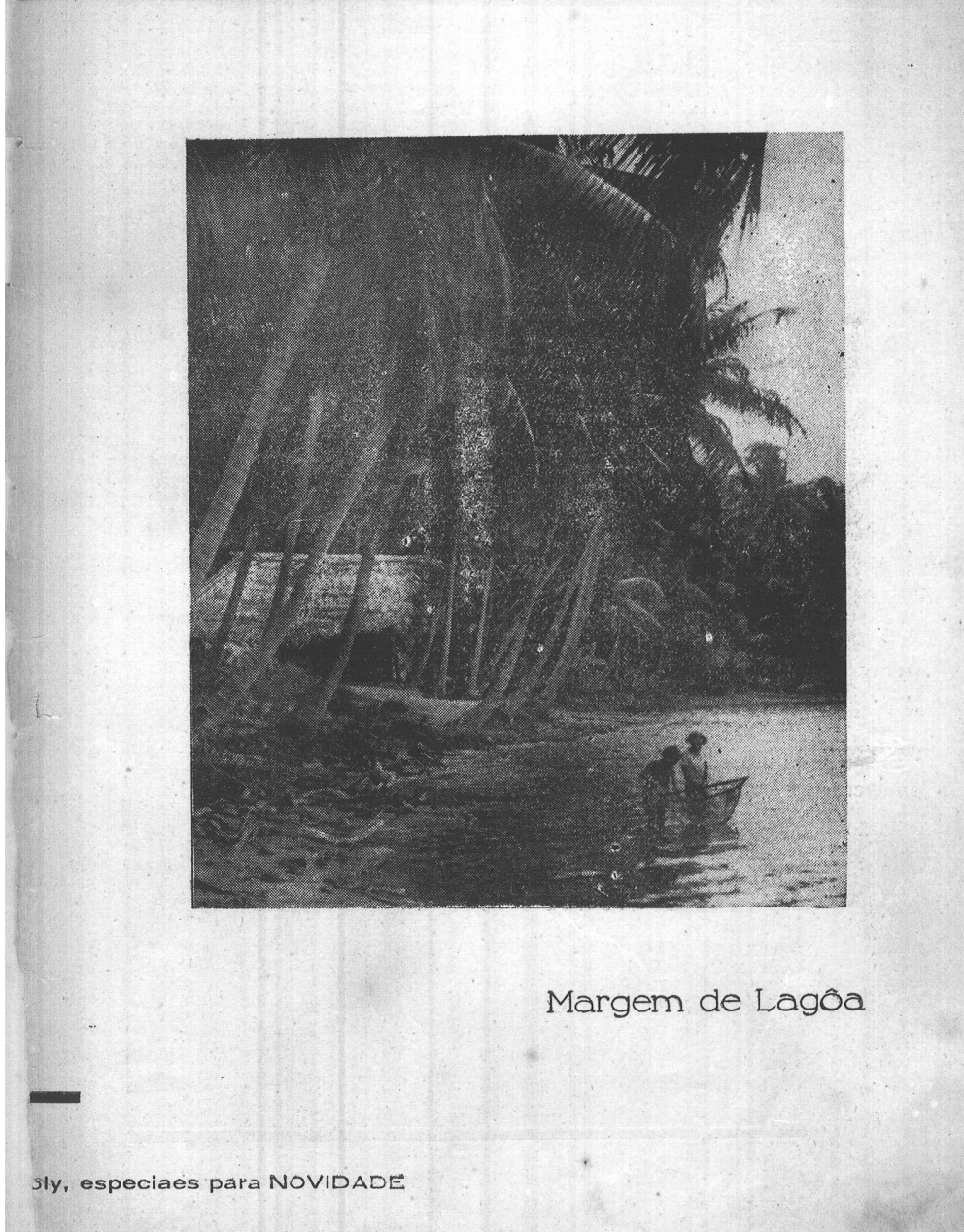

w.

Photográphias artisticas de Ismael 


\section{Cin e ma}

\section{Cinema Alagoano}

Prosegue a filmagem de Um bravo do Nordeste», o filme que Edson Chagas està fazendo.

Para tanto, já diversas sequencias foram filmadas.

Do conjunto artistico que, em boa hora, tomou aos hombros a brilhante iniciativa, se destacam rapzes e a senhoritas da nossa alta sociedade. Pondo de parte as tibiezas do momento, encorajando-se da melhor boa vontade, Edson Chagas, vem de publico dar uma prova de seu esforço, calcando mesmo futeis preconceitos, com a futura apresentação de um filme genuinamente alagoano.

Ao cinema brasileiro serão assim apresentados os nomes de Ernani Passos, Nyce Ayres, Francisco Rocha, Walmira Almeida e lilisabeth Montenegro.

\section{Alvorada do Amor}

-Alvorada do Amor» ê realmente um filme admiravel. Uma das mais bellas historias do cinema, escripta pelo genio incomparavel de Ernest Lubitsch, vivida superiormente por Maurice Chevalier e Jeanette Mac Donald.

A direcção, o đesempenho, maisła musica de Victor S. Shertzinger e o scenario de Ernest. Verja, tudo concorreu para fazer de "Alvorada do Amor o maior dos filmes sonoros até hoje aqui exhibidos e um dos maiores filmes de todos os tempos.

Há por ahi muita gente que ainda descrê do cinema sonoro.

Porem "Alvorada do Amor veio mostrar que o som não è inimigo đo cinema; que a voz introduzida com moderação e, sobretudo, com a cerebro torna-se até um novo factor que ainda mais o approxima dit realidade.

\section{F. Marroquim Souza}

O traballo de Reginald Denny em «lladame Satan", de i)e Mille, elevou-o á caregoria de importante na M. G. M.

Obteve o papel de Danillo na refilmugem de «Viuva Alegre", que Sydney Franklin vae itrigir.
- «Anna Christie» já foi apresentado ao publico.

E' a primeira vez que Greta Garbo fala nos filmes. Clarence Brown foi o directı $r$ e foram muito elogiados os Gesempenhos de Marie Dressl :r, Charles Bickford e George \. arion.
- O conhecido astro Ricardo Cortez que ha tanto tempo esteve ausente do cinema americano, acaba de ingressar nas fileiras daquella empreza, sob um contracto de larga duraçã

Continúa na pagina 15.

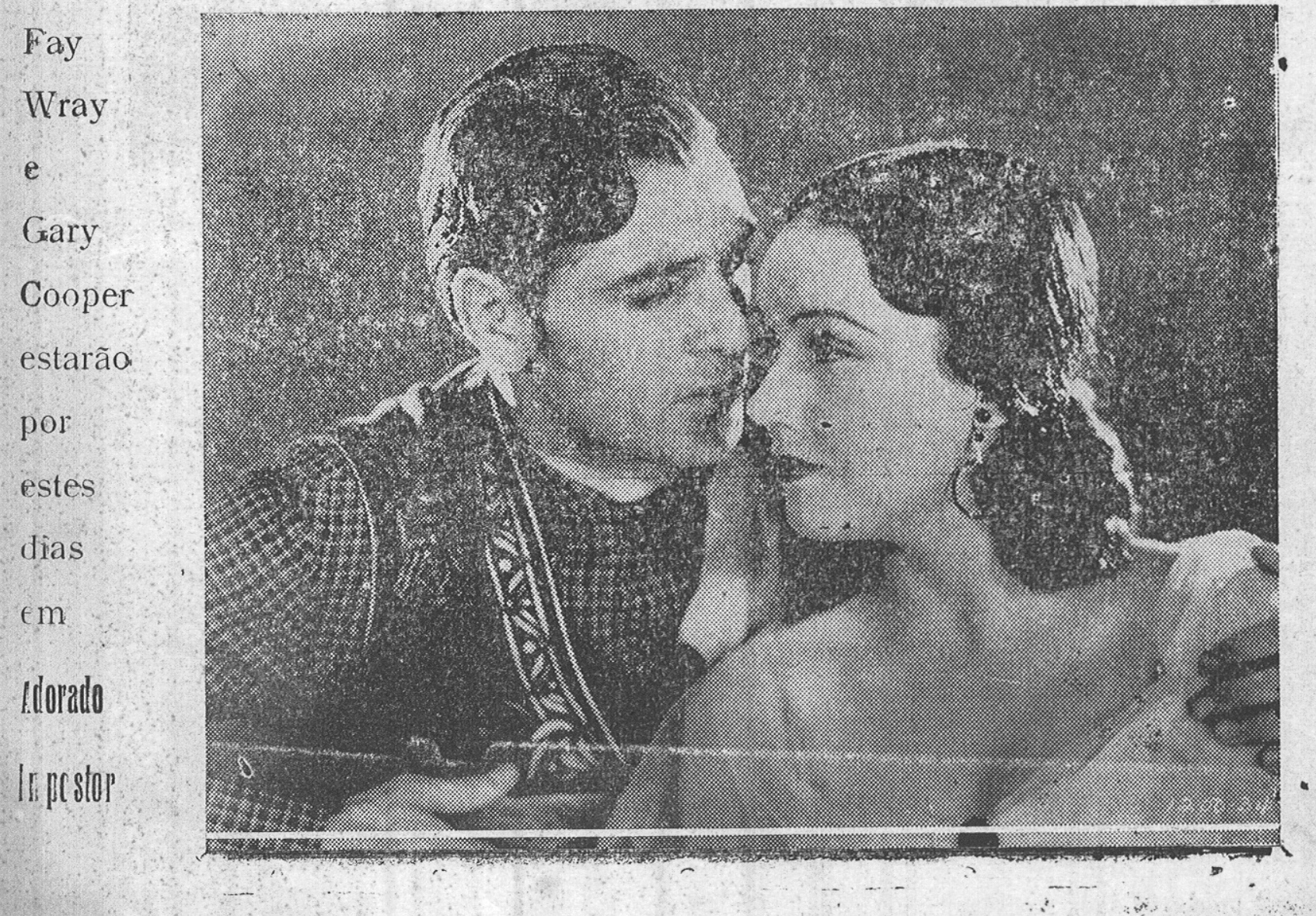


Para o habitante do littoral o sertanejo é um individuo meio selvagem faminto, csfarraparlo, sujo, cum um rosarlo de contas enurmes, cha en de couro laca re pontat. Falso, preguiçoso, colerico e vingativo Nào tem morada certa, desloca-se do Jouseiro do vadre Ciceto Dara o grupo de Lampião, abandona facilmente a mulhere os filhos, bebe cachaca e furta como rato.

E' essf, potrco m-is ou menos, o sertanejo que a gente da cidade se acostumou a ver em jornaes e em livros. Como, porém, livros e jurnaes de ordinario são feitos por cidadãos que nunca estiveram no interior, o typo que apresentam é um producto literativ. Essa mistura de retirante, beato $e$ cangaceiro, enfeitada com um patuá, duas alpercatas e muitas figuras de rhetorica, $t+$ rna-se rara. Os homens de minhaterra $p^{n}$ dem ter por dentro a cartucheira e os molambos, mas exteriormente são criaturas vulgares, som nenhum pittoresco.

Os sertanejos dos campos estiveram no Amazonas, em São Paulo e no Espirito Santo; tiraram borracha, plantaram café, voltaram com maços de notas e dispostos a esbanialas depressa. Alguns, inca azes de exercicios pesados, metteramse no exercito e na marinha, e os que haviam ido á radeia e levado pancada entraram na policia e vingaram-se.

Todos esses sujeitos regressaram muito sabidos, extranhando tudo, falanito difficil, desconhecendo os amigos,ignorando os nomes dos objectos mais corrqueiros, confundindo bode cum onça. Naturalmenet não quizeram mais criar bodes. Tornaram-se negociantes amhulantes ou arquiriram un pedaço de terra eforam $e x$. plorar otraba'ho dos ou'ros.

Os moradores das cidades leram iomaes e aprenderam bustante. A literatura e a sciencia delles que antigamente estavam contidas no Carlos $\mathrm{Mag}^{-}$ no e no Junarin Pertetuo, aug. mentou de modo consideravelConhecem o José de Alencar, o Julio Verne, a constituição brasileira e a seleccão natural.

Apparecem entre elles alguns doutores que defendem a liherdade, outros que atacam " vigario. E ha o rahula. o phar maceutico, o tabelliăa, o cai xeiro que estuda grammatica, o redactor da follhasemanal.

As pessoets notaveis do lugar são rommerciantes que passam metade dos dias encostados á carteira, cochilando,e a outra metaife debaixo das arvores do largo da "eira, tesourando a vida aiheia, tecendo mexericos. $n$ assumnto preferido é a politica. Escangatham o prefeito e o delegado de policia, vão subindo e, com ligeiras paradas nas secretarias e no gabinete do governa-

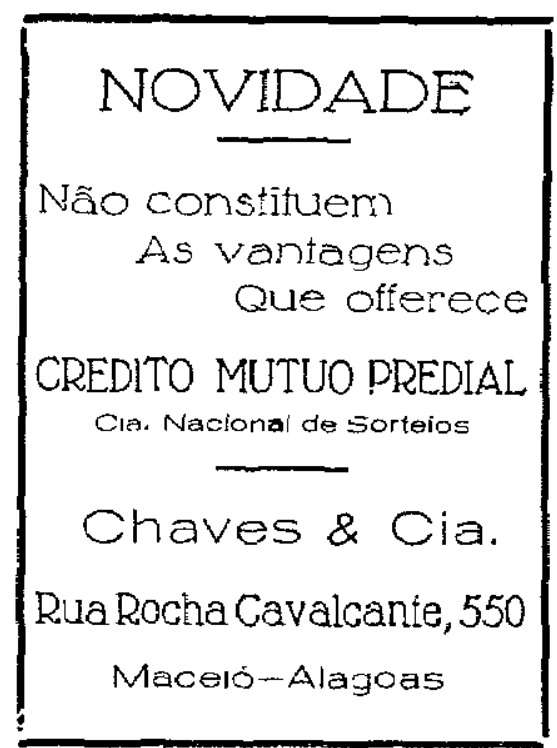

dor, acabam desmintelindo 0 miniverio a preshle!? da Republica.

Falam demais nian ginham quasi nada e comecam a sentir necessirlades exorbitantes Tìm rodovias, estrades fo ferra, luz electrica, cinema, pracas eom jardins, philarmonicas, machinas de escrever e pianos. Só faltam escolas e hospitaes. Por isso $n s$ sertaneins andam carregados de muita verminose e mula ignorancia.

Trabalham pnuco, pensam pouco. Mas querem progresso, o progresso queveem, encantados, nas fitas americanas. E progridem sem tomar folego. Numa casa velha de tajpa arranjam uma sala bonita e mettem dentro quadros, cortinas, penduricalhos.

Dancam o charleston. jogam o foot-ball. otvem o jazz, conherem obox a $\mathrm{a}$ ilizt. Ate nos jogos de cartas esqueceram o honesto sete e meio e adoptaram, sem nenhuma vergonha, as ladoeiras do poker. D'abi tiraram o bluff. que invadis o commercio e a politica. Em algumas regiões já existe 0 turf. E em toda a parte a gazo* lina, o motor U.S. A.

Entretanto os rios estāo seccos, o gado morre, a lagarta rosada deu no algodão. Tudo tãn pobre. .

Para que esse bendo de coí sas de nomes exquisitos? Não era melhor que continuasemos a cultivar a terco. $n$ reisa. do, o pastoril. a quadritha. a cavalhada, 0 bozó pelo Natal, as sortes em noites de S. Toão? Isto é nosso e é barato. O res to é dos outros e caro.

Dentro em pouco estarão todos no sertão falando inglez. Mas nós não somos inglezes +.. . 


\section{Notas}

da

\section{Semana}

$\mathrm{O}$ i jornates andinm cheios de noticias quabto à retividade dos labróes, ultimamente $A$ população de Pajussara, do Pharol, dos outros bairros, ja anda em constantes sobresal$10 \mathrm{~s}$.

0 Sur. Jack Romanguera, gerente da Cfa. Força e Luz Nordeste do Brasil, foi aggrerido, terça-felra ultima, por um motorneiro daquella companhá. Proseguem na policla as diligencias em torno do caso. vem saindo sob luma nora drecção, do Sur. Priamo Villas Bóas, tendo como redactores principaes os Surs Barreto Falcão e $M$ anoel Ondie.

"O Jornal fo Magoas" rem fayende uma (ampinha muitu jurtat quanto a localisarande de um deposito de milammares, em Jaraguá, fingto dos arinizenc a algodian, de propriedarle do Estado.

- Poi nomesilo Secretario Geral ro Estatio o Or. Amando

O Sinr. Dr. Flfredo de Maya perlia exonerarado do cargo de Secretario da Fazenda.
Destle terçateira "O Diario" fl Sampaio Costa.

\section{Escola de Gazeteiros}

Obra de um sentido admiravel de humanitarismo é a Escola de Gazeiciros que o sr. Mannel Candido acaba de inaugurar em nossa capital. Nâo se pode achar gente mais desprotegida da sorte do que esses pubres meninos, quase sempre orphãos,-especie de rebotalho da vida a quem a convivencia com a fome, a sêde, o frio e turlo, faz approximar-se demais los máos caminhos. Cảo desde cedo levados a viver por si mesmns, num doloroso «srja o que Deus quiser». F as companhias perversivas, talvez mais que a fôme, a sêde e o frio, văo aos poucos empurrando suas almas fracas para a lama, lcvand suas mâos para o virio e ás vezes para o roubo e até o crime. $O$ ensino carinhnsamente ministrado, um ensino a que nāo laltará decerto o éco le um manso catholicismo, tende a afastá essas probes criaturas de uma criminosa ignorancia, e, assim, dos, perigos de uma vida incerta.-V.
Exonerom-se do cargo de Presidente da Commissão de Syndicancia o Dr. Porto Ju nis, sendo substituido pelo Dr. Marjo da Silva Guimarães.

O Instituto Archeologico dará amanhã, ás 14 horas, a primeira "Tesperal" dat serie com que aquella associação quer seliciar a nosso publico -Tomarão parte o Dr. Orlando Araujo, presidente, o Dr. Lima Junin, Prof. Auryno Máciel, Dr. Alvaro Doria e Stas. Jerusa Porto. Hilala Calbeiros e Yryázinha Calmon.

Foi nomearlo Inspector da Alfandega de Maceió o Dr. Iulin Brasii Montenegro. conferente da Alfandeg, da Baha.

O Governo instituio $n$ dia - Pan-Ameri ano s. stendo consagrado o! de Abril aos festejos poptrlares em honra da confraternisacão das americas.

Fico! definitivamente marcalla para A custo e Selpmbro a rablinaçár da stande Feirá de

\section{Os Boateiros}

Estäo bem assanharlns os nossos boatciros. Continùa actıva, a cada esquina, a campanha inglorn do "me disseram», do cochicho q'ye retatha uma reputaçio ou uma posição verticalmente honestas. No Relogio Official, na porta do Ftoriano, nas mësas de bar, se encontram sempre os "linguas», requintando-sr. no boato como numa vercladeira obra de arte. E rebolam-se sunamante na mentir' e na infamia com aquelle mesmo deleile pervertich com que crotas crianras se esquerem a brincar com lama de sargeta. E' a revslia rat rbscuridade explustindo inconscientemente. Falam a honra de uma sia qu pass' como de nma aventureiratheatral da

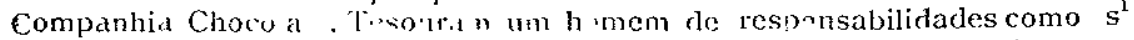
de tratasse de un a sure allatilhos cheius de medalbas, tão cheios que pareccon mesmo itvos para rommentarios.

Cá pela no i o i iñ devia a policia obrgar esses pobres 'i bos

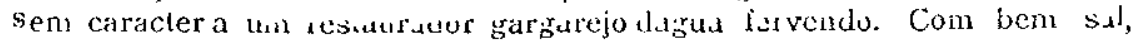
\{t se vê.-V.
Amnstras em S. Paulo, de que participarão todos os productores brasileiros.

- A policia teve uma actuação muito feliz varrendo de' nossa capital os exploradores gue se in itulavam de fakires e cartnmantes somente para illudir a bôa fé de meia duzia de crentes que infelizmente ainda existèm.

- OSnr. Secrelario Geral do-Es. tado está, muito justamente, entregure a cuidadọsos estudos dos nossos mais importantes problemas. Em breve serão postas em pratica as reformas com que iniciará a sura ohra de reorganisaç̃o administrativa.

\section{Louvado Seja N. S.}

\section{Jesus Christo}

Maceió já não pnde mais com tantrs mendigos. O pro blema fos semetrabelho estat se fundindo bem intensamen te $\mathrm{com} o$ da mendicancia. A cirlade anda cheia de mãos ma. gras, sulas. mãos em ossos como rriacóes deentias de um decenlis'a hoffmanico: mãos a que o azar da sorte imnos $n$ $n$ mais humilhantes dos misto. ros humanne A rata ascuina" sempre aquella dolorosa' supplica do Louvado Seja N. S. Jesus Christo, de tão plangente har monia que encheu os nuvidow de Joaruim Nabuen de 10 :na sensação quase inadita num, sua visita a Massangana.

A pobreza está vivenrlo hoir. mais do que nunca, uma vid: cheia de tragedia. de salour dra matico de romance ru-son

E' precion que rs h mons que controlam arfin the os destinns de tracrose... i risem surdos a esse conet... rest vungente Louralo bejar lusso Senhor Jesus Christo...-.-. 
Mille. Creme-de-Baunilha

A preferencit de mademoiselle pelas toilettes de um amarello suavemente des. colorido, fer-me marcal-a como un humano creme de baunitha que enfeita o menu da nossa vida muntana.

E' em tudo differente da nossal conhecida Mademoiselle Laranjada, que so destaca pela insuperavel antipathia.

Madrmoiselle Creme-de-baunilha, nos seus ensembles da côr dos canarios belgas, do liquido de Clirquot ou, dos thesouros patrioticos da bandira, c, acima rle tudo, uma criatura deliciosa, cuja graça a gente sorve gulosamente, mas em colherinhas, como um optimo, um requintado sorvete de ovos, leite e baunitha.

As palavras que se escepam do sor. riso de mademoiselle parecem de una pre. paração especial, de muito sabor et très raffinée.

Na companhia dessa encantadora pe quena todos. os nossos sentidos se concen. tram num só. No paladar. Nossos olhos, nossos ouvidos, fica tudo nos labios, sentindo a doçura da sua meiguice e o gosto da sua espiritualidade.

A elegante Mademoiselle Creme'de. baunilha éfndicada como suavissimo ve neno para as nossas tropicalissimas ses. sões cinematographicas. - RAMIL
MODAS

Não nos podemos queixar rigorosa. mente de absoluto máo gosto por parte das girls que imprimem un colorilo de vivacidade ás nossas ruas e no nosso fuoting, se o temos.

O nosso verão è longo. E ellas conti nuam explorando a nossa quasi eternd es tação de sol, usando interessantes trajes de sport.

Destes se des'acam os de linho li:o oll estampado, ou de fustão tambem estam. parlo, todos cum chapéo de abas largas, do mesmo tecido e das mesmas côres.

Ainda mais chics são naturalmente os ensembles de toile de soie, em côres sua ver

As boinas continúam com decidida preferencia, cedendo lugar somente aos tocs, que as imitam, collocados ao alto da cabeça.

Para os trajes de verão, que são $n$ assumpto desta chronica, os sapatos, em re. gra geral, são typo sport, isto é, muito commodos, brancos ou camouflés, e de saltos mexicanos.

Estes sapatos salientam vivamente a côt das meias, rigorosamente fumè rosèe, o clan da moderna toilette feminina.

São todos conjunctos muito elegantes que as pequenas de Maceiò estão usando com un certo it.-R.

\section{Registo de Anniversarios}

HOJE :

D. a. Bosa Merlesos Cabral e Thr. reza Duate: 'rtas bia fopea'Fer reir', Olintuna Babino, Dinira d; Oliveira santos e Maria do 1.ourdes Datrie; srs. Altonso da Rocha Y.y a, engenhwirn da Prfeitura dia capital, rel, jose' lulin, Iirannigrn de Paula fucá, Amerien de Soluza Barroc. Mujor Resinaldo Teixeira, De. neval constantino de Carvaliso e Aleysin d. Carmo lima.

AMANHA:

D. Magnolia Bimfim ; s'tos, Ridi l.esun \& Ramira Ramons : irs. Wanoel Jins de Bulboes Marques, Durval Suma Guedes, retavio Solano de Lima, José lictix do Nascimento o Sebastiano Correia.

\section{DIA 1:3:}

d. d. Naria Vieira da Silva e Re. gina Casado Cabral; srtas, Elvin a de Souza Silva, Eulina Assumpcão, Yolanda Bernardes e Glorinha Carvalho ; srs. cel, leobino Soares
Motta, Manoel de T.ima Albuquerque, Geraldo Brennand e Wilson Fiores ; a pectuena Maria Thereza, filla do dr. lorge de Lima.

DrA 14:

d. Fdla Lins Yeităo; srtas. Celestina Braga, Bellinha de I.jma Ruar. que c Luiza Bello; srs. Pedro Valeriano, Aristheu Calheiros, Luiz Ma* ciel Ferreira. Fausto Sarmento Jucá e Yuiz Lopes F. Pinto.

DIA 15:

d. rl. Allalgisa Lejte Soares, Maria, $Y$, do Cactro Arauio, Tsabel Augusta Wanderley e Cecilia Correla da Silva: srtas. Maria Josede Carva. tho, Telcilia de A raujo Lima, Cora' lina Casado de Mello e Regina de Hollanda Silva ; srs, cel, Yucio Fideles, Olympio Ferrcira Passos, Paulo Vianna de Vasconcellns, Josè Treitas Britto, Americo Coelho de Omena, Aloysio Uchua Braga e Moacyr Athayde.

DIA 16 :

d. d. Maria Jucia Duarte e Layr Braga Cavalcanti: srtas.Meria Josć cla Costa Miranda e Ienbina Correia da Silva: srs. engrnheiro João Cáa tello Branco, Alberto Passos Guima rães, Plinio Paes Barreto Cardoso dr. Santos Ferraz e Aloysio da Rocha Lima ; pequena Wanileth, filha do'sr. Brno Gonçalves, e Maria Thereza, filha do sr. Helvecio Auto DIA 17 :

d. d. Fnaura Taveiros Vano, Alda Trigueiros e Cecilia Correia da Silva ; stas. Julict da Costa Maia, Olivia de Araujo Farias e Mariinha Martirs ; srs. Antonio de Souza Araujo, cel.Joaquim Vieira Maciel, Marcos Damasceno Filho, Renat. Tavares, Agerico Vieira e Paulo Montenegro; a menina Neyde, fitha do sr. Raphael Vano Perrelli.

\section{Festas}

O "Clube de Regatas Brasil" rea" aliza hoje,ás 21 horas,na sua séde social, un sarau dansante offerecido aos seus associados e exmas, fami. lias. 


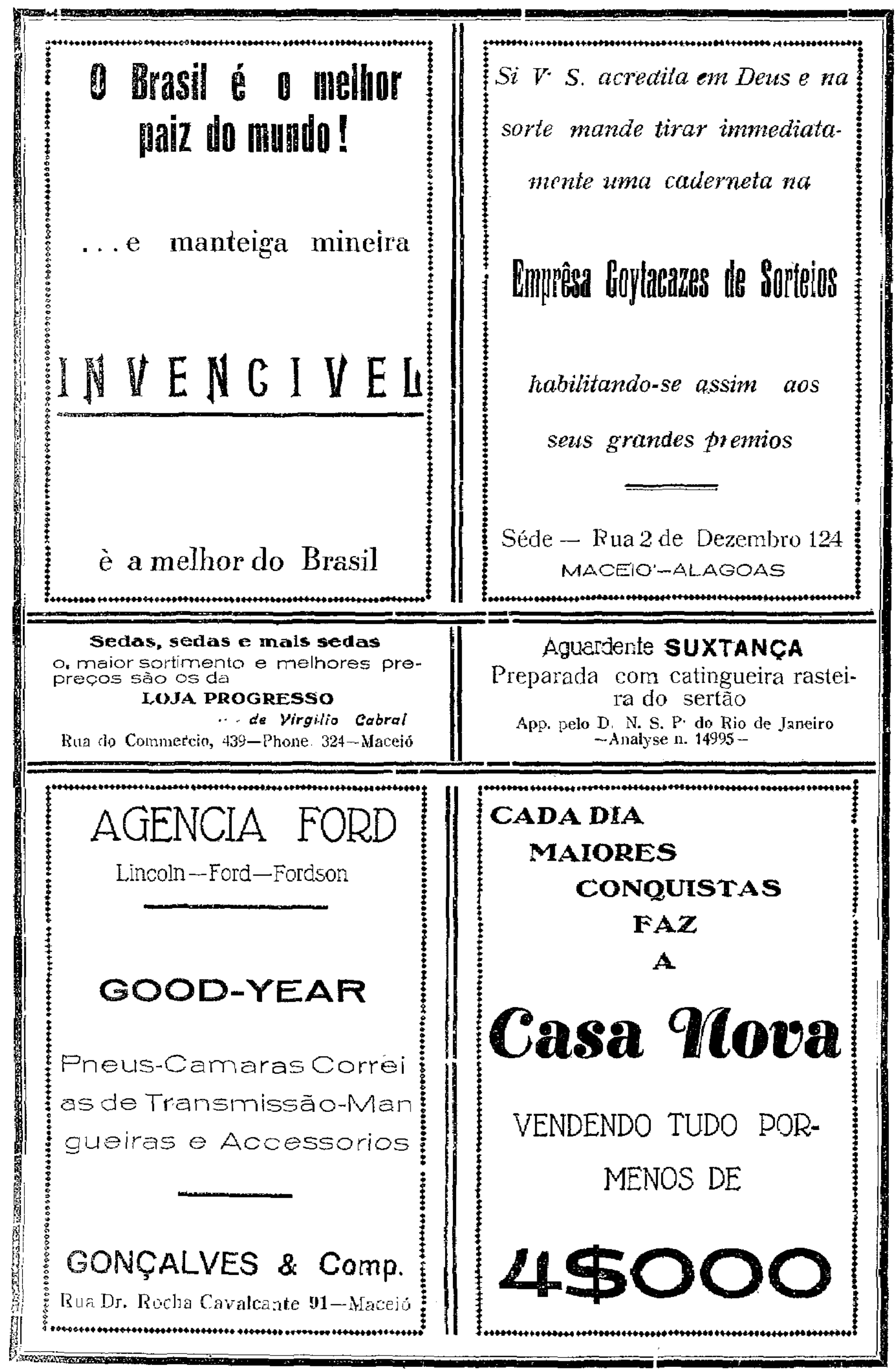




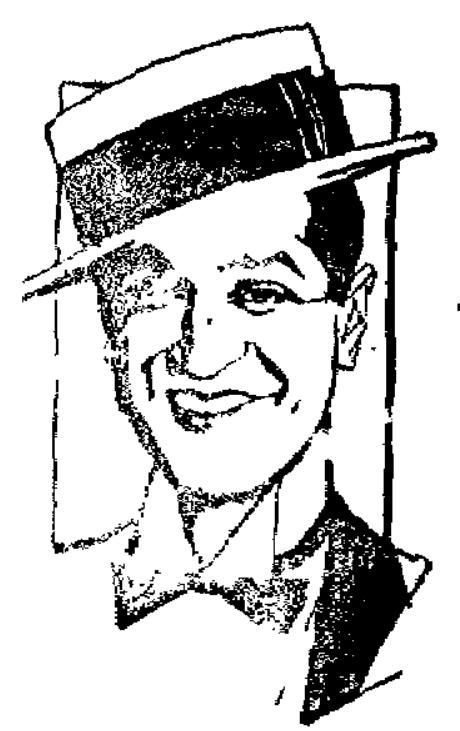

De passagem por esta capital, Maurice Chevalier, resolveu a presentar se hoje, no Capitolio, ao publico alagoano, em
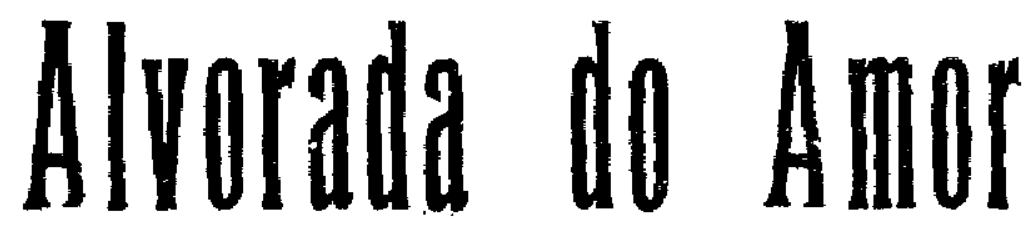

com

Jeannette Mac.Donald, Lilian Roth e Lupino Lane

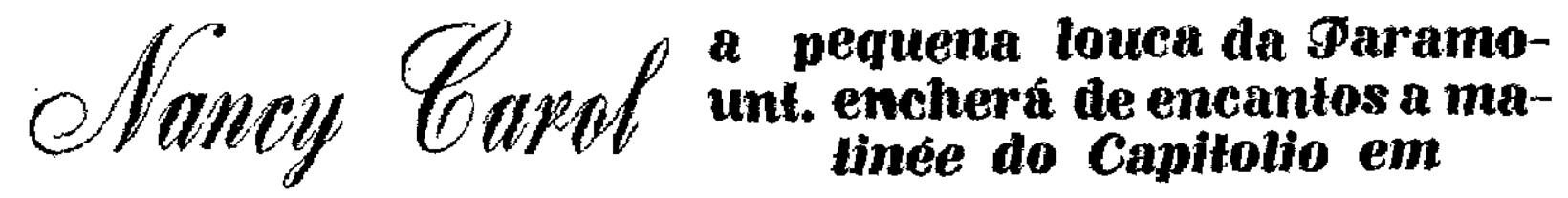
Doce como o Mel

Vejam depois:-ADORADO IMPOSTOR, com Gary CoOper; A maravilhosa mientira de Nina Petrowa e Por que te Amei.

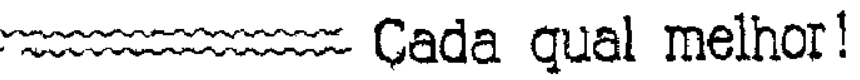

combarafar to pagina

Chama-se a Cancão do Bercro o primeiro filme inteiramantedialogads em portugues e posaro por artistris portu. gueses. foito nalak Paramount, oflmo-para cujopreparo se reu piram an Paris, jons studins de Joinvilie, os mais comeapration vuluos de moderno thentro pottugues.

- Há somente uma mulhar bellin no cinema. Fo Corinne Griffith. O rest de nos todas, sắ typrsa. E' a opiniảo de Glari: Suranson

Os melhores flimes de $19: \mathrm{n}$, na oujinio de Frederick Smith; critico dos mais coflsigrahos e jormalista de grande merito: - Cascellos no Ar. (M. G. M.) com Marie Tressler.

"Anna Christie-[M. G. M.] com Greta Garbo.

-Romancen - II. G M. com

Greta Gribo

*Caminho da Sortes - Paramount com Harolal Lloyd.

* Sem Novinade no Front-

Universal com Lew A Ares.

- Feet Firts-Parmount com

Hatold l.loyd.

c Morocent - Parasiaun te cen Gars Cooper.

- Comman Clay-liox Constance Eeanel.

-Hollidaly - Pathe com Ann

Harding.

Journey's Thd Tifang.

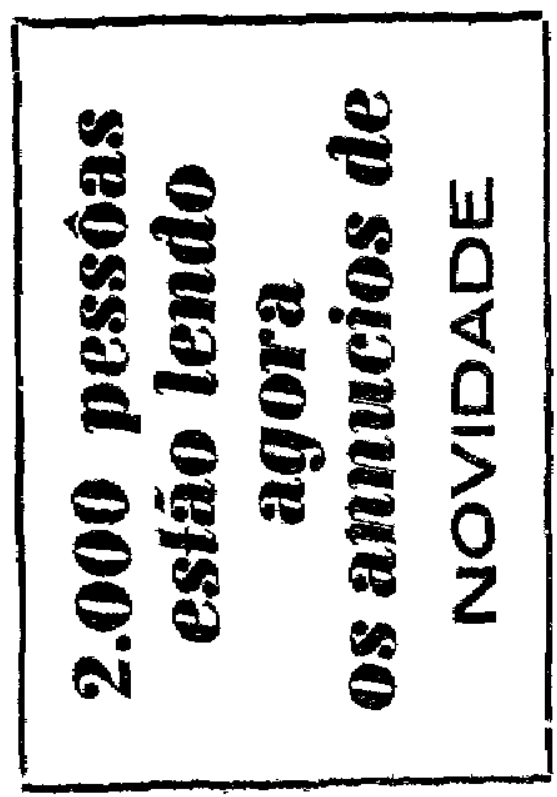




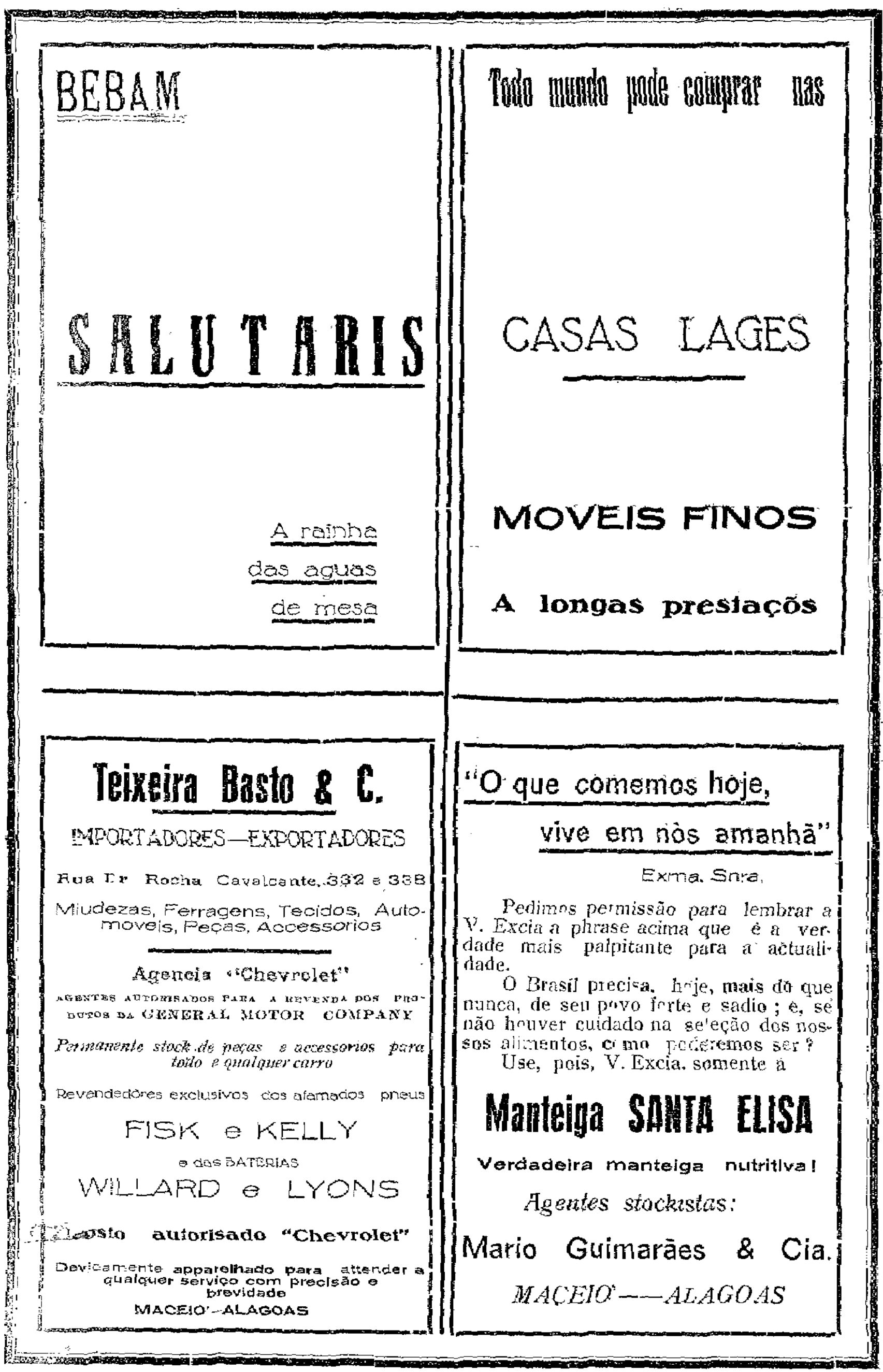




\section{Vida, paixão e morte de Novidade}

Propriamente não se quer passar aqui o atestado de óbito de Novidade. Como pais e médicos, ao mesmo tempo, fomos os primeiros a reconhecer a sua debilidade e, se apressamos a terapêutica, foi porque soubemos enxergar quanto bem lhe faria uma estação de repouso, em que se robustecesse, enchesse os pulmões de novos ares, exilando de sua vida a palidez intelectual hereditária.

Alegra-nos o lembrar, de consciência perfeita, não ter acontecido com nossa filha predileta o caso psicológico das duplas personalidades. Novidade atravessou a sua vida agitada com uma personalidade única, com uma única feição interior. Para os psiquiatras, talvez fosse preferível o contrário, porque então lhes interessaria particularmente o caso clínico endêmico. Para os políticos também, que nela veriam mais um adepto de suas virtudes de plasticidade.

A nós é que não nos agradaria essa anormalidade. Dizemos anormalidade propositadamente. Não é preciso grande descortino de vista para se perceber que a situação ruim de grande parte da imprensa brasileira impele-a para uma desgraçada falta de personalidade e de caráter. E disto concluímos que o jornal com caráter é um jornal positivamente anômalo, dessa anomalia incompreendida que obriga os homens a um miserável declínio, quando o ritmo da popularidade não os absorve.

No momento em que, fez sábado justamente seis meses, Novidade saiu à rua, uma ânsia nova de vencer nos impelia à perigosa aventura e foi como uma das nossas mais pitorescas aventuras de moços que criamos Novidade. Cheios de ideais, sem aquele pudor de surgir que vinha fazendo da nossa última geração intelectual uma geração platônica, lançamo-nos à vida dispersiva do periodismo como a um esporte. Justamente o esporte a que se deveriam lançar as inteligências abafadas no contato interrupto das bibliotecas. Não nos assustaram a largueza dos horizontes que procuramos, nem as perfídias do mar alto. Antes nos animava essa volúpia romântica do perigo na avançada. De um perigo infelizmente sem surpresas, tanto conhecíamos nós as decepções que nos desestimulariam mais tarde.

Nada, porém, nos deteve. As convulsões nervosas do meio nivelaram a simples traços tortos as linhas que tão cuidadosamente havíamos feito retas. Confundiram nesses anseios, malversaram do nosso bom-senso mas não desviaram dos nossos propósitos. Fizessem mais, tudo já estava previsto.

O que não prevíramos, e com sinceridade o confessamos, foi que nos ajudassem tantos amigos. Não nos faltava dentre os descrentes, os indiferentes e os agressivos, gente amiga e gente boa que nos animava e nos compreendia. E a estes, mais do que a nós, ficou Novidade devendo a sua vida feliz e o seu bem-aventurado descanso.

Fica entendido que não se trata de uma coroa mortuária sobre os restos mortais da filha do nosso melhor esforço. Ou talvez seja...

\section{Valdemar Cavalcanti e Alberto Passos Guimarães.}

(Jornal de Alagoas, 6 out. 1931). 


\section{Uma Revista}

Valdemar Cavalcanti

Se algum pesquisador está interessado no levantamento e estudo das publicações periódicas, de sentido cultural, lançadas na província depois de 30, espero que não esqueça o semanário Novidade, que apareceu em Maceió, há precisamente 29 anos. Uma revista pobre, de 16 páginas, que durante seis meses cumpriu o seu destino, realizando um trabalho intensivo de agitação intelectual: pôs em debate problemas da época e do meio, promoveu uma revisão de conceitos, difundiu idéias, estabeleceu correntes de opinião. E, ao lado disso, divulgou boa poesia e boa prosa.

Essa revista era feita no fundo de uma livraria - a Vilas-Boas - numa tipografia modesta: composta à mão, em tipos de caixa, e impressa numa pequena máquina desesperadoramente ronceira. Composta e impressa às vezes altas horas da noite, num ato de boêmia a que se associavam tipógrafos amigos. Um milagre de esforço e de boa vontade.

Pode-se dizer que Novidade, tal como se apresentava ao público da cidade pequena, era uma aventura de dois rapazes afoitos, insatisfeitos com a rotina da vida local, ansiosos por experiências novas. Eram eles, esses dois aprendizes de intelectuais, Alberto Passos Guimarães e este comentarista.

Mas a revista não foi obra apenas desses dois: foi de todo um grupo de poetas e escritores, empenhados naquele movimento de renovação do pensamento literário e político em Alagoas. Poetas e escritores, alguns deles, de projeção nacional, já naquela época.

Coleções completas dessa revista acredito que só existam duas. Raras, portanto. E é de ver que em Novidade se reflete todo um período, dos mais vivos e fecundos, da evolução cultural daquele pedaço do Nordeste.

O pesquisador que se dispuser a correr os olhos pelas páginas de tal semanário de 1931 achará coisas do maior interesse como documentos literários: em borrão, por exemplo, retalhos do primeiro romance de Graciliano Ramos, além de crônicas sobre tipos e aspectos do sertão; poemas inéditos de Santa Rosa (então funcionário do Banco do Brasil), Murilo Mendes e Mauro Mota; artigos de Jorge de Lima; panfletos de José Lins do Rego; e até, por incrível que pareça, poemas de Álvaro Lins e Ademar Vidal.

Colaboração, aliás, era o que não faltava em Novidade. Colaboração selecionada de valores novos e também de gente de outras gerações: prosa e verso. Em tudo, porém, a marca da novidade - era o critério de seleção. Havia o ruim - mas novo. E além da colaboração, reportagens e notícias, tudo feito num tom que, na província e na época, era uma inovação em técnica de jornal: um tom seco e direto, levemente irônico ou satírico, às vezes, quase sempre malicioso. E ainda tópicos. Tudo coisa dos dois responsáveis pela revista..

Os mais freqüentes na colaboração eram Aloísio Branco, Carlos Paurílio - mortos ambos -, Manuel Diegues Júnior, Raul Lima, Aurélio Buarque de Holanda, Moacir Pereira e Téo Brandão. Uma vez por outra, José Auto, Abellard França, Mendonça Júnior e Freitas Cavalcanti. Colaboração, diga-se de passagem, nem sempre ostensiva: de artigos assinados 
ou de poemas; uma colaboração que está oculta, em muitos casos, nas entrelinhas; nas sugestões; nos debates que se promoviam.

Pelos 24 números da Novidade se poderia organizar um cadastro de intelectuais de Alagoas. Alguns deles já desapareceram: além dos dois primeiros acima citados - Aloísio Branco e Carlos Paurílio -, Américo MeIo, Arnóbio Graça, Artur Accioli, Aurino Maciel, Barreto Falcão, Claudionor Espírito Santo, Jorge de Lima, Lobão Filho e Moreno Brandão. Mas os outros estão vivos - e vou citá-los: Abelardo Duarte, Álvaro Dória, Carlos de Gusmão, Carlos J. Duarte, Francisco Marroquim, Hildebrando Falcão, Humberto Bahia, Jaime d'Altavila, João Melo, José Morais da Rocha, Jurandir Gomes, Lauro Jorge, Lima Júnior, L. Lavenère, Luís Leça Dinis, Mendonça Braga, Paulino Jorge, Pedro Maia Gomes, Pedro Nunes Vieira, Rocha Filho e Túlio Lavenère. A esses alagoanos - muitos, hoje, deputados, professores, médicos, jornalistas, advogados de renome - juntaram-se intelectuais de outras terras, integrados no meio, então: Êider Pestana, Edmílson Falcão e Esdras Gueiros. E do Recife nos mandavam trabalhos Willy Lewin e Públio Dias.

O pesquisador topará, em muitas páginas de Novidade, com uns tantos nomes desconhecidos até hoje: José Maria de Assunção, Rubens Cardoso, Mário das Neves e outros. Nomes que seriam de elementos da nova geração do Nordeste, e que na realidade eram apenas pseudônimos meus.

Assuntos, sempre os mais variados. Os temas locais, os problemas brasileiros, as questões do mundo. Literatura e arte, economia e finanças. Variações sobre Dostoiévski e Ramón Novarro; sobre o banditismo e sobre a reforma do ensino. Ao lado de contos, poemas e esboços de ensaios.

Os dois responsáveis pelo semanário o que mais queriam era manter vivo o espírito de debate num clima de isenção, dando realce às opiniões pessoais, contanto que vivas e desde que não dessem lugar a simples bate-boca. O que era novidade - nas letras, nas artes, na política, na sociedade - era o que lhes interessava. E como repórteres catavam os fatos e os transformavam rapidamente em notícias. E como eram, modéstia à parte, um tanto vivos, estavam sempre em cima dos fatos, apanhando-os ainda quentes. E era quentes que os serviam à freguesia.

Com 24 números, Novidade acabou. Acabou antes o dinheiro para fazê-la. Mas não acabara o ímpeto nem o gosto de renovação dos que a sustentaram de abril a setembro de 1931.

O interessante é que a revista não desapareceu como em geral desaparecem essas publicações da província: sem choro nem vela. Enterradas no silêncio. O semanário pobre de Maceió teve, ao contrário, enterro de luxo, com direito a epitáfio: a quatro mãos, os rapazes que o fundaram escreveram, em jornal da cidade, um artigo, sob o título "Vida, Paixão e Morte de Novidade", contando a história de sua iniciativa e falando de suas lutas. Acentuaram que a revista se finara sem deixar dívidas, mas deixara um exemplo. Não fugira aos seus objetivos, nem se poluíra por interesses subalternos. Fôra fiel aos deveres da inteligência.

CAVALCANTI, Valdemar. "Uma Revista". In: Jornal literário. Rio de Janeiro: José Olympio, 1960, pp. 202-6. 


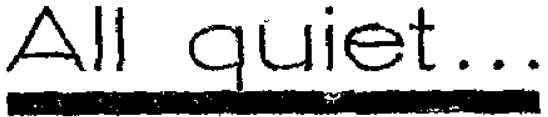

Jurandir Gomes

(Especial para NOVIDADE)

Nada de novo... Nem na frente ocidental, nem sub o sol.

Salomão e Remarquฺ tâm razão.

Cáiu-me sob as vistas um estu'to que, ha uma duzia de anos, Vito Lambardi cscreven sobre $O$ Infante na Trincheira. Ali está, siritêtico, em pilula de valur concentrailn, a drama pungrate de All quiet in the western front.

Todas as ubserv ço $s$ humanamen. te dolurosas de F. M. Remarque, se acham no trabalho ligeiro de Lombardi. the estāo a improvi. açāo das capacidades, a ancia pelas botas novas, os cirtazes de campanha, a giria das trincheiras, as comanieacöes noturnas, a boia unisa ... Sem falar no fla fla, fli fit... fla fu / vreen das bombar las impiedosa $\mathrm{e}$ is mil nutros incidentes coisas, proprios da vida lie guerta

Lá está tambem, n' O Infante na Trineheira, a passagem, th้ง emocio. nante e critica, do varguardeiro que alcanca hicenca e troca os peingos da tricheira pela admiraçäo dos incapazes : * visitado, interrogalo; tem de responter as pirgunas singulares de pess as completametate igno rantes dos horrores da guerra.

- -Na trincbeira, a que hora: vocets se deitam na cama para dormir ?

«Pobre hamem! E' ceno se the lançassem uma ducha de agua frià.

No front, a preocupaçāo com os parasitas ; na retaguarda, a máxima atençāo nas continèncias...

E' mais facil escapar á fúria duma granada, que á de um sargento es. túpido.

Toda a obra de Remarque, isso é, toda a angústia do homem das trincheiras - o humilde descenden. to do homem das cavernas, - está contida numas trezentas linhas de Vito Lombardi. เe !

-Tudocalmo no kfrentes do Oes-

E' num desses dias que morre o heról, a vitima anônima das chartcelaria belicosas: "Quando năo ha ofensivas, quando está tudo socegado na trincheira durante o dia, reina a maxima tranquilidade..., Beina a Paz.

Raul-Marques, proprie=

tario de Rio Comprido

(conclusâo)

uma gravata vermelha que trazia enrolada no pescoco. Re. 1mente era uma gravata estú. pida. Não sei como é que eu usava aquilo. Vou ver si amanhä consigo resolver o caso do Batista. Amanhã ou depois.

- Glorinha : tenho um assunto sério com você, fui logo dizendo.

Tinha me resolvido a tocar no caso. Lâ de Rio Comprilo Batista me mandara úma segunda carta. Nảo me deixa sossegado, o homem. E opio $r$ éque não sei como começar. Sinto mal-estar com esse assunto. E Glorinha espera, um delicioso at interrogativo nos ollos negrow.

- Ha a tguem que alimenta uma grande paixầ, por você, Glorinlia. (Que papel enl estou. fazenito ! S.nto Glormha dizer consigo : maluco !) Uma paixão que tem esperalo longos anos, sempre fiel e constante. Você talvez não saiba, mas é uma paix o capar até 'e sacrificios, de.. (E o bacharel comecou al ressurgir no solitário de Rio Comprido.)

Esse alguem, fui dizendo. era digno, etc. e tal. E terminei afirmando que ela podia hier a felicidade desse homem. Um $\mathrm{sim}$. Que ela teixasse pedi.la run casamento ao velho Coelho

Só faltava dizer : esse al. guen é o Batista. Justamente o princip zl. Porém eu devia estar bem perturbado. Falta de costume.

O certo é que, quando Glrrinha levantou os olhos (esta vam no chã ), eles foram tão doces, tão cheios, nem sei...

Elá se foi mais um ponto para o i do verbo simet"..

"Parto para Europa bordo Alcantara.-Batista.»

Meul bom, meu grande amigo Batista, bóa-viagen ..
LIVROS NOVOS

\section{Rubens Cardoso}

(Espectal para NGVIDADE)

Dostoiewski ainda hoje continùa a ser afigura mais impressionante da iteratura slava. $E$ dentro mesmo de toda a literafura européa a figura desse russo de gênio assume proporções de gigante, Tão extraordinária é a grandeza de sua obra. tal é a força de dramaticidade da vida que ele deixa em seus livros.

Esse epiletico admirável que Pio

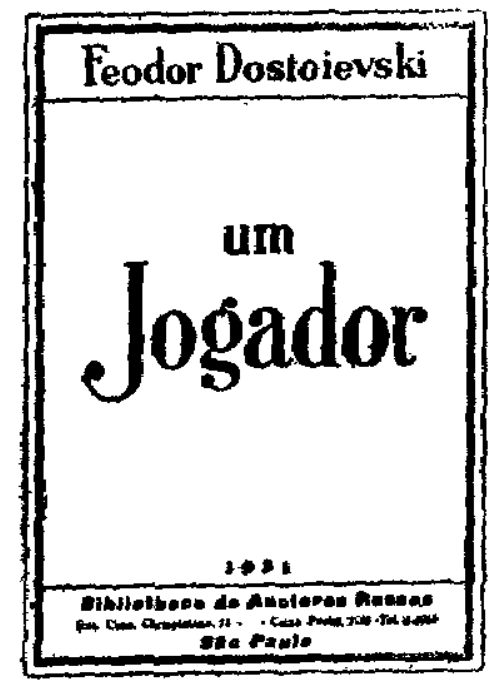

Baroja dizia ser o maior romancista do mundo deixou a mais hoffmâ. nica, a mais tragica galeria de tipos que a imaginação do homen já con. seguiv criar.

$E^{\prime}$ desse estirito formidavel a obra que a Biblioteca dos Autores Russos, de S. Paulo, acaba de editar: Um Togador. $O$ diretor resta Biblioteca, o sr. G. Selzoff, quer fazer um inte-cambio inteltectual en. tre o Brasif e a Rus.ia, começando por traduzir os grandes autr rrs ile sua terra, tais como Tolstoi, Gorki, Gogol, Tchecoff, Turguenieff, etc.

Lm Jogador é o sexto volume desta esplendirla roleçä́o

De am allor de livros tão fundameirte hum'nos como o Crime $e$ Castigo, Recordoçoes da Casa dos Mortos e $O$ Idiota, nada se porde dizer de bom nas acanhadai linhtis de um registn.

O melhor reclane para Un Jogo. dor é dizer se que é obra de Dostojewski, o maior r rmancista do sen temqo, ałém de o scr de sua terra. 
Existia um rapaz que tinha um cachimbo novo. Fumava. docemente a sombra dum parreiral carregado de cachos azues Sua mulher era joven. e formosa, arregaçava asmangas do casaco atéos cotovè los, e tirava agua do pogo. O bal. de de madeira resaltava contra o bocal do pogo e chorava como o arco:iris. Esse rapaz, fumando seucachimbo, era fe. liz, porque via, aqui e a li, voarem passaros; porque sua mãe estava viv', o velho pae ia passando bem e elle ama. 7) muito a esposa, por o'zusa de sua gentileza e dos seios duros e lisos como duas mäsâs froscas.

Eu disse que esse rapaz fis. mava u'n cuchimbo novo.

A mie adoeceu rum grande mal. Fizeram-lhe uma operaç̃o que a fez gritar muito, e ello morreit.

o pae, queia passando bem. onversava um dia com um operizio debizo wo portion d't igreginta diden que esta. va ein reparo quanilo uma pedra que se tentucm dir abobada lhe esmagou a c broga 0 bom filho chorou seus bons velhos amigos $e_{\text {, }}$ i noile, snlincona nos braços de sua for. mosa mulher.

Eu disse qur esse rapaz fu mava um a chimbo novo.

Tinhu'squeoid" de dizer que havia um veiho cão espanhol

Dezerete annos. A minha primeir namorath coincidiu com os meus exereiri s mililares no Tiro de Guerra 13 ("rernambucano). Um al s mens companheiros areulhava-s : de possuir uma "pirabe'lum" negra e luzidia, O sargento inst uctor obrigavalnos a decolar canticos guetreiros que falavan muito de Patria e offerta de virl's im hiloc tusto a Mae Commum. No melo de tudo i so, una literatura mais inoffousiva: Auri. Vorde Pendăo... Planicies côl de esmeralda., Co de anil... le Ao Ao domingos, pe a manhă, marcha para o «stan 1*. Caminhavamos en colum. n. por quatro, fuas a, h mbro es. que elle amava muito e que se chamava Thomus.

$E$ Thomas fisara muito doente depois que o bom pae $e$ a boa mãe morreram. Quando o chamavam, elle não podia mais que se arrasta1 nas patrs dianteiras.

Um dia, na pequena villa onde esse rapaz fumava um cachimbo novo, veio installasse um homom do mundo que era elegante e distincto e que tinhr uma encantadora voz. E'lles fizeram conhecimento $e$ uma vez em que o rapazque fumava um eachimbo novo entrava em sua propria c ısa, sem ahi ser esperado, achou o bello senhor deitado com a formosa mulher que tinht o: seios durnse lísos como duas macãs frescas

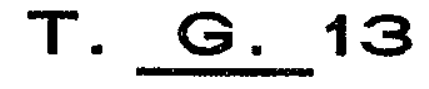 \\ (Especial para NOVIDADE)}

querdo. Eu era uma das melhores jontarias dá turmr. Picntava o alvo collocado a 150 metros e feria efficazmente as silbuetas moveis. Mas nunca q to o meu pensamento se concentrasse intciramente na recta jmasinaria que parte da alça de mira e vae atć o vertice do pequeno $\mathrm{tr}$ nngul, extremo. Eu sonbava com os olhos pretos da primeira mulher que me cortou mentiras bonitas, A lembrança obsiclente desses olhos ta vez me fizesse detestar os combrtes simulado: Nelles, eu me perdia em leus imentos dispersos. O sargento dava-nos as instrucçoes pre. liminares Organisiva os pelotoes em formaşa do de ataque. Volteation. res, munici idores, granarleiros, etc. Fxplicava-nos a raz 10 de ser da escola francesa adoptada pelo $r \times$ cito brasileiro. Com aquel a forma* căo estariamos menos expostos ao fogo inimigo e teriamos o minimo de perd is. O minino de perdas $1, \ldots 100$ homens em mil, na melhor das hy. potheses. Mas 100 homens $\mathrm{em}$ todo caso. Na Giverra Iuropéa, Charles Vi drac, Jean Coctear, Blaise Cen.

$$
\text { WILI, Y L E W Y N }
$$

() rapaz não disse nada, Ligou uma pobre e velha collei. ra ao pescosco de Thomas e, com uma corda de que sua mãe se servia outrora para a barrela, elle o conduziu oomsigo para uma grande cida. de onde ambos viveram na miseria e na dor.

O rapaz, tornodo velhn, fumava sempre o seu cachimbo, que se tornara velho tambem.

Uma noite Thomas morreu. Foram homens da policta que levaram o cadaver não, se sabe para onde.

Então o velho se achon só com seu velho cachimbo. Foi tomado durn grande frio $e$ dum grande tremor. $E$, como sontisse que ia morrer logo, $e$ que não podia mais fumar. tirou da maleta miseruvel que havia traztdo nutrora de casa um velho chapéo triste de fa. zer chorar e no qual enrolou seu cachimón. Isso feilo. langou sobre os ombros febris um manto enverdecido pelo tempo. Arrastou-se penosamente até uma praça "jardi$n a d a$ da vizinhança, $e$, botando sentido para que os guar. das não o percebessem, ajoelhou-se, esgaravatou a terra com as unhas e deposilou piedosamente seu velho cachim. bo debaixo duma moita de flores. Depois voltou para cusa e morreu.

drars poderiam ter sido tres desses 100 homens. I u năo podia cemprehender que o sargento falas:e calmamente de "um minimo de perdas" como se getratasse de uma ninharia. As detonações seccas dos cartuchos tie festim reprtiam-me espectaculosamente os velh's discursos: "A Patrinexige o sacrificio do nossa mocidale, dis nossas vidas, das nossas esperanças!" Mas, dominando esse grito, el senti outra voz mais fort", mais sincera, mais instinctiva que se erguia to fundo dos meus dez'sete annos cheins de ternura e sonhos aind intactos: "Uma mulher sim patria nos espera!" 
«Não podernos descrer que o mundo marcha para outro conficto-A 1550 é levado por muitos factores, consequen cias ainda da guerra de 1914, e quese desenvolvem dia a dias

A ninha bibliotneca bellícosa foi augmentida cum mais um livro. Aos volumes guorreiros do sr. Gustavo Barroso, ás edições de Remarque, ás obras de Taunvy; emfim ao que de melhor se tem escripto sobre guerra, juntei o "Postguerras de Ludwig Renn. Uma màgnifica ediçăo espanhola, encontrada numa modesta livraria de Recife que só mesmo os interessados conhecem. E' mais um livro que, junt ndo-se. ans muitos já escriptos sobre : guerra de 1911 , trata do grande conficto precursor e quasi causa daquelle que Ludentiorff preve para 1932.

Esse Manoelino allemão prophetiza uma grande luta em 1932 entre a França, Polonia, Tchecoslovaquia, Yugosl via e Rumania, de'um lado, Italia, Allemanha, Inglaterra e Austrik, de outro. E' um bocado exalggerado nos seus conceitos o general allemão. Não pudemos reesscrer que o mundo marcha pa a umoutro conflicto. A isso é levado por muitos factores, consequencias ainda da guerra de 1914, e que se desenvolvem dia a dia.

Nem o pacto Kellog, nem a União eur péa de Briand, nem as conferencias desarmamentistas, nada disso evitará que os estadista - procurem a sublevação do munro com a myopia de sua ambição. Nas os "xaggeros de Ludendorif podem precipitar os aronterimentos. E a tempestade virá sem narla que a evite.

Ludendorff chega a dizer que a luta serát pr vocrd, pela Jgreja. A guerra não será provocarla pela Igreja. Nem por este ou aquelle paiz. A guerra será como tem sido sempre - o producto la : mbicão de meiaduzia de estadistar sacrificando mi hares de vida. Chegando mesmo a inutilizar gr rações.

$E^{\prime}$ issn o que nos mostram as parinas de asem novidade no front., de Remarque, continula* das no "Depois...", outro livro que, se estadistas verdad iros, procurando a segurança e o bem eotar das nações, lessem. nunca teriam a ambição de provocar lutas.

0 "Postguerra:, de Ludwig é ber o dcsenho claro rleste ambiente doloroso de um campo de guerra. Esse ideal de hiberdade com que a literatura dos estadistas, até mesmo aquelles da Revolução Francềsa, têm rotulado as lutas entre povos, affirma-se cada vez como a expressão mais fina de uma ballela politica.

Subre a guerra de 1914 tudo se ten escripto. D campo sociologico tem sido pequeno para as exploraçóes de themas em torno do conflicto mundial. Os financistas encaram sob os seus olhos metalicos os aspecto economicos da guerra, Os militares rogiam as facanbas dos gandes herors traduzidas em cortiem do dian. Os politicos estudam este ou aquelle programma de governo. Apreciam outros a divirão que solfrea o majpa da Europar, a desamexaça de Estados, ett:

Emfim a geração estropiada pelos canhões, prejudicada no seu physico e até no seu moral encarou a guerra no lado verdadeiramente real que ella tem, despindo-a da pragmatica com que a cobrem.

Aliás os movimentos literarios tên sido sempre reflext (fo movimento social. Assim " foi n classicismo Assim o foi o romantismo. Apenas expres a literaria de uma epoca, de una sociedarle.

Essa literatura sobre a guerri, é o desenho doloroso, trajico, da grandeluta. 1:' a influencia reakla gue ra. Postguerra , em que Renu nos anresenta todo esse aspecto d'solador que foi a luta de 1914. ven no momen. to agudo dessa crise munrtial. As nacóes, os estadistis, os homens cultos se voliam para esse movim nto glite sa fizz sobre a guerr . le 1932 mevistal por ludendurff. E nä som $: n$. te por elle. Pur todos aquelles que acompantiam a marclia do mundo nessa vertigem de ambiçào e de odios. E' preciso quanto antes que os homens de Estado se dominem.

A hecatombe de 1 1144 nós não a devemos áquelles miseros soldad.s que, se não ficaram em Verdun ou no Marne, no Somme ou no Aisne, voltaram pata o lar com um menbro mutilado, com a vida inutilisada. Nós não a deventos au kheno porque guizesse chegaraté a Belgica,nem aos tlpes 1 orque tentassem se estender atś a Russiá Nós a devemos árs estadistas que estavam no poder. A Clemenceau na Franca, Ao Kaiser na Allemanha. Essa a unica e real verdade que se pode dizer.

As milliflóes não são c $\mathrm{m}$ sultadics para esses grandes movimentos. Ellas são impellidas a elles pelos chefes. E. isso mesmo que a observaçâo de Renu pegoal. E já era issn mesmo que em Lantag dizia Machiavel naquella sua phrase que arriplou muita ge te.

Quando os estadistas chegarem a comprehencler que tem sido a ambicáo de poder e a anc a de governo a causa do tantos desastres, então, terá o momdo chegado á paz defintival, a segurança inabalavel norque ha milhares de annos anceia a humanidirle

E os Ladendorffs clesapparecerĩo. Porque elles sentem utm prazer sadico, uma triste volupia em jogar nacões contra nações, governos contra gavernos. E os canboes estrugindo nos campos romanticos dal Rumania ou nas planici's geladis da Italia, as balas sem rotulos das metralhadoris e dos fusis vão inutilisando geraçòes intei as.

NOVIDADE organiz? franos originaes de annubios 


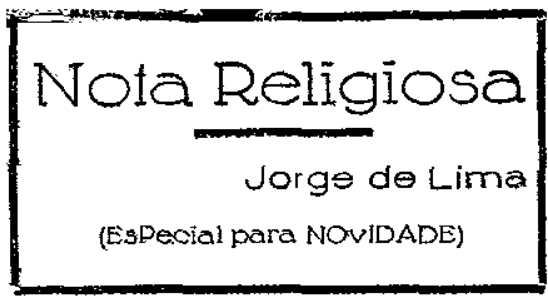

Uma coisa muito repetida e muito certa é que foi a Fé trazida pura eheroica pelo jesuita que fez o Brasil tão grande e milagrosamente tão uniforme. Naquelles tempos de Thomé de "ouza, de Mem de Sá e de João de Bolés só havia nas pindo'amas um sen. timento forte - a Fé. Sentimento rle patria não havia não. A Fé então uniu, para ulm mesmo destino de nação e de povo, o jalofo, o tapuia. e o portuga pé de chumbo.

M stu a difficil que no fimgldeu certo - uma homogeneidade d $\sim$ crenças quando a Terra de Santa Cruz era bellicosamente invadida ao norte $e$ an sul pelas heresias da Reforma. Os homens que succe eram aos jesuitas, estes jâ vinhan. rowa amin idos da ruindade pombalesca Aquelle matquẻs meti is a imilat $C$ loert e de quem Choiseul mangava na cara ( ellı.corrompen atè oclero portugues. com excepcão do jesuita, que ruagiu enquanto poude ir imp storas do ministro. Affastado o jesuita, o Marquês tomou conta de tud., inclusive a Universidarle de Coim. bra que ref rmou e abriu as portas à invasão enc fclope. dista.

Ne Cnimbra o virus pom. balino passou a Olinda, transportado por pedantes e batinas. Houve padres que fizeram revoluçños. vermelhos e innocuos porem. Hoje ha no Brasil uma religiosidade santera que o jesuita haveria de parific:tr. mai : um E-tado laieo muito penso a ruro que cheira a ath ismo. "Mas inn catholicismo de literstura (pue nem o pitiore co clas festas de porta de Igreja possue.

Mas ha, graças a Deus, uma trad ção tão forte e tão dôce como uma saudade: o exempo das vidas de Suluregra e de Anchiea.

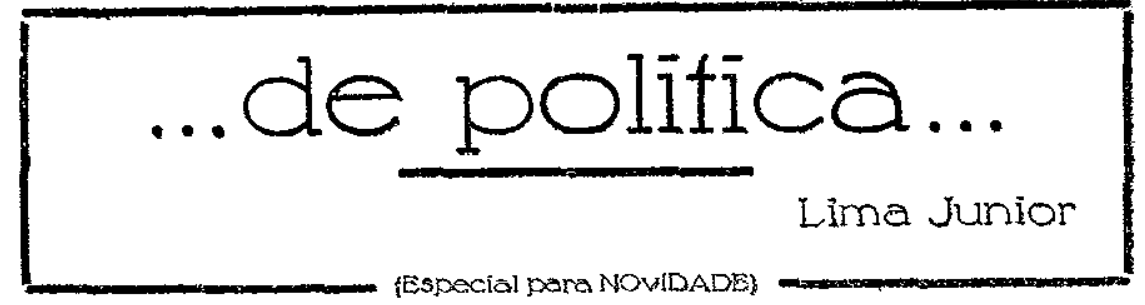

O conceito que, em regra, se faz de um dictafor é que é um homem aspero que gover* na tendo nas mãos um sabre. de soldado ou um pingalim de cocheiro de tilbury. O sr. Getulio Vargas está, entretanto, ciemonstrando que se pode ser dictador sendo-se apenas um pacato professor primario do tempo antigo : faz dictadura com a cafúa e a privação dá merenda. Só de raro em raro servindo-se da palmatoria.

Mandou pard fora os adversarios mais buliçosos Puniu os mais traquinas, tirando-lhes a merenda. Encafuou os mais iffoitos. E a ferula só sahe quando não é possivel evital-a.

Se ha, no Brasil, um homem que não tenha apparentemente geito para dictador esse è o sr. Getulio Vargas.

A gente quando pensa num dictarlor tem a ıiéa de que este es um soldado de feições aggressivas como o sr. Uriburú, da Argentina, ou um cavalheiro de olhos lampejantes como o sr. Mussolini ou mesmo um general de muitas barbas como o nosoo Deodoro.

Muito embora estes, para só falar no ultimo, que foi de casa ao assumir o governo provisorio, tenha sidlo, segundo a velho Macharlo de Assis, capaz da galanteria de levar os dedos á bocca, num beijo saudando as senhoras que o cum. primentavam ...

NOVIDADE è composto e impresso nas officinas graphicals da Livraria Villas Boas.

0 serviçn de "clicherie" $\dot{e}$ feiio no "Diario da Manhã" de Recife,
Se, tempos atraz, alguem me mostrasse o actual occupante do Cattete e me perguntasse para que daria elle, eu o apontaria para medico com clinica domiciliaria.

- Eu o acharia excellente com aquella bonhomia, com aquella despreoccupação, com aquella cara sempre aberta num sor. riso, um individuo a geito para se ficará cabeceira de um doente, consolando-the a familja e ajudando-o pacientemente a morrer.

Para dictador é que eu não o apontaria. A escolher pelá cara, peła expressão physio: nomica, pelo physico. emfim. um movimento revolucionario, eu não pensaaia nunca no ex-mresidente do Rio Grande.

Apezar. disso está elle no governo. á frente da dictadura, com ares de professor prima. rio do tempo antigo, mas um professor que não se irrita. que não esbraveja, que nào perde a calma um sò instante.

Gritam de todos os lados: chamam-o de todos os pontos; ha ruidos por todas as partes. fa\% o sr. Getulio Vargas? Aborrece-se? Queixa-se da sorte? Mette a palmatoria a tor to $\rightarrow$ a direito? Nao: o sr. Getulio Vargas não alteia a voz, häose inquieta, não perde a serenidade.

-Novidade publicará na seccão de "Arte Photographica" qua* esquer photographias de "ca. racter regional, contanto file is julguemos um chefe para a Nação, após Instantes ha em que a algazarra é ensurdecedora $\mathrm{E}$ o que 


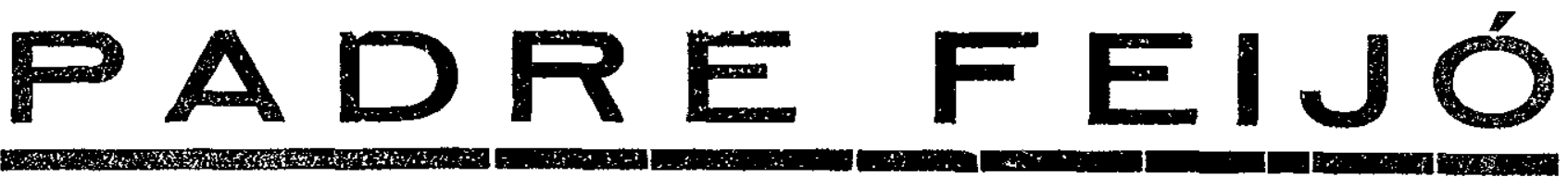

(ume pagina do live inedito "voais sobre o

sentimento religioso no Brasiln)

Jorge de Lima

Já vi um sujeit, de leitura recente atraves dos estudos de Kretschmer (Korberbau und Character) melt'r-se a faz'r diagnost cos rlassificando o fa$m$ 'so vigar o regente entre os schizides pela sua inadaptação an mindo politico e social em que víveu pe as variações de seu temperamento e pelas surprezas $d \div$ suas attitudes. Elle chamava então ao sacerdote de autista de Breul.r com a mesma facilidarle crm que o senhor Oliveira Vianna $n$ cha. mou de heroe de Carlyla. Oli. veira Vianna e Euclyd s. Tambem já vi outro encontrar n quelle politico brasileirn coisas de dissociação de personalidade e andar m'xendo a vida do padre com theorias proustianas e reminisconcias de Amiel. $\mathrm{Na}$ verdade, um homem que era liberal em religião e conservador como politico, sendo, ao mesmo tempo, minist ro ton. surado da Igreja. dá qu $\rightarrow$ pensar mesmo. Como politrco, dizem todas os $s$ us biographos que elle foi um homem providencial Com effeito: Peiro Primeiro, quando o vigario assumiu a govern , era o motivo de toda a desordem espalhada no paiz, porque o pe-soal mais achegado ao bragantino, não se acomodando com a abdicacão do imperador, distribuia o boato terrorista, impotente pa a tomar outra medida que não fôsse espalhar o mêdo e a confu*ão n, paiz. Não só na Côrte isso acontecir; em Panclas e Jacuhype andava um esfolaesfola medonho e no mesmo rojino a luta fratricicla pretendia afogar num diluvin de sangue is terras seccas do Ceará. Tambem dizen que o sentimento separatisla crescera muito por uma eipecie de excesso de autonomia local sobrevinda depois da abúlicacĩo. Veru o homem providencial e com simples palsanos transformados em Guarda-Nacional, dissolvendo o exercilo, delendeu a 'egalidade. E' bem verdade que nós vinhamos da Colonia, com um exercito que não era bem ex rcito. Mas seja como for, elle dissolveu aquelle exercito. Policiou a nação, moralisou todos os funccionarios publicos, uniu o Brasil desunido pelo furor separatista $\mathrm{e}$ assentou no Rio de Ianeiro o centro para onde deviam convergir as provincias entr̃o desorganisad is pelas intentonas, pela anarchia e pe'a guerra. Iss, quer dizer que a regencia trina entregs ao homem um paiz encrencadissimo e elle desencrencou o paiz.

Devia ser um sujeito muito energico. Asseguram que elle uma vez disse: Venço pela forca moral, e sendo preciso, pelo emprego das armis (e mostrava os seus julsos de ithleta). Contam tamben que gostava de ameaçar assim : * $\mathrm{Ou}$ faço isso ou entrio vae haver o diábo !?

Ou José Bonifacio deixa a tutoria ou eu deixo a past da Justiça!

Ou a confirmação do bispo do Rio de Janeiro faz-se em trinta dias ou o Brasil separase da communhão romana!

Vè-se que era homem capaz de ameaciar Nosso Senhur. Tudo para crear no Brasil isso: o respeito à autoridade. Creou - medo à autoridade fazendo a nação temente a ella. No meio

NOVIDADE - é compos. ta $\theta$ impressa nas ofilinas typographicas da L.iv. Villas Boas

NOVIDADE - nào tceita coliaboraça com pseudo. nymos dos palavrosos Andradas elle bancou sempre o callarlo, possivelmente não como reaccão á emphase daquelles politicos, mas talvez tambem porque não tivesse palavras. Pobre de palavras mas rico de acção e de energia. Mal o enfronham de ministro da Justiça e regente, corta preliminarmente as ami. sades, não quer saber de nin. guem para que os amigos não compromettessem o Estado Pelo Estado se tornou inimigo da religião, como se a ordem que elle aspirava para o Brasil não estivesse dentro da religião. Ameaça de prisão o proprio bispo da Bahia, elle um simples padre. Esse vigario nos dá a impressão de que se elle visse Jesilus expulsando da carcassa de um nessoal de Capharnaum (não estou certo se foi mesmo de Capharnaturin) os espiritos immundos que martyrisavam aquella gente e depois com a força do milagre mandar os demonios occupar as banhas de uns dois mil porcos que fussavam por ali, os quaes com a occupação demoniaca morreram logo afogarlos no mar, ordenaria, esquecendo 0 beneficio immenso do milagre. prender Jesus pelo prejuiso que houvess: dado ao rebanho nacional.

Desse modo foi um vigario que -sempre collocou em primeira plana o Estado, em se. gunda o homem (casar o padre por dever de obediencía a uma lei natural/, em terceira a roligião, que opprimiu atè quando dispoz do poder e da força. Para isso foi inflexivel $\mathrm{c}$ nunca consultou o coração, pondo em jogo todas as idé s líberaes que the latejavam na cabeça, tão isolada do coraçẫo por um colarinho enormissimo e duas dobras de gravata. 
Dom Casmurro. Rio de Janeiro, 12 de dezembro de 1942. Ano VI, n. 280, p. 3.

\title{
O MODERNISMO MORREU?
}

\begin{abstract}
DESAPARECEU EM 1930, DIZ O ROMANCISTA GRACILIANO RAMOS PREPAROU O CAMINHO ÀS NOVAS GERAÇÕES - OPORTUNIDADE AOS BURROS E MEDÍOCRES - OS ROMANCES EM UMA SEMANA - "NÃO SOU MODERNISTA" - OS MAIORES POETAS E PROSADORES DA ATUALIDADE BRASILEIRA - "TALVEZ SEJA NECESSÁRIA UMA NOVA REBELIÃO CONTRA OS GRAMÁTICOS!...” EXCLAMA O AUTOR DE ANGÚSTIA.
\end{abstract}

\section{Inquérito de Osório Nunes.}

O nome de Graciliano Ramos está inscrito entre os romancistas que melhor definiram o gênero, no Brasil, de vinte anos para esta data. A obra literária que tem criado assume expressão de grande atualidade. É sempre um espírito em busca de horizontes. Daí, talvez, ou muito provavelmente, a posição em que tacitamente o coloca o conceito geral: entre os "modernistas", ou seja, no seio dos emancipados de e após 1922. Essa enquadração não lhe satisfaz e empenha razões em contestá-la. Mesmo assim, continua a ser julgado desse modo. Tristão de Ataíde considera-o um escritor eminentemente do momento. E essa é a situação que, de fato, ocupa na literatura nacional.

À porta da Livraria José Olympio, encontramos o escritor nordestino em um grupo de confrades. Graciliano Ramos é quase arredio. Tem mesmo um ar reservado de sertanejo. Sua cabeça grande, onde os cabelos brancos começam a absorver os fios pretos, quase não se move. Está sempre na mesma atitude de pesquisa silenciosa. Apenas o olhar se agita e vem para baixo dos óculos de leitura, toda vez que uma observação mais curiosa se faz digna de exame.

\section{O MODERNISMO MORREU EM 1930}

O autor de Angústia responde com precisão à primeira pergunta:

- O modernismo morreu em 1930. Aliás, não se pode fixar, rigorosamente, esse ano como o do seu perecimento. O que se observa é que, pelo menos nas cercanias de 30 , o modernismo surgido com a Semana de Arte Moderna desapareceu.

Graciliano Ramos explica as razões de sua afirmativa:

- De 1922 a 1930, verificou-se um movimento de destruição dos cânones que precisavam desaparecer. O movimento não nasceu em 1922. Concretizou-se no aludido ano. Era um sentimento que tomou expressão e foi ao combate. Desde então - acentua o romancista - nada pôde ser realizado até 30, quando começou um trabalho de criação dos mais brilhantes, até 1936 . 
PERGUNTAMOS qual a contribuição que o modernismo ofereceu à inteligência nacional.

- Como reação, foi excelente. Mas, dentro do ciclo que já mencionei, não vejo outra realização de vulto que não a libertação das cadeias do espírito. Creio que é o seu melhor fruto. Porque na prosa nada conseguiu realizar. Mário de Andrade e Oswald de Andrade tentaram o romance. Mas sem êxito. Enquanto a poesia adquiria expressão, o romance modernista não tinha conteúdo. Creio, entretanto, que se não houvesse a independência do modernismo, José Lins do Rego não teria conseguido realizar o seu romance, tal como o é. A revolução concretizada na "Semana de São Paulo" teve um serviço: limpar, preparar o terreno para as gerações vindouras.

\section{NÃO SÓ OS MEDÍOCRES - BURROS, TAMBÉM}

- O modernismo fracassou - prossegue Graciliano Ramos, atendendo a uma pergunta sobre a mediocridade no movimento de há vinte anos. Pois fracassada está uma rebelião literária cujos soldados acabam na Academia. Renegaram a atitude do passado. Uns, de público. Outros sub-repticiamente. Nenhum dos seus poetas faz mais, a rigor, poesia modernista. Nem mesmo Manuel Bandeira, que, por sinal, escreveu os "Sapos" em 1918. O próprio Mário de Andrade está escrevendo direitinho, bem comportado. Só de longe em longe, surgem umas expressões que lhe são típicas. Oswald de Andrade modificou-se. Menciono apenas a camada superior da gente de São Paulo. E o grupo secundário? Nesse nem se fala...

As portas largas do modernismo abriram caminho não só às mediocridades: a autênticas burrices. Todo indivíduo que não sabia ou não podia escrever certo agarrou-se a liberalidades e extravagâncias. Queriam imitar Manuel Bandeira. Não possuíam, entretanto, a cultura e os conhecimentos deste. Daí o falso valor que certos cavalheiros ostentam orgulhosamente por aí, trepados na glória que de outro modo não teriam conquistado. E o outro resultado: todo menino saído do liceu pôde escrever poemas em cinco minutos e romances em uma semana. 


\section{E AS ESCOLAS DO PASSADO?}

- Em face das escolas que repudiou, qual seria então, a seu ver, a posição do modernismo? pergunta o jornalista.

O nosso interlocutor detém-se um instante. Retruca:

- O movimento impunha-se. As restrições e a improdutividade do ambiente que cercava os novos animaram a rebelião. Na poesia, o grande era Bilac. Por aí, pode-se inferir o que eram os demais. No romance, apenas Lima Barreto. $\mathrm{O}$ resto não merece consideração. O modernismo viria derrubar, num autêntico trabalho de menino, os gigantes de pé de barro, os ídolos sem consistência. Começou com as irreverências de Agripino Grieco e marcaria a sua data com o transporte de Graça Aranha aos ombros de Augusto Frederico Schmidt e Tristão de Ataíde.

\section{NÃO É MODERNISTA}

- Eu vendia fazendas no interior quando soube do movimento. Naquela época, lia tudo e acompanhava o barulho de longe. Apenas aplaudi.

- E não se sente, portanto, ligado à rebelião? - perguntamos.

- De modo nenhum. Não fui modernista, nem sou 'post-modernista'. Sou apenas um romancista de quinta ordem. Estava fora e estou.

- Como pode explicar, então, as versões que o classificam entre as expressões conseqüentes à 'Semana'? - queremos saber.

Graciliano Ramos esboça um sorriso divertido e diz:

- O modernismo presta-se, admiravelmente, a todas as confusões...

\section{O FAVOR PÚBLICO}

Fala, agora, o nosso entrevistado sobre a indiferença do público em relação à poesia modernista:

- O favor público nem sempre é expressivo. O povo ainda lê, com muito interesse, a Moreninha. 


\section{OS NOMES ATUAIS}

- Não obstante, há nomes que se impõem. Encontramos na poesia Manuel Bandeira, Augusto Frederico Schmidt, Carlos Drummond de Andrade, Jorge de Lima e Vinícius de Morais. O romance apresenta José Lins do Rego, Raquel de Queiroz, Jorge Amado, Érico Veríssimo, Otávio de Faria, Lúcio Cardoso, Amando Fontes e Cyro dos Anjos. O conto - uma das excelentes realizações do movimento - dá Luís Jardim, Marques Rebelo, Aurélio Buarque de Holanda, Telmo Vergara, João Alfonsus e Oswaldo Alves. No pensamento filosófico não vejo ninguém. E não sei por que ligar, na sociologia, o nome de Gilberto Freyre ao modernismo.

\section{ABAIXO OS GRAMÁTICOS}

PARA finalizar, Graciliano Ramos confia-nos uma observação, que denota o seu espírito investigador e penetrante:

- Receio que tudo isso - tão criadora agitação - desapareça e que o período que virá seja talvez pior do que em 1920. Voltará a crítica Duque Estrada, que já se ensaia, manhosamente, nos restabelecidos consultórios gramaticais pela imprensa.

Graciliano Ramos detém-se para acentuar o efeito da sugestão:

- E será preciso outro movimento modernista contra os gramáticos!...

O modernismo morreu? - Resposta de Graciliano Ramos ao Inquérito de Osório Nunes. Dom Casmurro. Rio de Janeiro, 12 de dezembro de 1942. Ano VI, n. 280, p. 3. 
Quem mais responsabilidades administrativas acarretou para as funçōes de mando na Segunda Republica foram justamente, $e$ irre* fletidamente, os homens desta Segunda Republica. E' que êles espalharam ter-se de abrir combate franco ao nosso mole temperamento de sentimentais, pondo em luta os tecnicos contra os romanticos de antigamente. Um compromisso, portanto, muito mais serio do que se pensa.

Em verdade, os erros da outra Republica estavam nesse sentimentalismo da herança etnica "Somos o pais mais rico do mundo». O mais belo» ete. $E$ olhavamos a paisagem. $E$ mais: legalizara-se uma triste conilescencia para com os amigos, um pendor afetivo para com os fieis da mesma igreja, lovando gente a mais seria a posições incomodas, $e$ predispondo-a, assim, para a chapa, muito comum na giria revolvcionaria, de Ladrões du Velha Republica.

U'm exemplo dessas fraquezas sentimentais, para citar um grande foi o sr. Washington Luis: entrou no Catete fazendo misticas e supersticiosas genuflexöes a um cruzeiro que nâo podia existir; instituiu em. seu regime externo $e$ interno aquelle esplendido e dubio "far-se-á" (a que faltava naturalmente o "se Deus quiser»); e saiu do leme do pais com os olhos melancolicos de exilado franciscanamente pregados na Imitação de Cristo.

Os tecnicos do Brasil Novo nâo vieram somente combater maies politicos nāo. Vieram verticalizar esse «baixo temperamento sentimentalista» que tanto nos prejudicava. Se bem que sejam talvez os nossos erros politicos a unica coisa verdadeira- mente nossa que o Brasil possue. Porque está se vendo que sâo erros do nosso temperamento, não são errostimportados da estranja.

Já parece enfraquecer, no entan. to, essecombate a nossa tara idea. lista. E' a impressão que nos dá a atual paisagem politica do Brasil, com os tecnicos falhando. Não falo, está se vendo, de um Whitaker, de um José Americo. Poróm, pará não deixay afirmaçôes no ar, olhemos a cinzenta situação do velho Assis Brasil, um homem que durante 20 e tantos annos intraduziu-se em li. vros immensos de agricultura. Comparando mal, o ministerio do velho gaúcho tem sido um tiro de polyora sêca...

Quando se esperava, portanto, dos homens da revolução purificadora um diagnostico exato das graves complicąões arganicas do pais, seguido das receitas de medicos es. pecialistas, romecam (iustamente estes) a bambear, a dar de banda as suas convieções.

Os tecnicos vâo sendo abafados pelo peso dos problemas a resolver. Edeixam para amanhã o que poditut fazer hoje. Instintivamente pensando em depois-de-amanhã...

Lembram em alguma coisă, esses teenicos da Segunda Republica, aqueles escritores do romantismo, vi. ciados em doces e bucolicos idilios, e que, com a apariệa do naturalis. mo. tiveram de entrar bruscamente peles alcovas. Mas apesar de tudo a gente sentia os romanticos mesmo quando remexiam panos sujos..

$E^{\prime}$ o nosso caso. Andamos, viramos mexemos, e no final das contas som mos os mesmissimos sentimontois de hontem $A$ diferença é apenas de perspectiva...
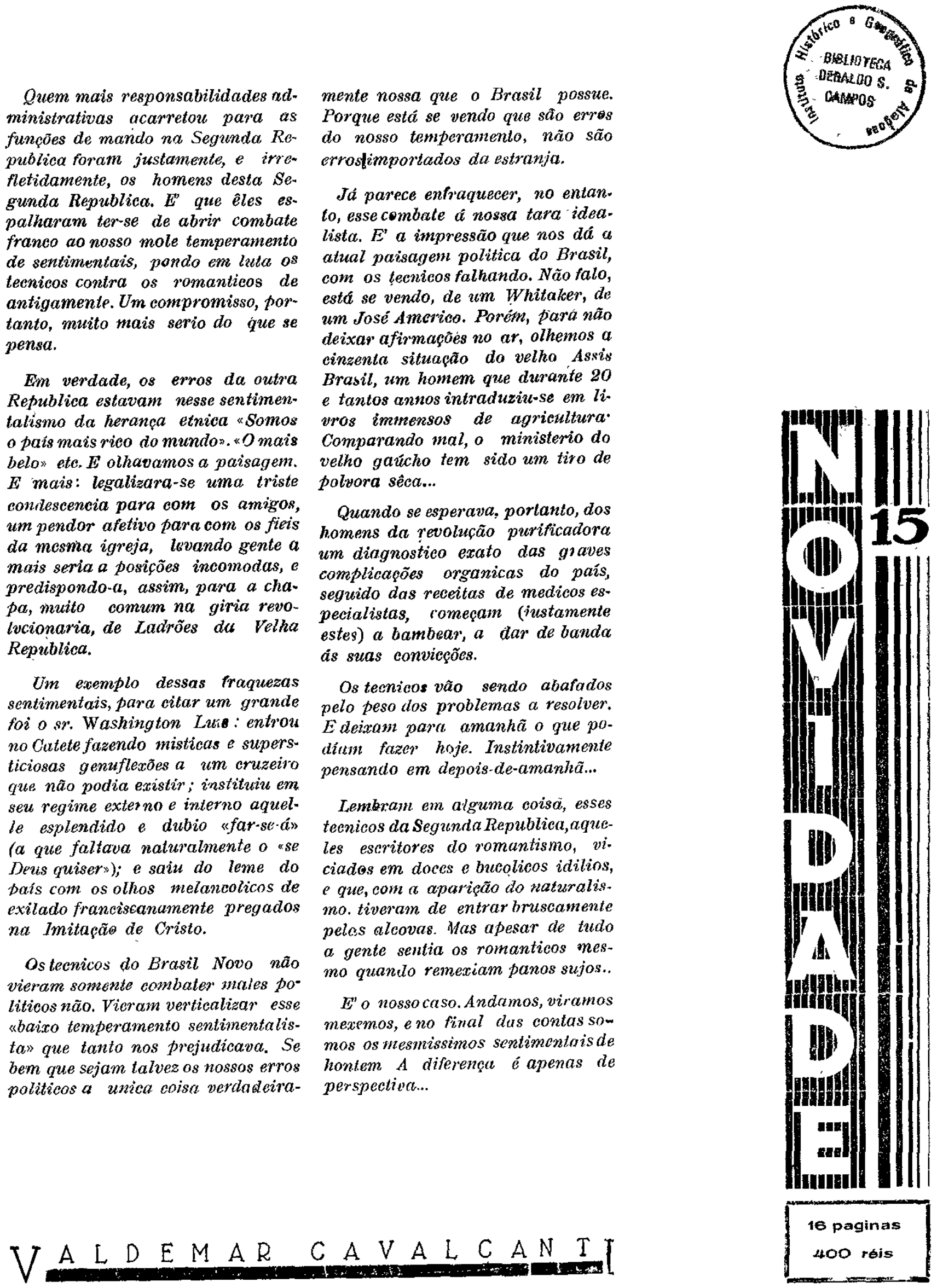


\section{$\begin{array}{llllllll}N & O & S & S & O & M & O & S\end{array}$ MESMO DO AMOR...}

Como fotografo o sr. Paulo Frado tem os seus defeitos. O retrato que tirou do Brasil não tïcou parecido não. Ele deu pra gente umas sombras carregadas de melancolia. Ficamos tristes como $\_$se estivessemos de luto fechado por dentro da alma. Aliás o Brasil tem pouca sorte com retratistas : ou é porqueme-ufano-do-meu-país oué esse sombrio retrato do sobrinho de Eduardo Prado. Embora se saiba que este, por mais triste que seja, é dez mil vezes menos prejudicial do que a balada sentimental do conde carola. "O Retrato do Brisil» $\dot{e}$ um livro aom os seus pantos falsos, mas um livro serio, que nos leva $a$. reflexão; $\dot{e}$ o livro do homem que em 28 jă previa'a Revoluçâo como uma das duas unicas soluçôes (a Guerra era a outra) pura os desregramentos do regime passado. $O$ "Porque me Ufano" é um livro imbecil, perigoso para a infancia porque dá do Brasil uma impressâo de paraizo; o estribilho a cada pagina é a mesmo-O Brasil é o melhor pais do mundo. A modos de quem leseobriu uma botija. Porém essa mistura de Paulo Prado com Afonso Celso é que está horrorosa.

o brasileire nâo é o bicho jururú de Paulo Prado. E' inegavel que suas ancestralidades cheias de defeitos, suas herancas de vicios e degenerescencias, acinzentaram-lhe um pouco a alma. Não somos um povo alegre, ianquemente divertido. Para isso é que nâo nascemos com a nctavel inferioridade intelectual do povo dos esportes.

Um material etnico muito do ruim, o que servin para a nossa formacão, fez no entanto uma obrinha regular.

Nós temos é um jeitão bom danado deolhar a vida. Sorvindo Achando graça.

lode-se fazer um ensaio de mão cheia, com sitaçôes pitorescas além das historicas, sobrea compreensão boemia da vida que o brasileiro criou. A propria Revolução, que foi a coisa mais seria que tivemos nestes ultimos anos, daria uma colaboraģão valiosa.

Até de passagem. pode-se citar sem nenhwm pedantismo o caso daqueles soldados nortistas das tropas revoluc onarias, quando passaram "yor aqui, terem mitos a barriga sêca de fome mas a boca cheia de cançôes e de piadas. lam pra trincheipa cantando embolada sobre carreiras governnmentais. enquanto outros se esbodegavam no realejo.

Outro exemplo de nossa to o. mia, de nossa distracão quanto ás tristezas do moio. é a criąäo da atual eamponha da boa-vontade. Num momento ruim para o pais (a situą̧ỗo é periclitante, como diz. un amigo meu, amador inabalavel de artigos de fundo), atarece a instituiça a do sorriso para tudo $P$. para todos. Naturalmente não $\hat{e}$ graea aguentar-se a gente enm o cambio a vacilar entre 2 e 3 , como um enfermo a vacilar entre a paralisia da endeira de rodas $e a$ morte; não é graça a inestabilidade politica de norte asul; nem a centiena de problemas a esperar medicamentos urgentes - mas que é que se hade fazer? Sorrir...

Com um punhado de maximas de earater mardeniano, o brasileiro enfrenta o seú mundo de difieuldades. $O$ assucar está baixando que não pode mais - e fazemos a cara alegre de quem nunca sofreu de calos. A impontaęâto estrangeira é ninharia -o sorriso é o mesmo. Por dentro a gente está sentindo. Se roendo. Mas pra que entristecer?...

E' da cantiga carioca : nós somos mesmo do amor...

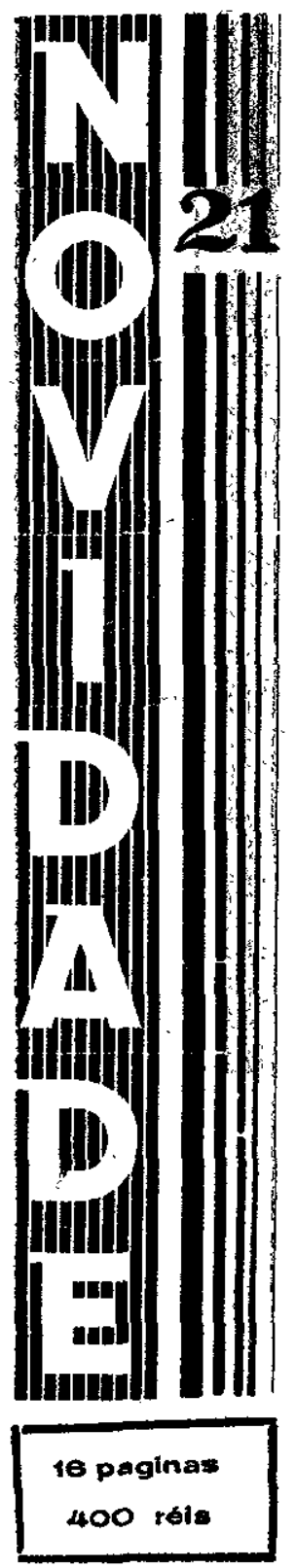




\section{...país \\ essencialmente \\ agricola}

A verdadeira compreensão do trabalho foi unna cousa que so apareceu no Brasil depois do abolicureismo. O que havia anies era umt muito facil realizaçâo de vontades por elementos invisivcis que se movian uutomaticamente no mesmo sentido da impetuosidade dos relhos.

O briço negro creára entre o pensamento da obra e a obra feita uma distancia tão insignificante que o branco a transpunha com os gestos mais subtis.

Nunca fôra notada a existencia do trabalho nem nunca foram sen. tidos os seus cansapos. A comodidnde do latifundiario apenas tinha nocão de que existiam uma eansa, que era a sua voniarle, $e$ os efeitos, que eram os seus produlos.

Isso, até quando os sonhos macios dos senhores, inconsolaveis, miram violentamente.

O choque trouxe a pcreppáo imediata da utilidade dos bracos. $E$ houve uma tristissima vacilação.

Não se podia compreender como seriam tateados por homens brancos os cabos das enxadas, manchadas tanto tempo pelo suor indigno de uma raৎa interior:

$\mathrm{O}_{3}$ campos foram assolados de uma peste de caracter desconhecido, a cujo conlagio ninguem se enriscava pelo merlo de ser moral mente inferiorizado.

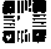

Friste hoje uma inoxplicavel incoerencia na vida comum do brasileiro: nosso caracteristico espirito de tolerancia se estende louva"elmente ao mestigio das racas de côr, ao sentimento rqualitario quanto aos de origem obseura, e, enquanto na sociedade nos afastarnos de quaesquer distincôes absurdas, chegamos a ser intransigentes na escoiha de nossas posifóes e na preferencia por certos trabalhos.

Entretanto estamos maito ennvencidos de que o nosso passado já se sumiu de nossas cogrtậôes habitucaes.

Julgamos, falsamente, ser um povo para quem o trabalho cons. titue uma condicão de elevacão moral. Se de facto assim fossemos nuĩo nos tinhamos habituato " olhat sempre com máus olhos " abnegacino do estrangeiro que aqui aporta ou do nacional que frige da regra geral.Nâo iviamos ao ponto de assacar apelidos youco lisonjerros ans que religiosamenle se dedicam a luta quotidiana.

I' que cada um de nós ler a consige " bocado das impressô's que nos legou a rristocracia indolente dos tempos idos.

Essa mesma arishoracia que pre. parou desostradomente wma in. compatibilidade entre o produtor a o intelectual. A principio, com o bacharelismo exportado do campo pelo capricho dos paes ponco satisfeitos de suas posicôes. Depois pelo literatismo urbanista, eterna tentaçâo dos mocinhos das provincias.

Foi por essa razão que os campos se abandonaram dos melhores cerobros e a producán ainda hoie se entrega ao sabor de am nasurismo semi-barharo que acredita na ferti. ludade inexinguivel do sólo.

O trabalho ficou sendo, ro pnves de uma cousa imprescindivel, aque. la cousa inevitavel enl que núo se toca sem lavar alepois as mãos.

Esse foi, pelo menos, o pensamento que se apoderon dos descendentes do campo - os fillhos de agricultores ou de senhores-de-engenhos que vieram pras cadades criar inhas de ponta e queimar assafras dos paes í sombra das academias.

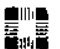

Um dos problemas nacionaes mais serios é sem.nuvida, a intelectualização do campo e a racionaliza. ção da preduecão. Para acabar de vez aom essa fama deterra de mi. lagresque a nossa formidavel ex tensão tervilorial eriou.

E' preciso, sobretudo, elevar o nivel moral do trabalho sob todos os aspectos. Não haveria nenhum mal em que se aiussem escolas tecnicus, onde as especializacoes atingissem ume guan de cultura compalivel $\mathrm{com}$ as elasses intele. ctuaes mais celtas.

Depois disso, talvez tivessemos a certeza de que nenhum despudor existe no facto de nos mosmos carregarmos os nossos livros e mossa cesta de compras.

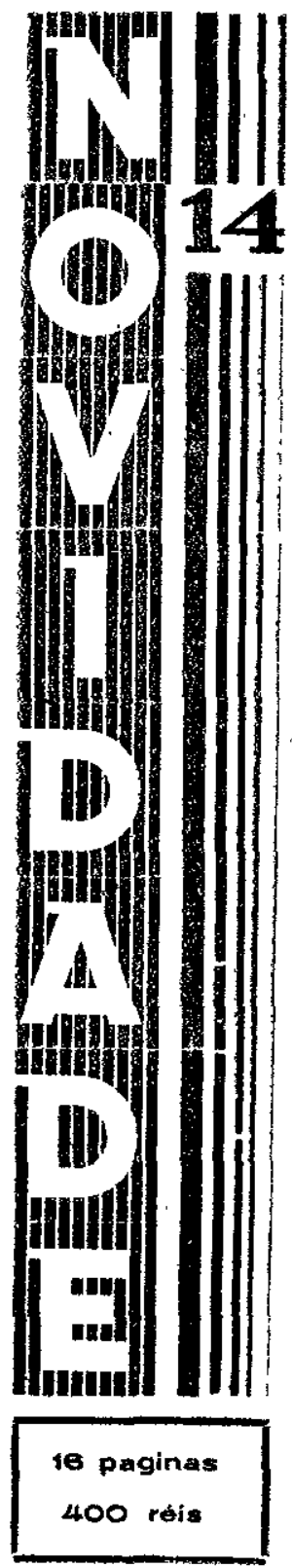

\section{Alberto \\ Passos \\ Guimarães}




\section{A ultima geração de burguêses}

Foi po ano de 1931. as erianeas usawam oezlos de gratu, caminhe. ram para as escolas sobragaudo muitos lioros, franziam responsabilidades em lugar de sobrancelhas.

th amor enorme pela tradieño agasalhava as mulheres dertro das casas, protegia os homens contra. a exberiencia $e$ tudo se fosia em. obediencia ás les derretadas por principios de direito. Principios de direito eram teorias herdadas dos primótios do sistema economico burguees e que naquela éposa cininta se conservavam intartas por natiralmente convirem ás classes abastadas, manejadoras, entấo, do organismo tinaneeiro do mundo.

A filosota dominante era a ilu. sionista. Escolas, doutrinas, teorias, sistemas-interpwhom-se entre a viulawe homem, afastando-o da'natureza, nistunciando o da renlidade para colocá-lo sempre diante de zma ilusäo. O homem vivia para as convencões. A união dos seros, o nascimento, a morte eram tidlos como atos sobrenaturais, atribuindo se interfereneia de um poden extrank em todos eles; o que concorria para que se revesfissem de ares misticos exoticos.

As religiōes sacrifieavam iudo om beneficio de Jews no envés de sacrificarem tudo em berceficio. dos homens rive délas mais careeiam. E havia descontentamentos, ehoques de raças, lutas de classe $e$ guerras.

Note-se que niquele tempo jat se ronheciam nilidamente as tausas de todos os males, assin como os meios mais imediatos de debelá-los. Entigetanto as solurôes sugeridas cram desprezadas por se oporem aos interesses economicos das classes burguësas dominantes; $e$ as rázoes financeiras se sobrepunham ás razões humanitarias.

Tamben multo aconlecia por wienderem os homens a for ra fal. sissima da Logica que nada mais era do que uma deducốo á primeira vista.

Patecia, por enemplo, Logico gue tres, qürrtos da populaçáco do mun. do se deixassen reger pelo quarto restante que constituia a elite plattocratica, porque se havia deduzido a prineiva visla que as conveniencias de toda a hwmanidade eran as mesmas. Esqueciam se as desharmonias dus interesses economicos na coletividade mas i essaltavamse en cada individuo a abastan. ca ou a indigeneia. As relagóes sosiais de homem para homem abriam abismos que as dibloma. cias tentavan aterrar quando estas rolacenes se tornavam de povo para. povo.

Essas divergencias fordm crescenco. $\mathrm{Vm}$ fator novo - a maquina creára a chômage e o pauperismo aumentava dia a dia impulsionado por tendencias inevitaveis. Com a e hômage de um lado surgira sdo outro o imperialismo porque og que a maquira tirára do operario der $a$ o ao patrẽo.

A burguêsia imprensada entre. esssas aluas forcts, wna que era $a$ sua propria origem e outra que se ria a sua maior ambicào pertia forcas e loncraw mâ de recersos extremos. As nacôes protextando de. fender patrimonios se atiravam $a$ politica proteciontsta fechanio as portas umas as outras. Dava-se a maior guerra economicu da historia.

Estas consequencias vieram sem demora. A queda financeira prizripion pelas grandes potencias, is $/ 0$ e velas nacoes que se tintham astucio. samellte tornado grandes polencias. Depois os mercados, paralisnramse; o ouro insuficienter ous superabunciante cireulava acmats ou não eircutava.

Sobreveio wma siltacroro insuportavel em que o mundo se as fiviava lentamente. Até que a ulima geraçâo de burgrceses se exting atu.

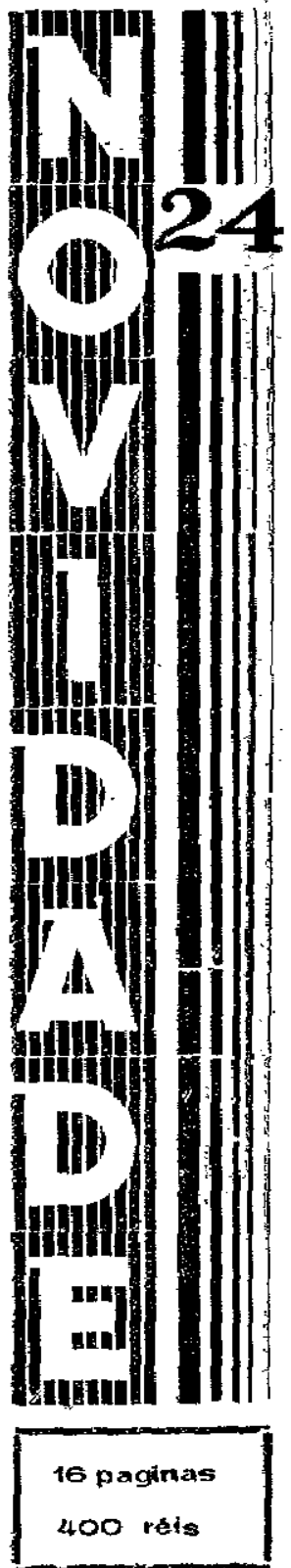

\section{Alberto passos Guimarães}




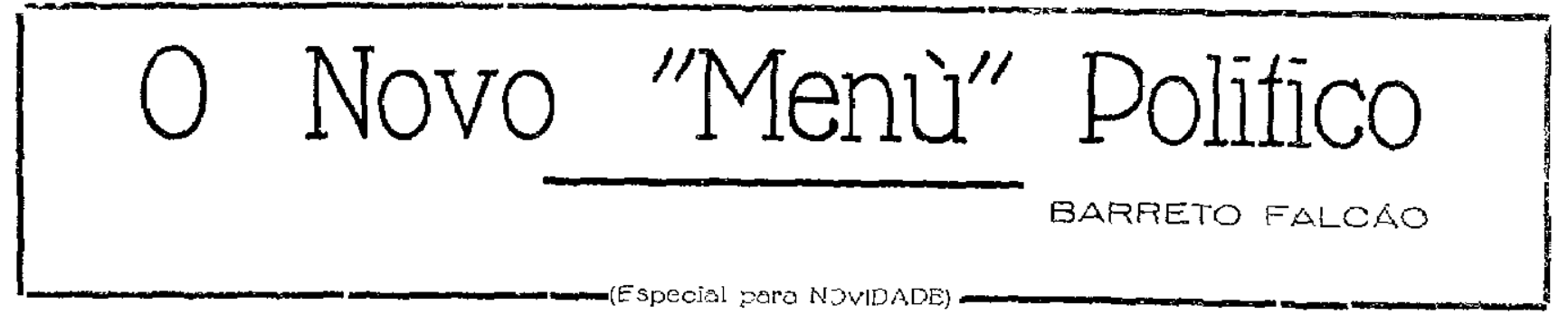

Com a victoria da Revoltcão, que implic u na mudança da situaciso politica geral do paiz, uma somma consideravel de nomes novos se trauspriteu do fundo anonymo da collectivifade parao cardanio de todos os dias. Muitos delles são nomes que representam valores incontestaveis. Valores que, dia a diá, pela energia moral e intellertuar, pela intelligencia productiva, pelo tarto politico ou pelas qualidades de administraço mais se vão firmando no conceito nacional ou regional, de accordo com a ampliture e importancia de sua actividade politica on administrativa.

Outros, riorém, que por um desses contns de vixario da comouflage politica. se haviam firmado como valores, ou que como tal foram proclamados pelo affecto pessoal de um dos chefes mu de um dos leaders, no entrarem no cardapio do restaurantezinho pol tico de seu estarlo natal on no dos oultos. foram $\log 0$ produzindo n effeito de um desses pratos ruins enfeitados, de nome tran. cês ou inglês, que an serem experinentados pein caboclo brasileiro foram repugnados.

A differença no simile só está em que o hoteleiro, num gesto te sentimento democratico, não deixa que o prato repugnado continue no cardapio. Supprime-o $\log 0$ ao perceber o nhenomeno da repugnancia. Enquanto o politico, o neophito recommendado pelo chefe, apezar de repugnado, ters de continuar no cardapio. E a $g^{n} n$ - te tem que come-lo todos os dias, sem fazer cara feia. E ainda dando mostras de que o prato é excellente.

Phenomeno mais ou menos semelhante se deu com os decahidos, fmbora em rircunstancias rifferentes. Todos os pratos foram eliminados do cardapio de uma sò vez. A maior parte delles nãonos deixou saudades A methor dizerse, nem lembranças mesmo nos deixou nerhum com a apresentacão daquelle immen. so cardapio, cheio de pratos resconhecidos, que se foi deslobrando, depois ro 3 de nutubro, ans othos da nossa gulodice democratica de povo desenganado de democracia.

Exnerimentamos todos elles e poucos nos satisfizeram o paladar.

Fomos então sentinio certo appetite nor alguns dos antigos pratos, dentro dos quaes o hoteleirn foi perversamente deitandn kerozene. F' verdade que alguns delles já voltaram aso cardapio em outros hoteis e, nãn obstania terem passado nela prova de kerozene, estão a estas horas sen. do servidos como optimos pra. tos.

Não sei se serúl um phenomeno de suggestão, mas o facto é que torlos se vão servindu delles gostosamente sem sentirem nem cheiro de kerozene.

Ora, imaginem que pratos eliminados cà em nossa terra estão hoje com grande cotaçấo em S. Pauln, em Pernanbuco e em nutros Estarlos do Norte
Os de S. Paulo, na Rahia, os de Minase do Isio, em outras partes. Dá-se o caso - aproveitaudo ainda uma imagem gostosamente culinaria - fo prato regional, (de um sururu, por exempio) fazendo as delicias do snobismo de todo um hotel cosmopolita.

Tudo no caso está é na mudanca de hotel,onde os clientes sejam outros.

Dizem que é porque o zenio culinario dos cozinheiros já se esgutou com a exigencia de tanta variedade e não tendo mais elementos para arranjar novos pratos, os hoteleiros, no ntuito de matar a fome doss clientes, vão permuttanda e ser vindo thes os pratos eliminados do cardapio dos outros.

O peior entretanto não é isso. Porque parece que nino ha probalidade de voltarem ao antigo carlapio muitos resses pratos que estão fazendo sriccesso em melhores hotcis.

O peor são aquelles em torno dos quaes se desenvolved gran do propaganda de sua excellen cia para depois do 3 de outubro, inesperarlamente, serem riscados do cardapio como pessimos pelos proprios agentes de sua propeganda. Dentro de nuitos delles, para privatlos do appe. tite da multilato, que se aguça va pela sua ausencia, lançaram kerozene. Hás mesmo assimo povotem comillo tanta coisa ruim que vive com pensnmento fixn nelles, como quem vive impressionado con um fructo prohibicto.

$O$ fructo às vezes năo presta mas a prohibiçãn ó n rierbo.. 
Meu gener so patricio :

recebo, nesta manhã chuvinhenta de Maio, a carta em que você,com uma candura que esteve quasi a commover-me, indaga de mim se me parece censuravel sua adhesão á nova situação politica to paiz.

Antes de tudo o que me sur. jrehende na sua inopinada pergunta é à verificação de que vucê ainda não se affirmou re. volucionario quando ha muita wente que of $z$ ha mais temjii) sem que, por o ter feito, estejat condemnado ao inferno.

Triumphante o movimento de Outubro, você não ignora que uma verdadeira enxurradi con. fluiu para o mar crespo da victoria e nella, no lado de revolucionarios authenticos, o que lodos viam eram respeitaveis e honestos cavalheiros que, nas vesperas, juravam por todos os santos do céo que eram mais leg listas do que o proprio presidente deposio.

Pelo que se pas:ou por aqui, facil the é calcalar o que houve por ahi fora. Quantos não se acotnyellaram como você, subindo as escadas do nalacio dos Martyrios para o juramento de suas convicçõ's ? Quantos não lhe tomaram o passo ansiosos por chegarem mais cêdo á atfirmação de commovira solidariedade? Aquelle cavalheiro risonho que se atravessou na sua frente para chegar primeiro á casa do governo, na noite lugubre em que ella foi abandonada, no dia seguinte só não pintou de vermelho os proprios cabellos porque já os havia pintado de preto. Aquelle cidadão illustre que lhe falou tantas vezes das virtuides dos homens que estavam no leme do Estado mal o leme ficara sem ter quem o segur'sse, os apodava de deshonestos e inc pazes. Aquelle moco cheio de brilho que tanta dedic ção affirmava aos governantes que em Outubro foram vencides, mal he chegou aos ouvidos o ruido da victoria da Revoluçãa sahiu á rua pira arrolar as pes. soas que the conheciam as convicções revolucionarias, de: de, talvez, antes de Juarez e João Alberto.

Você, port -nto, poderia ter ido francamente no meio desses, collocando logo o seu lenço encarna 10 , botando na porta de casa a sua bandeirinha vermelha e - pelo sim pelo não - apparecendo no Relogio Official para taxar de tran. polineiros e gatunos os mesmissimos cavalheiros que the mereceram até Outubro as palavras mais enternecidas.

Você, porem, não foi na onda e, agora, apos sete mezes de republica nova, é que se resol. ve a deixar essa incommoda situação de não star com o governo.

Sintn, porém, que a sua pudicicia politica o embaraça. Ahi está um demonstração de que voce não é um homem moderno. Notoro na posição daquelle Callipede, histrião, que se preparava para uma grande corrida no carro, dava um impulso ao corpo eficava no mesno lugar.

E é nessa posição que você, com uma candura que está quasi a trazer-me lagrimas aos olhos, indaga de mim se será censuravel o gesto a que o convidam as suas veneraveis tradições de governista.

Não dou opinião a respeito. Mando-o para as paginas da historia. Lá você verá que Sylla, Pompeu e Cezar fizeram muitas vezes o que é seu intento agora fazer. $\mathrm{E}$ Cicero tamben. E, mais modernamen. te, Thiers, com os applausos da França. E Castellar. E Gladstone. $\mathrm{E}$ Disraeli, que merecen, talvez por isto, o livro de Maurois.

Os exemplos não the faltam. Se resolver seguil-os, quando alguem the censurar a attitude, nẫ a justifique com a dos que. aqui mesmo, $o$ antecederam : r corra a Disraeli, que ficará mais bem amparado.

'E $\dot{c}$ este apenas o meu consetho.

Seu affectuoso LIBANIO .

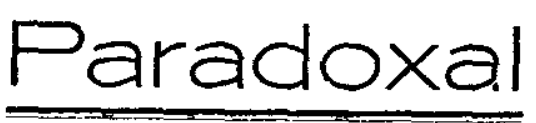

Ha no bôjo da minha vida

Ingratidôes dos homens,

Cynismo de mulheres,

Angustias e miserias,

Ha quem diga tambem

Que a minha franqueza é indiseripçâo, A's vezes, que a minha indiscrip̧çấ é franqueza.

Ehu digo que o nucleo da minha vida

E' uma odysséa paradoxal.

$E$ muita gente pensa que eu não disse nada!

Pedro Nunes Vieira

Recife-931 
Interessada, a Naçào leu a ontrevista de Pinto Serva que consti ue an larlo de João Cabral e Assis Brazil a sub-commissão encarregada de elaborar o ante-projecto da reforma deitoral brazleira.

E' na ural que assim fosso, pois esta reforma é geralmente considerata o mais mportante factor na rehabilitaça da Politica no Brazil, escopo da lievolução de Outubro.

Elogiamos no entrevistath o civismo amplo que perle a collaboraçáo da opiniáno publica nesta phase de esturios, preparatoria i, C nstituinte.

Os conceitos emittidos laquella entrevista que, limitados embora ao questionario jornalistico, abranger $m$ um raio de acção superior ao da propra commissano, sio algumas vezes incontestavelmentehons, outras, porem, disculiveis mesmo contr rios au surto 1enovador do momento.

Nas respostas dalas pelo i lustre public sta ás questóes abordatas, ha uma que nos yropomos a examinar, discor. dando iniciramente della.

A quesião a que nos referimos, de „valor excepri n:l, talvez nos traga o remedio por que anceia o Pai integrando-o na sadia Politica, até ágora extranha ao nosso poro.

Assim, ao ser inquerido sobre o voto proporcional, Pinto Serva foi-lhe contrario. A nossa tristezat aggravou.- ao analysarmos as razóes allegatas.

Respondendo, alle comeca - Parece-meque a assumpto 8 compl tamente ignorado pela opiniào brazileita".

Contestamo-l'o. A não ser que a elite da nossa onjinião não seja a verlatleira opinião brazileira. Ha poucos dias Gitberto Amado fez uma conferencias bre a \& Rresentação proporcional, seus effeitos e moralubdes:
Um regimen cleitoral adointado, como mais adiante o proprio Pinto Serva crniessa, no modelar e vizinho Uruguay, seguido em paizes cultos como a Suissa, Burgica, Austria, Allemanha e reputado como a $m$ is altá expressão da Democracia. nảo poderia ser ignorado no Brazil.

Con'inuando, rpós conciderar-nos não preparados para applicarmos os processos am tanto complic idos" do sys. thema $\mathrm{cm}$ apreço, aliás bas. tante simple; na modalidade alleman, e de dizer que onde está em vigor ex'stem parti. los já ronsolidados, elle profere as seguintes palavras :

*Esce systhema de voto exige que o eleitor vote, não em individuos. em nomes determinarlos, mas em chapas de partidos, em listas completas Pr estes ormanizadas.

Acompanhe-nos o leitor na analys do periodo acima $e$ verifícará que não é uma razão contraria, mas a maior propaganda que se possi fazer ao regimen. Sentirá que aquel'e voto cumo que foi feito para nós, e commigo, que é o antidoto para o vin n i cahotico 10 personalismo brazileiro, poîs resalta no voto prop'rcional a substituição do individuo-pes. sôa pelo individuo-idéa, do caudilho pelo estadista, e nelle se. troca o analphabetismo pela cultura.

1) douto Commissario conc'ue em seguida o seu nensamento - * Ora, no Brazil ha talvez 19 Estados em que não existem partidos politicos, onde não é possivel improvisal-os $e$ como é que nesses Estados to dos os eleitores votariam em ch pas de prtidos? Seria ignorar as realidades brazileiras."

Aqui tomamos a chave da questão. Não que nos Estados não hajam partidos, porem os existentes, na sua quasi totalidade, nào podem sertomados como taes, this que, rão defendendo príncipios de conducta nem tende uma orientação realizadora, serão expressões individuaes, aggresados de pessoas ambiciosas do Poder, mas nunca partidos politicos.

E a representação proporcional forma com os partidos um corpo só. Seria, por isso, inadiptavel ao paiz? $E^{\prime}$ o que pensa o illustre entrevistado levando em conta "as realidades brazileiras" que nảo ignoramos.

Não ignoramol-as, por certo. Constituem-n’as ns nossos com. plexos problemas...municipaes. E' o caso do padre fulano que disputa an coronel sicrano a chcfia do arraial, é ainda o genro-doutor dn Chefe que quer ser Prefeito... As soluções daquelles problemas decidem a sorte dos Estados e indicam em ultima estancia as directrizes da Unián.

São ess 's as "t calidades brazileiras.

Esquece-se Pinto Serva que a reforma ejeitoral tem como objectivo abrir novos horizrntes á narjon lidade, dando um rumo differente á nossa velha politica que só nos poderia dar uma caricatura de governo democratico.

A sua finalidade é justamente corrigir, melhorando, a rcalidade politica brazileira.

$A$ representação proporcional não presuppõe a existencia de partidos, mas cria-os automaticamen'e, como julga Assis Brazil, ou melhor, corporilicaos. colhendo e organizande as latentes aspiraçoes nacionaes.

Precisamos de partidos politicos e elles virão si não quizermos que o Brazil continue a ser um modelo de incultura civica e de incapacidare atministrativa. 
A phase historion que viremos não deve ser te mula espectativa. mas de acçán etfciente. de collatboraça anupla, de critica e riscussão.

O momenta deve ser, solor. tu 'o, a momento de todos os brasileiros libertos, pelo Exercito, do jugo infamante dos particlos politic s, chefes e chefe. tes de particlos.

Renovação corgrani-açăo, eio momento.

Livres es mossos palsos das cardeias do profissionialismo politico, todos estamos no dever e temos o direito de trabalhar pela restauração nacir nal E cada um trabalha com os ins. trumentos de sel officio : a espada pode vibrar tanto cuanto o pensamento pa fé, a simples attitude e o puro exemplo.

4 epocha dos oraculos ji passou. Os deuses, de ha muito, foram depostos de seus aluares. As doze taboas romanas foram revogitdas e os ministros estão sendo chamados para a prestação de contás.

Como em Roma, no fim de sua republica, os augurios bra sileirus ha muito cahiram - $\mathrm{e}$ sobre suas cabecas o ridiculo implacavel de ricero...

sob o pallio revolucionario, todos somus concidadãos; fithos da mesma familia civil e soldados d, mesmo credo cirico : a salvação do Brasil.

Todo o mundo encherga e proclama a $g$ avid.de e cleli. cadeza da situaça en que nos collocámos após o triumpho da revoluço, com a jmplanta. cão da ditaduragovernamental.

Paira ja em todos os espiritos uma inculietação, uma duvida: Quando teremos a Constiluinte?

E essa interrogação perturbadorá encerra em si um anceio generalisado.

Já vimos bem caracterisada uma crise de confiança. desde a agitaça frovocadat no Rio
Grande, prios libe tarlores, ao ruidoso caso dos democraticos èt Sà 1 alulo.

Nem se disfarç m on effeitos de tal estado de coisas, influndo lamentavelmente na grande marcha d, obra revolucionaria. .

Na ha vegar a diversidare re nossa posiça actual drquelIa cm que se encontrava o paiz, á queda fo thromo monarchico. guando Deodoro, de si mesmo, apressava $\mathrm{t}$ ordenava a convocaçáo da Coustwinte para a Republica nascente, ipregoando assim o seu rlesinteresse pelo poler.

Enfrentando uma crise economica generalis:ara que vem, de hat muto, abalando os alicerces do mundo in eiro, aggravara muito especialmente por uma hera"ca de erros systhematisados, tem a actual administracio do paiz gue evitar todat solução de continuidade na obra ja in ciata de nossa reslantacio financera por que se condu\%, guem no afan ule sanament' dos habitos socio joliticos.

Sem durida. concentar esse orgio smo roto e enfermado pelas convulsões de quasi me'o seculo, reajustar as pecis do machinismo gasto e enferrujado, é problema muito complexo que reclama, para sua solução, demorada e larga visão de estadistas

Entrementes, si folhearmos o nosso passado historico, veremos que o nosso povo jamatis se a moldou ao regime da atutoridrule abso'ula accentuando-se por phases exressivas.

Nào se diga, pois, qué cé cêdo para se cogitar le materia tão delicada.

Decorridos já sào oito mezes da victoria da Revolução e nunca atravessámos maior periodo sem se verificar um passo no sentido das prerogativ s constilucionaes.

Si bem que não regisle a Republica velha momat phase de tanta inici liva productora, de tato hôs moralidade atminis trativa. furça é recombeter a neces-idall de se assaguraren quanto antes e delunitivamente toujas as prerogativas do cidadão. integrando-se a nacà na legitima orden corst tuciomal.

Em tão rurto estac de tompo, a acção de rossoc dirigentes tem se revelato forte e inconfundivel no. vas o canpo das realisações mais praticas e immediatas, entretanto, para yue bem ato se assignale a sinceridade de suas conv eçócs e transpareca o espirito ve sacrificuo que os guíam, deye essa acção ser e caminha 'a no sentido das aspilacões que' empolgam a unaninidacie brasileira e que pre-entemente se co. cretizam no elevalo anhelo da constituc:onalisação da vida republucana

Salientamos que um piaso longo poderá ser de consequencias ruinosias par : a evoluça e se:urança da obra revolucionaria.

Năo defendemos o ponto de vista muto do agrado dos antigos probissionaes da politica que, cum suas ambições e interesses recalcados, aguardam o regresco das instituições que tanto aviltaram.

Pensamos que esse desejo de constiucionalisar se a Republica nova por um tracado luminoso de normas rigidas do Dircito não a apenas a náu monlante do despeto. o trabalho de s pa dos que jer.miam por dias idos, porom um forte destio collectivo, um ins. titivo impulso da alma nacional. tratuzindo o nosso arraigado sentimrnto de liberdade.

Como una legitima aspiração da conscicncia collectiva, agitemos pois o movimento pró-constituinte e dentro do: nossas melhore possibilidades cooperemos no grandioso objeclivo dits reformas raticaes, olhos fitos na grandeza do Brasil. 
Ha ainda em Alagôa -diz á NOVIDADE o dr. Migusl Baptista-um vasto programma de realizaçoes pedagogicas a empreender-se

- Vamoq ás suas idéas geraes sobre a Instrucents Publica cm Alaguas.

- Felizmente o nosso Estado vae ponito de prirte a escolít verbalista, tivresca, e comeca, fualmente, as trilhar o vereladero caminho: Dizemos verdadiro cammho uorque pensamos que a indulade da escola é preparar o homem pata a vida e facilitar-lise a ataptacăo ao meio social. Wahi a necessivade de cercar a Escola de tudo quanto é nocejsario á vidit, transforma-la num ambiente que esteji mas ou menos em harmonia com o moio que a circa. A escola antiga sefuia ciminho diametralmente upposto: clla representava para a criancia uma obrigacio que lhe era imposta, sem que se tuvesse cm vistá as suas c)nnicóes de soutle, de vida e desenvolvimento physico; representava un meio complatamente solado do lar, cm que o menino era forçado a cumprir uma taref a verdadorraments asphixiante para a natural inquietude d, espitito infantit.

Hoje, porétr, as idéas que hat muito dominavan o munclo da anthropologia, penetram nos clominios da escola: a crianca é um ser que vive, ponsa e quer. Por turlo isso se ve que, cono diz Claparéd ', rep tindo uns trectos do Emilio de Rousseau, a crianca quer o que liz e nảo fxz o que quer, na Escola de hoje,

Ponhrmos, prén, de loro essas icléas geraes, expostas aqui com a pressa cxigi la pelas entrevistas.

-E estará y nosso Fist do, en materia de Instru:ção, alcançnio a meta iclesl de aserfeicoamento? Ou faltará muito ainłl para alcangarmos essa .lmojada finalidad: educacional?

- Vuito ha ainda a fazer-se pela Ynctrutcrản Publica de Alaroas Nấo sei bem si. o redactor Je NO YIDA$D E$ leu as linhas geraes que ha algum tempo traçmos sobre o curso rutal.

E' muito para admirar que wm Fstado cortarlo por vall's rios calidalosos, como o nosso, tenha im orcamento infimo que the nato permitif, por si só, manter as escolas que sảo para flesejur. Essa penuria economica decorre, em regra geral do lacto de nós termos $80.1^{\circ}$ de analpuabetos a $78 . l^{\circ}$ de homens sem officio.

Pcrsunlar-se-á. por que trata gente sem emprego? mera por fa'ta de campo? ão, porque o meio éo mats favoravel possivel. O deferto é $e x$. clusivamente de educaçăo.

O nosso homem-essc conceito pode - extender a todo o Brasilnão é educady para o trabalho. No dia $\mathrm{t} \cdot \mathrm{m}$ que se citabelecer a erluca. ro pira a vida, as nossas condicóes Inanciras hão de por forca methorar. Podianos, por exemplo, ins-
Director da Instrucẹão Publica em Alaqoas, o dr. Mriguel Baptista é um estudioso de nossos problemas pedugogicos. Rstudioso só nâa : um technico. Frincipalmente isto. $A$, sua visão percuciente não escapam os menores detalhes de nossa-digamos claramente - dificiencia didaetiea-cultural. Nossa, como todo o mundo sabe, vae no sentido de brasileira. Por isso tudo é que NOVIDADE escolheu o nome do dr. $\mathrm{Mi}$ guel Baptista para falar sobre a Instrucção Publicu em Alagons.

assuman

tituir en o nosso Fstaclo a neces. saria educação rural com a criaço de cursos, cujo esboco já foi publicado no DIARIO OFIICIAL: cursos em qte o alumno aprende a necessaria "ultura regional, năo só ao que concerne ao plantio como ao combate das pragas e males $d$, $\mathrm{t}_{\mathrm{a}}$ voura e do gado. Foi assim que alguns estados do norte, activando o combate á lag rrta-rosea conseguir.um um grande augmento $\mathrm{cm}$ sua renda orçamen'aria.

E' preciso dizer que, alén dessa educação regional, a cra iça tem no curso rural a necessaria edu açăo literarı, ben como entra am contacto directo como as scienclas physicas e naturaes. Torlo esse ensino é ministrado do modo mais pratico possivel e feito em campos aproprialos.

Ha ainila no curso rural um? vantigem de ordem final: fixar o

Credito Mufuo Predial

Sociedade de

Sorteios que se impõe

Delos seus

Processos

CHAVES \& Cia.

Rua Dr. Rocha Cvie, 550

Maceió Alagôas homem ao soli, despertando-lhe um patriotico amor ás coisas de sua terra, evitando dess sorte o tantalismo urbanista, tăo bellamente $1 \mathrm{y}$ plficato $\mathrm{cm}$ o Lucien de Ribompret, de Ralzac, no vantas de Emie Zol, e no Ultimo Tantalo da Chave de Salomão (1) celebre escriptor Gilberto Amario. Estaria, desta sorte, resolvida a questrio do pento de! vista reral.

Quanto go lado do ensino profissional o problema poderia $\mathrm{Se}_{1} \mathrm{re}$ solvirio do seguinte modo: a montažrem da si ç̧ão de ofticinas do Instituto Gabino Besouro, em Penedo; a montagem de escolas-agricolas-pastoris em Palmerra dos Indios e en S. Luiz do Quitunde; a cração de uma escola profissional em União; o eslabelecimento de lostos z'otechnicos em -ant'Anna do Ipanema, em Paulo Affonso, em Muricy, em Maragogy; a cracá de uma escola de pesca em Cortripe ou Barra de S. Miguel e de uma outra do mesmo genrro em Barra de S. Antonio (não falamos em Penedo porque já está no Instituto Gabino Bezouro a criação de um curso de vesca; o agrupamento rlas aulas de todas as culades e de todis as villas.

Pensamos ter darlo uma visāo geral do que em materia educacinnil é preciso ainda fazer em Alagoas.

-E qu'tito â Escola Mixta, tão discuticla entre os trchnicos? Resolv rá ella, mesmo eth partr, a nossa crise de educação sexual?

Ha grande confusão $\mathrm{em}$ torno do assumpto: sup!nunham em um dos estados to norte d" Brasil que Escola Mixta, Fiscola Activa e Educacào Sexual era a mesma coisa. La. bora, quam assim $p \in n s a$, em granrle crro: f'scola activa consiste apenas no processo te ensine. Assim, tuma rsool de artifíces em que só baja homens, em que carla un procure 0 labor que mais the agrada, em que - erlucador procure acour panhar as terdencias boas da crianç', cultivar a expontaneirlade, é uma escola activa. Embora no num?ro de alumnos da mesma sò haja crianças de um scxo. O mrsmo poder-se-a dizer quanto a uma escola domestica $\mathrm{cm}$ que sò haj z meıinas. Fm segundo lugar não se dove co'fundir co-erlucacão nu escola mixta com educncốo sexual; a escolı mixta consiste no facto de ellucar crianças do ambrs os sexos no mesta predio; a educaçán sexual porle ser tath a moninase a meninos em prediosisolados.

Não ha desvantagens na escola mixta. uma vez que haja espaco $A$ fiscali/aço necessarios; a e luraçio sexual que se fitz magistraimente em muitos paizes da buropa é i, 'éa, prematura, perig sa entre nòs, por lalta de prepararáo no ambienic. 
E' umá situacão miseravel a do homem pobre que cae na liferatura e quer se dar ao delicioso contacto com os livios.

E' que os livreiros puxam do boloo lo literato pobre's mais recondilos lostôcs pelas 100 ou :2 O parginas de um , brochurra cualquer. I-so da literatura cá dil casa, dá tambem pobre liceratura brasileira. pirque está vist.) que um diabo que ja se sacrifica por um afranio I'cixpto ou un Venotti del Picchii, não vae se dar ao luxo de Jesejat Mauriac, Gide ou Green. que custam os olhos da corra.

Essa situaç̃o ainłla é mais triste porque as leitores pobres c'n Naceió não tên siquer um satro de leitura, a que se nossam ded car. em horas cortas e sol) vigilanc a policial de serventes, nos gosos culutraes. F i osr. Alvaro Paes que met. fent os pes na Blibliólyeca Pubheat do jostado, que er"i, pela falta de cuidado qur he dispensavam, a mauor criação de tracas de lodo o Norte,

Seria u'" desaperto para.o intel rectal poline yue o TustiLuto Archeolng on franqueasse ao publico a sua rica bibliothesa - rando uma finalidads. mais hum na as suas contenas e mais centenas de livros.

\section{$* * *$ \\ Com os estudantes}

Os nossos estudantes fizeram muits bem em organizar a sua linha de irente, para a defesa de seus interesses, de vez em quando em jrigo com a má intencĩo de alguns bacharis perlagogos

O Centro dr Fstudantes, si tiver o ponder por que os seus as. socialos devem lutar sert o melhor moio de refes' de sua classe contra, nor exemplo, is jevolucionallas tofornas do er. Eraveisen Cambors.

O Centro dos Esturlantes pide ainda ser o ponto de irradiacia onde os nossos joveas oymmasias polerào pò s's a contacto con a virla estudantesca de t da purte.

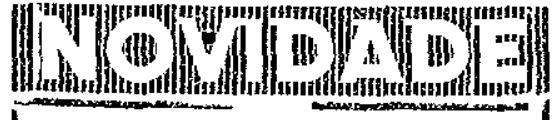

Semanario i.lustrad o

\section{Numero $723=55=931$ \\ Direcção de \\ Alberto Passos Guimarães $e$}

Valdemar Cavalcanti

\section{Assignaturas}

Semestre .........

10 : $0 \cap 0$

Anno................. 18 B 1000

Numero avulso.... $\$ 400$

Toda correspondencía para a Rua Barāo de Atalaia, 33 .

As collaboracoes devem ser absolutamente ineditas

Collaboracăo especial de Jorge de Lima, Graciliano Ramos, Gucdes de Miranda, Orlando Áraujo Arthur Accioly, Carlos de Gus mão, Lima Junior. Josć Lins do Rego, Seb istiāo P. Dias, Jayme santos, Alvaro Doria, Craveiro Costa, Auryno Maciel, Luiz Lavenćre, Jayme de Altavilla, Migucl Baptista, Abelario Duarte Barr to Falcin. Esdras Guciros, Iosć Auto, Willy Lewin, Alnysio Branco, Mendonça Junier, Carlos Paurilic Scbastiño Hora, Mendonca Braga, Jaul Lima, Aurelio Buarque, F. Marroquim Souza, José Borba, Pantino Jorge, Wea cyr Pereira, Leăo Tavitres Bastons, Abellard França, l obão Filho, Rocha Fitho, De Cavalcant: Freitas, Iljosues funior. Carlos r. Duarte, Thío Brandà̀o. Lauro !orge, Jost Rraga e outros

Reportur
Cajueimo photographico $-A$

Credito Mutuo Predial

Sociedade de

Sorteios que se impõe

Delos seus

Processos

CHAVES \& Cia.

Rua Dr. Rocha Cvie, 550

MaceiómAlagôas
A q'- estão é que os seus no. vos directores organ.zem um programma de dırecção de mocirlade, para orien açãr cultural e defesa de seus interesses,$$
\text { ** }
$$ \\ Uma obra hu- \\ manitaria}

O Instituto de $A$ scistencia e Protecção á Infancia tem in. tensificado en tre nós uma admiravel obra de humanitarismo, prestando a sua mais efficien. cià assistencia ás crianças po* bres de nossa terra.

Dia a dia, o Instituto alonga as suas possibilidarles caritativas, construindo dispensarios a cada bairo, críndo consulto. rios para consultas sobre hy. giene e recebendo a infancia deslembrada da sorte sob um tecto cheio de carinhos e cuidos.

O Instituto pretende criar um Curso Elementar de Puericultura, para moças e alumnas da Fscola Normal, ensinando, em ligeras lições, em licões praticas, noções de puericultura.

Será es'a uma obra de alto scntido humanitario, a que is moças não se devem esquivar por um estritissimo preconceito de jurlor, tão commum (e ião prejudicial!) entre nòs. .

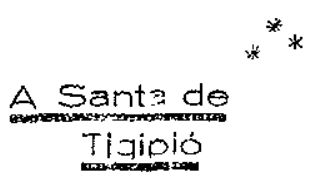

Continua na ordern do ria o mileyre, no Brasil.

Primeiro, foi a Santa de Coqueiros, carregando para seu longinquo logarejo milhares de crentes.

Agnra quem está na ponta é a Santa de Tigip!ó.

Pernambuco todo começa a se agitar com as novas dos milagres dessa mulata $\mathrm{cm}$ estado de graça divina.

Nessa historia toda de mila. g'es apenas uma coisa ha a salientar-se: è que num paiz em que já se vae, a passos lar. gos, perdendo a crença de tudo, faz renascer uma grande, uma illimitada fé na grande força e na bondarle illimitada de Deus. 
$-8-$

\section{a cidade mend iga}

Sentado no vão da porta o velho mendigo negro expóe a enorme e herrorosa ferida da perna sêca como o mais terrivel espetaculo de miseria degradação.

E' a imploração indiferente, quase compassiva da indife rençn alleia.

0 preto trinca um pão e compratodos os jornais da terra. Pára de vez em quando a leitura da nota politiea ou da reportagem social para lançar peditlo simples:

-Mocinho.

E continúa a leitura..

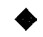

E conhecida na cidade torla. Conhecida pelos seus chapéos e não pela sua miseria fisica. E' a tragedia de uma consciencia em trévas abafando a tragedia de um corpo de aleijada. Arrastarido a sua desgraçar pela cidade, debaixo de umsorrisu de degenerada e um chapeo enfeitadio de llores ou plumas. Maria dos Chépéos é a que ri de sua que ri de sua intelicidade porolhar o tamantro de sua despraca 0

-Dê cá um tostão pra aleiiadinha, meu fitho...

$$
\checkmark
$$

O velho cego of un philosofo. $O$ philosofo da resignação Ele cré no céo, porque tambem crê ser a terra o defumador flos espiritos. O velho cego quer a sala cegueira na hor o caminho do cóo. Reśi- gna-se com o destino, porque destino é uma coisá que faz nesses casos deixar no anonimato a ação de Deus.

-Uma esmolinha pelo amor e. Devis.

- Perdôe, irmão.

- Perdão de Deus. Deus the dê saude e felicidade a todos de sua fa:milia.

E sai, deixando arrastar por Im merino a tréva de seus thos fechados e a claridyde sobreliumana de seu espirit

\section{$\checkmark$}

Esta é a demencia a serviço dá eacetcaçào. Uma idiotice que arrepia os nervos das suas vitimas. Mais que mulata, mepre calma com os seus cabelos revoltados pela ação dos ventos e esconde pelos seios um volume exquisito de panos tesconhecilos.

-Tem um tostão, hein ? E a voz é arrastada e fina. -Tem não, hein?

E' a desgraça feita ridiculo.

\section{$\diamond$}

Assovia como sabrá. E' uma especie de cartão de visita. Não se apresenta como um desgraçado que $\delta$, que não conhece o bilho do sol e a como um imitador inimitavel do sabiá. A esmola não é para do sabia. A esmola náo epara a sua desgrace. E' t tuez pela un alegra ele tera de instar vim. -Heu irmão : 'tê ao menos
cem mi' reis to ceguinho...
Dentro da cidade paca vida tem o dôce ritmo de coloniais, existe uma cidade samerte tragicas: é a cida a cidade que não tem pão

a vida o lado mais horro Em Maceió a cidade grande demais. E' como cer mas muito abertas, que ci queno vaso em que se ex. A cidade mendiga e a ga. Vive nos vãos das po do dia anterior de uma me las ruas inditerentes e seren de Deus a humilhação de e sempra vem; vive ao rele expondo stras miserias ou nesco de todos os espetacu

$$
\text { E' o infinitamente desg }
$$

gria do quotidiano feliz.

E a cidade mendiga vir
Para os que sentem da rista e para os que olham para o desconhecido do am populacão que sofre.

Esfarrapados, o estom:
E jejum forçado, o cèo a serv e chuvinhentas, molestias $t$ vos pelo organismo fracomendigà são a miseria na $r$ sentaçōes. Numa representa porque o palco é a rua, é o . que não exige pálco especial, 1vo, sen maquillagem e live. E a representação cría, Todos são iguais na. "ua infelicidade coletiva. A desculo é a mesma do cancer nea da do alrijado. A do tubesocialismo igualitario dos ti jartires obscuros. E a grande cidade mer dires a cidade

sem tecto e sem destino. $s$ fue a cidade dos sem pão, dia-a-dia, dentro da cidade cata, pequenina e burguêsa...
$-9-$

$\Lambda$ asma terrivel abafa-the Voz como unza esponja. Nagro morena, ela interpreta o pape de martir de sua resistencia f sica. E apesar do drama interior. ela é a florista unica da cidade. Em troca de dois tostões que as almas caridosa The riào, enfeita a lapela con um cravo. Ha allguma coisa de romanesco nesta alma encantadoramente dolorosa e abiltida pelo otitono melancolico. Seus cravos valem as palavras que a ésma hortorosa i baf cimo esponja..

-Dai uma esmola

Pendlendo uma banda do corpo miseravel por sobre uma bengala --a muleta que uñ teve coragem de crescer -0 pobra altijado, de faces denunciando verminose e fome muita, extende a mão ao niquel caridoso. Por perversidade alguem interroga:

- Porque não vai se tratar com aquela miseria do Padre

E o aleijado sai arrastando molemente o seu trâjo de cor$p o$, benzendo-se aterrorizado: -Ave Muria, Ave Maria,
Ave Maria...

Pequena, a cara total e grolescamente citiada, uns cilbelos postiços, em cơque, arquitecturados no itto da cabe. ca- ela e a degenerescencii feita misnria, a miserial feita ridicul $\cdot$ E o seu ar espalhafoso dá al ldea de un anuncio desajeitado da mendicancia em
Maceió. Un anuncio de segunda orden, como os dos cinemas de segunda linha.

-Cavalheiro..

Um sorriso parvo inundathe o rosto palhaç. Balanca os hombros, curva-se ligeirat mente, balança os braços co. bertes pelo vestido bem catóheo. E puxando pelos ss te rr: -Faz o obsequio de me dar um auxiliozinh

$\mathrm{E}^{*}$ un exemplo pitoresco de ruina de uma aristocracia. Ha um acento cavalheiresco no sell ar imponente, no seu todo de mulato delicado.

Nuns sapates de entrata baixa. cámbanto, umas roupas escuras e discretas, de casimira, e, dentro disso tudo, un cavallheiro que pede niqueis. Mas pede com uma elegancia de quem dá dinheiro. Humithando at os os indelicados. Pede de chapéo na mão e de surriso nos labios:

$\rightarrow$ O cavalheiro podia ter a gentileza de dar-me duzentos têis?.

A Curió vale màs como tipo popular. Todla Maceió conte ce aquela cara mirra 'a com o bagaço de um cajú. Conhece $n$ seu escolbido guarda-roupa con chapéos e vestidos contrasiando vivamente, como gue nurna terrivel caricatura á ele gabcia provinciana da terra Pedindo o seu tostão empreg metodos pouco aconselhaveis. Ameaça o transeunte com sombrimha suit. Me dê um tostão.
-Cadề o meu tostão, hein ?

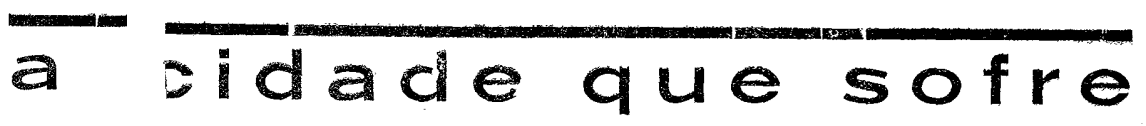




\section{Lampeão entrevistado por NOVIDADE}

Como o celebre cangaceiro, o heróe legendario do sertão nordestino, enc i certas coisas brasileiras : os direitos de propriedade, o progresso, a justiça, a farrilia, o sertão, es coroneis, zangaceirismo e a sua propria vida

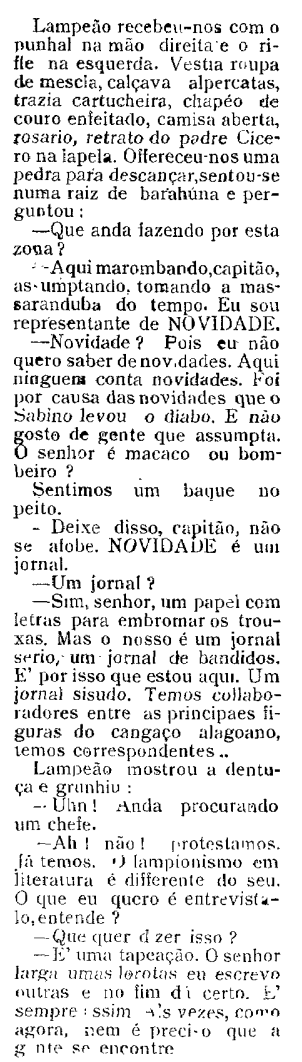

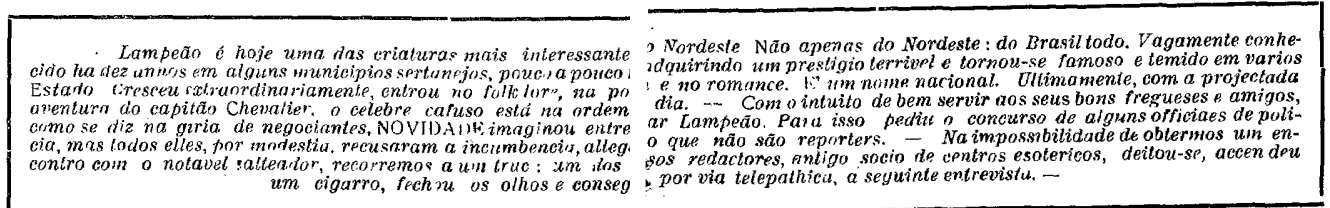

- Por que?

-Por que? P rque se ell iosce escrever o que o senhor diz, não escrevia nada.
Lampeâo matutou, balançou a cabeça e concordou : Pegur no lapis.

E romeçamos:

-Quaes são as suas idéas a respeito da propriedade?

amivel faseinora tirou dia patrona un pedaco de fupunhal. - Eu, para falar com franqueza, acho que essa historia o spphor deve sabor, como que um sujeilo agndanhaval era delie. Depo's vieram os padres e atrapalharam tudo, distrilusindo terra para um, espelho para tro... Fe' hou-se o tempo hasve um fusue da pieste. que está nos livros. Mas meu padrinho pidre cicero nan val Isso por ani is nosion? caclacal nuther tudo. Ge quem parsar a ona, entende?
- Perfeitamen't. E que ne diz din progresso?

-Do prograsso, da civilizacano. Roupses bowtes, sapatos
tracos de ch iro, cognac, dou-

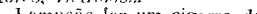
lampeño lez um cigarro de
patha do milho, tirou o binga,

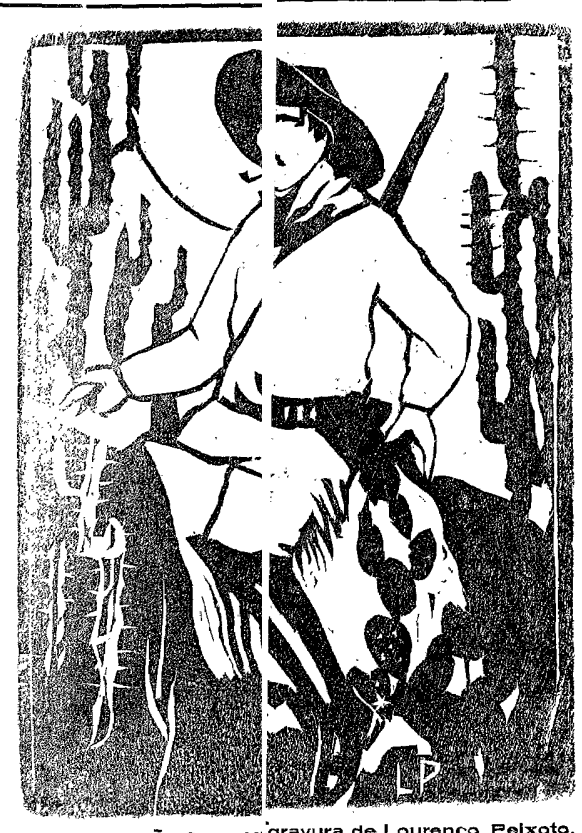

SERTÁ X Xigravura de Lourenco Pelxoto bateu o fuzil e poz-se a fumar. -Sapatos, como o senhor vê, não uso, mas o cognac eu são engraçadas. Quanto aos doutores, ate hoje riào me fizeram mal. Estudam nos papeis e lalam muto. Creio que não tenho queixa da civilizaçăo. $-($ emo considera a justiça? - Aqui mon sertão, quando um camarada tem raiva de $r$ urro, toca loga nelle. Eavar mosquetão e uma esconde-se por detraz dum pau, clorme napontaría, espera quin ze dias a queima o solredito. E' a justicat tnats usadia e não antos. demorada, mas que nåo é má, porque os promotnres se enrascam sempre e os jurados

-Sua opiniä. sobre a lamilia?
-De quem? De todo o mundo. A familin em geral. A nulher, "s mecho, $n$ papatgaio, o saguim, a trempe, as paneliss, isso tusto. esmungou:

$\rightarrow P$ ira dizer a verdade, nunrat pensei nissn. E o senhor dammarto de tuchiquetr. Na. ther, meninos as les sei la! nuncá deve dizer que os fillhos
que tẹm em cisa são delle. E quanto a mulher, hoje a gente pega uma, larga amanha, artanja outra, casa aqui, descas
acolá, e assim vamos indo. Isso de mulher è bichinho que não falta. Ese um homenn fosse
se lembrar de todas com quem fez vida, estava arrumado. -A sua vida assim agitada ithe -Lucros, lucros, nầo são ba grande coisa. Nem roubur hoie dá. lucro. Nào se tem mesmo o que roubar. Isse de tinheir aqui, homem,e uma bobagems ce o povo até nem aprecia ter dinheiro pra gastar tanto quanto se gasta com a vida de hoje. Agora o que eu ná faco, nei. de agora pra ir trabathar $\mathbf{n}$ enxada, que eu não sou... . Lampeao estacou, passo lenço peito pes coço.

E nós, aproveiando + deix.: senhor rosta mesnuo do sertâo? - Gostar, eu gosto, moco. a gente se acostuma depress. Um coronel noutro dla me disse que o povo da cidade acha isso rim, vorque e de dadăos que nunca viram o sertão, falam delle como se tivessem vivido nelle u'ta porçấo de tempo. $\mathrm{E}$ isso que estrag na. E relativamente aos core neis, que pensa o senfor? - Homem, elles até nâo sá ruins Ha realmente alguns existem pessnas itreitis. Te nho boas relaçâes com un Esstav y finda a nossa missão. De pecimc-sos: Virgulino. E adeu*, Desejolji mui as feli. idades nos seus. negoce $s$. 
Como antigamente, em que une nome, todo em rythmo dis hymmo, andava por estas bantas sob o calor de enthusiasmos populares-Juarcz, hoje é Lampeăo que enche todas as bócas do nordeste.

Cada passo do terrivel caôtho ó marco para uma cruz de caminho, para un drama pungente de sangue e luto. E o interior se alarma com os beatos de sua approximação como se fosse um terremoto. Isso tembra até em alguna coisa aq'e'le terrivel e desconheciao Putois de Anatole.

Aqui para nós, o iøterior devia se precaver muito mais com o lampionismo semi-cívilizado: o senhor promotor que fay politica e o boticario que machuca reputaçórs como lencos de assoar. Mas deixemos em paz - boticario, preparando os seus cachés de quinino e o sr. promotor tendo preguiçosamente uma ligeira litcratura criminal.

A ultíma noticia de Lampcão é curiosissima: o cafuso illustre conquistou para o seu bando rocambolesco umas quinze nulheres. Inclusive algumas gravirlas.

O. a, Lamp, um tipo representativo de raca forte, de barboro, está ás voltás com uma obra formidavel: o povoamento do sertāo. has povoamonto de uma especie birbara $\mathrm{c}$ forte, que saiba iutar com a aggressividade climatologica da terra e a resolaçáo brutal da natıreza. F. para esse refinamento da especie Lam* peão precisa da collaboraçào de mu- lheres sadias e productivas. E para a cscolla é que está fazendo essas viagens de experiencia.

$O$ homem fraco năo resivte ao sertão. E dísso resulta, como se sabe, aquillo que a literatura do sr. Alvaro Paes chamou de «tantalismo urbanista». Lma medida efficiente ć cercear-se aos fracos o direito de procrear miserias organicas e taras e covardias.

E’ por isso 'que eu não critico nunca quando Lampeäo castra certos homens natura'monte covardes que se lhe atravessam no caminho: é preciso que essa gente năo amofine uma raça com a inconsciencia de suas hereditariedades dolorosas.

Com cssa ob-a patriotica Lam. peăo está se arriscando a um cre. pusculo : as mulhcres que carrega para sua companhił vâo talvez cstragar-lhe a carreira A historia, como tridn o munclo sabe, está cheia de factos desses, em que a mulher tem fejto a desgraça de grandes homens. Yamp devia tetrer muto mais essas mulheres que todo o batalhão do sr. Chevalicr.

Eu creio mesmo que será este n unicr meio de dar fim a Lampeño: é dar-lhe mulheres, caboclas quentes e excitantes, que amolleçam o temperamento de aço do celebre cafusc.

Afóra este, sò conheço outı meio: o de continuar a suffocar, com a literatura diaria ding jornaes, a sua extraordinaria personalidade de heroe de romance.

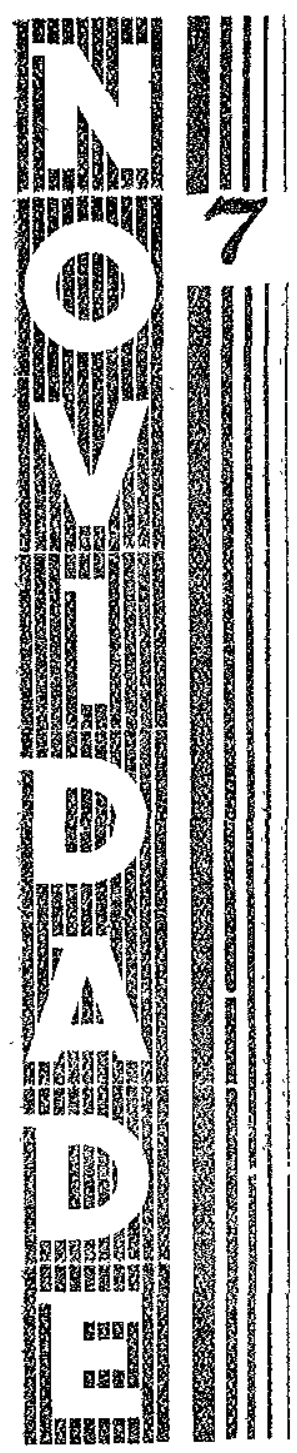

16 paginas 400 réls 


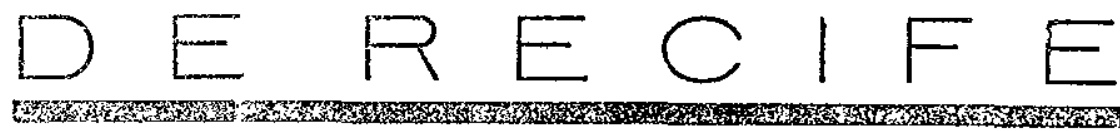

\title{
Correspondencia do Raul Lima, especial para NOVIDADE,
}

\begin{abstract}
A nove e grande mania de Rscife «Pê. erre-a-pé. Radio Club de Pernambuco» - Em toda parte e a qualquer hora.
\end{abstract}

Recife é actualmente uma cidade em absoluto empolgada pelis radio.

O Radio Club de Pernambuco tem um prestigioque ab fou completamente as noticias da Santa de Tigipió. Por falar nisso c'u digo de passagem, agora que ella jáé una humilde detenta, que, pelo mesmo motivo por que nuncal fti vero Prixe-lioi aqui, nem subirit ao 'ão de Assucar, no Ri, nunca fui vi ro arraial re dona Isabel. E, t mbem a proposito, não sei por que tanto interesse demonstrado por um jorn 11 rahi em arranjar inma santa, porque não tem sido asqueno o trabatho que " artigo tem dad' a policia de Mras e á de Pernambuco.

Mas... alo assumpto.

A' hora em que excrevo estas linhas Recife quasi torla enche os auridos com os cons. tantes programmas do Rarlio Club. Nem se s.lbe como d1:tinguir já as casas que ainda não têm sobre os telhados as duas varas das antenas.

E durante o dia todo e, á noitc, até as dez horas, os $T e$. lefunken e os Philips não param de funcirionar.

Vali se passando e o que se ruve, desde de-m nhã ć $\cdot P \hat{e}$ erre a-pê. Rardio Club de Per. nambucos. L; a voz sempre eloquente do speaker que intercala os discos e os numeros do programma com reclames de casas commerciaes e nomes de novas pessoas que adquiriram seus radiosinhos e que, desse modo, devem associarse ao "adio Club.

Das conf itarias, dos bars, dos sete andares do Hotel Central, saem sempre as program mações do l'ê-erre-a-pê.
Destle as onze da manhã são irradlados rdiscos Colombra, sem chiado, offerecidos pela casa Byington».

A' noile ha sempre uma no. viclade, uma programmação curiosi. E' a senhorita Ladyclaire Ferreira que canta em inglês os maic $\mathrm{b}$-llos blues americanos, como Orange b?os. som time; é seu irmão Nelson Ferreira tocando optimas coisas no piano, quanclo não resolve aggredir o sentimentalismo alheio com uma valsa; é a senhorita Maria de I,ourdes Souza Eeão que declama bons versos: sĩo frofessores do Conservatorio Permarybucano (le Musica que honram o pians do studio; 'é a senhorita Crição de Barros Barreto tirando lindas coisas do seu violino ; é Ascenso ferreira recitando Trent de Alagoas; é, finalmente, o senhor Mario Mello. mnha gente, tocando uma gaita historica.

Os raros cidalãos que não têm ainda em casa nem na casa do visinho um Telefunken, ouvem sempre tud. isso apenas tomando uma salada de fructas no'Armazem da Rua do Rangel.

Foi lá, justamente, que eu, outro dia, deante do arco-iris de gelo de um combinado, senti coisas bem estranhas, como saudlarles c desencanto da vida, porque o prof. Ernani Braga estava mettendo Chopin $\mathrm{em}$ cima da gente.

Mas o que serdarle ó que o ra lio matou mesmo a vitrola.

O radio não era tĩo bom porque só se tinha a horas certas. Mas igora se tem a toda hora. E, n que é mais, atê de relogio serve porque a mar. cação do tempo é tambem irratiada pelo Pé-erre-a-pé.

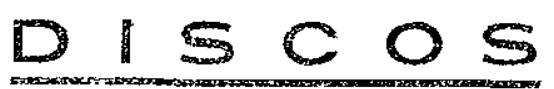

Como ainda não poude chegur para uma cidade pequena e pobre como Maceió a mania do radio, como ent Recife actualmente, continiua vigornnflo a modu das vitrolas. Foram mesmo as vitrola que fiztram a alma cantante de nossas mas tristes. Por isso NOVIDADE mandoutnos a uma das discolandias di capilal, a Lasa Ame. ricrna, e ouviu "lguns discos. que ricommenda a todos os que se interessam pela boa musica..-I

\section{Classicos}

9006 - La Verbena de la Poloma (Fantasia) 1a. e 2a. partes - Banda Municipal de Valencia.

91500 - Guarany - Sinto uno forza indonita - 1a e 2$\urcorner$. partes Dueto final do 1 . acto - Tenor Reis e hilva e soprano ('armen Gomes, com orehestra de soláu.

Bnol - Ave Maria - Back Gounod - Sopranoe violino.

9036 - The Walloyrie Tire Music (Wagner) lá. e 2 1. partes - Sym. phony Orchestra.

6641 - Rigoleto - Alfied Cirto ao piano -1 . e 2 a partes.

6614 - Carnaval de Veneza - 14. 2a. parles--Vocel com variasöes, por Toti Del Monte.

6651 - Wagner - Abcrtura - 1.1. e 2a. partes - Chicago Symphony Orchestra.

\section{Populares}

$22384-A l l i$ want is just one from picture - Fox do film "Parat mount em Grandr: G.⿲la».

22253 - The Roguc song - Fox do $11 m$ film da Irtro.

22073 - Vaiting at the road Fox do fih.s da Hetre «Hałlehiah».

$222+4$ - Youde Sometring to nue -Fox From the Wusical Comedy li:ti villi $n$ Frenchmem. 


\section{AGUAS PARADAS}

A revolução de Outubro, entre muitas coisas bôas, está nos mostrando, com muita clareza, o que nós realmente somos.

Já nos revelou uma porção de cifras que enfeitavam os cadernos de notas dos velhos politicos e agora nos dá provas do quanto valem os nossos homens novos.

Foi bem custosa a sua tarefa de coordenar os elementos dispersos, e se lhe forra relatívamente facil manejar algarismos de valor igual, enfrentou serias dificuluades para alinhar homens de um tom equivalente.

Dai surgirem, 'tanto os homens--tempestade, continuadores ardorosos da agitação inicial, sempre revoltos em suas proveitesas resoluções, como outros, bonançosos, retraidos nos seus atos, de uma serenidade dominical, de um sossego de agua-parada.

Não se sabe ao certo se os ultimos representam maioria, mas muitos deles espalham pelo pais todo um ambiente de armisticio ou de minuto-desilencio.

Por isso existem e suas qualidades interessantes merecem um certo destaque. São vaidosọs, preocupam-se excessivamente com o brilho e preferem simbolizar a calma dos riachos tranquilo; para melhor refletirem $o^{*}$ que acontecer por perto.

Teem tudo dos espelhos; a fidelidade no reproduzir eo brilho superficial. Só diferem um pouco por não conseguirem que alguem nêles se mire.

Esses aguas-paradas sómente andam mal numa cousa: não enxergam que uma simples pedrinha, atirada mesmo por descuido, iria desmanchi ${ }^{*}$.hes completamente o seu descanso.

Ahi então as aguas se mexeriam e ondas impelidas por uma forca central poriam tudo á margem, 


\section{O Laboratorio de Imagens}

(Especial para NOVIDADE)

Os tempos muaaram mas ...

Holyrwood ...

$$
\text { (Orangeade) }
$$

... é a bebida favorita da época

O cèu illuminado annuncia uma grande estréa

Passeio das estrellas

que chegam pelos trens rle Ohio New York Texas Oregon Iowa South Carolina esfe leste oeste

O Merijou old style de bigodes frisados

- Mademoiselle I bring to you

les anciennes traditions de la galanterie française

$O$ hand-kiss inevitavel

O mundo inteiro visto e ouvido

pelos ...

PARAMOUNT SOUND NEWS

FOX MOVIETONE NEIVS

Mesdames! E'pilez-vous les sourcils

Viss Annabelie (1. premio de belleza em Pittsburg)

dita ao reporter de Photoplay

algumas opiniōes standard

«Seu coraço e 100,000 dollares 1 .

Chovem as propostas

No entanto um jornalista escreve:

"Nossa lembrança centinúa fiel ás estrellas extinctas»

A affirnaçio romantica soffre commentarios desencontrados no Cocoanut Grove

onde Chaplin aturdido pelo jazz

lê os artigos de Walko Frank 


\section{Bucolico}

\section{(Especial para NOVIDADE)}

Esse gosto bom dos sentidos!

Acho daqui a paisagem completa.

(Se o trem passasse agora

os cabuclos empinariam os torsos lustrosos.

brilhando no sol!)

Mas a quietação ondula

pelos morros verdoengos

e bate de encontro ás cas̀as branquejando na luz.

Apenas

quebra a vista das cousas paradas

o movimento rythmico das enxadas dos que estão trabalhando

longe...

Sinto a alegria campestre do verde bem claro.

Vou tão feliz

que piso nas flores pequeninas,

meu Deus, até sem ser por maldade.

Santa Rosa Gumior

\section{Lição de geomehria}

\section{(Especial para NOVIDADE)}

\section{Para Aloysio Branco}

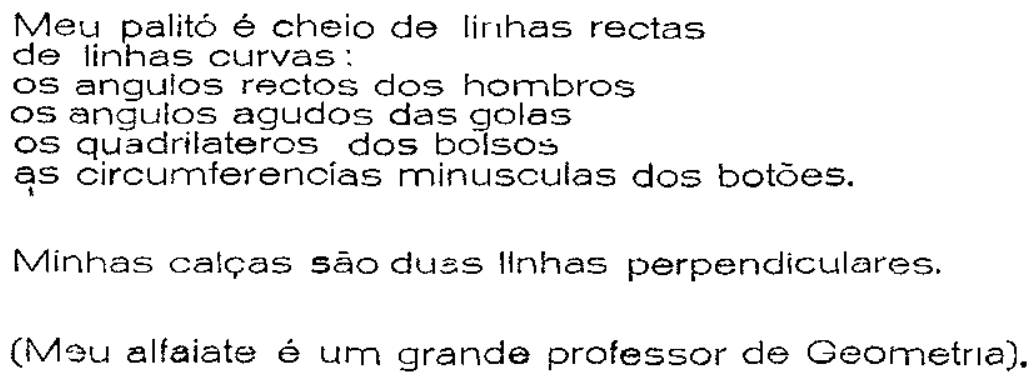


Ao silencio religioso da hor" avançadk,

ba to tique-taque do relogio uma intançâ, humana k prolanaçáa.

Ven-me un desejo de parar esta petadula incausavel te insensivel,

para mais profundanente auvir as queixas dos insomnes,

- elvir a respiracão oflesante dos miscraveis gue dormem,

ouvir os soluçes abafados das pobres mulleres que debafde esperam o dinheiro to

arear impstro,

ouvir o desespero dos tisicos que se despedaçam muna tosse convul a,

ouvir os gentidos, es gritos, as imprecaçöes escapadxs dle milhres de peitos nos

ouvir os estertores dos qृue partem, a estas horas...

hospitaes,

Todos esses reidos augarcntam a gravidarle do silencio.

Ouce perto o bahtio dic uma arelha.

A pendula multiplica todos os lamentos,

apressa a extincçáo de todos os lamentos.

continua insensivel a sua monotona viagem.

indifference ás viagens que conecan com os lam untos extinctos...

O balicio da ovelha, insistenie, magoado...

- As lagrimas rlos que fierm sós...

Três pancadis symbolicts

que se prolongam indelinifamente

tornam o silencio absolutuncrate raystico. 


\section{caso

O 17 tinha quase orgulho de tocar o maior instrumento da banda. Inchava comica. menle us bochêchas e soprava com enthusiasmo naquella tuba immensa. Dia e noite, no intervallo de aulas, não se cancava de ensaiar, tocan. do, soprando. Ninguem pensou jamais que esse ardor musical the fosse fazer mal, cêdo ou tarde. aos pulmões delicados Uns pobres pulmōesinhos que tilvez teriam de soffrer mais com a sauda. de cla tuba do quo mesmo da saude. Ou tilvez uns ponres pulmõesinhos para quem a tuba se confundia com a suude.

Em pouco e pouco, o 17 fôra se afinando. Nem tinha mais força: pura carregar o enor. me instrumento nos hombros envergados. O girb'sia mu. dando num ar ufflicto de su. erificio $E$ qunnilo soprava, com difficulia e, o som sahia seinpre (a)o "trenulo. () som sahia triste e filul como um sy nptoma. Cimo um reveludor som de tosse

Foi obrigado pelo director a ce. ler a tuba querida a um collega mais robusto. lisdi. grado, jurou entrino que não tocaria mris. Clarinete on pistom elle não queria apren. ler, porque nio lhe enthu. sizsmanum. Rem no fundo de s.eucoraç̃o, qualquer cousa doia, ao pensarque nã () sahi. ria mais na parala de sele de selembro, em que decerto iria fizer uma bella figura.

D. $u$ para toseir muilo durumle a noile. $\mathrm{E}_{\text {tinh }}$ febre. Uma preguica invenvinel amıl I cia lhe o corpo toilo p elle nai, tinha mais vontade de b:-incar no grande paleo do (riphanati. onde as arvores curinh ssas de sombras mater. nises comprehendiam o que e tiam tulvez substihuindo a li ( $\left.{ }^{\circ}\right)$ is horas de recrei $\cdot$, " 17 pusseava lá pelo fundo ulo piteo isol.ado e pensativo, mmon iá procurando alli só. men e lembrancus. Ebotava "M rihus comprilos paro os camaradas que salta. vame jogavam. Parecia estar recolhendo com o olhar uns restos de brinquedo para a sua infancia miseravel. Assim mesmo, o censor grita. va para elle nuin tom de rude advertencia :

- Saia do sol, 17! A' noite você vae tossir mais...

O 17 dizia que durante o dia ia melhor. mas si á noite tossia era porque se achava mais só.

Uma tarde, em que elle peiorára. um automovel veio buscal o, leval-o para o hospital. 1 professor Aurelio, (*) commovido, passou.lhe an pescôç" um grôsso cache-iol. de lâ, e pela primeira vez lhe. cham.'u pelo nome :

-Tenha coragem, Julio! Você fica bon logo, pura vol. tar gordo, fiste, pura soprar de nowo na tuba.

O 17 ficára admira lo ouvindo o seu proprio nome. li não era um numero. Agradeceu ao professor com um olhur doce, depois interrogıu:

- Professor, para o senhor eu era sempre o 17 Por que me chama agora pelo nom? ? Será porque estou doente?

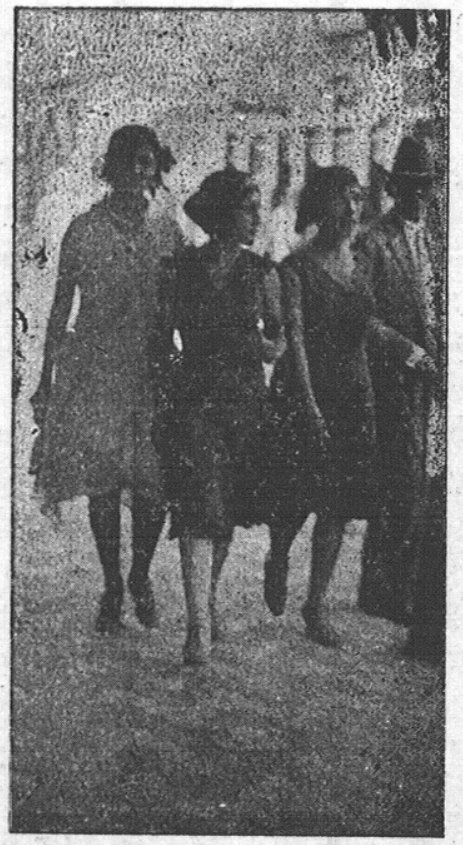

Os collegas espiavam através das grades, zombando.

- Olha a perna do 17 como está sêca!

- Vamos tomar conta da mesa delle.

Eilles não comprehendiam, coitados! Em vez ae rirem, deveriam se despedir do camaradinha que ia embora, da1-lhe adeus. Talvez esse. passeio até o hospital continuasse.depois até o cemiterio.

No dia seguinte, na aula, os meninos olhuvam insisten. temente a carterra deserta do 17. Alguns fizeram gestos de occupal-a, maso professor reprehendeu-os, dizendo que ninguem tocasse nas c usas do ausente, que esperassem.

() menino robusto, que o substituira na banda, disse resmungando :

- Ura, o 17 não volla mais, vae se ucabar por lá...

Boca de mau agouro. Com uma semana chegou a noti cia. $U$ professor Aurelio foi a. enterro, demanhãzinha. Depois voltou an orphanato e dolorosamente foi dividindo os livros do 17 enireos outros meninos. Dana uma grammatica a um, uma geographia a outro, uma arithmetica $a$ um terceiro. Em todiss os livros tir.ha o trabalho de passar a borracha e apagar aquelle nome - /ulin Maria da Conceição - mas era como si pstinesse anagando uma coisa maior, até u saudade.

( ) Meu amigo Aloysio Bran co coliaborou com esta nuta sobre as arvores e outras mais. For um inexplicavel escrupulo de consciencia é que não con sentiu em assignar tamben este conto.

(*) Aurelio Buarque de Hol. landa contou, a mim e a $A$ !nysion Branco, o caso do 17. Elle leciona português e outras materias no Orphanato São Dımingos. A'quelles meninos unfelizes, que nãı teem ni.. guem por si, preferıa antes pusinar a supunrtar a solidão. 


\section{Historia de Miôsca}

Era uma vez uma pequena môsca. Desde que saiu do ovo, vivia ali na casa dos Fonseca. $A$ 's vezes ensaiava un vôo mais atrevido, indo até o quintal, onde a lata do lixo era como uma caixa de surpresas, mas regressava logo.

Fazia parte duma compacta sociedade de pequenas môscas, todas desportivas e alegres. Deliciava-id o movimento. E inquieta e travessa, saltitava, voava, fazendoum zumzum que o velho Fonseca achava impertimente, mas que a ela deleilava, pois era a sua maneira de compreender a musica.

Por causa desse zumzum. ligeiro rumor produzido pelas asas miudas, resolvi batisá-la com o nome de Zizi: O outro. de môsca, inventado pelos homens, não deixa de ser indecoroso. E não é decente repeti-lo uma duzia de vezes nesta narrativa.

Como ia contando, Zizi passeava em voejos curtos e baixos por troda a casa; porém pre. feria a sala de jantár. O motivo desta preferencia não era a sôpa fumegando nos pratos e outrós sédutores petiscos. Felizmente nascera isenta do pe. cado da gula. O que a atraía era a toalha da mesa. Gostava re brincar.sobre esse pano liso e colorido, Mas si avistava a menina Alice, então ja rapida pousar em seus cabelos lourns ou na tez de leite e rosa. Aí demorava um tempo longo, como num pais ideal, desmenoriada dè sua condição infima, sonhando com cousas brancas e suaves. Até que se des. vanecia o sonho ans piparoles da máo enorme da menina Alice.

Teimosa, tornava Zizi a esse rosto em que se sentia como numa avelurlada planicie. Mas duma teita nào pôds reprimir - susto e quedou pasmada. perdida: havia se descermolo misicamento o traço verme-
Ho e firme dos labios, e una voz trovejante ribombado. Pouco a pouco se habituara com isto. E presentemente sabia que nāo era nenhuma tempestade, apenas palavras conuns com que a menina Alice conversava com os pais.

Zizi procurava tambem assiduamente um trapezlo escarlate, onde fazia acrobacias dificeis ou rondas ingenuas com as companheiras de traquinices Na realidade, o tal trapezio nāo era nem majs nem menos que o nariz do sr. Fonseca, o qual-tremia de indignação e muitas vezes quase explodia em espirros terrivejs. Zizi descobriu e dono do trapezio, e como the dedicava toda uma imensa ant patia de pequena mósea, divertia-se multiplicando as ginasticas e dando ferroadas duras.

-Não tolero mais estas môscas! (Berrava o homem, erguen. do os punhos em desafio a môseas invisiveis y.

A esse tempo, já Zizi estava longe, a salvo em qualquer refugio seguro. Um quadro da Ceia Larga, que ornava a parede, era o esconderijo uredileto. Daî ainda ouvia os tro. vões do sr. Fonseca :

- E e para isto que temos higiene? Que temos mata-mosquitos?

-Páciencia,men caro! (Acomodava a Graça, da cozínha, lavando os pratos.) Paciencia! Deixa chegar o Dia da Hora que as móscas desaparecem. .

- Desamarecem nada. O men lhor eu sei o que é : amanhã trago um tubo de Filit e estas pestes vãu para o inferno.

Zizi nāo compreendia as amencas. Vivia o breve calendario de sua existencia nas mesmas travessuras, pois o ve-

NOVIDADE - é compos ta $\theta$ impressa nas oflicinas typographicas da Liv. Villas Bo3s tho Fonseca não tinha bôa memoria ia esquecendo sempre o funesto tubo de Flit.

Pousada na cabeça loura da menina Alice, fantasiando cousas inexplicavelmente macias, Zizi viu a seu lado uma sua semelgante, porén mais débil e meror. Aproximaram.se docemente e tocaram-se num idilio de asas. Zizi tinha encontrado o seu par. Dahi por deante; adejaram junto as duas, em alacres nupcias, e amavam-se em tóla parte, até em cima do trapezio escarlate do sr. Fonseca.

E não se perdiam nunca. Apesar de serem todos aparentemente iguais $e$ facilmente confundiveis sobre a toalha colorida, Zizi e a outra se buscavam dos angulos opostos da sala de jantar. Uo mesmo modo se achaliame se reconheceriam si es'ivessem distantes.uma da outrá nos confins do mundo.

Una tarde, a sôpa cheirava nas loucas lavadás. Namorando-se, as duis môscas esperavam o momen'o de apanliar migalhas e farelos. Sentaramse o sr. Fonseca e a a menina Alice D. Graça demorava na cozinha, não se sabe fazendo oque. De subito, Zizi e a outra foram tentadas e comecaram a traçar espirais muito baix's sobre tôrres verdes de ervillas.

Então houve a grande ca. tástrofe, a dolososa hecatombe de tod.s as môscas. Um grosso tuba surgiu no ar expelindo um liquido finjssimo que entortecia e matava. Zizi \& a outra foram as primeiras alcancadas pelo veneno volutuoso e fulminante. Era of Flit, perfume jámais sentido, an «r go como o amor e a morte. $\mathrm{E}$ por epitafio, a mão enorme da menina $\mathrm{Al}$ ce er xotou com um ultimo pirarote, lá para debaixo da mesa, os carlaveres das duas, que tombaram de asas enlaçaras. 


\title{
Berceuse para embalar o mundo
}

(Especial para NOVIDADE)

\section{A Murilo Mendes}

\author{
Descansa um pouco ta que estảs dentro de mim, mundo ? \\ Foge de dentro de mïm, mundo ! \\ $\mathrm{E}$ eu sinto que no deserto do meu ser physico \\ a fuga do mundo năo deixou o vestigio sequer \\ đa saudade dos seios durinhos de uma menina que eu não bolikei. \\ O rumor dynamico de New-York, o silencio selvagem da Africa, \\ os rythmos mysticos da Asia, as ídeologias politicas européas, \\ a memoria demoniaca de Lenine, as revoluçőes argentinas, \\ totas as vozes, todos os rumores que andam vibrando na geographia universal \\ morreram neste momento para os meus ouvidos retigiosos \\ porque este meu desejo subito de fuga das cousas terrestres \\ cortou todos os arames de telegrapho todos os cabcs submarinos \\ que vivem enredando os corpos das sereias. \\ Porque este meu desejo subito de fuga das cousas terrestres \\ ordenou aos anjos maus \\ que levassem para a solidăo ardente do inferno \\ todas essas musicas dos cabarets de Broadway \\ e todos esses manifestos de Staline \\ que as onđas artesianas sacodem peio espaço. \\ Sou um desejo que sobe que vara as nuvens \\ e que encontra lá muito no alto a alma de Saint-Romain ouvindo com saudade \\ o ruido dos aviöes atrevidos que tornam menos doloroso \\ o exilio dos c.viadores mortos. \\ Sou um desejo que abandonen a met corpo todos as mìntas raizes com a tenra \\ que deixou o meu corpo desolado como um cego \\ que procurasse em vão o resto dos sentidos. \\ Sou um desejo puro gothico nú \\ que năo leva na sua viagem pelo azu1 \\ nem lembrança da litteratura nem das conversas de café \\ que talvez só leve a lembrança dos seios mornos 'da amada \\ como do ambiente casto em que cahia \\ o seu pequenino cricifixo de marfim preso ao pescoço por uma volta de oiro. \\ Mas agora eu jă sou um passaro tão doido tão bebedo \\ um desejo fraco que voou tão sem rumo tão desequilíbrado \\ que approximou do inferno sem querer \\ e o diabo cortou as axas delle \\ e deixou de repente cahir na terra sobre o tumulo de Renan \\ acreditando monstruosamente que os pequeninos crucifixos de narfina \\ teem apenas uma funcção decorativa \\ entre os seios mornos das mulheres morenas.
}

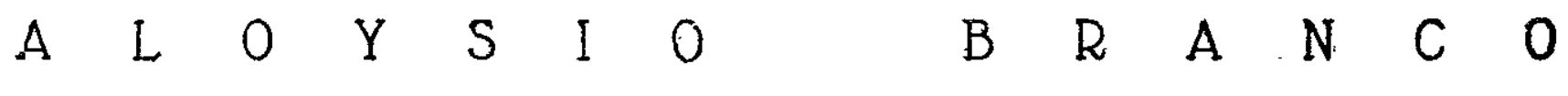


Escrevendo, uma vez, sobre a estranha poesia de le in Coctean, proc irei mostrar o fuanto de shamatico conflicto cxiste entre o seu meio aereo ideal de arte e sud poesia ate agora realisada. Entre a poesia que se lê nas cutrelinhas dos seus livios e a que for realmente composín pelo typographo. Mas é bom nàto se confundir semelhante conllicto esthetico com a busca impotente da perteição. Lissa horrivel busca que já hoje seria cruaz de entristecer apluelle insaciavel paladar do precioso que havia no bom do Conselheiro. O que distingue profundamente o ideal de arte ds Coctean desse c mmum anseio de perıcição, é que us melos para a realizaçio claquelle ideal se encontraram dentro do proprio $\mathrm{Co}$ cteau, ao passo que tal a'seio aspira aquillo que nảo è possivel effectuarse de tro do circulo intmo la persona idade. Aspira norbidamente aquillo cujos meios de realização pairam nut to acima dos recursos interiores de'qu'm anseia. Param dentro dis um plano absolutamente chime-ico. jean Cr.cteáli, para conseguir a sua poesia sonhada, bista vencer os flefeitos litterarios que the perseguem. I' uma simn, ples questaio de libertacão. Mas os anfrrmos taquelfa mystica perfecubiliuade, tenilo, atè ás vezé, icansado o limite do seu aperfecicam into razoavel, e insistindo nesse anseia de ineffaveis attributos, correm mesis no perigo de querer vencer ou, melhor, cle querer reneg ir ou esquecer as qualidades adquindiss na sua evohuçăo natural onde já os defeitos foram expurgados. As qualidades que, comtudo, ainda nem de longe lhes c srespondem ás pr proções lantasticos do seu delirio la periesán. bahi elles so vorleram julgal-as inclignas claquelle pathologico anst io. Neste caso, não se drata mais de li. $b$ rtacho, pelo menios num stnlido util da liberlar-se,-visto que nâo há mais defeiros-mas, s'm, de eseraviaçào a $1 \mathrm{~m}$ ideal qualquer de exe isitude. E, si elles se libertam, $\therefore$ de sua: proprias gudidares, para c thir logo dlepois presos a este atordoante ideai. A lula ite rocteau sena com os s'is proprios defeitos. A luta daquelles enfermss, com as $s$ uns proprias qualidarles, que clles passariam a considerar bastante inferiores em reiaça ao sea vago i leall.

E' umn arta a que proph lisa $\mathrm{cr} \mathrm{r}$ tos versos e certas imagens de coctcai, iona baseada em bos offerecer (lo real a visan m is metaphrsica possivel. E' ama arte arudamente volupstuosit no sendedo abstracto rlas colsias Uma arte onde a befl on fosse tum phenomeno mass angulico 'o que esth"tico. Essa arte que e'm rerdade existe acma de torlas cssas ro.as de paryol aquale que a con cebe não póle a tn il-a sencio por tuma sorte de arceli-non p'a onten gue nao deve co sistir sómente $\mathrm{cm}$ se purificar dio mumoso. Ho fundirio. Do hu i lo. Do cinze'ado. Jo obsceno infuiro. Da lilterat ara lie Becthoven $e$ de Kuy, romsromet idos por Balestrie ri e nor Bap is a Percira. O crro de Coctea é tro acreditarl ate th: b tstava o $v$ il loso exercicio

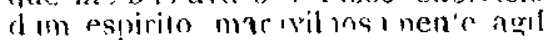

\section{A Poesia de Jean Cocteall}

Aloysio Branco

(EDpecul para WOITDADE)

a picantc. Erro que entre os nossos grandes poetas $f_{t} i$ fâo commum. Erro em que cahiu Rilac E Cruz e Souza. E Alphonsus de Guimaraens. (O) sr. Adelmar l'avares só nảo cahiu tamben porque em poesia elle nunca teve pernas para poder c.. hir.) trro em que cahiu quase toda a bistoria da litteratura brasilema. Erro em que cahem iodos os que submettem o sentil rento í camisa de força dos requntes intellectualistas. $E$ 'que a vicioria sobre o sentimento só vale, a mou ver, quando é alcancada no sejo doproprio sentimento, e wà̀o fóra riclle. Quando um senimento profundo vence e substitue um sentimento frivo'o. Quando uma emosño á laforgue toma o logir duma emoçáo á Gituilherme de Almeida.

Jean Cocteau confiou em exaggero na procligiosa industria duma interligencis mais rapida e prometa que o voo das pegas que curtam o céo do seu paiz:

Les anges, quelquefois, tachés $d$ ' enore et de neige,

Car ils font leur journal á lá polycopié,

Louns ailes sus le dos s'êchappent du Collége,

Volant un peu partout, plus oleur que des pies.

Fin todos os livros de Cocteau ha passaros que p'issam voando, e aos quaes Gabriel Bounoure, segundo a symbol ca oriental, considera como uim sigual do homem angelico. D homem qur tem a graca etherea da vida espiritual e contemplativa. Do homen di poesia nudern?. De.sa joesta que rlizem ser de essencia algebrica e anti-thomista. Mas o verd dero torem de l octcall-para usar umya pákivra muto amata do sr. Puntes de Mirankla ¿̇ 0 gal'o, a aic que sauda as aluroras dia presia mo.lerna on mesmo as prece lo com o seu presco canto marnal, as provoca. F' isso un indicio provando que Concteatu pertence á mesma tribu totemtea de roskanel E' verdrdte que o "l hanteder, a gallo de terreilo, enquanto que o gallo de Coctcan-Ici m o seu deliciuso "Le Cor et l' drlequins - $i$ antes um gallo die torre, profondement bariolé, sensivel a todos os sopros do céo da arie. Le rôle de l'art consiste à stuisir le sens de l'époque ("Le (.$o q$ et l'Arlequin:). As-in a agilidid a crities é consilerada operara de pocsia: vê-se o perigo que lsso offerece: couhecermos tão ben as invencós do: outros ć no; uersu' irmos muito depress a que ae invf' tim as novas promias invongonss que nós mesmos aperas suspeit vamos, tanto é vaidosá a intellipencia Assin Jean Coctati chega, ate contra as suts maximas, $-a$ faire de l'art daprés l'urt, e clle cae jrequentemente no uestylo ponto de particlas.

Quant as vezes năo vemos Coctean thmando o poema de Max Jacob e o accomodando ao capricho de seu gosto, imilando esses deslocamentos de iclentidade que fazen com os objectós saiam de si mesmos e ahi sejam locro substituidos. No entanto, isto náo é plagio, nem mesmo recalque: o funto de betume e de fuligem, csse ventre da poesia de $M a x$ Jacob desapparece; a de Cocteau sc constitue como por un milagre de illosionistas de music-hall. Ovidio dá suas "victamorphoses" no casino de Paris.

A arte de Coclean che ará a uma phase de ta intenso despotismolyrico, em que as imagens do concreto serão tầo abstractamente deformadas que, para identifícal. as ou comprehendel-as - é preciso que - leitor disoonha duma igual capacidaue de deformaçāo lyrica. Donde essa profunda tima interior que caracteriza a poesia moderna: essa nece-sidaric de intimo accordo entre leitor e pocla.

F ntão a nelaphora de Cncteau terá todo o seu valor de deslocamento: ella agirá como um elemento mesmo rle irrealização : esses anjos de Cocteau, seres serm terra e sem agua e talvez até cem céo, trarâo consigo o vivo ao inanimado; tudo - que é quente e doloroso será tra. duzido em siguaes mechanicos e brilhantes. F, essa degradaçăo que se censura justamente h.je nas metaphoras de Cocteau-a espuma do mar comecando a ser espuma de Champagne - darà effeitos poderosos de idealizacão : tolla a historia do coração e di mundo se projectará, como na modeına poesia russa, num puro graphico e emarabescos sublis.

E creio que virá um tempo $\mathrm{rm}$ que Jean Cocteau estará fitigado dns triumphns do espirito cruel e de tant. s vezes cortar a cauda ao seu cão. Enlão the será concedirla, sināo a graça d 'sua salvaçãn, pelo menos, si posso dizer, a graça de sua arie. Mas aind i que esta sef compre infinitamente menos cara que a outra, ć preciso pagal a na m sma moeda. Qtiero duzer. uma poesia puramente platonica tem rue nasen ató da propria renuncis plítonica. Jsto $\dot{c}$, uma pnesia que tem a volupia dos estartos platonucos apresenta antes um caracter cricuristico do que plainnico. li: o pan-sexulismo de Freur] em que se não deve acreditar tanto crmo pm Deus, ixis cm que tambem năo 5 c heve desacredita'r tanto como na perfeicăo.

louis Nasisnon nos contou que It) D woud, Principe firivolo ate liagrdad, pron bia até aos sfus propr is o'hosd.x cahirem sobre os bellos rostos dos fadolescentes de cillos negrose le faces jertumadas de rosas, onde os nrimciros e azulados fios rle bar'sa indecisa p'reciam uma extravagancia de maquéllage femenina. 


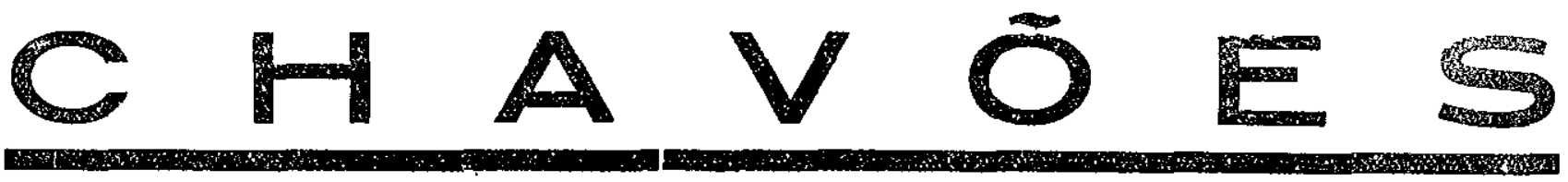

Atacam por ahi o lugar commum. Não sei porque. Sendo commum, deve ser conveniente ao i)ublico, e não valem cantra elle as opinióes de alguns cavalheiros que não são communs.

Se me aão licença, declaro que tenho predileccão especial pelos clichés. E a minha razão está aqui: é mais commodo viajar em automovel por uma estrada de rodanen sim bura cos que percirrer as criminhos srrtanejos cheios de surpresas de espinho rasga-beiço.

Comparindo mil (ou com. parando bem, como quizerem), a literritura encrencala dos homens de talento é como as veredas de minha terra: tem curvas fechadas, rampas que escangallam um carro, tocos preju. iciaes aos pneumaticos, pedras, atoleires, riachos, precipicius, at ene ramos indiscretos que batem na catra da gente.

l ud, isso é desagradavel e produz abalos e interrupçóes frequentes na riägem ou na leitura.

Vt jam agora a rorlovia bem (o)servadal a a chronica literarlat de um cidarlão inoffensivo. A mbas são planas, hatidas, rectas, extensas-e resvalamos por ellas facilmente, com velocitarle ble oitenta kilrmetros pror hora, sem precisão de enterdel-as. Quando muito, perguntamos ao chauffeur ou an crubecido que entra no cafć: -Onem foi nue fez isto ?"

Com eff ito, renhum viajante ou'leitor, por muito exigente que seja, sentiu ninnca a necessidarle de comprehender uma eselrada ou $11 \mathrm{~m}$ artigo campanurlo.

E precisamente prala sensação de pregulcáa que experimentamos lendo pinrases bom- basticas sympathizo com certos auctores. Sem elles, jornaes e livros se tornariam depressa intoleraveis.

Imaginem a maçada de estar um christão a catar pensamentos em todas as linhas que encontra E' trabalho penosi, porque ha sujeitos que pensam bem mas nãuse exprimem com clareza, outros que se agarram a assumptos terrivt is e nos obrigam a olhar para cima e a procurar uma brecha que rão apparece. Quasi sempre detestamos mysterios.

Por isso lemos com immenso prazer os escriptores que não dizem nada. Excellentes criaturas. Têm boas intenções e portam-se decent mente.

Ora vejam. Coberto de gloria, o sr. Graça Aranha resolve morrer. o que é uma perda irenaravel para a sua excel. lentissima familia e para a Academia Brazileira de I etras.

Um doutor que hat vinte e $t$ intos annos leu Chanaan enthusiasmou-se, como então pra costume, lembra-se de compor

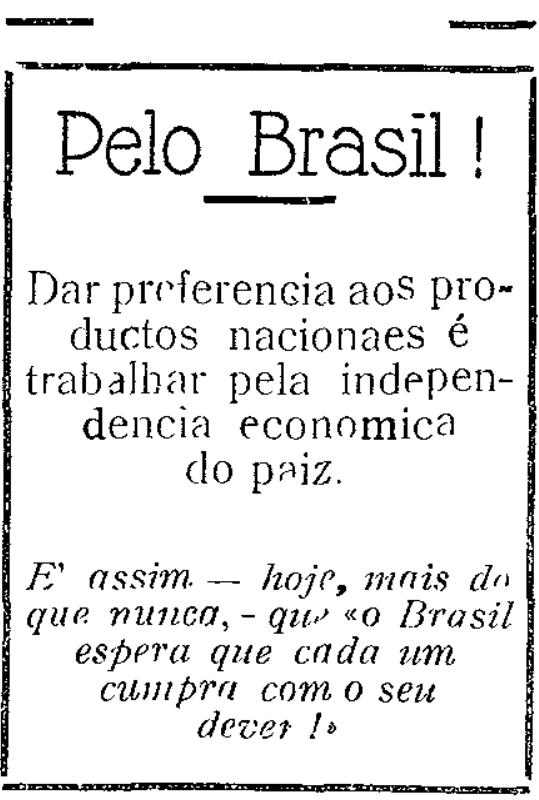

o necrologio do illustre diplomata. Arma-se de grammaticas, diccionarios e outros instrumentos analngos, senta-se, bebe café, fuma cig.. rros e atira quatro columnas e cima do finado. Pois essils quatro columnas, com pequenas modificaçóes no typo. no titulo e em alguns adjectivos, servem perfeitamente para defender o divorcio, para fazer declaracóes de amor e para insultar a Russia. Têm minas de ourn. cachoeiras, flor $f$ stas, a patria, a bandeira, o céo, o mar, um grande numero de instituiçóes consideraveis que a gente lê pensando na vida, pensando no cambio, ou não pensando em coisa nenhuma. E' admiravel.

Comparem um capitulo do sr. Ol veira Vianna sobre o Prazil colonial a um desses art gos que por ahi se publicam a respeito de Castro Alves ou da prefeitura municipal de Porto de Pedras. A primeira tem latifundios, engenhos de banguê, nohreza rural, pecuaria, mineração e grovernadores ger es; o segundo tem tudo. Ou não tem narla. E' optiro. Não nos perturba as occupações nrdinarias, porle ler-se no banho, em cima duma biry، leta ou junt a um taboleiro de xadrez. E adapta-se admiravelmente ás nossals condicões interiores. Se estamos zangados, affirma. mos que aquillo é insensatez; se estamos de bom humor, achamos engraçado e utul comso objecto de esturlo. Os catholicos levantam os othos para ") ceo e snrriem doremente : «Pobrezinho, é um bemarenturado: os atheus rasgam a jornal e gritam: "Ora sebo!"

Apresento uma sugrestão aos homens intelligentes: de!xem de escrever e entreguem a p'nna aos imbecis.

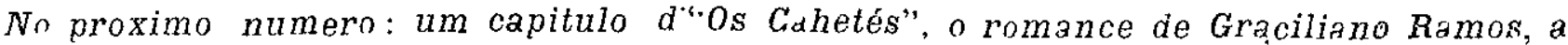
sair brevemente wo Rio 


\section{M i 1 a

Cartomantes, chiromantes, prophetas, espiritas, adivinhos de toda a casta, a santa de Coqueiros e o palre Cicero. Quando um desses está em evidencia, os jornaes augmentam a tiragem. Lemos as not.cias, bocejamos, sentimos desgosto. Realmente o povó supers'icioso.

Pensando assim, afastamos por un momento as nossas superstições e censuramos com azedume as superstições alheias Depois voltamos ás nossas.

Adoramos varios deuses, uns immateriaes, outros de ferr", movidos por agua ou alimentadns a carvão e a gazo. lina. E' necessario que alguem nos salve, a Divina Providencia ou Henrique Ford.

Faltam-nos muitas coisas, e o peor é não nos esforçarmos por obtel-as. Esperamos que ellas nos venham de fóra : do ceo, da Russia, dos Estados Unidos ou da I alia.

Milagres. Quem reduzirá o aluguel das cas's e elevara o cambio? O governo, provavelmente. Não podemos viver sem tảbus : el sições, por exemplo, o voto secreto.

0 essencial é que o paiz tenha um homem, ou antes um super-homem, um heroe. Em. quanto elle nâo chega, contentamo-nos imaginando alguns. Os que estão perto diminuem e os que estão longe augmentam, $\odot$ que parece tm disparate, mas não é.

Ha por ahi numerosos talen. tos. Deyiam ser aproveitad s. Acreditamos nelles, ob! temos grande confiança nelles. Um dia lemos o que elles escreveme o enthusiasmo encolhe-se.

Como é indispensavel darmos emprego ás nossas aptidóes de basbarfues, procuramos outros. Ondle andam elles? Meu Deus! porque foi que o Ruy Barbosa morreu? Um cavalheiro que produziu tantos discursos que a gente admirava sem perigo! Se clle ainda vivesse, a constituiçáo $\mathrm{f} s-$ taria prompta. A constituiçio e uma replica.

A constitrição, sim, senhor, é o que val fazer milagres. Como será a constituicão ? Comprida ou curta ? semelhante á primeira ou differente del= la? escripta em portuguez ou en brazileiro? Nínguem sabe, e inspira por isso um immenso respeito.

$M$ is o milagre que nos convem será gran matical ou geographico? Projectaram estraçalhar o mappa e cosel-o de novo. Improvisaram um t divisão encrencada, com estados, provincias e territorios. Conn ficaria essa manta de retalhos? Os pedaços seriam irregulares, como em toda a parte. ou quadrados, como na America do Norte, onde a propria terra é quadrada?

De qualquer modo desejamos un mi'agre de oito milhöes de kilometros para o Brazil e outro muito maior para o resto do mundo. Democratico ou aristocratico? Quem sabe lá?
Uns querem um governo popular, outros appellam para os figurões.

Milagre de natureza parlamentar ou de ordem technica?

Necessitamos estradas, portos, um bando de coisas que todos pedem e ninguem se aventura a executar.

E a iustruçãa, é bom não esquecer a instruıção. Como estamos longe do tempo em que. pela graga divina, sem professores, diccionarios e outras maçadas, um sujeito aprendia do pé para a mão as linguas do mundo inteiro! A verdade é que $h$ je seria muito bem recebido um milagre, um decreto, que nos armasse depressa, não apenas com ats linglass, mas com todos os conhecimentos que distinguem os homens da Academia de Letras, dn Lyceu Alagonno, da Sociedade de Medicina, etc.

Tambem seria importsnte a suppressão repentina dos bandidos do Norieste e o desapparecimento das seccas.

Milagre estupendo era o que Pernambuco nos queria impingir ha dias, essa historia de. agarrar a electriridade que anda pelas nuvens. Um milagre terrivel! Infelizmente a electricidade portou-se mal, fez como esses defunctos mal educados que jas sessões de espiritismo, quancio se annurcia uma demonstração espalhafatosa, mettem a viola no sacco.

E o milagre gorou.

E' conveniente que se arranjem autros. 


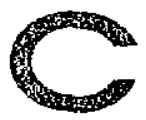

\section{XXIV}

Seria uma felicidate para min, de certo, a morte de Adriâo. Desgraçadan"nie aquella criatura tinha sete folegos. Hoje quasi a morrer, de olho duro, velat debaixo do travesseiro, at casa cheia, padre ato lado, os amigos escovando a roupa preta-e amalinhã arrimado á ber. gala, perna aqui, perna acolá, manquejando.

D cididamente o Dr. Liberato é um sujeito desastrarlo: deixa qu se vão os doentes que fazen falta e adia of fim dos inuteis. Guiomar Mesquit a, com dezoito annos, flor de graca e bondade, como diz $\mathrm{X}_{\text {avjet filho, }}$ depois de quatro mezes ora arriba ora abaixo, lá se foi em Março. E at nulher do sapateiro. a lisica, aintla vive. Emquanto, carregado d a prehen. sões, eu tentava accre-centar uma pagina aos meus cahetés, ouv a-lhe a tosse calemosa.

Vendo Adrião estiralo, a gente perguntava :

$-\mathrm{H}: \mathrm{s}$ perigo doutor?

E o Or. liberato falava no ventriculo, na auricula, nas valvulas, e r pinava:

- S. Ge na sobrevierens complicáçóes, julgo que rão ha perigo.

Năo sobrevinham romplicaçóes. A auricula, o ve triculo, as vatualas, continuácam a funccionar-e Adiäro, combalido, existia

E t.do seria tão f ril se elle desalpjarecesse! Afinal não ela ingratidan minlla desejal the o passem mento, que nase the devia favor. Conserwaymfom porgus" o meu trabalho the era provedtoso. Amizate protecea , loro ta ! Hoje ano ha disiso. Sie an não tiv sse habulumerle para sa. pecat a corsesponti neia com desemharaço e ene ivarar uma partida sem raspar o livere, panfia-me nis reat

En daval didio do atue recolbia, na opinião do Wendonç. Em todo o caso nunca ousei descobrir a mim mesmo o fundo do meu coracào. Não chegaria a pedir ans santos, se acreditasse n's santos, que abreviassem ns padecimentos do Teixeira. Tergiversava. As minhas iıleas fluctuavam, como fluctuan sempre.

A' noite passava tempo sem fim sentado á banca, tentando macular a virgindade duma tira pira o jornal de padre Athanasio. Impotencia. O relogio batia nove horas, dez horis. O pigarro de Dr. Liberato era ab :minavel. Nis sila do jantar Isidoro, Paschoal e l). Maria jogavam as cartas, tinham ás vezes contendas molonhas.

Dança ma na na cabeça imagens indecis s, fugiam rum turbilhão, rebelales. Palavras d sirmanadas, vazias. cantavam-me aos ouvidos. Eu po. curava coordenatis, dar-ihes fórma acceilavel, extrahir del. las uma idea. Nata.

Cites larlranto alo tonge, gall. los nos quntales, gato no te tharlo, seresat ss an rua, n nordeste furiosos at soprar, sacudinclo as jantellits.

e Jirado amign..." Carta a un jusz de facto, mof nat contra o jury, qua absolvet Mr: noel Tavares, assassin". Depois re muito esforen. consesui descrever o rrbunal, o presidente magro e asthmatico, gente nos bancos, o advog. do tris e e com a barba rescida, a 1)r. ("astro suletrando " ll. bello. Nãu ia, emperrava. Talito melhor que radre Alhanasio, bem relacionuto com o Barrosen, nán hesvia de querer publucar acluilln. li que me iospóticua dile llanoel Tavares sahisse liver on fo se onteinrute? Lom eriminos'l solto. Nã vinha o mumbo abai

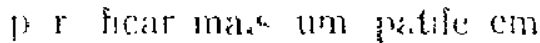
liburel ende

intes o s neto retureando- nei por falta de rima. Torci, expremi-trabalho perrlido. Eu sou lá homem para cımpór verso! Tudo falso, medido isto é poesia? Ninguem fala contando as syllabas.

O que eu devia fazer fra atirar-me aos cahetés. Difficil. Em 1556 isto por aqui era uma peste. Bicho portoda a parte, mundeos traiçoeiros, a floresta povoada do juruparys e curupiras. Mais de cem folhas, quasi illegiveis de tanta emenda, inutilizadas! Talvez não fosse mal aprender um pouco de histori nara concluir o romance. Mas nã jos:o aprender historia sem estudar.

E viver como o dr. Liberato e Nazarelin, curvado sobre iivios, matutando, annotando, ganhando corcunda, é terrivel Näo terbo raciencia.

Emfim ler como Nazareh lê. tudo e stmpre, è um vicio como fualquer outro. Que necessidare t m rl e, simples a bellião em Palmeita dos Inthos, de ser tấn instruirin? Quem dizia bem era Adriálo: - Essas philosolhias não servem parat

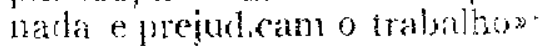

Adráa! la vipha novamente o Adrian! Q e aciso infeliz ana rarn áduel est estromo a muliser glue dria ser minh:?

Chegatrey t rile. Quando a conher í ella era do nita.

E prensar que ha individios (que tem tudo ganta peressitam I Apenas ine- vem un desejo. dethses amave is se ducarregam ele realizalo. Para mim, difficuldardes, complicaçós.

Tinha medo do gom diziem

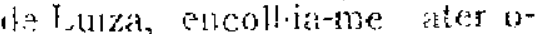
rizarlo, es itasa os conheciojos, mãn ousava encarar hazeth. No escriptario certas moros mpacientes do Adriar daramme tremuras. Santo Deus! Que

(ciant arliaile) 
$O$ «O Esperado*, o novo ro mance do sr. Plinio Salyado, não me deixou uma impressĩo deromance An'es de um poemá biblico, de um canto re um Jeremias mediocre. $O$ fogo da paixão está nelle, estão nolle as imagens abundantes, e sobretudo a negro tom pessimism sta, uma especie de dor e de calastrophe inevitaveis.

O livro é todo feito num sentido só, todo o sea barulho verbal nôo visa senão um f as suas palavras abrundantes só procuram uma direccion: darem para o Brasil uma soluçĩo de tragedia.

Tudo neste romance cami3, ha para o desenlace fatal. Tudo vae morrer, porque tuds está errado: a raça não é meomo nadr, os homens sĩo meins homens.unshero's deformados, corcundas, gente falando por imagens fraquinhas.

0 iivro do sr. Plinio Salgado, que podia ser o grande livr - do Brasil, não me parec: mais que um plan : truncado pela obceśm são de fazer a roisa mais preta do que é na ralidade. Não é, portanto, um livro real, un Jivro onde a gente leia o drama que and a apontando jor todo canto do Brasil.

Falta ao sr. Plínio Salgado qualquer coisa de essencial firn fazer um romance.

$\mathrm{O}$ <Estrangeiro ' já fôr + aquelle grand oso espectacu'o cheio rie actos admiraveis, de pedacos de tragedia, como ninguem tivera feito antes; um especta culo, porém, estragado pela scenographia. Ha no st. Plinio Salgado um pessimo scenogrpho embaraçando os seus grandes achados de escriptor.

A preoccupação da decora. ção. das tintas, vae pondo at perder os seus mais humanos quarlens da vida macional, bor. rando turlo de uma porção de vulgaridades, Quando as suas figuras de gente vão dando mesmo da reakidade uma inipressão de verdade pungente, la vom a scenatio e estraga tudo. Flle não sabe pintar é qu'r fazer do descriptivo a coisa inpressionante dos seus livros. No "Estrangeiro" ha pe* daços ness - gener" de encher de vergonha a um homen de mediano talento.

E' para mim airda um enigma essa mediocridarde que esmaga o talento do grande escriptor que ha de facto no sr. plinio Salgado.

Algumas vezes plle chega a nos espantar pela forte expressão de algumas de suas paginas, mas no meio de tuto isto lá vem a fraqueza verbal, os surtos gongoricos de imagina-

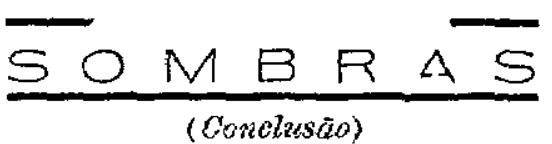

dias. Mas se demorava muito no aposento cortiguo, eonversando enm Alzira

$A$ 's nezes. as mozes se ealaram por muito tempo. 0 menor ruido não se ouvio. Mas plle näo tinhar monor suspeila da finlelidade de Alzira. porque quindo o medi.n ia embora, elle via, atraziés a port $n$ abertr do seu quarto. as sombras de ambos projectadlos na parede em frente $B$ medico apenns apertona corr. tezniente a mão de Alzira

Irma noile, porém, na orersiono do despeditra, as sombras se juntaram. Oh! o horror dosce momento! E olle viu muito bem as duns bncras se unirem num longo beijo.

Fez um exforpo tão grimnle para se irmantar. que a tosse veio suffonante aterradoramen-te suffocante. e elle dosis. tiu do sem intento Equando a mulher the appareces. na so levra do quarfo, elle the pediu com voz sumida para nẫo tos. sir, que sempre deixassecer ratia a porta do seu quarto - or que? - pergicntou the eila, meio desconfiada.

- Porque assim meu repou. so se torna maior. men re pouso se torna muito maior. fão para fazerem um irritante barutho dá guizos. E parece que este barulho de gu zos empolgou de tal modo o joven escriptor paulista que não pode passar sem elle e cada vez mals se apega a esse arranjo instru. mental dos palhaços. Elle mesmo nesse seu ultimo livro rebella um de seus heroes contra $\checkmark$ medo que anda entre os novos escriptores brasileirus do excesso verbal, e chega a fazer uma apologia das ousudias nesse genero.

O escriptor paulista procura a olhos vistos criar o grande livro de sua terra Mas não foi assim que Dostoiewski fez o romance da Russia. Foi entrando na alma de sua gente como uma verruma, se despindo ife turlo que era vaidade de homen de letras para ser somente Dostoiewski.

Mas o s: Plinio é de uma vaidade doentia. E' incapaz de recolher-se modestamente, de agar no silencio. $O$ seu trabatho mental não conhece o recolhimento. Elle é los que gostam te apparecer sempre em uniforme de grancle gala sempre num tinque damnado.

Ora, o romance que se ha de fakzer do Brasil precisa é de um homem mais modesto, mais recolhido sobre elle mesmo

A prenccupação do sr. Plinio é bem outra. Elle quer fazer o livro nacional. E isto já é um embaraço para a obra.

Muitas vezes o tal livro que será todo um povo sáe, como o de Cervantes, de um fundo fedorento de earcere. chero de humildade, e de uma riqueza que não se esgotará nunca.

Esses outros que querem e aspiram a gloria da etermade a gente vê morrer numa gera. çăo.

is do sr. Plinin vêm á luz c im essa ambição de ir muito além. Mas infelizmente o pes? de sua thetorica é como que chumbo, não o deixando fazer esse caminho que atravessa as idades. 
A revolução trouxe ao Brasil a certeza de que não é só de poetas a nossa abundancia. Temos tambem sociologos para exportação a granel. Não ha jornal brasileíro que não pub ique por dia um ponto de vista sobre $o$ que devemos e o que não devemos fazer.

Os medicos são de todos os feitios, de todas as medicinas. Ha os homeopathas, os doces homeopathas que nos offerecem os mais candidos remedios desses que são as delicias das crr $\cdot$ nças, e querem a cura lenta: o Brasil curado com os trasquinho do dr. Sabino. Ha os a'lopathas chegadinhos das Faculdades, doidos para aplicar as suas novidades a qualquer pobre que lhes caia nas mãos. Ha os oculistas, que :ó, querem é abrir os olhos fecha(los da nacionalidade, assim como os que prescrevem lietas de matar o doenle de fome. Ha ainda os medicos naturistas, que affirmam salvar o paiz, descle que elle se disponha a andar de pés no chão e a co* mer milho.

Peior do que todos os medicos de prospectos, os senhore: Homais, esses Mario Pinto Servaque leem revistas de propaganda therapeutica julgamse capazes de curar o mundo.

Elles veem o remedio antes do doente. Os a entes para elles não são quasi nada. $O$ que vale mais é a injecção a app icar on a pillula a 1 gerir O dr. Bovary caluiu sob a seducção de um deste desgraça- do e foi o que Flaubert n's contou.

Falam de uma doença como si conhecessem a doença mesmo c soubessem o remedio infullivel para tudo.

Estes homens são mais perniciosos do que a pro iria doença, porque, elles criam nos temperamentos fracos todas as especies de males. $E$ saem pra a rua, pelos cafés, por ti)da a parte, atrás de suas victimas, a insinuar, a suggestionar.

O Brasil está a soffrer nos dias de hoje a perseguição pertinaz desses srs. Homais. Elles não se cançam de fazer artigos de fundo e consideraçóes, a prescrever in isi'ntemente as suas povidades, os seus purgativos, as suas panacéas de faz'r milagres.

Era cr ntra esses suje tos que a policia da Revolução devia agi Porque muito mais per. niciosos que as santas presas em Pernambuco e em Minas sãorstr's teceitadores de constituições, estes f lsos dou. tores de patrias novas.

O Brasil precisa de mais juizo qu? de remedios.

$O$ que nos ia matanclo era a vida artificia! que levavamos,as extravapancias contra a natureza com que nos deliciavamos. Cançamos as nossas energias en noitadas, em excessos, do minados por umalriste mania de grandeza, de gastos, de esbanjamentos de todo o'genero.

$O$ paiz ectragou o seu systema nervoso perdendo o con trole sobre os seus actos. Era. mos uns bohemios e os bohemios soffrem é de falta de juizo.

Para uma volta sobre si mesmo, nada como os bons conselhos e os bons exemplos.

E' o qua a Egreja Catholica nos offerece. Ella nos diz quaes são os nossos erros e os perigos que corremos. Ella nos vê debaixo de umá tensa excitaça nervosa, perto que estamos de um esgotamento geral, e nos mostra um lugar onde o ar é mais puro e a agua é bóa.

A Egreja é o melhor san tı + r:o do mundo. Em seu seio os doentes não se desesperam e não morrem nunca.

E' o inico medico de cujas mios sae a saúde cterna.

Os homens do Brasil se arredaram della, fugiram de seu confortn. Mas quando, batidos de desventuras e machucalos de erros, se desesperam, a bôa Egreja de Jesus Christo lhes chega com os braços abertos e o peito cheio de ternura.

A sua medicina não tem o duro coração dos cirurgiões e nãa abana a cabeça á be ra dos leitos. A Egreja não falha nas suas promessas.

Ha rincoenta amnos atrás, um bispo gritava de cima de um pulpito : . O Brasil precisa de cath licismo'. E é de catho. licismo que o Brasil continúa a precisar

Os collaboradores de NOVI. I). $A D E$ - têm absoluta independencia d. idéas 